\title{
AsPeCtS OF THE TECTONO-Magmatic EVOLUTION OF LATE Mesozoic Silicic Magmatic Systems IN Hong Kong
}

BY

\section{DENISE LAI KWAN TANG}

A thesis

submitted to the Victoria University of Wellington in fulfilment of the requirements for the degree of Doctor of Philosophy

\section{VICTORIA UNIVERSITY OF WELLINGTON}

2016 
"Brick walls are there for a reason.

They give us a chance to show how badly we want something."

-- Randy Pausch 


\begin{abstract}
Hong Kong represents a microcosm of the magmatic and tectonic processes that are related to formation of the Southeast China Magmatic Belt (SCMB, 1,300 km long by $400 \mathrm{~km}$ wide). The SCMB is dominated by extensive Mesozoic (Yanshanian Orogeny) igneous rocks, which form part of an extensive, long-lived circum-Pacific igneous province. In Hong Kong, large silicic ignimbrites, produced from several calderas identified through geological mapping, together with their sub-volcanic plutons record a 26-Myr period of magmatic activities from 164 to $138 \mathrm{Ma}$. This work studies these volcanic-plutonic assemblages with the associated Lantau and High Island caldera complexes, with an emphasis on the $143-138$ Ma period from the latter complex. This study uses multiple techniques, including field studies, zircon geochronology and trace element analyses, and zircon and apatite low-temperature thermochronology, to gain new insights into the Mesozoic tectono-magmatic history in this region.
\end{abstract}

Field studies demonstrate that the High Island caldera complex (with its main collapse at 140.9 $\pm 0.4 \mathrm{Ma}$ in association with the High Island Tuff) is structurally more complex than previously suggested and represents a long-lived, large $\left(320 \mathrm{~km}^{2}\right)$ feature. The volcanic strata exposed in the eastern part of the caldera are inferred to have been tilted during syneruptive, asymmetric collapse of the caldera floor, whereas those in other parts have been affected by block faulting but not overall tilting. Two ignimbrites (e.g. Long Harbour: 141.4 $\pm 1.0 \mathrm{Ma}$ ) exposed within the caldera outline are now interpreted to have accumulated in local volcano-tectonic basins, confined by faults that were later exploited by dyke intrusions. Field observations offer important constraints on the ages of volcanic and plutonic units, which have been tested by zircon U-Pb dating in this study. The field evidence also negates a previous interpretation that there was an overall tilting of the High Island caldera complex.

$\mathrm{U}-\mathrm{Pb}$ dating and trace element analyses using secondary-ion mass spectrometry (SIMS) techniques have been carried out on zircons separated from 21 samples, chosen from both volcanic and plutonic samples within the Lantau and High Island Caldera complexes. The SIMS age datasets reveal two groups: (1) seven samples with unimodal age spectra; and (2) fourteen samples yielding multiple age components. Five samples in group 1 yield mean ages indistinguishable from their previously published ID-TIMS ages, demonstrating that the SIMS techniques have generated results fully in agreement with the ID-TIMS methods, 
although with overall less precision. Of the two other samples, one is slightly younger than the published ID-TIMS age, and the other has no previous age determination. Thirteen samples in group 2 are interpreted to have crystallisation/eruption ages that are younger (although often within 2.s.d. uncertainties) than their corresponding ID-TIMS values. The remaining sample from this group has no previous age determination. The overall age patterns from both groups suggest that, instead of separate phases of activity at 143 and 141-140 Ma as previously inferred, magmatic and volcanic activities were continuous (within age analytical uncertainties) over a 5 Myr period. Direct linkages between several plutonic and volcanic units in this period of activity (e.g. High Island Tuff and the Kowloon Granite) are no longer supported by the age data, and magmatic activity represented by exposed plutons continued until 137.8 $\pm 0.8 \mathrm{Ma}$, as with the Mount Butler Granite.

Under CL imagery, a wide variety of zircon textures is evident, indicative of complex processes that operated in the magmatic systems. Zircon trace element data coupled with textural characteristics enable identification of some common petrogenetic processes. Overall, the intra-grain (cores-rims, sector-zoned zircons) and intra-sample variations in trace element abundance and elemental ratios are more significant than the differences between individual samples. Zircon chemistries in samples from both the volcanic and plutonic records indicate that there are two groups of volcanic-plutonic products through the history of the High Island Caldera magmatic system. Two evolutionary models are proposed here to explain these two groups. In the first model, the magmatic system comprises a single domain that fluctuated in temperature through varying inputs of hotter melts (and was randomly tapped). In the second model the intrusive and extrusive products represent interplay of two magmatic domains in the crust, with contrasting characteristics.

Zircon and apatite fission track analyses have been carried out on several of the rocks dated by U-Pb methods (either SIMS or TIMS), together with a selection of other Mesozoic igneous rocks and post-magmatic Cretaceous and Eocene sediments to cover the geographic area of Hong Kong. The fission-track dataset and associated thermal modelling show that the igneous rocks and Cretaceous sediments (but not the Eocene sediments) together experienced post-emplacement or post-depositional heating to $>250{ }^{\circ} \mathrm{C}$, subsequently cooling through $120-60{ }^{\circ} \mathrm{C}$ after $\sim 80 \mathrm{Ma}$. The heating reflects the combined effects of an enhanced geothermal gradient and burial. The enhanced geothermal gradient 
is interpreted to represent continuing Yanshanian magmatic activity at depth, without any documented surface eruption products, until 100-80 Ma. The data also indicate a longterm, slow cooling ( $\left.\sim{ }^{\circ} \mathrm{C} / \mathrm{Myr}\right)$ since the early Cenozoic, linked to $\sim 2-3 \mathrm{~km}$ of erosiondriven exhumation. The thermo-tectonic history of Hong Kong reflects the mid-Cretaceous transition of southeast China from an active to a passive margin bordered by marginal basins that formed in the early Cenozoic. The inferred cessation of magmatism at depth below Hong Kong at $~ 100-80 \mathrm{Ma}$ is broadly coincident with the cessation of plutonic activity in many other circum-Pacific magmatic provinces related to reorganisation of Pacific Plate motion. 


\section{ACKNOWLEDGMENT}

I wish to thank my supervisor, Colin Wilson. Colin, you have shown me how much I don't know and inspired me to go further. You have taught me diligence and enthusiasm in geology that I shall keep learning from for the rest of my career. My co-supervisors, Diane Seward and Rod Sewell. Di, thank you for your patience and generosity, especially in spending countless hours with me to ensure my fission-track numbers are right. Rod, thanks for sharing your ideas on the High Island Caldera and assistance in the field. Thank you very much for your guidance and encouragement in the past 5 years.

Special thanks to Dr. Chan for all your support and encouragement over the years. Thanks are due to Pat Browne for discussions on alteration mineralogy. My collaborators, Andrew Carter and Bence Paul, on the low-temperature thermochronological work, are gratefully acknowledged. I wish to thank all technical and administration staff at SGEES for their assistance, in particular Stewart Bush who prepared thin sections for this study and showed me the fine art of sample polishing. Thanks Jiao for helping me in so many trivial and notso-trivial matters in the lab. This research is supported by a VUW Doctoral Scholarship and the Civil Engineering and Development Department of HKSAR.

Thanks Di and Terry for your hosting me at Days Bay. I shall never forget the "flying sheet event" and the "morning calls" from Moko-the-cat. My academic brothers and sisters, and fellow postgraduates, Melissa, Simon, Alexa, Katy, Jenni, Loretta, Jiao, George, Aidan, Julene, Sarah, Chris, Elliot, Emily, Netty, Juliet and many others, who provided moral support and countless coffee breaks. Even though my stays in Wellington were often short and irregular, your friendships have made my PhD experience so much more enjoyable. Girls at ' 8 LC', Monique, Fenty, Lydia and Angelique, I shall miss the chit-chats and cakebaking times with you in those freezing cold evenings. Thank you!

Thanks are also due to my colleagues and friends in Hong Kong. Sam Ng is thanked for your support and encouragement, YK Lai and HM Lam for assisting in the field. Sin, Florence, Alice, Loi and Chris, you cheered me up when I struggled between my work and study. My dear friends, Brandon, George, Johnson and their families, are thanked for their friendships over the years.

To my parents, who never quite understand why their daughter is still studying at an age of 37, thank you for your love and always trusting me. Thanks to my sisters, Phoebe and Sherise, for looking after mom and dad while I was busy doing my research and to my inlaws for their kindness and caring.

Last but certainly the most important - Justin, your love, patience, tolerance, endless support and encouragement have saved me and helped to keep me sane. I am truly blessed to have you. 


\section{CONTENTS}

$\begin{array}{lr}\text { ABSTRACT } & \mathrm{v} \\ \text { ACKNOWLEDGEMENTS } & \mathrm{ix} \\ \text { TABLE OF CONTENTS } & \mathrm{xi} \\ \text { LIST OF FIGURES } & \mathrm{xvi} \\ \text { LIST OF TABLES } & \mathrm{xxi} \\ \text { PUBLICATIONS ARISING FROM THIS THESIS } & \mathrm{xxiii}\end{array}$

Chapter 1 / Introduction

1.1. Thesis overview 3

1.2. Thesis objectives and structures 5

1.3 Silicic magmatic systems 11

1.3.1. Crystal mush model $\quad 11$

1.3.2. Volcanic-plutonic connections 13

1.3.3. Framework of this study with respect to younger silicic magmatic system 15

1.4. Techniques used in this research 16

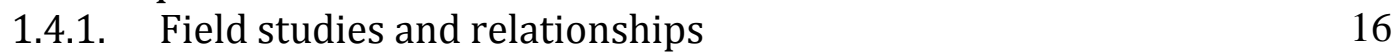

$\begin{array}{ll}\text { 1.4.2. U-Pb zircon age determination } & 17\end{array}$

$\begin{array}{ll}\text { 1.4.3. In-situ analysis of trace elements in zircons } & 19\end{array}$

$\begin{array}{ll}\text { 1.4.4. Fission-track thermochronology } & 19\end{array}$

Chapter 2 / Overview of Geological Background to Hong Kong and the Yanshanian Magmatism

2.1. Introduction 25

2.2. Geological setting of southeast China 25

2.2.1. Basement structures 25

2.2.2. Southeast China Magmatic Belt 26

2.2.3. Tectonic evolution of the South China Magmatic Belt 29

2.3. Overview of Hong Kong geology 34

2.3.1. Pre-magmatic units and stratigraphy 34

2.3.2. Middle Jurassic to Early Cretaceous volcanic-plutonic
assemblages

2.3.3. Post-magmatic sedimentary sequences $\quad 39$

2.4. Volcanic-plutonic assemblages in Hong Kong 39

2.4.1. Middle Jurassic: Tsuen Wan Volcanic Group and the
Lamma Suite

2.4.2. Late Jurassic: Lantau Volcanic Group and the Kwai Chung
Suite

2.4.3. Early Cretaceous: Repulse Bay Volcanic Group and the Cheung Chau Suite $\quad 42$

2.4.4. Early Cretaceous: Kau Sai Chau Volcanic Group and the
Lion Rock Suite 
2.5. Caldera complexes 52

2.5.1. Lantau caldera complex 52

2.5.2. Nested caldera complex in southeast Hong Kong 53

2.6. Summary 56

\section{Chapter 3 / Geological Constraints from New Field Studies}

3.1. Introduction 59

3.2. Major findings of fieldwork $\quad 61$

3.2.1. Structural aspects of Repulse Bay Volcanic Group 61

3.2.1.1. Northern and eastern part of High Island Caldera $\quad 61$

3.2.1.2. Clear Water Bay Peninsula 63

3.2.1.3. Che Kwu Shan ignimbrite on Tung Lung Chau 65

3.2.1.4. Dismembered sequences on Hong Kong Island 67

3.2.2. Structural aspects of Kau Sai Chau Volcanic Group 67

3.2.2.1. Clear Water Bay Formation 67

3.2.2.2. Tilting of columnar-jointed High Island Tuff 70

3.2.3. Textural characteristics of Lion Rock Suite 72

3.2.3.1. Kowloon and Mount Butler granites $\quad 72$

3.2.3.2. Sok Kwu Want Granite and D'Aguilar Quartz

3.2.3.3. Quartz monzonitic and feldspar porphyry dykes 75

3.2.4. Tectono-magmatic structures of High Island Caldera 78

$\begin{array}{ll}\text { 3.2.4.1. } & \text { Cheung Sheung-Chek Keng Fault and Wong Chuk } \\ \text { Fault } & 81\end{array}$

3.2.4.2. Tin Ha Shan Fault and Tiu Ken Leng Fault 83

3.2.4.3. Jordan Valley Fault 83

3.2.4.4. East Lamma Channel Fault and Sheung Sze Mun
Fault

$\begin{array}{ll}\text { 3.3. Summary } & 85\end{array}$

Chapter 4 / Evolution of the Magmatic Systems in Hong Kong reflected in Zircon Textures, U-Pb Ages and Trace Elements

4.1. Introduction $\quad 89$

4.2. Geological background 93

4.2.1. Geology of Hong Kong 93

4.2.2. Lantau caldera complex 93

4.2.3. High Island caldera complex 96

4.3. Samples and methods $\quad 97$

$\begin{array}{ll}\text { 4.3.1. Sample preparation } & 97\end{array}$

4.3.2. In-situ U-Pb age determination 97

4.3.3. Zircon trace element analysis $\quad 99$

4.4. Results 100

$\begin{array}{ll}\text { 4.4.1. Zircon zoning patterns } & 100\end{array}$ 
4.4.1.1. Presence of distinct cores 105

4.4.1.2. Plain, euhedral grains $\quad 105$

4.4.1.3. Oscillatory zoning 106

4.4.1.4. Sector zoning 106

4.4.2. Zircon U-Pb age data 106

4.4.2.1. Volcanic units from Lantau caldera complex 106

4.4.2.2. Intrusive units from Lantau caldera complex 110

4.4.2.3. Volcanic units from High Island caldera complex 110

4.4.2.4. Intrusive units from High Island caldera complex 113

$\begin{array}{ll}\text { 4.4.2.5. Xenocrystic grains } & 117\end{array}$

4.4.3. Trace element data 117

4.4.3.1. Hafnium (Hf) 121

4.4.3.2. Uranium and Thorium ( $U$ and $T h$ ) abundances 122

4.4.3.3. Trivalent trace elements (Sc, $\left.Y, R E E^{3+}\right)$ abundances 123

4.4.3.4. Scandium $(S c) \quad 125$

$\begin{array}{lll}\text { 4.4.3.5. } & \text { Yttrium }(Y) & 126\end{array}$

$\begin{array}{ll}\text { 4.4.3.6. Titanium (Ti) } & 126\end{array}$

4.4.3.7. $\quad$ Europium and Cerium anomalies $\quad 128$

4.4.3.8. Elemental ratios: $T h / U, Y b / G d, U / Y b \quad 129$

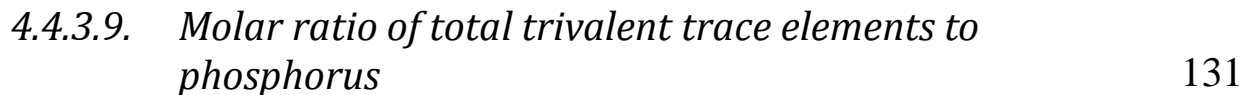

4.5. Discussion 132

4.5.1. Limitation on the SIMS age data sets 132

4.5.2. Contrasting SIMS ages with published ID-TIMS ages 133

4.5.2.1. Unimodal age datasets 133

4.5.2.2. Samples with multiple age components 135

4.5.2.3. Effects of U contents on zircon $U$-Pb ages 136

$\begin{array}{ll}\text { 4.5.2.4. Implications to the magmatic cycles in Hong } & 138\end{array}$

$\begin{array}{ll}\text { 4.5.3. Petrogenetic information revealed from zircon textural } & \\ \text { and trace element information } & 141\end{array}$

4.5.3.1. Dark cores and bright rims $\quad 141$

4.5.3.2. Light CL cores and dark rims 143

4.5.3.3. Structure-less cores and cores separated by thin bright intermediate growth zone

4.5.3.4. Zircons with large variety of complex zoning textures 144

4.5.3.5. Role of sector zoning on trace element patterns 146

4.5.4. Xenocrystic versus antecrysts: inheritance patterns in age and trace element data $\quad 150$

4.5.5. Variations in trace element pattern through time 154

4.6. Conclusion 157 


\section{Chapter 5 / Thermo-Tectonic History of Southeast China since the}

Late Mesozoic: Insights from Detailed Thermochronological Studies of Hong Kong

$\begin{array}{ll}\text { Abstract } & 163\end{array}$

5.1. Introduction 164

5.2. Geological setting 166

5.2.1. Regional geology 166

5.2.2. Geology of Hong Kong 168

$\begin{array}{ll}\text { 5.3. Methods } & 170\end{array}$

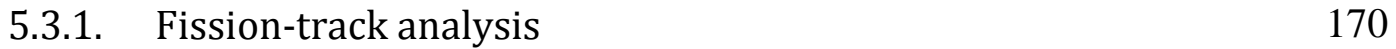

5.3.2. U-Pb dating of detrital zircon using LA-ICP-MS 171

$\begin{array}{lll}\text { 5.4. } & \text { Results } & 171\end{array}$

5.4.1. Apatite and zircon fission-track analysis of magmatic $\begin{array}{ll}\text { rocks } & 171\end{array}$

5.4.2. Detrital U-Pb zircon dating using LA-ICP-MS 175

5.4.3. Detrital apatite and zircon fission-track analysis of
sedimentary rocks

5.4.4. Inverse modelling of low-temperature 179

$\begin{array}{ll}\text { 5.5. Discussion } & 181\end{array}$

5.5.1. Provenance of post-magmatic sediments 181

5.5.2. Post-eruption or post-emplacement reheating 181

5.5.3. Source of heating: thermal event or re-burial heating? 183

5.5.4. Post-volcanic thermal and tectonic evolution 184

5.5.5. Regional and global context 186

5.6. Conclusions 188

$\begin{array}{lr}\text { Acknowledgements } & 189\end{array}$

Chapter 6 / New Perspectives on Volcanic-plutonic Evolution of Hong Kong

6.1. Introduction 193

6.2. Temporal relationships of volcanic and intrusive units 194

6.2.1. Repulse Bay Volcanic Group - Cheung Chau Suite 194

6.2.2. Kau Sai Chau Volcanic Group - Lion Rock Suite 195

6.3. Zircon chemistry of igneous samples from the High Island
caldera complex

$\begin{array}{ll}\text { 6.3.1. Volcanic records } & 197\end{array}$

6.3.2. Plutonic (intrusive) records 200

6.4. Two granite types: "high-" and "low-temperature" granites 204

6.5. Assembly and storage of High Island caldera complex 208

6.5.1. Mount Davis and Long Harbour units 208

6.5.2. Ap Lei Chau, Chek Kwu Shan and Pan Long Wan units 210

6.5.3. Clear Water Bay Formation and High Island Tuff 211

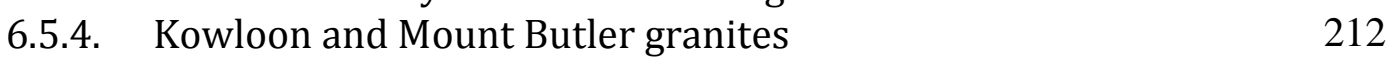


6.6. New perspectives on the High Island caldera complex 214

6.7. Compare and contrasts with global and regional analogues 217

6.7.1. Spirit Mountain Batholiths, western USA 218

6.7.2. Lower Sidewinder volcanic series, central Mojave Desert, USA

6.7.3. Glencoe caldera-volcano complex, Scotland

6.7.4. Xiangshan volcanic-plutonic complex, southeast China

6.8. Implications for large silicic magmatic systems 222

$\begin{array}{lll}\text { 6.8.1. Volcanic-plutonic connections } & 222\end{array}$

6.8.2. Lifespan of silicic magmatic systems 224

6.9. Insights into the evolution of Yanshanian magmatism 226

6.10. Southeast China Magmatic Belt to circum-Pacific silicic provinces

\section{Chapter 7 / Key findings and future research}

7.1. Key findings 233

7.1.1. Age relationships in the $<143$ Ma period 233

7.1.2. The High Island caldera magmatic system 234

7.1.3. Post-eruptive thermo-tectonic history of Hong Kong 235

7.1.4. New perspectives on the High Island caldera complex 236

7.1.5. Implications for the evolution of Yanshanian magmatism in the SCMB $\quad 237$

$\begin{array}{lll}\text { 7.2. } & \text { Future research } & 238\end{array}$

$\begin{array}{ll}\text { REFERENCES } & 241\end{array}$

\section{APPENDICES}

Appendix A Lithological map of Hong Kong

Appendix B List of rock samples analysed in this thesis

Appendix C Low-temperature fission track thermochronology -

Principles and Methodology

\section{ELECTRONIC APPENDICES}

Electronic Appendix A Zircon U-Pb age determination data

Electronic Appendix B Zircon trace element data

Electronic Appendix C Zircon and apatite fission track data

Electronic Appendix D Detrital zircon U-Pb age determination data 


\section{LIST OF FIGURES}

\section{Chapter 1}

Fig. 1.1. The four late Mesozoic volcanic-plutonic assemblages and their associated caldera structures in Hong Kong (modified after Campbell and Sewell, 1997; Sewell et al., 2000; 2012a).

Fig. 1.2. Schematic illustration of the crystal-mush magma chamber model (modified after Hildreth, 2004; Hildreth and Wilson, 2007).

Fig. 1.3. Evolutionary model of magmatic systems and the connections between construction of granitic plutons and large ignimbrite eruptions proposed by Glazner et al. (2004).

Fig. 1.4. Illustration of different techniques in ID-TIMS and SIMS age determination methods.

Fig. 1.5. Illustration of the principle of fission-track thermochronology techniques.

\section{Chapter 2}

Fig. 2.1. Tectonic elements of southeast China at the present-day. 26

Fig. 2.2. Distribution of magmatic rocks in southeast China (modified after 28 Zhou et al., 2006; Li and Li, 2007).

Fig. 2.3. $\quad$ Simplified geological map of Hong Kong showing the distribution of pre- and post-magmatic sediments (modified after Sewell et al., 2000).

Fig. 2.4. Distribution of four late Mesozoic volcanic-plutonic assemblages and corresponding inferred calderas and volcanic centres (modified after Campbell and Sewell, 1997; Sewell et al., 2000, 2012b).

Fig. 2.5. Distribution of formations in the Repulse Bay Volcanic Group (modified after Sewell et al., 2000).

Fig. 2.6. Composite volcanic stratigraphy of the RBVG and KSCVG within the nested High Island caldera complex (modified after Sewell et al., 2012a).

Fig. 2.7. Distribution of intrusive rocks of the Cheung Chau and Lion Rock suites in Hong Kong (modified after Sewell et al., 2000).

Fig. 2.8. Distribution of eruptive units forming the Kau Sai Chau Volcanic Group (modified after Sewell et al., 2000).

Fig. 2.9. Proposed nested High Island caldera complex in southeast Hong Kong (after Sewell et al., 2012a). 


\section{Chapter 3}

Fig. 3.1. Location plan of key field observations of the High Island caldera complex, southeast Hong Kong, described in this chapter.

Fig. 3.2. Field photographs showing the outcrop characteristics of the RBVG in the Sai Kung and East Kowloon areas.

Fig. 3.3. Field photographs of the RBVG in the Clear Water Bay Peninsula area.

Fig. 3.4. Field photographs of the Che Kwu Shan ignimbrite on Tung Lung Chau.

Fig. 3.5. Field photographs showing the representative outcrops of the Clear Water Bay Formation.

Fig. 3.6. Field photographs showing the representative outcrops of the High Island Tuff.

Fig. 3.7. Field photographs of the Kowloon and Mount Butler granites.

Fig. 3.8. $\quad$ Field photographs of Sok Kwu Wan Granite. 75

Fig. 3.9. Field photographs of quartz monzonitic intrusions and the 77 associated dykes.

Fig. 3.10. Location plan of tectonic-magmatic structures of the nested High Island caldera in southeast Hong Kong, based on new field observation and modified after Swell et al. (2012a).

Fig. 3.11. Field photographs showing the geological features of the caldera boundary and related structures.

\section{Chapter 4}

Fig. 4.1. Geology of southern Hong Kong (modified after Sewell et al., 2000) with the locations marked (HK numbers) for samples analysed in this study.

Fig. 4.2. Illustration of systematic classification of zircon textures in CL imagery in this study.

Fig. 4.3. Stacked age histograms and relative probability curves (left panels) and ${ }^{206} \mathrm{~Pb} /{ }^{238} \mathrm{U}$ ages versus $\mathrm{U}$ concentrations (right panels) for volcanic rock samples from the Lantau caldera complex.

Fig. 4.4. Stacked age histograms and relative probability curves (left panels) and ${ }^{206} \mathrm{~Pb} /{ }^{238} \mathrm{U}$ ages versus $\mathrm{U}$ concentrations (right panels) for intrusive rock samples from the Lantau caldera complex.

Fig. 4.5. Stacked age histograms and relative probability curves (left panels) and ${ }^{206} \mathrm{~Pb} /{ }^{238} \mathrm{U}$ ages versus $\mathrm{U}$ concentrations (right panels) for ignimbrite samples from the RBVG. 
Fig. 4.6. Stacked age histograms and relative probability curves (left panels) and ${ }^{206} \mathrm{~Pb} /{ }^{238} \mathrm{U}$ ages versus $\mathrm{U}$ concentrations (right panels) for samples from the KSCVG.

Fig. 4.7. Stacked age histograms and relative probability curves (left panels) and ${ }^{206} \mathrm{~Pb} /{ }^{238} \mathrm{U}$ ages versus $\mathrm{U}$ concentrations (right panels) for intrusive rock samples from the High Island Caldera.

Fig. 4.8 Stacked age histograms and relative probability curves (left panels) and ${ }^{206} \mathrm{~Pb} /{ }^{238} \mathrm{U}$ ages versus $\mathrm{U}$ concentrations (right panels) for intrusive rock samples from the High Island Caldera.

Fig. 4.9. Plots of selected trace elements and trace element ratios showing all data from volcanic and plutonic rock samples from Hong Kong.

Fig. 4.10. Summary plots of ranges in Hf abundances in zircons from the volcanic and plutonic units in this study. White line illustrates the average values of all data.

Fig. 4.11. Summary plots of ranges in $U$ abundances in zircons from the volcanic and plutonic units. White line illustrates the average values of all data.

Fig. 4.12. Summary plots of ranges in the total abundances of $3^{+}$elements in zircons from the volcanic and plutonic units. White line illustrates the average values of all data.

Fig. 4.13. Summary plots of ranges in Sc abundances in zircons from the volcanic and plutonic units. White line illustrates the average values of all data.

Fig. 4.14. Summary plots of ranges in $\mathrm{Y}$ abundances in zircons from the volcanic and plutonic units. White line illustrates the average values of all data.

Fig. 4.15. Summary plots of ranges in $\mathrm{Ti}$ abundances in zircons from the volcanic and plutonic units. White line illustrates the average values of all data.

Fig. 4.16. Summary plots of ranges in $\mathrm{Eu} / \mathrm{Eu}^{*}$ values in zircons from the volcanic and plutonic units. White line illustrates the average values of all data.

Fig. 4.17. Summary plots of ranges in $\mathrm{Yb} / \mathrm{Gd}$ ratios in zircons from the volcanic and plutonic units. White line illustrates the average values of all data.

Fig. 4.18. Summary plots of ranges in $\mathrm{Th} / \mathrm{U}$ ratios in zircons from the volcanic and plutonic units. White line illustrates the average values of all data.

Fig. 4.19. Plots of selected zircon trace elements to illustrate the intra-grain core-rim variations from the Pan Long Wan trachydacite (HK13277), and to compare them with those of the Ap Lei Chau and Che Kwu Shan ignimbrites (HK11840 and HK11836). 
Fig. 4.20. Plots of selected zircon trace elements to illustrate the intra-grain variations from Kowloon Granite (HK11042).

Fig. 4.21. Plots of selected zircon trace elements to illustrate the influence of sector zoning in volcanic units, using samples (A) HK11835 (Mount Davis ignimbrite) and (B) HK12073 (Clear Water Bay rhyolite) as examples.

Fig. 4.22. Plots of selected zircon trace elements to illustrate the influence of 149 sector zoning in granitic units, using samples (A) HK12022 (Sok Kwu Wan Granite) and (B) HK13407 (Mount Butler Granite) as examples.

Fig. 4.23. Plots of selected zircon trace elements of (A) Shing Mun ignimbrite (HK12025, left panels) and (B) undifferentiated Kau Sai Chau ignimbrite (HK12070, right panels), highlighting the characteristics of some dated xenocrystic cores that plot outside the main trends.

Fig. 4.24. Plots of averaged values of trace element concentrations and ratios for zircon rims from the volcanic samples, plotted in chronological order.

\section{Chapter 5}

Fig. 5.1. Regional tectonic setting of southeast China (after Sewell et al., 165 2000). Study areas of previous low-temperature thermochronology studies relevant to this paper: a, Li et al. (2005); b, Yan et al. (2009); c, Tsang (2010).

Fig. 5.2. Geology of Hong Kong (modified after Sewell et al., 2000) with sample locations and ages.

Fig. 5.3. Emplacement age v. (a) ZFT age and (b) AFT age; elevation of sample v. (c) ZFT age and (d) AFT age.

Relative age probability plots of detrital U-Pb zircon ages of postvolcanic sedimentary units.

Fig. 5.5. Inverse modelled temperature-time paths (Ketcham, 2005) for samples (a) HK8758, (b) HK11042, (c) HK12022, (d) HK11835 and (e) HK12001.

\section{Chapter 6}

Fig. 6.1. Selected zircon trace element plots of the RBVG units.

Fig. 6.2. Selected zircon trace element plots of the KSCVG units.

Fig. 6.3. Selected zircon trace element plots of intrusive units from the High Island caldera complex.

Fig. 6.4. Selected variation diagrams for (A) Lion Rock plutonic units and

(B) KSCVG units within the High Island caldera complex. 
Fig. 6.5. Schematic diagrams illustrating the development history of the High Island caldera magmatic system.

Fig. 6.6. Schematic diagrams illustrating the two possible evolutionary models of the High Island caldera magmatic system.

Fig. 6.7. Tectono-magmatic structures of the nested High Island caldera complex in southeast Hong Kong, based on new field observations (Chapter 3) and modified after Sewell et al. (2012a). 


\section{LIST OF TABLES}

\section{Chapter 1}

Table 1.1. Four late Mesozoic volcanic-plutonic assemblages and their main distribution in Hong Kong.

\section{Chapter 2}

Table 2.1. Summary of features of some reported caldera complexes in southeast China.

Table 2.2. Summary of the volcanic-plutonic assemblages and existing ID-

TIMS U-Pb zircon age data for late Mesozoic igneous rocks in Hong Kong (after Sewell et al., 2012a).

Table 2.3. Petrological characteristics of ignimbrites and volcanic units of the nominal 143 Ma Repulse Bay Volcanic Group (modified after Sewell et al. 2000; 2012a and references therein).

Table 2.4. Petrological characteristics of granitoids of the nominal $\sim 143 \mathrm{Ma}$ Cheung Chau Suite (modified after Sewell et al. 2000; 2012b and references therein).

Table 2.5. Petrological characteristics of ignimbrites and volcanic units of the 141 Ma Kau Sai Chau Volcanic Group (modified after Sewell et al. 2000; 2012b and references therein).

Table 2.6. Petrological characteristics of granitoids of the nominal $\sim 141-140$ Ma Lion Rock Suite (modified after Sewell et al. 2000; 2012a and references therein).

\section{Chapter 3}

Table 3.1. Summary of caldera-bounding structures and related ring-intrusions (after Campbell and Sewell, 1997; Sewell et al., 2000, 2012a with additional new field observations).

\section{Chapter 4}

Table 4.1. Summary of the late Mesozoic volcanic-plutonic assemblages in Hong Kong (after Sewell et al., 2012a) and samples (HK numbers) analysed in this study.

Table 4.2. Characterisation of zircon textures under CL imagery.

Table 4.3. Weighted mean ages and age components of volcanic and intrusive rocks from in-situ SHRIMP U-Pb age determinations. 
Table 4.4. Summary of the zircon trace element data for volcanic and 118-119 intrusive units.

Table 4.5. Summary of suggested eruption/emplacement ages and the 139 identified inheritance ages of the volcanic and plutonic units from this study.

\section{Chapter 5}

Table 5.1. Zircon fission-track ages for magmatic rock samples.

Table 5.2. Apatite fission-track ages for magmatic rock samples.

Table 5.3. Detrital zircon and apatite fission-track ages for sedimentary rock samples.

\section{Chapter 6}

Table 6.1. New groupings of volcanic-plutonic assemblages of the Cretaceous magmatic rocks in Hong Kong, based on in-situ SIMS U-Pb zircon ages and zircon trace element characteristics obtained from this study.

Table 6.2. Zircon saturation temperatures of rock units calculated using thermometry established by Watson and Harrison (1983) and whole-rock geochemical data from Sewell (2002). 


\section{Publications arising from this thesis}

\section{Journal articles}

Tang, D.L.K., Seward, D., Wilson, C.J.N., Sewell, R.J., Carter, A., Paul, B.T., 2014. Thermo-tectonic history of SE China since the late Mesozoic: insights from detailed thermochronological studies of Hong Kong. Journal of the Geological Society, London 171, 591-604.

Sewell, R.J., Tang, D.L.K., Campbell, S.D.G., 2012. Volcanic-plutonic connections in a tilted nested caldera complex in Hong Kong. Geochemistry, Geophysics, Geosystems 13, Q01006.

\section{Conference abstracts}

Tang, D.L.K., Seward, D., Wilson, C.J.N., Paul, B.T., Carter, A., Sewell, R.J., 2014. Late Stage evolution of the Yanshanian Orogeny in southeast China: insights using detailed thermochronological studies from Hong Kong. Poster presented at $24^{\text {th }}$ International Conference on Thermochronology, Chamonix-Mont Blanc, France.

Tang, D.L.K., Wilson, C.J.N., Sewell, R.J., 2013. Evolution of the Early Cretaceous large silicic magmatic systems in Hong Kong, southeast China recorded in zircon trace element patterns. Poster presented at Geosciences 2013, Annual Conference of the Geoscience Society of New Zealand, Christchurch, New Zealand.

Tang, D.L.K., Seward, D., Carter, A., Wilson, C.J.N., Sewell, R.J., 2013. Thermo-tectonic history of southeast China since the late Mesozoic: insights from detailed thermochronological studies of Hong Kong. Poster presented at Geosciences 2013, Annual Conference of the Geoscience Society of New Zealand, Christchurch, New Zealand. 

Chapter 1 / Introduction 


\subsection{Thesis overview}

Large silicic magmatic systems are capable of producing the most explosive volcanic eruptions on Earth, generating colossal amounts of pyroclastic materials in association with caldera volcanoes. On the other hand, the emplacement of granitic batholiths represents the complementary geological processes of these igneous systems, contributing to the growth and development of continental crust. Voluminous ignimbrites and extensive granitoids are therefore the products of diverse, and perhaps contrasting, geological processes operating cojointly in large silicic magmatic systems. Because of the similarities in composition, and the generally close spatial and temporal relationships of these rocks, they have been considered as genetically related and co-magmatic, even though volcanic rocks and their related subvolcanic plutons might represent products formed at different stages in the lifespan of the magmatic systems (e.g. Hildreth, 1981; Lipman, 1984; Lipman and Bachmann, 2015). And yet, the answers to some fundamental questions remain. These include: (1) how do silicic magmatic systems build spatially and temporally; (2) how do volcanic and sub-volcanic plutonic rocks relate to each other; and (3) what are the controls on why a silicic magmatic system erupts as opposed to generating silicic plutons (e.g. Miller et al., 2003; Coleman et al., 2004; Glazner et al., 2004; Bachmann et al., 2007; Lipman, 2007; Barth et al., 2012; Davis et al., 2012; Mills and Coleman, 2013; Frazer et al., 2014)?

The crystal mush model (Brophy, 1991; Bachmann and Bergantz, 2004; Hildreth, 2004; Hildreth and Wilson, 2007) was proposed to account for the observed compositional gaps in silicic magmatic systems and to provide a framework for the generation of rhyolitic melts. In the model, plutons are considered as the frozen remnants of crystal mush after the rhyolitic melts are extracted and expelled. This model demands that a proportion of crystals are left in the crust to counterbalance the generation of rhyolitic melts. For a mantle-derived basalt to evolve to a high-silica rhyolite (excluding crustal assimilation), about $90 \%$ of the original magma is left behind as crystals (e.g. Cameron et al., 1980; Knesel and Davidson, 1997). It is therefore reasonable to assume that a voluminous intrusion would have been left behind in in the crust for every large rhyolite volcanic system. An alternative view of volcanic-plutonic connections has, however, been presented by other workers (e.g. Coleman et al., 2004; Glazner et al., 2004; Barth et al., 2012; Davis et al., 2012; Mills and Coleman, 2013; Frazer et al., 2014) who considered that large granitic bodies are assembled incrementally over several million years, and are unrelated to 
any high-silica rhyolite eruptives. This viewpoint has arisen in large part from studies of the Sierra Nevada batholith in California, part of the Mesozoic igneous activity of the palaeo-Pacific margin. Evidence relevant to this debate from other parts of this margin is sparse and this thesis is aimed at providing data from another part of the palaeo-Pacific margin that was active contemporaneously with the Sierra Nevada igneous activity. This thesis attempts to add a measured opinion to the above end-member ideas regarding these debates.

Exposures of both the late Mesozoic silicic caldera volcanoes and their plutonic roots in Hong Kong offer the opportunity to investigate the evolution of large silicic magmatic systems from source chamber to surface eruptives within a geographically constrained area. The igneous rocks concerned can be grouped into four temporally distinct magmatic episodes between 164 and $140 \mathrm{Ma}$, representing a record of magmatic activity occupying 24 Myr (Davis et al., 1997; Sewell and Campbell, 1997; Campbell et al., 2007; Sewell et al., 2000, 2012a, 2012b). These episodes were part of the long-lasting Jurassic-Cretaceous Yanshanian magmatism which was responsible for the creation of the Southeast China Magmatic Belt (SCMB, Wang and Ren, 1996; Lu et al., 1997; Wang and Zhou, 2002; Zhou et al., 2006; Li and Li, 2007; Wang et al., 2011; P. Li et al., 2013). Hong Kong, located at the southeastern end of the SCMB, represents a microcosm of this belt. This research builds on and modifies the work of Sewell et al. (2012a) to investigate the tectonomagmatic evolution of the late Mesozoic silicic magmatic systems in Hong Kong. There is a particular focus on two major volcanic episodes ( 143 Ma and 141-140 Ma), which formed an overlapping nested caldera complex. The youngest system generated at least one ‘super-sized' high-silica rhyolite ignimbrite eruption at 140.9 Ma (Sewell et al., 2012a). In addition to investigating the volcanic-plutonic connections in the Hong Kong magmatic system, this research offers an opportunity to examine the evolution of the Yanshanian event in a localised context and provides a window into the large silicic magmatic province of the SCMB. 


\subsection{Thesis objectives and structures}

This thesis is concerned with the four late Mesozoic paired volcanic and plutonic assemblages that have been identified in Hong Kong (Table 1.1; Campbell and Sewell, 1997; Sewell et al., 2000; 2012a; 2012b). Detailed summaries of these volcanic units and sub-volcanic plutons and their stratigraphic groupings, and how they form part of the regional magmatic belt in the southeast China, are presented in Chapter 2.

These paired volcanic and plutonic assemblages, being broadly coeval on the basis of zircon U-Pb age data (Davis et al., 1997; Campbell et al., 2007; Sewell and Campbell, 1997; Sewell et al., 2000, 2012b), were considered as generally co-magmatic and related to the development of several caldera-related systems established during the four magmatic episodes (Fig. 1.1). Even with the substantial amount of existing data though, questions remain regarding the evolution of the magmatic systems in Hong Kong, and how the volcanic eruptions might have been linked to their sub-volcanic plutons, if indeed they were. In addition, the post-volcanic thermo-tectonic history of Hong Kong is still not well understood, especially within the regional framework of the evolution of the continental margin in southeast China.

Table 1.1. Four late Mesozoic volcanic-plutonic assemblages and their main distribution in Hong Kong.

\begin{tabular}{|c|c|c|c|c|}
\hline \multirow{2}{*}{$\begin{array}{c}\text { Magmatic } \\
\text { Episode (Ma) }\end{array}$} & \multicolumn{2}{|c|}{ Volcanic Group } & \multicolumn{2}{|r|}{ Granitic Suite } \\
\hline & Name & Main distribution & Name & Main distribution \\
\hline $164-160$ & $\begin{array}{l}\text { Tsuen Wan Volcanic } \\
\text { Group (TWVG) }\end{array}$ & NE and NW New Territories & $\begin{array}{l}\text { Lamma Suite } \\
\text { (LS) }\end{array}$ & $\begin{array}{l}\text { Central and western New Territories, } \\
\text { Lamma and Lantau islands }\end{array}$ \\
\hline $148-146$ & $\begin{array}{l}\text { Lantau Volcanic Group } \\
\text { (LVG) }\end{array}$ & $\begin{array}{l}\text { Western and central Lantau } \\
\text { Island }\end{array}$ & $\begin{array}{l}\text { Kwai Chung } \\
\text { Suite (KCS) }\end{array}$ & $\begin{array}{l}\text { Eastern Lantau and southern New } \\
\text { Territories }\end{array}$ \\
\hline 143 & $\begin{array}{l}\text { Repulse Bay Volcanic } \\
\text { Group (RBVG) }\end{array}$ & $\begin{array}{l}\text { Southern Hong Kong Island, } \\
\text { northern Kowloon and Sai Kung }\end{array}$ & $\begin{array}{l}\text { Cheung Chau } \\
\text { Suite (CCS) }\end{array}$ & SW Lantau Island \\
\hline $141-140$ & $\begin{array}{l}\text { Kau Sai Chau Volcanic } \\
\text { Group (KSCVG) }\end{array}$ & SE New Territories & $\begin{array}{l}\text { Lion Rock } \\
\text { Suite (LRS) }\end{array}$ & $\begin{array}{l}\text { Northern Hong Kong Island, } \\
\text { Kowloon and eastern Lamma Island }\end{array}$ \\
\hline
\end{tabular}




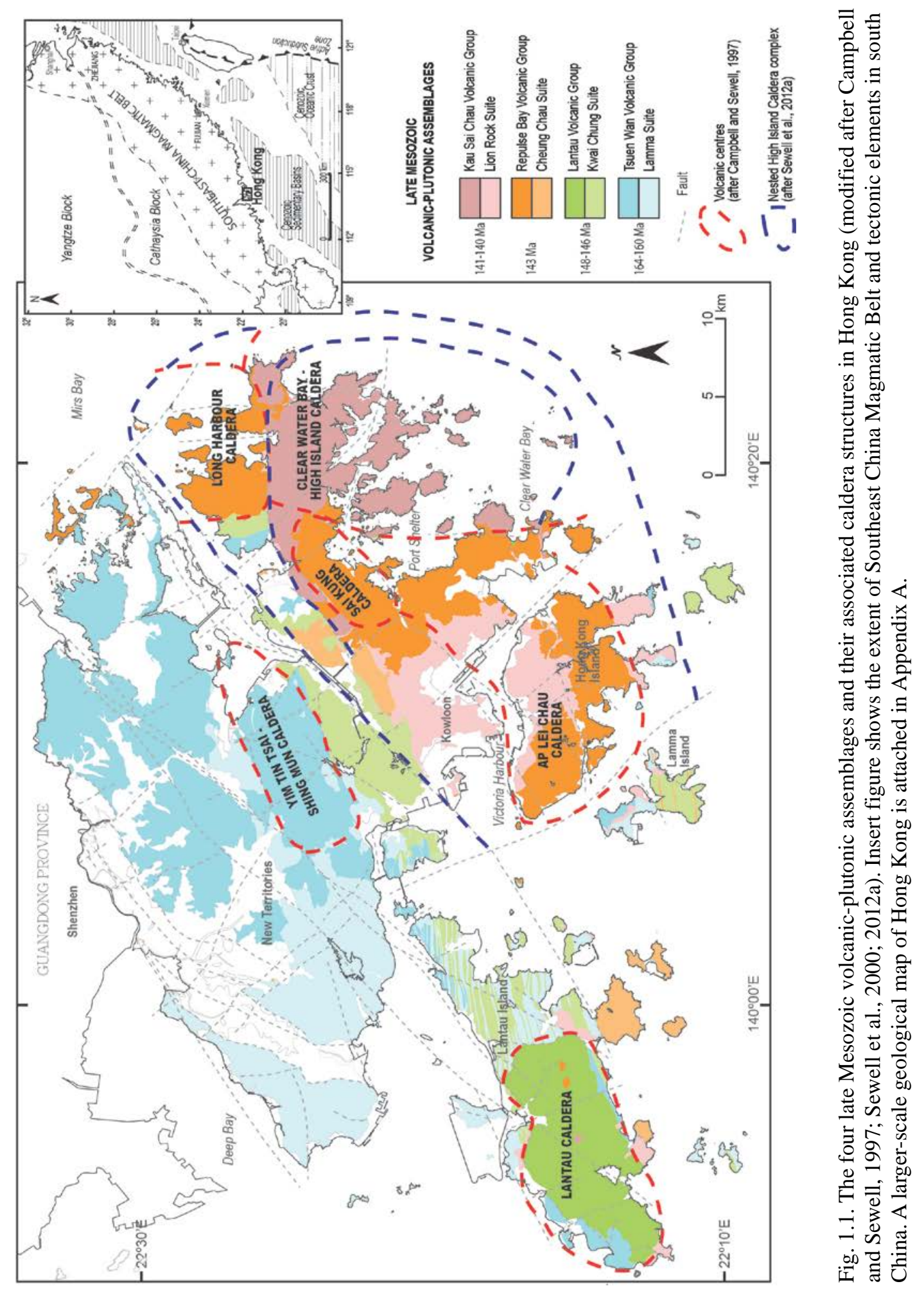


The key questions of the research presented in this thesis are thus as follows:

\section{(A) Were the two Early Cretaceous (143 Ma and 141-140 Ma) magmatic systems genetically related, or are they spatially overlapping but independent?}

The two Early Cretaceous volcanic groups ( 143 Ma and 141-140 Ma) spatially overlap in southeastern Hong Kong (Sewell et al., 2000, 2012a). Previous work, based on the Isotope Dilution- Thermal Ionisation Mass Spectrometry (ID-TIMS) ages obtained on zircons from these units (Davis et al., 1997; Campbell et al., 2007; Sewell et al., 2012b), had suggested a time gap of 2 Myr between the two episodes. It was thus inferred, although not explicitly, that these two episodes represented independent systems. The work in this thesis attempts to detect any genetic linkage between these two systems. Two different hypotheses arise. One is that the younger units were sourced from an entirely new magmatic system that was assembled only after the 143 Ma magmatic system had completely ceased. Alternatively, the younger $\sim 141-140$ Ma system might have rejuvenated the existing but moribund magma chambers of the $\sim 143$ Ma system by addition of heat and/or new magmas. If the latter hypothesised scenario could be demonstrated, it would then suggest that large silicic magma systems can be reactivated over periods of up to several million years or more between major eruptions or magmatic pulses. This result would contrast, for example, with the assessment by Hildreth (2004) on the magmatic systems at Long Valley. He, based on the significant diminished rate of eruptions at Long Valley Caldera, suggested that the Long Valley system is moribund about 0.76 Myr after the main caldera-forming Bishop Tuff event.

\section{(B) What are the specific connections between the 141-140 Ma volcanic units and the sub-volcanic plutons?}

The close spatial (Fig. 1.1) and temporal (Table 1.1) overlap of the 141-140 Ma volcanic sequences (Kau Sai Chau Volcanic Group) and intrusive units (Lion Rock Suite) have led to a general view that they represent extrusive and intrusive products of the same calderarelated system (Campbell and Sewell, 1997; Sewell and Campbell, 1997; Sewell et al., 2000, 2012a, 2012b). The recently proposed nested caldera model (Sewell et al., 2012a) specifically considered that the granitic plutons of Lion Rock Suite might either represent the remnant of the magma chamber, or resurgent intrusions into the emptied magma chamber following the eruptions of the Kau Sai Chau Volcanic Group. The work in this 
thesis aims to interrogate the evidence for any specific connections between the $~ 141-140$ Ma volcanic rocks and sub-volcanic plutons from further fieldwork (Chapter 3) and crystal-specific zircon analyses (Chapter 4). In particular, this study considers whether any specific zircon trace element patterns are evident in the volcanic and intrusive units that could be used to infer the magmatic processes or evolutionary pathways. The findings will contribute to the global debate regarding volcanic-plutonic connections in general (e.g. Bachmann and Bergantz, 2004; Glazner et al., 2004; Bachmann et al., 2007; Lipman, 2007; Annen, 2009a, 2009b; Lipman and Bachmann, 2015).

\section{(C) How were the granites of 140 Ma Lion Rock Suite assembled? Did they grow incrementally and can they be linked to specific volcanic units?}

As mentioned in Section 1.1, two contrasting views on how granitic plutons develop are currently under debate: that based on the crystal mush model in which granites represent the frozen fossil mush zone, and the other which considers that large batholith-sized granites are developed incrementally over prolonged time periods. The most debatable concepts are whether or not voluminous high-silica rhyolites are eruptive counterparts of large granitic bodies, and the causes of the apparently different time scales for accumulating eruptible melt bodies of several hundred cubic kilometres volume versus constructing granitic batholiths. In order to obtain new perspectives on how the Hong Kong granitic plutons grew, the research in this thesis employs in-situ Secondary Ion Mass Spectrometry (SIMS) analytical techniques for zircon U-Pb age and trace element determinations (Chapter 4). The SIMS techniques have the advantage of high spatial resolution such that specific domains in individual zircon grains can be targeted and dated. I use the Hong Kong examples to compare and contrast with the data from extensively studied batholiths in North America (e.g. Coleman et al., 2004; Glazner et al., 2004; Wenner and Coleman, 2004; Walker et al., 2007; Claiborne et al., 2006, 2010; Davis et al., 2012; Barth et al., 2012). In addition, the SIMS age determinations are compared against the findings from published ID-TIMS age data, and the comparative merits and limitations of both U-Pb geochronological techniques considered for late Mesozoic systems, such as the ones in Hong Kong. 
(D) Whether the two Early Cretaceous magmatic systems show inheritance from the older Middle and Late Jurassic systems? How did the magmatic systems evolve through time?

Published studies on large granitic batholiths imply that many such magmatic systems are likely to have recycled melt and crystals from previous magmatic episodes (e.g. Coleman et al., 2004; Miller et al., 2007; Lackey et al., 2012). It is uncertain whether the late Mesozoic magmatism in Hong Kong involved formation of new crust through fractionation from mantle-derived magmas or simply the recycling of pre-existing crust. The research will address the question of whether there is evidence from both zircon $\mathrm{U}-\mathrm{Pb}$ age determination and trace element patterns of inheritance in successive magmatic episodes and if so, whether any genetic links can be discerned among the temporally separated systems. If such inheritance can be identified, this could imply that the younger magmatic systems simply recycled materials from previous magmatic episodes such that formation of new crust was minimal. Some previous studies on large granitic batholiths inferred that many large magmatic systems probably involved solely recycling or modification of existing crust with limited addition of new materials (e.g. Coleman et al., 2004; Miller et al., 2007; Lackey et al., 2012). In addition, this study uses the zircon trace element patterns of the volcanic and intrusive rocks to track the evolution of the magmatic system(s) for over the 24 Myr of activity in Hong Kong. Similar approaches have been undertaken, for example, by Barth et al. (2013) who studied the development of the magmatic arc in California from Triassic to Jurassic time.

\section{(E) What are the post-eruptive thermal, tectonic and exhumation histories of the volcanic-plutonic assemblages in Hong Kong?}

The Hong Kong magmatic systems seem to have ceased activity at 140 Ma (Davis et al., 1997; Sewell et al., 2000, 2012a, 2012b). The end of magmatism was considered by those authors to be coincident with the conclusion of the 'early' Yanshanian event in this part of southeast China. Other workers have generally agreed that in the Early Cretaceous ( 140 Ma) a change in geodynamics of the palaeo-Pacific Plate subduction caused a shift in the locus of magmatism along the SCMB (e.g. Charvet et al., 1994; Zhou and Li, 2000; Zhou et al., 2006; Li and Li, 2007; Chan et al., 2010; Wang et al., 2011). However, a comprehensive thermal, tectonic and magmatic history of Hong Kong and this part of southeast China since the Early Cretaceous has not been clearly resolved. This research 
specifically addresses in Chapter 5 the details of the tectono-thermal history of Hong Kong, in particular to unravel any evidence of thermal and / or tectonic activities during the magmatic arc decline or collapse. Using low-temperature thermochronological analyses, additional insights of when and how the granites were exhumed from depth in the crust can be obtained.

\section{(F) What new perspectives from the magmatic systems in Hong Kong can be offered to understand the evolution of the Yanshanian Orogeny in southeast China?}

Some twenty, possibly more, volcanic-plutonic complexes have been reported within the SCMB (Yin et al., 1991; Wang and Ren, 1996; Wang and Zhou, 2002), although most of these are yet to be investigated in any detail. A review of the characteristics of these complexes from the published literature is undertaken in this research (Chapter 2). From this, I use the Hong Kong systems as a case study to illustrate the geological features of these volcanic-plutonic complexes and the magmatic evolution within the regional SCMB (Chapter 6). In addition, my findings regarding the Hong Kong magmatic systems are compared and contrasted with the identified regional trends of the spatial and temporal evolution of Yanshanian magmatism (e.g. Guo et al., 2012; Li et al., 2014). The results of this research yield a broader view such that the magmatic province in southeast China can be compared and contrasted with the other better known, late Mesozoic systems of comparable scale around the Pacific basins including, for instance, the Sierra Nevada batholiths (Chapter 6).

The thesis consists of seven chapters which will address these questions.

Chapter 1 establishes the context of this thesis by introducing relevant concepts on the development of large silicic igneous provinces in relation to the growth of continental crust, silicic magmatic systems, and current knowledge on volcanic-plutonic connections. The research objectives and questions are then defined.

Chapter 2 incorporates an overview of the geological background of southeast China, considering the nature of the Yanshanian Orogeny and its role in the South China Magmatic Belt, then focusing on the late Mesozoic volcanic-plutonic assemblages in Hong Kong. This chapter lays the foundation for the studies discussed in the subsequent chapters. 
Chapter 3 presents the results of field studies carried out for this thesis with an objective to establish or test specific field relationships and characteristics of the volcanic sequences and granitic units within the High Island caldera complex. The field-based spatial and temporal connections between the volcanic and granitic units and the evidence for largescale tilting of the caldera complexes set out in the previous studies (particularly Sewell et al., 2012a) are critically re-evaluated.

Chapter 4 presents the results of investigation of the Early Cretaceous caldera complexes in Hong Kong using U-Pb age determinations and in-situ trace element analyses from zircons. These data are used to constrain the evolution of the magmatic systems, to identify inheritance characteristics of the volcanic-plutonic assemblages, and to compare and contrast the magmatic processes recorded in volcanic rocks and sub-volcanic plutons. The research offers case-study insights into the volcanic-plutonic connections of large silicic magmatic systems.

Chapter 5 presents a study of the thermo-tectonic history of Hong Kong since the midCretaceous by applying fission-track thermochronology methods. This chapter has been published as Tang et al. (2014), and the only changes made have been to reformat the published manuscript into a uniform style for incorporation into the thesis.

Chapter 6 comprises a reconsideration of the magmatic systems in Hong Kong, in particular the High Island caldera system, and presents the new perspectives drawn from the findings of this research. The chapter also compares and contrasts the volcanic and plutonic records of Hong Kong with large silicic magmatic systems in other parts of the world.

Chapter 7 summarises the key findings of this research and discusses their implications towards answering the research questions. In conclusion, further research opportunities identified on the basis of this research are presented.

\subsection{Silicic magmatic systems}

\subsubsection{Crystal mush model}

The connections between large scale, caldera-related volcanism and sub-volcanic granitic batholiths have been recognised and investigated for many decades, especially in the Mesozoic to Cenozoic calderas and their sub-volcanic composite plutons in the western 
Cordillera of North America (Lipman, 1984, 2007; Schermer and Busby, 1994; du Bray and Pallister, 1999; Coleman et al., 2004; Glazner et al., 2004; Bryan et al., 2008; FoheyBreting et al., 2010; Hildebrand et al., 2010; Barth et al., 2011, 2012; Tappa et al., 2011; Zimmerer and McIntosh, 2012; Davis et al., 2012; Mills and Coleman, 2013; Nelson et al., 2013; Frazer et al., 2014). More recently, new perspectives on the linkages of voluminous silicic ignimbrites and their sub-volcanic granitic plutons have been proposed through the development of the crystal mush model (Fig. 1.2; Bachmann and Bergantz, 2004; Hildreth, 2004; Hildreth and Wilson, 2007). In this model, silicic magmatic systems are inferred to be dominated by a crystal mush that contains $\geq 50 \%$ crystals and is thus rheologically locked (Brophy, 1991; Bachmann and Bergantz, 2004; Huber et al., 2011). When the crystal content of the magma is $<45 \%$, the crystals are suspended in the melt, allowing convection, mixing and stirring of the magma. Once the crystallinity reaches a threshold of $\sim 45-50 \%$, wholesale melt convection is hindered owing to the rheological locking of the crystal mush, but the permeability remains sufficiently high for melt extraction from the rigidified crystal framework by crystal compaction and settling. Further increases in the crystal content gradually reduce the permeability of the mush and eventually stop the meltcrystal separation processes.

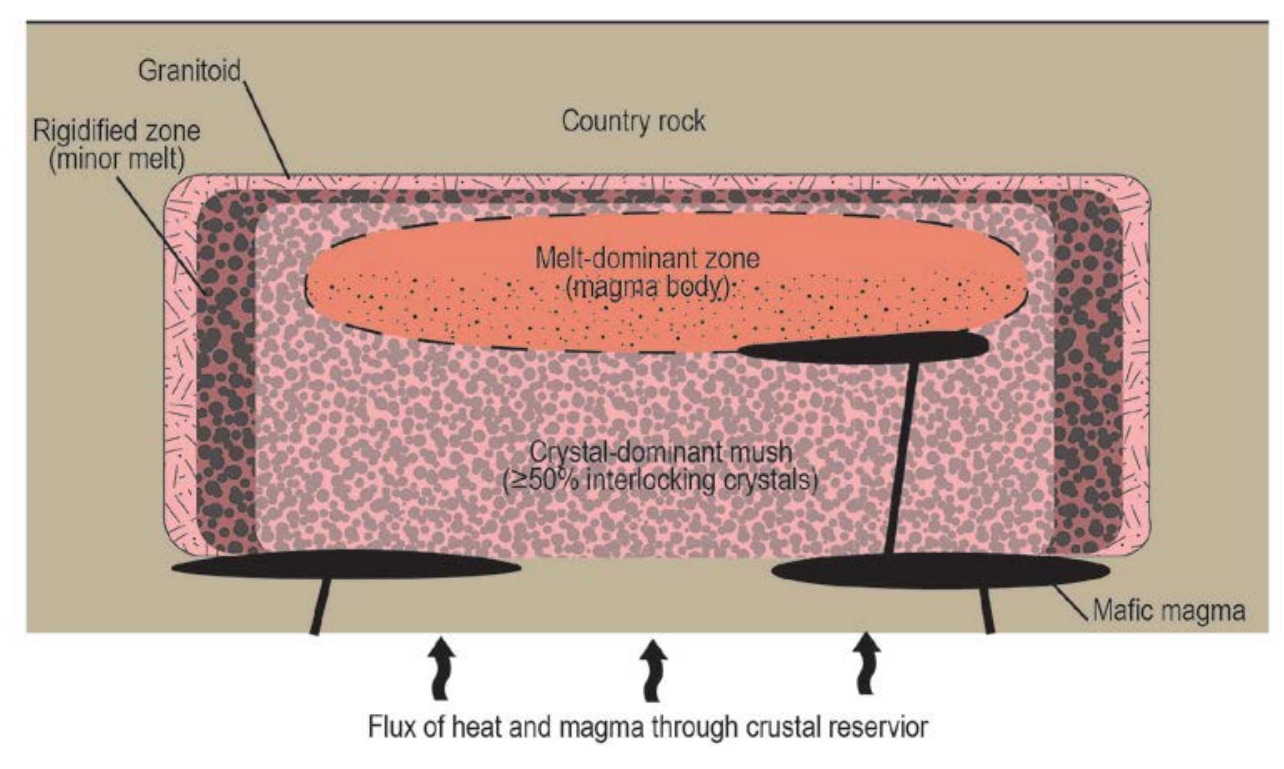

Fig. 1.2. Schematic illustration of the crystal-mush magma chamber model (modified after Hildreth and Wilson, 2007). The magma chamber comprises a melt-dominant zone (magma) of variable crystal content up to $\sim 50 \%$, a crystal mush with $\geq 50 \%$ interlocking crystals, enclosed by a rigidified zone with progressively higher crystal content and less melt, with a final gradation to completely crystallised granitoid. Black areas represent dykes and sills of mafic (less-evolved) magmas that penetrate into the upper crust, allowing partial melting, hybridisation of magmas and providing heat for sustaining the system. 
The crustal magmatic system is generally inferred to be thermally sustained by mafic (lessevolved) magmas from deeper crustal levels penetrating into the mush and its roots (Hildreth, 1981), allowing partial melting and hybridisation of magmas of contrasting compositions (Fig. 1.2; see also Hildreth and Moorbath, 1988; Annen et al., 2006). The crystal mush model has been proposed to explain the generation mechanism of large volumes of rhyolitic melt from intermediate magmas and account for the compositional gaps observed in silicic magmatic systems (Brophy, 1991; Bachmann and Bergantz, 2004; Hildreth, 2004).

\subsubsection{Volcanic-plutonic connections}

Two end member groups, of crystal-rich (often intermediate in composition) and crystalpoor (generally rhyolitic) ignimbrites, are considered to represent eruptions of thermally or tectonically disturbed crystal mush (e.g. Fish Canyon Tuff, San Juan Volcanic Field, USA: Hildreth, 1981; Bachmann et al., 2002), or of rhyolitic melts extracted from the mush (e.g. Oruanui, Taupo Volcanic Zone, New Zealand, Wilson et al., 2006; Allan et al., 2013), respectively. The crystal mush model implies that sub-volcanic granitic plutons represent in part either the completely crystallised non-erupted crystal mush, or the remnant of the crystal dominated part of a silicic system after the withdrawal of rhyolitic melt (e.g. Smith, 1979; Hildreth, 1981; Shaw, 1985; Bachmann and Bergantz, 2004). In both cases, the volcanic products and sub-volcanic plutons are considered to be related, connected temporally and spatially, and to share a common, complementary magmatic origin (Bachmann and Bergantz, 2004; Hildreth, 2004; Hildreth and Wilson, 2007). Then again, it has been suggested that some large eruptions have left relatively little plutonic record, whereas some plutonic systems may have never erupted (Smith, 1979; Shaw, 1985).

Contrasting perspectives on the relationships between large-scale silicic ignimbrites and granitic batholiths have been raised by Coleman et al. (2004) and Glazner et al. (2004), who studied Mesozoic granitic suites of the Sierra Nevada batholith. They used geochronological data and thermal modeling to infer that granitic batholiths were emplaced incrementally over an extended time period of $>10^{7}$ years, and therefore only small volumes of granitic melts were present at any one point of time. The timescale of emplacement of granitic plutons depends, of course, on how a single pluton/emplacement event is defined. They therefore argued that voluminous magma chambers, that would be required to support super-sized eruptions, were not linked to the development of granitic 
batholiths. They argued that large scale ignimbrites are essentially supported by transient magma chambers that are assembled very rapidly in shallow crustal levels during a period of intense heat influx (Fig. 1.3; Glazner et al., 2004). In this respect, their model indicates that the magmatic processes of generating voluminous eruptible melts for large rhyolites are fundamentally different for the construction of large granitic batholiths which are developed over a protracted period of time (of several million years) in somewhat normal thermal input (Glazner et al., 2004; Annen, 2009a, 2009b). If their views that large silicic volcanic systems are not supported by or linked to large granitic plutons are valid, questions still remain as to what are the volcanic plumbing systems of the voluminous rhyolite eruptives. Their model does not address, for example, the implications of the geochemical signatures of high-silica rhyolites (such as the Bishop Tuff and the Huckleberry Ridge Tuff), both of which have high Rb/Sr ratios and extremely negative Euanomalies. Both of these signatures imply complementary generation of substantial amounts of felsic crystalline material that must form some kind of plutonic product.

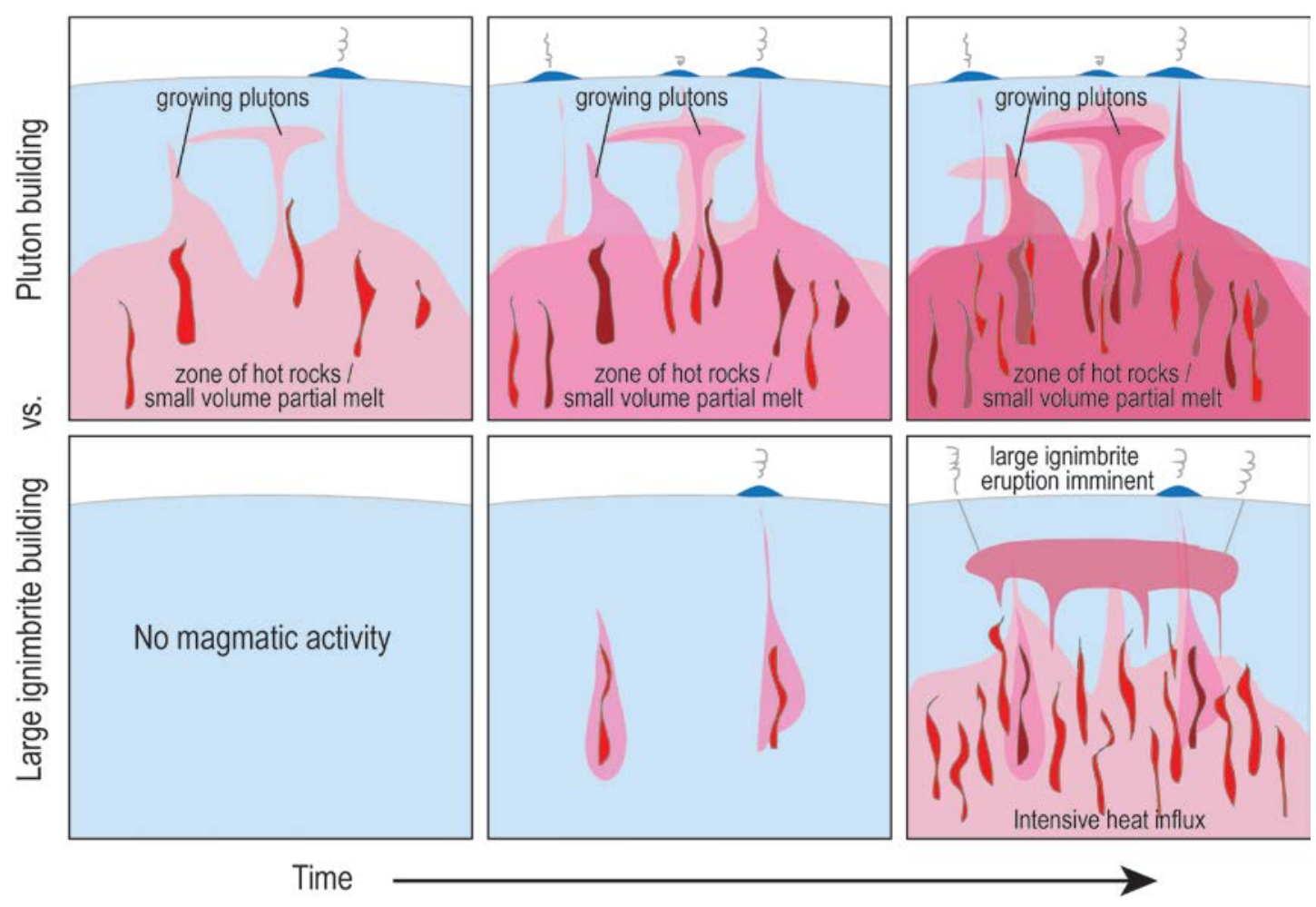

Fig. 1.3. Evolutionary model of magmatic systems and the connections between construction of granitic plutons and large ignimbrite eruptions proposed by Glazner et al. (2004). In this model, the magmatic processes involved in building plutons and magma chambers for large ignimbrite eruptions are considered to be essentially different. Granitic plutons are considered to be incrementally emplaced over $10^{6}$ to $10^{7}$ years by addition of small volume of melts, and are linked to continual small-scale volcanism on the surface (upper panels); whereas magma chambers of voluminous eruptible melts for ignimbrite eruptions only form during a period of intense heat flux, and therefore develop rapidly but are transient (lower panels). 
These contrasting ideas of how silicic magmatic systems evolve and produce different eruptive and intrusive rocks are the subject of on-going debate (e.g. Bachmann et al., 2007; Lipman, 2007; Miller, 2008; Annen, 2009a, 2009b; Fohey-Breting et al., 2010; Barth et al., 2012; Lipman and Bachmann, 2015). Many of these studies, however, have focused only on either the volcanic or the plutonic records separately. The research presented in this thesis, which examines both the volcanic and plutonic rocks exposed in Hong Kong, provides some new perspectives on the characteristics of large scale silicic magmatic systems, and in particular, how or whether the volcanic rocks and sub-volcanic granitic plutons are genetically related.

\subsubsection{Framework of this study with respect to younger silicic magmatic systems}

In recent years, there have been considerable advances in our understanding of how large silicic magmatic systems operate through detailed studies of Quaternary examples (e.g. Taupo Volcanic Zone, New Zealand, Wilson et al., 2006; Shane et al., 2008a, b; Allan et al., 2012, 2013; Long Valley caldera, USA, Hildreth, 2004; Hildreth and Wilson, 2007; Chamberlain et al., 2014a, b, 2015; Valles Caldera, USA, Wilcock et al., 2013, Goff et al., 2014; Wolff and Ramos, 2014; Yellowstone caldera, USA, Hildreth et al., 1991; Girard and Stix, 2009; Watts et al., 2012). In most contemporary silicic magmatic systems (i.e. those of Quaternary age for the purposes of this thesis), detailed records of volcanic eruptions are preserved in the stratigraphic record, which have been demonstrated to be critical for constraining the dynamics of the magmatic systems. For instance, meticulous field observations combined with careful crystal specific studies were carried out at Taupo volcano to investigate the magmatic processes that operate on time-scales of months to $10^{5}$ years (Wilson, 1993, 2001; Sutton et al., 2000; Charlier et al., 2005, 2008, 2010; Wilson et al., 2006; Wilson and Charlier, 2009; Allan et al., 2012, 2013; Barker et al., 2014, 2015). Individual eruptions separated by intervals of a decade or so up to thousands of years could be distinguished from stratigraphic and geochronological evidence. These studies demonstrated that the generation of large volumes of eruptible melt from a crystal mush and recovery of a magmatic system, even after a supersized eruption, could occur more rapidly than previously envisaged in other examples or theoretical models. However, while such comprehensive eruption records are preserved in these young systems, their magmatic roots are not normally exposed for direct examination. Indirect methods, such as geophysical techniques are generally employed to investigate the characteristics of their 
magmatic sources (e.g. Yellowstone, USA, Husen et al., 2004, Farrell et al., 2014; Toba, Indonesia, Koulakov et al., 2009; Taupo Volcanic Zone, New Zealand, Ellis et al., 2007; Heise et al., 2010).

The exposures of silicic volcanic-plutonic assemblages in Hong Kong, therefore, offer an exceptional opportunity to investigate the magmatic records from both of the contrasting products of large silicic magmatic systems and to gain better insights into the nature of volcanic-plutonic connections. However, given that the volcanic systems are late Mesozoic in age, most of the detailed volcanic records have either been removed by erosion and/or obliterated by post-eruption alteration or deformation. Therefore, the level of detail regarding magmatic system dynamics permitted in this study will be less in comparison to those on the younger systems. The age resolution of individual volcanic and intrusive units in Hong Kong, and inferences about their temporal connections are also limited by the precision of the age data. Modern analogues, such as the Taupo Volcanic Zone and Long Valley, show rapid turnover times, on the order of less than $10^{4}$ to $10^{5}$ years. This timeframe implies that even with the resolution of ID-TIMS ages $( \pm 0.2-0.3 \mathrm{Myr}$ for published ages from volcanic and plutonic rocks in Hong Kong: Davis et al., 1997; Campbell et al., 2007; Sewell et al., 2012b), detailed linkages of individual eruptions with specific plutons and/or magmatic systems of Mesozoic age may only be able to be made in general terms. The research in this thesis will, however, provide invaluable information on the longer-term evolution of silicic magmatism in a broader sense over timescales of $10^{6}$ to $10^{7}$ years by detailed analysis of key volcanic and plutonic units, and help answer questions on aspects related to, for example, the lifespan and the demise of volcanism in a long-lived arc system.

\subsection{Techniques used in this research}

\subsubsection{Field studies and relationships}

Field evidence is of paramount importance in establishing the spatial and temporal relationships of individual volcanic units and exposed granitic plutons. Basic field mapping of the entire territory of Hong Kong at 1:20,000-scale was completed by the mid-1990s (Geotechnical Control Office [GCO], 1986a, 1986b, 1987, 1988a, 1988b, 1989a, 1989b, 1989c, 1989d, 1991; Geotechnical Engineering Office [GEO], 1991, 1992, 1994, 1995, 1996), although a thorough investigation of specific volcanic features in the context of eruption styles is still missing. The objectives of the geological fieldwork undertaken for 
this thesis research were thus fourfold.

(1) To gather field evidence of eruption styles in the volcanic units, and to verify their stratigraphic contacts and spatial relationships.

(2) To evaluate the spatial and temporal connections between volcanic units, granitic plutons, and dykes.

(3) To investigate the textural characteristics of intrusive rocks, which can provide critical information on emplacement mechanisms and other processes operated in the magmatic systems.

(4) To investigate the caldera bounding structures and ring intrusions identified by earlier studies (Langford et al., 1995; Campbell and Sewell, 1997; Sewell et al., 2012a), with the aim of better constraining the characteristics, geometries and dimensions of the caldera complexes.

\subsection{2. $\mathrm{U}-\mathrm{Pb}$ zircon age determination}

The geochronological framework of volcanic-plutonic assemblages in Hong Kong has previously been established using high-precision ID-TIMS techniques coupled with application of mechanical or chemical abrasion to zircon grains (Fig. 1.4; Davis et al., 1997; Campbell et al., 2007; Sewell et al., 2012b). The ID-TIMS technique commonly yields U$\mathrm{Pb}$ zircon ages with high analytical precision (normally $<0.2 \%$; Davis et al., 2003; Parrish and Noble, 2003), but intra-grain (core-rim) age relationships cannot be resolved using this technique and often multiple grains have to be analysed. The research in this thesis employs SIMS techniques using Sensitive High Resolution Ion Microprobe - Reverse Geometry (SHRIMP-RG) instruments to carry out in-situ zircon U-Pb age determinations (Fig. 1.4). The advantage of SIMS methods is that the age data obtained can be linked to various growth zones in individual grains, as revealed by cathodoluminescence (CL) imagery (e.g. Goetze et al., 1999; Nasdala et al., 2003). The trade-off in employing the SIMS techniques is the lower precision of individual age data points (typically $>2 \%$; Ireland and Williams, 2003; Schmitt, 2011; Schoene et al., 2013). In this study, longer count times were used to obtain better precision than is normal for the age determinations. In addition, by employing statistical treatments on a large quantity of spatially-constrained analyses, an improved precision level approaching that of the ID-TIMS ages is possible for 
the SIMS age suites. Recent studies using SIMS methods in much younger Quaternary magmatic systems have been successful in reaching agreement with ID-TIMS ages with a precision of a factor of only two times the uncertainty of the latter technique (e.g. Crowley et al., 2007; Chamberlain et al., 2014b).

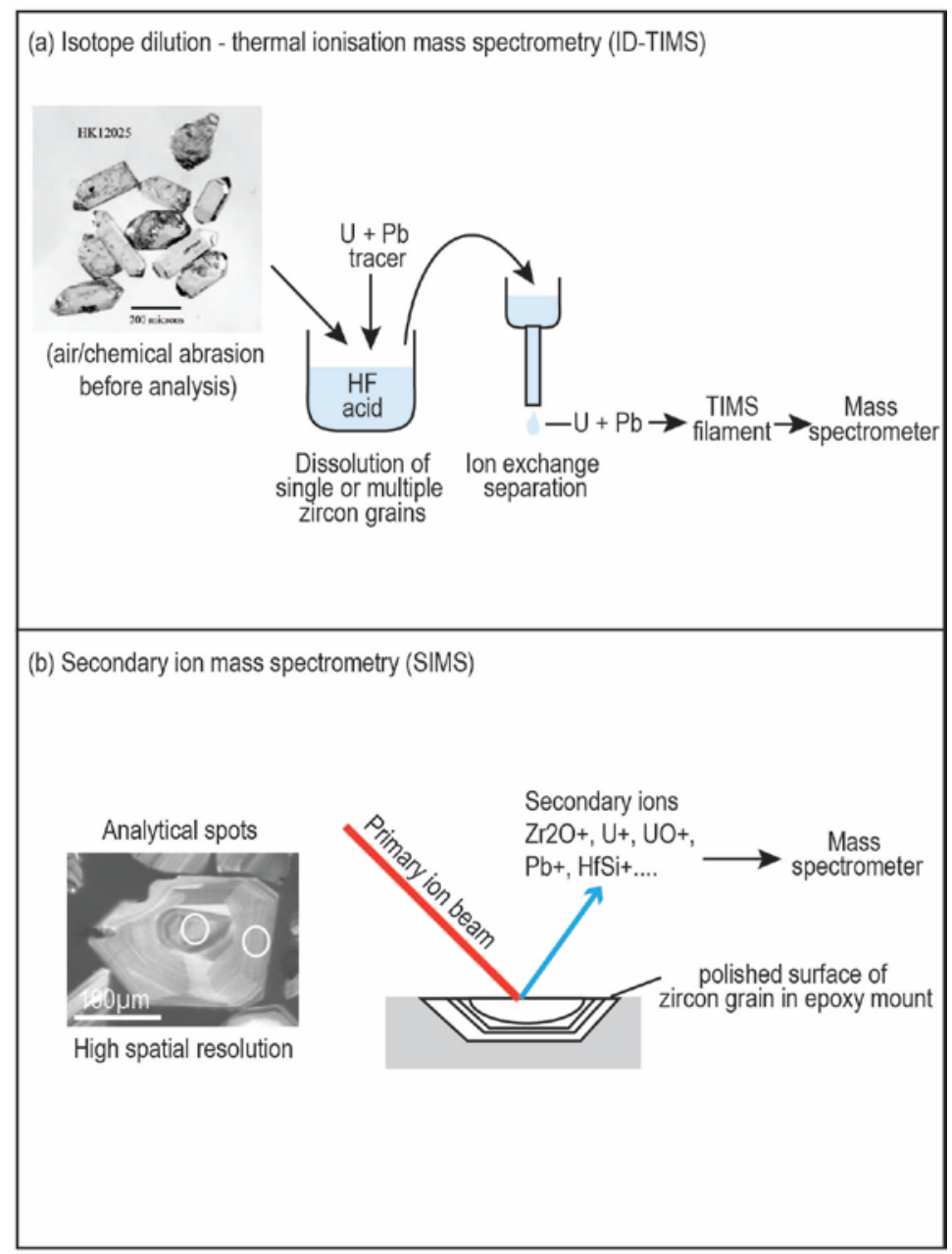

Fig. 1.4. Illustration of different techniques in ID-TIMS and SIMS age determination methods. (a) The IDTIMS technique involves complete dissolution of single or multiple zircon grains in acid for analysis. The age data have better analytical precision but the technique requires sophisticated sample preparation procedures and relatively extended analytical times (Schoene et al., 2013; Schaltegger et al. 2015). (b) The SIMS techniques provide high spatial resolution of age data and involve relatively straightforward sample preparation processes. However, the precision of single SIMS age determinations is poorer than those obtained using ID-TIMS techniques.

The objectives of the zircon $\mathrm{U}-\mathrm{Pb}$ age analyses undertaken for this thesis are: 1) to constrain the temporal evolution of the late Mesozoic magmatic systems in Hong Kong; and 2) to understand the inheritance characteristics or recycling of zircons among volcanic and granitic units of successive magmatic episode. The SIMS age data are combined with petrographic observations (cores versus rims; high U versus low U growth zones) to 
distinguish any intra-grain age variations (Ireland and Williams, 2003; White and Ireland, 2013). By comparing the SIMS spectra ages with the previous ID-TIMS ages, it can be assessed whether, within the limits of analytical precision, the higher precision ID-TIMS ages are accurate representations of eruption/emplacement ages of the units or if there is evidence for inheritance, in which case the ID-TIMS ages may be highly precise but are inaccurate.

\subsubsection{In-situ analysis of trace elements in zircons}

Trace element concentrations and their ratios in zircons vary systematically with fractionation of the melt in the magma body in which they crystallise (Hoskin and Schaltegger, 2003; Wooden et al., 2006; Claiborne et al., 2006, 2010; Barth and Wooden, 2010; Reid et al., 2011). The correlations between geochemical signatures in zircons and melt evolution have been used to constrain the magmatic environments of either granitic or volcanic systems (e.g. Claiborne et al., 2006, 2010; Barth and Wooden, 2010; Fohey-

Breting et al., 2010; Gagnevin et al., 2010; Colombini et al., 2011; Reid et al., 2011; Barker et al., 2014; Chamberlain et al., 2014b; Cooper et al., 2014). For the research in this thesis, in-situ analysis of trace elements in zircons has also been carried out by SIMS techniques to offer a new perspective for assessing the genetic connections of the paired volcanicplutonic assemblages in Hong Kong, and for unravelling the crystallisation/fractionation paths within the volcanic and plutonic units. The analytical spots were located with the aid of CL imagery such that the ranges of textural variations and CL intensities observed in the zircon populations from individual samples were covered. In addition, by targeting trace element analyses in the dated growth zones, the geochemical signatures could be identified and coupled with age data for interpretation of the chemical evolution of the magmatic systems. The analyses also targeted specific growth zones, including cores and rims, zircon tips versus sides, and sector-zoned pairs within single growth zones to identify any intragrain variations in trace element abundances. Such information then allows for assessment of whether and how intra-grain variations could influence trace-element interpretations of the dynamics of the magmatic systems.

\subsubsection{Fission-track thermochronology}

Fission-track (FT) thermochronology provides a means to determine the time-temperature histories of rock bodies (Fig. 1.5). The technique is commonly used to establish the lowtemperature (generally $\leq 250{ }^{\circ} \mathrm{C}$ ) thermal history of rocks, particularly related to the 
exhumation of the upper crust caused by tectonic and/or surface processes (Ehlers, 2005; Tagami and O’Sullivan, 2005; Reiners and Brandon, 2006). The thermo-tectonic evolution after the major magmatic episodes in Hong Kong, was explored using zircon and apatite fission-track analysis (ZFT and AFT, respectively).

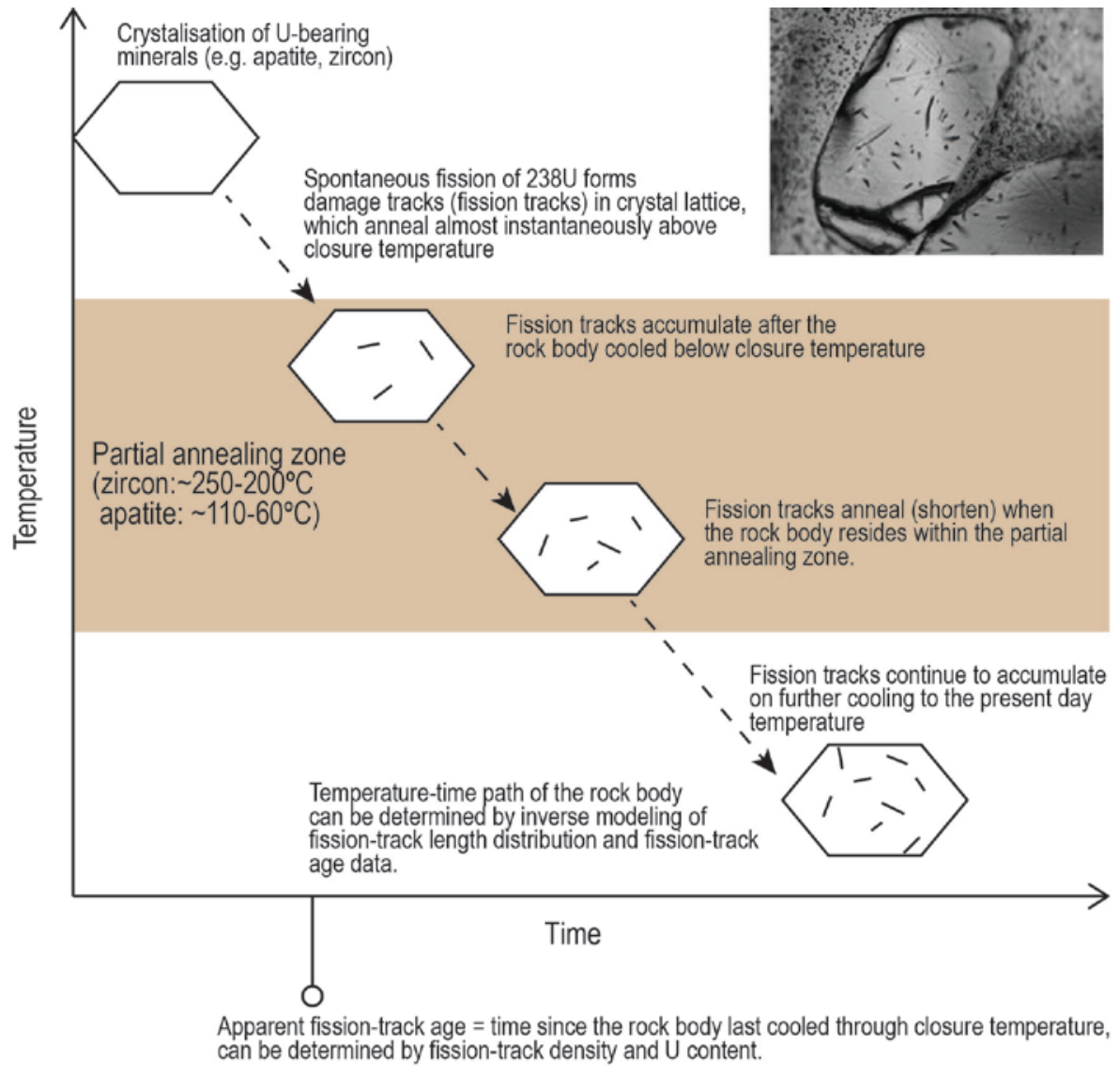

Fig. 1.5. Illustration of the principle of fission-track thermochronology techniques. A detailed review of the principle and techniques is given in Appendix 2.

The late Mesozoic Yanshanian magmatism was considered to have lasted until sometime around $~ 80$ Ma in the northern part of the SCMB (Zhou and Li, 2000; Zhou et al., 2006). The timing of the magmatic shut-down in the southern part of the magmatic arc, including Hong Kong and surrounding areas, however, remains somewhat uncertain. A conventional interpretation is that Yanshanian magmatism ceased in the southern part of the SCMB after $\sim 140 \mathrm{Ma}$, and that subsequently the magmatic front shifted to the north and northeast along the magmatic province (e.g. Zhou et al. 2006; Sewell et al. 2012a; Z. Li et al., 2013). However, by combining the FT age data with established aspects of the geological history, the regional post-magmatic thermal events are interpreted in this thesis in terms of larger- 
scale tectonics (cf. Ehlers, 2005; Tagami and O’Sullivan, 2005) and an alternative interpretation put forward (Tang et al., 2014: Chapter 5).

In addition, a novel topic of this study is to constraint the depositional and thermal history of the Cretaceous post-volcanic sediments in Hong Kong. These sediments formed within small continental basins lying directly on top of the outcropping igneous sequences. The depositional ages of these sediments have never been well constrained as fossils or other age indicators, such as interbedded volcanic ashes, are absent. U-Pb dating of detrital zircons from these sequences using LA-ICP-MS methods (collaborative work with University of Melbourne) has been carried out to identify potential sources of the sediments and also to constrain maximum depositional ages. Detrital ZFT analysis has then been employed on the same crystals to reveal their post-depositional thermal records (Armstrong, 2005; Bernet and Garver, 2005). By comparing and contrasting the thermal histories of the igneous rocks with those of the sediments, the thermo-tectonic history can be established and constrained within the local geological framework.

The specific objectives of the fission-track thermochronological study were therefore to determine the post-magmatic thermal histories by 1) constraining temporally the burial and exhumation of the Mesozoic volcanic complexes in Hong Kong; 2) assessing whether and when there was significant sedimentation across the region after magmatism had ended and 3) identifying the timing of regional inversion, rock uplift and exhumation. 
Chapter 2 / Overview of

Geological Background to

Hong Kong and the

Yanshanian Magmatism 


\subsection{Introduction}

Hong Kong is located at the southern edge of the Southeast China Magmatic Belt (SCMB). The geology of Hong Kong has been well-defined by basic field mapping (Addison, 1986; Strange and Shaw, 1986; Langford et al., 1989, 1995; Strange et al., 1990; Lai et al., 1996; GCO, 1986a, 1986b, 1987, 1988a, 1988b, 1989a, 1989b, 1989c, 1989d, 1991; GEO, 1991, 1992, 1994, 1995, 1996), combined with extensive geochemical (Sewell et al., 1992; Darbyshire and Sewell, 1997; Sewell and Campbell, 1997, 2001) and geochronological data (Davis et al., 1997; Campbell et al., 2007; Sewell et al., 2012b). The broadly coeval late Mesozoic volcanic-plutonic assemblages in Hong Kong provide a microcosm of the large-scale silicic magmatic systems that form the SCMB in southeast China. A brief summary of the geological setting of the SCMB is given here to provide a regional context for the magmatic systems in Hong Kong which are the focus of this thesis. Additionally an overview of Hong Kong geology and more specific details of the late Mesozoic magmatic assemblages are given in this chapter. Further, detailed descriptions of two caldera complexes, i.e. the Lantau caldera complex and the High Island caldera complex, which are relevant to this thesis, are then presented here.

\subsection{Geological setting of southeast China}

\subsubsection{Basement structures}

The South China Block (SCB) forms the basement of south China and consists of two crustal terranes: the Yangtze Block in the north and the Cathaysia Block in the south (Fig. 2.1), comprising basement rocks of Palaeoproterozoic to Mesoproterozoic, as well as Archean ages (Jahn et al., 1990; Wang and Mo, 1995; Li and McCulloch, 1996; Chen and Jahn, 1998; Li et al., 2011; Zheng et al., 2011). These crustal blocks amalgamated with other crustal terranes in Asia and Europe and collectively became part of the Eurasian landmass during Permian to Jurassic time (Metcalfe, 1996). Widespread late Mesozoic magmatic rocks developed on the eastern edge of the SCB, forming a broad magmatic province known as the Southeast China Magmatic Belt (SCMB). Two major NE-trending regional fault zones, namely the Changle-Nanao Fault Zone and the Lianhuashan Fault Zone, have been identified within the SCMB (Fig. 2.1; Gilder et al., 1995, 1996). These structures are essentially sub-parallel to the current coastline, and have been regarded as the surface expressions of deep-seated structures in the Cathaysia Block (Gilder et al., 
1995, 1996). Their offshore extensions are considered as a main controlling factor on the geometry of Cenozoic basins (Hayes et al., 1995).

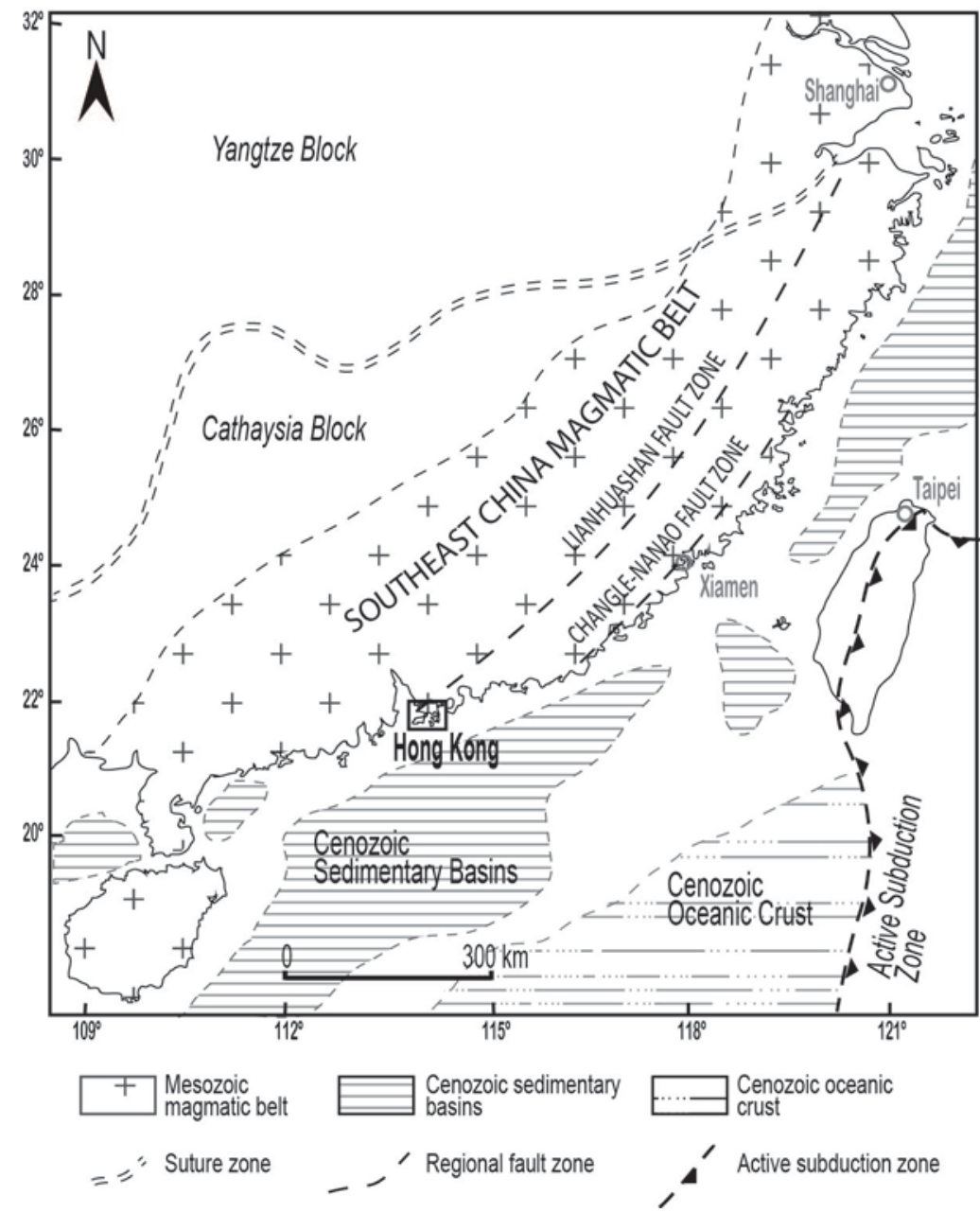

Fig. 2.1. Tectonic elements of southeast China at the present-day (modified after Sewell et al., 2000). The Southeast China Magmatic Belt (SCMB) is located on the seaboard of southeast China, which is a passive continental margin bordered by a series of marginal basins and Cenozoic oceanic basins. A complex subduction system now exists to the east, intersecting Taiwan, several hundred kilometres from the mainland.

\subsubsection{Southeast China Magmatic Belt}

The SCMB is an extensive, 1,300-km long by 400-km wide, NE-SW trending igneous belt located along the present seaboard of China ( $\mathrm{Li}$ and $\mathrm{Li}, 2007)$. It is characterised by widespread Mesozoic silicic igneous rocks, covering $>220,000 \mathrm{~km}^{2}$ (Fig. 2.2; Zhou et al., 2006; $\mathrm{Li}$ and $\mathrm{Li}$, 2007), and is comparable in scale to other silicic large igneous provinces around the world (Bryan et al., 2002; Bryan and Ferrari, 2013). Studies of the SCMB 
commenced in the 1920s; however, the evolution of the belt is still not well understood because of three issues. First, most studies were concerned with the petrogenesis of particular volcanic units or granitoids through petrological, whole-rock and isotopic geochemical and geochronological analyses (e.g. Pei and Hong, 1995; Wang and Ren, 1996; Lu et al., 1997; Tao et al., 1998; Wang and Zhou, 2002; Zhou et al., 2006). The specific focus of these studies was commonly to recognise the associated mineral resources, rather than to understand how the parental magmatic systems operated. Second, although regional mapping has provided a basic outline of the volcanic sequences in southeastern China (Yin et al., 1991), systematic investigations of physical volcanology are generally lacking. Only recently have some studies concentrated on examining the detailed characteristics of the calderas and volcanic complexes in the region (e.g. Wang and Zhou, 2002; Jiang et al., 2005; Yang et al., 2010, 2011). Third, most of these studies were published in the Chinese literature (e.g. Lu et al., 1997; Tao et al., 1998), making access difficult to researchers outside China. For this reason, comparison and contrast of the SCMB with other similar magmatic provinces around the world has been restricted.

The SCMB as defined represents the combined igneous products of two Mesozoic orogenies: the Triassic Indosinian ( 250-200 Ma) and Middle Jurassic to Cretaceous Yanshanian ( 180-80 Ma, Zhou et al., 2006; Li and Li, 2007). The Indosinian Orogeny commonly refers to the series of tectonic events that were related to the closing of eastern palaeo-Tethys Ocean and the collision and suturing of Asian crustal blocks (e.g. Metcalfe, 1994; Li et al. 2006; Cho et al., 2008; Zheng et al., 2013). In comparison, the Yanshanian “orogeny” is loosely defined as comprising the tectonic deformations that occurred anywhere in the landmass of China during Jurassic and Cretaceous time (e.g. Gilder et al., 1991, 1996; Li, 2000; Lim and Cho, 2012; Zheng et al., 2013). Specifically, the Yanshanian event as expressed in the SCMB is generally dominated by the development of an extensive magmatic arc that generated most ( $90 \%$ by area of exposure) of the igneous province of the SCMB (e.g. Yin et al., 1991; Charvet et al., 1994; G. Chen et al., 2003; Zhou et al., 2006; C.H. Chen et al., 2008; He et al., 2009). Yin et al. (1991) proposed that the Yanshanian volcanic sequences could be subdivided into two parts. The lower sequence included high-K calc-alkaline, dacite to rhyolite rocks, dominated by welded and rheomorphic ignimbrites, with minor basaltic, tuffaceous and sedimentary units, whereas the upper sequence comprised volcanic rocks with bimodal, high-K basaltic-rhyolitic signatures, followed by dacitic to high-K, high-silica rhyolites. Based on early 
geochronological data (mostly Rb-Sr ages), the lower sequence was considered to have been erupted in the Middle to Late Jurassic, while the upper sequence was Early to midCretaceous in age (Yin et al., 1991). The model presented by Yin et al. (1991), which was later adopted by many Chinese researchers, including Zhou et al. (2006) and L. Liu et al. (2012), was evidently oversimplified for the extensive volcanic exposures in the SCMB without any reference to local details.

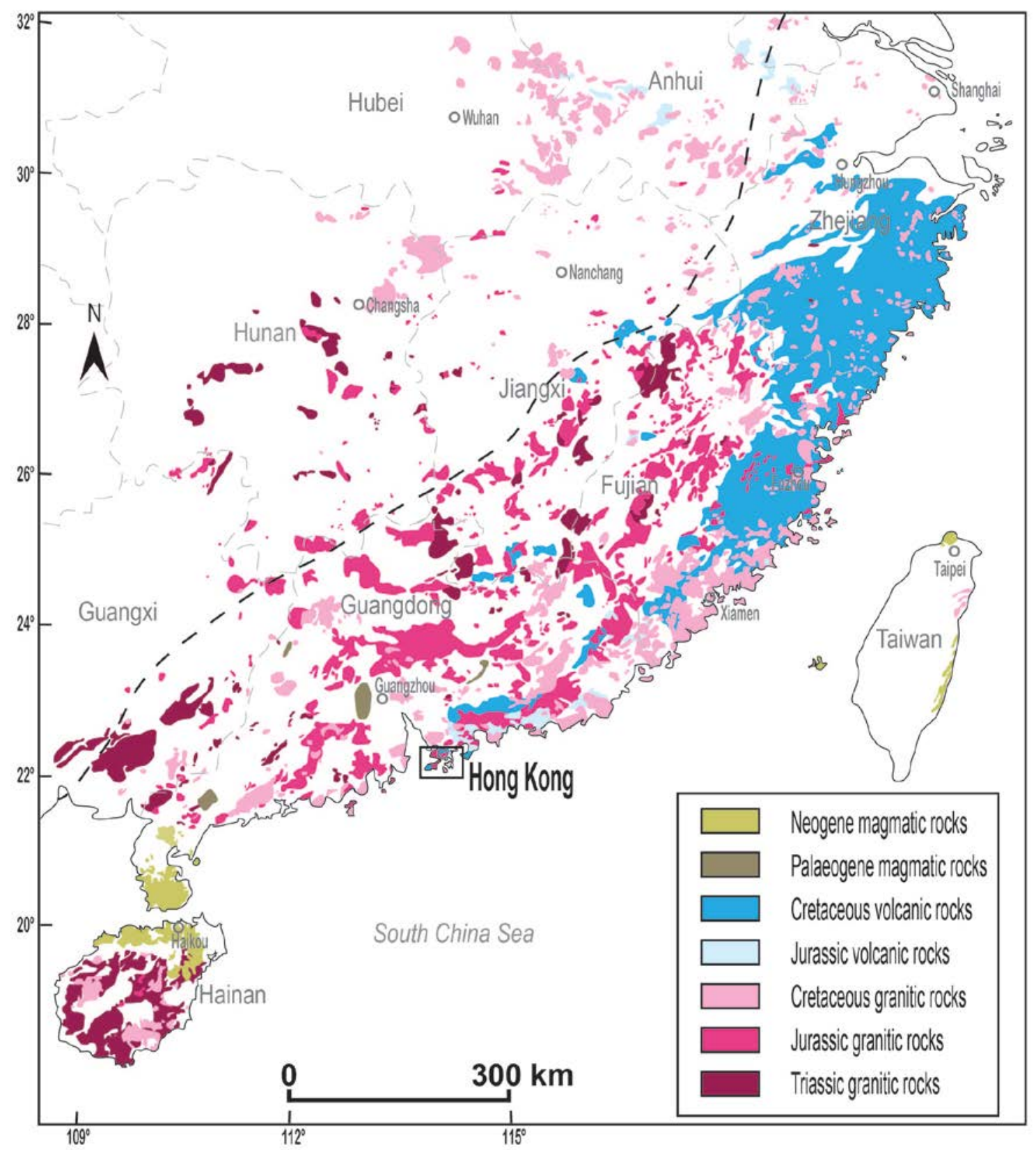

Fig. 2.2. Distribution of magmatic rocks in southeast China (modified after Zhou et al., 2006; Li and Li, 2007; L. Liu, et al., 2012). The Jurassic to Cretaceous volcanic and granitic rocks generated during the Yanshanian event comprise the major part of the Southeast China Magmatic Belt (SCMB). 
Lu et al. (1997) claimed that over 100 calderas, 50 volcanic domes and 17 large volcanotectonic complexes or “depressions” could be identified within the SCMB in Hainan, Guangdong, Jiangxi, Zhejiang and Fujian provinces. Detailed descriptions and records of these volcanic features were, however, not provided. Features of some reported calderas and volcano-tectonic complexes within the SCMB are presented in Table 2.1. These calderas and volcano-tectonic complexes were generally described as sub-circular to elliptical topographic structures, bounding late Mesozoic silicic to intermediate volcanic rocks that were found associated with coeval sub-volcanic intrusions of granites and porphyry dykes that share similar petrological characteristics and geochemical signatures (Wang and Ren, 1996; Lu et al., 1997; Wang and Zhou, 2002). The associated intrusive rocks include I-type granitoids emplaced mainly during the early part of the Yanshanian magmatism, gradually transiting to A-type granitoids that were generated in the later period of the event, that is, from the Lower Jurassic to mid-Cretaceous in total (e.g. Li et al., 2003a; Zhou et al., 2006; Wang et al., 2011; Li et al., 2014).

\subsubsection{Tectonic evolution of the South China Magmatic Belt}

Various tectonic models have been proposed to account for the origin of widespread Mesozoic magmatism in southeast China, although a consensus is still lacking. An active continental margin, associated with subduction of the palaeo-Pacific Plate beneath continental crust of the Eurasian Plate, is commonly considered as the origin for extensive silicic magmatism in southeast China during the late Mesozoic (e.g. Jahn, 1974; Charvet et al., 1994; Lapierre et al., 1997). Alternatively, a continental rifting model featuring lithospheric extension, caused by the collision between Indochina and SCB or crustal extension post-dating the Triassic Indosinian Orogeny, has been proposed (Gilder et al., 1991; Li, 2000). This alternative model has been accepted by some workers (e.g. Li et al., 2003a, 2004; Chen et al., 2008) as an explanation for the presence of A-type, rift-related granites and intraplate mafic rocks in the region. More recent studies, in contrast, have suggested that the geochemical signature of an extensional regime was related to the development of a back-arc environment adjoining the subduction zone (e.g. Qiu et al., 2004; Jiang et al., 2005, 2009; Zhou et al., 2006). 


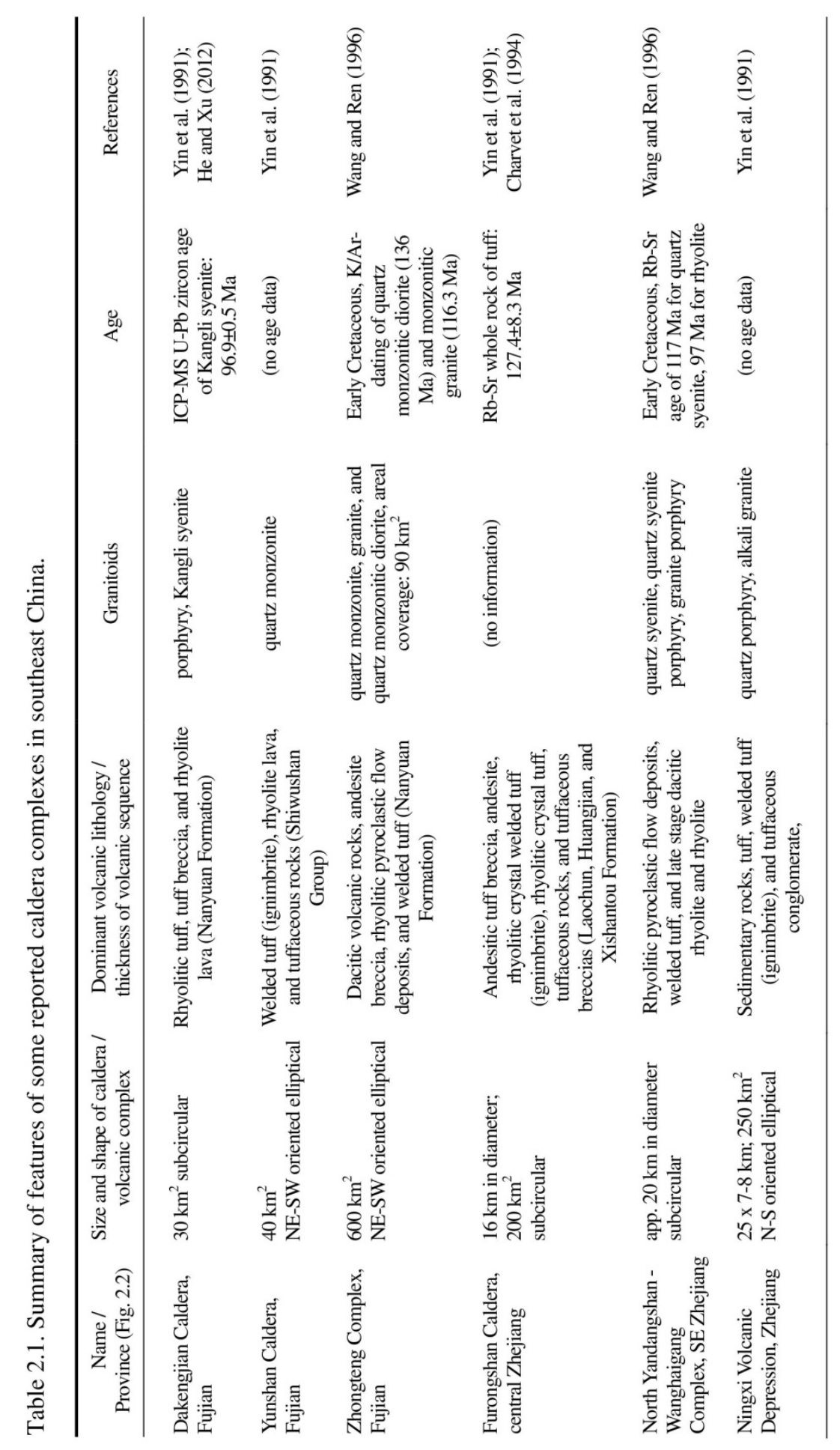




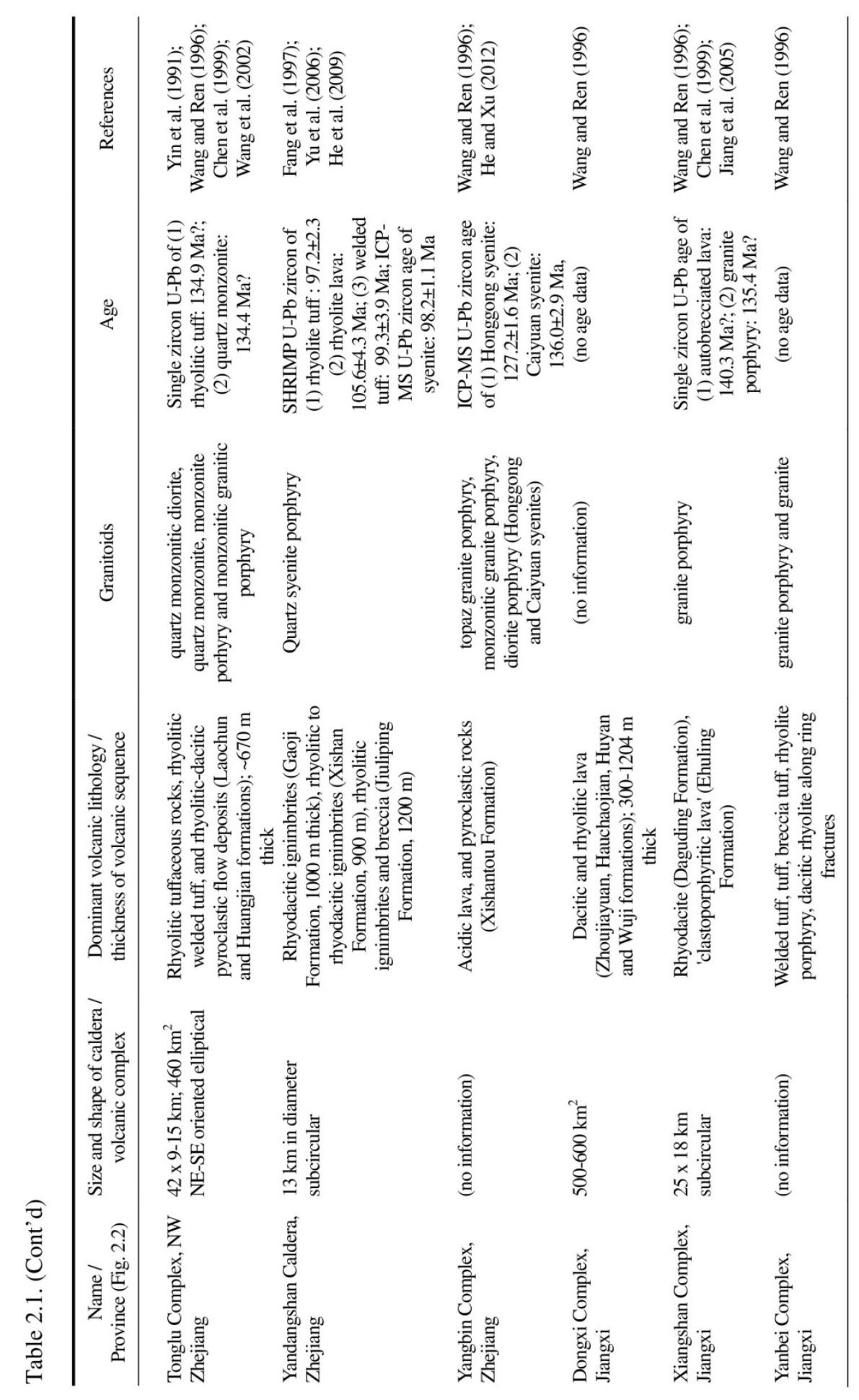




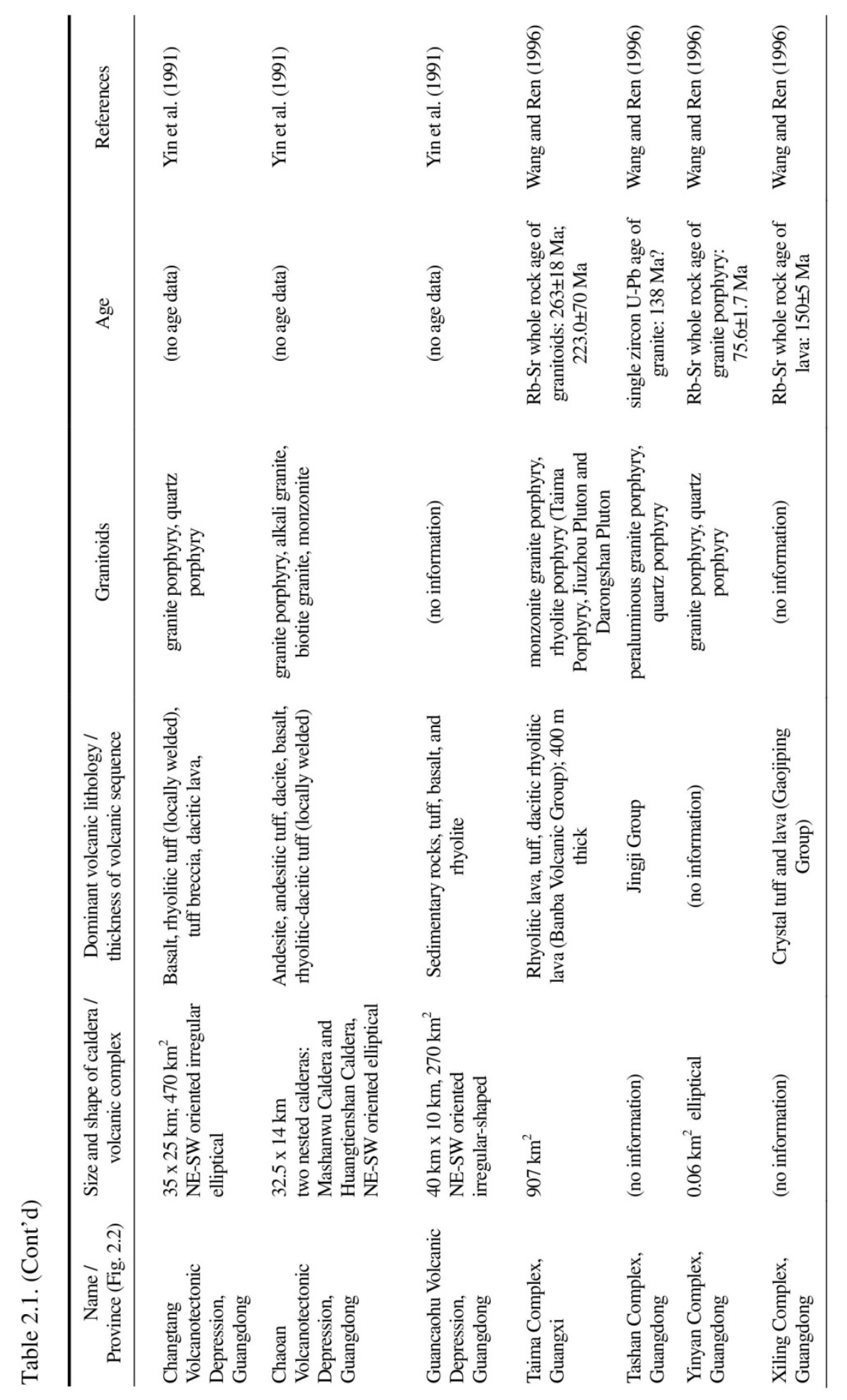


To account for the exceptional width of the magmatic province, Zhou and Li (2000) inferred that the dip of the subducting palaeo-Pacific Plate increased from a low to a medium angle over time, causing a wide zone of basaltic underplating that generated voluminous silicic magma by partial melting of the lower to middle crust. $\mathrm{Li}$ and $\mathrm{Li}$ (2007) reconsidered the subject and proposed a flat-slab subduction model to account for formation of a broad magmatic belt. Break-up and foundering of the flat subducted slab beneath southeast China was proposed by $\mathrm{Li}$ and $\mathrm{Li}$ (2007) to be the cause of bimodal alkaline basaltic-rhyolitic magmatism between 190 Ma and $150 \mathrm{Ma}$. They also suggested that the apparent younging of magmatism from the interior towards the coastal region of southeast China since 150 Ma could be explained by slab rollback. This model was questioned by Chen et al. (2008), who pointed out that the model conflicted with some important observations, such as the presence of extensive Triassic granitoids, and a nonmagmatic period during the Early Jurassic in south China.

As well as the continuing debate over the tectonic settings of the Indosinian and Yanshanian orogenies in southeast China (Zheng et al., 2013), the tectonic controls that caused the ending of Yanshanian magmatism are also still obscure. The questions of how and when these transitions occurred and the relationship between the tectonic shifts and the change in characteristics and distribution of magmatism require further investigation. The onset of post-Yanshanian continental extension and rifting was considered to be associated with the retreat of the subduction zone and magmatic arc collapse in the late Mesozoic (Ren et al., 2002; Shi and Li, 2012). Numerous studies have investigated this evolution through geochemical and isotopic analyses on post-Yanshanian magmatic rocks (e.g. Chung et al., 1997; Huang et al., 2013), facies and provenance analysis of offshore sediments (e.g. Wu, 1994; Li et al., 2003b), detailed structural mapping (e.g. Chan et al., 2010), analysis of onshore and offshore rift basins (e.g. Gilder et al., 1991; Zhou et al., 1995; Shu et al., 2009), and modelling of geophysical data (e.g. Hayes et al., 1995; Nissen et al., 1995a, 1995b; Shi and Li, 2012). Despite this level of detail, the timings of the shutdown of silicic magmatism, collapse of the magmatic arc and evolution of associated marginal basins are not well constrained. 


\subsection{Overview of Hong Kong geology}

\subsubsection{Pre-magmatic units and stratigraphy}

Hong Kong is located at the southeastern edge of the SCMB where the regional NEtrending Lianhaushan Fault Zone extends offshore (Fig. 2.1). About 85\% of the land area is made up of late Mesozoic igneous rocks related to the Yanshanian event. Archean and Proterozoic crystalline rocks, although not exposed at the surface, have been inferred to underlie these Yanshanian magmatic rocks on the basis of geochemical, isotopic and geophysical properties (Darbyshire and Sewell, 1997; Fletcher et al., 1997; Sewell and Campbell, 1997). By modelling gravity data from Busby et al. (1992), Fletcher et al. (1997) proposed the presence of a major NE-trending crustal discontinuity within the middle and lower crust (deeper than 6-8 km) and separates the Archean and Proterozoic crust at depth. This NE-trending structure was interpreted to coincide with the regional Lianhaushan Fault Zone that cuts across Hong Kong (Fig. 2.1).

Outcrops of late Palaeozoic sediments are exposed mainly in the northern and northeast New Territories (Fig. 2.3; Ruxton, 1960; Allen and Stephens, 1971; Addison, 1986; Langford et al., 1989). These strata include Devonian terrestrial sandstones and conglomerate, Carboniferous limestone, deltaic sandstone and siltstone, and Permian deep marine sediments (Addison, 1986; Langford et al., 1989; Frost, 1992; Jones, 1995, 1996; Lai et al., 1996; Lee et al., 1997, 1998). Most of these late Palaeozoic rocks have been deformed and metamorphosed during multiple phases of tectonic events (Langford et al., 1989; Frost, 1992; Lai et al., 1996). Younger Early to Middle Jurassic sedimentary successions are preserved now only as relatively small, isolated outcrops scattered across Hong Kong (Fig. 2.3; Ruxton, 1960; Langford et al., 1995; Lai et al., 1996; Sewell et al., 2000). These strata comprise fossiliferous Lower Jurassic marine siltstones and mudstones, and Middle Jurassic terrestrial sandstones deposited in fluvial environments (Jones, 1996; Lee et al., 1997, 1998; Sewell et al., 2000). 


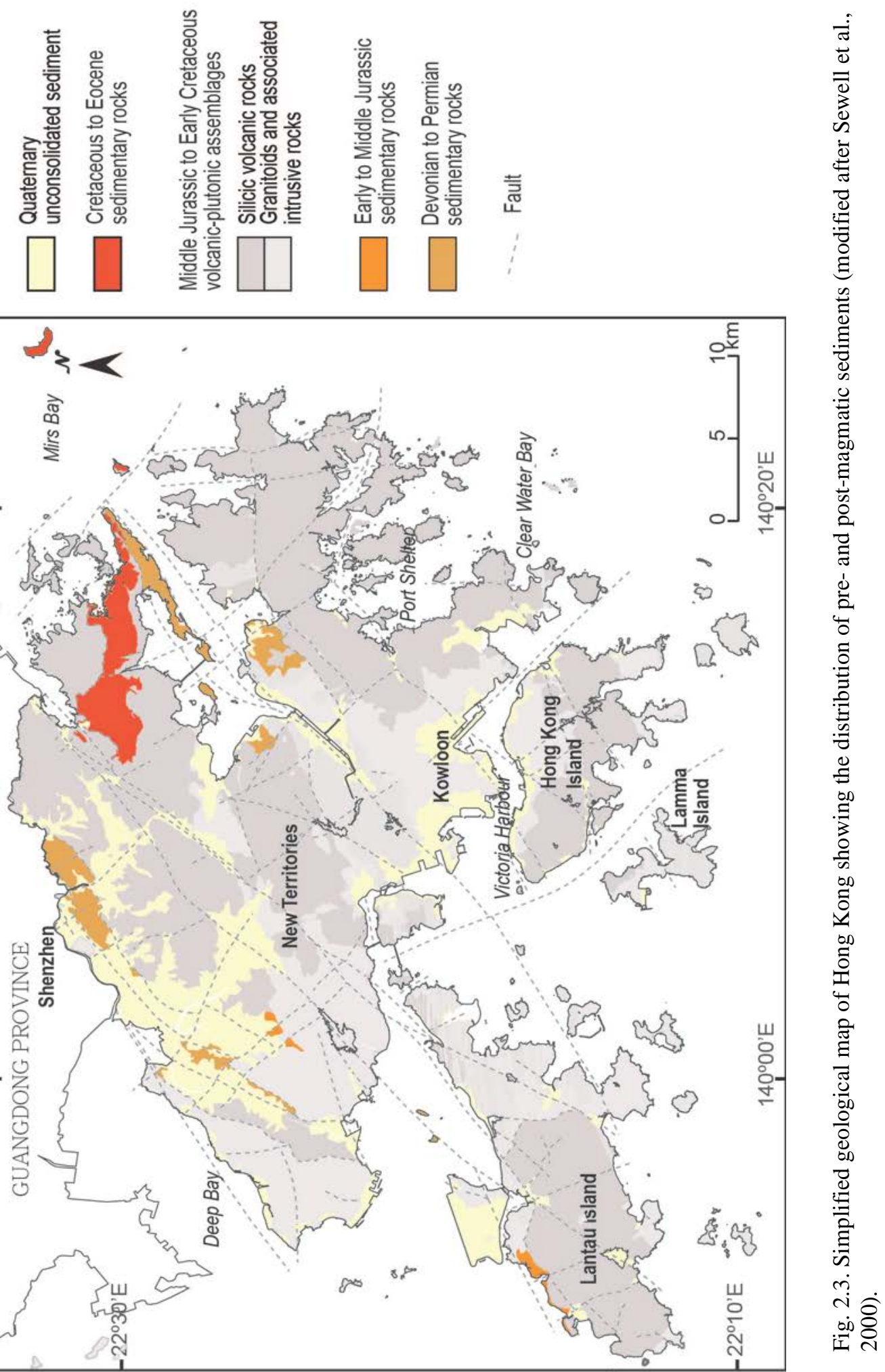




\subsubsection{Middle Jurassic to Early Cretaceous volcanic-plutonic assemblages}

The Mesozoic Yanshanian igneous rocks in Hong Kong comprise dacitic to rhyolitic ignimbrites and lavas with intercalated tuffaceous sedimentary units, as well as intrusions of granodiorite, granite, quartz monzonite and minor dykes of various compositions (Sewell et al., 2000, 2012a). Spatial and temporal distributions of the late Mesozoic silicic volcanic and their sub-volcanic plutons were constrained by detailed mapping (Campbell and Sewell, 1997 and references therein), supported with ID-TIMS zircon geochronological data (Davis et al., 1997; Campbell et al., 2007; Sewell et al., 2012b). Four volcanic-plutonic assemblages, corresponding to temporally distinct magmatic episodes at $\sim 164 \mathrm{Ma}, \sim 148-146 \mathrm{Ma}, \sim 143 \mathrm{Ma}$ and 141-140 Ma were identified (Table 2.2, Fig. 2.4; Davis et al., 1997; Sewell et al., 2000, 2012b). Although the ages of the igneous rocks reported in this chapter are from the published studies, the work presented later in this thesis (Chapter 4) modifies some of these figures. The volcanic and plutonic rocks were considered to be largely co-genetic representing ancient caldera-related large-scale silicic magmatic systems (Campbell and Sewell, 1997). The genetic correlations of the volcanic groups and igneous suites were established on the basis of broadly coeval eruption and intrusion ages, and similarities in whole-rock geochemical signatures (in particular whole-rock $\mathrm{TiO}_{2}$ versus $\mathrm{Zr}$ concentrations, Fig. 2 in Sewell and Campbell, 1997). It is noteworthy that matching of individual volcanic units to specific plutons was not explicitly done, and that a sub-volcanic equivalent might not be positively identified for each volcanic unit, and vice versa (Sewell and Campbell, 1997). Detailed descriptions of the four volcanic-plutonic assemblages are presented in Section 2.4., below.

Campbell and Sewell (1997) identified a series of fault structures that controlled caldera development in Hong Kong. They outlined at least six calderas formed during the four major volcanic episodes (Fig. 2.4). These structures comprise nearly complete, ellipsoidal calderas, delineated by ring faults and ring-like intrusions for the two Jurassic volcanic centres, the Yim Tin Tsai-Tsuen Wan Caldera and the Lantau Caldera (Fig. 1, Campbell and Sewell, 1997). At least four other dismembered calderas were proposed to be the sources related to the two younger Early Cretaceous volcanic groups, the outcrops of which are spatially connected (Campbell and Sewell, 1997; Fig. 2.4). Further assessment of the spatial relationships of the two Early Cretaceous volcanic-plutonic assemblages led to a renewed interpretation of the anatomy of the calderas in southeast Hong Kong by Sewell et al. (2012a). Instead of four dismembered calderas, Sewell et al. (2012a) 


\section{considered that the Repulse Bay Volcanic Group (RBVG) and Kau Sai Chau Volcanic}

Group (KSCVG) were erupted from the nested High Island Caldera (Fig. 2.4).

Table 2.2. Summary of the volcanic-plutonic assemblages and existing ID-TIMS U-Pb zircon age data for late Mesozoic igneous rocks in Hong Kong (after Sewell et al., 2012a).

\begin{tabular}{|c|c|c|c|c|c|}
\hline \multicolumn{3}{|c|}{ Volcanic Rocks } & \multicolumn{3}{|c|}{ Granitoid Rocks } \\
\hline Group & Formation & $\begin{array}{l}\text { ID-TIMS U- } \\
\mathrm{Pb} \text { zircon age } \\
\text { (Ma) }\end{array}$ & Suite & Intrusion & $\begin{array}{l}\text { ID-TIMS U- } \\
\text { Pb zircon age } \\
\text { (Ma) }\end{array}$ \\
\hline $\begin{array}{c}\text { Kau Sai Chau } \\
\text { Volcanic Group } \\
\text { (KSCVG) }\end{array}$ & $\begin{array}{l}\text { High Island } \\
\text { Clear Water Bay } \\
\text { Undifferentiated } \\
\text { Pan Long Wan }\end{array}$ & $\begin{array}{l}140.9 \pm 0.2^{\mathrm{a} \#} \\
140.7 \pm 0.2^{\mathrm{a} \#} \\
140.9 \pm 0.2^{\text {c\# }} \\
141.1 \pm 0.2^{\mathrm{b \#}} \\
141.2 \pm 0.3^{\text {c\& }}\end{array}$ & $\begin{array}{l}\text { Lion Rock } \\
\text { Suite }\end{array}$ & $\begin{array}{c}\text { Mount Butler Granite } \\
\text { Kowloon Granite } \\
\text { Fan Lau Granite } \\
\text { Sok Kwu Wan Granite } \\
\text { Tei Tong Tsui Qz } \\
\text { Monzonite } \\
\text { Tong Fuk Qz Monzonite } \\
\text { D’Aguilar Qz Monzonite }\end{array}$ & $\begin{array}{c}\text { Not dated } \\
140.4 \pm 0.2^{\text {a\# }} \\
\text { Not dated } \\
140.6 \pm 0.3^{\text {c\# }} \\
\text { Not dated } \\
140.4 \pm 0.3^{\text {a\# }} \\
140.6 \pm 0.3^{\text {c\# }}\end{array}$ \\
\hline $\begin{array}{c}\text { Repulse Bay Volcanic } \\
\text { Group (RBVG) }\end{array}$ & $\begin{array}{l}\text { Mount Davis } \\
\text { Long Harbour } \\
\text { Mang Kung Uk } \\
\text { Che Kwu Shan } \\
\text { Ap Lei Chau } \\
\text { Ngo Mei Chau }\end{array}$ & $\begin{array}{c}142.8 \pm 0.2^{\mathrm{b \#}} \\
143.0 \pm 0.2^{\text {c\& }} \\
142.7 \pm 0.2^{\text {a\# }} \\
142.8 \pm 0.2^{\text {a\# }} \\
142.9 \pm 0.2^{\text {c\# }} \\
142.5 \pm 0.3^{\text {a\# }} \\
142.7 \pm 0.2^{\text {a\# }} \\
<143.7 \pm 0.1^{\text {c\# }}\end{array}$ & $\begin{array}{l}\text { Cheung } \\
\text { Chau Suite }\end{array}$ & $\begin{array}{c}\text { Luk Keng Qz Monzonite } \\
\text { Chi Ma Wan Granite } \\
\text { Shui Chuen O Granite }\end{array}$ & $\begin{array}{c}\text { Not dated } \\
<143.7 \pm 0.2^{\mathrm{a} \#} \\
144.0 \pm 0.3^{\text {c\# }}\end{array}$ \\
\hline $\begin{array}{l}\text { Lantau Volcanic } \\
\text { Group (LVG) }\end{array}$ & $\begin{array}{l}\text { Lai Chi Chong } \\
\text { Undifferentiated }\end{array}$ & $\begin{array}{l}146.6 \pm 0.2^{\mathrm{b \#}} \\
146.6 \pm 0.2^{\mathrm{a} \#} \\
147.5 \pm 0.2^{\mathrm{b \#}}\end{array}$ & $\begin{array}{l}\text { Kwai } \\
\text { Chung } \\
\text { Suite }\end{array}$ & $\begin{array}{c}\text { Shatin Granite } \\
\text { East Lantau Rhyolite } \\
\text { East Lantau Rhyodacite } \\
\text { Needle Hill Granite } \\
\text { Sham Chung Rhyolite } \\
\text { Po Toi Granite } \\
\text { Shan Tei Tong Rhyodacite } \\
\text { South Lamma Granite }\end{array}$ & $\begin{array}{l}146.2 \pm 0.2^{\mathrm{a \#}} \\
146.3 \pm 0.3^{\mathrm{ad}} \\
146.5 \pm 0.2^{\mathrm{a} \#} \\
146.4 \pm 0.2^{\mathrm{a} \#} \\
146.6 \pm 0.2^{\mathrm{b \#}} \\
146.5 \pm 0.2^{\text {c\& }} \\
147.3 \pm 0.2^{\text {c\# }} \\
148.1 \pm 0.2^{\text {c\# }}\end{array}$ \\
\hline $\begin{array}{c}\text { Tsuen Wan Volcanic } \\
\text { Group(TWVG) }\end{array}$ & $\begin{array}{l}\text { Sai Lau Kong } \\
\text { Tai Mo Shan } \\
\text { Shing Mun } \\
\text { Yim Tin Tsai }\end{array}$ & $\begin{array}{c}164.1 \pm 0.3^{\mathrm{c \#}} \\
<164.6 \pm 0.7^{\mathrm{a} \#} \\
164.2 \pm 0.3^{\mathrm{b \#}} \\
164.7 \pm 0.3^{\mathrm{b \#}} \\
164.5 \pm 0.2^{\mathrm{a \#}}\end{array}$ & $\begin{array}{l}\text { Lamma } \\
\text { Suite }\end{array}$ & $\begin{array}{c}\text { Tai Lam Granite } \\
\text { Tsing Shan Granite } \\
\text { Chek Lap Kok Granite } \\
\text { Chek Mun Rhyolite } \\
\text { Lantau Granite } \\
\text { TaiPo Granodiorite }\end{array}$ & $\begin{array}{c}159.3 \pm 0.3^{\mathrm{a}^{\#}} \\
<159.6 \pm 0.5^{\mathrm{a} \#} \\
160.4 \pm 0.3^{\mathrm{a} \#} \\
160.8 \pm 0.2^{\mathrm{c \#}} \\
161.5 \pm 0.2^{\mathrm{a} \#} \\
<164.6 \pm 0.2^{\mathrm{a}}\end{array}$ \\
\hline
\end{tabular}

Note: All ages are ID-TIMS U-Pb zircon averaged ages, with 95\% confidence level uncertainties.

$\mathrm{a}-\mathrm{U}-\mathrm{Pb}$ ages from Davis et al. (1997)

$\mathrm{b}-\mathrm{U}-\mathrm{Pb}$ ages from Campbell et al. (2007)

$\mathrm{c}-\mathrm{U}-\mathrm{Pb}$ ages from Sewell et al. (2012b)

\# - zircons treated by air abrasion (Krogh, 1982)

$\&$ - zircons treated by chemical abrasion (Mattinson, 2005) 


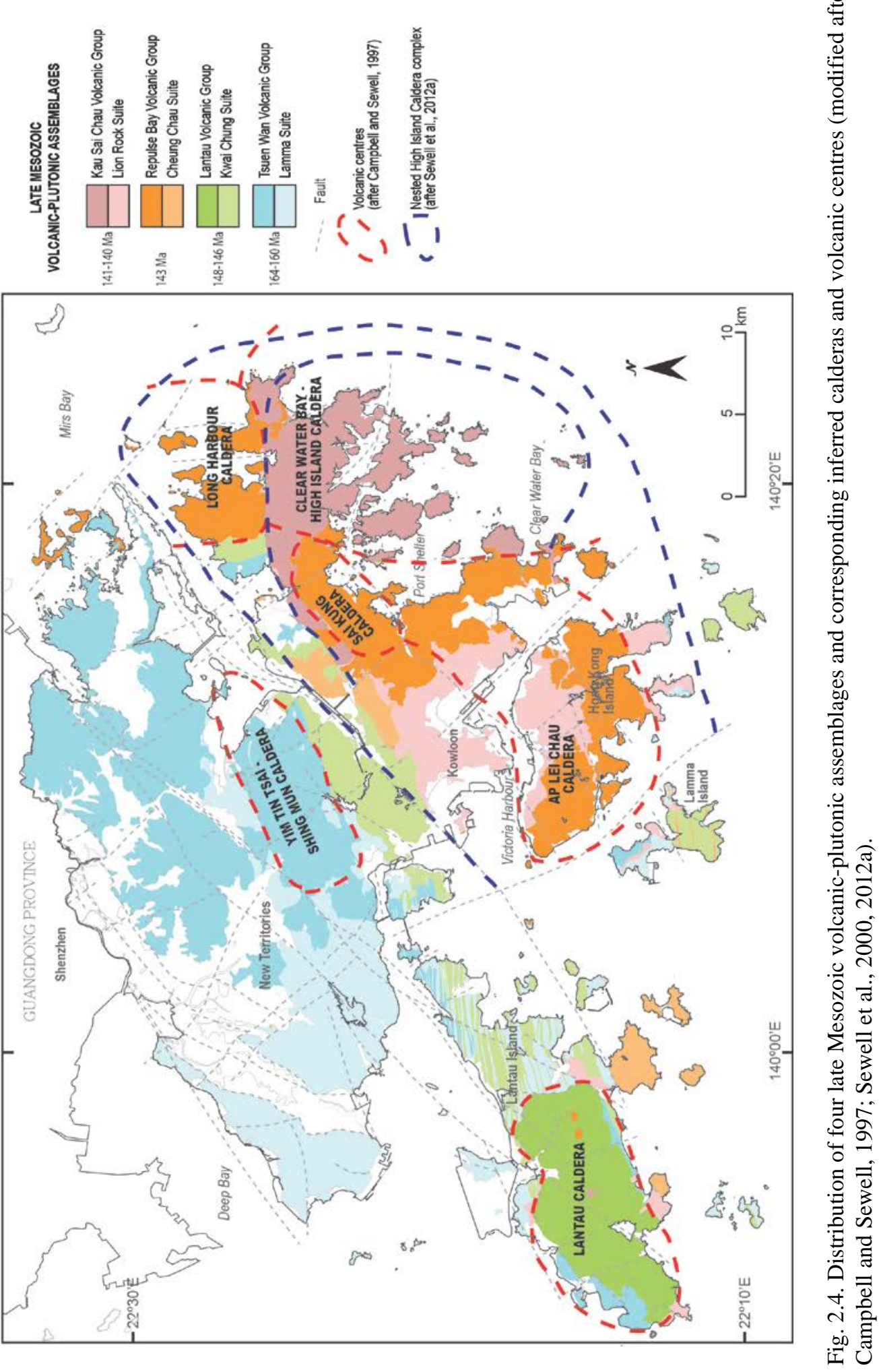




\subsubsection{Post-magmatic sedimentary sequences}

Four post-volcanic sedimentary units: the Cretaceous Pat Sin Leng, Port Island and Kat O formations (collectively known as the Mirs Bay Group), and the Eocene Ping Chau Formation have been identified in Hong Kong (Fig. 2.3; Sewell et al., 2000). The Cretaceous units are dominated by non-fossiliferous reddish sandstone, siltstone and conglomerate deposited in fluvial environments (Jones, 1995, 1996; Lai et al., 1996). All units unconformably overlie the Middle Jurassic to Lower Cretaceous volcanic rocks in northeast Hong Kong, but their stratigraphic ages are only loosely constrained (Sewell et al., 2000). Their stratigraphic relationships to each other have also not been established given that they form separate outcrops with no contiguous boundaries (Sewell et al., 2000). The sequences have been generally correlated with the fossil-bearing Early to Late Cretaceous Baihedong, Sanshui and Dalangshan formations in neighbouring Guangdong Province (Lai et al., 1996; Sewell et al., 2000). Lai et al. (1996) carried out a provenance study of the Hong Kong sediments based on petrographic comparison of lithic clasts, concluding that the sediments were probably sourced in general terms from the underlying volcanic sequences. The Eocene Ping Chau Formation consists of dolomitic and calcareous siltstone, bearing a diverse assemblage of fossil plants and insects, deposited in a lacustrine environment (Lai et al., 1996). This formation represents the youngest preserved rock formation in Hong Kong, and a major hiatus exists between indurated Eocene rocks and unconsolidated Quaternary sediments (Fig. 2.3; Sewell et al., 2000).

\subsection{Volcanic-plutonic assemblages in Hong Kong}

\subsubsection{Middle Jurassic: Tsuen Wan Volcanic Group and the Lamma Suite}

The nominal 164 Ma Tsuen Wan Volcanic Group (TWVG) includes four formations that crop out mainly in the central and northern New Territories, with some isolated exposures on Lantau, Lamma and southern Hong Kong islands (Fig. 2.4). These units, including the Yim Tin Tsai, Shing Mun, Tai Mo Shan and Sai Lau Kong formations, are dominated by massive crystal-rich, rhyodacitic ignimbrites (65-71 wt \% $\mathrm{SiO}_{2}$ ) with interbedded tuffaceous sediments and block-bearing volcanic units (Langford et al., 1989, 1995; Sewell and Campbell, 1997; Sewell et al., 2000). On the northwestern coast of Lantau Island, the 164 Ma volcanic strata unconformably overlie Middle Jurassic sediments (Langford et al., 1995). The volcanic units were generally interpreted as the products of extensive 
pyroclastic flows, with thick accumulations of intervening lahars deposited during the waning stage of volcanism (Langford et al., 1995; Sewell et al., 2000).

The Lamma Suite comprises five granodiorite and granite plutons (62-72 wt\% $\mathrm{SiO}_{2}$ ), exposed mainly in northwestern and central New Territories, northern Lantau Island, and as isolated outcrops on Hong Kong and Lamma islands (Fig. 2.4; Sewell and Campbell, 1997; Sewell et al., 2000, 2012a). This intrusive suite was considered to be associated with the TWVG (Sewell and Campbell, 1997; Sewell et al., 2000, 2012b), although only the Tai

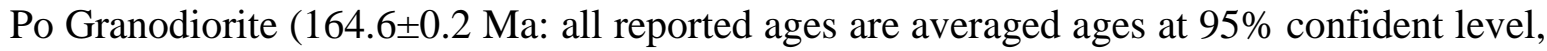
see Davis et al., 1997, for further details) is broadly coeval with the volcanic rocks, while the other granitic plutons are at least 2-3 Myr younger (Table 2.2). Sewell and Campbell (1997) proposed that these plutons could be divided into two types, an earlier I-type and a younger A-type. The I-type sub-suite includes Tai Po Granodiorite and Lantau Granite (161.5 $\pm 0.2 \mathrm{Ma}$ ), and the A-type sub-suite includes Chek Lap Kok Granite (160.4 $\pm 0.3 \mathrm{Ma}$ ),

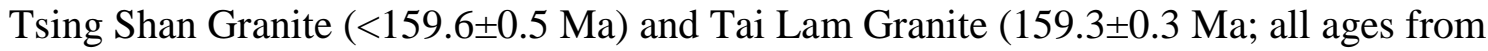
Davis et al., 1997). A rhyolitic dyke swarm (160.8 $\pm 0.2 \mathrm{Ma}$; Sewell et al., 2012b), which intruded pre-volcanic sediments in the New Territories, was also assigned to the Lamma Suite on the basis of its similar age.

Campbell and Sewell (1997) proposed that the volcanic centre of the TWVG was located in the central New Territories, i.e. the Tsuen Wan-Yim Tin Tsai Caldera that was delineated by them from a series of granodiorite bodies and associated fault structures (Fig. 2.4). The proposed caldera is elongate with a NE-trending long axis, $15 \mathrm{~km}$ long by $5 \mathrm{~km}$ wide (Campbell and Sewell, 1997). However, the presence of metamorphosed rocks and evidence of shear deformation, especially in the northwestern New Territories (Langford et al., 1989), has obscured much of the field evidence and deterred detailed investigation on the eruptive styles and stratigraphy of the volcanic group. In addition, the locations of eruption sources have not been identified for the 164 Ma volcanic episode.

\subsubsection{Late Jurassic: Lantau Volcanic Group and the Kwai Chung Suite}

The Lantau Volcanic Group (LVG; 148-146 Ma) comprises a >1,700-m thick volcanic succession exposed mainly on central and western Lantau Island (Fig. 2.4; Langford et al., 1995; Sewell et al., 2000). The volcanic group comprises multiple, massive rhyodacite to rhyolite ignimbrite sheets and flow-banded lavas (67 to $>75 \mathrm{wt} \% \mathrm{SiO}_{2}$ ), separated by 
tuffaceous sedimentary units (Langford et al., 1995; Sewell and Campbell, 1997). These volcanic rocks were inferred to reflect a continuum of eruption styles from hightemperature, low-viscosity fountain-fed lava to rheomorphic pyroclastic flow (Langford et al., 1995; Sewell et al., 2000). A 180 m-thick, fossil-bearing volcaniclastic succession, the Lai Chi Chong Formation, exposed along a coastal section to the south of the Tolo Channel in eastern New Territories was also assigned to the LVG based on similar stratigraphic and geochronological correlations (Fig. 2.4; Sewell et al., 2000; Campbell et al. 2007). This unit was interpreted as resulting from sedimentation in a lacustrine environment that was close to a volcanic centre (Strange et al., 1990; Sewell et al., 2000).

The Kwai Chung Suite was paired with the LVG mainly on the similarity in ID-TIMS U$\mathrm{Pb}$ ages and whole-rock geochemical evidence, although the field relationships of the intrusive units with the volcanic sequences were not well constrained (Sewell et al., 2000). The intrusive suite comprising four granitic plutons and some dyke swarms, crops out mainly in the southern New Territories, northeast Lantau Island and some outlying islands in southern Hong Kong (Fig. 2.4; Addison, 1986; Strange and Shaw, 1986; Sewell and Campbell, 1997; Sewell et al., 2000, 2012b; Wong and Shaw, 2010). Based on their whole rock compositions, these granitic plutons were classified as I-type granites (Sewell and Campbell, 1997). The South Lamma Granite (73-76 wt\% SiO ${ }_{2} ; 148.1 \pm 0.2$ Ma: Sewell et al., 2012b) is the oldest pluton of the Kwai Chung Suite, and is cut by numerous E-Wtrending rhyodacitic dykes of slightly younger age (147.3 $\pm 0.2 \mathrm{Ma}$; Sewell et al., 2012b). The Shatin (72-77 wt\% $\mathrm{SiO}_{2}$, biotite monzogranite) and Needle Hill (75-77 wt\% $\mathrm{SiO}_{2}$, monzogranite) granites are two elliptical plutons in the southern New Territories, whereas the Po Toi Granite (74-77 wt\% $\mathrm{SiO}_{2}$, biotite monzogranite) crops out only on the outlying islands south of Hong Kong Island (Sewell et al., 2000). These three granite plutons yielded similar ID-TIMS ages of 146 Ma (Davis et al., 1997; Sewell et al., 2012b; Table 2.2.).

Numerous E-W- to ENE-trending rhyodacitic to rhyolitic dykes (69-76 wt\% $\mathrm{SiO}_{2}$ ), outcropping in an $8 \mathrm{~km}$-wide zone in northeast Lantau Island and southwest New Territories (Fig. 2.4), intrude volcanic and plutonic rocks of the TWVG-Lamma Suite (Langford et al., 1995; Sewell and James, 1995; Li et al., 2000; Sewell et al., 2000). These dykes are characterised by the presence of phenocrysts of bipyramidal quartz and euhedral alkali feldspar and plagioclase in an aphanitic groundmass (Langford et al., 1995; Sewell 
and James, 1995; Li et al, 2000). At least three emplacement phases were identified (based on cross-cutting relationships) some of which formed composite dykes with incorporated high-K calc-alkaline basaltic andesite to andesite material (51-59 wt\% $\mathrm{SiO}_{2}$; $\mathrm{Li}$ et al., 2000). Three ID-TIMS zircon U-Pb ages were obtained from the dykes at $146.3 \pm 0.3$, 146.4 \pm 0.2 and 146.5 \pm 0.2 Ma (Davis et al., 1997; Sewell et al., 2012b), suggesting that they are temporally related to the $\sim 148-146$ Ma volcanic and plutonic assemblages. Sewell et al. (2000) proposed that the dyke swarms were probably emplaced during a phase of rapid crustal extension.

\subsubsection{Early Cretaceous: Repulse Bay Volcanic Group and the Cheung Chau Suite}

The Repulse Bay Volcanic Group (RBVG) crops out in southern Hong Kong Island, northeastern Kowloon, Sai Kung, Long Harbour and Clear Water Bay Peninsula (Fig. 2.5). The volcanic group, nominally 143 Ma in age, comprises five units, the Long Harbour, Mount Davis, Che Kwu Shan, Ap Lei Chau and Mang Kung Uk formations in southeast Hong Kong (Table 2.3; Sewell et al., 2000, 2012b). Earlier interpretations proposed that two volcanic rock assemblages, defined on the basis of different geochemical characteristics, were erupted from three calderas (Campbell and Sewell, 1997; Sewell et al., 2000). A dacite-rhyolite assemblage was interpreted as being sourced from the 'Long Harbour' and 'Sai Kung' calderas and a second trachyte-rhyolite assemblage from a strongly dismembered and incomplete inferred 'Ap Lei Chau Caldera' centred on Hong Kong Island (Fig. 2.4; Campbell and Sewell, 1997; Sewell et al., 2000).

The stratigraphy of the RBVG was subsequently reviewed by Sewell et al. (2012a; Fig. 2.6) based on a detailed revision of field relationships and re-interpretation of whole-rock geochemical signatures. The faulted strata of the Mount Davis and Long Harbour formations, comprising mainly voluminous dacite to rhyolite (66-75 wt\% $\mathrm{SiO}_{2}$ ) crystalrich tuff (40-50\% phenocrysts) with intermittent volcaniclastic sediments, represent the lower part of the RBVG in the Sai Kung and east Kowloon areas (Fig. 2.5: Sewell et al., 2012a). The upper successions, represented by the faulted Ap Lei Chau Formation in western Hong Kong Island, and the largely undisturbed strata of the Che Kwu Shan and Mang Kung formations outcropping in the Clear Water Bay Peninsula area (Fig. 2.5), include locally strongly welded ignimbrites of trachydacite to high-silica rhyolite (63-77 wt\% $\mathrm{SiO}_{2}$ ) composition with 15-20\% phenocrysts (Strange et al., 1990; Sewell et al., 2000; 2012a). The overlying Mang Kung Uk Formation is a 170 m-thick volcaniclastic unit 
inferred to represent the final eruptions of the 143 Ma volcanic episode and a subsequent period of reworking (Strange et al., 1990; Sewell et al., 2000).

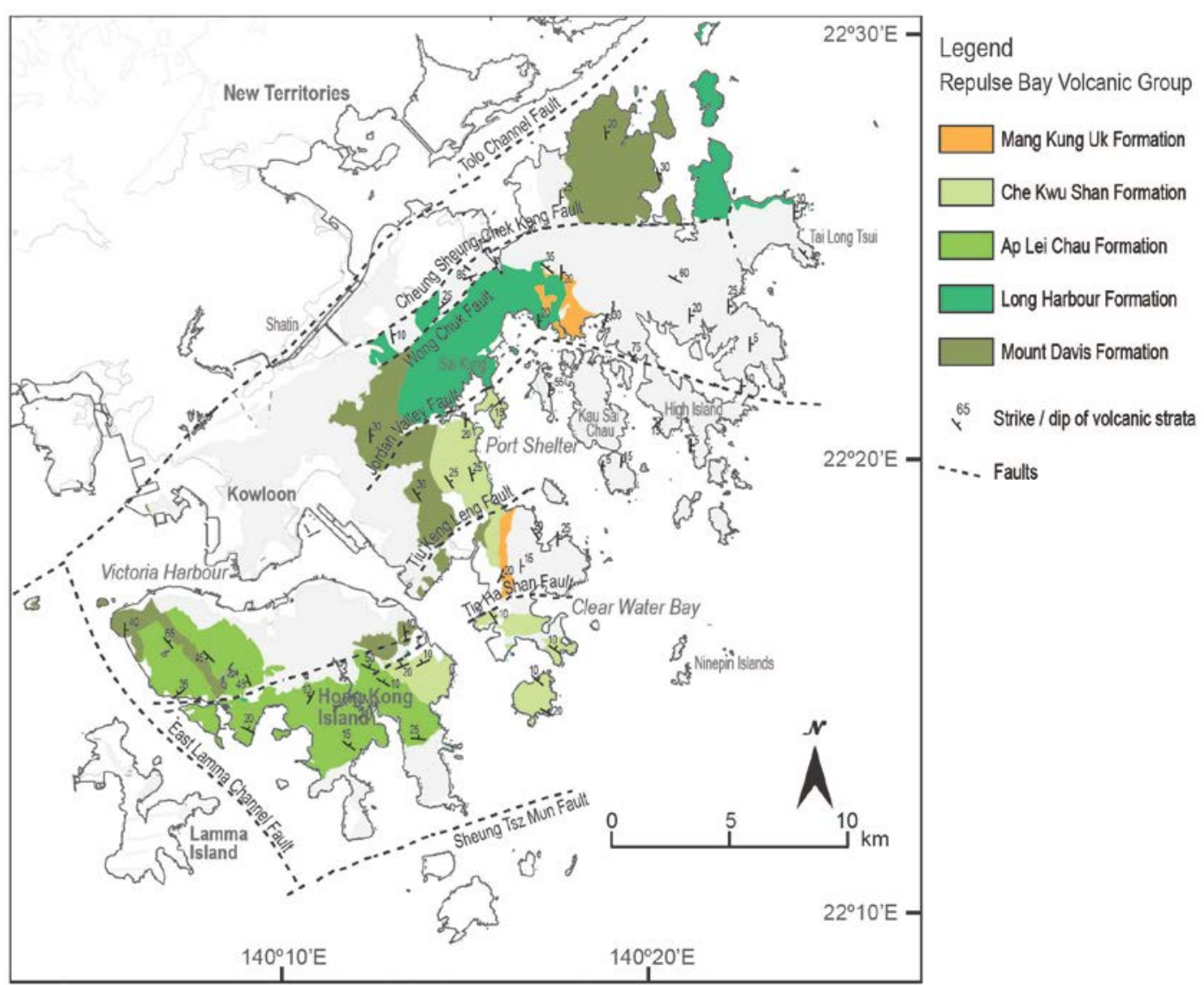

Fig. 2.5. Distribution of formations in the Repulse Bay Volcanic Group (modified after Sewell et al., 2000). 


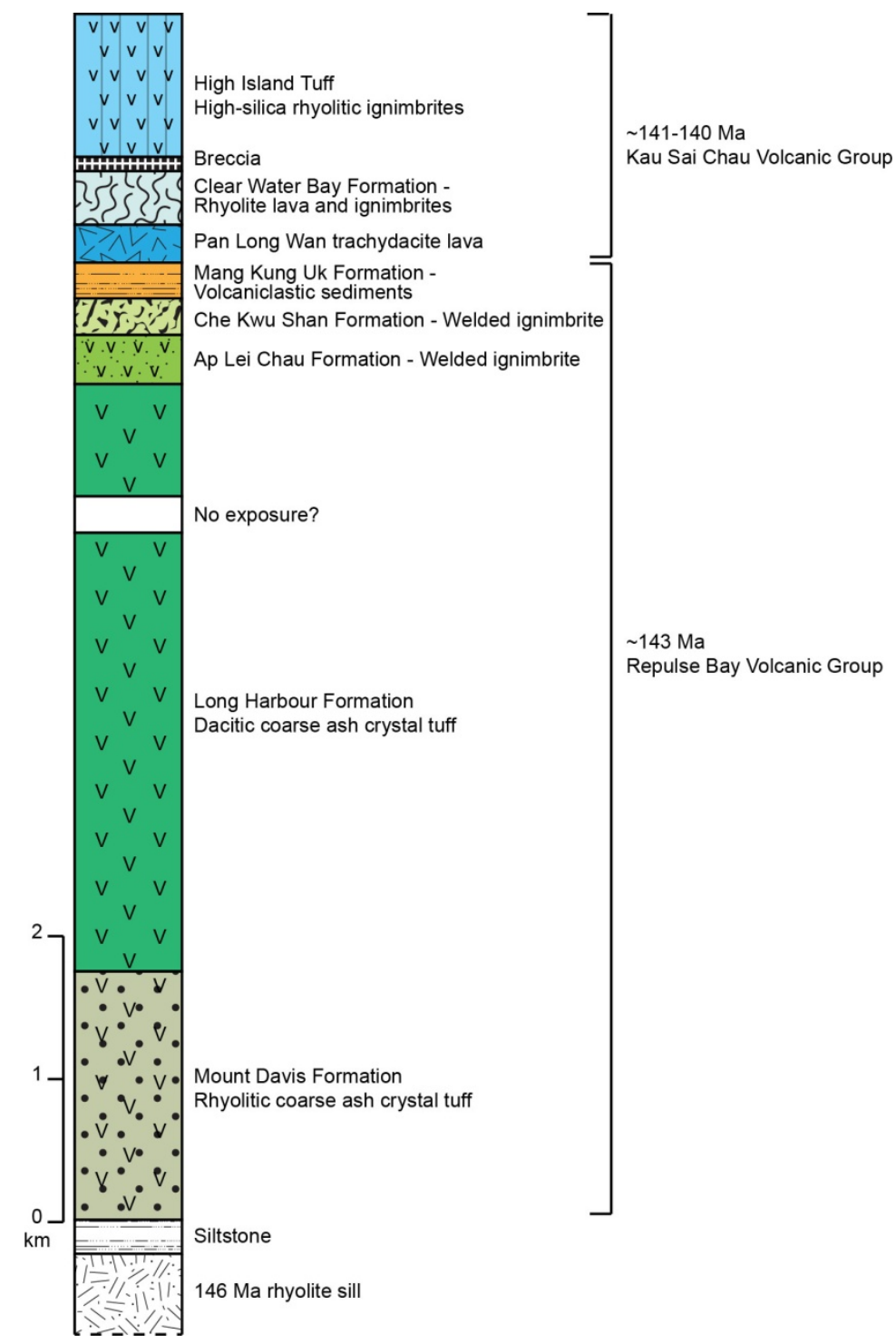

Fig. 2.6. Composite volcanic stratigraphy of the RBVG and KSCVG within the nested High Island caldera complex (modified after Sewell et al., 2012a). 


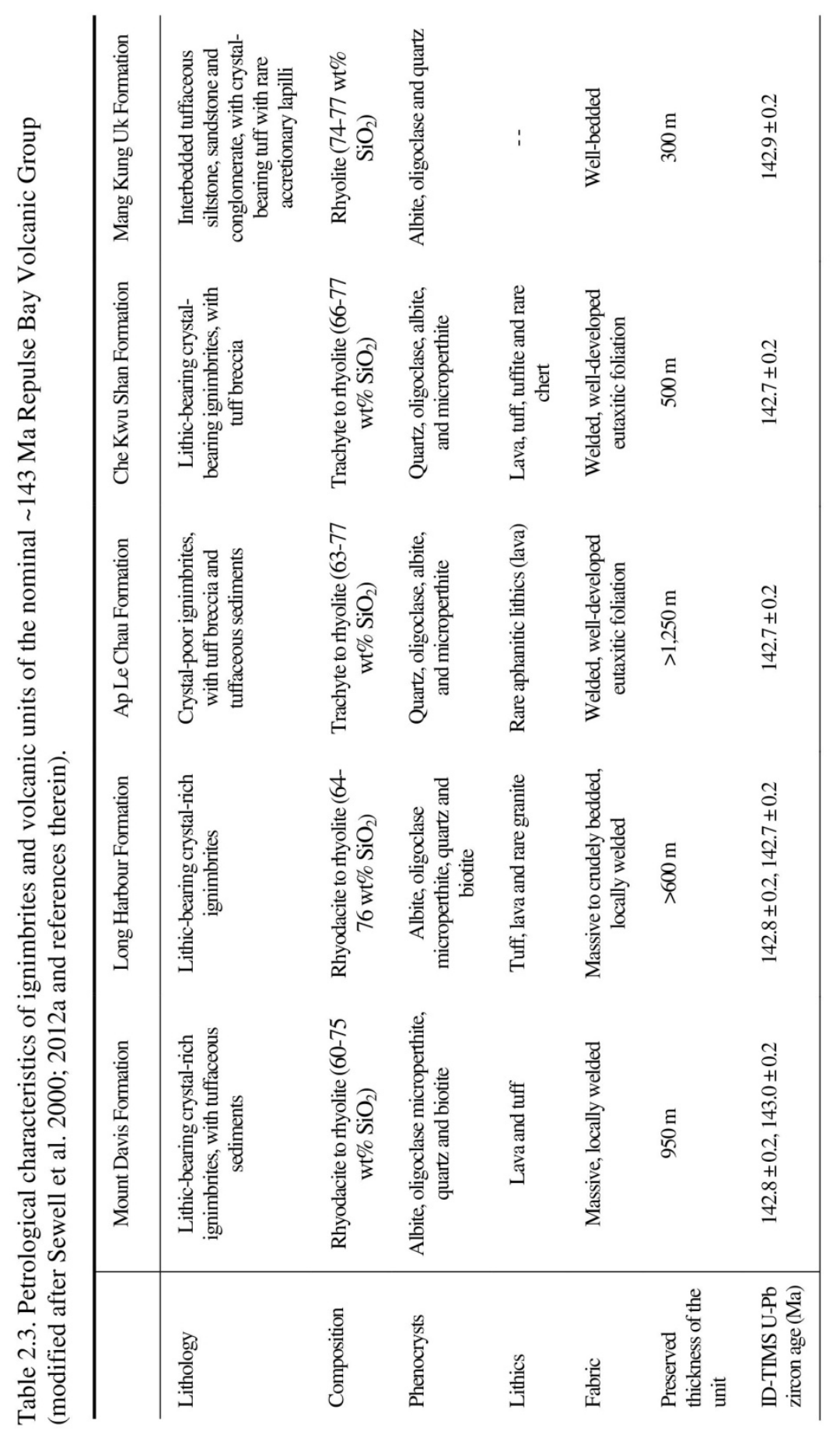


The Cheung Chau Suite comprises two granite plutons, the Chi Ma Wan and Shui Chuen O granites, and the Luk Keng Quartz Monzonite (Table 2.4; Sewell et al., 2000, 2012b). Although these plutons have been considered to be associated with the RBVG, the spatial connections of these intrusive and volcanic units are unclear because in no place do they crop out together. The Shui Chuen O Granite (144.0 $\pm 0.3 \mathrm{Ma}$, Sewell et al., 2012b) is perhaps the only pluton which is geographically related to the RBVG volcanic units. This unit is an ellipsoidal pluton of medium-grained granite (72-77 wt $\mathrm{SiO}_{2}$ ) which outcrops in the eastern part of the New Territories (Fig. 2.7). However, in parallel with the RVBG, the pluton was considered to have been strongly dissected by subsequent caldera development, and to have been offset dextrally along the prominent NE-trending Wong Chuk Fault (Sewell et al., 2000; 2012a). The other two units, the Chi Ma Wan Granite

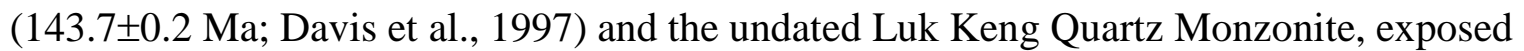
on the southern side of Lantau Island, were considered to have been emplaced along the ring structures of the Lantau caldera (Fig. 2.7; Langford et al., 1995; Campbell and Sewell, 1997; Sewell et al., 2000; Campbell et al., 2007). The Chi Ma Wan Granite is a subcircular pluton comprising dominantly equigranular medium-grained biotite monzogranite (72-77 wt\% $\mathrm{SiO}_{2}$ ). In contrast, the Luk Keng Quartz Monzonite is a megacrystic quartz monzonite stock, tentatively assigned to the Cheung Chau Suite on the basis of its cross-cutting relationships with the younger intrusive units of the Lion Rock Suite ( 140 Ma) (Sewell et al., 2000).

Table 2.4. Petrological characteristics of granitoids of the nominal $143 \mathrm{Ma}$ Cheung Chau Suite (modified after Sewell et al. 2000; 2012b and references therein).

\begin{tabular}{|c|c|c|c|}
\hline & Shui Chuen O Granite & Chi Ma Wan Granite & Luk Keng Quartz Monzonite \\
\hline Colour & Light grey or pink & Light grey or pink & Light pinkish white \\
\hline Lithology & $\begin{array}{l}\text { Biotite monzogranite } \\
\left(72-77 \mathrm{wt} \% \mathrm{SiO}_{2}\right)\end{array}$ & $\begin{array}{l}\text { Biotite monzogranite } \\
\left(72-77 \mathrm{wt} \% \mathrm{SiO}_{2}\right)\end{array}$ & $\begin{array}{l}\text { Quartz monzonite } \\
\left(\sim 68 \mathrm{wt} \% \mathrm{SiO}_{2}\right)\end{array}$ \\
\hline Dominant texture & Porphyritic medium-grained & Equigranular medium-grained & Megacrystic medium-grained \\
\hline Mafic minerals & Biotite & Biotite & Hornblende and biotite \\
\hline Feldspar & $\begin{array}{l}\text { Zoned oligoclase and perithic } \\
\text { orthoclase }\end{array}$ & $\begin{array}{l}\text { Microcline mesoperthite and } \\
\text { albite }\end{array}$ & Orthoclase and albite \\
\hline Accessory minerals & Zircon, apatite and $\mathrm{Fe}$-oxides & $\begin{array}{l}\text { Zircon, titanite, allanite, apatite } \\
\text { and Fe-oxides }\end{array}$ & $\begin{array}{l}\text { Zircon, titanite, allanite, apatite } \\
\text { and Fe-oxides }\end{array}$ \\
\hline $\begin{array}{l}\text { Alkali feldspar } \\
\text { megacrysts }\end{array}$ & Common & Absent & Common \\
\hline Area exposed & $8 \mathrm{~km}^{2}$ & $14 \mathrm{~km}^{2}$ & $8 \mathrm{~km}^{2}$ \\
\hline $\begin{array}{l}\text { ID-TIMS U-Pb } \\
\text { zircon age (Ma) }\end{array}$ & $144.0 \pm 0.3$ & $<143.7 \pm 0.3$ & No ID-TIMS age \\
\hline
\end{tabular}




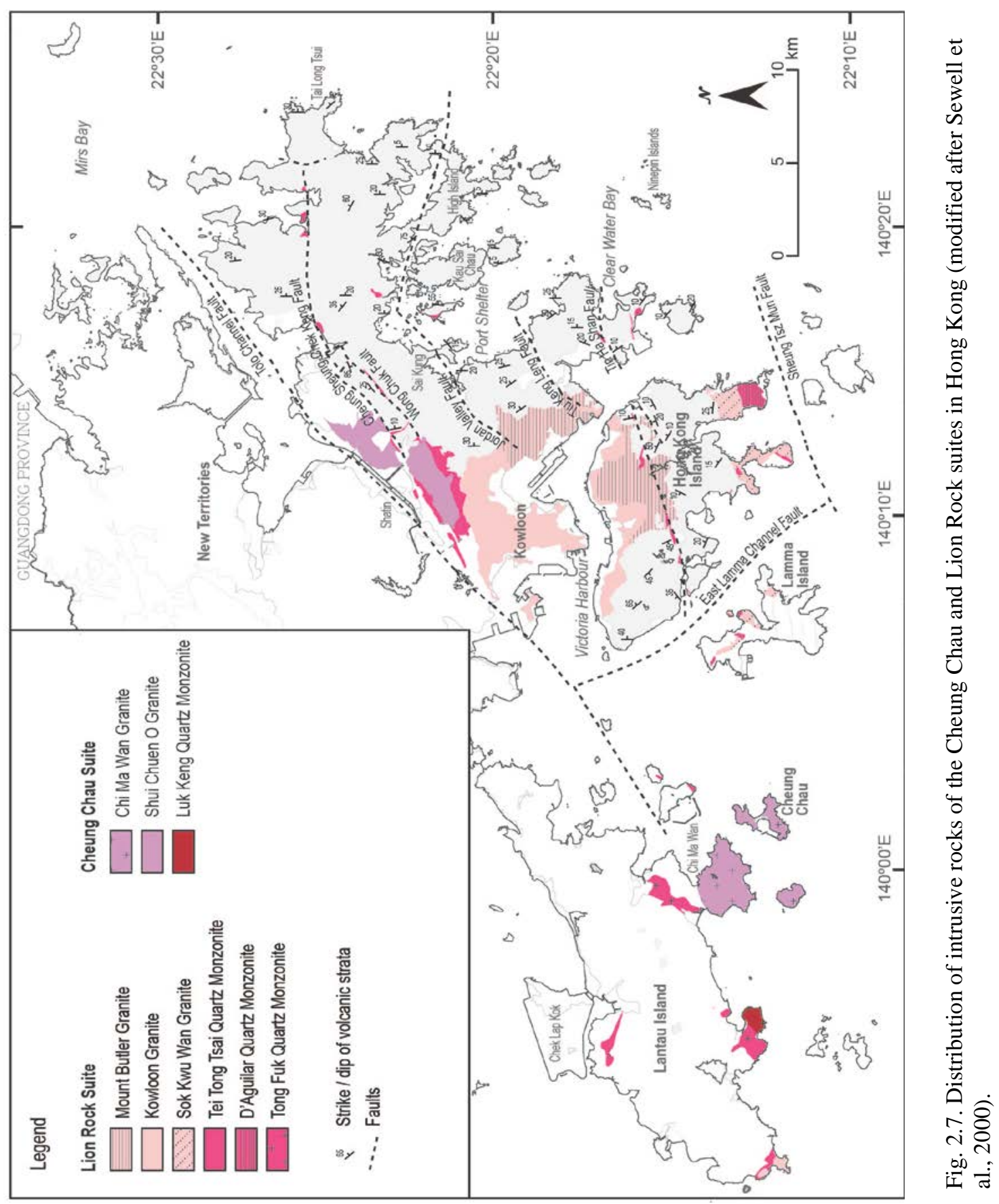




\subsubsection{Early Cretaceous Kau Sai Chau Volcanic Group and the Lion Rock Suite}

The Kau Sai Chau Volcanic Group (KSCVG) comprises three units: the Pan Long Wan, Clear Water Bay and High Island formations (Table 2.5; Sewell et al., 2012b), outcropping in areas around Clear Water Bay Peninsula, Port Shelter, High Island, Kau Sai Chau and the Ninepin Islands in southeast New Territories. The Pan Long Wan Formation is a flowbanded trachydacite lava (62-70 $\mathrm{wt} \% \mathrm{SiO}_{2}$ ) found in the southern part of the Clear Water Bay Peninsula (Fig. 2.8). This unit was originally interpreted as the basal lava flow of the Clear Water Bay Formation by Strange et al. (1990). However, recent re-interpretation has suggested that the unit is a separate precursor lava dome erupted before the major pyroclastic phases of the 141-140 Ma volcanic events (Sewell et al., 2012a; 2012b).

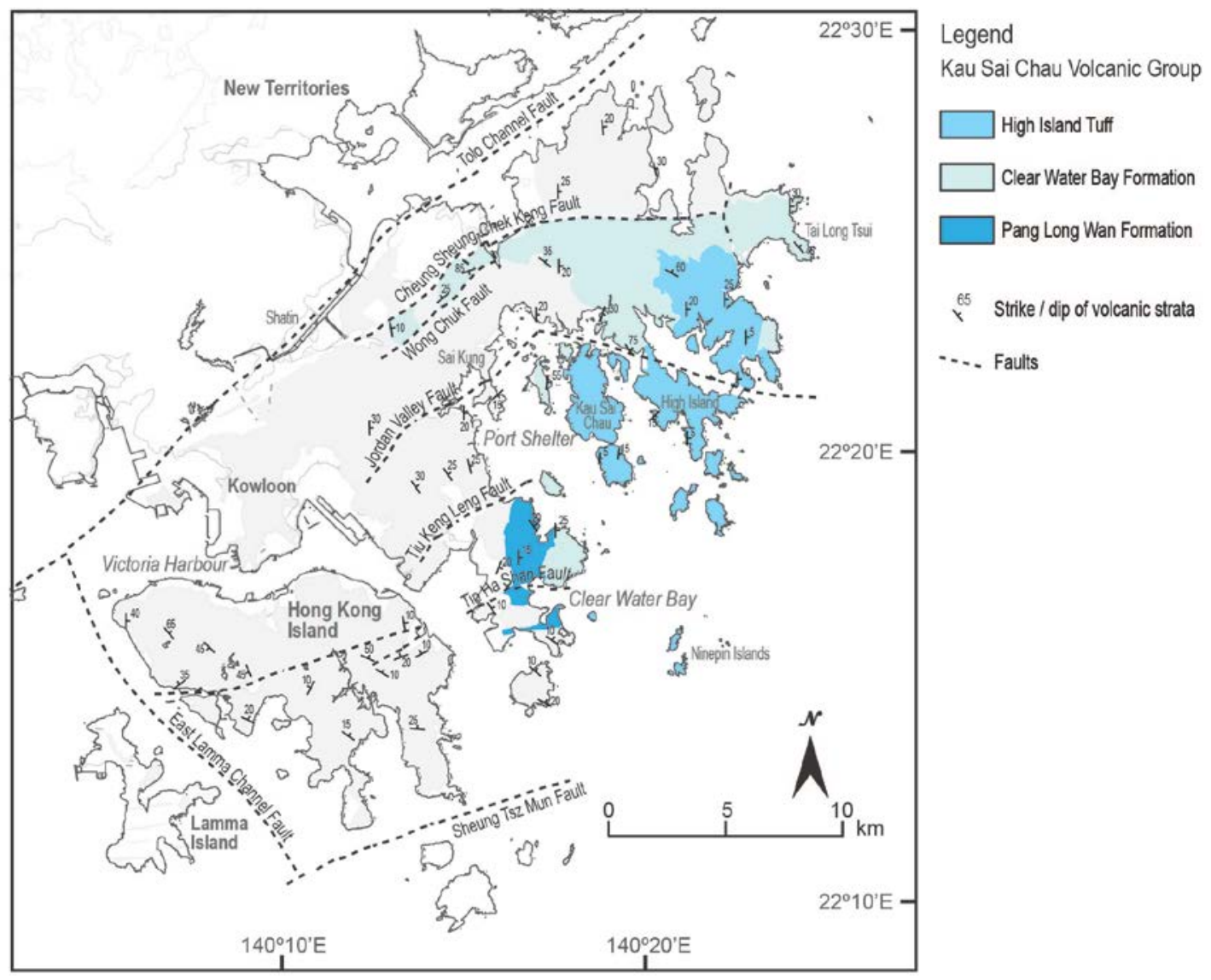

Fig. 2.8. Distribution of eruptive units forming the Kau Sai Chau Volcanic Group (modified after Sewell et al., 2000).

The dominant lithologies of the Clear Water Bay Formation (140.7 \pm 0.2 Ma: Davis et al., 1997) include flow-banded rhyolite lava, autobrecciated lava, eutaxitic tuff (70-77 wt\% $\mathrm{SiO}_{2}$ ) and volcaniclastic layers, with a total estimated thickness of $>400 \mathrm{~m}$ (Table 2.5; Figs. 2.6, 2.8). The original mapping by Strange et al. (1990) suggested that the formation 
consisted of several types of distinct volcanic facies, which were interpreted to represent varying eruption styles from lava flow to strongly rheomorphic pyroclastic flow.

The High Island Tuff (140.9 \pm 0.2 Ma: Davis et al., 1997) comprises a single cooling unit of compositionally uniform, high-silica rhyolitic (>75 wt\% $\left.\mathrm{SiO}_{2}\right)$, crystal-bearing ( 20\% quartz and alkali feldspar phenocrysts) ignimbrite (Sewell et al., 2000, 2012a). Strange et al. (1990) noted that the High Island Tuff is particularly homogeneous in terms of its whole-rock geochemistry. This unit is non-welded to partly welded at its base, grading upward over 30 m into densely welded tuff (Tam and Chan, 1983; Strange et al., 1990). The High Island Tuff is characterised by spectacularly well-developed columnar jointing, with column diameters up to $2 \mathrm{~m}$ and observed vertical extents of at least $30 \mathrm{~m}$ (Strange et al., 1990). The base of the High Island Tuff locally rests on a 35 m-thick volcaniclastic unit, characterised by tuff breccia, tuffaceous sandstone and mudstone, which in turn overlies the Clear Water Bay Formation (Fig. 2.6; Strange et al., 1990; Sewell et al., 2012a). The published ID-TIMS U-Pb zircon ages of Clear Water Bay Formation (140.7 $\pm 0.2 \mathrm{Ma}$ ) and High Island Tuff (140.9 $\pm 0.2 \mathrm{Ma}$ ) overlap within error (Davies et al., 1997), although field relationships were interpreted to indicate that the Clear Water Bay Formation is overlain by the High Island Formation (Strange et al., 1990).

Table 2.5. Petrological characteristics of ignimbrites and volcanic units of the $141 \mathrm{Ma}$ Kau Sai Chau Volcanic Group (modified after Sewell et al. 2000; 2012b and references therein).

\begin{tabular}{|c|c|c|c|}
\hline & Pan Long Wan Formation & Clear Water Bay Formation & High Island Formation \\
\hline Lithology & $\begin{array}{l}\text { Porphyritic lava, rare crystal- } \\
\text { poor ignimbrites }\end{array}$ & $\begin{array}{l}\text { Porphyritic lava and crystal- } \\
\text { poor ignimbrites, with } \\
\text { tuffaceous sediments }\end{array}$ & $\begin{array}{l}\text { Crystal-bearing ignimbrites, } \\
\text { with basal tuff breccia }\end{array}$ \\
\hline Composition & $\begin{array}{c}\text { Trachydacite to rhyolite (62-70 } \\
\left.\text { wt } \% \mathrm{SiO}_{2}\right)\end{array}$ & $\begin{array}{l}\text { Rhyodacite to high-silica } \\
\text { rhyolite }\left(70-77 \mathrm{wt} \% \mathrm{SiO}_{2}\right)\end{array}$ & $\begin{array}{l}\text { High-silica rhyolite (>75 wt } \% \\
\left.\qquad \mathrm{SiO}_{2}\right)\end{array}$ \\
\hline Phenocrysts & $\begin{array}{l}\text { Albite, sanidine, microperthite, } \\
\text { and quartz }\end{array}$ & Albite, orthoclase and quartz & $\begin{array}{l}\text { Quartz, oligoclase, orthoclase, } \\
\text { perthite, sanidine and biotite }\end{array}$ \\
\hline Lithics & Rare & Rare & Rare \\
\hline Fabric & Flow-banded & $\begin{array}{c}\text { Flow-banded, locally } \\
\text { autobrecciated lava; densely } \\
\text { welded ignimbrites }\end{array}$ & $\begin{array}{l}\text { Non-welded to densely welded, } \\
\text { well-developed columnar joints }\end{array}$ \\
\hline $\begin{array}{l}\text { Preserved } \\
\text { thickness of the } \\
\text { unit }\end{array}$ & $>150$ to $400 \mathrm{~m}$ & $>400 \mathrm{~m}$ & $>400 \mathrm{~m}$ to $1,000 \mathrm{~m}$ \\
\hline $\begin{array}{l}\text { ID-TIMS U-Pb } \\
\text { zircon age (Ma) }\end{array}$ & $141.2 \pm 0.3$ & $140.7 \pm 0.2$ & $140.9 \pm 0.2$ \\
\hline
\end{tabular}


The Lion Rock Suite includes six granitic plutons and quartz monzonitic stocks and related intrusions that are identified on their petrological and geochemical characteristics (Table 2.6; Sewell et al., 2000). Sewell and Campbell (1997) considered that these granitic rocks varied from fractionated I-type to A-type in composition. The Kowloon Granite (140.4 \pm 0.2 Ma: Davis et al., 1997) forms a sub-circular pluton of broadly equigranular, mediumgrained granite (72-77 wt\% $\mathrm{SiO}_{2}$ ) centred on Kowloon and northern Hong Kong Island (Fig. 2.8; Sewell et al., 1992; Campbell and Sewell, 1997). The pluton intrudes volcanic rocks of the RBVG units near eastern Kowloon and in western and central Hong Kong Island (Strange and Shaw, 1986; Sewell et al., 2000). The northeastern and eastern margins of the Kowloon Granite are in turn intruded by the Mount Butler Granite, which is an inequigranular fine-grained, leucocratic monzogranite (75-78 wt\% $\mathrm{SiO}_{2}$ : Strange and Shaw, 1986; Sewell et al., 1992, 2000). The pluton has been dated using Rb-Sr whole rock methods at $136 \pm 1$ Ma (Sewell et al., 1992). However, based on field relationships, the Mount Butler Granite is probably nearly coeval with or only slightly younger than the

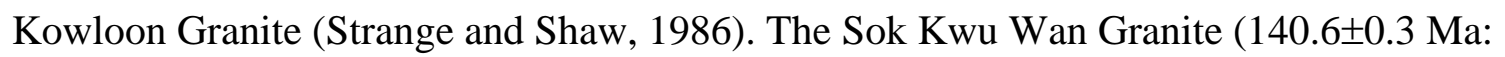
Sewell et al., 2012b), exposed on Lamma Island and in southeast Hong Kong Island (Fig. 2.8), is a porphyritic (monzonitic) granite (68-77 wt\% $\mathrm{SiO}_{2}$ ) with megacrysts of euhedral pink feldspar up to $3 \mathrm{~cm}$ long.

Three quartz monzonite intrusive units are grouped in with the Lion Rock Suite: the Tei Tong Tsui, Tong Fuk and D’Aguilar quartz monzonites. The Tei Tong Tsui Quartz Monzonite comprises a series of composite dykes (quartz monzonite to monzogranite) in southeast New Territories and on Hong Kong Island (Sewell et al., 2000; Fig. 2.7). It has not yet been dated radiometrically, although field relationships suggest that it has intruded the Kowloon Granite (Strange and Shaw, 1986). The Tong Fuk Quartz Monzonite (140.4 \pm 0.3 Ma: Davis et al., 1997) includes a series of quartz monzonite stocks and dyke intrusions along the structural margin of the Lantau caldera (Sewell et al., 2000). The D’Aguilar Quartz Monzonite (140.6 \pm 0.3 Ma: Davis et al., 1997) is exposed on the southeast Hong Kong Island and eastern Lamma Island (Fig. 2.7). A similar quartz monzonite was also identified from marine boreholes and surface exposures on small islands immediately west of Hong Kong Island. Magmatic foliations of aligned feldspar crystals and cumulate textures are commonly seen in these quartz monzonites. 


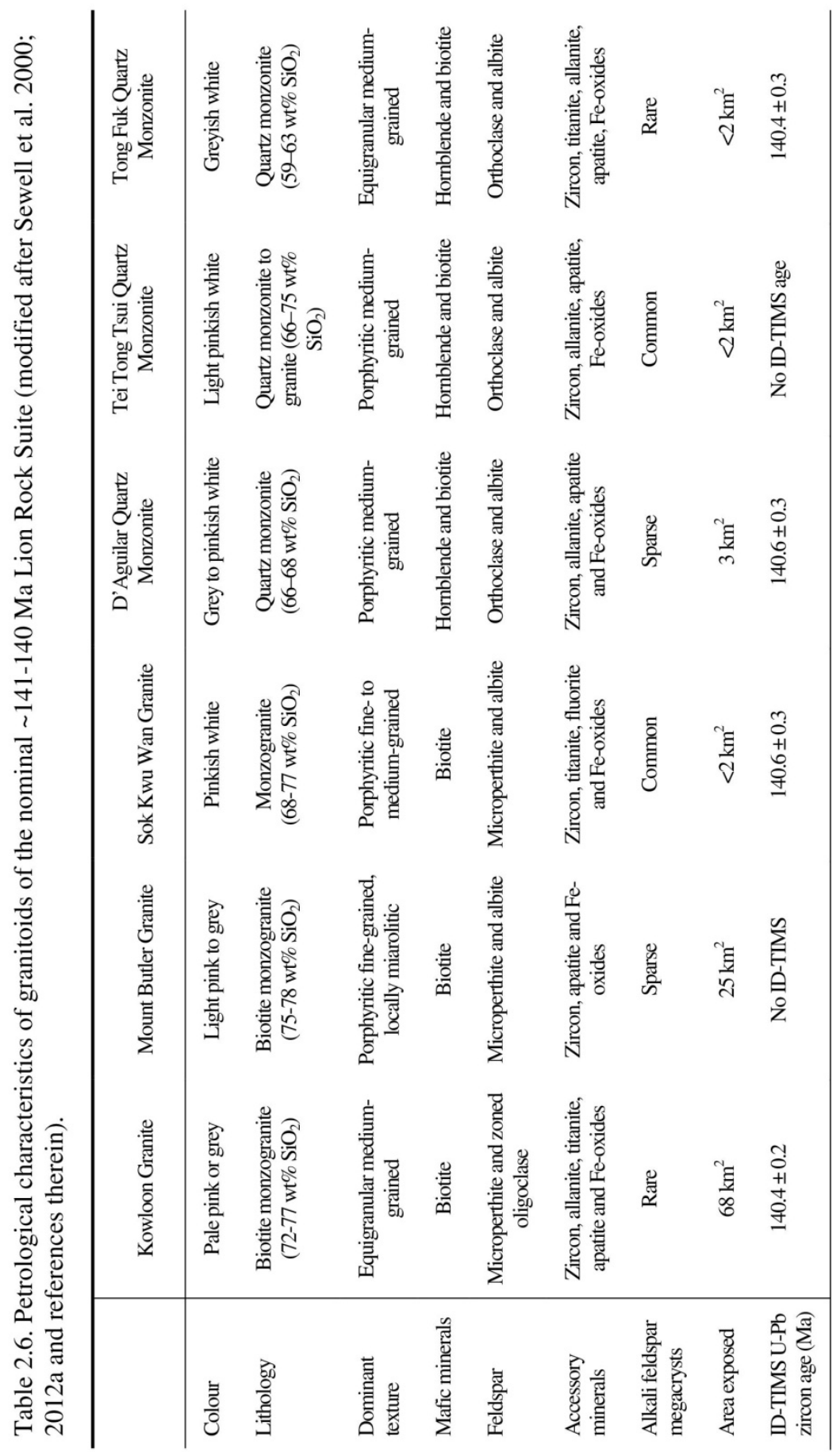




\subsection{Caldera complexes}

\subsubsection{Lantau caldera complex}

The $15 \mathrm{~km}$ long by $8 \mathrm{~km}$ wide Lantau caldera was identified by Langford et al. (1995) based on the distribution of fault-bounded volcanic outcrops on Lantau Island and the interpretation of several quartz monzonitic stocks and dykes as ring-fault intrusions (Figs. 2.4, 2.8). Early mapping suggested that the volcanic strata within the Lantau caldera were dominated by the LVG, underlain by relatively limited exposures of the TWVG in the southern part of the caldera (Strange et al., 1995). Later, So (1999) identified a 230-m thick sequence of welded tuff, flow-banded rhyolite and tuff breccia capping the peaks of Lantau Island, and demonstrated that the petrological and whole-rock geochemical characteristics of these volcanic sequences were largely different from those of the bulk of the LVG. Combining these field observations with geochronological (ID-TIMS U-Pb zircon ages) and whole-rock geochemistry (particularly $\mathrm{TiO}_{2}$ versus $\mathrm{Zr}$ ) data, Campbell et al. (2007) confirmed that the volcanic successions within Lantau caldera include a condensed record of all four major Middle Jurassic to Early Cretaceous volcanic episodes. The timing of caldera collapse, however, had not been well constrained in previous studies. Nonetheless, given that the caldera bounding structures truncated 146 Ma dyke swarms (Lantau dyke swarms, Langford et al., 1995) and were subsequently exploited by 140 Ma quartz monzonitic intrusions (Tong Fuk Quartz Monzonite, section 2.4.4), the Lantau caldera probably underwent a collapse between 146 and 140 Ma.

Within Lantau caldera, the volcanic strata show complex internal structures, including abrupt changes in bedding orientation and lithology, folding, local unconformities and faults (Langford et al., 1995). Langford et al. suggested that although individual beds dip variably, the entire volcanic sequence is tilted broadly at $20-30^{\circ}$ to the north (Fig. 2.5). These structures were interpreted as largely primary and related to piecemeal collapse and infilling of the associated Lantau caldera (Sewell et al., 2000). Reconstruction of regional fault structures demonstrated that the Lantau caldera had been distorted by strike-slip extensional movements along some major NE-trending faults, and implied that the original caldera was probably sub-circular with a diameter of $\sim 10 \mathrm{~km}$ (Sewell et al., 2000).

Another notable attribute of the Lantau caldera is the identification of Early Cretaceous granitic plutons and quartz monzonite stocks ( 143 Ma and 140 Ma) along its inferred structural margin (Figs. 2.4 and 2.7; Langford et al., 1995; Campbell and Sewell, 1997). 
These intrusions exploited the caldera bounding structures of Lantau caldera, implying that the underlying magmatic system was probably either still active or was reactivated in the Early Cretaceous magmatic episodes. The close relationship of these intrusions with the caldera bounding structures provides a comparative tool for identification of similar tectono-magmatic structures in southeast Hong Kong.

\subsubsection{Nested caldera complex in southeast Hong Kong}

The geology of southeast Hong Kong was interpreted by Sewell et al. (2012a) as incorporating an eastward-tilted, nested caldera complex, encompassing volcanic-plutonic assemblages from the Repulse Bay and Kau Sai Chau volcanic groups and their subvolcanic igneous suites (Fig. 2.9). In their model, the caldera complex was dominated by the High Island caldera and its co-magmatic subvolcanic intrusions of the Lion Rock Suite. In eastern Kowloon and the Sai Kung area, the Early Cretaceous volcanic successions have been tilted eastward up to $30^{\circ}$ and block-faulted by a series of caldera-related structures (Fig. 2.9). On southwest Hong Kong Island, the RBVG volcanic strata were strongly dismembered by block-faulting and folding during the 141 Ma caldera collapse (Strange and Shaw, 1986; Sewell et al., 2012a). The different structural characteristics of the volcanic sequences were interpreted as reflecting crustal tilting of the nested caldera and deep foundering of the RBVG volcanic sequences, now represented by the volcanic strata in southeast Hong Kong (Fig. 2.9; Sewell et al., 2012a). The structural interpretation of the volcanic sequences within the High Island caldera complex has been further reviewed based on the findings from additional fieldwork undertaken in this study (see Chapter 3).

The boundaries of the nested caldera complex were identified from mapped fault structures, discontinuous outcrops of quartz monzonite and related intrusions, as well as tectonomagmatic structures recognised from offshore geophysical lineaments (Sewell et al., 2012a). Several tectono-magmatic faults, including the Tolo Channel, Cheung SheungChek Keng, Wong Chuk, Tin Ha Shan, Jordan Valley, Tiu Keng Leng, and Sheung Sze Mun faults were specifically defined. These faults were considered to be related to the caldera collapse, contributing kilometre-scale vertical subsidence and/or serving as magma conduits during the two Early Cretaceous volcanic episodes (Fig. 2.9; Sewell et al., 2012a). The field characteristics of these structures are further described in the following Chapter 3 on the discussion of my new fieldwork results. 


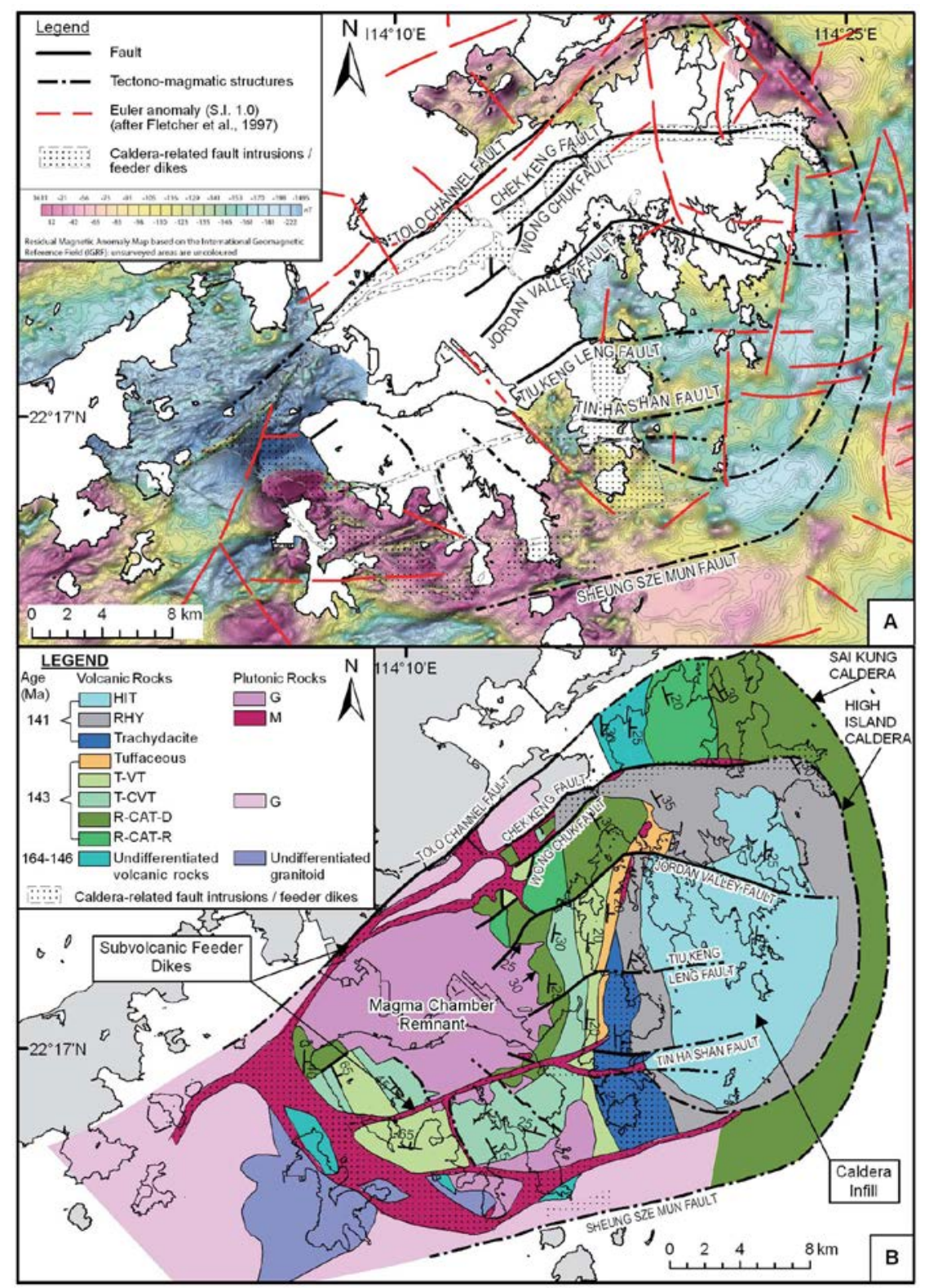

Fig. 2.9. Proposed nested High Island caldera complex in southeast Hong Kong (after Sewell et al., 2012a). (A) Caldera boundary and tectonic magmatic structures identified based on field evidence of major faults and interpretation of the existing offshore magnetic map and Euler gravity anomaly data (after Fletcher et al., 1997, 2000; Sewell et al., 2000). (B) Anatomy of the tilted nested caldera complex which comprises volcanic sequences of the RBVG ( 143 Ma) and KSCVG ( 141 Ma) exposed in the east and southeast and plutons of the Cheung Chau Suite and Lion Rock Suite exposed in the central and western part of the complex. The volcanic and plutonic units are spatially linked by the quartz monzonite dykes and stocks, which were interpreted as closely related to the caldera bounding structures. Abbreviations: HIT = High Island Tuff; RHY = rhyolite lava; T-VT = trachytic subgroup - welded fine ash tuff; T-CVT = trachytic subgroup crystal-bearing fine ash tuff; R-CAT-D = rhyolitic subgroup - dacitic coarse ash tuff; R-CAT-R = rhyolitic subgroup - rhyolitic coarse ash tuff; $\mathrm{G}$ = granite; $\mathrm{M}=$ quartz monzonite. 
The southern and northern boundaries of the High Island caldera are delimited by faultcontrolled tabular quartz monzonite to monzogranite intrusions which fed the trachydaciterhyolite domes and volcanic conduits exposed in easternmost outcrops. The eastern boundary of the caldera is delimited by N-S trending magnetic and gravity (Euler) lineaments (Fig. 2.9) which are inferred to mark intrusions along faults at depth, based on other examples intersected in tunnel excavations. The western boundary, exposing a deeper crustal level, is marked by NW- to N-trending cumulate-textured quartz monzonite to monzogranite intrusions that are exposed on Lamma Island (Sok Kwu Wan Granite) as well as underlying the floor of the East Lamma Channel, west of Hong Kong Island.

Estimates of eruptive volumes of the late Mesozoic volcanic units in Hong Kong had not been previously made until Sewell et al. (2012a). The main problem was the difficulty in recognition of individual flow units and the associated co-ignimbrite ash deposits due to limited preservation. Sewell et al. (2012a) assessed the scale of eruption of the High Island Tuff and estimated that the total volume of magma erupted was $\sim 570 \mathrm{~km}^{3}$ (dense rock equivalent, DRE). This estimated volume falls within the general definition of a supereruption (Mason et al., 2004). This estimate was based on knowledge from younger ignimbrites (e.g. Sparks and Walker, 1977; Lipman, 1984, 1997), especially the empirical observation that the volume of intracaldera ignimbrite is approximately equal to that of the outflow deposit and that of the co-ignimbrite ash-fall deposit. Such estimation, however, was necessarily speculative owing to uncertainties over the amount of regional postvolcanic erosion, and the assumed volume of ash deposits outside the proposed caldera boundaries (Sewell et al., 2012a). The estimated eruptive volume of the High Island eruption is, however, comparable to those generated from calderas of similar dimension. For instance, the $25.4 \mathrm{ka}$ Oruanui eruption ( $530 \mathrm{~km}^{3}$ (DRE) from Taupo volcano, New Zealand: structural caldera $140 \mathrm{~km}^{2}$; Wilson, 2001; Wilson et al., 2006); the $25.1 \mathrm{Ma}$ Amalia Tuff ( $\sim 500 \mathrm{~km}^{3}$, from Questa Caldera, U.S.: 14 by $>15$ km in dimension; Lipman, 2007); and the 0.76 Ma Bishop Tuff ( $600 \mathrm{~km}^{3}$, from Long Valley Caldera, U.S.A.: 12 by $22 \mathrm{~km}$ in dimension; Hildreth, 2004) are examples that fall within this general size category. 


\subsection{Summary}

This chapter has presented an overview of the large silicic igneous province of the Southeast China Magmatic Belt (SCMB) and the relevant geological background of Hong Kong. An extensive volcanic arc was formed in southeast China during the Mesozoic Yanshanian event when a subduction-related active continental margin was developed. Large caldera complexes comprising both the voluminous volcanic products and their subvolcanic plutons are now commonly exposed within this southeast China magmatic belt. Hong Kong, although only a small part of this extensive igneous province, is underlain mainly by silicic volcanic and intrusive rocks emplaced during a period of active magmatism that lasted for over 24 Myr. As discussed in this chapter, the general connections of these volcanic and sub-volcanic plutons have been established based on field relationships, in conjunction with geochemical and geochronological data. These previous studies have laid a solid foundation for further investigation of the evolutionary history of the magmatic systems in Hong Kong, and the connections between the paired volcanic and intrusive units.

The continuing sections of this thesis focus primarily on the Mesozoic volcanic-plutonic assemblages in Hong Kong. Three aspects of the volcanic-plutonic assemblages, including field relationships (Chapter 3); zircon trace element and geochronological data (Chapter 4); and low-temperature thermochronology (Chapter 5) are investigated. Chapter 6 presents a synthesis of the findings, and discusses the evolution of the Mesozoic large silicic magmatic systems in Hong Kong and the implications to the history of the Yanshanian Southeast China Magmatic Belt (SCMB). 
Chapter 3 / Geological

Constraints from New Field Studies 


\subsection{Introduction}

Field evidence has been of paramount importance in establishing the spatial and temporal relationships of individual volcanic units and exposed granitic plutons in Hong Kong. Basic field mapping of the entire territory at 1:20,000-scale was completed in the mid1990s (GCO, 1986a, 1986b, 1987, 1988a, 1988b, 1989a, 1989b, 1989c, 1989d, 1991; GEO, 1991, 1992, 1994, 1995, 1996). The objective of the fieldwork carried out under this study was therefore not to re-survey the area, but to establish specific field relationships and characteristics of the volcanic sequences and granitic units within the High Island caldera complex in southeast Hong Kong. In addition, the spatial and temporal connections between the volcanic and granitic units were critically evaluated. The findings presented in this chapter are aimed at refining the interpretations of the High Island caldera complex presented in Sewell et al. (2012a).

This chapter focuses on four main aspects. These are: (1) stratigraphy and structural interpretations of the Repulse Bay Volcanic Group (RBVG); (2) structural aspects of the High Island Tuff and Kau Sai Chau Volcanic Group (KSCVG); (3) textural features of the granitic units of the Lion Rock Unit; and (4) field characteristics of the inferred tectonomagmatic structures of the High Island caldera. The findings provide new insights into the characteristics, geometries and dimensions of the High Island caldera complex in southeast Hong Kong. Location of the key field observations is shown in Fig. 3.1. 


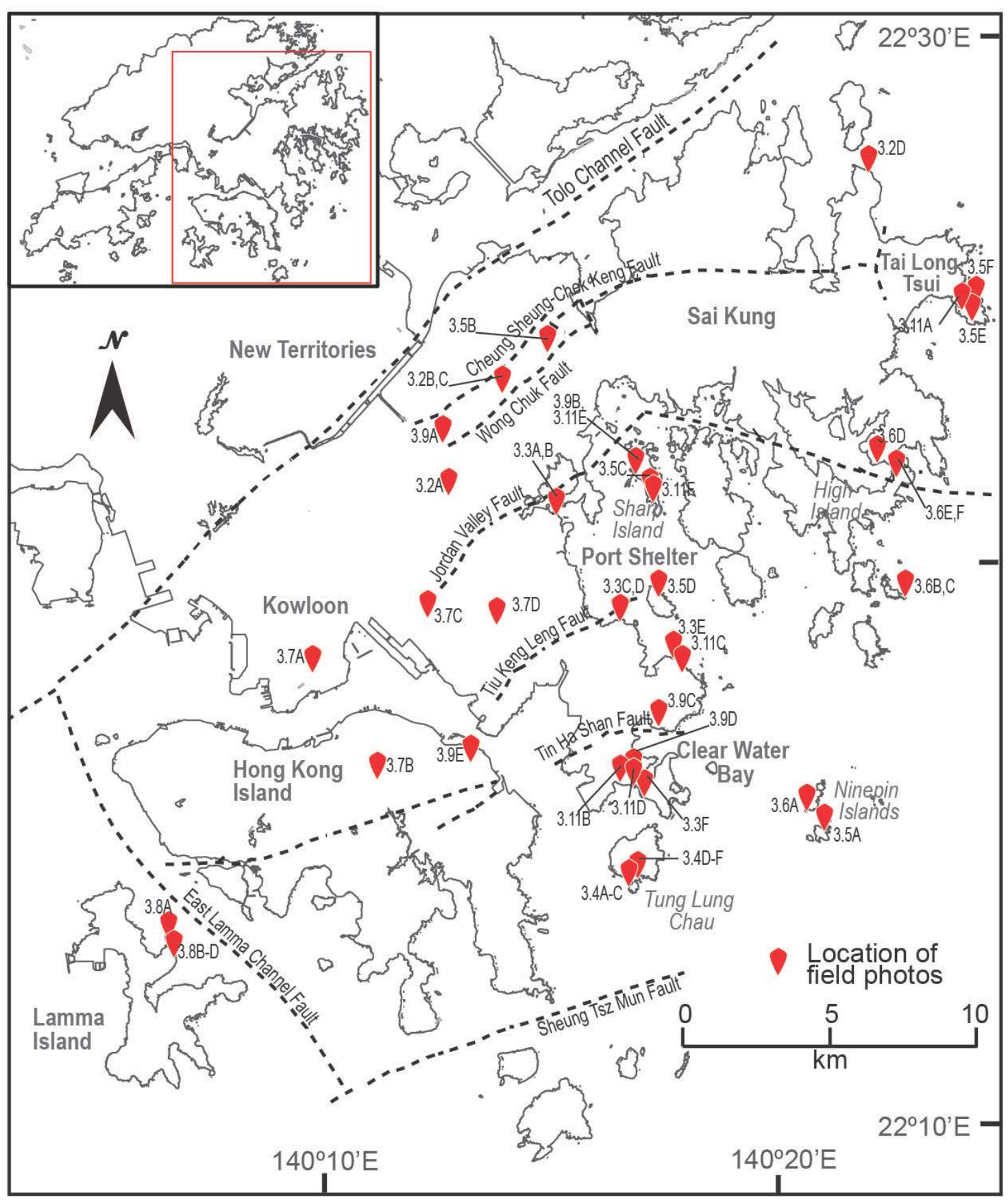

Fig. 3.1. Location plan of key field observations of the High Island caldera complex, southeast Hong Kong, described in this chapter. The inset in the left upper corner shows the entire territory of Hong Kong. 


\subsection{Major findings of fieldwork}

\subsubsection{Structural aspects of Repulse Bay Volcanic Group}

\subsubsection{Northern and eastern part of High Island Caldera}

In the Sai Kung and eastern Kowloon areas, the Repulse Bay volcanic successions dip variably to the east at $10-30^{\circ}$, and are overlain unconformably by the Kau Sai Chau volcanic sequences that are exposed further to the east (Fig. 3.2A). A composite stratigraphic column of the RBVG and KSCVG (Fig. 2.6) was established by Sewell et al. (2012a) essentially based on the identification of relatively intact, faulted volcanic strata, comprising the Mount Davis and Long Harbour formations, and the 148-146 Ma and 164 Ma volcanic successions, exposed in the area south of the Tolo Channel and around Long Harbour. Within this area, the Mount Davis Formation comprises thick deposits of lithic-bearing, crystal-rich tuff (Fig. 3.2B) with intercalated, discontinuous tuffaceous layers. Crude cooling columns are developed in the Mount Davis ignimbrite close to the bounding structures of Cheung Sheung and Wong Chuk faults (Section 3.2.4, Fig. 3.2C).

The Long Harbour ignimbrite is spatially restricted to the Sai Kung area and not found elsewhere in Hong Kong. The unit has textures that are very similar to those of the Mount Davis ignimbrites, but is characterised by massive lithic-bearing, crystal-rich ash tuff (without tuffaceous interbeds) which diagnostically contains abundant alkali feldspar phenocrysts and granitic lithic fragments (up to $20 \mathrm{~cm}$ in size) at the lower part of the unit (Fig. 3.2D; Strange et al., 1990 and this study).

Previous interpretations by Campbell and Sewell (1997) suggested that the Long Harbour ignimbrite was erupted from two proposed calderas, namely the 'Sai Kung' and 'Long Harbour', which were roughly delineated by intermittent quartz monzonite bodies. The distribution of the Long Harbour ignimbrite was considered to be restricted within the two proposed collapse calderas. This original proposal is considered to no longer be valid because the interpretation could not explain the stratigraphic relationships of the Long Harbour ignimbrite with the underlying volcanic units seen in the field. The spatial distribution of Long Harbour ignimbrite is re-interpreted here as reflecting the initial ponding of the deposit within a depression defined by the Tolo Channel and Jordan Valley faults, and its subsequent offset along the Cheung Sheung-Chek Keng Fault as a result of 
the collapse of High Island caldera and/or later tectonic activities along this fault structure.

This interpretation is supported by field observations which show an abrupt change in

lithologies from the Long Harbour ignimbrite to the KSCVG units across the Cheung

Sheung-Chek Keng Fault (Strange et al., 1990).

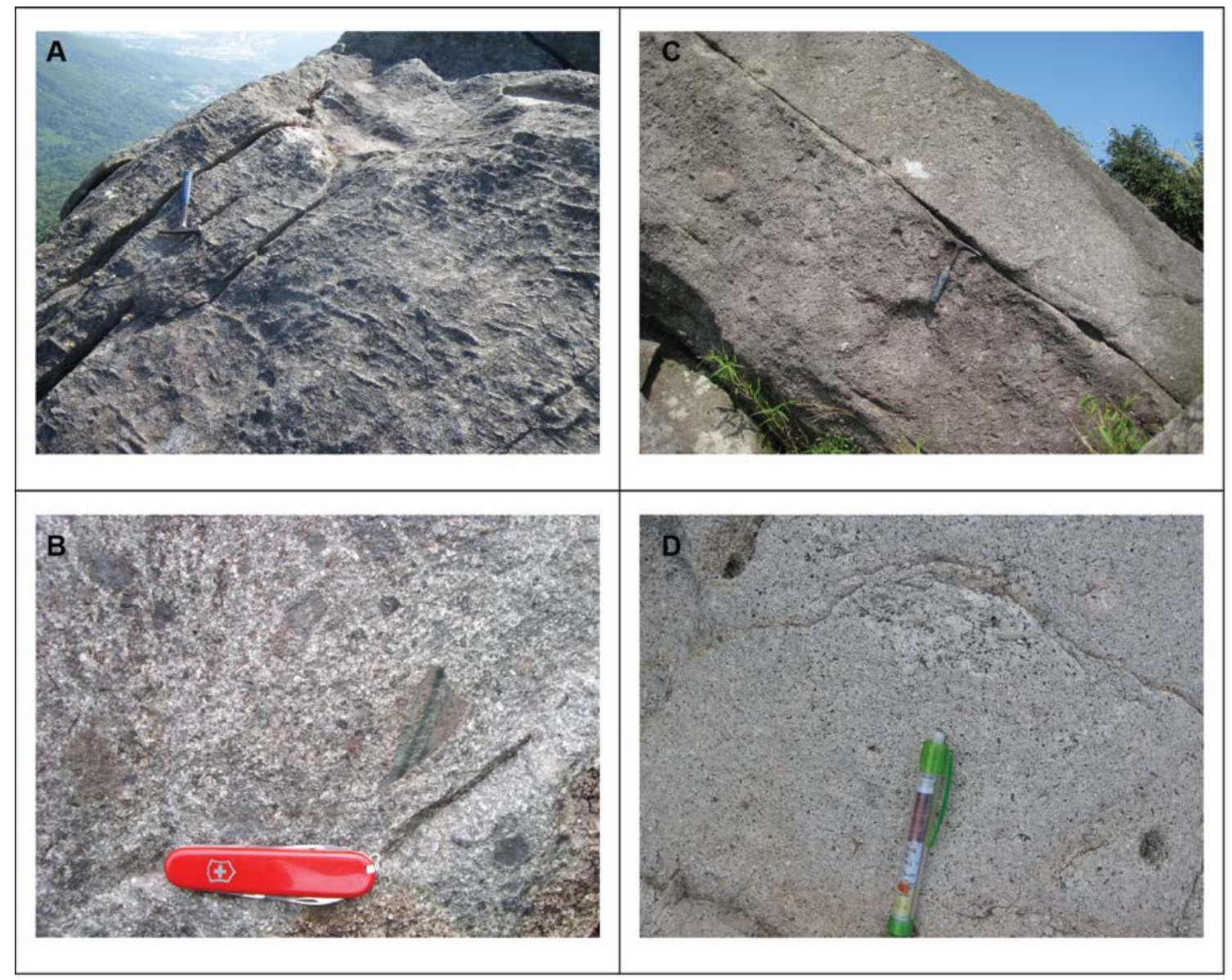

Fig. 3.2. Field photographs showing the outcrop characteristics of the RBVG in the Sai Kung and east Kowloon areas. (A) [824934N 841115E $]^{1}$ Eutaxitic foliated ignimbrite, showing the inclined volcanic sequence of the Mount Davis Formation: Buffalo Hill, east Kowloon. (B) and (C) [828576N 843403E] Lithic bearing, crystal-rich ignimbrite of the Mount Davis Formation, Ma On Shan, eastern New Territories. (C) Crude columnar cooling joints developed in the Mount Davis ignimbrite (D) [835501N 855738E] Granitic lithic clasts in crystal-rich ignimbrite of the Long Harbour Formation, Sai Kung. For scale, in (A) and (C), geological hammer = $28 \mathrm{~cm}$ long; in (B) pocket knife = $7 \mathrm{~cm}$ long; in (D) pen = $12 \mathrm{~cm}$ long.

${ }^{1}$ Grid references are to the nearest metre in the Hong Kong 1980 Grid System. 


\subsubsection{Clear Water Bay Peninsula area}

On the Clear Water Bay Peninsula, the welded ignimbrites of the Chek Kwu Shan (Fig. 3.3A) and Ap Lei Chau formations generally dip to the east and are overlain by the Mang Kung Uk volcaniclastic sediments, and in turn by the flow-banded Pang Long Wan trachydacite lava (Figs. 3.3A, B, C; Strange et al., 1990; Sewell et al., 2012a). Although the Mang Kung Uk Formation was shown as a rather persistent tuffaceous layer across Port Shelter (Sai Kung Hoi) by Sewell et al. (2012a; reproduced in Fig. 2.9B), the unit is essentially confined to two key outcrop areas, in Sai Kung and Clear Water Bay Peninsula respectively, and is apparently bounded by the tectono-magmatic structures of the High Island caldera. In the Clear Water Bay Peninsula, the tuffaceous unit includes relatively continuous, well-bedded, eastward-dipping strata, comprising tuffaceous sandstone, siltstone, conglomerate and ash tuff (Strange et al., 1990 and this study, Figs. 3.3D, E, F). Here, the tuffaceous layers are intruded by trachydacitic dykes and monzonitic bodies (see Section 3.2.4.2).

Rare thin layers containing accretionary lapilli were reported at the south-western coast of the peninsula by Strange et al. (1990), although this exposure was later destroyed by reclamation projects. In contrast, the tuffaceous unit is composed of mainly clast-supported, polymictic tuffaceous breccias, accumulated in close vicinity of the Jordan Valley Fault in Sai Kung (see Section 3.2.4.3). The Mang Kung Uk Formation is therefore reinterpreted here as representing two volcanic facies. In the Clear Water Bay Peninsula, the unit is inferred to be reworked epiclastic sediments deposited in a local fault-bounded basin, and with occasional ash layers from sporadic eruptions through a lake or other water bodies, as evidenced by the presence of accretionary lapilli beds. In contrast, the unit in Sai Kung is interpreted to represent an accumulation of faulted volcaniclastic materials, comprising angular blocks of rhyolite, welded tuff, tuffaceous sandstone and cherty siltstone, adjacent to the caldera-bounding structures. 


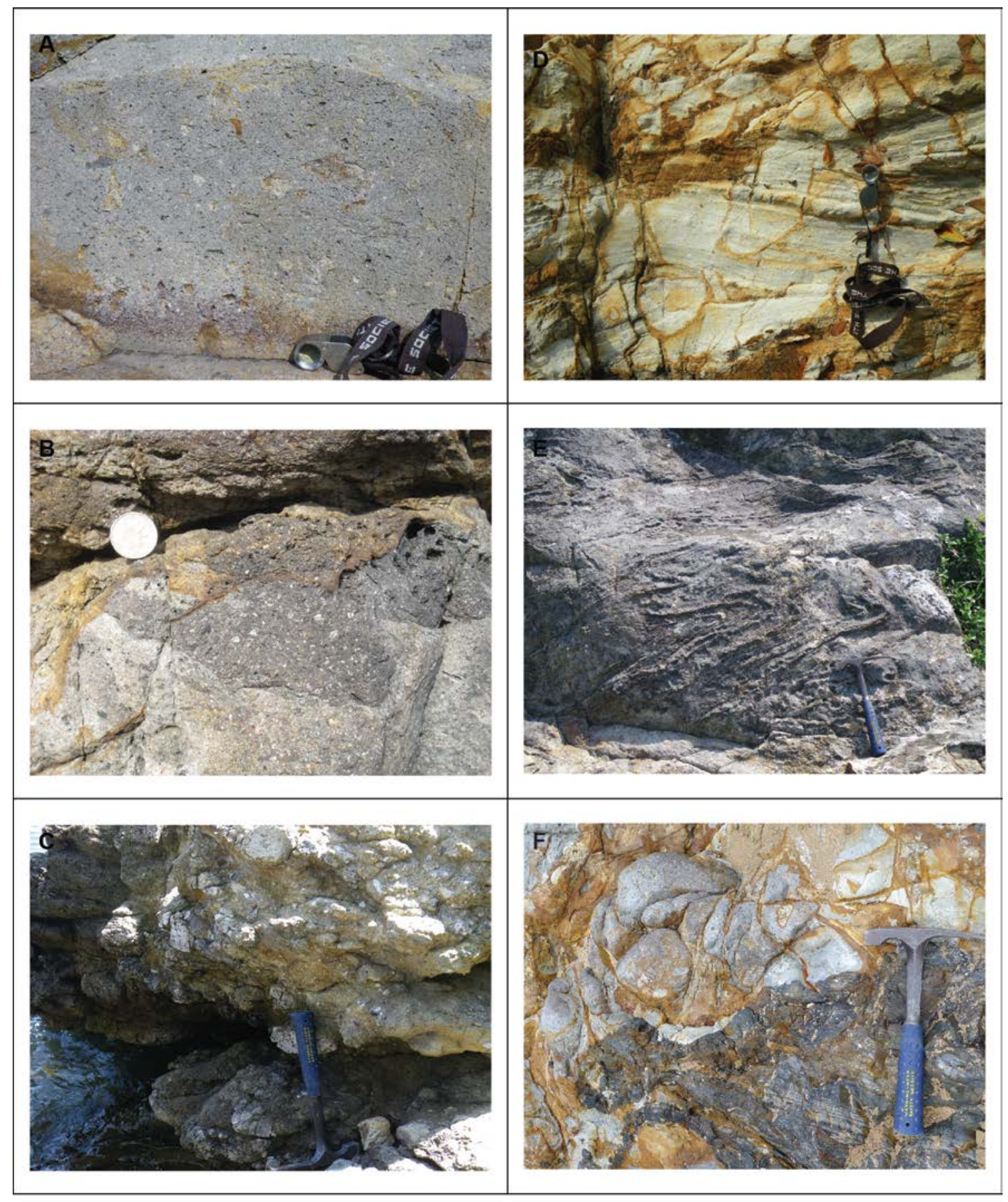

Fig. 3.3. Field photographs of the RBVG in the Clear Water Bay Peninsula area. (A), (B) [823739N 845408E] Lithic-bearing welded ignimbrite of the Che Kwu Shan Formation, Camper's Beach, Sai Kung. In (B), irregular-shaped, juvenile clasts of trachydacitic composition are present in welded Che Kwu Shan ignimbrite. (C) [820263N 847139E] Tuffaceous conglomerate, consisting of poorly sorted, matrix supported clasts (including cherty siltstone, mudstone and crystal tuff, up to $10 \mathrm{~cm}$ in size), Mang Kung Uk Formation, near Pik Sha Wan, Clear Water Bay Peninsula. At this location, the tuffaceous layer dips at $\sim 10^{\circ} \mathrm{SE}$. (D) [814553N 847973E] Layered tuffaceous sandstone, Clear Water Bay Peninsula. (E) [819030N 848848E] Flow-banded trachydacite lava of the Pan Long Wan Formation, Clear Water Bay Peninsula. (F) [814500N 847980E] Tuffaceous sandstone and mudstone layers, Tai Mui Wan, southern Clear Water Bay Peninsula. Soft sediment deformation in the tuffaceous mudstone is evident. For scale: in (A) and (D), hand lens $=6 \mathrm{~cm}$ long; in (B), coin $=2.5 \mathrm{~cm}$ in size; in $(\mathrm{C}),(\mathrm{E})$ and $(\mathrm{F})$, geological hammer $=28 \mathrm{~cm}$ long. 


\subsubsection{Che Kwu Shan ignimbrite on Tung Lung Chau}

The strongly welded ignimbrite unit exposed on Tung Lung Chau (Island), located south of the Clear Water Bay Peninsula (Fig. 2.5), was assigned to the Che Kwu Shan Formation by Sewell et al. (2000). Field observations carried out in this study reveal that the ignimbrite unit exhibits pronounced eutaxitic foliation and comprises abundant lithic fragments (commonly several centimetres in size) of a range of lithologies, including cherty siltstone, eutaxitic tuff, rare granitic clasts, and juvenile clasts of notably trachydacitic composition (Figs. 3.4A, B, C). The presence of these juvenile clasts suggests that mixing and mingling of trachydacitic magma contributed to the ignimbritic eruptions. The orientation of the eutaxitic fabric is changeable, dipping from sub-horizontal to $40-50^{\circ} \mathrm{E}$ to SE. At the southern side of the island, the ignimbrite unit was deposited with a brecciated basal layer on a trachydacite lava (Figs. 3.4D, E). In addition, crude cooling joints (with joint spacing less than $0.5 \mathrm{~m}$ ) are developed in the ignimbrite at this location (Fig. 3.4F).

The overall field evidence is interpreted to mean that this location at Tung Lung Chau was probably a small, fault-bounded volcanic depression within the larger proto-High Island caldera. The ignimbrite sheet is variably dipping and structurally distinct from the easterly dipping Che Kwu Shan unit exposed in the Clear Water Bay Peninsula. However, both units have comparable compositional and textural characteristics (i.e. comprising abundant, assorted lithic fragments and pronounced eutaxitic foliation), suggesting that they belong to the same pyroclastic unit, but might represent depositional packages in different structural domains. The welded ignimbrite at Tung Lung Chau might have been ponded within the small depression where earlier trachydacite lava was extruded through a key volcanic conduit (now overprinted by the Tin Ha Shan Fault, Section 3.2.4.2). The variation in thickness of the Che Kwu Shan unit is thus interpreted as reflecting the original topographic relief when the unit was deposited. 


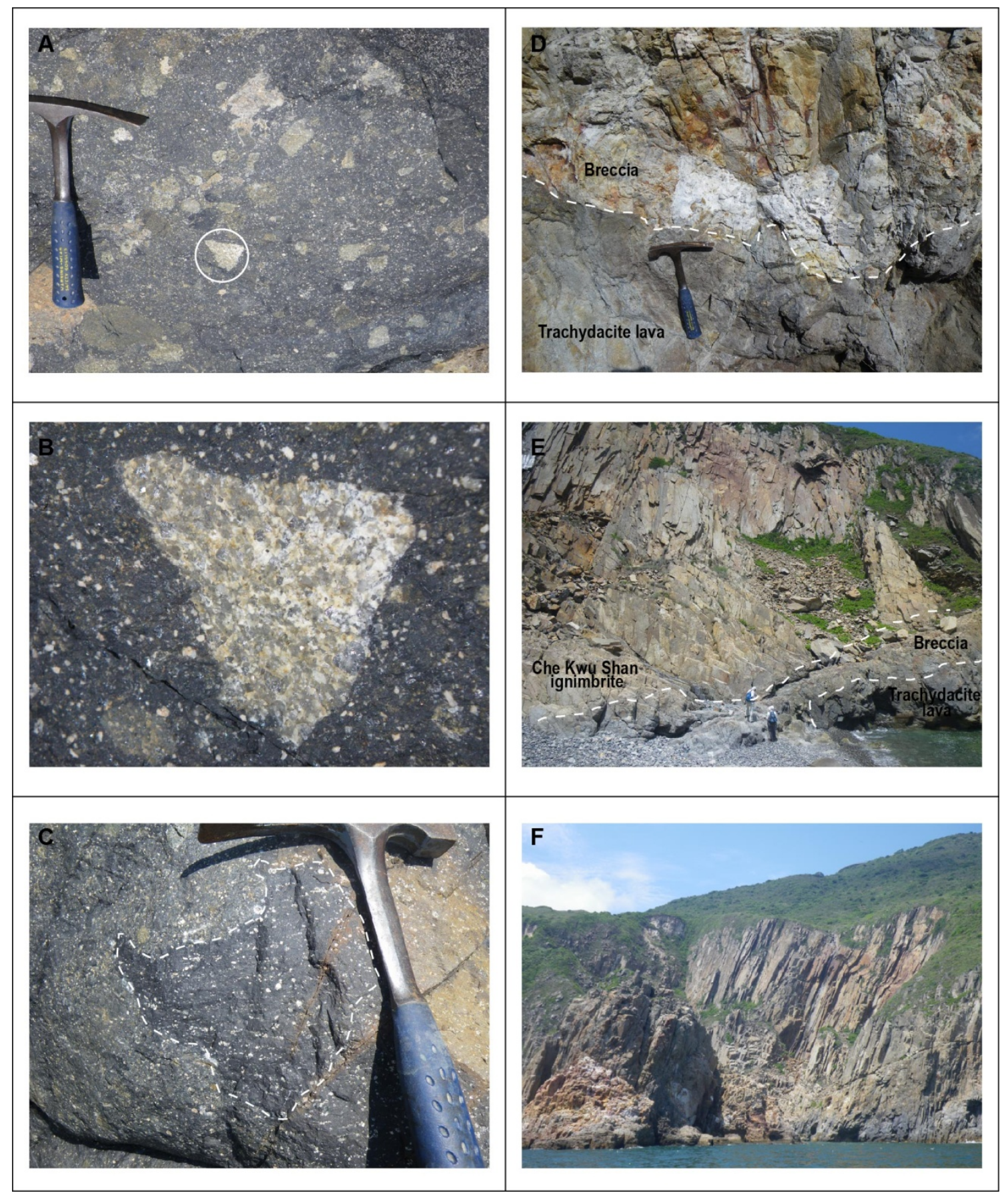

Fig. 3.4. Field photographs of the Che Kwu Shan ignimbrite on Tung Lung Chau. (A), (B), (C) [811113N 847592E] Lithic-rich, welded ignimbrite of the Che Kwu Shan Formation, Tung Lung Chau. (B) Close up view of a granitic fragment in the ignimbrite in (A) (white circle). (C) Same outcrop as (A) and (B), a juvenile clast of trachydacitic composition with a flow fabric. (D) [811585N 848097E] Contact of trachydacite lava and the overlying breccia at the base of the Che Kwu Shan ignimbrite, southern Tung Lung Chau. (E), (F) [811586N 848125E] An overview of the contact of trachydacite lava with the Che Kwu Shan ignimbrite. The ignimbrite sheet exhibits crude cooling joints. Two geologists at the base of the cliff as scale. (F) A general view of the columnar jointed Che Kwu Shan ignimbrite of the same exposure in (E). The cliff is about $60 \mathrm{~m}$ high. For scale: (A), (C) and (D), geological hammer $=28 \mathrm{~cm}$. 
In contrast to the relatively intact volcanic sequences exposed in the northern and eastern part of the nested caldera complex, the Repulse Bay volcanic strata on southern and western Hong Kong Island have been strongly dismembered. Strange and Shaw (1986) suggested that the volcanic strata on Hong Kong Island were deformed into a series of synclines and anticlines. In the tilted nested caldera complex model, Sewell et al. (2012a) proposed that the volcanic strata represent deep foundering of crustal blocks collapsed down into the magma chamber. Further interpretation of the field evidence does not support extensive folding of the volcanic successions on Hong Kong Island as suggested by Strange and Shaw (1986). Instead, the apparently variably oriented volcanic layers are inferred to be the consequence of block faulting and tilting, interpreted as such on the basis of offsets of the strata across major faults in the area (Fig. 2.5). Four main fault blocks are identified in the RBVG strata at Hong Kong Island: the volcanic strata at the western Hong Kong Island (two fault blocks) dip $\sim 40-65^{\circ}$ east or northeast; the block in the southwest Hong Kong Island dips at $\sim 45^{\circ}$ to the southwest; whereas the layers close to the southern margin of the High Island caldera complex in southern Hong Kong Island are in general gently dipping at $10-20^{\circ}$ variably to the northeast and northwest.

The structural aspects of the RBVG volcanic strata in the southern part of the nested caldera complex are re-interpreted here as expressing an asymmetrical caldera collapse of the High Island caldera. The tilted successions in the eastern part of the caldera probably reflect a trap-door type collapse, in which the subsidence of caldera floor was deeper on the eastern edge of the caldera than in the west. The resulting structural features include the observed eastward dipping of the Repulse Bay and Kau Sai Chau volcanic strata, and thickening of intra-caldera fill. The volcanic strata on Hong Kong Island are interpreted here to have been distorted by the combined effects of caldera collapse related to the High Island Tuff eruption, as well as the deformation due to the later intrusion of the Kowloon and Mount Butler granites against the base of the RBVG sequences.

\subsubsection{Structural aspects of Kau Sai Chau Volcanic Group}

\subsubsection{Clear Water Bay Formation}

The Clear Water Bay Formation comprises a wide range of volcanic lithologies, including flow-banded lava, autobrecciated lava, strongly welded ignimbrites, ash tuff and tuffaceous 
sediments, suggesting that they are the product of various eruption styles (Strange et al., 1990; and this study). The contact between the Clear Water Bay Formation and the High Island Tuff can be observed in a number of localities, including the West Dam of the High Island Reservoir, Yim Tin Tsai in Port Shelter, and South Ninepin Island (Fig. 2.9). At these locations, the High Island Tuff overlies autobrecciated lava of the Clear Water Bay Formation, comprising autobreccia clasts that are commonly flow-banded and with sparse feldspar phenocrysts (Fig. 3.5A). The field evidence thus confirms earlier interpretation by Strange et al. (1990) of the stratigraphic relationship of the Clear Water Bay Formation and High Island Tuff, even though their ID-TIMS ages are indistinguishable (Section 2.4.4).

A 100 m-wide, NE-trending, flow-banded rhyolite lava of the Clear Water Formation is here interpreted as having been extruded along a caldera-bounding structure (i.e. the Wong Chuk Fault, Fig. 3.5B). Rhyolite lava of this formation is also exposed in several islands (including Sharp Island and Shelter Island) in Port Shelter, and at the headland of the Clear Water Bay Peninsula. The lava locally contains spherulites and lithophysae which are formed from devitrification of volcanic glass (Fig. 3.5C). In addition, the Clear Water Bay Formation also comprises densely-welded, rheomorphic ignimbrites (Fig. 3.5D) and intervening fine ash layers, which might imply multiple eruptions of ignimbrite and coignimbrite ash deposits. However, due to limited exposures and faulted nature of the sequence, lateral correlations of individual ignimbrite and fine ash layers are not feasible.

The autobrecciated rhyolite exposed at Sharp Peak and Tai Long Tsui, Sai Kung, originally mapped as part of the Clear Water Formation, has been re-interpreted as a post-High Island extrusion of lava dome (Sewell et al., 2012a; 2012b, Fig. 3.5E), consistent with the age data presented in Chapter 4. The autobrecciated lava contains jig-saw-shaped, angular blocks of flow-banded rhyolite, and overlies a volcanic sequence of tuffaceous breccias and sediments (Fig. 3.5F). The volcaniclastic sequence was originally considered as part of the RBVG (Strange et al., 1990), but is re-interpreted here to be sediments deposited adjacent to the caldera boundary and into the local depression formed after the collapse of High Island caldera. 


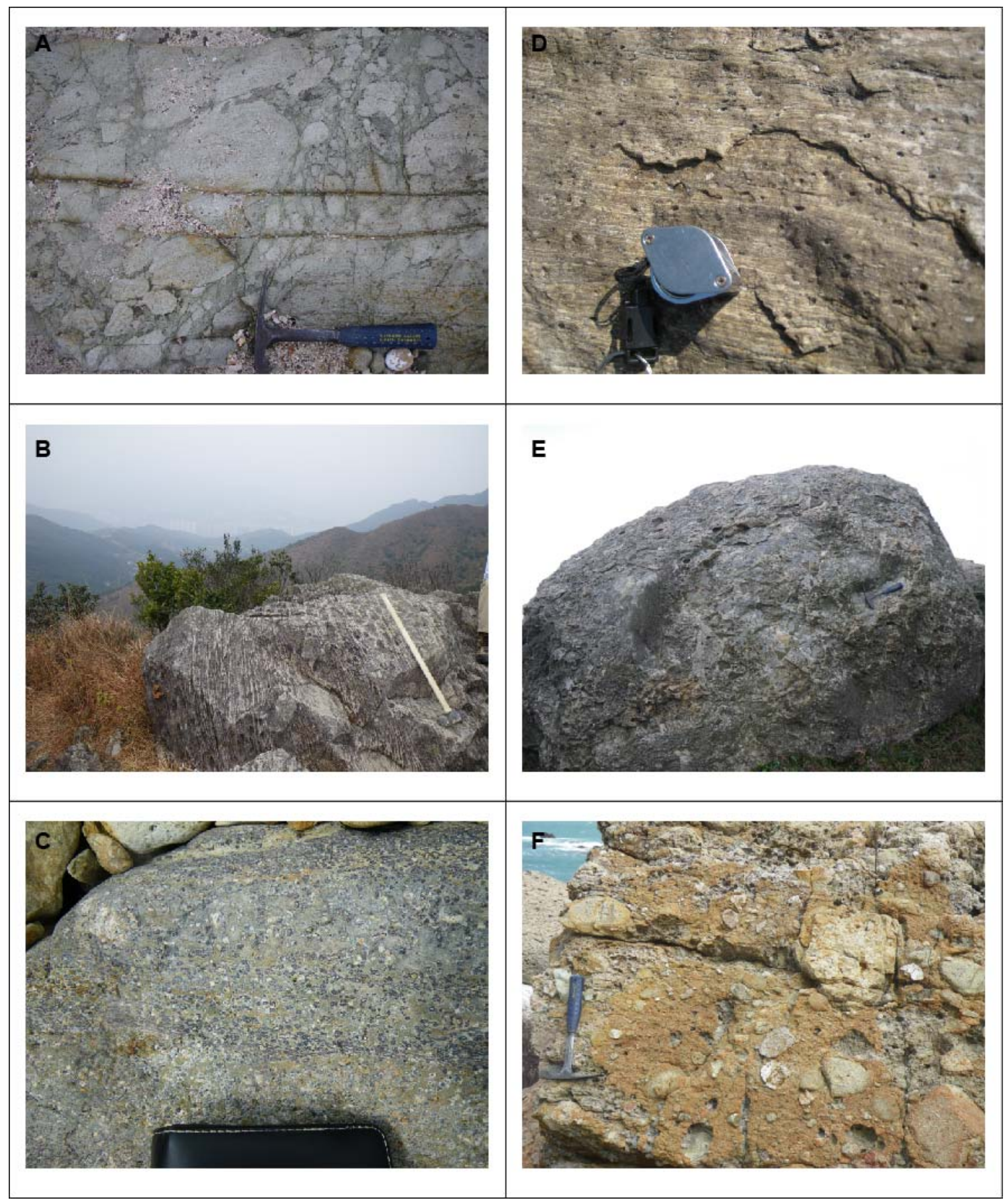

Fig. 3.5. Field photographs showing the representative outcrops of the Clear Water Bay Formation. (A) [813161N 854233E] Autobrecciated lava of Clear Water Bay Formation, which underlies the High Island Tuff, South Ninepin Island. (B) [829012N 844084E] Flow-banded rhyolite of the Clear Water Bay Formation, Pyramid Hill, Sai Kung. (C) [824500N 848200E] Spherulites (several mm in size) in rhyolite lava, Sharp Island, Sai Kung. (D) [821198N 848634E] Densely-welded, rheomorphic ignimbrite, showing parataxitic foliations, Shelter Island in Sai Kung. (E) [830501N 859226E] Autobrecciated post-High Island rhyolite lava at Tai Long Tsui, Sai Kung (F) [830770N 859619E] Polymictic tuff breccia, Tai Long Tsui, Sai Kung. For scale: in (A), (E) and (F), geological hammer = $28 \mathrm{~cm}$ long; in (B), sledgehammer = $1 \mathrm{~m}$ long; in (C), leather case $=15 \mathrm{~cm}$ long; in (D) hand lens $=3 \mathrm{~cm}$ long. 


\subsubsection{Tilting of columnar-jointed High Island Tuff}

Exceptionally well-developed cooling columnar joints are present in the 141 Ma High Island Tuff. The jointed columns are dominantly 6-or 5-sided with diameters of up to $2 \mathrm{~m}$ at the base of the unit (Fig. 3.6A), and gradually become 4-sided with joint-spacing of $\sim 0.3$ $\mathrm{m}$ in the upper part (Fig. 3.6B). The continuous nature of columnar jointing in the ignimbrite sheet and the apparently homogeneous whole-rock composition have been regarded as evidence for it being a single cooling unit (Strange et al., 1990; Sewell et al., $2000 ; 2012 a)$. The ignimbrite sheet generally dips to the east or northeast at $10-30^{\circ}$. Kinkbands are commonly seen in all levels of the High Island tuff and are persistently leaning to the east or northeast, i.e. the same orientation of the tilting unit (Fig. 3.6C). Curvatures in cooling columns are normally considered as a primary feature formed during propagation of the cooling joints perpendicular to the cooling front, such that contorted columns are generally interpreted as related to curved isotherms of the cooling material (Spry, 1962). However, the kink-bands in the High Island Tuff cannot be explained by curved cooling fronts, because the expected isotherms are either converging or diverging at the kink-bands (Fig. 3.6D). Furthermore, these kink-bands lack conjugate sets and therefore render them unlikely to be caused by tectonic stress.

At the type location of the High Island Tuff at the East Dam of High Island Reservoir, the columnar jointed ignimbrite sheet is cut by a mafic dyke $\sim 0.6-0.8 \mathrm{~m}$ wide (Fig. 3.6E). At this exposure, the mafic dyke apparently follows the fracture formed at the flexures of the kink-bands, which appear crumpled. The dyke contact is crenulated, suggesting that the dyke was emplaced while the ignimbrite was still hot and ductile (Fig. 3.6F). The overall field observations thus suggest that the kink-bands in the rock columns were probably formed during consolidation of the ignimbrite sheet when it was still warm and semi-solid, and was able to deform under its own weight. As proposed by both Spry (1962) and Grossenbacher and McDuffie (1995), who studied cooling joints in basaltic lava, development of columnar jointing probably occurs at a slightly subsolidus temperature, which is around $900{ }^{\circ} \mathrm{C}$ for basalt. For rhyolite, the solidus temperature is around $750-650$ ${ }^{\circ} \mathrm{C}$, dependent on the water content of the magma. This temperature range implies that development of cooling joints probably started soon after the deposition of the rhyolite ignimbrite sheet. Thus, the tilting of High Island Tuff and the kinking of columnar jointing were essentially syn-eruptive processes, accompanying caldera collapse. 


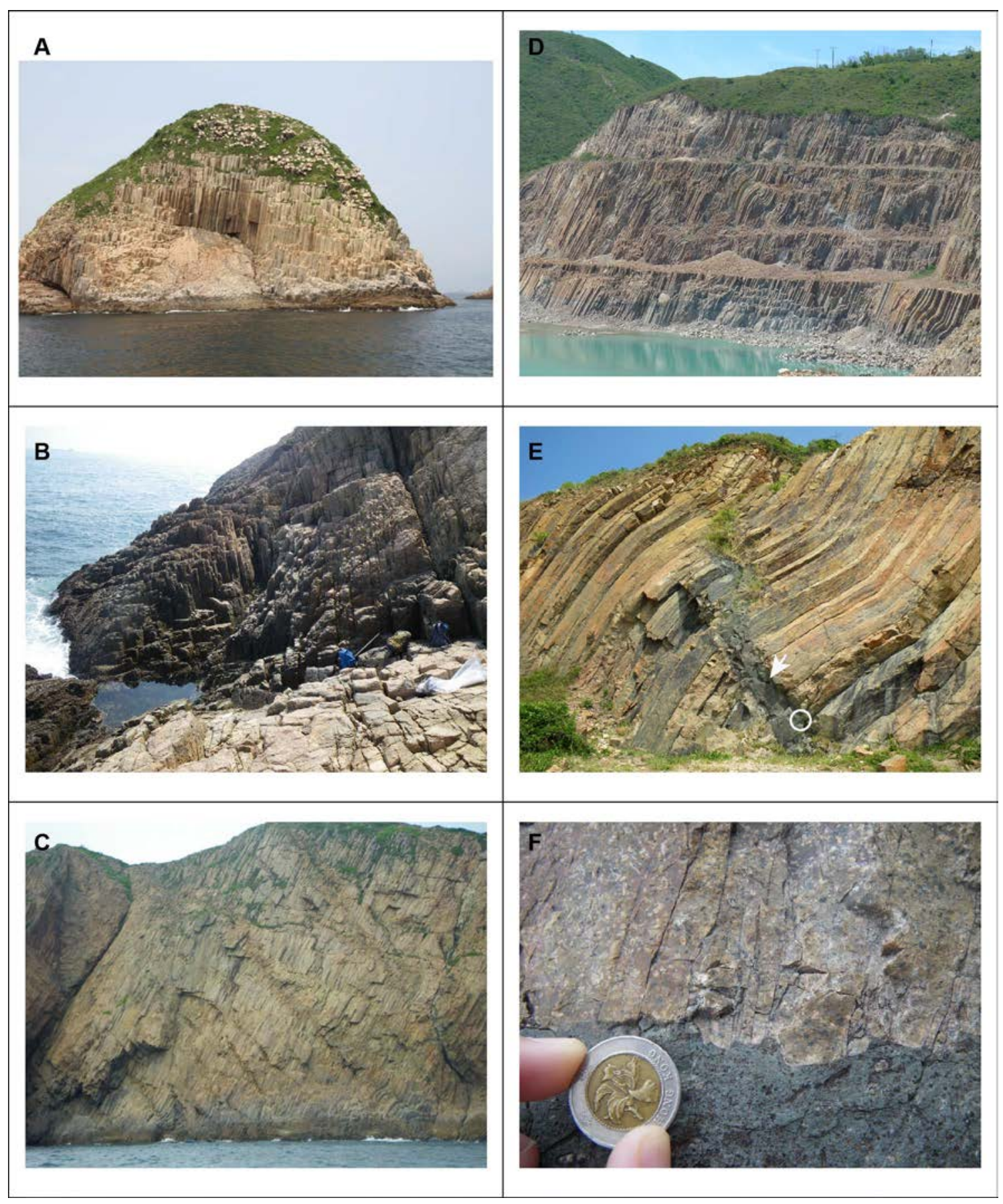

Fig. 3.6. Field photographs showing the representative outcrops of the High Island Tuff. (A) [813797N 853593E] Well-developed columnar joints at Ninepin Islands, Sai Kung. The diameter of columns is up to $\sim 2$ m. (B) [821178N 856981E] Less-well developed, 4-sided columnar joints at Wang Chau (island), Sai Kung. The size of the columns is $0.2-0.4 \mathrm{~m}$. (C) [821024N 856822E] Rock column consistently tilted to the east and northeast, Wang Chau, Sai Kung. Rock face is approximately 50 m high. (D) [825547N 856440E] Kinkbands of the columnar joints is inferred to have developed during consolidation of the ignimbrite sheet when it was still warm and semi-solid and deformed under its own weight, East Dam of the High Island Reservoir, Sai Kung. Rock face is approximately 50 m high. (E) and (F) [825025N 856639E] Mafic dyke intrudes the columnar jointed High Island Tuff, East Dam. The rock face is $\sim 12 \mathrm{~m}$ high. (F) Close up view of the dyke contact in (E, white circle). The crenulated nature of the contact implies that the dyke was emplaced while the ignimbrite was still hot and ductile. For scale: in (F), coin $=2.4 \mathrm{~cm}$ in diameter. 


\subsubsection{Textural characteristics of Lion Rock Suite}

\subsubsection{Kowloon and Mount Butler granites}

The equigranular, medium-grained Kowloon Granite forms a sub-circular granitic pluton centred on Kowloon, and is remarkably uniform in texture and composition (Strange and Shaw, 1986; Sewell et al., 1992, 2000). Further field evidence undertaken for this thesis reveals that the pluton is in fact texturally variable and shows evidence of alteration in many places. In the central part of Kowloon, the pluton is characteristically porphyritic and fine-grained (Fig. 3.7A); while core samples from the western part of Kowloon are coarser-grained. The close association of the Kowloon and Mount Butler granites have been demonstrated by their closely adjoining outcrop areas, and similarities in their emplacement ages, geochemical and isotopic characteristics (Strange and Shaw, 1986; Sewell et al., 1992, 2000; Sewell and Campbell, 1997). The Mount Butler Granite is inequigranular and commonly shows miarolitic cavities (crystal-lined irregular vugs formed by exsolution of volatile phases from crystallising magmas) and/or schlieren textures (concentrations of mafic minerals in a granitic rock), particularly near the intrusive contact with the Kowloon Granite (Fig. 3.7B). In addition, pegmatites and aplite veins are commonly seen in the Mount Butler Granite, and are also found locally in the Kowloon Granite in particular near the boundary with the Mount Butler unit (Fig. 3.7C). These textural characteristics of the Mount Butler Granite imply that the intrusion was probably crystallised from late-stage, highly-evolved melts, consistent with its whole-rock characteristics (Table 2.6). The intrusive contacts between Kowloon and Mount Butler granites are irregular and locally gradational. Field evidence suggests that the Mount Butler Granite, locally chilled against the Kowloon Granite, is the younger intrusive unit, but at some locations, their contacts appear to be gradational (Strange and Shaw, 1986; this study). I test the temporal relationships of these two plutons with U-Pb dating of zircon in Chapter 4.

The intrusive contact of the fine-grained granite of Mount Butler with the Mount Davis ignimbrite (crystal tuff) is well exposed in the face of Anderson Road Quarry (Fig. 3.7D) and some road side cuts in east Kowloon. This contact is sharp (over several millimetres), irregular and gently dipping to the northeast, with evidence of contact metamorphism in the volcanic rocks at Anderson Road Quarry. In western Hong Kong Island, the intrusion of the Kowloon Granite against the volcanics of the RBVG generally resulted in hornfelsed, 
silicified and recrystallised volcanic rocks (Fig. 3.7C). More advanced contact metamorphism of the crystal-rich ignimbrite is seen in two isolated outcrops in southeastern Kowloon, where the volcanic rocks are completely engulfed by fine-grained granite (Mount Butler Granite). The granite itself is greisenised here, and comprises mostly equigranular quartz and muscovite in a saccharoidal texture. Strange and Shaw (1986) considered that the volcanic outcrops represented roof pendants that had been enclosed by the granite intrusion. Overall, the field relationships suggest that both the Kowloon and Mount Butler granites are shallowly-emplaced plutons (within 2-3 km of the surface) that intrude into the overlying volcanic piles of the RBVG.

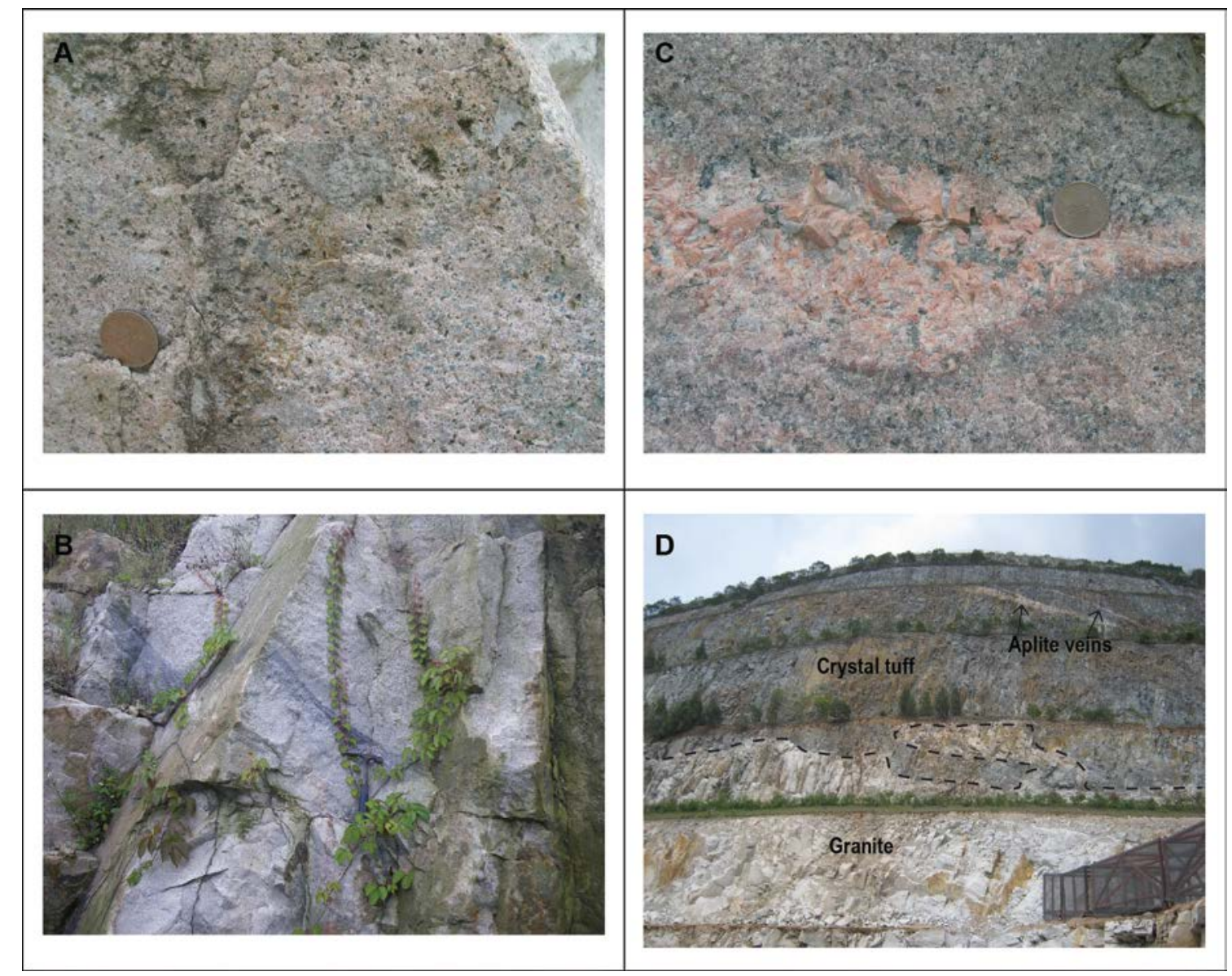

Fig. 3.7. Field photographs of the Kowloon and Mount Butler granites. (A) [819082N 837030E] Porphyritic fine-grained variant of the Kowloon Granite. (B) [814477N 839036E] Fine-grained Mount Butler Granite with schlieren, old Mount Butler Quarry, Hong Kong Island. (C) [821192N 840095E] Pegmatite lens near the contract between Kowloon Granite and Mount Butler Granite, eastern Kowloon. (D) [820448N 842633E] Intrusive contact (marked by black dash line) between Kowloon Granite and Mount Davis Formation, exposed in a quarry face in east Kowloon. The quarry face is $\sim 100 \mathrm{~m}$ high. For scale: in (A) and (C), coin = $2.5 \mathrm{~cm}$ in diameter; in (B) geological hammer $=28 \mathrm{~cm}$ long. 


\subsubsection{Sok Kwu Wan Granite and D'Aguilar Quartz Monzonite}

The Sok Kwu Wan Granite is exposed only on the eastern Lamma Island and a neighbouring Luk Chau (islet), where it intrudes older granites (Strange and Shaw, 1986; Sewell et al., 2000). The unit is characterised by the presence of euhedral pink feldspar megacrysts (up to $5 \mathrm{~cm}$ long), which are generally aligned to give the rock a trachytic texture. Locally, the feldspar laths in the Sok Kwu Wan Granite are closely packed to give the granite a cumulate texture (Fig. 3.8A). The D’Aguilar Quartz Monzonite, which displays similar textural characteristic, intrudes the Sok Kwu Wan Granite on Lamma Island. Another notable feature of the Sok Kwu Wan Granite is the presence of irregular to blocky mafic microgranular enclaves up to $1 \mathrm{~m}$ in size (Fig. 3.8B). Some of these mafic enclaves show wavy but sharp, chilled contacts against their host rock; while in some other cases, the contact is diffuse with feldspar phenocrysts mechanically mixed with the mafic blobs (Figs. 3.8C, D). These irregular-shaped mafic enclaves, with their crenulated, chilled margins, indicate that mingling occurred of two essentially immiscible magmas of contrasting compositions. These field observations also imply that the mafic magma was coeval with and involved in the emplacement of the Sok Kwu Wan Granite.

Sewell et al. (2012a) proposed that the Sok Kwu Wan Granite might represent the crystal cumulate left behind after the High Island Tuff eruption and was emplaced at the deeper part of the system, now exposed by inferred tilting of the caldera complex. However, the distribution of the Sok Kwu Wan Granite and D’Aguilar Quartz Monzonite suggests that both of these intrusive units were emplaced along the structures defining the High Island Caldera. Here, I re-interpret that the two plutons (stocks) exploited and were emplaced along the fractures after the caldera collapse. 


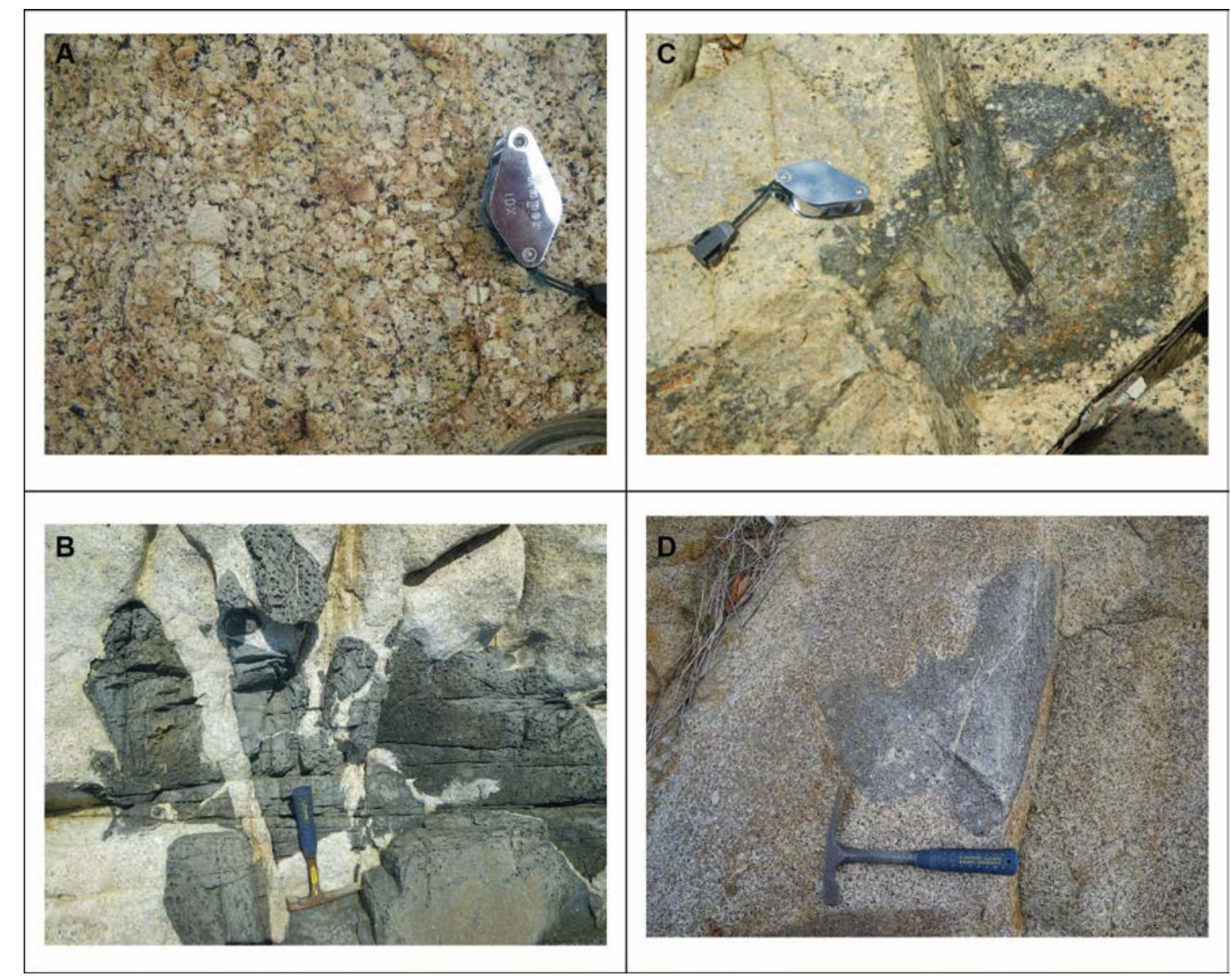

Fig. 3.8. Field photographs of Sok Kwu Wan Granite. (A) [809456N 831759E] Megacrystic Sok Kwu Wan Granite with closely packed feldspar phenocrysts which gives the rock a cumulate texture, eastern Lamma Island. (B) [808732N 832150E] Blocky to irregular-shaped, mafic enclaves within the Sok Kwu Wan Granite, eastern Lamma Island. (C) and (D) [808860N 832129E] Irregular-shaped mafic enclaves containing feldspar phenocrysts in Sok Kwu Wan Granite, eastern Lamma Island. For scale: in (A) and (C), hand lens $=5 \mathrm{~cm}$ long; in (B) and (D), hammer $=28 \mathrm{~cm}$ long.

\subsubsection{Quartz monzonitic and feldspar porphyry dykes}

A series of quartz monzonite bodies and feldspar porphyry dykes are present in northern Kowloon and Hong Kong Island. These quartz monzonitic intrusions are collectively assigned to the Tei Tong Tsui Quartz Monzonite unit of the Lion Rock Suite (Sewell et al., 2000). In northern Kowloon, the unit occurs as a NE-trending, 100-m wide zone of composite intrusions comprising quartz monzonite and porphyritic monzogranite dykes, which are characterised by the presence of aligned feldspar phenocrysts up to $3 \mathrm{~cm}$ long (Fig. 3.9A). The northeastern end of this chain of intrusions apparently connects to the flow-banded rhyolite of the Clear Water Bay Formation, suggesting that both the quartz monzonitic dykes and rhyolite were probably emplaced along a NE-trending tectonomagmatic structure (i.e. the Wong Chuk Fault, see Section 3.2.4.1). These quartz 
monzonitic intrusions, however, did not necessary directly feed the eruption of the Clear Water Bay rhyolite lava. Further north of this composite dyke zone, a chain of quartz monzonite subcrops, which defines a similar NE trend, have been identified in some existing drillholes in Shatin, southern New Territories. In addition, the presence of an irregular, vertical quartz monzonite dyke (of several meters thick) intruding Palaeozoic sedimentary rocks, was reported in the underground old Ma On Shan Mine in Shatin (Addison, 1986). These subcrops, together with some isolated quartz monzonite outcrops exposed in northern Sai Kung, are interpreted here to have been intruded along and closely linked to the Cheung Sheung-Chek Keng Fault (see Section 3.2.4.1). Likewise, quartz monzonite outcrops exposed on Sharp Island and Tai Mong Tsai in Sai Kung Hoi are related to the Jordan Valley Fault (Fig. 3.9B).

Similarly, in southern Hong Kong Island, discontinuous outcrops of quartz monzonite stocks and porphyritic monzonitic dykes define a NE-trending zone that is interpreted as an extension of the Tin Ha Shan Fault (see Section 3.2.4.2). Along this fault structure on the Clear Water Bay Peninsula, the quartz monzonite and feldspar porphyry dykes intrude tuffaceous sediments underlying the Pan Long Wan trachydacite, and are closely associated with the trachydacite unit (Fig. 3.9C). In this location, rare garnet phenocrysts (less than $5 \mathrm{~mm}$ in diameter) are scattered in the quartz monzonite (Fig. 3.9D) and the feldspar phenocrysts give a trachytoidal texture to the unit. Previous interpretation by Strange and Shaw (1986) suggested that the quartz monzonite stocks and dykes intruded the Kowloon and Mount Butler granites exposed on Hong Kong Island. However, my fieldwork has revealed, on the contrary, that the granites actually intruded and are chilled against the quartz monzonite (Fig. 3.9E). The age relationships of these intrusive units are also tested by zircon U-Pb dating in Chapter 4 . 


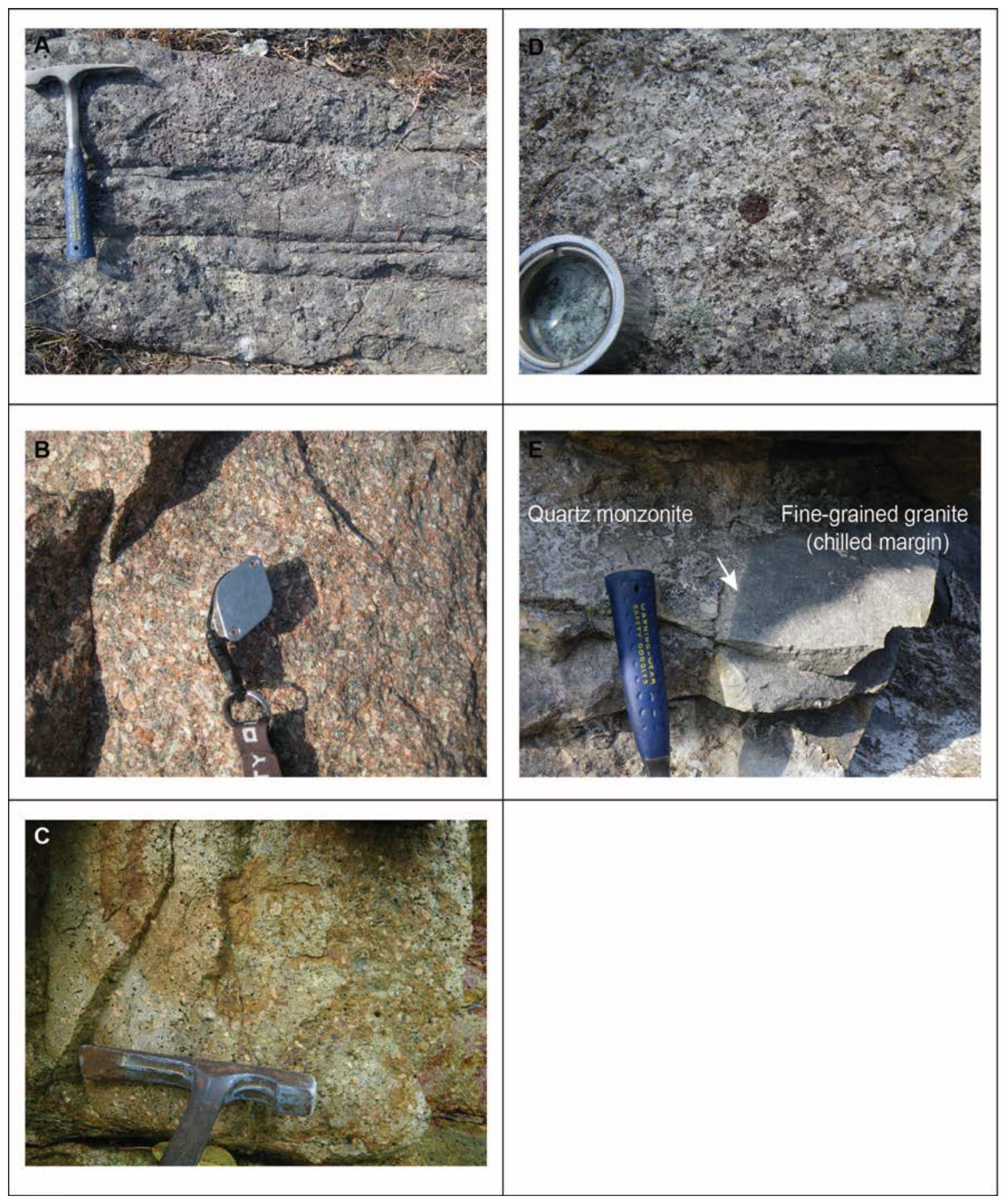

Fig. 3.9. Field photographs of quartz monzonitic intrusions and the associated dykes. (A) [825649N 841286E] ENE-trending composite porphyritic quartz monzonite/feldspar porphyry dyke at Buffalo Hill, southern New Territories. At this location, quartz monzonite and feldspar porphyry intrusions are intermingling. Contact of the composite dyke with Mount Davis crystal ignimbrite is not exposed, and the dyke is inferred to be $>10 \mathrm{~m}$ wide. (B) [825000N 848000E] Porphyritic quartz monzonite, containing abundant alkali feldspar megacrysts, on Sharp Island, Sai Kung Hoi. (C) [816794N 848377E] E-trending feldspar porphyry dyke (25-30 m wide), closely associated with Pan Long Wan trachydacite lava, at Clear Water Bay Peninsula. (D) [814860N 847945E] Rare garnet phenocrysts (up to $3 \mathrm{~mm}$ ) in quartz monzonite intrusions near Tai Mui Wan, Clear Water Bay Peninsula. (E) [815520N 842230E] Intrusive contact of granite (with chilled margin) against quartz monzonite at Lei Yu Mun Park, Chai Wan. Arrow points to the intrusive contact. For scale: in (A), (C) and $(\mathrm{E})$, hammer = $28 \mathrm{~cm}$ long; (B) and (D), hand lens $=5 \mathrm{~cm}$ long. 


\subsubsection{Tectono-magmatic structures of High Island caldera}

Several tectonic-magmatic structures have been identified as being major controls on the development of High Island caldera (Campbell and Sewell, 1997; Sewell et al., 2012a; Fig. 3.10). These structures include the Tolo Channel, Cheung Sheung-Chek Keng, Wong Chuk, Tin Ha Shan, Jordan Valley and Tiu Keng Leng faults (Table 3.1). Together with the offshore structures, the East Lamma Channel and Sheung Tsz Mun faults, inferred from geophysical data, these tectono-magmatic structures were considered as marking the caldera boundary of the nested High Island caldera complex in southeast Hong Kong (Sewell et al., 2012a). Detailed field descriptions of the structures are presented here to offer an updated view of the connections among various volcanic units and intrusive rock units of the High Island caldera complex and how they controlled the development of the caldera complex (Table 3.1).

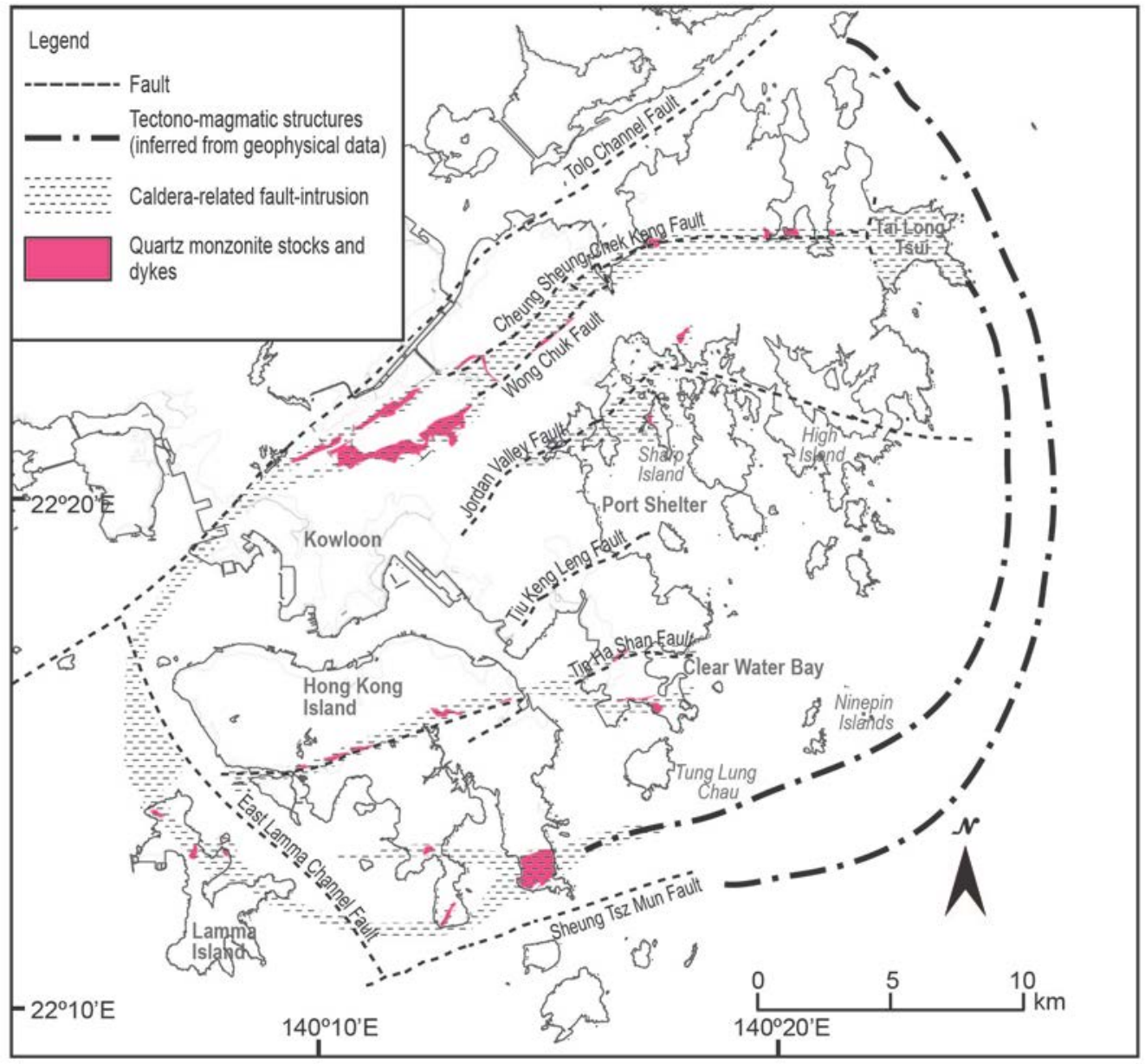

Fig. 3.10. Location plan of tectonic-magmatic structures of the nested High Island caldera in southeast Hong Kong, based on new field observation and modified after Sewell et al. (2012a). 


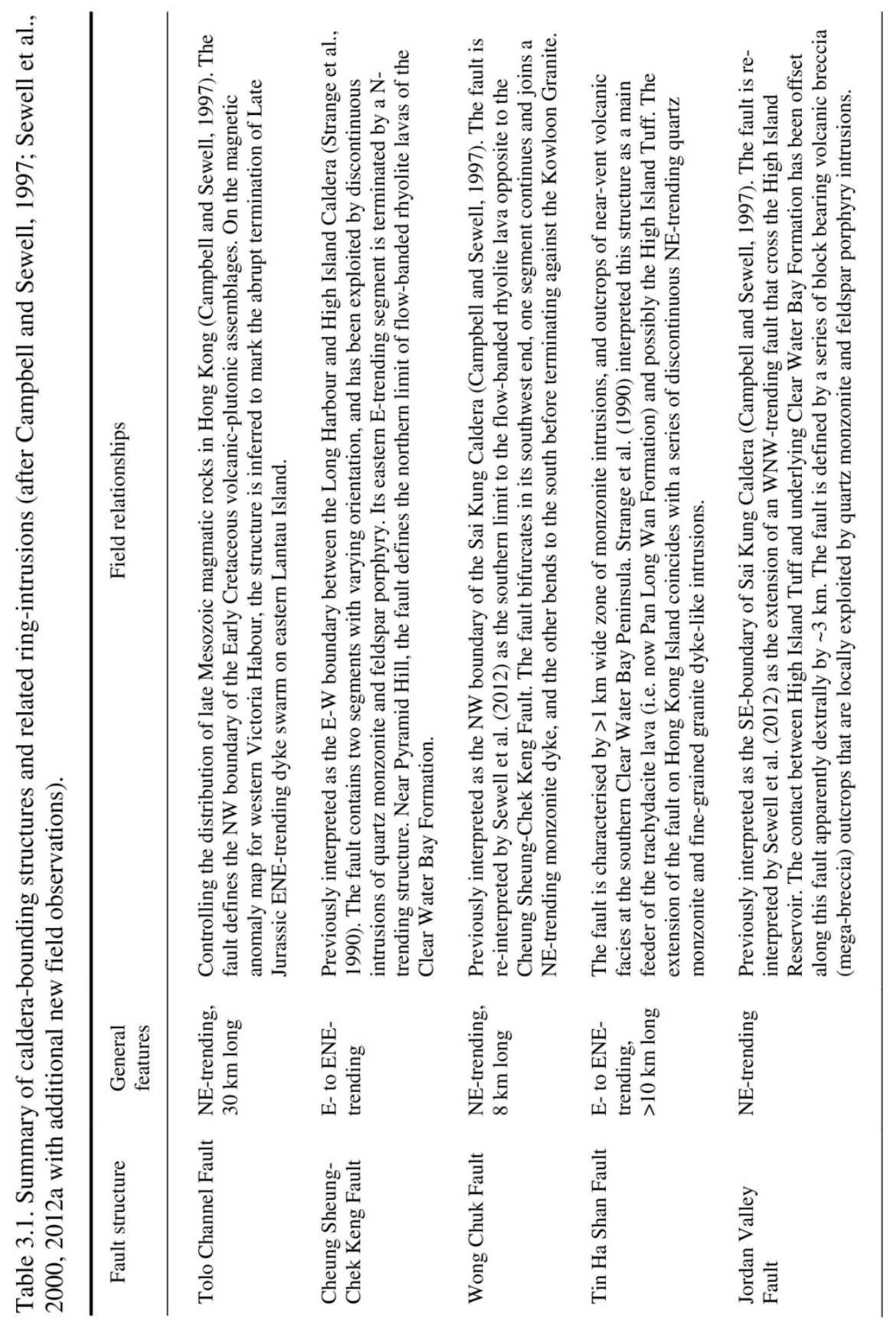




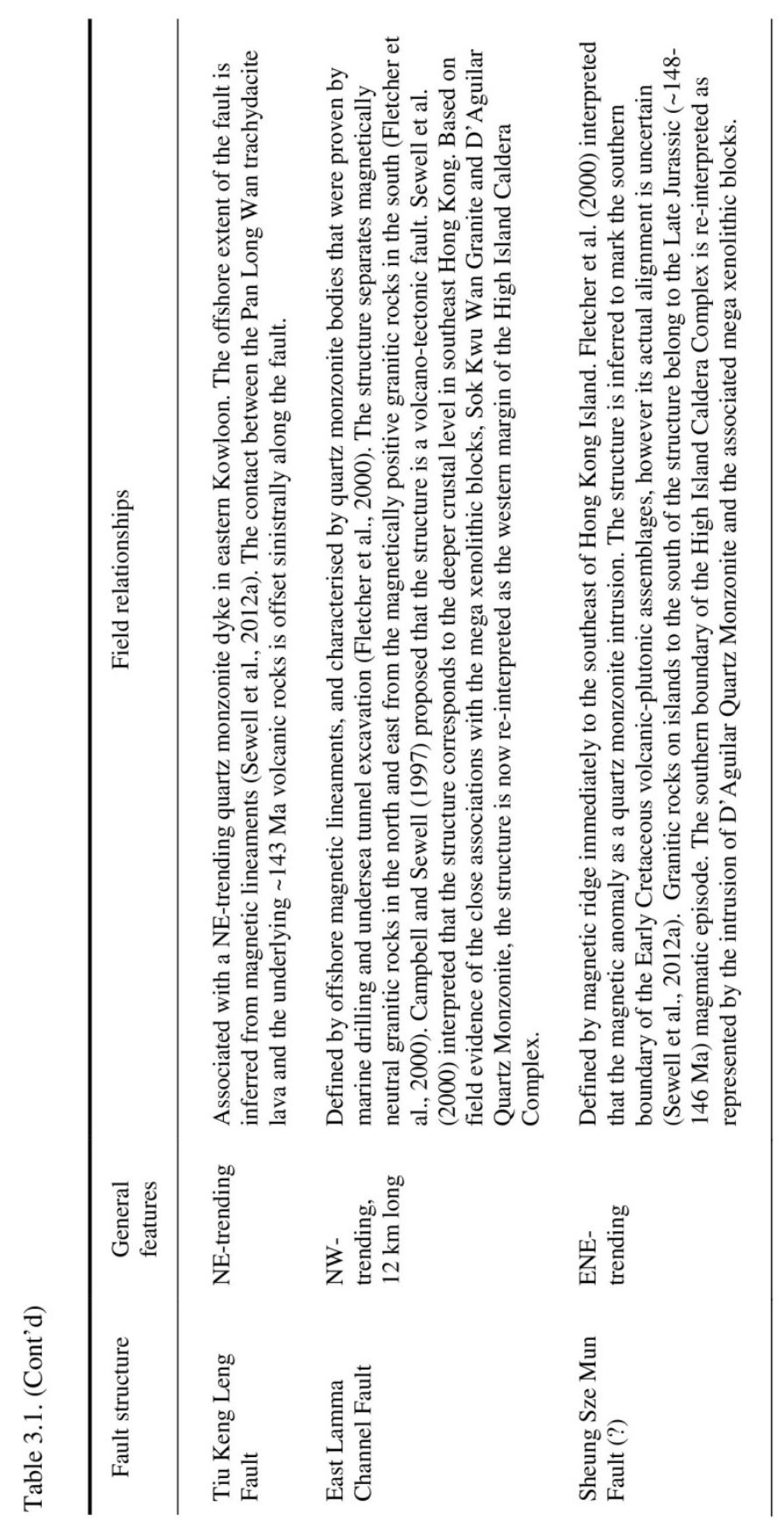




\subsubsection{Cheung Sheung-Chek Keng and Wong Chukfaults}

The E- to ENE-trending Cheung Sheung-Chek Keng Fault was previously interpreted as the E-W boundary between the Long Harbour caldera and the High Island caldera in Sai Kung (Strange et al., 1990; Figs. 7 and 8 in Campbell and Sewell, 1997). This fault contains two segments with varying orientations, and has been exploited by discontinuous intrusions of quartz monzonite and feldspar porphyritic dykes (Tei Tong Tsui Quartz Monzonite; see discussion in Section 3.2.3.3 above; Fig. 3.9A). The western segment of the Cheung Sheung-Chek Keng Fault defines the northern limit of the flow-banded rhyolite lava outcrops of the Clear Water Bay Formation near Pyramid Hill (Fig. 3.5B). A 100 mwide zone of feldspar porphyritic dykes and quartz monzonite stocks probably defines the southern boundary as marked by the NE-trending Wong Chuk Fault. Collectively, the western segment of the Cheung Sheung Chek Keung Fault and the Wong Chuk Fault are interpreted here as the northern structural boundary of the High Island caldera complex, which was exploited by ring fault intrusions.

The eastern segment of Cheung Sheung-Chek Keng Fault is E-trending and is truncated by an N-trending structure at a point coincident with the autobrecciated rhyolite lava exposed at Tai Long Tsui, Sai Kung (Fig. 2.9). As mentioned above, the cross-cutting relationships observed in the field suggest that the autobrecciated lava post-dated the eruptions of the Clear Water Bay Formation and the High Island Tuff (see Section 3.2.1). The age relationship of the autobrecciated rhyolite and the High Island Tuff has been confirmed by $\mathrm{U}-\mathrm{Pb}$ dating presented in Chapter 4. In addition, the rock outcrops at the headland of Tai Long Tsui are affected by extensive quartz stockwork and intruded by felsic dykes (Fig. 3.11A), indicating that the Cheung Sheung-Chek Keng Fault might have been a major conduit for magmatic/hydrothermal fluids. 

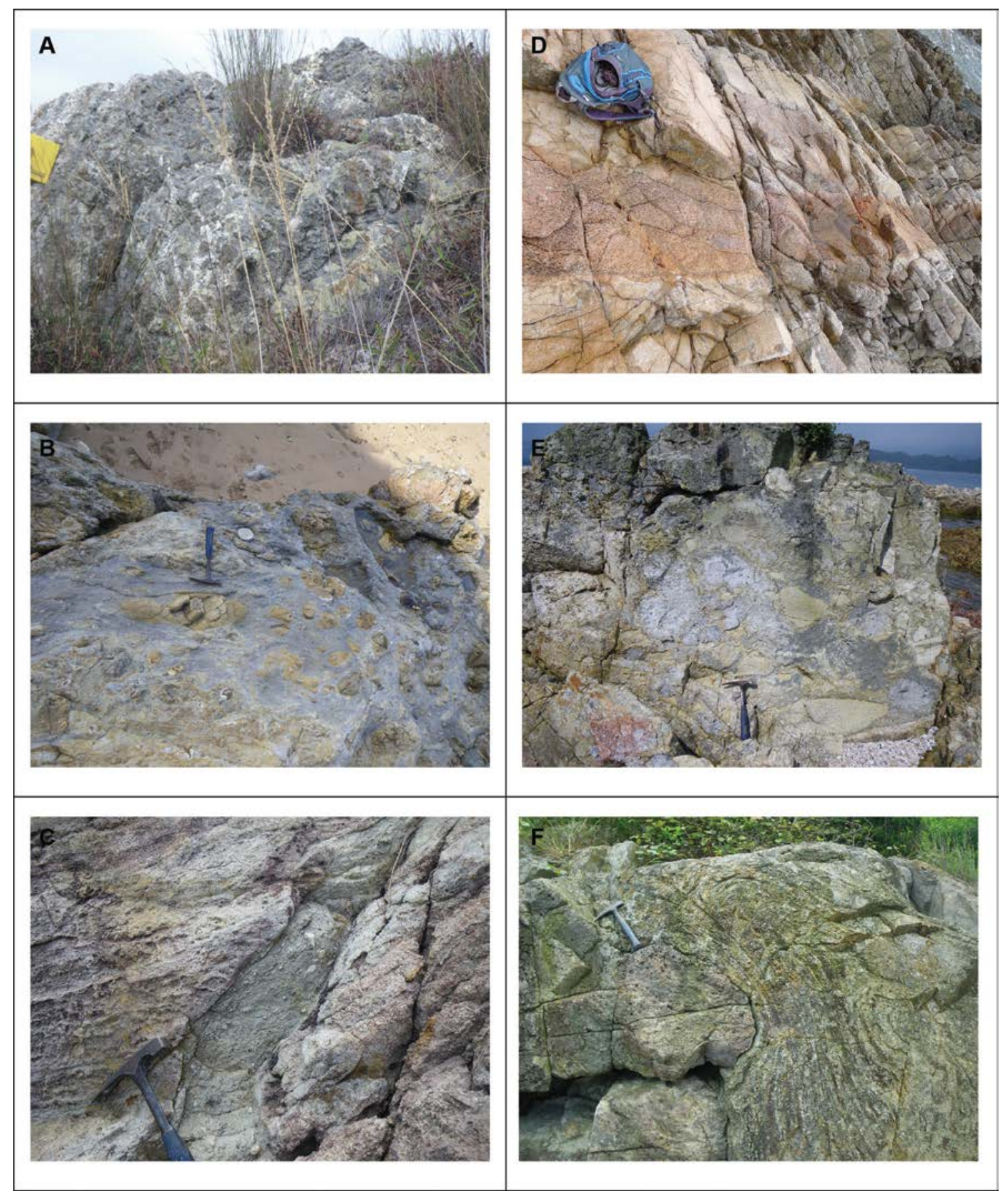

Fig. 3.11. Field photographs showing the geological features of the caldera boundary and related structures. (A) [830715N 859137E] Quartz stockwork in autobrecciated rhyolite lava exposed on Tai Long Tsui, Sai Kung. (B) [814656N 847351E] Peperitic soft-sediment deformation feature along the Tin Ha Shan Fault, Clear Water Bay Peninsula. (C) [818981N 849031E] Intrusive breccia dyke in Clear Water Bay Formation tuff along the Tin Ha Shan Fault, Clear Water Bay Peninsula. (D) [814634N 847795E] Feldspar porphyry dyke intruded along the Tin Ha Shan Fault, Clear Water Bay Peninsula. (E) [825339N 847648E] Polymictic tuff breccia, denoting the trace of the Jordan Valley Fault, on Sharp Island, Sai Kung. (F) [824253N 848392E] Flow-banded porphyry dyke intruded along the volcanic conduits on Sharp Island, Sai Kung. For scale: in $(\mathrm{A})$, note book = $13 \mathrm{~cm}$ long; in $(\mathrm{B}),(\mathrm{C}),(\mathrm{E})$ and $(\mathrm{F})$, geological hammer = $28 \mathrm{~cm}$ long; in $(\mathrm{D})$, backpack = $35 \mathrm{~cm}$ long. 


\subsubsection{Tin Ha Shan and Tiu Keng Leng faults}

The Tin Ha Shan Fault in the southern part of Clear Water Bay Peninsula (Fig. 3.10) is characterised by a $>1-\mathrm{km}$ wide zone of monzonitic intrusions (see Section 3.2.3.3). Here, discontinuous monzonitic bodies are closely associated with a peperite-like volcaniclastic sequence comprising polymictic tuff breccia (Figs. 3.11B, C, D), which were interpreted as a near-vent volcanic facies by Strange et al. (1990). The Pan Long Wan trachydacitic lava is exposed at the eastern end of the Tin Ha Shan Fault, which is interpreted as a main feeder of the lava. The discontinuous monzonitic bodies and the peperite-like volcaniclastic sequence exposed in the southern end of the Clear Water Bay Peninsula are interpreted here to mark a volcanic conduit complex.

The extension of the Tin Ha Shan Fault on Hong Kong Island coincides with a series of discontinuous NE-trending quartz monzonite intrusions (Tei Tong Tsui Quartz Monzonite). In eastern Hong Kong Island, the Tin Ha Shan Fault is inferred from the presence of a quartz monzonite body intruding a fault block of volcanic breccia (mega-breccia) [at 842371E 815414N], which are both intruded by later granitic intrusions. These dyke-like quartz monzonitic intrusions can be traced westward through to western Hong Kong Island and cut across the RBVG volcanic strata (Fig. 3.10).

The NE-trending Tiu Keng Leng Fault runs sub-parallel to the Tin Ha Shan Fault on the Clear Water Bay Peninsula (Fig. 3.10). The southwestern segment of the Tiu Keng Leng Fault in east Kowloon was associated with a quartz monzonite dyke, whereas its offshore extent to the northeast was inferred from magnetic lineaments (Strange et al., 1990; Sewell et al., 2012a). The volcanic strata of the RBVG are offset along this structure. In addition, the outcrops of the layered volcaniclastic sediment of the Mang Kung Uk Formation appear to be bounded by the offshore extent of the fault in the north. Further evaluation of field evidence suggests that the Tiu Keng Leng Fault is of relatively limited lateral extent, and may not be one of the major tectonic-magmatic structures related to the collapse of High Island caldera as suggested previously by Sewell et al. (2012a).

\subsubsection{Jordan Valley Fault}

The NE-trending Jordan Valley Fault (Fig. 3.10) was previously thought to mark the southeastern boundary of the 'Sai Kung' caldera and was inferred to link up with sporadic monzonite intrusions farther northeast (Campbell and Sewell, 1997). Sewell et al. (2012a) 
re-interpreted a WNW-trending fault, which was mapped through the High Island Reservoir by Strange et al. (1990), to be the extension of the Jordan Valley. Along this fault, the contact between the High Island Tuff and the underlying Clear Water Bay Formation has been offset, apparently dextrally, by $\sim 3 \mathrm{~km}$. In Sai Kung, the Jordan Valley Fault is represented at the surface by a series of block-bearing volcanic breccia (megabreccia) outcrops, exposed around Port Shelter, which are locally cut by quartz monzonite and flow-banded feldspar porphyritic dykes (Figs. 3.11E, F). This fault structure also defines the northern limit of the Che Kwu Shan Formation, and might represent an original caldera topographic boundary against which that unit was deposited.

\subsubsection{East Lamma Channel and Sheung Sze Mun faults}

The NW-trending East Lamma Channel Fault and NE-trending Sheung Sze Mun Fault were inferred from existing offshore geophysical data including magnetic and Euler gravity anomalies (Fletcher et al., 1997, 2000; Sewell et al., 2000; Fig. 3.10). Campbell and Sewell (1997) interpreted the East Lamma Channel Fault as a volcano-tectonic structure bounding the distribution of RBVG and Kowloon Granite, although its role was not clearly defined in the tilted nested caldera model. Sewell et al. (2012a) interpreted the Sheung Sze Mun Fault as the southern limit of the nested High Island caldera complex and the western limit was represented by the Sok Kwu Wan Granite, which was inferred to have emplaced in a deeper crustal level of the system. The importance of these two fault structures is reconsidered here in light of the new observations and their field relationships with the Sok Kwu Wan Granite and D’Aguilar Quartz Monzonite.

These two intrusive units are exposed on the southern part of Hong Kong and on eastern Lamma Island. In both two locations, exposures of the 164 Ma volcanic-plutonic units are present and are inferred from my observations to represent kilometre-scaled megaxenolithic blocks that are surrounded by either or both of the Sok Kwu Wan Granite and D’Aguilar Quartz Monzonite. Both the existing whole rock geochemical data (Sewell et al., 2012a) and the zircon trace element and U-Pb age data obtained from this study (Chapter 4) strongly suggest a genetic and temporal correlation of these plutonic units with the KSCVG units. It is therefore interpreted here that the two intrusive units represent ringfault intrusions emplaced along the margins of the High Island caldera. Thus, the East Lamma Channel Fault is inferred as a broad zone ( $3 \mathrm{~km}$ wide) of ring-fault intrusions, defining the western boundary of the caldera. Similarly, the southern boundary, originally 
inferred as marked by the Sheung Sze Mun Fault, is now considered to be represented by the $~ 3-4$ km wide zone of quartz monzonite and monzogranite in southern Hong Kong Island.

\subsection{Summary}

This chapter has presented the key field observations of the volcanic units and the subvolcanic granitic plutons within the nested High Island caldera complex in southeast Hong Kong. The work has focused on evaluating the field relationships of these units, and thereby establishing their spatial and temporal connections. This information is of paramount importance for the overall, updated review of the tectono-magmatic evolution of the High Island caldera complex in the later part of this thesis (Chapter 6). The key findings are summarised below:

(1) The structures of the High Island caldera complex are re-interpreted here to be associated with asymmetric caldera collapse, such that the High Island Tuff unit, originally deposited on sub-horizontal caldera floor, sagged and leaned eastward during caldera collapse, while the RBVG strata on Hong Kong Island were divided into multiple fault blocks. The field relationships and the kink-banding of the tuff suggest that the unit was deposited on a sub-horizontal caldera floor that was tilted, causing the hot, still-plastic tuff to slump sideways and induce the kink-banding, and was accompanied by mafic dyke intrusion. The tilting of the High Island Tuff was syn-eruptive and accompanied with caldera collapse, rather than due to subsequent regional tectonic movement.

(2) Two fault-bounded volcanic depressions are identified, nested within the High Island caldera complex. The distribution and changes in thickness of the Long Harbour and Che Kwu Shan ignimbrites probably reflect the original ponding of ash deposits within these depressions, and were subsequently modified by fault activity. The Cheung Sheung-Chek Keng, Wong Chuk, Jordan Valley and Tin Ha Shan faults are interpreted to be part of the fault graben systems.

(3) The Kowloon, Mount Butler and Sok Kwu Wan granites and D’Aguilar Quartz Monzonite are all grouped under the Lion Rock Suite ( 140 Ma) and considered as the intrusive counterparts of the Kau Sai Chau Volcanic Group (Sewell et al., 2000; Sewell et al., 2012a, b). The field relationships imply that these granitic plutons (or 
stocks) were emplaced in different settings within the High Island caldera complex. The Kowloon and Mount Butler granites intrude the RBVG units and are considered to have been emplaced within 2-3 km of the contemporaneous land surface. In contrast, the Sok Kwu Wan Granite and D’Aguilar Quartz Monzonite probably exploited and were emplaced along the bounding structures of the High Island Caldera.

In conclusion, the field evidence suggests that the previous proposed tilted caldera model for the High Island caldera complex in Sewell et al. (2012a) is open to reinterpretation. The structural aspects of the RVBG and KSCVG are considered here to reflect the asymmetric collapse of the High Island caldera, and to infer that the sub-volcanic plutons were not exposed by tilting of the entire crustal block. The age relationships inferred from this new field evidence are tested using zircon $\mathrm{U}-\mathrm{Pb}$ dating in Chapter 4, and the tilting hypothesis tested using thermochronology in Chapter 5. 
Chapter 4/ Evolution of the Magmatic Systems in Hong Kong reflected in Zircon Textures, Ages and Trace Elements 


\subsection{Introduction}

Large silicic systems (that is, those generating dacites and rhyolites) produce two contrasting products: voluminous ignimbrite sheets of up to hundreds to thousands of cubic kilometers erupted at the surface, and granitic batholiths that accumulate at shallow crustal levels (e.g. Lipman, 1984, 2007; Shaw, 1985). Silicic magmatism involves complex processes in the crust and upper mantle that, among other things, control the growth and development of continental crust. In recent years, there have been considerable advances in our understanding of how large silicic magmatic systems operate, but at present there is some degree of separation between models and understanding derived from the volcanic versus plutonic records.

From the volcanic perspective, models generally infer that silicic magma chambers are temporally dominated by crystal mush that contains less than $50 \%$ melts and are thus rheologically locked (Mahood, 1990; Bachmann and Bergantz, 2004; Hildreth 2004; Hildreth and Wilson, 2007). Two end-member products are envisaged to be generated by such systems (Bachmann and Bergantz, 2008). The first is voluminous crystal-rich ignimbrites (e.g. Fish Canyon Tuff, San Juan Volcanic Field), considered to represent erupted crystal mushes at upper crustal levels that were thermally recharged by the arrival of more mafic magmas (e.g. Bachmann et al., 2002; Maughan et al., 2002; Huber et al., 2011, 2012). The other end-member product is crystal-poor rhyolites, extracted from the crystal mush system and accumulated at shallow levels prior to eruption (Bachmann and Bergantz, 2004; Hildreth and Wilson, 2007; Allan et al., 2013). The crystal mush model implies that there are some sub-volcanic granitic plutons that represent either the crystallised mush, or the residue left after the withdrawal of rhyolitic melt (Bachmann and Bergantz, 2004; Hildreth, 2004; Hildreth and Wilson, 2007). Large silicic magmatic systems generally operate in two contrasting timescales. The lifespan of crystal mushes, i.e. hot, partially molten bodies, can be of the order of $10^{6}-10^{7}$ years, a period much longer than the $10^{2}-10^{5}$ years lifespans of the crystal-poor melt-dominant bodies which actually erupt (Charlier et al., 2005; Wilson and Charlier, 2009; Allan et al., 2013; Chamberlain et al., 2014b; Barker et al., 2015). Furthermore, based on the evidence from the degrees of crystal fractionation required (or the volumes of mafic intrusive material required to cause crustal melting) and consideration of the thermal fluxes in young systems like Yellowstone, or the central Taupo Volcanic Zone (TVZ) in New Zealand, it is evident that large volumes 
of intrusive materials (in proportions ranging from 3:1 to 10:1) are associated with erupted rhyolite (e.g. Cameron et al., 1980; Knesel and Davidson, 1997). Many of these studies focused on recent magma chamber dynamic of Quaternary volcanic systems (e.g. TVZ: Wilson et al., 2006, Shane et al., 2008, Allan et al., 2012; Long Valley caldera, USA, Hildreth, 2004; Hildreth and Wilson, 2007; Chamberlain et al., 2014a, 2014b, 2015; Valles caldera, USA, Wilcock et al., 2013, Goff et al., 2014; Wolff and Ramos, 2014; Yellowstone caldera, USA, Girard and Stix, 2009; Watts et al., 2012).

The plutonic records of large silicic magmatic systems superficially seem to represent a much longer timescale of magmatic processes. Exhumed granitic plutons have generally been considered as the 'fossil' magma chambers (e.g. Miller and Miller, 2002). Geochronological studies have been used to argue that large granitic batholiths grow incrementally over extended time period of $>10^{7}$ years (e.g. Coleman et al., 2004; Glazner et al., 2004; Matzel et al., 2006). The suggestion of protracted and stepwise growth of granitic plutons implies that only small quantities of magma exist for any particular time during the construction of granitic batholiths, and therefore, these composite granitic plutons were not linked to any large magma chamber that would be required to support voluminous ignimbrite eruptions. This presumption also implies that large silicic magmatic chambers that could feed eruptions of thousands of cubic kilometers magma are geologically rare and short-lived (Glazner et al., 2004; Miller, 2008). These contradictory views imply a large difference, of several orders of magnitude, in the time scales of generation of voluminous eruptible magma and of emplacement of large sub-volcanic plutons. Lipman (2007) proposed that the eruption of large silicic ignimbrites and emplacement of plutons reflect the variable waxing and waning stages of a magmatic system with a total lifespan of $10^{7}$ years. Yet, the questions remain about (1) how do silicic magmatic systems build spatially and temporally, and (2) how do the volcanic and subvolcanic plutonic rocks relate to each other?

In most modern silicic magmatic systems, only the products of volcanic eruptions (except maybe accidental inclusions of granitic xenoliths brought up from the crust and entrained in the volcanic products) are available at the surface for direct study. Detailed field observations with careful crystal specific studies are able to constrain the dynamic of magma systems and processes that operate at a time-scale of decades to thousands of years (Wilson, 2001; Wilson et al., 2006; Allan et al., 2013, Cooper et al., 2014; Barker et al., 
2015). However, direct observations of the plumbing systems of these young caldera volcanoes are not possible, and they are normally studied using geophysical techniques (e.g. Yellowstone, Husen et al., 2004, Huang et al., 2015; Toba, Indonesia, Koulakov et al., 2009; TVZ, Heise et al., 2010). For older silicic magmatic systems (e.g. Sierra Nevada, western US), typically only the subvolcanic granites are well exposed while the overlying volcanic sequences have been largely eroded. The preservation of both the volcanic and sub-volcanic roots of a magmatic system is relatively uncommon (e.g. Lipman and McIntosh, 2008; Quick et al., 2009; Barth et al., 2012; Zimmerer and McIntosh, 2012) and seems to be favoured mostly in syn-magmatic extension tectonic settings (e.g. Schermer and Busby, 1994).

Hong Kong is dominated by late Mesozoic silicic igneous rocks (Chapter 2, Fig. 2.1). Here, large-scale caldera-related silicic ignimbrites and their contemporaneous subvolcanic granitic plutons are now exposed side by side (Sewell et al., 2012a). The spatial, temporal and compositional connections of the volcanic products and their coeval plutons have been well-constrained by field relationships (Campbell and Sewell, 1997; Sewell et al., 2000; 2012a; Chapter 3), and supported by ID-TIMS U-Pb zircon ages (Davis et al., 1997; Campbell et al., 2007; Sewell et al., 2012b), whole-rock geochemical data (Sewell et al., 1992; Darbyshire and Sewell, 1997; Sewell and Campbell, 1997, 2001) and geophysical surveys (Fletcher et al., 1997). The exposures in Hong Kong provide an excellent opportunity to study the connections between caldera volcanoes and their underlying plumbing systems by comparing and contrasting the voluminous ignimbrites and their contemporaneous sub-volcanic plutons (Sewell et al., 2012a). The large scale of the Hong Kong systems makes comparisons possible with their broadly coeval counterparts in the western USA, particularly in the Sierra Nevada batholith.

This chapter presents an investigation of magmatic systems in Hong Kong using secondary-ion mass spectrometry (SIMS) techniques to undertake in-situ U-Pb dating and trace element analyses on zircons separated from samples from both the ignimbrites and sub-volcanic plutons of four temporally distinct magmatic episodes. The analytical spots have been carefully located with the aid of CL imagery such that the range of textural variations observed in the zircon populations from individual samples were covered. The age data have been obtained to explore whether the more-precise but multiple-grain IDTIMS data are genuinely representative of the rocks concerned, or whether they represent 
average values concealing patterns of inheritance. The trace element data are used to assess any genetic connections of the paired volcanic-plutonic assemblages, and to unravel crystallisation/fractionation paths within the volcanic and plutonic units. The analyses have targeted specific growth zones, including cores versus rims, tips versus sides and sectorzoned areas to identify any intra-grain variations in trace element abundances. In addition, by targeting trace element analyses in the dated growth zones, geochemical signatures can be identified and coupled with age data for interpretation of the chemical evolution of the magmatic systems.

Trace element concentrations and ratios in zircons vary systematically with the fractionation of elements in the melt from which they crystallised (Hoskin and Schaltegger, 2003; Wooden et al., 2006; Claiborne et al., 2006, 2010; Barth and Wooden, 2010). In turn, changing trace element patterns shown through zonation in the grains reflect changes in melt compositions through time (e.g. Claiborne et al., 2006, 2010; Barth and Wooden, 2010; Fohey-Breting et al., 2010; Gagnevin et al., 2010; Colombini et al., 2011; Reid et al., 2011; Barth et al., 2013; Barker et al., 2014; Chamberlain et al., 2014b; Cooper et al., 2014). Correlations between geochemical signatures in zircons and melt evolution have, however, tended to be used to constrain the magmatic environments of either volcanic or granitic systems. In the former case, previous studies focused on zircon characteristics from a single volcanic unit (e.g. Reid et al., 2011; Wotzlaw et al., 2013; Chamberlain et al., 2014b), a single volcanic centre (Cooper et al., 2014; Barker et al., 2014) or multiple volcanic centres within a single volcanic field (e.g. Bryan et al., 2008) or arc (Barth et al., 2013). Other studies were concentrated on multiple granitic plutons within a large silicic batholith (e.g. Claiborne et al., 2006, 2010; Barth and Wooden, 2010; Gagnevin et al., 2010; Colombini et al., 2011). In comparison, studies that link the trace element signatures in zircons from ignimbrites and their associated plutons are rare (e.g. Fohey-Breting et al., 2010). Here, I contribute to the volcanic-plutonic comparisons with U-Pb age and trace element data from late Mesozoic volcanic and plutonic rocks of Hong Kong. I focus on ignimbrites and their associated contemporaneous granitic plutons from two caldera complexes in southeast Hong Kong and Lantau Island to examine in crystal-specific fashion their 24 Myr history of magmatic evolution. 


\subsection{Geological Background}

\subsubsection{Geology of Hong Kong}

Hong Kong is located on the southern margin of the Southeast China Magmatic Belt (SCMB; Chapter 2), and its surface geology is dominated by volcanic and plutonic rocks generated by large-scale silicic magmatism during the late Mesozoic as part of the Yanshanian Orogeny (Chapter 2). Four Yanshanian volcanic groups, and their proposed source calderas and plutonic equivalents, have been identified in Hong Kong (Fig. 2.3, Table 4.1). These rocks record an extended period of large-scale igneous events over $\sim 24$ Myr from around 164 Ma to 140 Ma (Campbell and Sewell, 1997; Sewell et al., 2012a, b). In this chapter I focus in particular on two clearly defined caldera centres in Hong Kong, the Lantau and High Island caldera complexes (Fig. 2.4) to investigate the evolution of their magmatic systems. The volcanic stratigraphy, caldera-related structures and the associated intrusive units of these two caldera complexes have been documented by Langford et al. (1995), So (1998) and Campbell et al. (2007) on Lantau caldera complex; and Sewell et al. (2012a) and this study (Chapter 3) for the High Island caldera complex.

\subsubsection{Lantau caldera complex}

Lantau caldera, located in the central part of Lantau Island in southwest Hong Kong (Fig. 4.1) contains a condensed record of all four volcanic episodes, from Middle Jurassic to Early Cretaceous. The lowest unit is the $~ 164$ Ma rhyolitic ignimbrite of the Shing Mun Formation (Campbell et al., 2007) which unconformably overlies Early Jurassic sediments. This ignimbrite is overlain by the $148-146$ Ma Lantau Volcanic Group (Langford et al., 1995; Campbell and Sewell, 1997). On Lantau Peak itself, small outcrops of volcanic rocks from the $143 \mathrm{Ma}$ and $~ 141-140$ Ma episodes were identified on the basis of petrological, geochemical and geochronological evidence (Langford et al., 1995; So, 1999; Sewell et al., 2000; Campbell et al., 2007). 
Table 4.1. Summary of the late Mesozoic volcanic-plutonic assemblages in Hong Kong (after Sewell et al., 2012a) and samples (HK numbers) analysed in this study.

\begin{tabular}{|c|c|c|c|c|}
\hline \multirow[t]{2}{*}{ Age* } & \multicolumn{2}{|l|}{ Volcanic Rocks } & \multicolumn{2}{|l|}{ Granitic Rocks } \\
\hline & Volcanic Group/Formations & sample no. & Plutonic Suite/Units & sample no. \\
\hline \multirow[t]{8}{*}{ 141-140 Ma } & Kau Sai Chau Volcanic Group & & Lion Rock Suite & \\
\hline & Post-High Island lava & (HK13343) & Mount Butler Granite & (HK13407) \\
\hline & High Island Tuff & (HK12001) & Kowloon Granite & (HK11042) \\
\hline & Clear Water Bay tuff & (HK11834) & Fan Lau Granite & \\
\hline & Clear Water Bay lava & (HK12072) & Sok Kwu Wan Granite & (HK12023) \\
\hline & Pan Long Wan lava & (HK13277) & Tei Tong Tsui Qz Monzonite & \\
\hline & Undifferentiated tuff & (HK12070) & Tong Fuk Qz Monzonite & (HK8758) \\
\hline & & & D'Aguilar Qz Monzonite & (HK12022) \\
\hline \multirow[t]{7}{*}{$143 \mathrm{Ma}$} & Repulse Bay Volcanic Group & & Cheung Chau Suite & \\
\hline & Mount Davis & (HK13275) & Luk Keng Qz Monzonite & \\
\hline & Long Harbour & (HK11835) & Chi Ma Wan Granite & (HK8353) \\
\hline & Mang Kung Uk & & Shui Chuen O Granite & (HK12073) \\
\hline & Che Kwu Shan & (HK11836) & & \\
\hline & Ap Lei Chau & (HK11840) & & \\
\hline & Ngo Mei Chau & & & \\
\hline \multirow[t]{9}{*}{ 148-146 Ма } & Lantau Volcanic Group & & Kwai Chung Suite & \\
\hline & Lai Chi Chong & & Shatin Granite & \\
\hline & Undifferentiated tuff & (HK11052) & East Lantau Rhyolite & \\
\hline & & & East Lantau Rhyodacite & (HK11831) \\
\hline & & & Needle Hill Granite & \\
\hline & & & Sham Chung Rhyolite & \\
\hline & & & Po Toi Granite & \\
\hline & & & Shan Tei Tong Rhyodacite & \\
\hline & & & South Lamma Granite & \\
\hline \multirow[t]{7}{*}{$164-160 \mathrm{Ma}$} & Tsuen Wan Volcanic Group & & Lamma Suite & \\
\hline & Sai Lau Kong & & Tai Lam Granite & \\
\hline & Tai Mo Shan & & Tsing Shan Granite & \\
\hline & Shing Mun & (HK12025) & Chek Lap Kok Granite & \\
\hline & Yim Tin Tsai & & Chek Mun Rhyolite & \\
\hline & & & Lantau Granite & (HK11822) \\
\hline & & & Tai Po Granodiorite & \\
\hline
\end{tabular}

Note: * Ages of volcanic-plutonic assemblages are based on published ID-TIMS works (after Sewell et al., 2012b). 


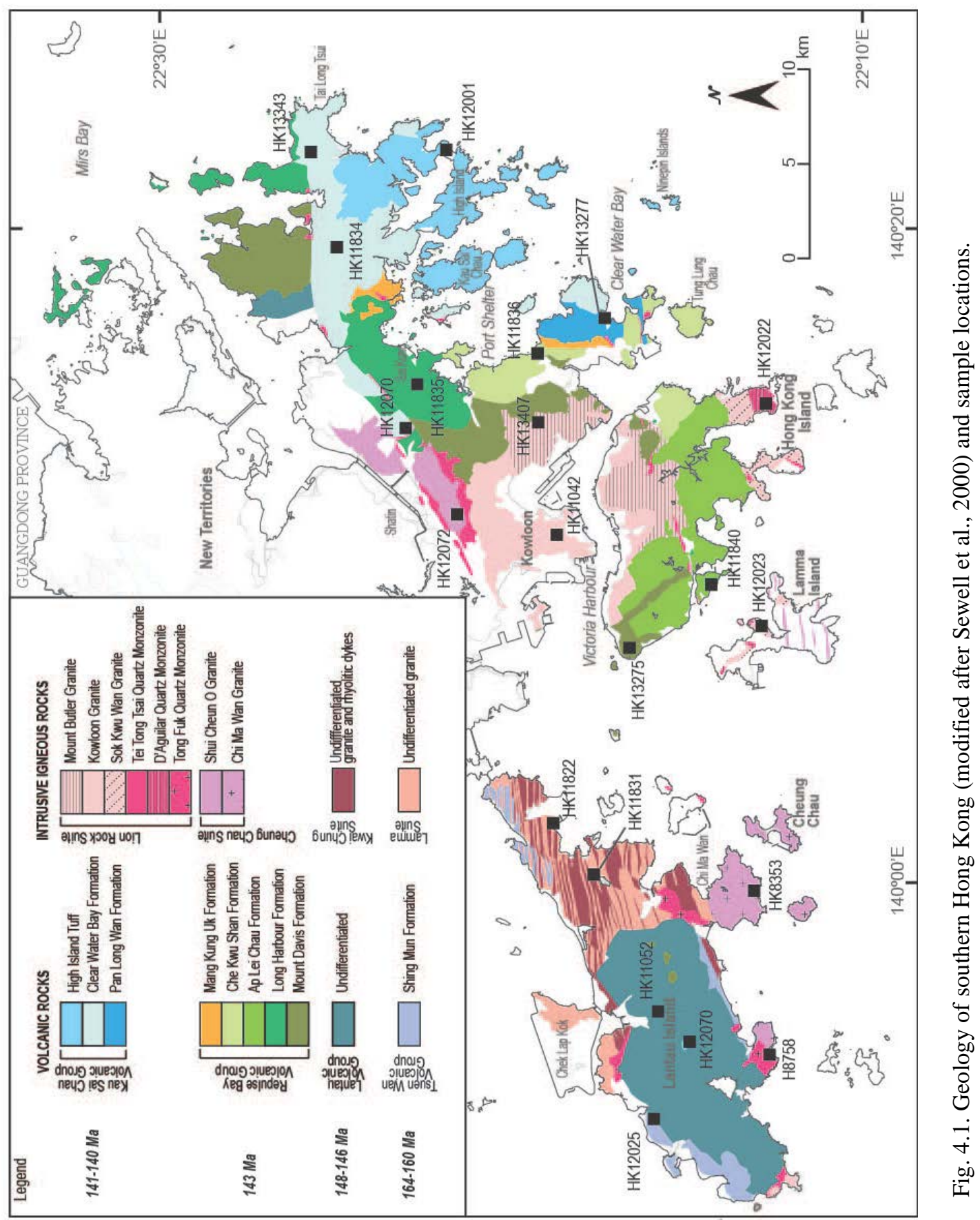


Outcrops of Late Jurassic granites ( 160 Ma Lamma Suite) are exposed in the northern and northeastern part of Lantau Island, and have been largely dismembered by 146 Ma felsic to intermediate dykes (East Lantau Rhyodacite Dyke Swarm) and tectonic activities (Langford et al., 1995). The dyke swarms form a 6-km wide, ENE-trending zone developed by multiple stages of intrusions accompanying a period of rapid crustal extension (Langford et al., 1995; Li et al., 2000). The Chi Ma Wan Granite ( 143 Ma), exposed at the southern fringe of the Lantau caldera complex, is intruded by quartz monzonite bodies of the Lion Rock Suite (Langford et al., 1995; Sewell et al., 2000). These quartz monzonite bodies ( 140 Ma Tong Fuk Quartz Monzonite) have been interpreted as ring fault intrusions (Langford et al., 1995; Campbell and Sewell, 1997, Campbell et al., 2007).

\subsubsection{High Island caldera complex}

Voluminous dacitic to rhyolitic ignimbrites and lavas of the two younger volcanic episodes (Early Cretaceous: 143 Ma and 141-140 Ma) spatially overlap and, along with their associated granitic plutons, are exposed within the nested High Island caldera complex (Fig. 4.1, Chapter 2). The 143 Ma Repulse Bay Volcanic Group (RBVG) comprises two main sub-groups (Table 4.1). The lower parts of the volcanic strata are dominated by dacitic to rhyolitic crystal-rich ignimbrites (of the Long Harbour and Mount Davis formations), while the upper sequence comprises trachytic to high-silica rhyolitic, crystalbearing, locally-welded ignimbrites (of the Ap Lei Chau and Che Kwu Shan formations). The 141-140 Ma Kau Sai Chau Volcanic Group (KSCVG) represents a series of volcanic activities that began with the eruption of trachydacite lava (Pan Long Wan Formation), followed by the Clear Water Bay rhyolite lava and densely welded ignimbrites, and culminated with the caldera-forming High Island Tuff (Strange et al., 1990; Sewell et al., 2012a).

Two groups of plutonic rocks, the Kwai Chung ( 143 Ma) and Lion Rock suites ( 140 Ma) were linked to the RBVG and KSCVG, respectively, as paired volcanic-plutonic assemblages (Campbell and Sewell, 1997; Sewell et al., 2000, 2012a). The Shui Chuen O Granite, exposed in the south New Territories, is the only pluton belonging to the $\sim 143 \mathrm{Ma}$ Kwai Chung Suite that forms part of the High Island caldera complex (Sewell et al., 2000; 2012a). Several granitic plutons, including the Kowloon, Mount Butler and Sok Kwu Wan granites and D’Aguilar Quartz Monzonite of the 140 Ma Lion Rock Suite have been 
interpreted to represent the sub-volcanic roots of the High Island caldera (Sewell et al., 2012a).

\subsection{Samples and Methods}

\subsubsection{Sample preparation}

In this study, zircons from 21 representative samples from 10 volcanic and 11 granitic units from the Lantau and High Island caldera complexes have been analysed (Fig. 4.1; Table 4.1.). For seventeen of these samples, zircon separates remaining from the previous ID-TIMS studies were obtained from the Hong Kong Geological Survey archive. In addition, extra materials from the same localities of two previously dated samples (HK11052 and HK12070) and two new samples (HK13343 and HK13407) were collected and crushed to obtain zircon for this study. Zircons were separated from bulk rock samples by mechanical crushing, sieving, and then standard heavy liquid and magnetic separation methods. Zircon grains were mounted in epoxy resin and polished to expose the approximate mid-section of the grains. Cathodoluminescence (CL) images of the polished mounts were taken on a JEOL JSM6610 LV Scanning Electron Microscope at Victoria University of Wellington (VUW) using a Robinson detector to reveal the crystal morphology, internal zoning and growth patterns of individual grains. The CL images were used as a guide for locating age and trace element analysis spots at specific growth zones of representative grains. Analytical spots were selected to cover a broad range of various growth patterns and zoning features identifiable from the CL images.

\subsubsection{In-situ U-Pb age determinations}

In-situ U-Pb age determinations were carried out by SIMS techniques using the SHRIMPRG instruments at the joint USGS-Stanford University facility (SUMAC) and at the Research School of Earth Sciences, Australian National University (ANU). In this study, I have aimed towards an improved precision level comparable to that of the previous IDTIMS ages by carrying out a large quantity of spatially-constrained analyses, i.e. analyses that were targeted at specific growth zones, such as cores, intermediate zones or rims of grains. By calculating the weighted means from these spatially targeted groups of analyses, a better precision than that achievable for individual age determinations can be achieved, linked to intra-grain characteristics and tested against the published highly precise ID- 
TIMS age data on multiple whole grains (Davis et al., 1997; Campbell et al., 2007; Sewell et al., 2012b).

Before each analytical session, the mounts were cleaned thoroughly in detergent, petroleum spirits and $1 \mathrm{M} \mathrm{HCL}$, rinsed in distilled water in between cleanings, and then gold coated. Analytical spots were carefully located to avoid inclusions visible in CL imagery or reflected light. Prior to data acquisition, the primary beam was rastered for 2 minutes over an area of 35 x $45 \mu \mathrm{m}$ to remove the gold coat and any surface contamination. Secondary ions were then sputtered from zircons with a 5-6 nA primary $\mathrm{O}_{2}{ }^{-}$beam focused to a $\sim 25 \mathrm{x} 35 \mu \mathrm{m}$ spot. The mass spectrometer was cycled through peaks corresponding to ${ }^{90} \mathrm{Zr}_{2}{ }^{16} \mathrm{O}(2 \mathrm{~s}),{ }^{204} \mathrm{~Pb}(2 \mathrm{~s})$, background (10 s), ${ }^{206} \mathrm{~Pb}$ (30 s), ${ }^{207} \mathrm{~Pb}(10 \mathrm{~s}),{ }^{208} \mathrm{~Pb}(2 \mathrm{~s}),{ }^{238} \mathrm{U}$ (7 s), ${ }^{232} \mathrm{Th}^{16} \mathrm{O}(2 \mathrm{~s})$ and ${ }^{238} \mathrm{U}^{16} \mathrm{O}(2 \mathrm{~s})$. Six scans were run through the mass sequence for each analytical spot. The concentration standard was MAD (Madagascar green: Barth \& Wooden 2010; 4196 ppm U) at SUMAC and SL13 (238 ppm U) at ANU. The U-Pb age standards used were R33 (420 Ma: ID-TIMS age from Zeh et al., 2015) or Temora 2 (417 Ma: Black et al., 2004). The concentration standard was measured once for each session, and the $\mathrm{U}-\mathrm{Pb}$ age standard was measured three times at the beginning of each round of analyses then subsequently once for every four unknowns. Data reduction was carried out using SQUID 2 (version 1.5.1: Ludwig, 2009), and data plotted using Isoplot version 3.7.6 (Ludwig, 2008). All uncertainties are reported here at $1 \sigma$, while for grouped data sets, uncertainties are given at 95\% confidence interval, as generated in Isoplot. The reported ages are derived from the ${ }^{207} \mathrm{~Pb}$-corrected ${ }^{206} \mathrm{~Pb}^{238} \mathrm{U}$ systematics, and no correction has been made for initial ${ }^{230}$ Th disequilibrium because of its trivial influence ( $<100 \mathrm{kyr}$ ) on the age patterns when compared with the analytical uncertainties associated with counting statistics. The presence of common $\mathrm{Pb}$ was monitored by the measured ${ }^{204} \mathrm{~Pb}$ and ${ }^{207} \mathrm{~Pb} /{ }^{206} \mathrm{~Pb}$ values. Analysis of grains with $<20 \%$ common $\mathrm{Pb}$ were considered acceptable for the purpose of this study. A correction for common $\mathrm{Pb}$ was applied using the recorded ${ }^{207} \mathrm{~Pb} /{ }^{206} \mathrm{~Pb}$ values and a common $\mathrm{Pb}$ isotopic composition $\left({ }^{207} \mathrm{~Pb} /{ }^{206} \mathrm{~Pb}=0.836\right.$; average crust model of Stacey and Kramers, 1975) for the sample age.

Two algorithms offered in Isoplot have been employed to present the age data for each unit: 1) the weighted mean ages determined for cores and rims, and for all data from a single sample; and 2) multiple age components identified by employing the Gaussian distributions of the Sambridge and Compston (1994) “mixture modeling” method. The mean square weighted deviation (MSWD, also known as the reduced chi-squared) is a 
statistical method which evaluates the goodness of fit of a dataset to the statistical model. An MSWD of $\approx 1$ indicates that the scatter in the age values is the same as the uncertainties attributed to those measurements. If an MSWD is significantly greater than 1 , the ages are dispersed either due to (1) the presence of significantly older inherited grains or zircon cores (antecrystic or xenocrystic components: Charlier et al., 2005); (2) Pb loss; or (3) instrumental limitations such as matrix effects (White and Ireland, 2013). An MSWD less than 1 , on the other hand, means that the analytical uncertainties (derived from the counting statistics) are much larger than the scatter in the absolute values. The weighted averages of the dates are also calculated for individual samples using Isoplot and are reported at the 95\% probability level as yielded in Isoplot. These SIMS age data are compared with the published ID-TIMS ages of the relevant unit, if available.

\subsubsection{Zircon trace element analytical techniques}

Trace element analyses on zircons were undertaken by Secondary Ion Mass Spectrometry (SIMS) techniques on the SHRIMP-RG instrument at the joint USGS-Stanford University facility (SUMAC). After U-Pb dating, the zircon mounts were re-polished prior to trace element analyses to remove the earlier analytical spots. The analytical routine included $\mathrm{Li}$, Be, B, F, Na, Al, Si, P, K, Ca, Sc, ${ }^{48} \mathrm{Ti}$, ${ }^{49} \mathrm{Ti}$, Fe, Y, Nb, ${ }^{94} \mathrm{ZrH},{ }^{96} \mathrm{ZrH}$, the complete suite of rare earth elements (REEs) except $\mathrm{Pr}, \mathrm{Zr}_{2} \mathrm{O}$, HfO, ThO, and ${ }^{238} \mathrm{U}^{16} \mathrm{O}$. The oxide peaks for Yb, Gd, Tb, Dy, Er, Tm, Lu, Hf, Th and U were measured due to the greater ion production during sputtering. For the operating parameters of SHRIMP-RG, a primary beam current of $2.4 \mathrm{nA}$, spot size of $20 \mu \mathrm{m}$ and mass resolution of 10,000 were used. The concentration standard was MAD (Madagascar green: Barth and Wooden, 2010). Data reduction was done using SQUID 2 (version 1.51, Ludwig, 2009) and data plots were generated using Isoplot (version 3.75, Ludwig, 2008). The MAD concentration standard was measured multiple times during each analytical session to determine the overall reproducibility of the trace element data. I use selected elements to track potential contamination by minor mineral and/or melt inclusions that were accidentally intersected during sample sputtering. These elements include: $\mathrm{Li}, \mathrm{Ca}, \mathrm{Al}, \mathrm{Na}, \mathrm{K}$, La for feldspar or glass; Ca, P, F for apatite; Fe for Fe-Ti oxides, and Ca, Fe, La for allanite. Analyses that yield strong enrichment of these elements were considered contaminated, and the reported data below exclude any data considered to be badly affected by accidental analysis of inclusions. The full dataset is presented in Electronic Appendix B. The external 
reproducibility of zircon trace element data (Mazdab and Wooden, 2006) generally varies with count statistics, but also reflects heterogeneities in the MAD natural zircon standard. The majority of measured elements reproduce to $\sim 2-5 \% 2$ s.d., whereas the lowconcentration elements (usually $\mathrm{Li}, \mathrm{Be}, \mathrm{F}, \mathrm{Ca}, \mathrm{La}$ and $\mathrm{Eu}$ ) show poorer reproducibility (Electronic Appendix B).

For each sample, >60 to 120 analyses were carried out, depending on the number and size of zircon grains available and the diversity of zoning patterns observed under CL imagery. The analytical spots were located such that the range of textural variations seen in the zircon populations from individual samples were covered, including core-rim, tip-side, and sector-zoned pairs from the same growth zone, and if feasible, placed in the same growth zones of the crystals where $\mathrm{U}-\mathrm{Pb}$ age determination analyses had been done.

\subsection{Results}

\subsubsection{Zircon zoning patterns}

For each sample, at least 150 grains were classified based on their zoning patterns, including the presence or absence of cores, the relative CL intensity (brightness) of the cores versus rims, and the presence or absence of oscillatory zoning and sector zoning in the rim zones (Fig. 4.2). These patterns reflect the conditions under which the zircons grew and can be used to infer evolution of magmatic processes (Hanchar and Miller, 1993), especially when combined with trace element analysis and U-Pb age determination. The CL emission of zircon is attributed dominantly to the presence of $\mathrm{Dy}^{3+}$, and probably also to other REEs including $\mathrm{Er}^{3+}, \mathrm{Sm}^{3+}, \mathrm{Tb}^{3+}, \mathrm{Gd}^{3+}, \mathrm{Nd}^{3+}$ and $\mathrm{Eu}^{2+}$ (Hanchar and Miller, 1993; Corfu et al., 2003), while the presence of hydrothermal alteration, which is associated with enrichments of $\mathrm{U}, \mathrm{Th}, \mathrm{Y}, \mathrm{Ca}, \mathrm{P}$ and $\mathrm{Fe}$, and radiation damage of the crystal lattice structure (metamictisation) are likely to suppress CL emission (Nasdala et al., 2003). All samples, both volcanic and plutonic, yield zircons that exhibit a widely diverse range of textures and zoning patterns in CL imagery. The proportion of zircons showing different textural characteristics is illustrated in Fig. 4.2 and Table 4.2. Common zoning patterns observed include the presence of cores, which show varying internal textures, oscillatory zoning and sector zoning. 


\section{CLASSIFICATION OF ZIRCON TEXTURES IN CL IMAGERY}

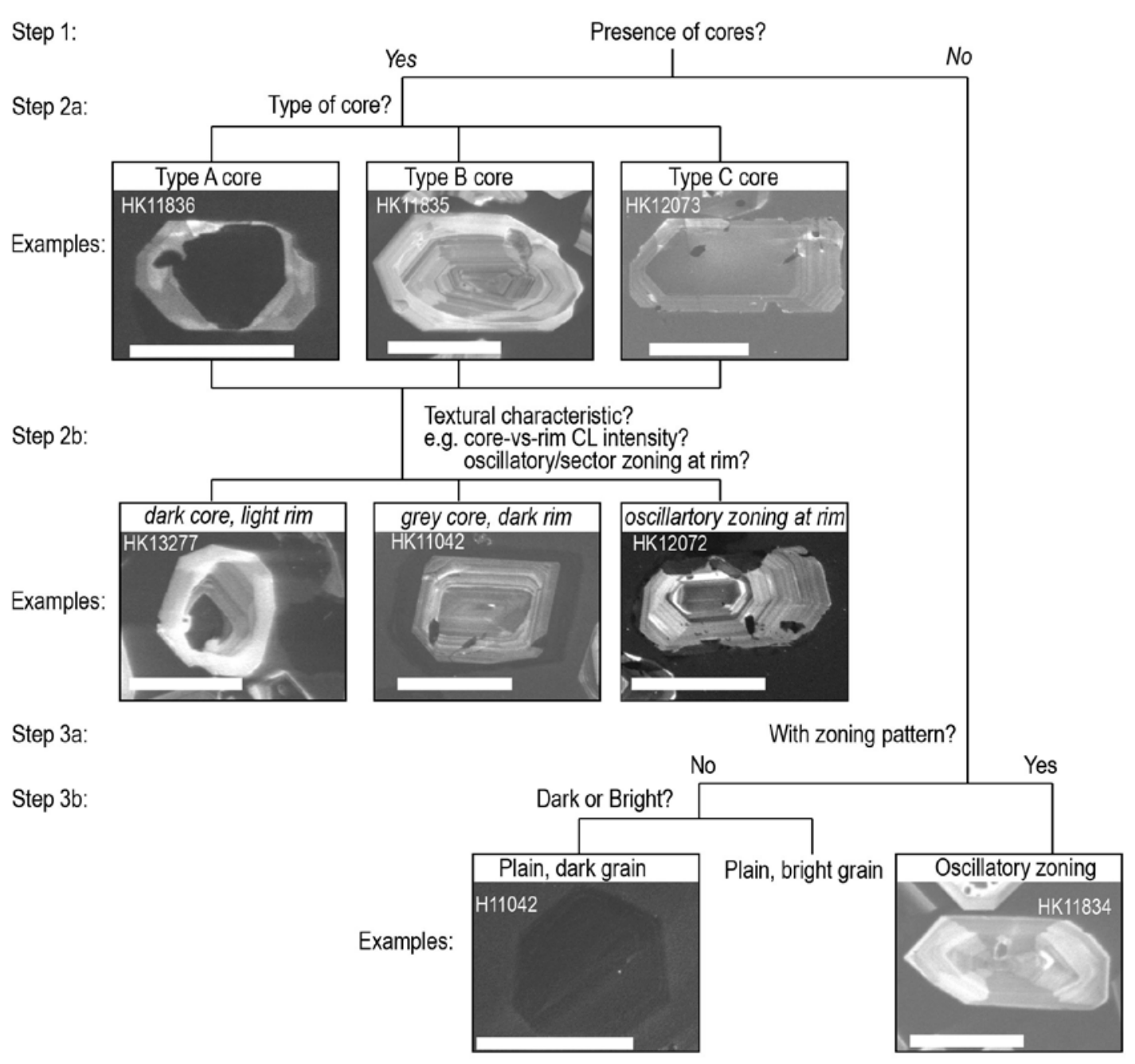

Step 4: Other textural characteristic? oscillatory zoning? sector zoning? or both?

Notes: (1) Types of zircon cores: A: Rounded, structureless; B: Rounded, zoned; C: Euhedral, structureless (2) Scale bar $=100$ microns

Fig. 4.2. Illustration of systematic classification of zircon textures in CL imagery. See text for details. 
Table 4.2. Characterisation of zircon textures under CL imagery.

\begin{tabular}{|c|c|c|c|c|c|c|}
\hline Sample No. & $\begin{array}{l}\text { No. of } \\
\text { grains }\end{array}$ & $\begin{array}{c}\text { With core? } \\
\text { (Y/N) } \\
\text { Step 1* }\end{array}$ & $\begin{array}{c}\text { Core } \\
\text { Type } \\
\text { Step 2a* }\end{array}$ & $\begin{array}{c}\text { Textural characteristics } \\
\text { Steps } 2 \mathrm{~b}, 3 \mathrm{a} \& 3 \mathrm{~b}^{*}\end{array}$ & $\begin{array}{l}\text { Oscillatory } \\
\text { Zoning } \\
\text { Step 4* } \\
\end{array}$ & $\begin{array}{l}\text { Sector } \\
\text { Zoning } \\
\text { Step 4* }\end{array}$ \\
\hline \multicolumn{7}{|l|}{ Volcanic Rocks } \\
\hline $\begin{array}{l}\text { HK12025 } \\
\text { Shing Mun fine } \\
\text { ash tuff }\end{array}$ & 299 & $\begin{array}{l}76 \%(\mathrm{Y}) \\
24 \%(\mathrm{~N})\end{array}$ & $\left\{\begin{array}{l}74 \%(\mathrm{~B}) \\
2 \%(\mathrm{C})\end{array}\right.$ & $\begin{array}{l}\text { 26\%: Dark core, light rim } \\
21 \% \text { : Light core, dark rim } \\
\text { 29\%: Dark core, dark rim } \\
\text { 23\%: Grain with OZ pattern } \\
\text { 1\%: Dark or intermediate grain }\end{array}$ & $91 \%$ & $22 \%$ \\
\hline $\begin{array}{l}\text { HK11052 } \\
\text { Lantau volcanic }\end{array}$ & 295 & $\begin{array}{l}59 \%(\mathrm{Y}) \\
41 \%(\mathrm{~N})\end{array}$ & $\left\{\begin{array}{l}24 \%(\mathrm{~A}) \\
35 \%(\mathrm{~B})\end{array}\right.$ & $\begin{array}{l}\text { 37\%: Dark core, light rim } \\
\text { 18\%: Light core, dark rim } \\
4 \% \text { : Dark core, dark rim } \\
\text { 20\%: Dark grain } \\
\text { 2\%: Light or intermediate grain } \\
\text { 19\%: Grain with OZ pattern }\end{array}$ & $46 \%$ & $15 \%$ \\
\hline $\begin{array}{l}\text { HK11835 } \\
\text { Long Harbour } \\
\text { crystal-rich } \\
\text { ignimbrite }\end{array}$ & 364 & $\begin{array}{l}57 \%(\mathrm{Y}) \\
43 \%(\mathrm{~N})\end{array}$ & $\left\{\begin{array}{l}7 \%(\mathrm{~A}) \\
50 \%(\mathrm{~B})\end{array}\right.$ & $\begin{array}{l}\text { 39\%: Dark core, dark rim } \\
\text { 13\%: Light core, dark rim } \\
5 \% \text { : Dark core, bright rim } \\
\text { 42\%: Grain with OZ pattern } \\
1 \% \text { : Dark or intermediate grain }\end{array}$ & $91 \%$ & $36 \%$ \\
\hline $\begin{array}{l}\text { HK13275 } \\
\text { Mount Davis } \\
\text { crystal ignimbrite }\end{array}$ & 184 & $\begin{array}{l}85 \% \\
15 \%\end{array}$ & $\left\{\begin{array}{l}19 \%(\mathrm{~A}) \\
62 \%(\mathrm{~B}) \\
4 \%(\mathrm{C})\end{array}\right.$ & $\begin{array}{l}\text { 64\%: Dark core, light rim } \\
\text { 19\%: Light core, dark rim } \\
\text { 2\%: Dark core, dark rim } \\
\text { 4\%: Dark grain } \\
\text { 1\%: Light grain } \\
\text { 10\%: Grain with OZ pattern }\end{array}$ & $48 \%$ & $23 \%$ \\
\hline $\begin{array}{l}\text { HK11836 } \\
\text { Che Kwu Shan } \\
\text { tuff }\end{array}$ & 323 & $\begin{array}{l}73 \%(\mathrm{Y}) \\
27 \%(\mathrm{~N})\end{array}$ & $\left\{\begin{array}{l}27 \%(\mathrm{~A}) \\
40 \%(\mathrm{~B}) \\
6 \%(\mathrm{C})\end{array}\right.$ & $\begin{array}{l}\text { 66\%: Dark core, light rim } \\
6 \% \text { : Light core, dark rim } \\
\text { 1\%: Dark core, dark rim } \\
\text { 14\%: Grain with OZ pattern } \\
\text { 6\%: Dark grain } \\
\text { 7\%: Light grain }\end{array}$ & $41 \%$ & $20 \%$ \\
\hline $\begin{array}{l}\text { HK11840 } \\
\text { Ap Lei Chau tuff }\end{array}$ & 570 & $28 \%(\mathrm{~N})$ & $\left\{\begin{array}{l}31 \%(\mathrm{~A}) \\
39 \%(\mathrm{~B}) \\
2 \%(\mathrm{C})\end{array}\right.$ & $\begin{array}{l}\text { 69\%: Dark core, light rim } \\
\text { 3\%: Light core, dark rim } \\
\text { 14\%: Dark grain } \\
\text { 7\%: Light grain } \\
7 \% \text { : Grain with OZ pattern }\end{array}$ & $23 \%$ & $9 \%$ \\
\hline $\begin{array}{l}\text { HK12070 } \\
\text { Kau Sai Chau tuff }\end{array}$ & 364 & $37 \%(\mathrm{Y})$ & $\left\{\begin{array}{l}31 \%(\mathrm{~B}) \\
6 \%(\mathrm{C})\end{array}\right.$ & $\begin{array}{l}\text { 28\%: Dark core, light rim } \\
\text { 7\%: Light core, dark rim } \\
\text { 2\%: Dark core, dark rim } \\
\text { 31\%: Grain with OZ pattern } \\
\text { 30\%: Dark grain } \\
\text { 2\%: Bright grain }\end{array}$ & $42 \%$ & $11 \%$ \\
\hline $\begin{array}{l}\text { HK13277 } \\
\text { Pan Long Wan } \\
\text { trachydacite }\end{array}$ & 522 & $38 \%(\mathrm{~N})$ & $\left\{\begin{array}{l}48 \%(\mathrm{~A}) \\
14 \%(\mathrm{~B})\end{array}\right.$ & $\begin{array}{l}\text { 62\%: Dark core, bright rim } \\
\text { 5\%: Dark grain } \\
29 \% \text { : Bright grain } \\
4 \% \text { : Grain with OZ pattern }\end{array}$ & $15 \%$ & $9 \%$ \\
\hline
\end{tabular}


Table 4.2. (Cont'd).

\begin{tabular}{|c|c|c|c|c|c|c|}
\hline Sample No. & $\begin{array}{l}\text { No. of } \\
\text { grains }\end{array}$ & $\begin{array}{l}\text { With core? } \\
\text { (Y/N) } \\
\text { Step 1* }\end{array}$ & $\begin{array}{c}\text { Core } \\
\text { Type } \\
\text { Step 2a* }\end{array}$ & $\begin{array}{l}\text { Textural characteristics } \\
\text { Steps 2b, 3a \& 3b* }\end{array}$ & $\begin{array}{l}\text { Oscillatory } \\
\text { Zoning } \\
\text { Step 4* }\end{array}$ & $\begin{array}{l}\text { Sector } \\
\text { Zoning } \\
\text { Step 4* }\end{array}$ \\
\hline Volcanic Rocks & & & & & & \\
\hline $\begin{array}{l}\text { HK11834 } \\
\text { Clear Water Bay } \\
\text { rhyolite tuff }\end{array}$ & 778 & $\begin{array}{l}50 \%(\mathrm{Y}) \\
50 \%(\mathrm{~N})\end{array}$ & $\begin{array}{l}11 \%(\mathrm{~A}) \\
21 \%(\mathrm{~B}) \\
18 \%(\mathrm{C})\end{array}$ & $\begin{array}{l}\text { 45\%: Dark core, light rim } \\
4 \% \text { : Dark core, dark rim } \\
\text { 1\%: Light core, dark rim } \\
\text { 19\%: Dark grain } \\
\text { 31\% Grain with OZ pattern }\end{array}$ & $41 \%$ & $20 \%$ \\
\hline $\begin{array}{l}\text { HK12073 } \\
\text { Clear Water Bay } \\
\text { rhyolite lava }\end{array}$ & 256 & $\begin{array}{l}75 \%(\mathrm{Y}) \\
25 \%(\mathrm{~N})\end{array}$ & $\begin{array}{l}32 \%(\mathrm{~A}) \\
10 \%(\mathrm{~B}) \\
33 \%(\mathrm{C})\end{array}$ & $\begin{array}{l}\text { 65\%: Dark core, light rim } \\
6 \% \text { : Light core, dark rim } \\
\text { 4\%: Dark core, dark rim } \\
\text { 7\%: Dark grain } \\
\text { 18\%: Grain with OZ pattern }\end{array}$ & $66 \%$ & $13 \%$ \\
\hline $\begin{array}{l}\text { HK12001 } \\
\text { High Island Tuff }\end{array}$ & 842 & $\begin{array}{l}62 \%(\mathrm{Y}) \\
38 \%(\mathrm{~N})\end{array}$ & $\begin{array}{l}32 \%(\mathrm{~B}) \\
30 \%(\mathrm{C})\end{array}$ & $\begin{array}{l}\text { 58\%: Dark core, dark rim } \\
\text { 3\%: Light core, dark rim } \\
\text { 1\%: Dark core, light rim } \\
\text { 23\%: Dark grain } \\
1 \% \text { : Light grain } \\
14 \% \text { Grain with OZ pattern }\end{array}$ & $54 \%$ & $2 \%$ \\
\hline $\begin{array}{l}\text { HK13343 } \\
\text { Post-High Island } \\
\text { rhyolite lava at } \\
\text { Sharp Peak }\end{array}$ & 254 & $\begin{array}{l}52 \%(\mathrm{Y}) \\
48 \%(\mathrm{~N})\end{array}$ & $\begin{array}{l}18 \%(\mathrm{~A}) \\
11 \%(\mathrm{~B}) \\
23 \%(\mathrm{C})\end{array}$ & $\begin{array}{l}\text { 30\%: Dark core, light rim } \\
\text { 17\%: Dark core, dark rim } \\
5 \% \text { : Light core, dark rim } \\
\text { 15\%: Dark grain } \\
4 \% \text { : Light grain } \\
\text { 29\%: Grain with OZ pattern }\end{array}$ & $61 \%$ & $17 \%$ \\
\hline $\begin{array}{l}\text { HK11822 } \\
\text { Lantau Granite }\end{array}$ & 252 & $\begin{array}{l}80 \%(\mathrm{Y}) \\
20 \%(\mathrm{~N})\end{array}$ & $\begin{array}{l}27 \%(\mathrm{~A}) \\
49 \%(\mathrm{~B}) \\
4 \%(\mathrm{C})\end{array}$ & $\begin{array}{l}\text { 60\%: Light core, dark rim } \\
\text { 15\%: Dark core, dark rim } \\
5 \% \text { : Dark core, light rim } \\
\text { 3\%: Dark grain } \\
\text { 4\% Light grain } \\
\text { 13\%: Grain with OZ pattern }\end{array}$ & $26 \%$ & $8 \%$ \\
\hline $\begin{array}{l}\text { HK11831 } \\
\text { Feldspar porphyry }\end{array}$ & 300 & 73\% (Y) & $\begin{array}{l}29 \%(\mathrm{~A}) \\
41 \%(\mathrm{~B}) \\
3 \%(\mathrm{C})\end{array}$ & $\begin{array}{l}67 \% \text { : Dark core, light rim } \\
5 \% \text { : Light core, dark rim } \\
1 \% \text { : Dark core, dark rim } \\
25 \% \text { : Grain with OZ pattern } \\
2 \% \text { : Dark or intermediate grain }\end{array}$ & $65 \%$ & $24 \%$ \\
\hline $\begin{array}{l}\text { HK12072 } \\
\text { Shui Chuen O } \\
\text { Granite }\end{array}$ & 157 & $60 \%(\mathrm{Y})$ & $\begin{array}{l}5 \%(\mathrm{~A}) \\
42 \%(\mathrm{~B}) \\
13 \%(\mathrm{C})\end{array}$ & $\begin{array}{l}\text { 49\%: Dark core, light rim } \\
7 \% \text { : Light core, dark rim } \\
4 \% \text { : Dark core, dark rim } \\
\text { 16\%: Dark or intermediate grain } \\
24 \% \text { : Grain with OZ pattern }\end{array}$ & $69 \%$ & $47 \%$ \\
\hline $\begin{array}{l}\text { HK8353 } \\
\text { Chi Ma Wan } \\
\text { Granite }\end{array}$ & 336 & $70 \%(\mathrm{Y})$ & $\begin{array}{l}28 \%(\mathrm{~A}) \\
40 \%(\mathrm{~B}) \\
2 \%(\mathrm{C})\end{array}$ & $\begin{array}{l}\text { 29\%: Dark core, light rim } \\
\text { 25\%: Light core, dark rim } \\
\text { 16\%: Dark core, dark rim } \\
\text { 17\%: Dark grain } \\
\text { 3\%: Light to intermediate grain } \\
10 \% \text { : Grain with OZ pattern }\end{array}$ & $38 \%$ & $7 \%$ \\
\hline
\end{tabular}


Table 4.2. (Cont'd).

\begin{tabular}{|c|c|c|c|c|c|c|}
\hline Sample No. & $\begin{array}{l}\text { No. of } \\
\text { grains }\end{array}$ & $\begin{array}{l}\text { With core? } \\
\text { (Y/N) } \\
\text { Step 1* }\end{array}$ & $\begin{array}{c}\text { Core } \\
\text { Type } \\
\text { Step } 2 \mathrm{a}^{*}\end{array}$ & $\begin{array}{c}\text { Textural characteristics } \\
\text { Steps 2b, 3a \& 3b* }\end{array}$ & $\begin{array}{l}\text { Oscillatory } \\
\text { Zoning } \\
\text { Step 4* }\end{array}$ & $\begin{array}{l}\text { Sector } \\
\text { Zoning } \\
\text { Step 4* }\end{array}$ \\
\hline \multicolumn{7}{|l|}{ Intrusive Rocks } \\
\hline \multirow{2}{*}{$\begin{array}{l}\text { HK12023 } \\
\text { Sok Kwu Wan } \\
\text { Granite }\end{array}$} & \multirow{2}{*}{301} & $58 \%(\mathrm{Y})$ & \multirow[t]{2}{*}{$\begin{array}{l}39 \%(\mathrm{~B}) \\
19 \%(\mathrm{C})\end{array}$} & $\begin{array}{l}53 \% \text { : Dark core, light rim } \\
3 \%: \text { Light core, dark rim } \\
2 \%: \text { Dark core, dark rim }\end{array}$ & \multirow{2}{*}{$52 \%$} & \multirow{2}{*}{$14 \%$} \\
\hline & & $42 \%(\mathrm{~N})$ & & $\begin{array}{l}27 \% \text { : Grain with OZ pattern } \\
13 \% \text { : Dark to intermediate grain } \\
2 \% \text { : Light grain }\end{array}$ & & \\
\hline \multirow{2}{*}{$\begin{array}{l}\text { HK12022 } \\
\text { D'Aguilar Quartz } \\
\text { Monzonite }\end{array}$} & \multirow{2}{*}{262} & $79 \%(Y)$ & \multirow[t]{2}{*}{$\begin{array}{l}55 \%(\mathrm{~A}) \\
24 \%(\mathrm{~B})\end{array}$} & $\begin{array}{l}\text { 76\%: Dark core, light rim } \\
2 \% \text { : Light core, dark rim } \\
\text { 1\%: Dark core, dark rim }\end{array}$ & \multirow{2}{*}{$32 \%$} & \multirow{2}{*}{$38 \%$} \\
\hline & & $21 \%(\mathrm{~N})$ & & $\begin{array}{l}\text { 4\%: Dark grain } \\
6 \% \text { : Light grain } \\
11 \% \text { : Grain with OZ pattern }\end{array}$ & & \\
\hline \multirow{2}{*}{$\begin{array}{l}\text { HK8758 } \\
\text { Tong Fuk Quartz } \\
\text { Monzonite }\end{array}$} & \multirow[b]{2}{*}{313} & $62 \%(\mathrm{Y})$ & \multirow[t]{2}{*}{$\begin{array}{l}36 \%(\mathrm{~A}) \\
18 \%(\mathrm{~B}) \\
8 \%(\mathrm{C})\end{array}$} & $\begin{array}{l}60 \% \text { : Dark core, bright rim } \\
2 \% \text { : Light core, dark rim }\end{array}$ & & \\
\hline & & $38 \%(\mathrm{~N})$ & & $\begin{array}{l}\text { 12\%: Dark grain } \\
6 \% \text { : Bright or intermediate grain } \\
\text { 20\%: Grain with OZ pattern }\end{array}$ & $36 \%$ & $17 \%$ \\
\hline \multirow{2}{*}{$\begin{array}{l}\text { HK11042 } \\
\text { Kowloon Granite }\end{array}$} & \multirow[t]{2}{*}{674} & $87 \%(\mathrm{Y})$ & \multirow[t]{2}{*}{$\begin{array}{l}82 \%(\mathrm{~B}) \\
5 \%(\mathrm{C})\end{array}$} & $\begin{array}{l}\text { 76\%: Light core, dark rim } \\
6 \% \text { : Dark core, dark rim } \\
5 \% \text { : Dark core, light rim }\end{array}$ & \multirow[t]{2}{*}{$8 \%$} & \multirow[t]{2}{*}{$2 \%$} \\
\hline & & $13 \%(\mathrm{~N})$ & & $\begin{array}{l}\text { 10\%: Dark grain } \\
3 \% \text { : Grain with OZ pattern }\end{array}$ & & \\
\hline \multirow{2}{*}{$\begin{array}{l}\text { HK13407 } \\
\text { Mount Butler } \\
\text { Granite }\end{array}$} & \multirow{2}{*}{297} & $63 \%(\mathrm{Y})$ & $\begin{array}{l}33 \%(\mathrm{~A}) \\
29 \%(\mathrm{~B}) \\
1 \%(\mathrm{C})\end{array}$ & $\begin{array}{l}\text { 50\%: Light core, dark rim } \\
\text { 4\%: Dark core, dark rim } \\
\text { 9\%: Dark core, light rim }\end{array}$ & \multirow{2}{*}{$56 \%$} & \multirow{2}{*}{$12 \%$} \\
\hline & & $37 \%(\mathrm{~N})$ & & $\begin{array}{l}\text { 18\%: Dark grain } \\
\text { 19\%: Grain with OZ pattern }\end{array}$ & & \\
\hline
\end{tabular}

Note: See Fig. 4.2 and associated text for the classification system used and descriptions of each step. 
4.4.1.1. Presence of distinct cores

All samples yielded zircons with varying percentages (34-85\%) of grains having discrete 


\subsubsection{Oscillatory zoning}

Oscillatory zoning is commonly seen in magmatic zircons (Hancher and Miller, 1993). The mechanism of generating oscillatory zoning in zircon is not well-understood, but has been attributed to various processes, including interactions at the crystal-melt boundary, cation substitution, rate of diffusion, and melt polymerization of fractionating magma (e.g. Mattinson et al., 1996; Watson, 1996; Hoskin et al., 2000). Most of the samples (both volcanic and intrusive rocks) have $\sim 40 \%$ and in some cases up to $~ 90 \%$ (e.g. Long Harbour and Shing Mun formations) of crystals showing oscillatory zoning (Table 4.2).

\subsubsection{Sector zoning}

In general, I observe that sector zoning in the outer growth zones is more common in volcanic than plutonic zircons in these samples (sector zoning in zircon cores is not counted; Table 4.2). Several factors have been proposed to explain sector zoning, including kinetic factors, rapid changes in growth environment, or rapid fluctuation in growth rates (e.g. Paterson and Stephens, 1992; Hanchar and Miller, 1993; Watson and Liang, 1995; Vavra et al., 1996). All volcanic samples, except the High Island Tuff (HK12001), contain $9-36 \%$ of grains with sector zoning, whereas the High Island Tuff has only $2 \%$ of grains showing sector zoning. For plutonic units, most of the zircon populations contain 2-24\% of grains with sector zoning, with the exceptions of the Shui Chuen O Granite and D'Aguilar Quartz Monzonite (47\% and 38\%, respectively).

\subsubsection{Zircon $\mathrm{U}-\mathrm{Pb}$ age data}

A total of 883 age determinations were carried out on the 21 samples (Table 4.3). The full dataset is given in Electronic Appendix A. For individual samples, the weighted mean ages of all data and only rim analyses, and the multiple age components are compared against the previously reported ID-TIMS ages. The probability distribution curves and histograms of the SIMS age data for the volcanic and plutonic units within the High Island caldera and Lantau caldera complexes are presented in Figs. 4.3 to 4.8.

\subsubsection{Volcanic units from Lantau caldera complex}

The volcanic units from the Lantau caldera complex, including the Shing Mun, Lantau and undifferentiated Kau Sai Chau ignimbrites, all appear to contain multiple age components 
(Fig. 4.3, Table 4.4). The weighted mean ages of all analyses (both cores and rims) of these samples are thus not useful for determining the eruption age of the units and the weighted mean ages of rim analyses are used instead. The Shing Mun ignimbrite (HK12025) and undifferentiated Kau Sai Chau ignimbrite (HK12070) yield weighted mean rim ages of

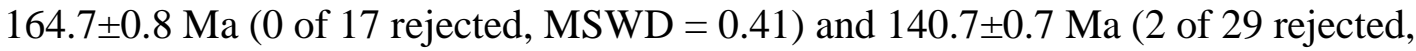
MSWD $=2.7$ ) respectively, which are within uncertainty the same as the ID-TIMS ages of the same samples (Table 4.3). The zircon rims of the Lantau ignimbrite (HK11052) yield a weighted mean age of $144.5 \pm 0.7$ Ma ( 0 of 17 rejected, MSWD $=0.67$ ), which is $\sim 2 \mathrm{Myr}$ younger than the ID-TIMS age estimate for this unit (Table 4.3).
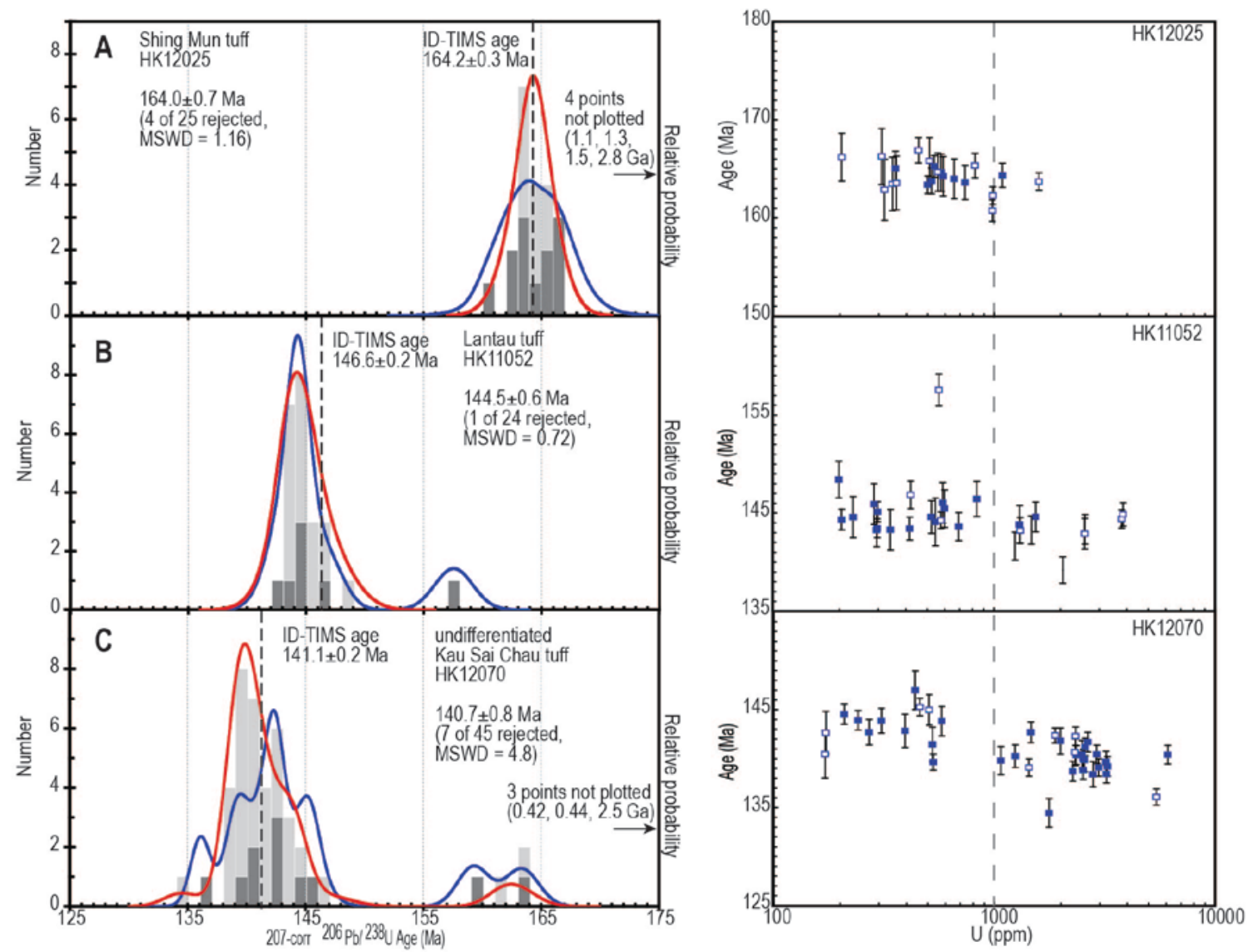

Fig. 4.3. Stacked age histograms and relative probability curves (left panels) and ${ }^{206} \mathrm{~Pb} /{ }^{238} \mathrm{U}$ ages versus $\mathrm{U}$ concentrations (right panels) for volcanic rock samples from the Lantau caldera complex. A: Shing Mun ignimbrite (HK12025); B: Lantau tuff (HK11052); and C: undifferentiated Kau Sai Chau ignimbrite (HK12070). Left panels: darker-grey histograms and blue relative probability curves are data from cores; lighter-grey histograms and red relative probability curves are data from rims. Ages given are the weighted mean age of all (cores and rims) data. Right panels: open squares represent data from cores and closed squares represent data from rims. Error bars represent 1 s.d. uncertainties. 


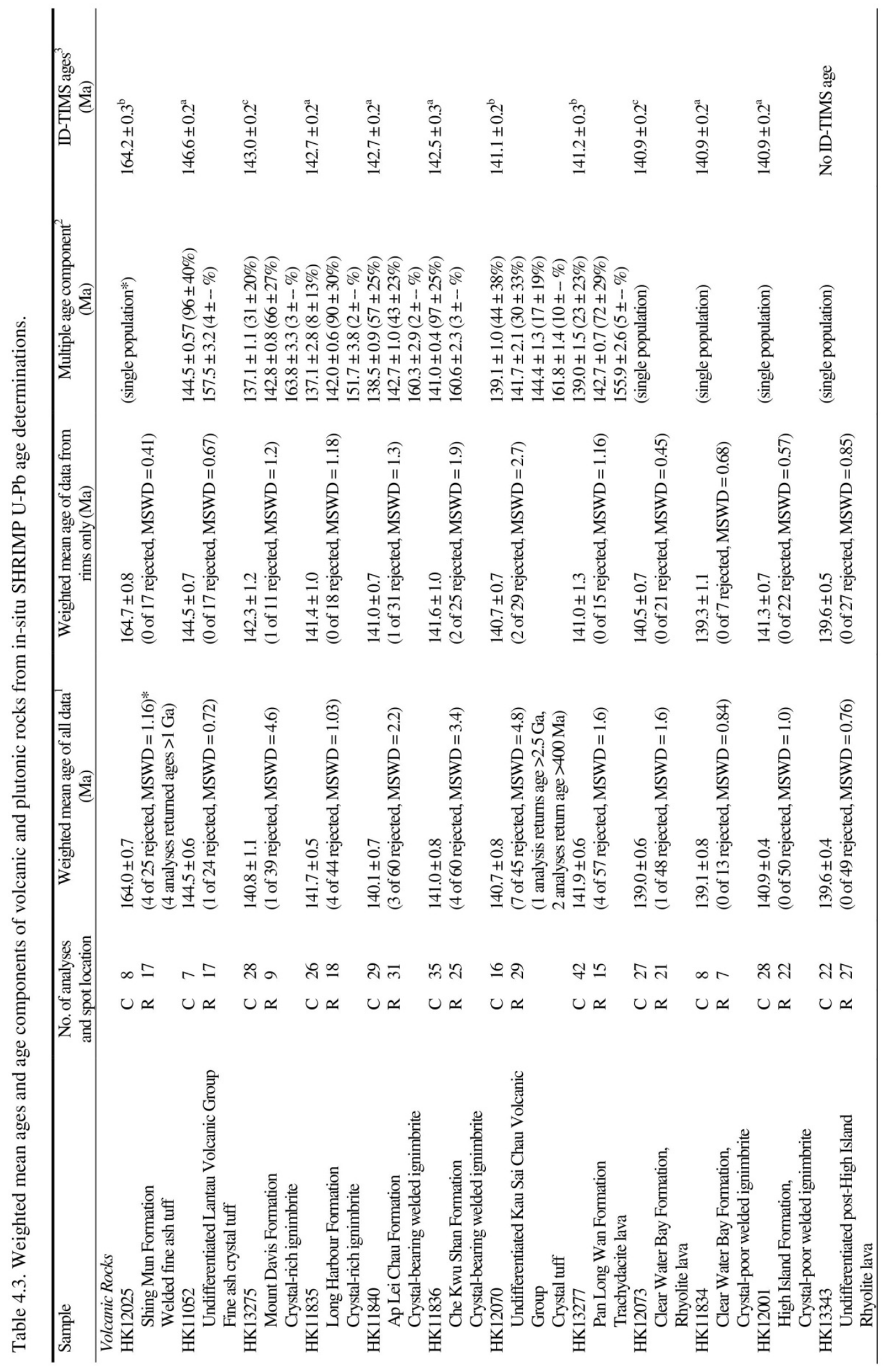




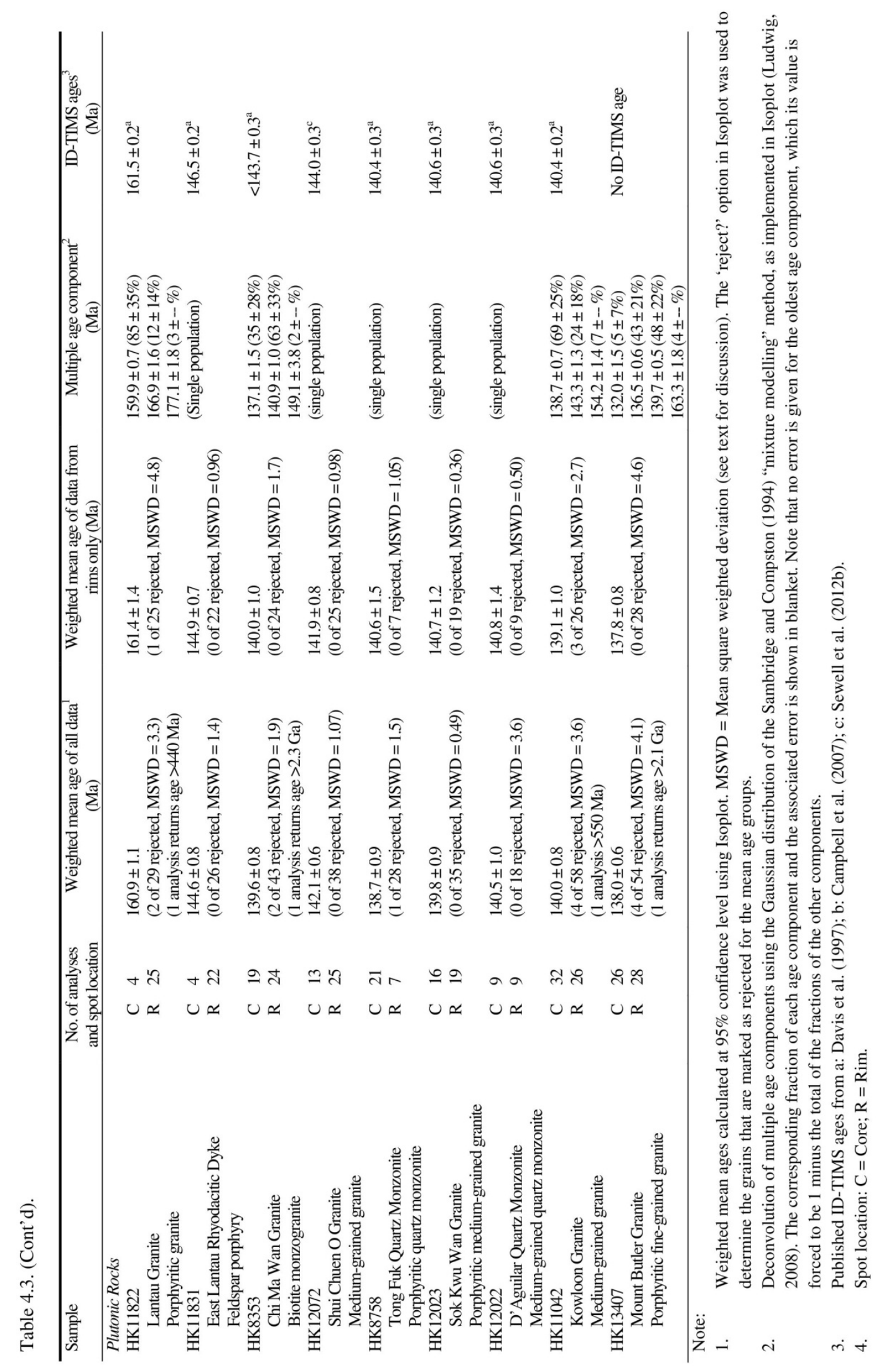


The East Lantau porphyry and Tong Fuk Quartz Monzonite from the Lantau caldera complex both yield a single age component (Fig. 4.4, Table 4.3). Twenty-six age determinations from East Lantau porphyry (HK11831) yield a weighted mean age of 144.6 \pm 0.8 Ma ( 0 of 26 rejected, MSWD = 1.4), almost $\sim 2$ Myr younger than its ID-TIMS age (Table 4.3). It is noted that, however, the core analyses of this unit yield multiple peaks in the relative probability curve (Fig. 4.4B). The weighted mean rim age of Tong Fuk Quartz Monzonite (HK8758) is 140.6 \pm 1.5 Ma (0 of 17 rejected, MSWD = 1.05), which is identical within 2 s.d. uncertainty to its ID-TIMS age (Table 4.3). When all analyses from both cores and rims of the unit are considered, a slightly younger weighted mean age of $138.7 \pm 0.9 \mathrm{Ma}(1$ of 28 rejected, MSWD = 1.5) is obtained, which is attributed to some apparently younger cores of $<140$ Ma.

Multiple age components are identified in the Lantau Granite and Chi Ma Wan Granite (Fig. 4.4, Table 4.4). The weighted mean rim age of Lantau Granite (HK11822) is 161.4 \pm 1.4 Ma (1 of 25 rejected, MSWD =4.8), which is only 0.1 Myr different to the reported ID-TIMS age (Table 4.3). In contrast, twenty-four analyses from zircon rims of

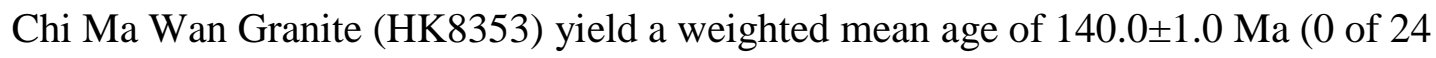
rejected, MSWD = 1.7), at least 2-3 Myr younger than the reported ID-TIMS age of the pluton (Table 4.3).

\subsubsection{Volcanic units from the High Island caldera complex}

Within the High Island caldera complex, all units from the RBVG contain multiple age components (Fig. 4.5, Table 4.3). The Mount Davis ignimbrite (HK13275) yields mean rim age of 142.3 \pm 1.2 Ma (1 out of 11 rejected, MSWD = 1.2), which overlaps within 2 s.d. uncertainty the reported ID-TIMS age of the unit (Table 4.3). Three other samples, Long Harbour ignimbrite (HK11835), Ap Lei Chau ignimbrite (HK11840) and Che Kwu Shan ignimbrite (HK11836), give younger weighted mean rim ages when compared with their ID-TIMS ages (Table 4.3). The weighted mean rim ages of these units are, respectively 141.4 \pm 1.0 Ma (0 of 18 rejected, MSWD =1.18), 141.0 \pm 0.7 Ma (1 of 31 rejected, MSWD = 1.3) and 141.6 $\pm 1.0 \mathrm{Ma}(2$ of 25 rejected, MSWD = 1.9). Age components younger than $\sim 140$ Ma are identified from all of the RBVG units except the Che Kwu Shan ignimbrite. 
These younger age components, however, may be erroneous due to high $U$ content in the dated grains (see Section 4.5.2.3).
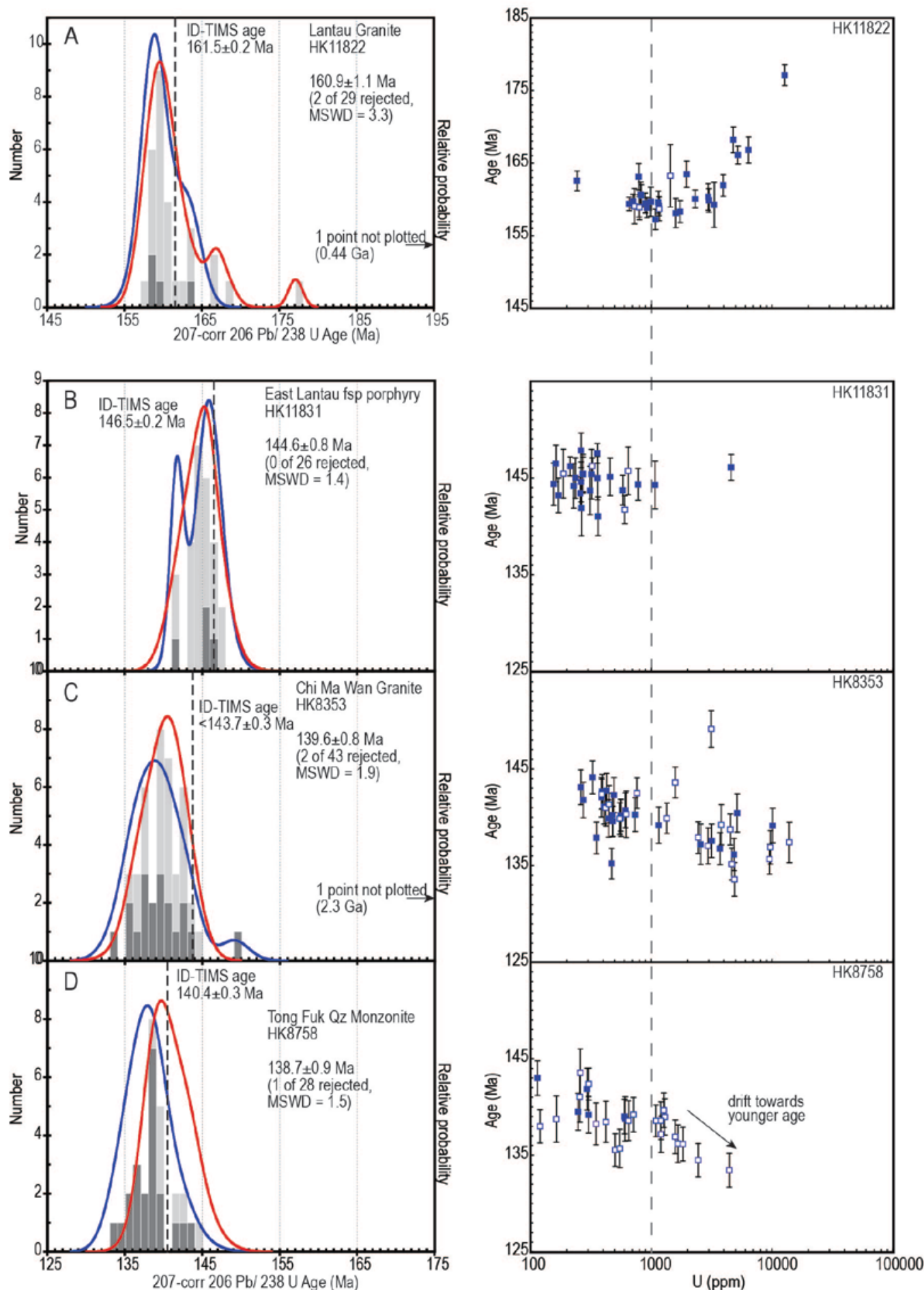

Fig. 4.4. Stacked age histograms and relative probability curves (left panels) and ${ }^{206} \mathrm{~Pb} /{ }^{238} \mathrm{U}$ ages versus $\mathrm{U}$ concentrations (right panels) for intrusive rock samples from the Lantau caldera complex. A: Lantau Granite (HK11822); B: East Lantau porphyry (HK11832); C: Chi Ma Wan Granite (HK8353); and D: Tong Fuk Quartz Monzonite (HK8758). Left panels: darker-grey histograms and blue relative probability curves are data from cores; lighter-grey histograms and red relative probability curves are data from rims. Ages given are the weighted mean age of all (cores and rims) data. Right panels: open squares represent data from cores and closed squares represent data from rims. Error bars represent 1 s.d. uncertainties. 

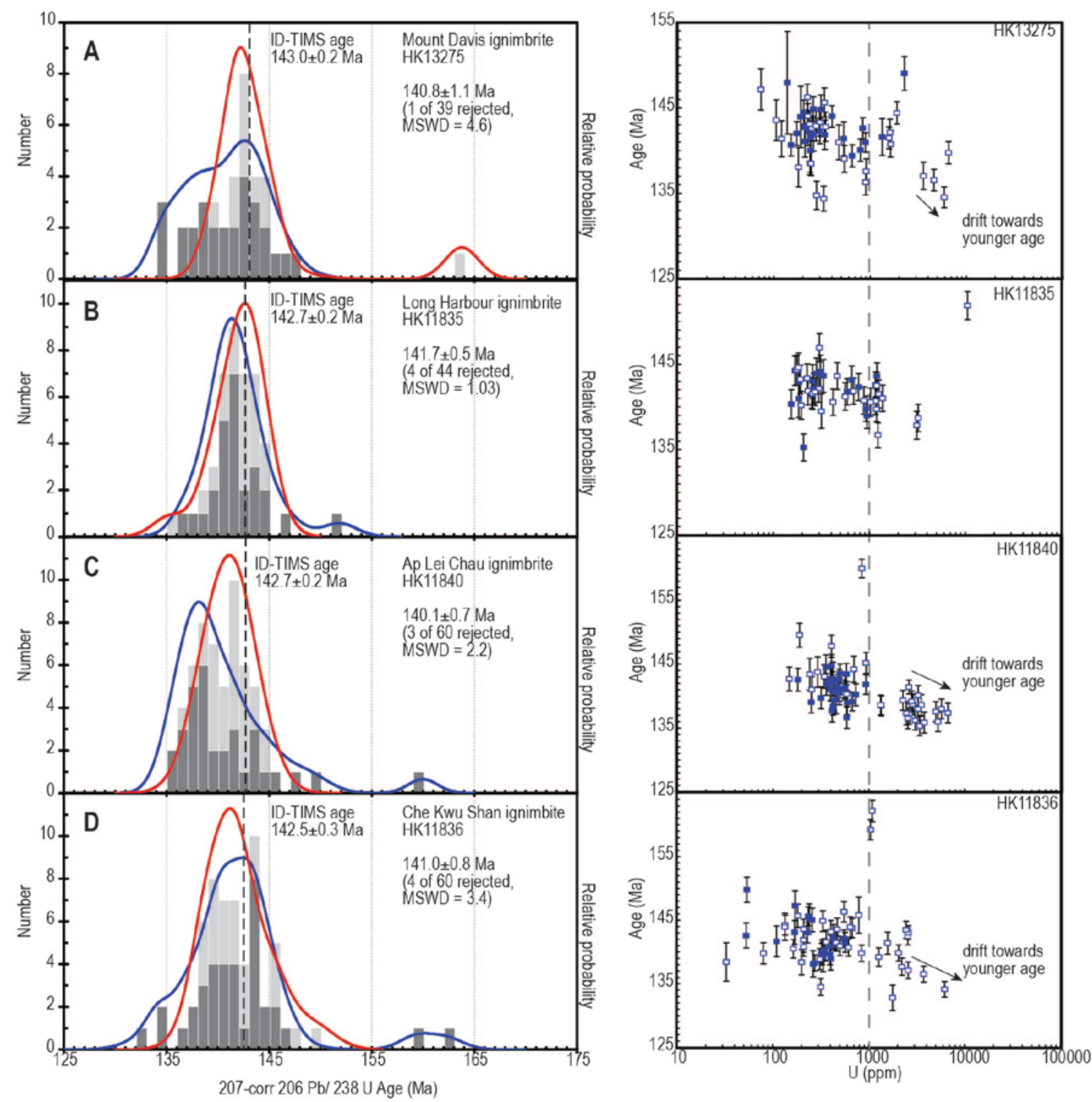

Fig. 4.5. Stacked age histograms and relative probability curves (left panels) and ${ }^{206} \mathrm{~Pb} /{ }^{238} \mathrm{U}$ ages versus $\mathrm{U}$ concentrations (right panels) for ignimbrite samples from the RBVG. A: Mount Davis (HK13275); B: Long Harbour (HK11835); C: Ap Lei Chau (HK11840); D: Che Kwu Shan (HK11836). Left panels: darker-grey histograms and blue relative probability curves are data from cores; whereas lighter-grey histograms and red relative probability curves are data from rims. Ages given are the weighted mean age of all (cores and rims) data. Right panels: open squares represent data from cores and closed squares represent data from rims. Error bars represent 1 s.d. uncertainties. 
The KSCVG units, except for the Pan Long Wan trachydacite (HK13277), yield unimodal, normally-distributed age spectra, although for some samples the age data from rims and cores considered separately do not yield identical peaks (Fig. 4.6). The Pan Long Wan trachydacite contains multiple age components and yields a weighted mean rim age of 141.0 \pm 1.3 Ma (0 of 15 rejected, MSWD = 1.16), identical within uncertainty to the IDTIMS age (Table 4.3). The weighted mean ages (all analyses) of the Clear Water Bay ignimbrite (HK11834) and lava (HK12073) are closely comparable: 139.1 $\pm 0.8 \mathrm{Ma}$ (0 of 13 rejected, MSWD = 0.84) and 138.9 $\pm 0.6 \mathrm{Ma}(1$ of 48 rejected, MSWD = 1.6), respectively. These mean ages overlap, within 2 s.d. uncertainty, but are slightly younger than the reported ID-TIMS ages (Table 4.3). Interestingly, if the analyses from zircon cores and rims are considered separately, the weighted mean ages of the zircon cores from these two samples are younger than that of analyses from rims. The reliability of these younger ages will be discussed below (Section 4.5.2.3). For the High Island Tuff (HK12001), the weighted mean age of all dates is $140.9 \pm 0.4 \mathrm{Ma}(\mathrm{MSWD}=1.0)$, identical to the ID-TIMS age (Table 4.3). The peaks generated from the rim and core analyses separately are also identical (Fig. 4.6). The post-High Island rhyolite lava (HK13343) yields a weighted mean age of 139.6 $\pm 0.4 \mathrm{Ma}(0$ of 49 rejected, MSWD $=0.76)$. As this lava has not had an age determination by ID-TIMS, this figure represents the first estimate for its eruption age.

\subsubsection{Plutonic units from High Island caldera complex}

For plutonic rocks within the High Island caldera complex, the Sok Kwu Wan Granite (HK12023), D’Aguilar Quartz Monzonite (HK12022) and Shui Chuen O Granite (HK12072) all show uniform single age populations (Table 4.3; Fig. 4.7). Thirty-five analyses from the Sok Kwu Wan Granite zircons yield a weighted mean age of $139.8 \pm 0.9$ Ma ( 0 of 35 rejected, MSWD $=0.49$ ), with the core analyses forming a younger peak than that of analyses from the rims (Fig. 4.7). The weighted mean age of 18 analyses from D’Aguilar Quartz Monzonite zircons is $140.5 \pm 1.0 \mathrm{Ma}(0$ of 18 rejected, MSWD = 0.59), identical within uncertainty to the ID-TIMS age (Table 4.3). Thirty-eight analyses from the

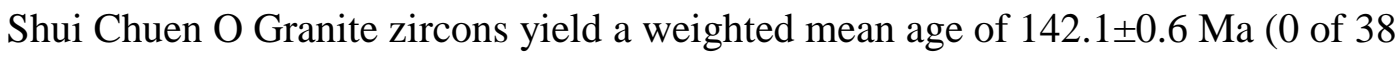
rejected, MSWD = 1.07), which is $>2$ Myr younger than the ID-TIMS age. 

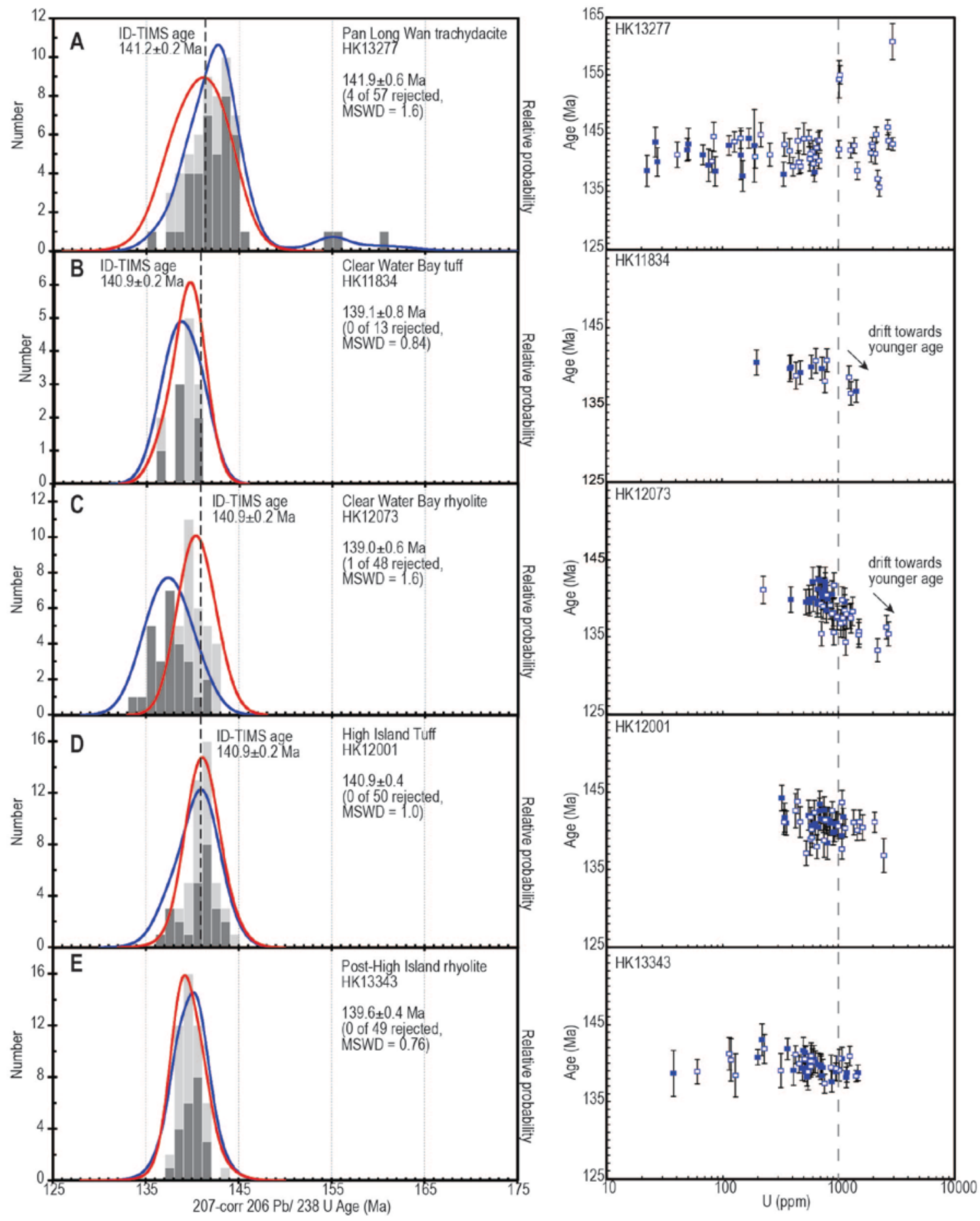

Fig. 4.6. Stacked age histograms and relative probability curves (left panels) and ${ }^{206} \mathrm{~Pb} /{ }^{238} \mathrm{U}$ ages versus $\mathrm{U}$ concentrations (right panels) for samples from the KSCVG. A: Pan Long Wan trachydacite (HK13277); B: Clear Water Bay tuff (HK11834); C: Clear Water Bay rhyolite (HK12073); D: High Island Tuff (HK12001); and E: post-High Island rhyolite lava (HK13343). Left panels: darker-grey histograms and blue relative probability curves are data from cores; whereas lighter-grey histograms and red relative probability curves are data from rims. Ages given are the weighted mean age of all (cores and rims) data. Right panels: open squares represent data from cores and closed squares represent data from rims. Error bars represent 1 s.d. uncertainties. 

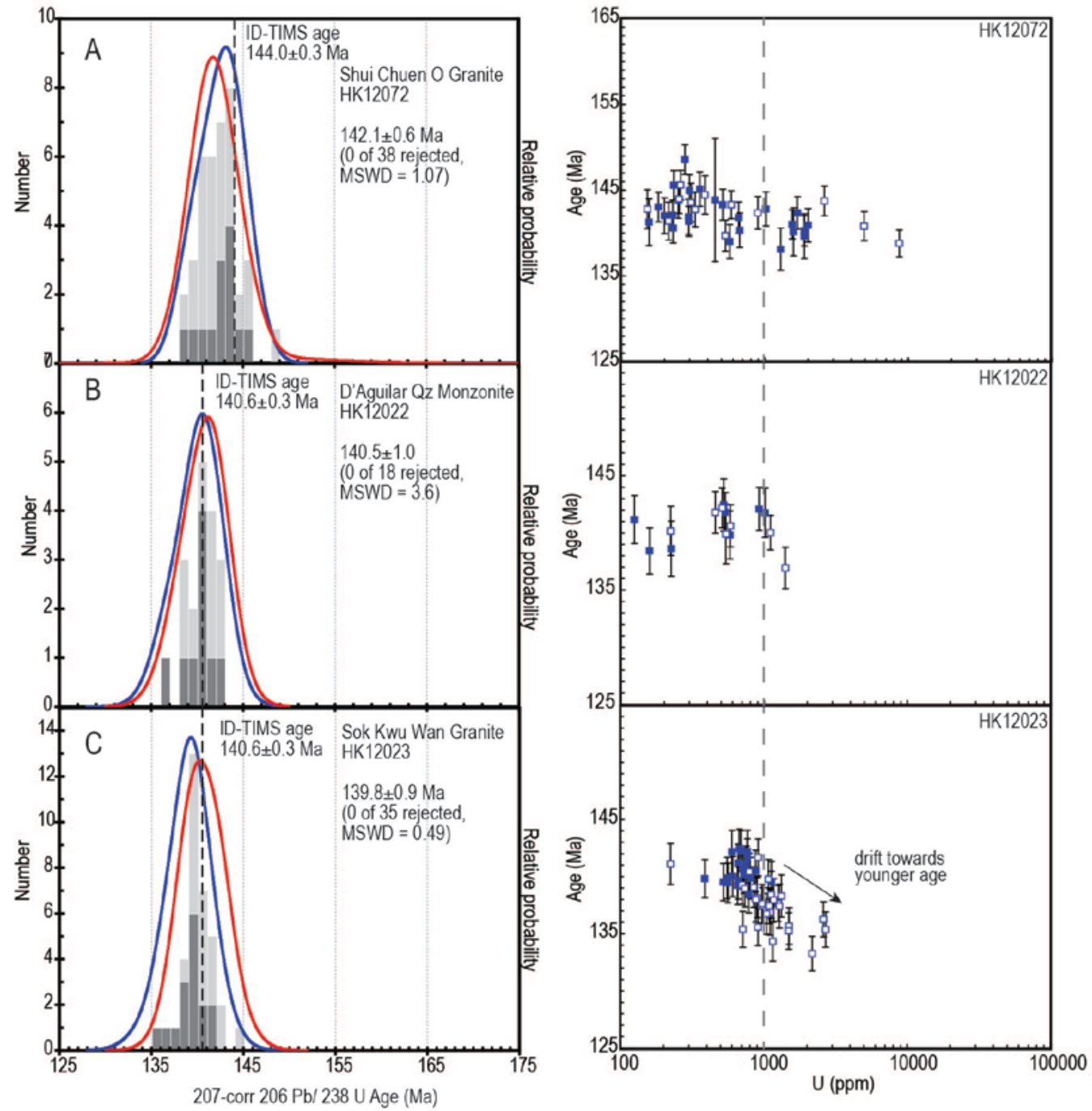

Fig. 4.7. Stacked age histograms and relative probability curves (left panels) and ${ }^{206} \mathrm{~Pb} /{ }^{238} \mathrm{U}$ ages versus $\mathrm{U}$ concentrations (right panels) for intrusive rock samples from the High Island Caldera. A: Shui Chuen O Granite (HK12072); B: D’Aguilar Quartz Monzonite (HK12022); and C: Sok Kwu Wan Granite (HK12023). Left panels: darker-grey histograms and blue relative probability curves are data from cores; whereas lightergrey histograms and red relative probability curves are data from rims. Ages given are the weighted mean age of all (cores and rims) data. Right panels: open squares represent data from cores and closed squares represent data from rims. Error bars represent 1 s.d. uncertainties. 
Multiple age components are present in the Mount Butler Granite and, as with the

Kowloon Granite, some of the age components are younger than 140 Ma (Table 4.3).

Fifty-eight U-Pb age determinations from the Kowloon Granite zircons (HK11042) give a weighted mean age of $140.0 \pm 0.8 \mathrm{Ma}$ ( 4 of 58 rejected, MSWD =3.6), similar to the IDTIMS age of the same sample (Fig. 4.8 and Table 4.3). It is noted that the MSWD is much larger than 1 , suggesting that there is some spread in the age distribution that is greater than the uncertainties associated with individual ages in the dataset. Using the Gaussian deconvolution unmixing of the age data, however, three age components are identified (Table 4.3), suggesting the zircons were crystallised or recycled from several magmatic phases. The weighted mean age of $54 \mathrm{U}-\mathrm{Pb}$ zircon age determinations from the Mount Butler Granite (HK13407), which has not been previously dated, is 138.0 \pm 0.6 Ma (4 of 54 rejected, MSWD $=4.1$ ). If only rim analyses are considered, the weighted mean age is $137.8 \pm 0.8 \mathrm{Ma}(0$ of 28 rejected, MSWD $=4.6$ ), which is almost identical to the weighted mean of all age data.
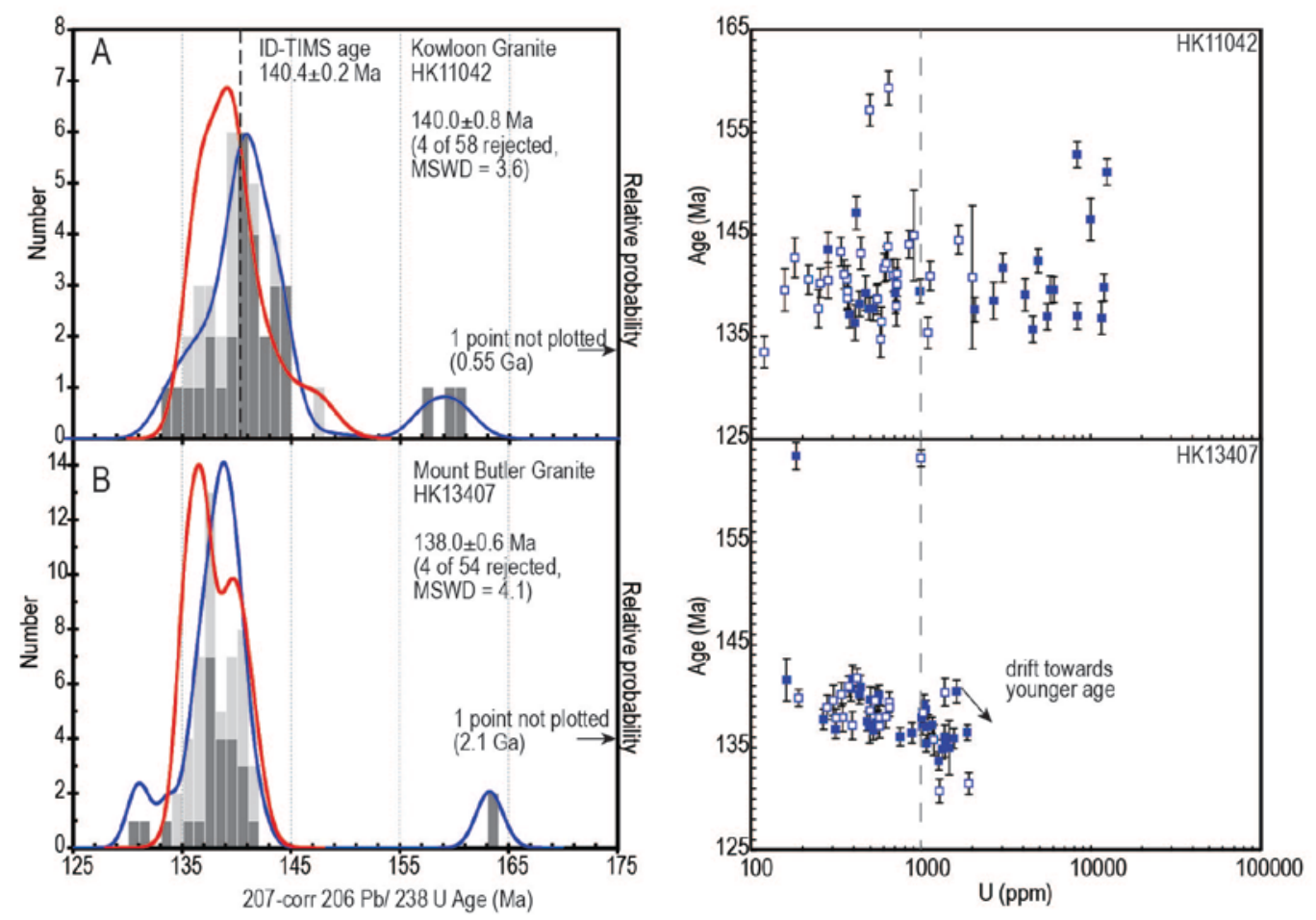

Fig. 4.8. Stacked age histograms and relative probability curves (left panels) and ${ }^{206} \mathrm{~Pb} / 238 \mathrm{U}$ ages versus $\mathrm{U}$ concentrations (right panels) for intrusive rock samples associated by Sewell et al. (2012) with the High Island caldera complex. A: Kowloon Granite (HK11042); and B: Mount Butler Granite (HK13407). Left panels: dark-grey histograms and blue relative probability curves are data from cores; whereas light-grey histograms and red relative probability curves are data from rims. Ages given are the weighted mean age of all (cores and rims) data. Right panels: open squares represent data from cores and closed squares represent data from rims. Error bars represent 1 s.d. uncertainties. 


\subsubsection{Xenocrystic grains}

Some of the zircons, in particular their cores, yielded Palaeozoic to Proterozoic ages, and are xenocrysts (terminology in Charlier et al., 2005) incorporated into the magma bodies from the surrounding basement rocks. The Shing Mun Formation sample (HK12025) contains old xenocrystic cores with ages of $>1 \mathrm{Ga}$ (4 of 11 core analyses, Table 4.3). Similarly, the undifferentiated Kau Sai Chau tuff (HK12070) also yields zircon cores (3 of 14 core analyses) with much older ages than its eruption age, implying that these cores were recycled from country rocks. For plutonic units, the Lantau Granite (HK11822), Chi Ma Wan Granite (HK8353), Kowloon Granite (HK11042) and Mount Butler Granite (HK13407) also contain xenocrystic cores (Table 4.3).

\subsubsection{Trace element data}

A total of 1,681 acceptable zircon trace element analyses (i.e. those without significant accidental contamination from micro-inclusions) was obtained (Table 4.4). The suite of samples studied here represents a wide compositional spectrum of silicic magmatic rocks, for instance from trachydacite (Pang Long Wan trachydacite lava, HK13277) to high-K high-silica rhyolite (High Island Tuff, HK12001); and from quartz monzonite (D’Aguilar Quartz Monzonite, HK12023) to highly-evolved granites (e.g. Mount Butler Granite, HK13407). The number of analyses for individual samples and their distributions among different growth zones of the zircon grains, i.e. cores or rims, are given in Table 4.4. The ranges and median values of abundances of $\mathrm{Hf}, \mathrm{U}$, Th, total trivalent trace elements $\left(\mathrm{Sc}+\mathrm{Y}+\mathrm{REE}^{3+}\right), \mathrm{Sc}, \mathrm{Y}$, and $\mathrm{Ti}$ in zircons, the ranges of $\mathrm{Eu} / \mathrm{Eu}^{*}$ values, the elemental ratios of $\mathrm{Ce} / \mathrm{Sm}, \mathrm{Th} / \mathrm{U}, \mathrm{Yb} / \mathrm{Gd}, \mathrm{U} / \mathrm{Yb}$, and the molar ratio of total trivalent trace elements/P of the sample suites are also summarised there. The full dataset is given in Electronic Appendix B.

All trace element data are plotted together to illustrate the overall patterns of volcanic and plutonic units (Fig. 4.9). In general, the volcanic and plutonic zircons yield very similar, if not identical, trace element patterns. All units show a common trend with $\mathrm{Eu} / \mathrm{Eu}{ }^{*}$ and $\mathrm{Ti}$ decreasing with increasing Hf concentration implying, not surprisingly, that the Euanomaly deepens and melt temperature (with Ti concentration used as a proxy) decreases with melt evolution. The ranges of trace element concentrations (e.g. Ti, Sc, P, Y, total 3+, $\mathrm{U}$ and $\mathrm{Th}$ ) in zircons from the volcanic and plutonic rocks are also comparable. 


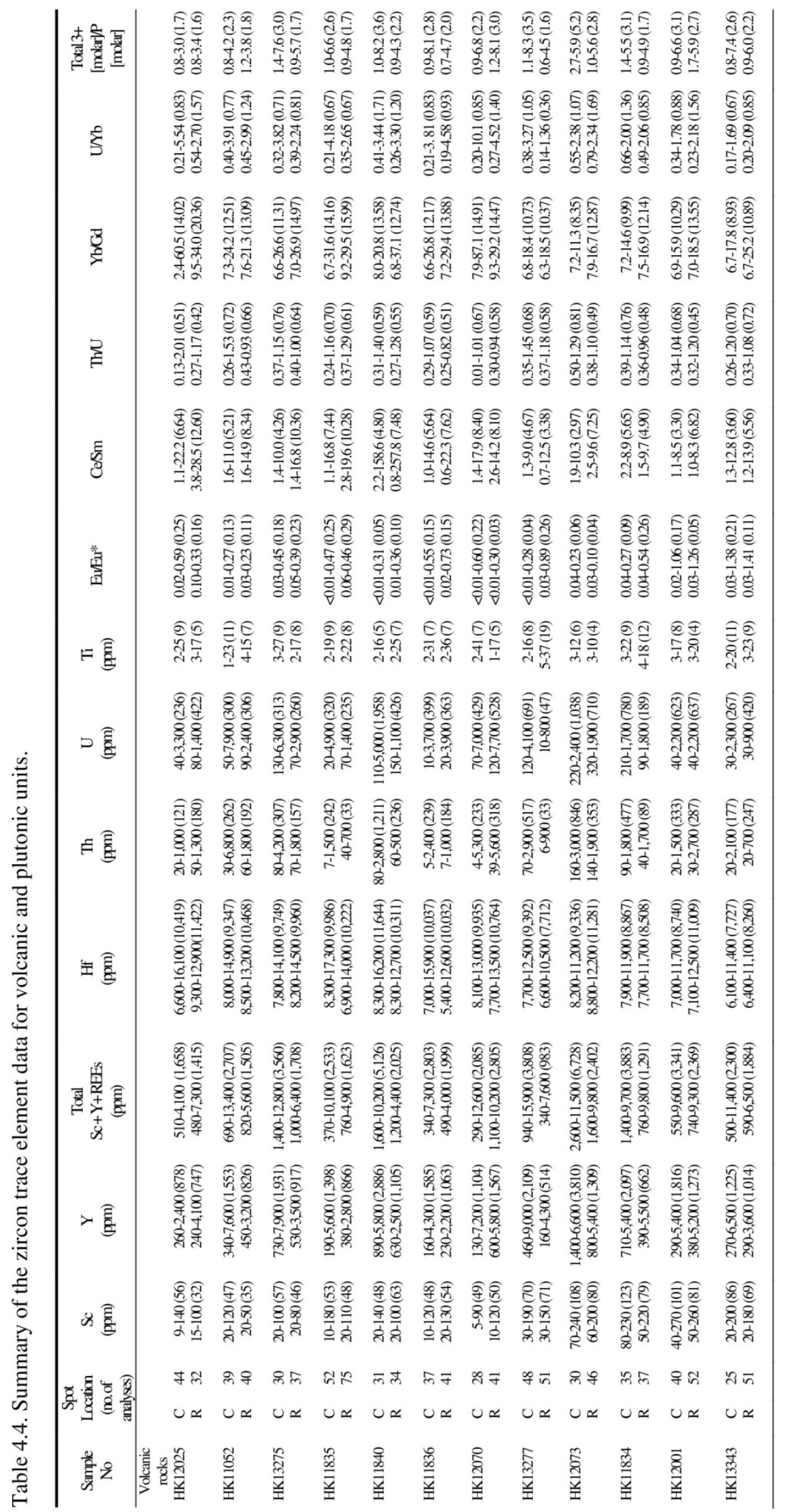




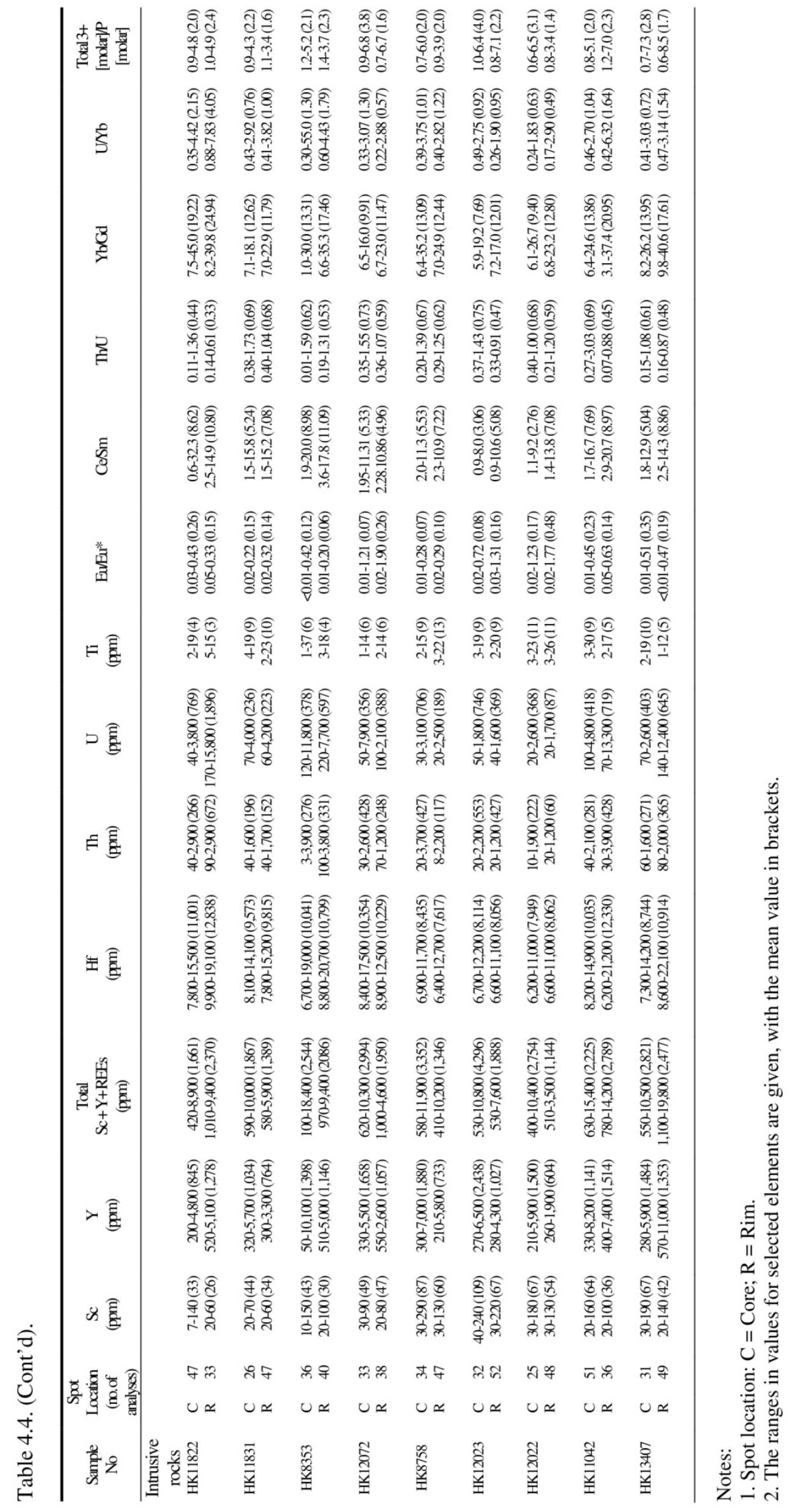



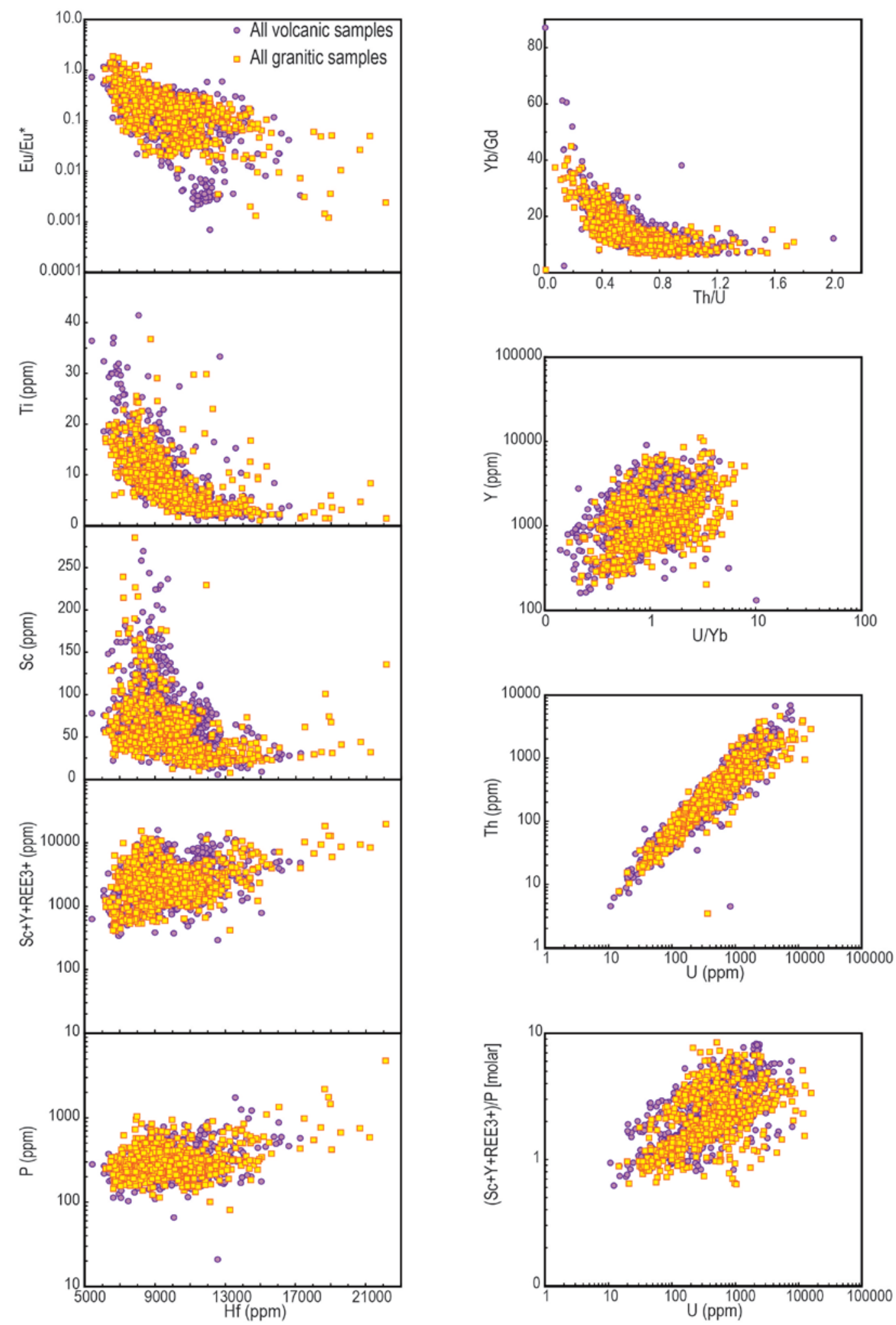

Fig. 4.9. Plots of selected trace elements and trace element ratios showing all data from volcanic and plutonic rock samples from Hong Kong. 


\subsubsection{Hafnium (Hf)}

Hf concentrations in zircon have been demonstrated to be a useful tracer of melt evolution, with higher values linked to increasing degrees of magmatic differentiation and cooling of the melt (e.g. Wooden et al., 2006; Claiborne et al., 2006; 2010; Barth and Wooden, 2010; Reid et al., 2011). Most zircons from the older volcanic units within the Lantau caldera complex (samples HK12025 and HK11052) and the Repulse Bay volcanic units (samples HK13275, HK11835, HK11840 and HK11836) contain Hf concentrations ranging from 7,000-14,000 ppm, but some CL-darker cores are slightly enriched in Hf up to 16,000 ppm. For these volcanic units, the ranges of Hf concentrations in zircon cores are generally larger than those of the rims. The lowest zircon Hf concentrations are recorded in the Che Kwu Shan tuff (HK11836) and Pan Long Wan trachydacite (HK13277) at 5,500 and 6,500 ppm, respectively. The Kau Sai Chau volcanic units yield zircons with Hf concentrations of $\sim 6,000-13,000$ ppm (both cores and rims, Table 4.4, Fig. 4.10).
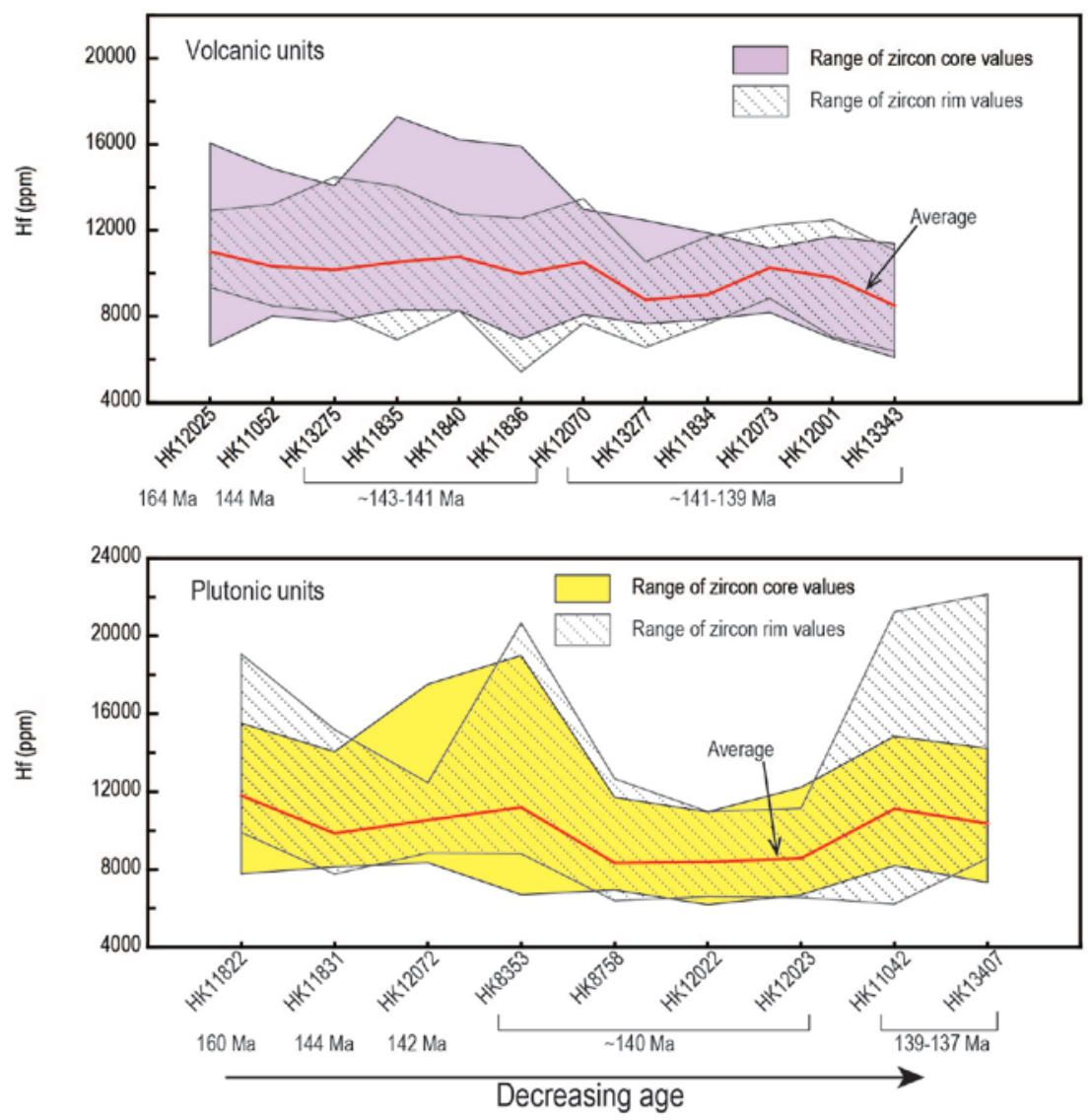

Fig. 4.10. Summary plots of ranges in Hf abundances in zircons from the volcanic and plutonic units in this study. Red line illustrates the average values of all data. 
The granitic units contain zircons with Hf concentrations of typically 6,000-19,000 ppm, with some exceptional enrichment in Hf in the zircon rims of the Kowloon and Mount Butler granites (samples HK11042 and HK13407, >21,000 ppm, Fig. 4.10). In contrast, the quartz monzonite units and the So Kwu Wan Granite (samples HK8758, HK12022 and HK12023) yield zircons with a narrower range of Hf abundance ( 6,000-12,000 ppm for both cores and rims), comparable to the typical ranges in the volcanic samples.

\subsubsection{Uranium and Thorium ( $U$ and $T h$ ) abundances}

For all samples, the concentrations of $U$ and Th in zircons generally co-vary (Fig. 4.9). The intra- and inter-grain variations in $\mathrm{U}$ and Th abundances, however, generally span 2-3 orders of magnitude, from tens to several thousands of ppm (Table 4.4, Fig. 4.11). Zircon rims from the Pan Long Wan trachydacite (HK13277) record the lowest $U$ and Th concentrations: $50 \%$ of the analyses contain less than $\sim 50 \mathrm{ppm} U$ and $\sim 30 \mathrm{ppm}$ Th. Rare zircon cores and rims from the Che Kwu Shan ignimbrite (HK11836) also show similarly low abundances in $\mathrm{U}$ and Th down to $\sim 10 \mathrm{ppm}$. On the other hand, enrichment of $\mathrm{U}$ and Th is common in zircon cores from the volcanic units, for instance up to $\sim 8,000 \mathrm{ppm} U$ and $\sim 7,000 \mathrm{ppm}$ Th are present in cores from the undifferentiated Lantau ignimbrite (HK11052). For the plutonic units, the highly-evolved Kowloon (HK11042) and Mount Butler (HK13407) granites contain some U-enriched rims with $>\sim 12,000 \mathrm{ppm}$, although the accompanying Th concentrations are lower. The variability in Th/U ratios appears to be of greater significance (see Section 4.4.3.8) in understanding melt evolution than the absolute values. 

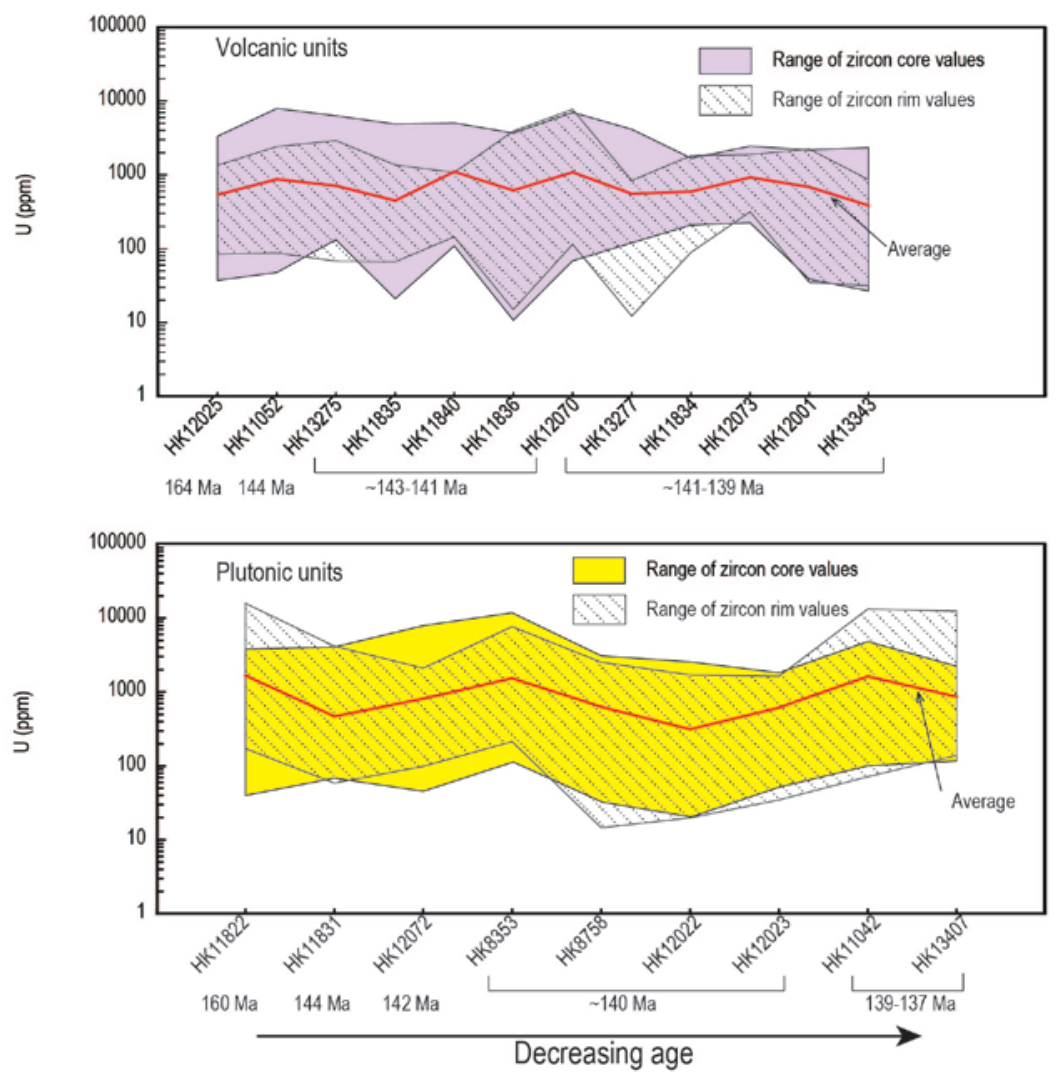

Fig. 4.11. Summary plots of ranges in $U$ abundances in zircons from the volcanic and plutonic units in this study. Red line illustrates the average values of all data.

\subsubsection{Trivalent trace element (Sc, Y, $\left.R E E^{3+}\right)$ abundances}

The incorporation of trivalent trace elements (i.e. $\mathrm{Sc}+\mathrm{Y}+\mathrm{REE}^{3+}$ ) in zircon involves complex substitution mechanisms. Their relative proportions are dependent primarily on ionic radii such that larger LREE (except $\mathrm{Ce}$ ) are generally incompatible in zircons compared with MREE or HREE, whereas their absolute abundances also depend on the melt compositions from which the zircon crystallised (Hoskin and Schaltegger, 2003). For all the studied samples, the total $\mathrm{Sc}+\mathrm{Y}+\mathrm{REE}^{3+}$ (hereafter 'total 3+ elements') concentrations co-vary with the abundance of U in zircons (Fig. 4.9).

In general, zircons from the volcanic units contain from several hundred up to $\sim 10,000$ ppm total 3+ elements, although some analyses from CL-dark zircon cores yield totals between 10,000 and 16,000 ppm (Fig. 4.12). The RBVG and Pan Long Wan zircons exhibit a wide range of total $3+$ element concentrations that spread across the minima and maxima of the earlier units. Among all the samples, zircons from the KSCVG units (except the Pan Long Wan trachydacite) contain the highest concentration of total 3+ elements. If 
only the rim analyses are considered, the ranges and absolute values of total 3+ element concentrations of all volcanic samples are comparable. Zircons from the plutonic units generally yield a similarly wide range of total 3+ element concentrations to those of volcanic samples (several hundreds to $\sim 10,000 \mathrm{ppm}$ ). The cores from the plutonic units generally contain higher concentrations of total 3+ elements than the rims. The Kowloon and Mount Butler granites are the exceptions, which show enrichment of total 3+ elements, especially in some rim analyses, to maximum values in the latter of up to 20,000 ppm. In contrast, values of total 3+ abundances down to as low as $100 \mathrm{ppm}$ are observed in some zircon cores from the Chi Ma Wan Granite (HK8353) of the Lantau caldera complex.
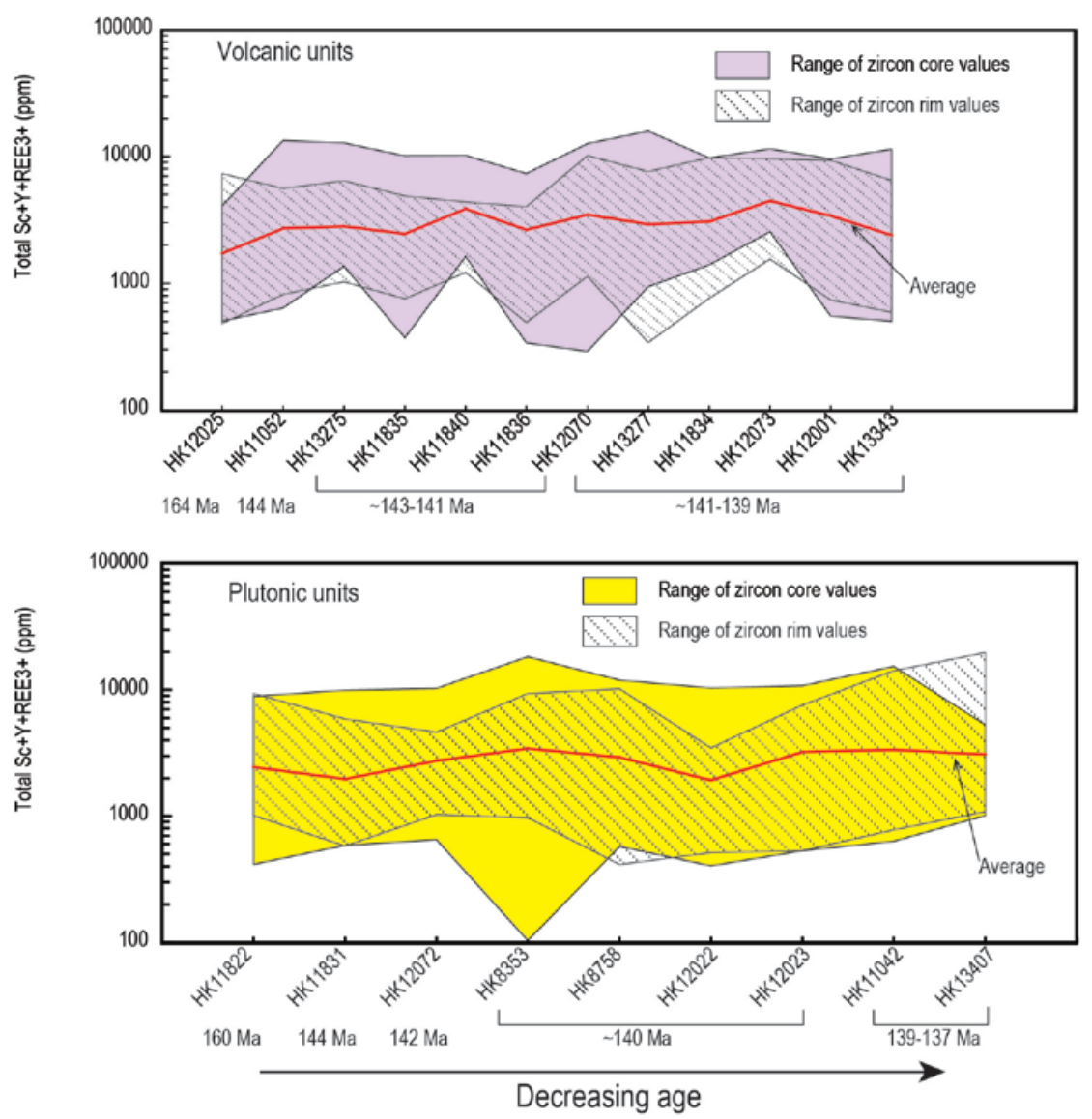

Fig. 4.12. Summary plots of ranges in total abundances of 3+ elements in zircons from the volcanic and plutonic units in this study. Red line illustrates the average values of all data. 


\subsubsection{Scandium $(S c)$}

For this study, Sc concentrations were measured also due to its potential contribution to the trivalent trace element budget. The Sc concentrations in Hong Kong zircons range between 10-270 ppm for the volcanic samples, although analyses from the cores commonly yield wider ranges in Sc abundance (Fig. 4.13). When only the rim analyses are considered, older volcanic units (e.g. HK12025 and HK11052) seem to have lower Sc concentrations than those of the younger units (e.g. HK12001). Plutonic units, except for the quartz monzonites (samples HK8758 and HK12022), generally yield lower concentrations in Sc (10-200 ppm). In similar fashion to the volcanic units, zircons from older granites contain less Sc. The Tong Fuk Quartz Monzonite and D’Aguilar Quartz Monzonite (samples HK8758 and HK12022) contain the highest amount of Sc, ranging up to 290 ppm. The amount of Sc in zircon generally shows a negative trend with increasing Hf abundance (Fig. 4.9).
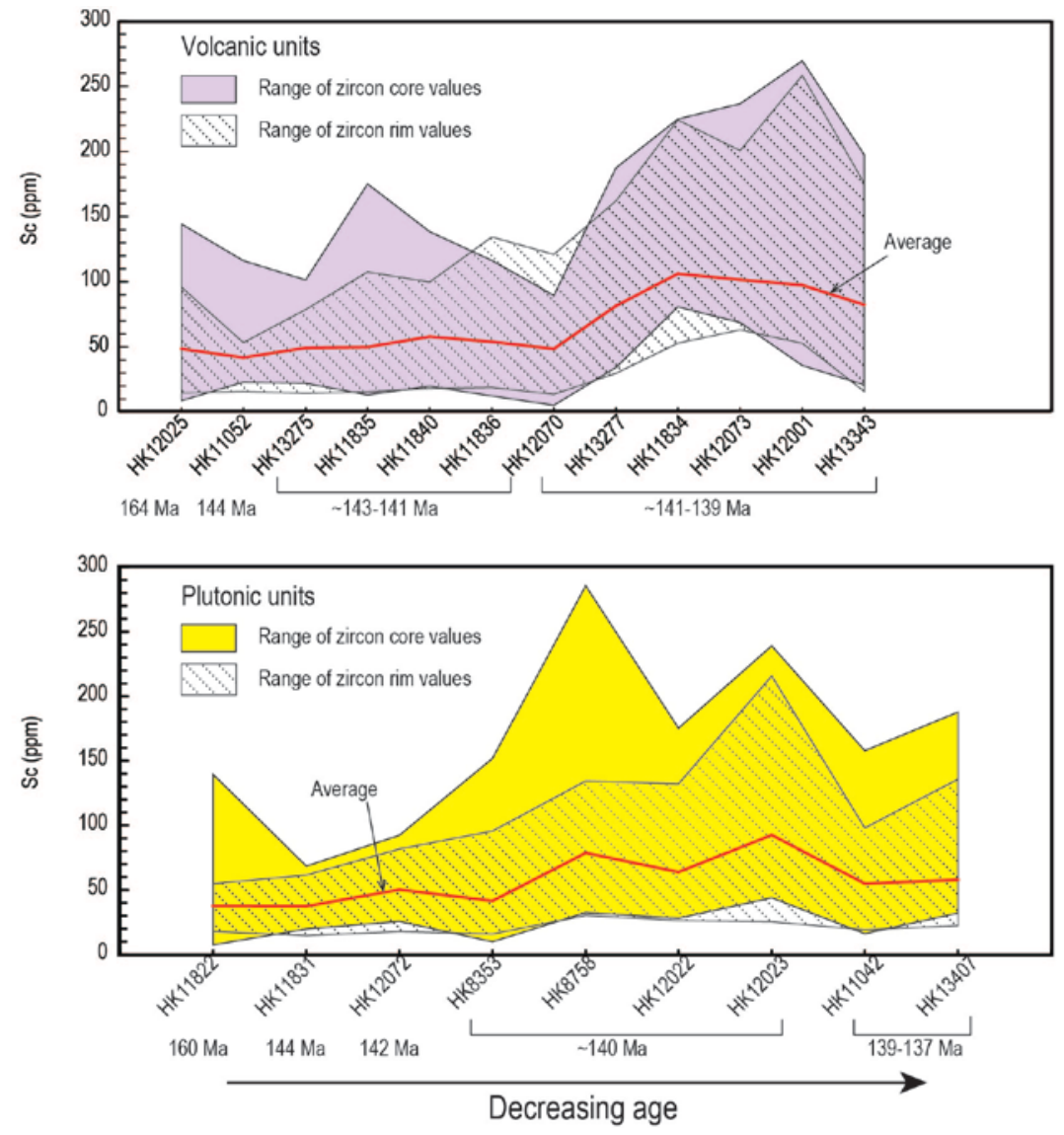

Fig. 4.13. Summary plots of ranges in Sc abundances in zircons from the volcanic and plutonic units in this study. Red line illustrates the average values of all data. 
The concentration of $\mathrm{Y}$ in zircons from all samples ranges from $~ 200 \mathrm{ppm}$ to several thousand ppm. These higher Y abundances are more common in zircon cores, although the highest values of all are in zircon rims from the Mount Butler Granite (up to 14,000 ppm). Significant intra-grain and inter-grain variations in $\mathrm{Y}$ abundance are evident in all samples. In general, zircon cores contain higher $\mathrm{Y}$ abundance than the rims, with the exceptions of samples HK12025, HK11822 and HK13407 (Shing Mun tuff, Lantau Granite and Mount Butler Granite).
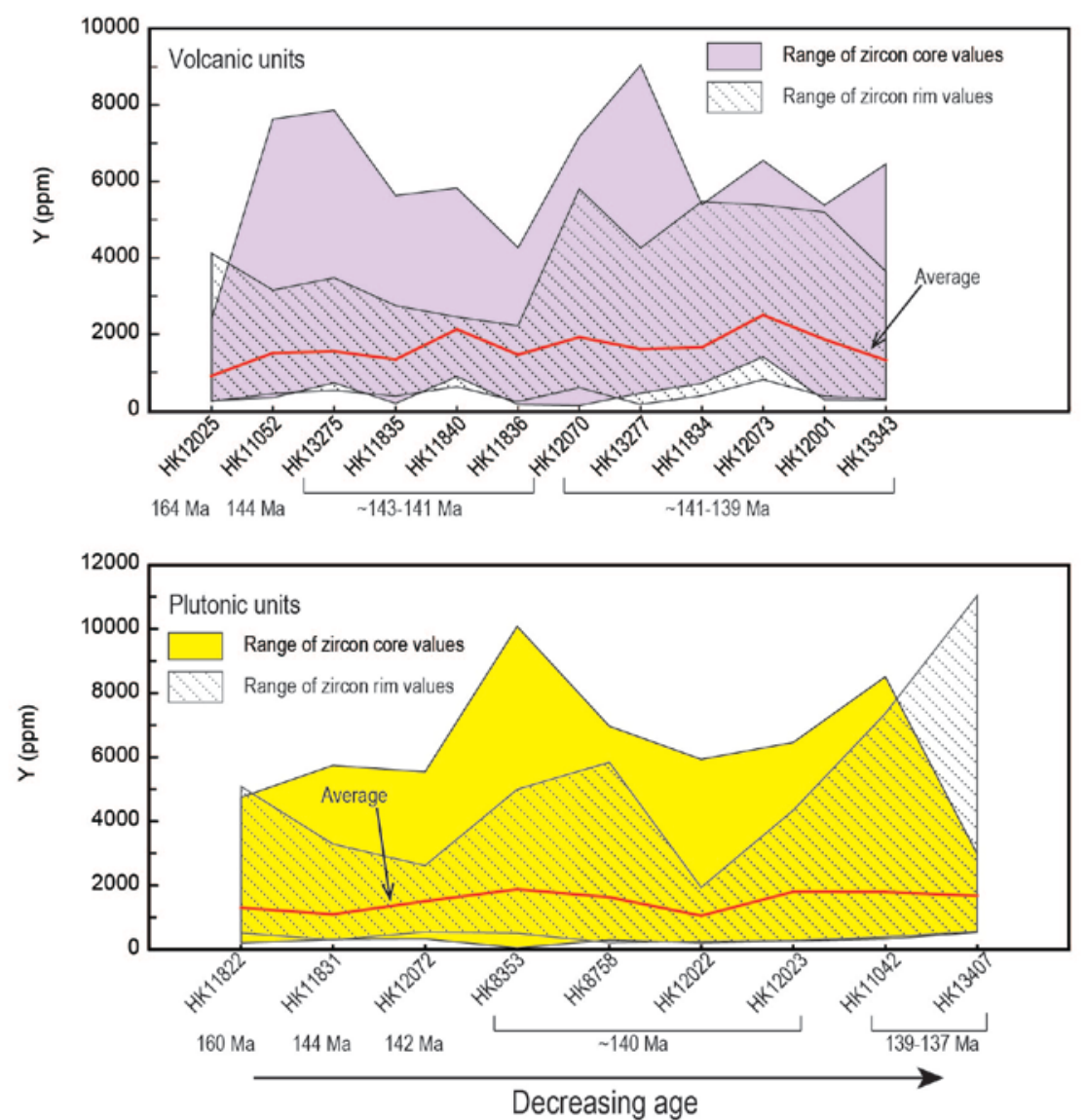

Fig. 4.14. Summary plots of ranges in $\mathrm{Y}$ abundances in zircons from the volcanic and plutonic units in this study. Red line illustrates the average values of all data.

\subsubsection{Titanium (Ti)}

The incorporation of $\mathrm{Ti}$ in zircon is dependent on the elemental concentration and temperature of the melts (Watson and Harrison, 1983, 2005; Watson et al., 2006; Ferry and Watson, 2007; Fu et al., 2008; Boehnkr et al., 2013). Ti concentrations in zircons from all the samples analysed generally show negative correlations with Hf concentration, interpreted as reflecting cooling of magma accompanying melt evolution (Fig. 4.9; Barth 
and Wooden, 2010). Concentrations of $\mathrm{Ti}$ in zircons from the volcanic units generally span from 1-40 ppm (Fig. 4.15). Higher Ti concentrations (those $>25$ ppm), associated with bright CL emissions, are found in zircon cores from the undifferentiated Kau Sai Chau tuff (HK12070) and the rims in the Chek Kwu Shan ignimbrite (HK11836) and Pan Long Wan trachydacite lava (HK13277). For the plutonic units, the Ti abundances typically range between 1 and 25 ppm, with only one value (of 36 analyses) from the Chi Ma Wan Granite (HK8353) reaching $37 \mathrm{ppm}$. The maximum Ti concentration is up to $40 \mathrm{ppm}$ in the Pan Long Wan trachydacite (HK13277) and the minimum is 1 ppm is found in post-High Island rhyolite lava (HK13343) and Mount Butler Granite (HK13407).
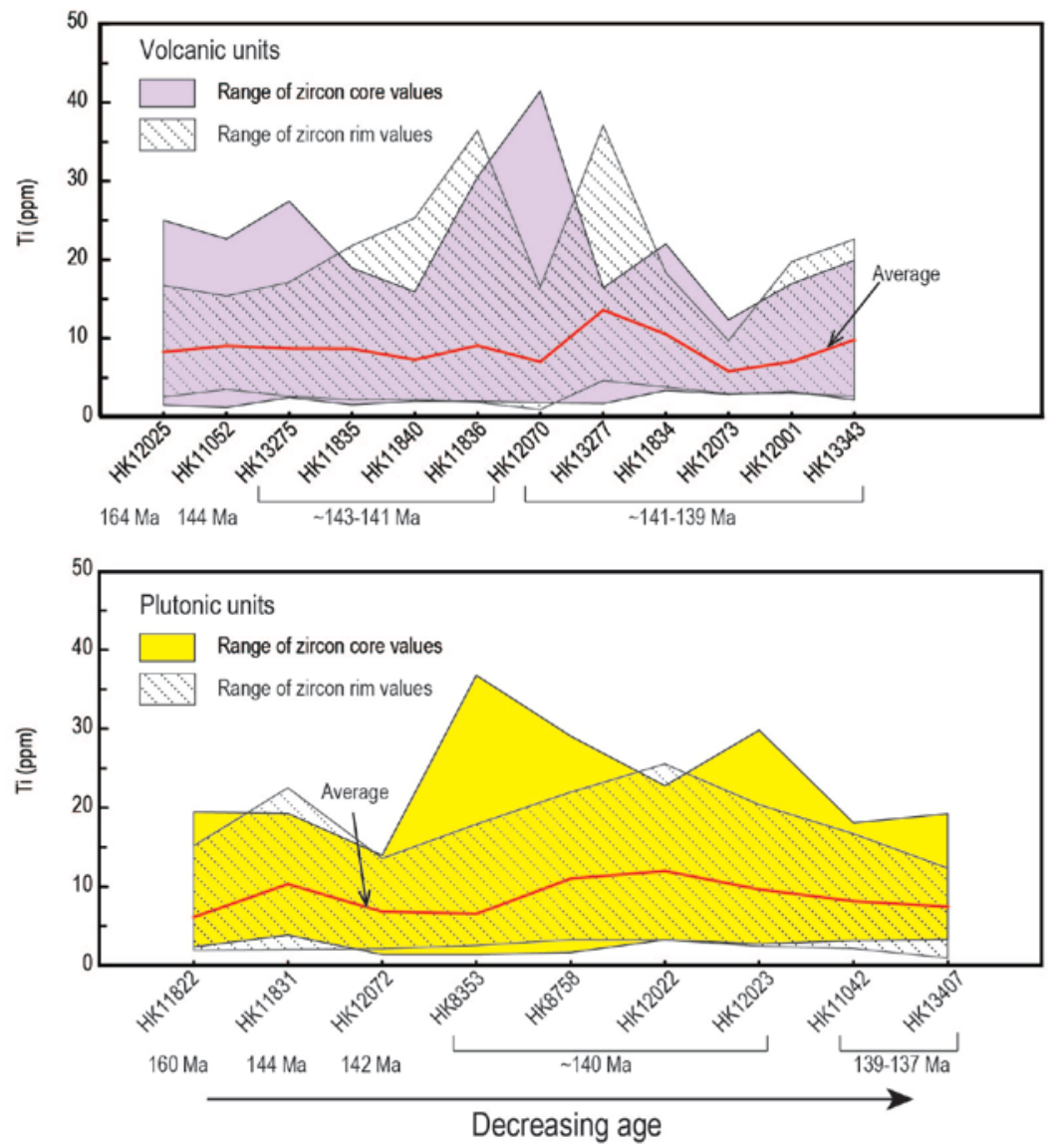

Fig. 4.15. Summary plots of ranges in Ti abundances in zircons from the volcanic and plutonic units in this study. Red line illustrates the average values of all data. 


\subsubsection{Europium (Eu) and Cerium (Ce) anomalies}

Anomalies in $\mathrm{Ce}$ and $\mathrm{Eu}$ abundances in zircons have been proposed as indicators of melt conditions, especially the oxidation state (i.e. oxygen fugacity; Trail et al., 2011, 2012). However, it has been noted that the Eu anomalies are equally or more likely to reflect depletion of $\mathrm{Eu}$ in the melt due to feldspar fractionation during or before zircon crystallisation (Hoskin et al., 2000; Hoskin and Schaltegger, 2003; Reid et al., 2011). Here, I use the $\mathrm{Ce} / \mathrm{Sm}$ ratio rather than the Ce-anomaly due to the generally very low concentrations of La in zircons, and its susceptibility to contamination by micro-inclusions of melt or other minerals (cf. Cooper et al., 2014).

The typical Eu/Eu* values of the volcanic units considered in this chapter range between 0.01 to 1 (Fig. 4.16), although more negative Eu anomalies (Eu/Eu* value $<0.001)$ are evident for some zircon cores, most notably from Pan Long Wan trachydacite (HK13277, 43 of 48 core analyses), undifferentiated Kau Sai Chau tuff (HK12070, 1 of 28 core analyses), Che Kwu Shan ignimbrite (HK11840, 9 of 31 core analyses), Ap Lei Chau ignimbrite (HK11836, 7 of 37 core analyses) and Long Harbour ignimbrite (HK11835, 1 of 52 core analyses). In contrast, some zircons from the High Island Tuff (HK12001) and post-High Island rhyolite lava (HK13343) yield positive Eu anomalies (Eu/Eu* >1). These two samples are the only volcanic units that yield zircons (both cores and rims) with $\mathrm{Eu} / \mathrm{Eu}^{*}$ values $>1.0$. Zircons from the plutonic units appear to have smaller ranges in $\mathrm{Eu} / \mathrm{Eu}^{*}$ values when compared with the volcanic zircons, typically from 0.01 to $<0.6$, with some outliers (Table 4.4). Some zircons from Chi Ma Wan Granite (HK8353, 7 of 36 cores analyses) and Mount Butler Granite (HK13407, 4 of 49 rim analyses) show evidence for deeper Eu anomalies $\left(\mathrm{Eu} / \mathrm{Eu}^{*}<0.01\right)$, whereas some zircons from the Shui Chuen $\mathrm{O}$ Granite (HK12072), So Kwu Wan Granite (HK12023), and D’Aguilar Quartz Monzonite (HK12022) yield positive Eu anomalies.

The ranges of $\mathrm{Ce} / \mathrm{Sm}$ ratios in zircons from the volcanic units are typically between $\sim 1$ and 30 (Table 4.4). The apparently much larger range from Ap Lei Chau tuff (HK11840) reflects two outliers (Ce/Sm ratios of $\sim 160$ and 260). There appears to be a slight decreasing trend for the Ce/Sm ratios from older to younger volcanic units. The plutonic units yield zircons with a slightly smaller range in Ce/Sm ratios than the volcanic samples, between $\sim 1$ and 20 (Table 4.4). 

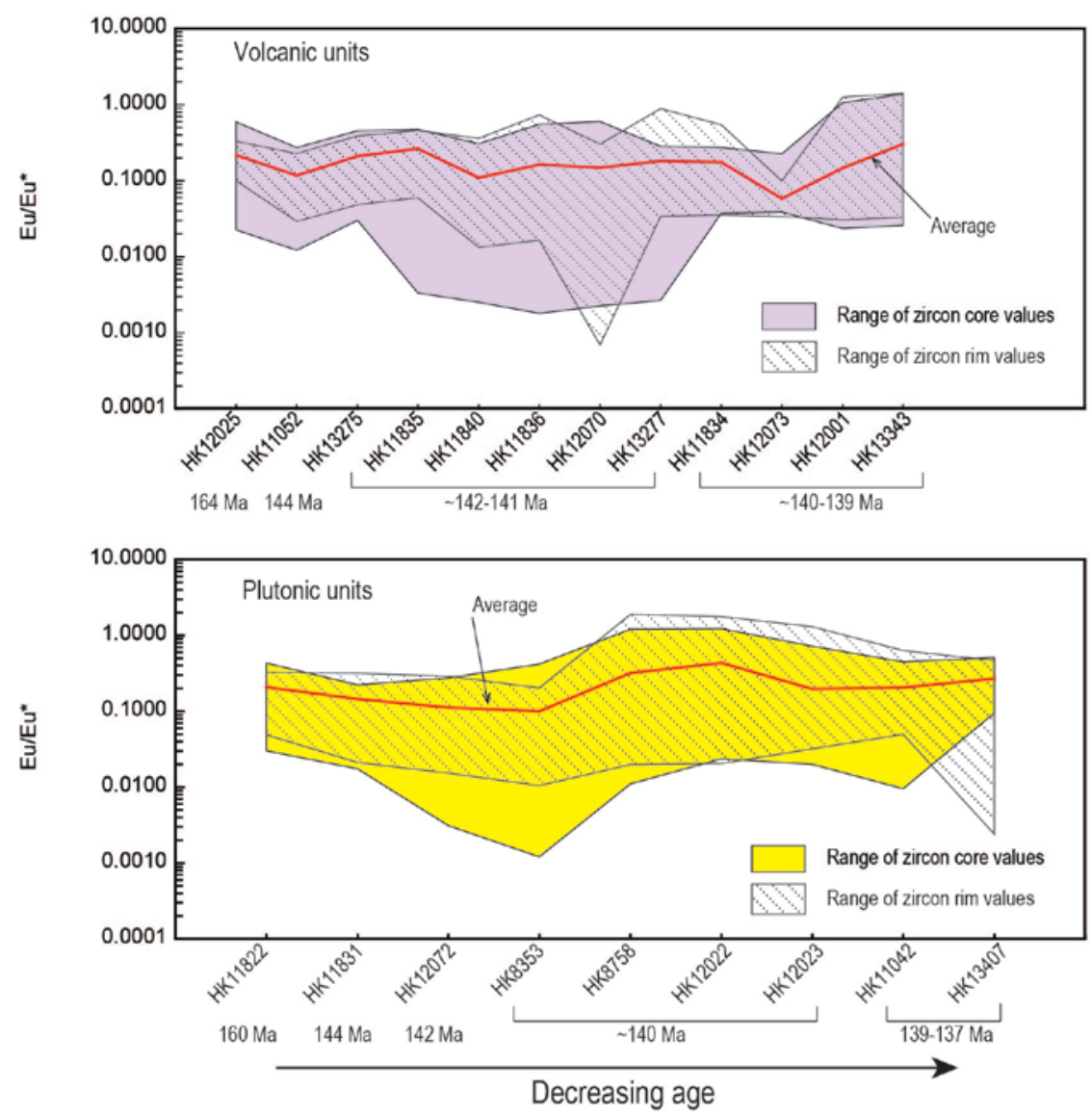

Fig. 4.16. Summary plots of ranges in $\mathrm{Eu} / \mathrm{Eu}^{*}$ values in zircons from the volcanic and plutonic units in this study. Red line illustrates the average values of all data.

\subsubsection{Elemental ratios: $T h / U, Y b / G d, U / Y b$}

Trace element concentrations and their ratios (particularly Th/U, $\mathrm{Yb} / \mathrm{Gd}$ and $\mathrm{U} / \mathrm{Yb}$ ) in zircons have been shown to vary systematically with magma fractionation (e.g. Wooden et al., 2006; Claiborne et al., 2006, 2010; Barth and Wooden, 2010). The variation patterns of these elemental ratios have been used to infer the magmatic processes and geochemical evolution of both plutonic and volcanic systems (e.g. Barth and Wooden, 2010; Claiborne et al., 2010; Barth et al., 2013; Chamberlain et al., 2014b; Cooper et al., 2014). The absolute values of the $\mathrm{Yb} / \mathrm{Gd}, \mathrm{Th} / \mathrm{U}$ and $\mathrm{U} / \mathrm{Yb}$ ratios in zircon are likely to reflect the signature of the magma source (e.g. Hoskin and Ireland, 2000; Grimes et al., 2007; Barth et al., 2013).

The trace elemental ratios ( $\mathrm{Th} / \mathrm{U}, \mathrm{Yb} / \mathrm{Gd}$ and $\mathrm{U} / \mathrm{Yb}$ ) of all volcanic and plutonic units are comparable, although some volcanic units have notably higher $\mathrm{Yb} / \mathrm{Gd}(>80)$ and Th/U $(\sim 2)$ ratios (e.g. Shing Mun and undifferentiated Kau Sai Chau ignimbrites, HK12025 and HK12070, respectively; Figs. 4.17 and 4.18). Th/U ratios measured range from 0.1 to 2 in 
most samples (Table 4.4). Some extremely low Th/U ratios $(<0.1)$ are evident from the zircon rims of the highly-evolved Kowloon and Mount Butler granites (HK11042 and HK13407) with unusual enrichment of U. Although Hoskin and Schaltegger (2003) suggested that the $\mathrm{Th} / \mathrm{U}$ ratio of igneous zircons is $\geq 0.5$ in general, our data demonstrate that most of the samples studied contain a high proportion of grains with $\mathrm{Th} / \mathrm{U}<0.5$.

Overall, a negative correlation between $\mathrm{Yb} / \mathrm{Gd}$ and $\mathrm{Th} / \mathrm{U}$ ratios is common in volcanic and intrusive units, indicating melt evolution of the magmatic system. It is noted that for samples (both volcanic and intrusive units) in this study, the $\mathrm{Yb} / \mathrm{Gd}$ ratios gradually tail off at $\sim 10-15$ at $\mathrm{Th} / \mathrm{U}$ ratios $>\sim 0.8$ (Fig. 4.9). Similar trends are also noted in other volcanic zircons from silicic systems (e.g. Bishop Tuff, Chamberlain et al., 2014b; Ongatiti and Kidnappers units, New Zealand, Cooper et al., 2014). This feature appears to be an intrinsic property, independent of the mineral phases present, for the silicic magmatic rocks considered in this study.
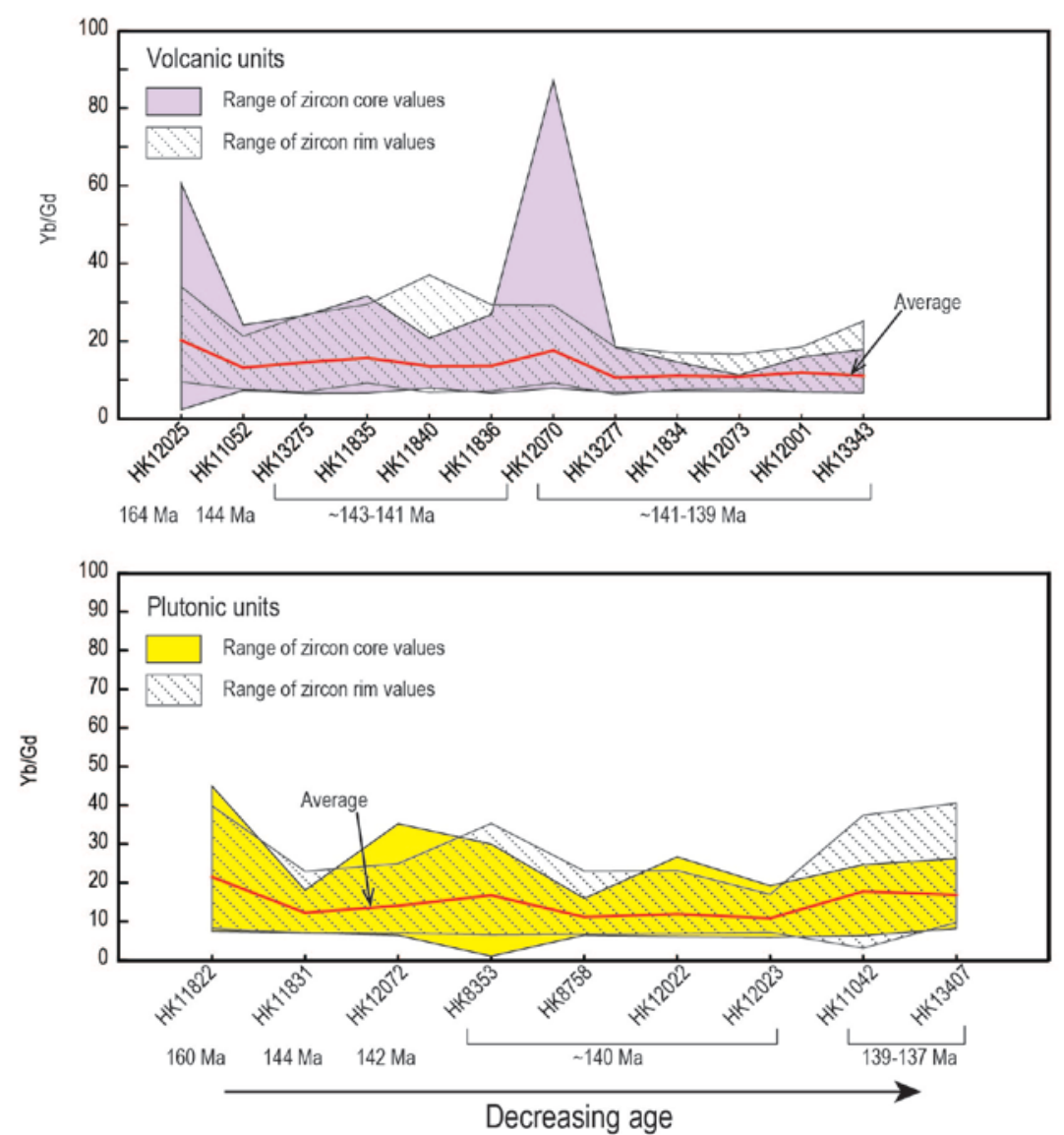

Fig. 4.17. Summary plots of ranges in $\mathrm{Yb} / \mathrm{Gd}$ ratios in zircons from the volcanic and plutonic units in this study. Red line illustrates the average values of all data. 

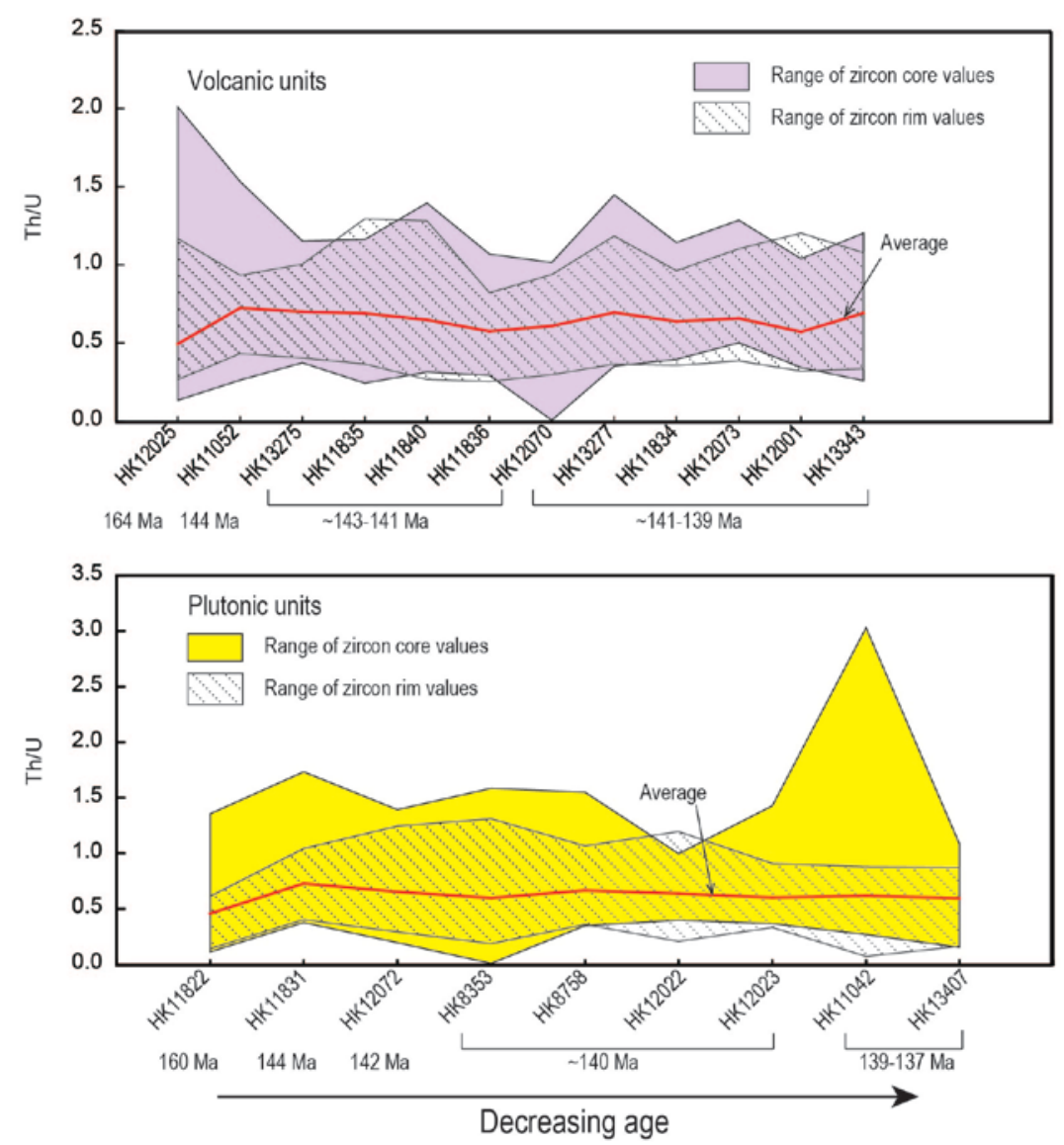

Fig. 4.18. Summary plots of ranges in Th/U ratios in zircons from the volcanic and plutonic units in this study. Red line illustrates the average values of all data.

The U/Yb ratio in zircon shows a positive trend with Hf concentration (Fig. 4.9). The two Jurassic units and the early RBVG units have a wide inter-grain variation of U/Yb ratio, between around 0.4 and 3.0. A decline in $\mathrm{U} / \mathrm{Yb}$ value, to less than 1.5, is found in the later RBVG units and Pan Long Wan trachydacite. Zircons from the remaining KSCVG have a slightly higher $\mathrm{U} / \mathrm{Yb}$ ratio ( 0.1 to 2.5 ), but the correlation with Hf concentration is less well-defined.

\subsubsection{Molar total $3^{+} /$P ratio}

An apparent agreement of molar ratio of $\left(\mathrm{Y}+\mathrm{REE}^{3+}\right) / \mathrm{P}$ with values of 1.0 led to the proposed 'xenotime' substitution as a dominant mechanism for replacement of trivalent trace elements in zircons, coupling with incorporation of $\mathrm{P}$ for charge balancing (Speer, 1980). However, this original study did not consider or measure the concentration of Sc, which is another trivalent element that can be incorporated into zircons. In fact, the departure of the molar $\left(\mathrm{Y}+\mathrm{REE}^{3+}\right) / \mathrm{P}$ ratio from unity has been recognised by many previous studies (e.g. Finch et al., 2001; Hoskin and Schaltegger, 2003; Chamberlain et al., 
2014b; Cooper et al., 2014), implying that the 'xenotime' substitution is not the only mechanism for incorporating trace elements into zircons. In this study, the molar $\left(\mathrm{Sc}+\mathrm{Y}+\mathrm{REE}^{3+}\right) / \mathrm{P}$ ratios in most samples ranges between 1 and 6 (Table 4.4), with some grains, especially from plutonic samples, having values up to 9 (e.g. Mount Butler Granite, HK13407). The wide range of the ratios suggests that the substitution mechanisms involved are complex. When plotted against $\mathrm{Yb}, \mathrm{U}, \mathrm{Hf}$, and Ti concentrations and the $\mathrm{U} / \mathrm{Yb}$ ratio, in many cases two apparent positive arrays are defined which probably reflect the influence of sector zoning (cf. Chamberlain et al., 2014b). Values of the $\left(\mathrm{Sc}+\mathrm{Y}+\mathrm{REE}^{3+}\right) / \mathrm{P}$ ratio become more scattered with increasing melt evolution, as monitored by $\mathrm{U}$, Hf concentrations and $\mathrm{U} / \mathrm{Yb}$ ratio.

\subsection{Discussion}

\subsubsection{Limitations on the SIMS age data sets}

The geochronological framework of volcanic-plutonic assemblages in Hong Kong was previously established using ID-TIMS techniques and interpreted to comprise 4 temporally distinct magmatic episodes between 164 and 140 Ma (Davis et al., 1997; Campbell et al., 2007; Sewell et al., 2012b). The ID-TIMS technique generally produces U-Pb zircon ages with high analytical precision (normally $<0.2 \% 2$ s.d.: Davis et al., 2003; Parrish and Noble, 2003), but inter-grain and intra-grain (core-rim) age relationships are obscured by this technique as applied to the Hong Kong rocks. In contrast, SIMS methods yield lower precisions for individual age data points (normally >2\% 2 s.d.: Ireland and William, 2003; Schoene et al., 2013), but the age data obtained can be linked to various growth zones in individual grains, as revealed by CL imagery (e.g. Goetze et al., 1999; Nasdala et al., 2003). Furthermore, the relatively straightforward sample preparation and analytical procedures for SIMS methods when compared to ID-TIMS techniques means that orders of magnitude more analyses can be achieved by SIMS in a similar amount of time. By employing statistical treatments on a larger quantity of spatially-constrained analyses, a precision level approaching or comparable to that of fewer, but more precise ID-TIMS ages is possible for the SIMS model ages (cf. Crowley et al., 2007; Chamberlain et al., 2014b).

In young (Quaternary) volcanic systems, such as those in Taupo Volcanic Zone, New Zealand, the evolution of magma chambers have been investigated in meticulous detail by integrating crystal-specific analyses and U-Th-Pb system dating, coupled with field 
observational constraints (e.g. Charlier et al., 2005; Wilson and Charlier, 2009; Charlier \& Wilson, 2010; Storm et al., 2012; Allan et al., 2013; Cooper et al., 2014, Barker et al., 2014). Most recently, Barker et al. (2014) have demonstrated the use of combined zircon trace element analyses and U-Th-Pb age determinations on the same grains or domains to track the chemical evolution of the TVZ system after the colossal Oruanui eruption down to a time-scale of several hundreds to thousands of years.

The modern analogues offered by the contemporaneous volcanic systems show that the turnover times of volcanic eruptions are on the order of less than $10^{4}$ to $10^{5}$ years (see references above). In addition, detailed investigations of well-preserved volcanic deposits from young caldera (Quaternary) systems, combined with evidence from crystal specific studies, have demonstrated that magmatic processes operate on time-scales of months to $10^{5}$ years (Wilson, 1993, 2001; Sutton et al., 2000; Wilson et al., 2006; Wilson and Charlier, 2009; Allan et al., 2012, 2013; Barker et al., 2014, 2015). This timeframe implies that for the Mesozoic systems in Hong Kong, even with the resolution of ID-TIMS ages ( \pm 0.2-0.3 Myr for published ages from volcanic and plutonic rocks in Hong Kong: Davis et al., 1997; Campbell et al., 2007; Sewell et al., 2012b), detailed linkages of individual volcanic and plutonic units and the dynamic processes within magmatic system cannot be distinguished. Therefore, connections of individual eruption units with specific plutons and/or magmatic systems can only be able to be made in general terms. With these limitations, the geochronological study presented in this thesis nonetheless provides invaluable information on the longer-term evolution of silicic magmatism in a broader sense over timescales of $10^{6}$ to $10^{7}$ years by detailed analysis of key volcanic and plutonic units, and answer questions on aspects related to the lifespan and the demise of volcanism in an arc system.

\subsubsection{Contrasting SIMS age with published ID-TIMS ages}

\subsubsection{Unimodal age datasets}

The new age data presented in this study reveal the presence of two groups: samples that yield normally-distributed unimodal age spectra, and those show multiple age components which imply the presence of inherited grains (Tables 4.3, 4.5). The first important observation when comparing the U-Pb ages obtained by the SIMS techniques in this study and those of the published ID-TIMS studies is that five of the simple unimodal age data 
sets yield model ages that are the same within uncertainty as their ID-TIMS ages. For example, the High Island Tuff (HK12001) returns a weighted mean SIMS age and IDTIMS age that are identical (Table 4.5). The concurrence of ages obtained from both techniques provides confidence that the ages of the relevant units are accurately defined and therefore that the values are non-controversial. Such results also imply that where the two methodologies yield contrasting age estimates, these are due to sound analytical issues or genuine differences in the age spectra, and not just due to issues with the SIMS techniques.

For plutonic units, the Sok Kwu Wan Granite, and D’Aguilar and Tong Fuk quartz monzonites (samples HK11834, HK12073, HK12001, HK12023, HK12022 and HK8758) also yield SIMS datasets with unimodal age spectra (Table 4.5). Three interpretations are likely. First, that these samples essentially lack inherited grains because the silicic magma bodies were fractionated directly from hot, mafic magmatic sources and no recycling of the existing crustal materials was involved. This interpretation would imply that all zircon grains are newly crystallised, and new crust was formed in these events. Second, that generation of the host magma bodies involved partial melting of existing crust by injection of less-evolved melts, but that all zircons recycled from the older crust were completely redissolved. Such complete resorption could be caused either by heating up of the magma bodies or by influx of compositionally contrasting melts that caused dissolution of zircons (Watson and Harrison, 1983; Reid et al., 2011; Boehnke et al., 2013). Third, that inherited grains are present but the age gaps between different zircon domains (cores versus rims) are too small to be resolved by SIMS methods and are obscured by the ID-TIMS techniques. Recent studies of zircon texture and U-Pb age from Bishop Tuff (eruption age of $0.76 \mathrm{Ma}$ ) has demonstrated that the age difference between zircon core and rim of "bright-rimmed" grains is less than $10^{5}$ years (Chamberlain et al., 2014b). In those Hong Kong samples with a single age component, some (e.g. sample HK12022) yield zircon with discrete resorbed cores (i.e. Types A and B) visible in CL images, but the age of these cores are effectively indistinguishable from the rims due to the limited resolution of SIMS techniques. These samples all yield weighted mean age (cores and rims) that are slightly younger than their respective ID-TIMS zircon U-Pb ages (Table 4.3). In addition, some Uenriched cores give questionable younger ages compared with the rim analysis of the same grains. Further discussions of these results are presented in Section 4.5.2.3. 


\subsubsection{Samples with multiple age-components}

From both the new SIMS and the previous ID-TIMS age data, the presence of inherited grains is evident in 15 of the 21 samples studied here (Table 4.5). Note that 6 samples (volcanic units HK11052, HK13275, HK12070 and HK13277; plutonic units HK12072 and HK11042) yielded inherited cores that had not been identified in the previous IDTIMS studies. The ages of inheritance grains are either late Mesozoic or much older, from Palaeozoic to Archean. For the late Mesozoic inherited grains, a first order observation is that their model mean ages yielded by the Sambridge and Compston (1994) methods are roughly coincident with the major local magmatic episodes identified by Davis et al. (1997) and Sewell et al. (2012b). These zircons thus are interpreted to represent crystals that grew in earlier magmatic pulses and were recycled in subsequent magmatic injections. The survival of whole or partial zircon grains in successive magmatic episodes implies that the magmatic conditions (temperature, composition) did not greatly exceed the zircon saturation temperature (cf. Charlier et al., 2005).

Some zircon cores, from both volcanic and plutonic units, yield much older Palaeozoic to Archean ages (Table 4.5). The oldest grain identified is $\sim 2.8 \mathrm{Ga}$ from the Shing Mun tuff (sample HK12025). These grains are xenocrysts, i.e. they are crystals picked up by the magma bodies from the surrounding basement rocks and are much older than any of the Yanshanian episodes. The Kowloon and Mount Butler granites also yield Palaeozoic and Palaeo-Proterozoic grains, respectively, implying the presence of basement rocks of these ages underneath this part of Hong Kong. This finding provides further evidence to support the terrane model proposed by Fletcher et al. (1997), which was based mainly on the interpretation of geophysical data and isotopic characteristics of granites identified by Darbyshire and Sewell (1997) (see Section 2.3.1).

For volcanic units that yield multiple age component data, the weighted mean ages of their zircon rim analyses are better representative of the eruption ages. The weighted mean rim ages of these samples are often younger than their respective ID-TIMS U-Pb ages. The clearest cases are the Repulse Bay volcanic units, which have weighted mean SIMS rim ages at least 0.5 Myr and up to 2 Myr younger. The Pan Long Wan trachydacite lava (HK13277) also yields multiple age components. I infer that the eruption age of the unit is 141.0 \pm 1.3 Ma, which is indistinguishable at the 95\% confidence limits from the ID-TIMS age of the unit by Sewell et al. (2012b). The age data thus suggest that the RBVG volcanic 
units represent a sequence of eruptions that occurred episodically at 143-141 Ma, which were closely followed by the eruption of Pan Long Wan trachydacite ( 141 Ma) that overlies the RBVG in the Clear Water Bay Peninsula area (section 3.2.1.2).

Here, I consider possible explanations for the differences in age populations and associated implications. A first possible reason for the disparity is the pretreatment methods of zircon grains in the ID-TIMS studies, in which zircon grains were either mechanically abraded (by air) to remove the outer part of the crystals or chemically abraded before they were dissolved (Davis et al., 1997; Campbell et al., 2007; Sewell et al., 2012b). The air abrasion technique, first introduced by Krogh (1982), aimed to minimise the influence of Pb loss by removing the outer rims of crystals which are considered more susceptible to alteration, and also by hand-picking only clear grains that are free of any cracking in the cores to alleviate the problem of metamictisation in the crystal interiors. In contrast, Mattinson (2005) developed the chemical abrasion technique in which the crystals are first annealed at $800-1000{ }^{\circ} \mathrm{C}$ before multiple, step-wise treatment with $\mathrm{HF}$ to remove portions of the crystals with radiation damage and accompanying Pb-loss. Both methods, however, undesirably remove some geochronological information present in the crystals. Another possible explanation is also related to the ID-TIMS techniques applied, which required dissolution of single or a group of zircon grains for age determination (Davis et al., 1997; Campbell et al., 2007; Sewell et al., 2012b). In Hong Kong rocks, the presence of older zircon cores (antecrysts and/or xenocrysts) is common, based on observations from the CL images as well as from the SIMS age data. The reported ID-TIMS ages therefore may represent an 'averaged' value of the older cores, if present and surviving the chemical abrasion technique, and younger rims.

\subsubsection{Effects of $U$ contents on zircon $U$-Pb ages}

From the relative probability plots of the age data, it is obvious that some samples (including both volcanic and plutonic units) show a younger peak age for the cores than that for the rim analyses (Figs. 4.3 to 4.8). Here, I test whether these U-Pb zircon ages record true crystallisation (magmatic) events, or reflect potential bias of the SIMS U-Pb ages due to possibly the matrix effect in the instrument (c.f. White and Ireland, 2013), and/or to a Pb loss associated with metamictisation associated with high $\mathrm{U}$ concentrations. The matrix effects in the ion microprobe cause an increase in apparent age (i.e. older) of high-U zircon grains, but White and Ireland (2013) suggested that the effects were more 
pronounced in their younger samples ( 20-50 Ma) than the older Mesozoic rocks ( $\sim 180$ $\mathrm{Ma}$ ) they examined, and would occur in grains with over 2,000 ppm U. However, more recent analyses on Quaternary examples (e.g. New Zealand, Long Valley, Yellowstone) illustrated that no matrix effects were detected in Bishop Tuff data with $\mathrm{U}$ concentrations up to 6,000 ppm and in a Glass Mountain rhyolite dome sample with U concentrations up to 12,000 ppm (e.g. Chamberlain et al., 2014b). It is worth pointing out that almost all dated grains in the Hong Kong samples yield U concentration well below these values (Table 4.4), which were considered to be required for matrix effects to become apparent.

To further investigate the effect of $U$ concentrations on the reliability of age data, the SIMS $\mathrm{U}-\mathrm{Pb}$ age data are plotted against $\mathrm{U}$ contents to detect any obvious trends (Figs. 4.3 to 4.8). In samples HK8353, HK8758, HK11836, HK11840, HK12023, HK12073, HK13275 and HK13407, some high-U grains (>1,000 ppm U) apparently show a negative trend in the plots, i.e. the ages tend to gradually drift toward the younger age spectrum of the spectrum with increasing $\mathrm{U}$ concentration. This trend is considered here to reflect a bias in $\mathrm{U}-\mathrm{Pb}$ ages caused by $\mathrm{Pb}$ loss, most likely caused by metamictisation (radiation damage) of the high-U domains, particularly in some zircon cores, and/or leaching of $\mathrm{Pb}$ during posteruption/emplacement hydrothermal events that are evident both from the thermochronological study (Chapter 5; Tang et al., 2014) and seen in the alteration minerals (e.g. epidote and chlorite from the breakdown of primary ferromagnesian minerals) in the volcanic and plutonic rocks. The potential erroneous ages imply that the weighted mean ages of the rim analyses from the above samples are more close to the actual eruption or emplacement ages of the units. However, further examination of the data shows that not all high-U grains appear to yield inconsistent (unreliable) young ages. In addition, some young grains contain moderate amounts of $U$ (several hundred ppm) and yet yield ages younger than $140 \mathrm{Ma}$. These younger age components are identified in Kowloon and Mount Butler granites which probably correspond to magmatic activities lasting after $\sim 140 \mathrm{Ma}$, till as young as $138 \mathrm{Ma}$ (Table 4.5 ). This indication is corroborated by the findings of thermochronological studies in this thesis, which suggest that Yanshanian granitic intrusions continued after 140 Ma in this part of the southeast China, even though these magmatic pulses might not have resulted in volcanic activity in the surface, or that their products had been completed eroded away (Chapter 5 [Tang et al., 2014]). 


\subsubsection{Implications for the magmatic cycles in Hong Kong}

The proposed eruption/emplacement ages of the volcanic and plutonic units dated by SIMS methods in this study are compared in Tables 4.3 and 4.5 with available published IDTIMS ages of the same units. With the new insights from the SIMS age results, the geochronological framework of the Mesozoic magmatic episodes in Hong Kong, previously established using ID-TIMS ages (Davis et al., 1997; Campbell et al., 2007; Sewell et al., 2012b), warrants reconsideration.

First, the age data reported here suggest that the RBVG, instead of being a single major pulse of volcanic activities at 143 Ma (Davis et al., 1997; Sewell et al., 2000; 2012b), reflects a series of eruptions from $\sim 143$ to $141 \mathrm{Ma}$. These eruptions were followed closely by the extrusion of Pan Long Wan trachydacite lava and units within the KSCVG. Two intrusive units, the Shui Chuen O and Chi Ma Wan granites (i.e. the Kwai Chung Suite), were originally considered as the plutonic equivalent of the RBVG (Sewell et al., 2000; 2012b). In this study these two plutons yield SIMS U-Pb ages that are younger than their corresponding ID-TIMS ages (Table 4.5) and imply that a discrete 143 Ma pulse of granitic intrusions (corresponding to the RBVG eruptions) is absent. That is, the pairing of the RBVG with the Kwai Chung Suite, as based on the comparable ID-TIMS ages of the units, is no longer valid.

Second, the KSCVG units, except for the Pan Long Wan trachydacite, all exhibit unimodal age spectra datasets. In the Clear Water Bay rhyolite (HK12072), the U-Pb ages of some zircon cores are younger than their own rims. These younger cores are in general enriched in $\mathrm{U}$ and other trace elements and are inferred to have suffered some Pb-loss. Therefore, we considered that the weighted mean of the rim analyses at $140.5 \pm 0.7 \mathrm{Ma}$ is the best estimation of the eruption age of the Clear Water Bay rhyolite. 
Table 4.5. Summary of proposed eruption/emplacement ages and the identified inheritance ages of the volcanic and plutonic units from this study.

\begin{tabular}{|c|c|c|c|c|c|c|}
\hline Sample No. & $\begin{array}{c}\text { Suggested } \\
\text { eruption / } \\
\text { emplacement } \\
\text { age (Ma) }\end{array}$ & \multicolumn{2}{|c|}{$\begin{array}{l}\text { ID-TIMS age (Ma)/ } \\
\text { Is suggested age } \\
\text { comparable within } \\
\text { uncertainty with published } \\
\text { ID-TIMS age? }\end{array}$} & $\begin{array}{l}\text { Presence of } \\
\text { U-enriched } \\
\text { zircon } \\
\text { cores? }\end{array}$ & $\begin{array}{c}\text { Inheritance } \\
\text { identified in this } \\
\text { work }\end{array}$ & $\begin{array}{l}\text { Inheritance } \\
\text { identified in } \\
\text { previous ID- } \\
\text { TIMS works }\end{array}$ \\
\hline \multicolumn{7}{|l|}{ Volcanic units } \\
\hline $\begin{array}{l}\text { HK12025 } \\
\text { Shing Mun Formation }\end{array}$ & $164.7 \pm 0.8$ & $164.2 \pm 0.3^{b}$ & $\mathrm{Y}$ & $\mathrm{N}$ & $\begin{array}{l}\sim 1 \mathrm{Ga}, 1.3 \mathrm{Ga} \\
1.5 \mathrm{Ga}, 2.8 \mathrm{Ga}\end{array}$ & $>1.8 \mathrm{Ga}^{\mathrm{b}}$ \\
\hline $\begin{array}{l}\text { HK11052 } \\
\text { Lantau Volcanic Group }\end{array}$ & $144.5 \pm 0.7$ & $146.6 \pm 0.2^{\mathrm{a}}$ & $\mathrm{N}$ & $\mathrm{N}$ & $\sim 157 \mathrm{Ma}$ & $\mathrm{Nil}^{\mathrm{a}}$ \\
\hline $\begin{array}{l}\text { HK13275 } \\
\text { Mount Davis Formation }\end{array}$ & $142.3 \pm 1.2$ & $143.0 \pm 0.2^{c}$ & $\mathrm{Y}$ & $\mathrm{Y}$ & $\sim 164 \mathrm{Ma}$ & $\mathrm{Nil}^{\mathrm{c}}$ \\
\hline $\begin{array}{l}\text { HK11835 } \\
\text { Long Harbour Formation }\end{array}$ & $141.4 \pm 1.0$ & $142.7 \pm 0.2^{\mathrm{a}}$ & $\mathrm{N}$ & $\mathrm{Y}$ & $\sim 152 \mathrm{Ma}$ & $>3.0 \mathrm{Ga}^{\mathrm{a}}$ \\
\hline $\begin{array}{l}\text { HK11840 } \\
\text { Ap Lei Chau Formation }\end{array}$ & $141.0 \pm 0.7$ & $142.7 \pm 0.2^{\mathrm{a}}$ & $\mathrm{N}$ & $\mathrm{Y}$ & $\sim 160 \mathrm{Ma}$ & $>2.4 \mathrm{Ga}^{\mathrm{a}}$ \\
\hline $\begin{array}{l}\text { HK11836 } \\
\text { Che Kwu Shan Formation }\end{array}$ & $141.6 \pm 1.0$ & $142.5 \pm 0.3^{\mathrm{a}}$ & $\mathrm{Y}$ & $\mathrm{Y}$ & $\sim 161 \mathrm{Ma}$ & $\sim 146 \mathrm{Ma}^{\mathrm{a}}$ \\
\hline $\begin{array}{l}\text { HK12070 } \\
\text { Undifferentiated Kau Sai Chau } \\
\text { ignimbrite }\end{array}$ & $140.7 \pm 0.7$ & $141.1 \pm 0.2^{b}$ & $\mathrm{Y}$ & $\mathrm{N}$ & $\begin{array}{l}\sim 144 \mathrm{Ma}, 162 \\
\mathrm{Ma}, 430 \mathrm{Ma} \\
>2.5 \mathrm{Ga}\end{array}$ & $\mathrm{Nil}^{\mathrm{b}}$ \\
\hline $\begin{array}{l}\text { HK13277 } \\
\text { Pan Long Wan trachydacite lava }\end{array}$ & $141.0 \pm 1.3$ & $141.2 \pm 0.3^{b}$ & $\mathrm{Y}$ & $\mathrm{N}$ & $\begin{array}{c}\sim 143 \mathrm{Ma}, 156 \\
\mathrm{Ma}\end{array}$ & $\mathrm{Nil}^{\mathrm{c}}$ \\
\hline $\begin{array}{l}\text { HK12073 } \\
\text { Clear Water Bay lava }\end{array}$ & $140.5 \pm 0.7$ & $140.9 \pm 0.2^{c}$ & $\mathrm{Y}$ & $\mathrm{Y}$ & Nil & $>1.8 \mathrm{Ga}^{\mathrm{c}}$ \\
\hline $\begin{array}{l}\text { HK11834 } \\
\text { Clear Water Bay ignimbrite }\end{array}$ & $139.3 \pm 1.1$ & $140.9 \pm 0.2^{\mathrm{a}}$ & $\mathrm{N}$ & $\mathrm{Y}$ & Nil & $\mathrm{Nil}^{\mathrm{a}}$ \\
\hline $\begin{array}{l}\text { HK12001 } \\
\text { High Island Tuff }\end{array}$ & $140.9 \pm 0.4$ & $140.9 \pm 0.2^{\mathrm{a}}$ & $\mathrm{Y}$ & $\mathrm{N}$ & Nil & $\mathrm{Nil}^{\mathrm{a}}$ \\
\hline $\begin{array}{l}\text { HK13343 } \\
\text { Post-High Island rhyolite }\end{array}$ & $139.6 \pm 0.4$ & (No ID-TIMS & ge) & $\mathrm{N}$ & Nil & $\begin{array}{l}\text { (This study } \\
\text { only) }\end{array}$ \\
\hline \multicolumn{7}{|l|}{ Plutonic units } \\
\hline $\begin{array}{l}\text { HK11822 } \\
\quad \text { Lantau Granite }\end{array}$ & $159.9 \pm 0.7$ & $161.5 \pm 0.2^{\mathrm{a}}$ & $\mathrm{N}$ & $\mathrm{N}$ & $\begin{array}{c}\sim 169 \mathrm{Ma}, 177 \\
\mathrm{Ma}, 440 \mathrm{Ma}\end{array}$ & $\sim 713 \mathrm{Ma}^{\mathrm{a}}$ \\
\hline $\begin{array}{l}\text { HK11831 } \\
\text { East Lantau Porphyry }\end{array}$ & $144.9 \pm 0.7$ & $146.5 \pm 0.2^{\mathrm{a}}$ & $\mathrm{N}$ & $\mathrm{N}$ & Nil & $\sim 150 \mathrm{Ma}^{\mathrm{a}}$ \\
\hline $\begin{array}{l}\text { HK8535 } \\
\quad \text { Chi Ma Wan Granite }\end{array}$ & $140.0 \pm 1.0$ & $<143.7 \pm 0.3^{\mathrm{a}}$ & $\mathrm{N}$ & $\mathrm{Y}$ & $\begin{array}{c}\sim 149 \mathrm{Ma},>2.3 \\
\mathrm{Ga}\end{array}$ & $>1.8 \mathrm{Ga}^{\mathrm{a}}$ \\
\hline $\begin{array}{l}\text { HK12072 } \\
\quad \text { Shui Chuen O Granite }\end{array}$ & $141.9 \pm 0.8$ & $144.0 \pm 0.3^{\mathrm{c}}$ & $\mathrm{N}$ & $\mathrm{N}$ & Nil & $\mathrm{Nil}^{\mathrm{c}}$ \\
\hline $\begin{array}{l}\text { HK8758 } \\
\quad \text { Tong Fuk Quartz Monzonite }\end{array}$ & $140.6 \pm 1.5$ & $140.4 \pm 0.3^{\mathrm{a}}$ & $\mathrm{Y}$ & $\mathrm{Y}$ & Nil & $\mathrm{Nil}^{\mathrm{a}}$ \\
\hline $\begin{array}{l}\text { HK12023 } \\
\text { Sok Kwu Wan Granite }\end{array}$ & $140.7 \pm 1.2$ & $140.6 \pm 0.3^{\mathrm{a}}$ & $\mathrm{Y}$ & $\mathrm{Y}$ & Nil & $\mathrm{Nil}^{\mathrm{c}}$ \\
\hline $\begin{array}{l}\text { HK12022 } \\
\text { D'Aguilar Quartz Monzonite }\end{array}$ & $140.5 \pm 1.0$ & $140.6 \pm 0.3^{\mathrm{a}}$ & $\mathrm{Y}$ & $\mathrm{N}$ & Nil & $\mathrm{Nil}^{\mathrm{c}}$ \\
\hline $\begin{array}{l}\text { HK11042 } \\
\text { Kowloon Granite }\end{array}$ & $139.1 \pm 1.0$ & $140.4 \pm 0.2^{\mathrm{a}}$ & $\mathrm{N}$ & $\mathrm{N}$ & $\begin{array}{l}\sim 143 \mathrm{Ma}, 154 \\
\text { Мa, } 550 \mathrm{Ma}\end{array}$ & $\mathrm{Nil}^{\mathrm{a}}$ \\
\hline $\begin{array}{l}\text { HK13407 } \\
\text { Mount Butler Granite }\end{array}$ & $137.8 \pm 0.8$ & (No ID-TIMS & ge) & $\mathrm{N}$ & $\begin{array}{c}\sim 163 \mathrm{Ma},>2.1 \\
\mathrm{Ga}\end{array}$ & $\begin{array}{l}\text { (This study } \\
\text { only) }\end{array}$ \\
\hline
\end{tabular}

Notes: Published ID-TIMS U-Pb age data from a - Davis et al. (1997); b - Campbell et al. (2007); c - Sewell et al. (2012b); Nil - No inheritance ages identified. 
The emplacement age estimates of some plutonic rocks are also influenced by the presence of recycled zircon cores. The Kowloon and Mount Butler granites are inferred here to have crystallisation ages at 139.1 $\pm 1.0 \mathrm{Ma}$ and 137.8 $\pm 0.8 \mathrm{Ma}$, respectively. These ages are at least 1 Myr younger than the eruption ages of the Kau Sai Chau Volcanic Group units, which are inferred here to have erupted at 141-140 Ma. The differences in emplacement ages would suggest that that the volcanic and plutonic components were not coeval and not necessarily co-genetic even if the rocks are spatially overlapping. The Sok Kwu Wan Granite, D’Aguilar Quartz Monzonite, Tong Fuk Quartz Monzonite and the Chi Man Wan Granite all yield age spectra that suggest that they crystallised at 140 Ma (Table 4.5), closely matching the eruption ages of the Kau Sai Chau volcanic units, and implying an intense magmatic flux at that time.

Finally, the SIMS age data of the Shui Chuen O Granite give a unimodal age component dataset with MWSD value close to unity. The best estimated crystallisation age of the granitic pluton is inferred to be $141.9 \pm 0.8 \mathrm{Ma}$, i.e. younger than the published ID-TIMS age (Table 4.5). However, the ID-TIMS dating works identified the presence of multiple age components, which are separated by less than $1 \mathrm{Myr}$ in age, of this pluton (fig. 7A in Sewell et al., 2012b). It is likely that the SIMS works carried out in this study is unable to resolve this time range of less than $1 \mathrm{Myr}$. Instead of being generated as a single intrusion at $143 \mathrm{Ma}$, the pluton probably underwent multiple stages of thermal waxing and waning before a final crystallisation period at $\sim 142 \mathrm{Ma}$. 


\subsubsection{Petrogenetic information revealed from zircon textural and trace element information}

A wide range of growth patterns and textures have been identified from the Hong Kong magmatic zircons under CL images. The presence of an array of zircon populations, having textures ranging from relatively simple and homogeneous to more complex and diverse in different magmatic units suggests the presence of a corresponding complexity in the magmatic systems. This section discusses the compositional (trace element) variations in different growth zones of zircon grains, especially the core-versus-rim variations, which are linked to various petrogenetic processes.

\subsubsection{Dark cores and bright rims}

This group of samples yields zircon populations dominated by grains with CL-dark cores and bright rims. The Ap Lei Chau ignimbrite (HK11840), Che Kwu Shan ignimbrite (HK11836) and Pan Long Wan trachydacite lava (HK13277) belong to this group ( 60$70 \%$ of the zircons show this pattern: Table 4.3 and Fig. 4.2). Of these, the Pan Long Wan trachydacite exhibits the most obvious and systematic variations (Fig. 4.19): cores have significantly higher Hf, U, Th, total 3+ trace elements and lower Ti than the rims in individual grains. Significant proportions of the zircon cores from two RBVG units, the Ap Lei Chau (HK11840; 31\%) and Che Kwu Shan (HK11836; 27\%) tuffs, share a common appearance of dark, rounded grains in CL images (i.e. Type A cores: Table 4.2.) and common trace element signatures with those of the Pan Long Wan trachydacite (HK13277; 48\%: Fig. 4.19). Some of these dark cores from the two ignimbrite units plot in the same regions as those of the Pan Long Wan trachydacite in the Eu/Eu*, Ti and U/Yb versus Hf, and $\mathrm{Y}$ versus Nd plots (Fig. 4.19). In addition, some of the cores from these three units yield similar inheritance ages, ranging between 143 Ma and 162 Ma (Table 4.5). 

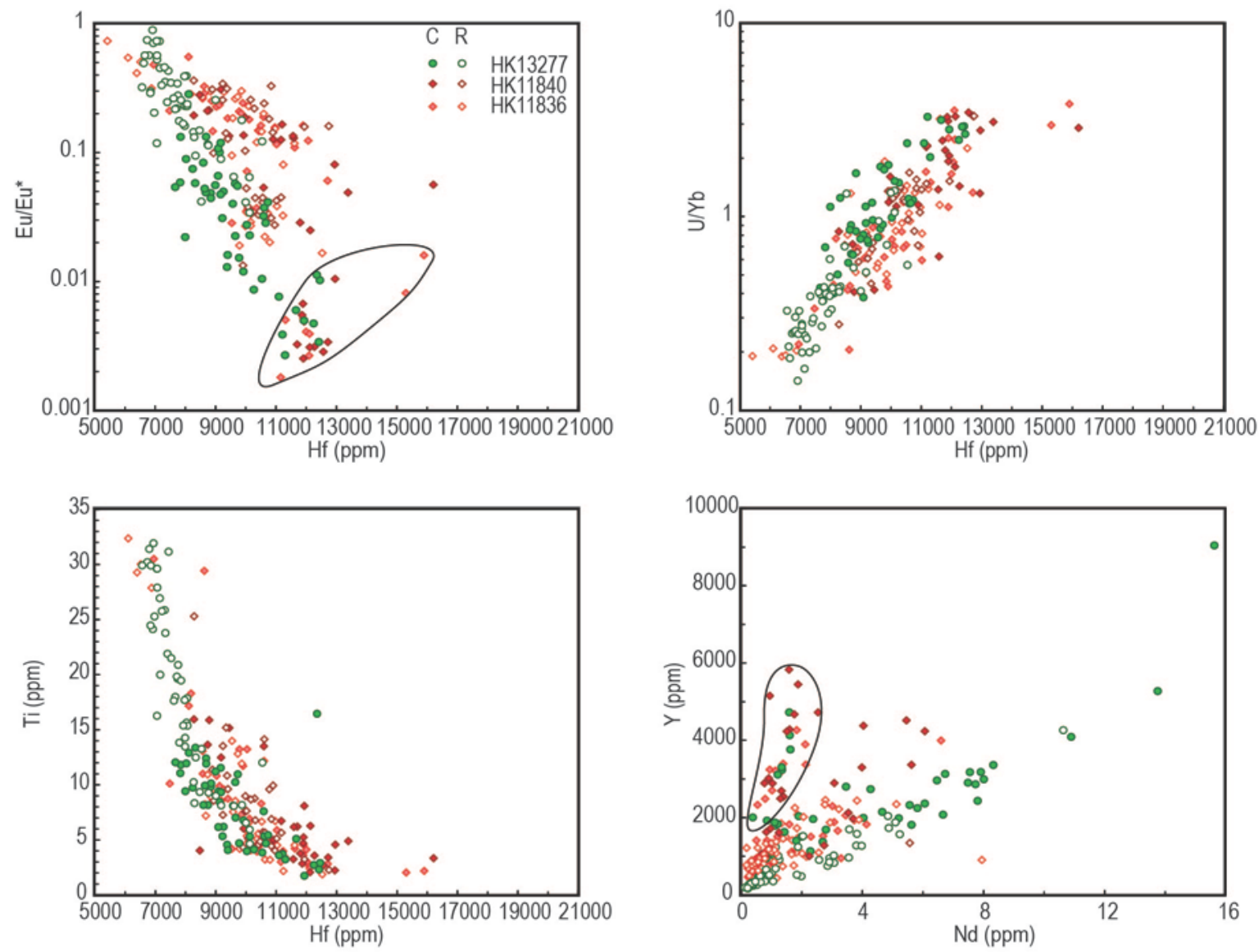

Fig. 4.19. Plots of selected zircon trace elements to illustrate the intra-grain core-rim variations from the Pan Long Wan trachydacite (HK13277), and to compare them with those of the Ap Lei Chau and Che Kwu Shan ignimbrites (HK11840 and HK11836). Ovoid outlines highlight the zircon cores that show common CL textural characteristics and trace element signatures in the three samples. Closed symbols are core (C) data and open symbols are rim (R) data.

Zircon growth zones that exhibit a bright CL emission from these three units are characterised by comparable low Hf, U, Th and trace element concentrations, but higher Ti abundance (as proxy of melt temperature). These cores are inferred to have been entrained by hot and less-evolved melts in the assembling magma where they were partly resorbed then overgrown. Similar features, although with very limited amounts of resorption, were also reported in Bishop Tuff zircons by Chamberlain et al. (2014b), who interpreted them as representing the arrival of less evolved, slightly hotter melts in the final stages of zircon crystallisation. In both cases, the assembly process must have been rapid or else these entrained grains would have completely dissolved back into the less-evolved melt (cf. Charlier et al., 2005, 2010). Furthermore, the similarities in trace element signatures and CL appearances suggest that the zircon cores of these three volcanic units are likely to have come from a common plutonic source, which had been reactivated and mobilised by 
the magmatism that led to the Ap Lei Chau, Che Kwu Shan and Pan Long Wan volcanic units.

Apart from these volcanic samples, the D’Aguilar and Tong Fuk quartz monzonites (HK12022 and HK8758) also yield zircon populations dominated ( 60-80\%: Table 4.2) by 'CL-dark core-bright rim' textures. Such zircon textures have rarely been reported from plutonic rocks. Most of these cores from these quartz monzonite units are resorbed and rounded (i.e. Types A or B, Table 4.2), which implies that they had been destabilised and partially dissolved in less-evolved melt and then subsequently overgrown. The occurrence of bright-rimed zircons (with lower $\mathrm{U}$, Th, Hf and higher Ti concentrations) from the D’Aguilar and Tong Fuk quartz monzonites implies that the plutons were crystallised from relatively high-temperature or less-evolved magma. In addition, the narrow range of $\mathrm{Hf}$ concentrations from the zircon rim analyses of these plutonic units indicates that fractionation of melts in which the zircons were crystallised was limited.

\subsubsection{Lighter CL cores and dark rims}

In contrast with the dark core-light rim samples, the second group of samples contains dominantly zircons with CL-lighter cores surrounded by darker growth zones or rims. For instance, the Lantau Granite (HK11822), Chi Ma Wan Granite (HK8353), Kowloon Granite (HK11042) and Mount Butler Granite (HK13407) have significant proportions ( $40-80 \%$ ) of grains with dark rims. Some volcanic samples also yield minor proportions of grains with similar textures, but not as common as in plutonic samples (Table 4.2). These dark CL-growth zones, typically characterised by enrichment of U, Th, Hf and total 3+ elements, but low Ti concentrations are interpreted as corresponding to crystallisation from cooler, more-evolved melts.

The ‘dark-rim’ zircons are interpreted as reflecting crystallisation in progressively moreevolved cooler melts, probably corresponding to the thermally waning stage of a magmatic system. In addition, the exceptional enrichment of $\mathrm{Hf}$ and $\mathrm{U}$ in the zircon rims of the Mount Butler Granite probably suggests that the pluton had undergone an extended period of fractionation before completely solidifying. This observation is supported also by the whole rock geochemical characteristics of the unit (Sewell and Campbell, 1997; 2001; see Section 6.5 for discussion), which signify a highly-evolved melt. A warmer crust might be 
present to sustain such an extended period of fractionation during the emplacement of the Mount Butler pluton.

\subsubsection{Structureless cores and cores separated by thin bright intermediate}

\section{growth zone}

The zircon populations of the Clear Water Bay Formation and High Island Tuff are dominated by the presence of either euhedral cores (Type C cores: 20-30\%) or cores with vague resorption boundary but essentially euhedrally overgrown by thin (generally $<10$ $\mu \mathrm{m})$, CL-bright growth zones ( 10-30\%: Table 4.2). Unlike zircons from the Pan Long Wan trachydacite which show distinct and systematic intra-grain, core-versus-rim trace element variations, the zircon cores (both Type B and C) from the Clear Water Bay Formation and High Island Tuff have identical trace element characteristics compared with those of the rims. Both units display a similar bimodal Hf concentration pattern, which is unrelated to sector zoning. In addition, the SIMS U-Pb ages of zircon cores are also indistinguishable from the unimodal age component of the rim ages.

The Type C zircon cores might be attributed to particular growth environment and kinetics, or the lack of evidence of zoning might be due to insufficient resolution of imaging techniques or that original zoning patterns have been destroyed (Corfu et al., 2003). On the other hand, the presence of a resorption boundary around the cores can be interpreted to represent a transient change in melt environment (zircon saturation controlled by temperature and composition of the melt: e.g. Reid et al., 2011), rather than reflecting major recycling or resorption events in hotter and/or zircon under-saturated melts. The presence of resorption boundaries between zones of fairly similar temperature, and trace element composition variations may imply some thermal influx into the system (without mixing of magma), with zircons being resorbed to maintain $\mathrm{Zr}$ contents in equilibrium in the melt with rising temperature (cf. Reid et al., 2011). The findings of the age dating of zircons also support the interpretation that the High Island Tuff did not contain an inheritance signature or have recycled zircons from older magmatic episodes.

\subsubsection{Zircons with large variety of complex zoning textures}

In contrast to the structureless cores described in the previous section, some units yield a wide variety of zircon textures and complex resorption boundaries in zircon cores (Type A cores). For instance, in the Lantau Granite, East Lantau porphyry (HK11822 and HK11831, 
respectively), and Shing Mun, Lantau, Long Harbour and Mount Davis ignimbrites (HK12025, HK11052, HK11835 and HK13275, respectively) the zircon population contains a combination of various types of cores and CL intensities. The undifferentiated Kau Sai Chau ignimbrite zircons (HK12070) exhibit the widest range in CL intensity (Table 4.2), which is also reflected by notably large ranges in trace element concentrations when compared to other volcanic units (except the Pan Long Wan trachydacite, HK13277; Table 4.4). The complexity of these zircon textures with evidence of inherited cores (antecrystic or xenocrystic cores with multiple age components) reflects multiple episodes of zircon growth and resorption.

Some of the complex zircons are characterised by the presence of well-defined intermediate growth zones with distinct trace element patterns. For instance, zircons from the Kowloon Granite (HK11042) exhibit systematic trace element variations that can be linked with specific CL-dark growth zones, characteristically lacking oscillatory zoning. The analyses from these intermediate growth zones yield distinct trace element signatures, which are higher in Hf, $\mathrm{U}$, total 3+, $\mathrm{Yb} / \mathrm{Gd}$ ratio, lower in Ti concentrations and Th/U ratio and with a deeper $\mathrm{Eu} / \mathrm{Eu}^{*}$ anomaly $(<0.1)$. These characteristics indicate that these zircons had crystallised for some time period in a more-evolved, cooler melt when compared with the earlier or later melts (Fig. 4.20). This period of zircon crystallisation might represent the lower-temperature stage of a magmatic system, which then was rejuvenated prior to eruption, with growth of the CL-brighter rims.

Intermediate dark CL growth zones with similar trace element characteristics are also found in some grains from the Long Harbour (HK11835) and Mount Davis (HK13275) crystal-rich ignimbrites (Type B zircon cores: 50\% and 62\% of all grains respectively, Table 4.2). The presence of multiple resorption and dark CL intermediate growth zones in zircon grains provide strong evidence of the recycling of material from some plutonic sources that were repeatedly cooled and then rejuvenated for one or more cycles before final assembly of the magma bodies and eruption. The zircon textures combined with trace element and geochronological data of these units suggest that their respective volcanic systems recycled materials from earlier plutonic units which had underwent phases of waning. Analysed examples of these recycled cores yield U-Pb ages of 144-146 Ma and $\sim 165$ Ma (Tables 4.3, 4.5). 

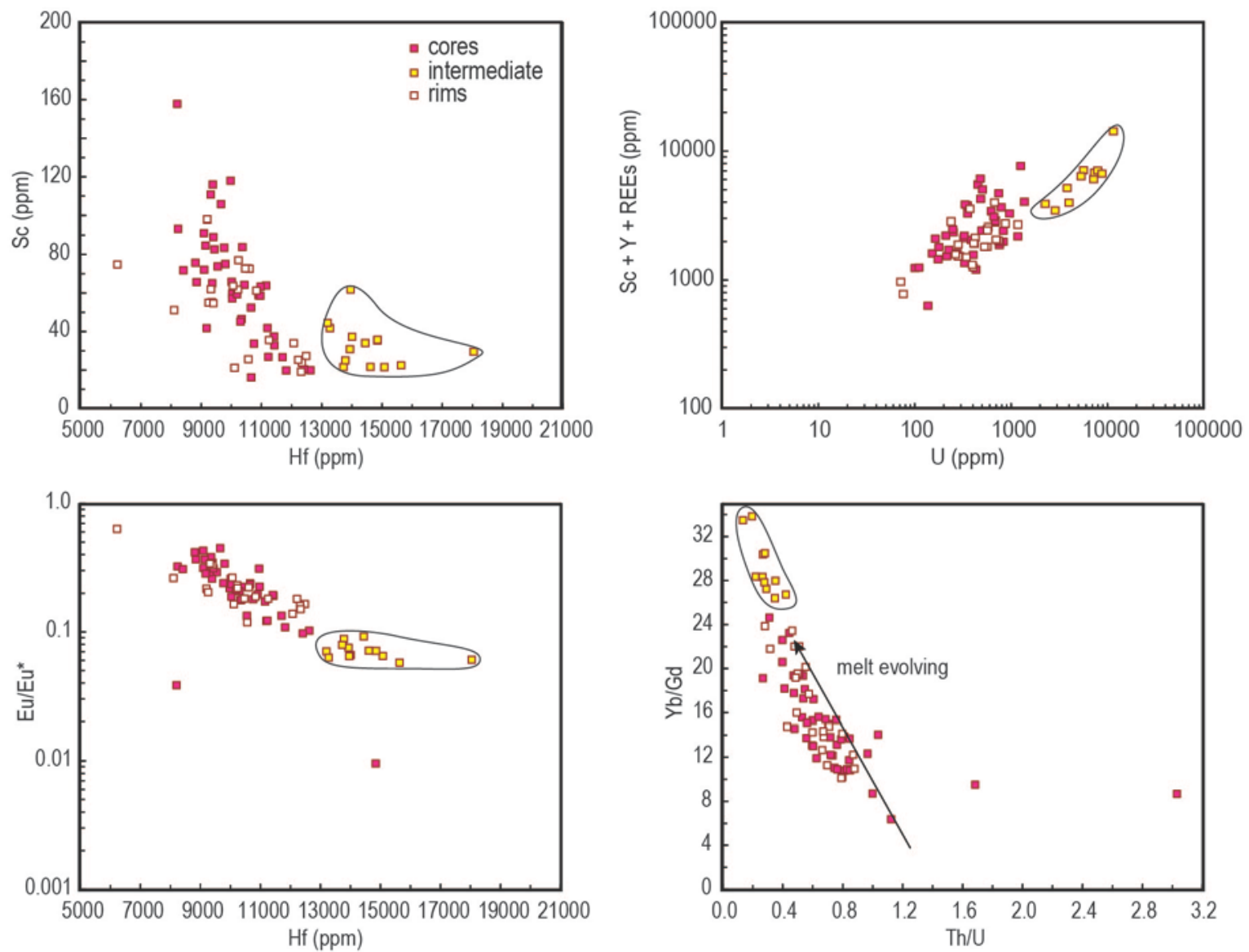

Fig. 4.20. Plots of selected zircon trace elements to illustrate the intra-grain variations from Kowloon Granite (HK11042). Ovoid outlines highlight the evolved intermediate zones in this sample. See text for discussion.

\subsubsection{Role of sector zoning on trace element patterns}

The effects of sector zoning on the distribution of trace elements in single zircon grains have long been recognised (e.g. Corfu et al., 2003). More recently, Chamberlain et al. (2014b) quantified variations of trace elements between CL-darker and -lighter sectors in the same growth zones in single grains from the Bishop Tuff. They concluded that the LREEs, U and Th are more enriched in the darker sectors (crystal tips; growth along the caxis) and there is a depletion of $\mathrm{P}$ in the lighter sectors (crystal sides; growth along the aand b-axes). In addition, Cooper et al. (2014) demonstrated that trace element variations are present between sides and tips of zircon grains even in cases where sector zoning is not evident in CL images. Here, selected suites of trace element data are plotted to illustrate the influence of sector zoning in the Hong Kong volcanic and plutonic zircons (Figs. 4.21, 4.22). The effects are best displayed in plots of the total $3+$ elements versus $U$, and the molar total 3+/P ratio versus $\mathrm{U}$ concentration, where two roughly sub-parallel arrays are generally evident (cf. Chamberlain et al., 2014b). It is noteworthy that the variations in 
trace element concentrations across dark-bright sectors are non-systematic, i.e. particular trace elements may exhibit enrichment, depletion or even no noticeable difference in dark versus light sectors in individual grains. The non-systematic changes are highlighted by the variable gradients (negative/positive) of the tie-lines connecting data from the dark-bright sectors of individual grains (Figs. 4.21, 4.22). As discussed earlier, zircons from the Clear Water Bay rhyolite lava and ignimbrites (HK12073 and HK11834) apparently contain bimodal Hf concentrations. As evident in $\mathrm{Eu} / \mathrm{Eu}^{*}$ versus $\mathrm{Hf}$ plot of the Clear Water Bay rhyolite, however, the Hf bimodality is not associated with sector zoning (Fig. 4.21). Cooper et al. (2014) observed that the CL-lighter sectors of zircons from the Kidnappers unit ( 1.0 Ma, Mangakino volcanic centre, New Zealand) generally returned molar ratios of total 3+/P close to 1, independent of $\mathrm{Yb}$ or $\mathrm{Hf}$ concentrations. As such, these grains showed behaviour approximating to the 'xenotime substitution' (Hoskin and Schaltegger, 2003). The Hong Kong samples, in contrast, yield of ranges of total 3+/P molar ratio between 1 to 3 in the lighter sectors and show gentle positive trends with increasing Hf, $\mathrm{U}$ and $\mathrm{Yb}$ abundances. The positive trend probably reflects either a different substitution mechanism of trace elements in the zircon crystal structure or, more likely, the relative depletion of $\mathrm{P}$ with the enrichment of trivalent elements in the progressively more evolved melt (higher Hf, or U concentration). The implication is that in the more evolved melt, the charge balance required for the incorporation of trivalent trace elements has to be though mechanisms other than the 'xenotime substitution'. 
(A) Mount Davis ignimbrite HK11835
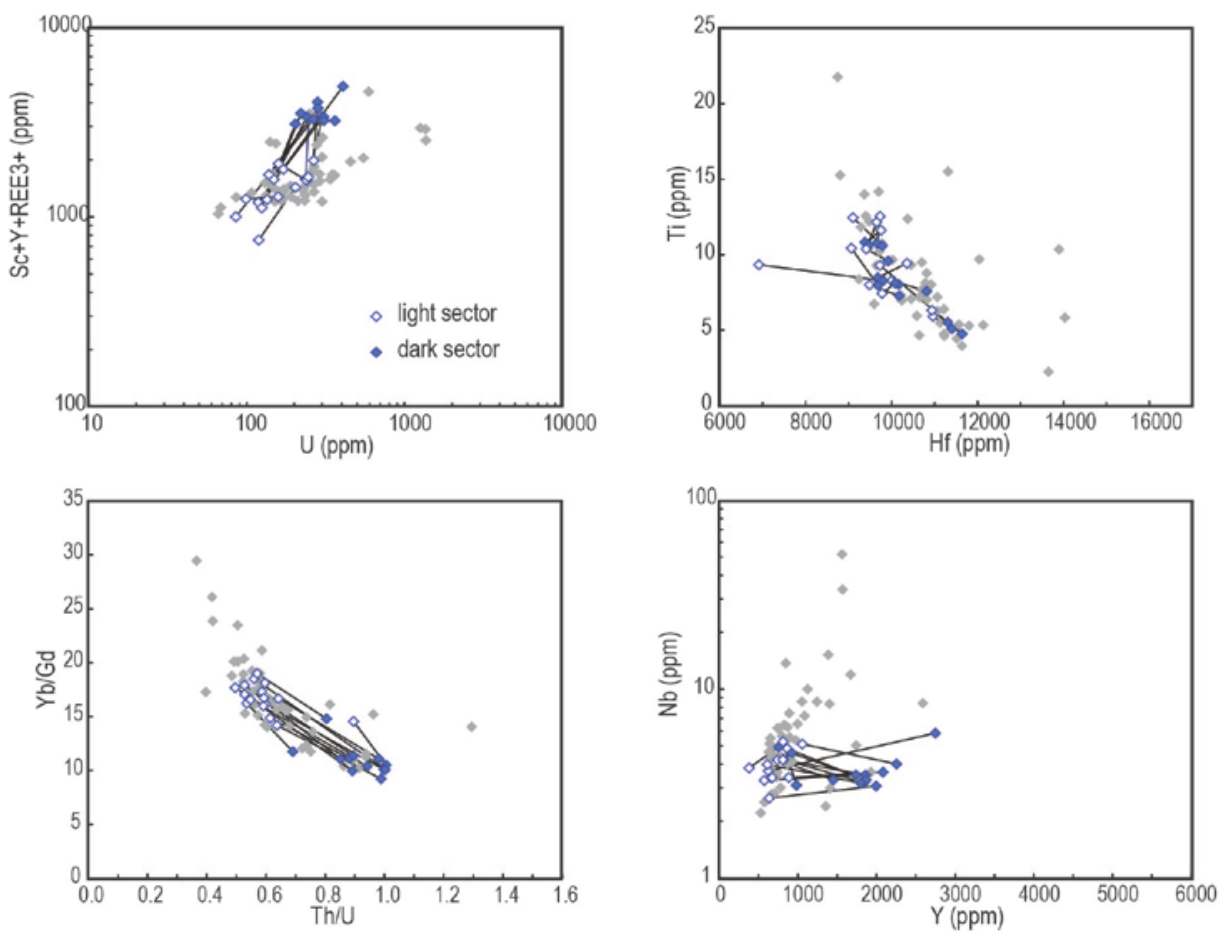

(B) Clear Water Bay rhyolite HK12073
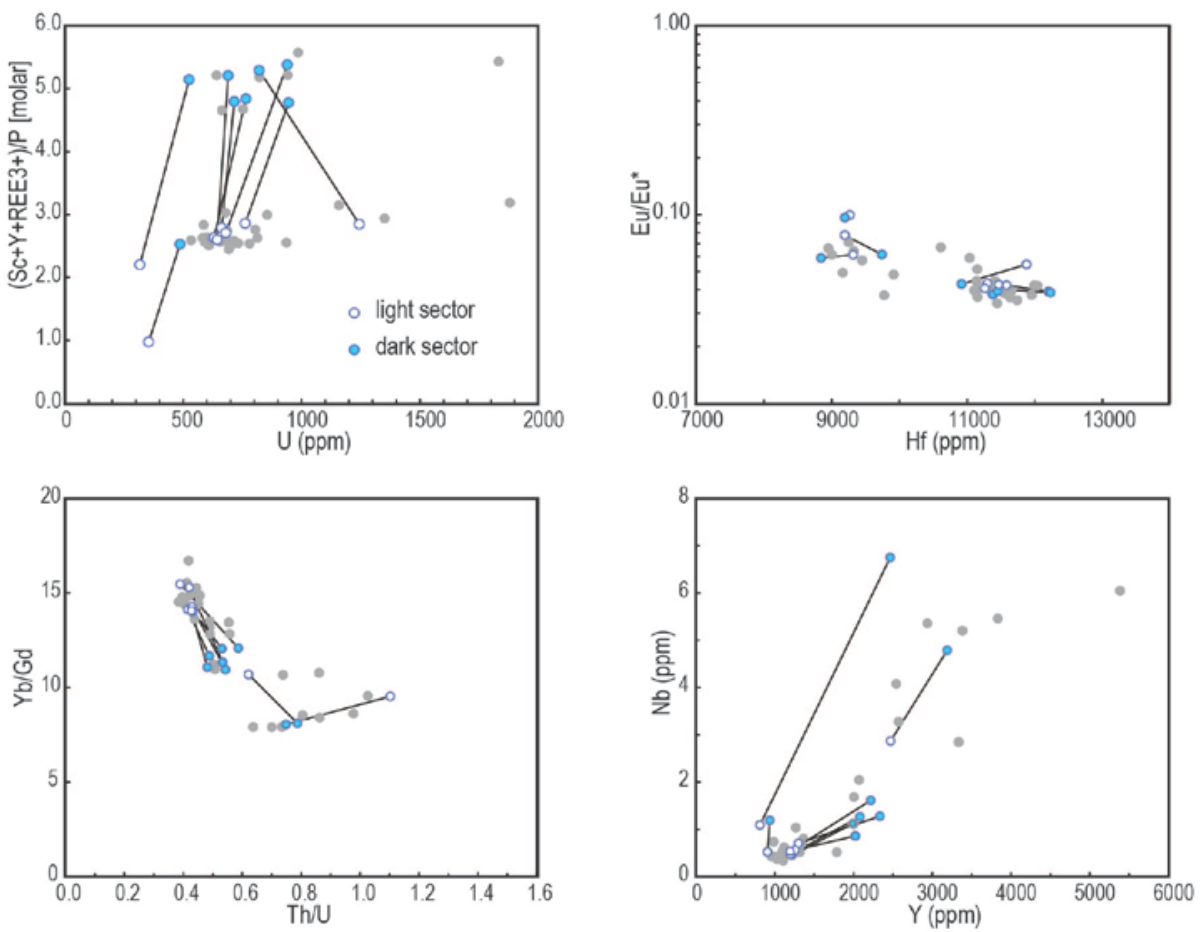

Fig. 4.21. Plots of selected zircon trace elements to illustrate the influence of sector zoning in volcanic units, using samples (A) HK11835 (Mount Davis ignimbrite) and (B) HK12073 (Clear Water Bay rhyolite) as examples. Only data from zircon rims are plotted. Tie-lines connect the data points from the light-dark sectors of the same growth zones in the sample rims. Open symbols represent data from lighter sectors and closed symbols represent data from darker sectors. 

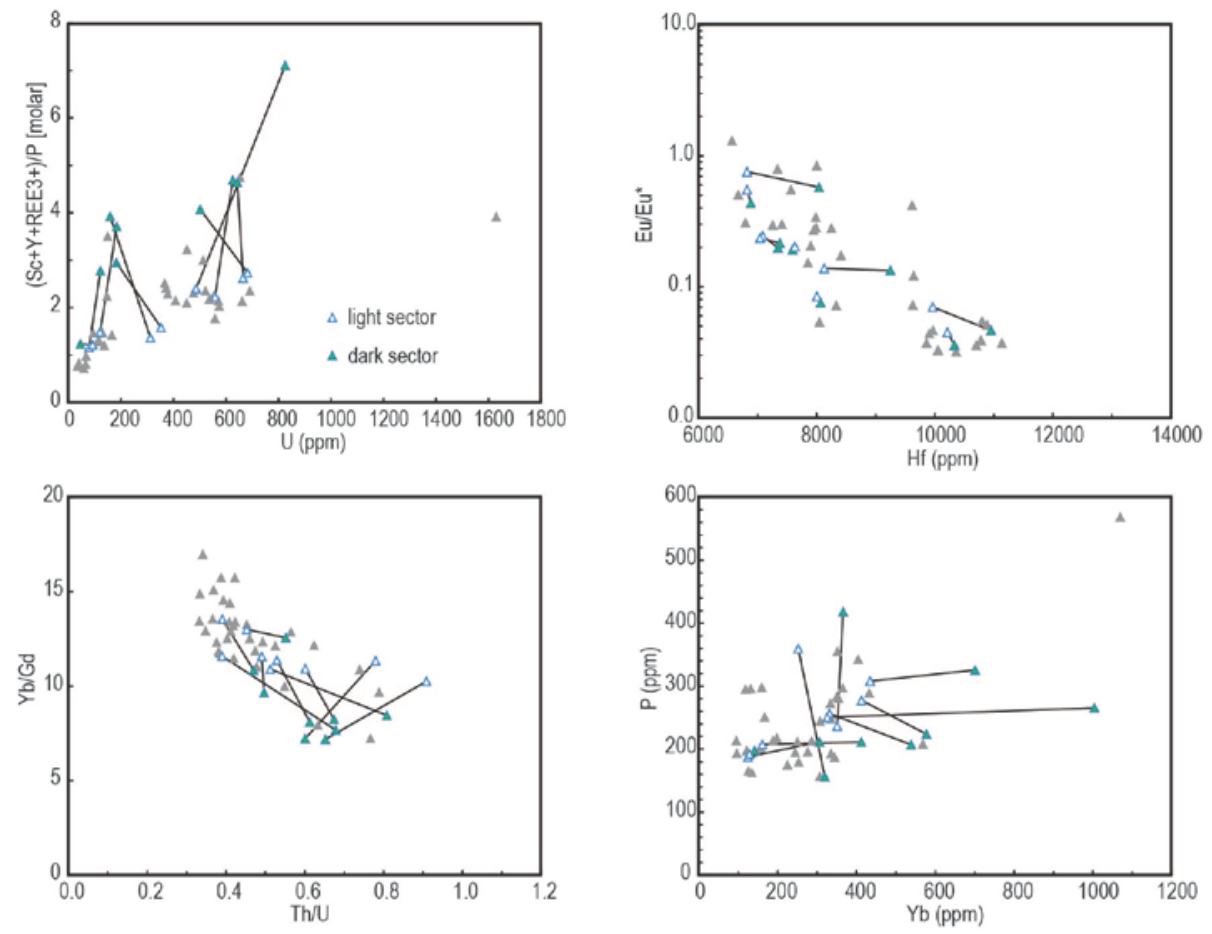

(B) Mount Butler Granite HK13407
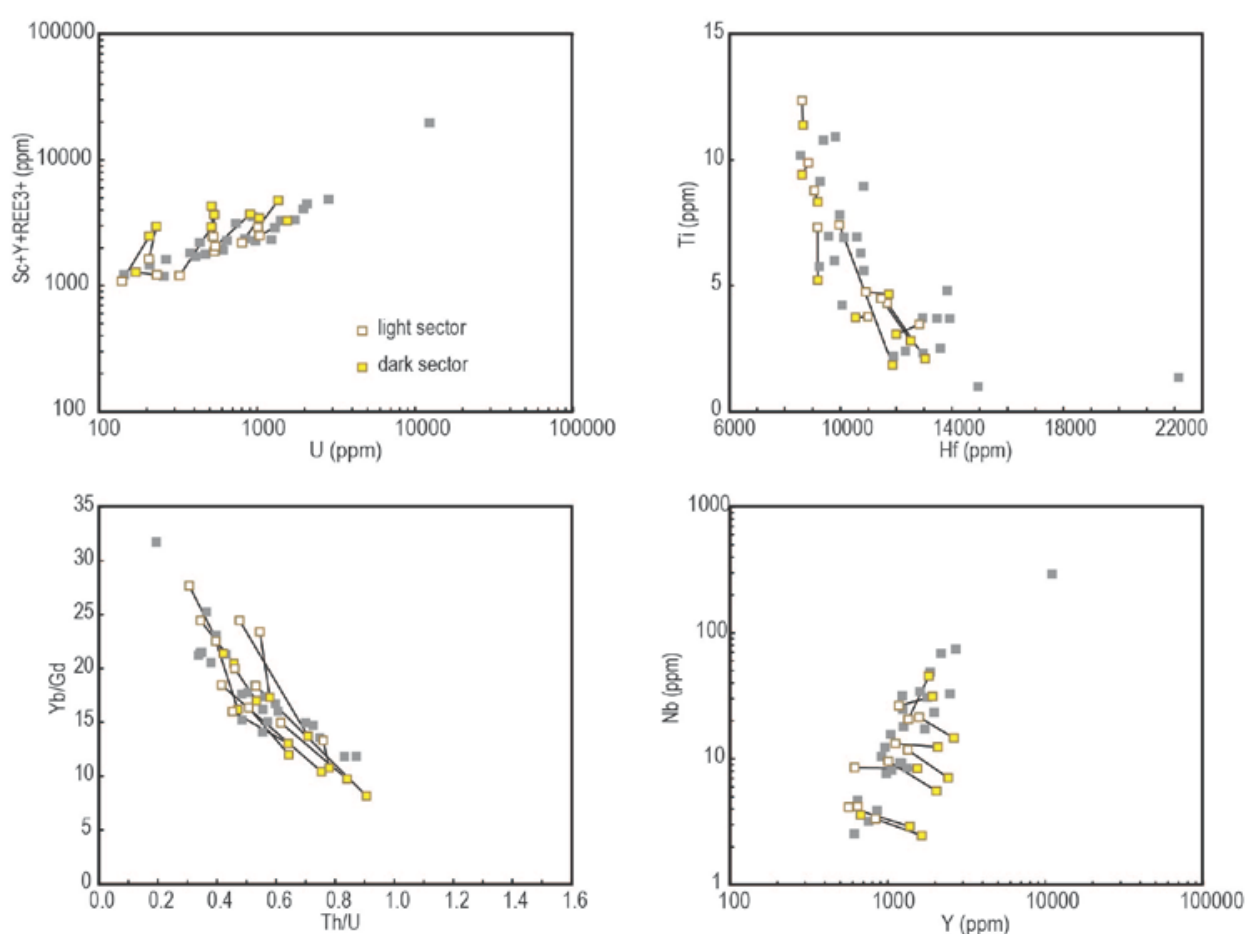

Fig. 4.22. Plots of selected zircon trace elements to illustrate the influence of sector zoning in granitic units, using samples (A) HK12022 (Sok Kwu Wan Granite) and (B) HK13407 (Mount Butler Granite) as examples. Only data from zircon rims are plotted. Tie-lines connect the data points from the light-dark sectors of the same growth zones in the sample rims. Open symbols represent data from lighter sectors and closed symbols represent data from darker sectors. 


\subsubsection{Xenocrysts versus antecrysts: inheritance patterns in the age and trace element data}

The presence of inherited zircons, identified on the basis of age data or strongly contrasting trace element compositions in the samples, provides direct evidence for involvement (recycling) of crustal materials in the Hong Kong magmatic systems. The inherited grains can be considered to either be xenocrysts, sourced from older, unrelated host rocks, or antecrysts, derived from crystal mush of earlier magmatic episodes (Charlier et al., 2005). Based on CL imagery, a range of growth patterns and textures have been identified from the Hong Kong magmatic zircons, of which variable percentages of grains (ranging from 34-85\%) contain noticeable cores (Table 4.2). Judging from the CL textural characteristics alone, there seems to be a significant amount of inheritance (recycling) involved in the Hong Kong magmatic system. In this study, these various types of zircon cores were analysed for $\mathrm{U}-\mathrm{Pb}$ ages and trace elements to investigate whether these cores are readily distinguishable from their ages and geochemistry.

Considering both the SIMS age data and the previous ID-TIMS studies, the presence of inherited grains is evident in 15 of the 21 samples studied here (Table 4.5). It is noteworthy that several samples (volcanic units HK11052, HK13275, HK12070, HK13277; plutonic units HK12072 and HK11042) yielded inherited cores, the presence of which had not been identified in ID-TIMS studies (Davis et al., 1997). The relevant ages are either late Mesozoic or much older (Palaeozoic to Archean). For the late Mesozoic inherited grains, a first order observation is that their model mean ages yielded by the Sambridge and Compston (1994) methods are roughly coincident with the major local magmatic episodes identified by Davis et al. (1997) and Sewell et al. (2012b). These zircons are inferred to represent crystals that grew in earlier magmatic pulses and were then recycled in subsequent magmatic injections. Whether such grains are considered to be antecrysts or xenocrysts (sensu Charlier et al., 2005) depends on the duration of time between these grains and their host igneous rocks, and the differentiation between the two types is somewhat tricky in these cases. For instance, the 137.8 \pm 0.8 Ma Mount Butler Granite contains inherited zircon cores that are Mesozoic ( $\sim 160 \mathrm{Ma})$ and Palaeoproterozoic ( 2.1 $\mathrm{Ga}$ ) in age (Table 4.5). The Mesozoic inherited grains are broadly interpreted here as antecrysts, i.e. they were remobilised from precursor crystal mush or plutons of earlier magmatic episodes (cf. Charlier et al., 2005; Hildreth and Wilson, 2007; Miller et al., 
2007), although these grains are over 20 Myr older than the crystallisation age of the Mount Butler Granite. A large age gap between the inherited cores and the host units, however, were used as one of the key criteria for discriminating xenocrysts and antecrysts in other studies (e.g. Charlier et al., 2005; Miller et al., 2007).

The data presented here suggest that identification of antecrysts versus xenocrysts in part is a function of the age resolution and temporal precision of geological controls. Caution must be taken when the presence of recycled dated zircons is used to determine the 'residence time' of a magma chamber or duration of pluton assembly in case of intrusive rocks. Regardless of their designation, the survival of whole or partial zircon grains in successive magmatic episodes implies that the magmatic conditions (temperature, composition) of these inheritance-bearing units did not greatly exceed the zircon saturation temperature (cf. Charlier et al., 2005). In addition, the presence of inherited zircons in intrusive rocks implies that the crystallisation age of zircons might not strictly correspond to their emplacement ages as normally considered. This study demonstrates that if inherited grains are present, the ID-TIMS ages of a granitic unit may represent highly precise but inaccurate ages. The presence of multiple zircon age components in some of the granitic plutons in Hong Kong, results in the complications for interpreting the age data derived from both the ID-TIMS and SIMS techniques.

Some zircon cores, from both volcanic and plutonic units, yield much older Palaeozoic to Archean ages (Table 4.5). The oldest grain identified is $\sim 2.8 \mathrm{Ga}$ from the Shing Mun tuff (HK12025). These grains are definitively xenocrysts, incorporated into the host magma from the surrounding basement rocks, and are considerably older than the magmatic host rock itself. The Kowloon and Mount Butler granites also yield Palaeozoic and PalaeoProterozoic grains, respectively, implying the presence of basement rocks of these ages underneath this part of Hong Kong. This finding supports the terrane model proposed by Fletcher et al. (1997), which was based mainly on geophysical data and the isotopic characteristics of granites identified by Darbyshire and Sewell (1997) (see Section 2.3.1).

Here, I consider the trace element characteristics of the inherited zircon cores to investigate whether they show any distinctiveness. Zircon cores/growth zones that have been analysed both for age and trace elements are highlighted in selected trace element plots. Examples from two of the samples show that some old xenocrystic cores might exhibit distinct trace element characteristics that generally plot outside the main trend of other zircons (Fig. 
4.23). Xenocrystic cores (1.1 to $2.8 \mathrm{Ga}$ ) from Shing Mun ignimbrite (HK12025; Fig. 4.23A) in general show broader ranges, and more variable trace element characteristics than the rims. These xenocrystic cores commonly show distinctive growth patterns characterised by dark CL emission with oscillatory zoning and, complex multiple resorption boundaries (i.e. Type B cores), implying multiple recycling and growth stages. Some of these cores were surrounded by lighter CL intermediate growth zones that plot within the main trace element trends. Age determinations targeted at these light CL growth zones yield ages broadly similar to the weighted mean age of the unit (i.e. 164 Ma, Table 4.3), and the light-CL zones are therefore likely antecrystic. Similarly, the undifferentiated Kau Sai Chau ignimbrite (HK12070) from the Lantau caldera also yields xenocrystic grains with trace element characteristics that derivate from the main trends (Fig. 4.23B). 
(A) Shing Mun ignimbrite HK12025
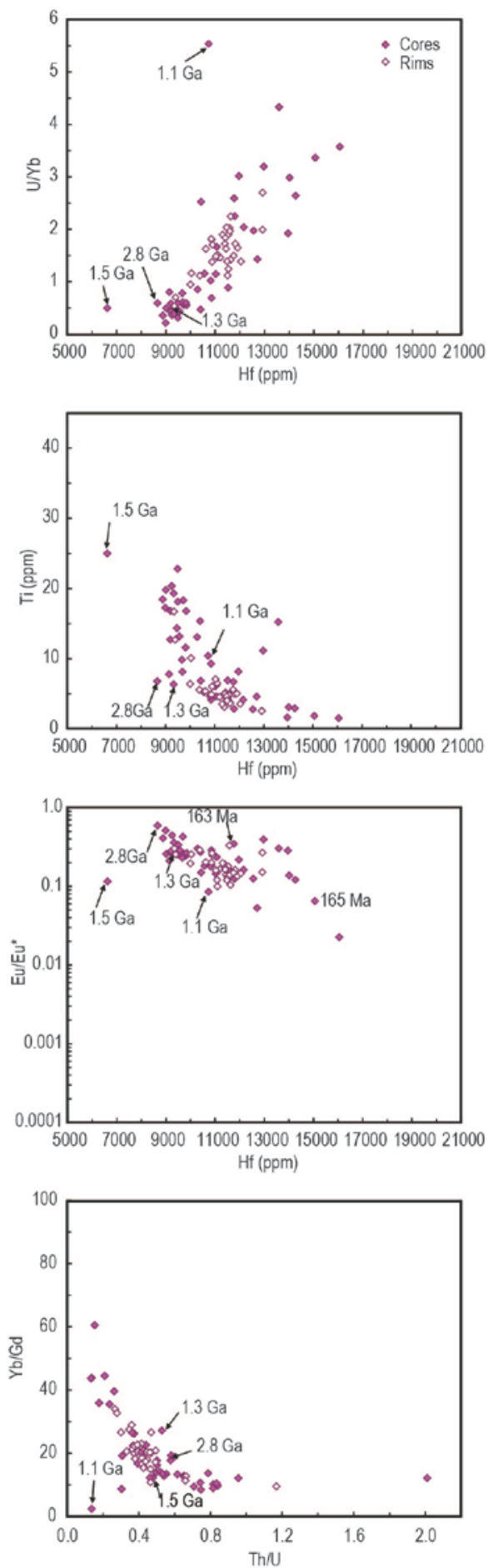

(B) Kau Sai Chau ignimbrite HK12070
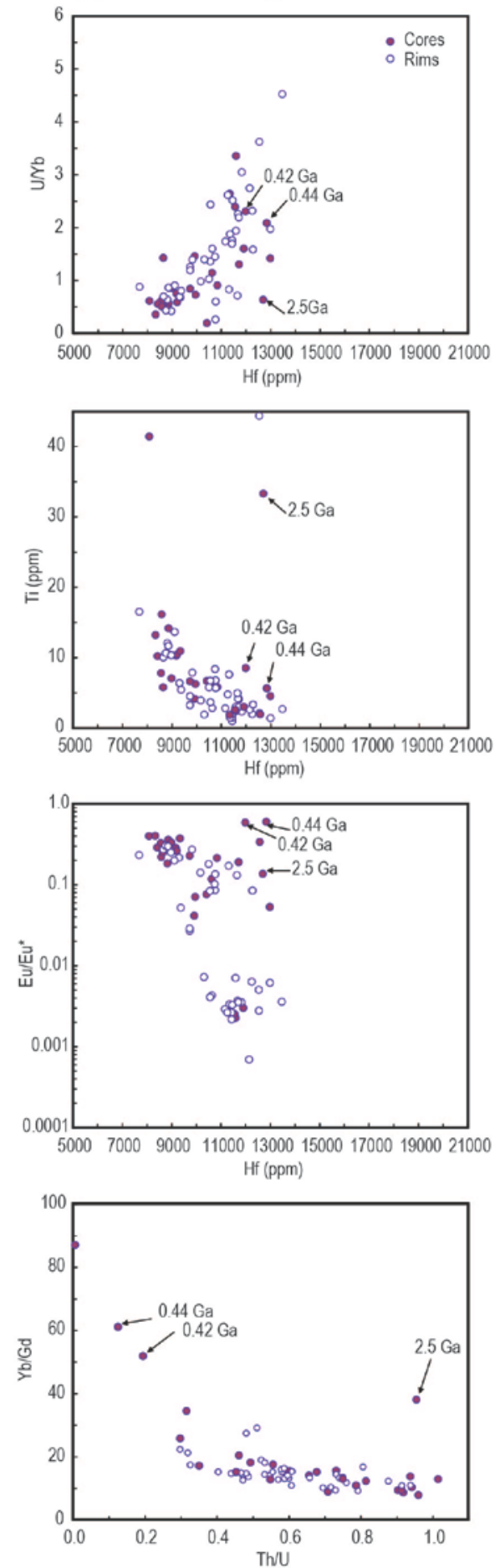

Fig. 4.23. Plots of selected zircon trace elements of (A) Shing Mun ignimbrite (HK12025, left panels) and (B) undifferentiated Kau Sai Chau ignimbrite (HK12070, right panels), highlighting the characteristics of some dated xenocrystic cores that plot outside the main trends. Closed and open symbols represent zircon cores and rims, respectively. In-situ SIMS ages of selected cores were obtained from the same analytical spots as the trace element analyses. See text for detailed discussion. 


\subsubsection{Variations in trace element patterns through time}

Here, I use the trace element signatures of zircons from the volcanic units to track the evolution of the Middle Jurassic to Early Cretaceous Yanshanian magmatic episodes in Hong Kong. Since zircon cores tend to exhibit wider variations in trace element characteristics (Figs. 4.10-4.18), due in part to their inherited nature, only the rim analyses are considered here. Trace elemental ratios (such as $\mathrm{Th} / \mathrm{U}, \mathrm{Yb} / \mathrm{Gd}$ and $\mathrm{U} / \mathrm{Yb}$ ) in zircons can be an indicator of melt compositions, reflecting the relative influences of mantle-derived magmas and/or crustal sources during the evolution of the magmatic system (Barth et al., 2013). In addition, variations in the ranges of Sc, Ti and Hf concentrations are considered here to investigate whether there were systematic changes through time that could reflect the evolution of the crust and magmatic systems below Hong Kong (Fig. 4.24).

In general, zircon trace element data from all units exhibit similar partly overlapping trends, and variations in their ranges reflect changes of the magmatic systems through time. The two Jurassic volcanic units (Shing Mun and Lantau ignimbrites, HK12025 and HK11052), have narrower ranges than the younger RBVG and KSCVG units (Figs. 4.10 to 4.18). Generally higher Hf concentrations occur in zircons from these two Jurassic units together with the RBVG units (Long Harbour and Mount Davis ignimbrites, HK11835 and HK13275, Fig. 4.24). The amount of Sc shows a general increase from the oldest Shing Mun ignimbrite (HK12025), through the Lantau ignimbrite (HK11052) and the RBVG units. 


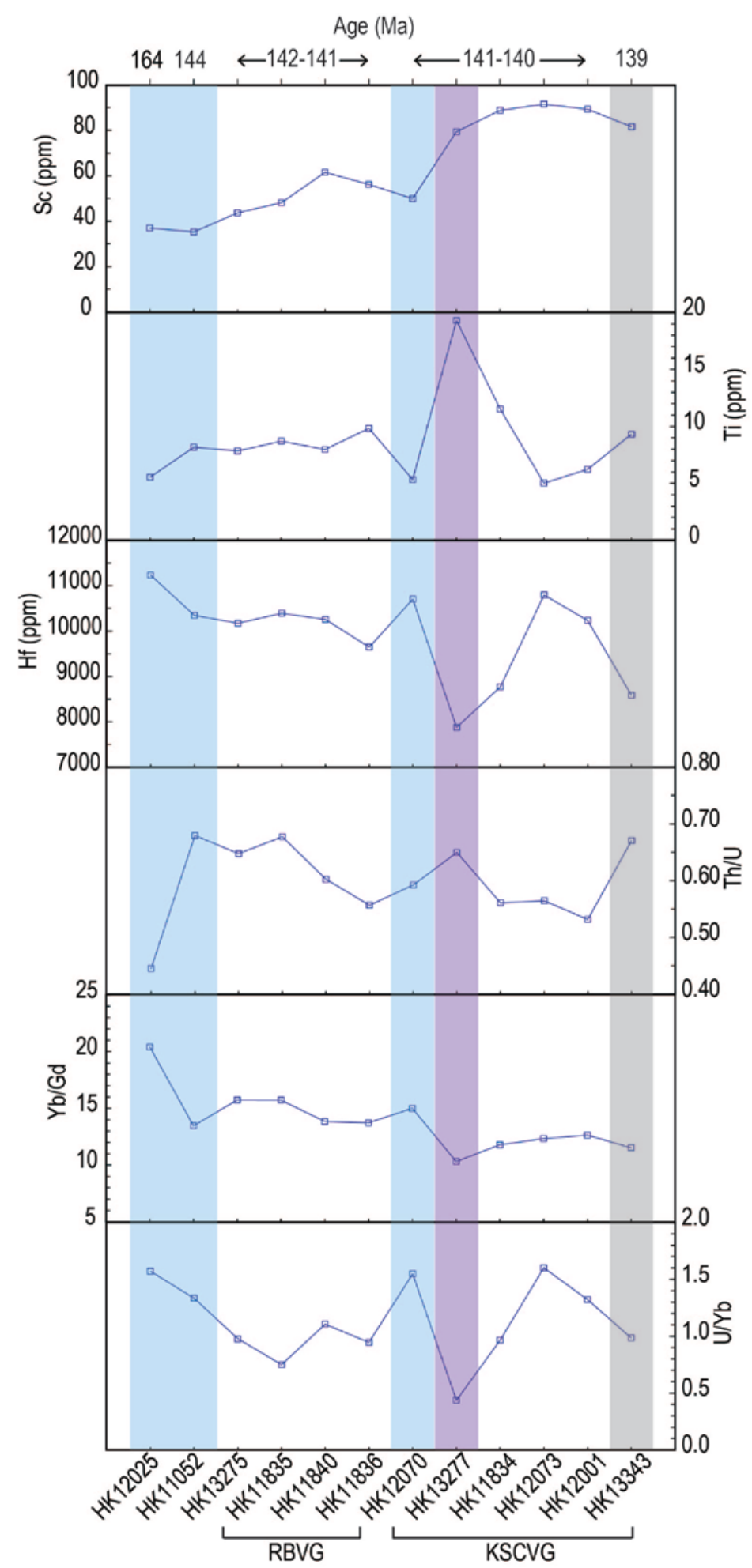

Fig. 4.24. Plots of averaged values of trace element concentrations and ratios for zircon rims from the volcanic samples, plotted in chronological order. Blue strips highlight the volcanic units from the Lantau Caldera; white strips highlight the volcanic units from the High Island Caldera; purple and grey strips highlight the Pan Long Wan trachydacite and post-High Island Tuff rhyolite lavas, respectively, both of which were extruded along the caldera boundary of the High Island Caldera. 
Since Sc primarily occurs as trace component and is enriched in Fe-Mg minerals (such as amphibole-hornblende and biotite), a decrease in Sc concentrations in zircons with melt evolution (monitored by Hf concentration) implies crystallisation of these minerals, and vice versa. Variations in Sc abundance in zircons have been proposed as an indicator of amphibole fractionation and/or dissolution in the parental magmas to the Mangakino and Taupo volcanic systems, New Zealand (Barker et al., 2014; Cooper et al., 2014). The relatively low and stable amount of Sc in zircons in Shing Mun and Lantau ignimbrites suggest either fractionation of Sc-bearing phases or depletion of Sc in source. On the other hand, the gradual increase in the quantity of Sc for the RBVG units and Pan Long Wan trachydacite probably implies a limited involvement of amphibole fractionation in the melts. However, the zircon data from the remaining KSCVG units show no obvious trend in Sc versus Hf plot, and these units contain the highest Sc abundance ( 50-260 ppm; Table 4.4) compared with the other units. Combined with the apparent increase in melt temperatures as monitored by Ti concentrations, dissolution of Sc-bearing phases might have contributed to the additional levels of Sc in zircons from these later units (cf. Barker et al., 2014).

The elemental ratios, including $\mathrm{Yb} / \mathrm{Gd}, \mathrm{Th} / \mathrm{U}$ and $\mathrm{U} / \mathrm{Yb}$, have been used as tracers of magmatic evolution (e.g. Barth et al., 2013; Cooper et al., 2014). The value of Yb/Gd ratio probably reflects the composition of magmatic source contributed from various crustal levels. Zircons from the oldest unit (Shing Mun ignimbrite, HK12025) and the RBVG are characterised by generally higher $\mathrm{Yb} / \mathrm{Gd}, \mathrm{U} / \mathrm{Yb}$ and lower $\mathrm{Th} / \mathrm{U}$ ratios. In contrast, zircons from the younger Lantau ignimbrite and KSCVG units give a lower range of values of $\mathrm{Yb} / \mathrm{Gd}$ and $\mathrm{U} / \mathrm{Yb}$ ratios (Fig. 4.24), inferred to be an indication of HREE-depletion involved in the melt generation of these systems. The decrease in $\mathrm{Yb} / \mathrm{Gd}$ ratio in these units can be interpreted as reflecting either (1) a melt from deeper source where fractionation of higher pressure mineral assemblages (such as garnet) occurs, or (2) partial melting of lower crustal rocks by mantle-derived magma, and in the processes separating the garnet residues. A decrease in $\mathrm{U} / \mathrm{Yb}$ ratio in zircons in the RBVG and KSCVG is evident, which might indicate diminishing influence by fluids derived from the subducting slab in these younger Cretaceous systems (cf. Barth et al., 2013). It is worth noting that the magmatic zircons from Hong Kong have relatively low Th/U and high U/Yb values, owing to a general enrichment of $U$, when compared with other examples of magmatic rocks from the western USA (e.g. Claiborne et al., 2010; Barth et al., 2013; Chamberlain et al., 2014b). 
Notwithstanding the issues associated with Ti-in-zircon thermometry (e.g. Cooper et al., 2014; Chamberlain et al., 2014b), Ti concentration in zircons can be used as a tracer of melt temperature, in which case a decreasing Ti concentration with increasing Hf concentration reflects in part the falling temperature during melt evolution (e.g. Ferry and Watson, 2007; Barth and Wooden, 2010). The negative trend of Ti concentration in zircon suggests that the temperature of the magmatic systems were higher and/or the Ti activities were lower for the younger KSCVG units than the older volcanic units (Figs. 4.9, 4.24), including Shing Mun and Lantau ignimbrites and the Repulse Bay volcanic units. Similarly, high Ti concentrations are present in the bright CL rims of the Che Kwu Shan and Pan Long Wan zircons, as well as grains from the undifferentiated Kau Sai Chau ignimbrite (HK12070) from the Lantau caldera complex.

\subsection{Conclusions}

New SIMS U-Pb age and trace element data from 21 volcanic and intrusive rock samples from two caldera complexes in Hong Kong are presented in this chapter. These zircon age and geochemical data are combined with detailed characterisation of zircon textures from CL imagery to investigate the features of the late Mesozoic magmatic systems. The key findings of this investigation are summarised below.

(1) Detailed characterisation of zircon textures shows the presence of a wide range of growth patterns in both volcanic and plutonic zircons (Section 4.4.1). Individual units show varying zircon populations either having simple, homogenous textures (e.g. Pan Long Wan trachydacite, HK13277) or relatively more complex and diverse growth patterns (e.g. Kowloon Granite, HK11042), indicative of widely variable zircon crystallisation conditions and/or inherited histories during development of the magmatic systems. The CL textural patterns, in particular the core-rim relationship, are considered together with the results of zircon trace element analysis, to interpret the common petrogenetic processes that operate within the large silicic magmatic systems for generating either voluminous eruptions or emplacement of granitic plutons.

(2) Based on the SIMS U-Pb dating results, both volcanic and plutonic samples can be placed into two groups: one group showing a unimodal, normally distributed age population and the other with multiple age components (Sections 4.4.2). The 
unimodal age group includes the Clear Water Bay Formation, High Island Tuff, post-High Island rhyolite lava, Sok Kwu Wan Granite, D’Aguilar Quartz Monzonite, and Tong Fuk Quartz Monzonite. These samples do not contain any inherited grains, although from CL imagery some zircons show contrasting cores which reflect varying conditions in the magma systems during crystallisation. My data, however, are unable to resolve any time differences between these texturally contrasting cores and rims (Table 4.5), although studies of Quaternary rhyolites show that such contrasts may have chronological and magmatic significance when age resolutions are sufficiently precise (e.g. Barker et al., 2014; Chamberlain et al., 2014b; Cooper et al., 2014). The group of samples with multiple age components includes the Shing Mun Formation, Lantau Tuff, volcanic units of the RBVG, Pan Long Wan trachydacite lava, and the Lantau Granite, East Lantau porphyry dyke, Chi Ma Wan, Shui Chuen O, Kowloon and Mount Butler granites. The age data, combined with textural observations, show that these samples contain antecrystic and/or xenocrystic cores that were recycled from earlier Yanshanian magmatic phases or much older basement rocks. For these samples, the weighted mean ages of rim analyses (Tables $4.3,4.5$ ) are considered to represent the most accurate (albeit less precise than the data obtained by ID-TIMS) estimates of eruption/intrusion ages.

(3) Fifteen of the samples yield SIMS weighted mean ages younger than their published ID-TIMS ages. Although the differences in most cases overlap within 95\% confidence level, the accurate matching of the SIMS and ID-TIMS ages from those samples with unimodal distribution (point (2), above) suggests that the differences, where present, are real. Two possible explanations for the observed discrepancies are (i) the uncontrolled air/chemical abrasion techniques employed in the ID-TIMS analysis might have removed some geochronological information in the zircon grains; and/or (ii) zircons enriched in $\mathrm{U}(>1,000 \mathrm{ppm})$ may have been affected by metamictisation, leading to Pb-loss affecting the SIMS measurements. Nonetheless, if the younger age data from high-U grains are set aside, the weighted mean ages of some samples (e.g. Kowloon Granite and Mount Butler Granite) are still younger than $140 \mathrm{Ma}$, which was previously considered as the close of Yanshanian magmatism in the Hong Kong region. 
(4) The findings show significant inter-grain and intra-grain variations in zircon trace element concentrations, both between cores and rims and between bright (side)dark (tip) sectors. As previously shown (e.g. Chamberlain et al., 2014b; Cooper et al., 2014), the presence of intra-grain variations in zircon trace elements poses significant challenges in the use of zircon trace element concentrations to infer the magmatic conditions (e.g. Ti-in-zircon thermometry: cf. Reid et al., 2011 and Chamberlain et al., 2014b). Zircon trace element patterns show common trends that are valid in deciphering evolution of the magmatic systems and identifying the potential linkages of volcanic and plutonic units. Combining the findings from field studies (Chapter 3) and thermochronological studies (Chapter 5), the evolutionary linkages of the volcanic and plutonic units of the magmatic systems in Hong Kong are further discussed in Chapter 6. 
Chapter 5/ Thermo-tectonic

history of Southeast China since

the Late Mesozoic: Insights from

detailed thermochronological

studies of Hong Kong

Published as:

Tang, D.L.K., Seward, D., Wilson, C.J.N., Sewell, R.J., Carter, A., Paul, B.T., 2014. Thermo-tectonic history of SE China since the late Mesozoic: insights from detailed thermochronological studies of Hong Kong. Journal of the Geological Society, London 171, 591-604. 


\begin{abstract}
The late Mesozoic Yanshanian volcanic arc affected an extensive region of southeast China, but the conclusion of magmatism and later evolution are not fully understood. Widespread Yanshanian ignimbrites and their contemporaneous granites exposed in Hong Kong represent a microcosm of this magmatic arc. To constrain the post-magmatic thermal history of the region, we present zircon and apatite fission-track analyses from these rocks. Double dating using laser ablation inductively coupled plasma mass spectrometry U-Pb and fission-track techniques on detrital zircons from post-volcanic Cretaceous sediments is used to further constrain the tectono-thermal evolution. The resulting dataset and thermal modelling suggest that the igneous rocks and Cretaceous sediments together experienced post-emplacement or post-depositional heating to $>250{ }^{\circ} \mathrm{C}$, subsequently cooling through $120-60{ }^{\circ} \mathrm{C}$ after $\sim 80 \mathrm{Ma}$. The heating reflects the combined effects of an enhanced geothermal gradient and burial. We interpret the enhanced gradient to represent continuing Yanshanian magmatic activity until $\sim 100-80 \mathrm{Ma}$, much later than previously considered. Our data also indicate a long-term, slow cooling ( $\left.1^{\circ} \mathrm{C} / \mathrm{Myr}\right)$ since the early Cenozoic, linked to $\sim 2-3 \mathrm{~km}$ of erosion-driven exhumation. The thermo-tectonic history of Hong Kong reflects the mid-Cretaceous transition of southeast China from an active to a passive margin bordered by marginal basins that formed in the early Cenozoic.
\end{abstract}




\subsection{Introduction}

During the late Mesozoic era, an active magmatic arc was present in southeast China during the Yanshanian Orogeny. Widespread and voluminous magmatism and volcanism occurred along the southern margin of the Eurasian landmass, now represented by the 1,300-km long and 400-km wide Southeast China Magmatic Belt (SCMB, Fig. 5.1; Zhou et al., 2006; $\mathrm{Li}$ and $\mathrm{Li}, 2007)$. Southeast China then underwent a transition from an active continental margin to a passive tectonic setting through multiple phases of crustal extension after the late Mesozoic (Gilder et al., 1991; Chan et al., 2010). Numerous studies have investigated this evolution through geochemical and isotopic analyses on postYanshanian magmatic rocks (e.g. Chung et al., 1997; Huang et al., 2013), facies and provenance analysis on offshore sediments (e.g. Wu, 1994; Li et al., 2012), detailed structural mapping (e.g. Chan et al., 2010), analysis of onshore and offshore rift basins (e.g. Gilder et al., 1991; Zhou et al., 1995; Shu et al., 2009), and modelling of geophysical data (e.g. Hayes et al., 1995; Nissen et al., 1995a, b; Shi and Li, 2012). Despite this level of detail, the timing of shutdown of silicic magmatism, collapse of the magmatic arc and evolution of marginal basins is not well constrained.

Studies employing low-temperature thermochronology have been carried out in Guangdong Province, the northern neighbour of Hong Kong, to understand the thermal evolution of the SCMB. Li et al. (2005) reported zircon fission-track (ZFT) and apatite fission-track (AFT) ages ( 97-133 Ma and 43-68 Ma, respectively) from western Guangdong (Fig. 5.1), and proposed that the region had experienced exhumation of $>4 \mathrm{~km}$ since 130 Ma. Yan et al. (2009) used ZFT, AFT and (U-Th)/He techniques to reconstruct the exhumation history of granitic rocks along a northwest-southeast transect in central Guangdong Province (Fig. 5.1). They proposed a three-stage cooling history of the granites based on inverse modelling of the data: a rapid initial cooling during the Late Cretaceous, followed by a thermally stable period at around $60{ }^{\circ} \mathrm{C}$ from $\sim 60$ to $15 \mathrm{Ma}$, and a final stage of cooling from 15-10 Ma to the present day. A subsequent ZFT and AFT study undertaken by Tsang (2010) along the coastal region of Guangdong Province (Fig. 5.1), however, implied the presence of cooling periods that were inconsistent with those determined by Yan et al. (2009). Tsang (2010) reported ZFT ages ( 165-77 Ma) and AFT ages ( 46-0.8 Ma) from a wide range of lithologies, and postulated that there were at least two episodes of cooling during the Cenozoic: a rapid cooling at $\sim 30 \mathrm{Ma}$ and a slower 
cooling at $\sim 15-10 \mathrm{Ma}$. The results of these studies were, in general, inconsistent with each other.

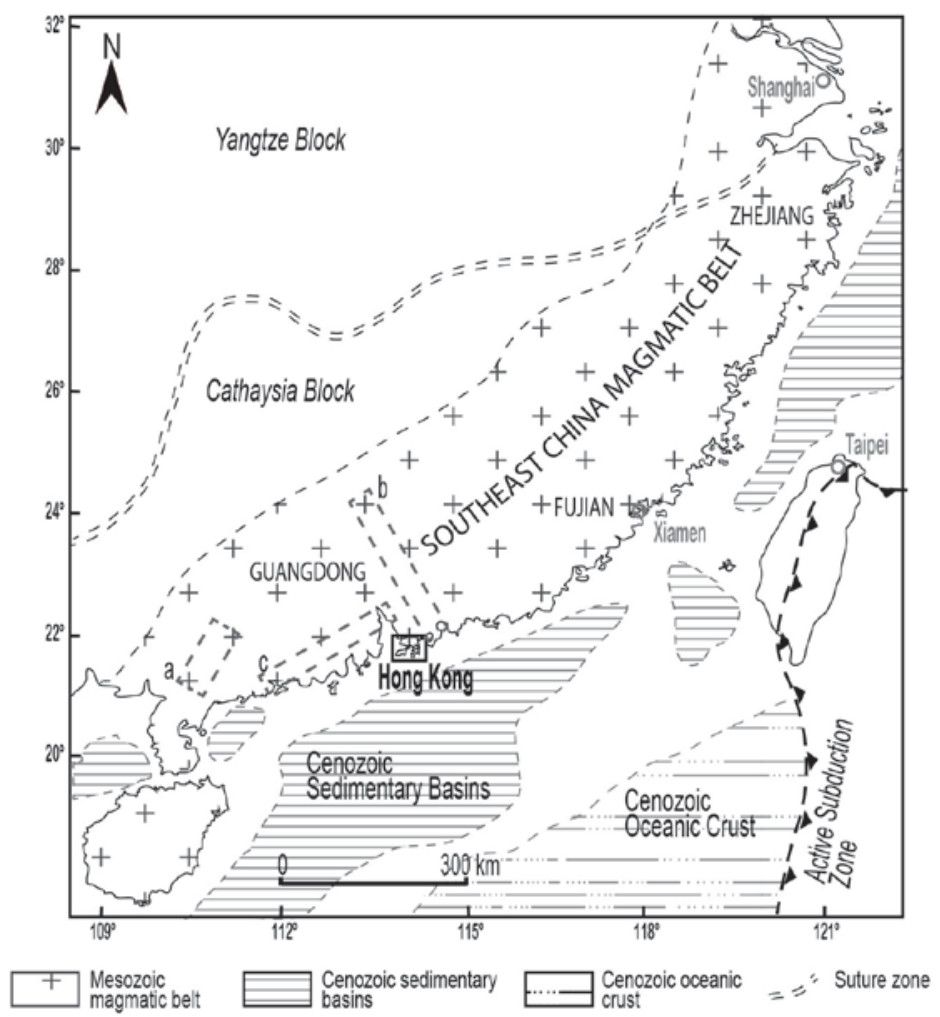

Fig. 5.1. Regional tectonic setting of southeast China (after Sewell et al., 2000). Study areas of previous lowtemperature thermochronology studies relevant to this paper: a, Li et al. (2005); b, Yan et al. (2009); c, Tsang (2010).

Hong Kong, located on the coastal margin of southeast China, represents a microcosm of the SCMB. The geology, well understood through detailed mapping, is dominated by lateMesozoic volcanic rocks and sub-volcanic plutons, now exposed as a result of crustal uplift and erosion (Sewell et al., 2012a). The post-magmatic evolution has generally been considered to be fairly simple with the development of a series of Cretaceous faultbounded basins followed by a long tectonically stable period (Lai, 1985; Sewell et al., 2000). However, some geochronological evidence points to possible periods of later tectonic and/or thermal activity. Campbell and Sewell (2005) reported ${ }^{40} \mathrm{Ar}^{3}{ }^{39} \mathrm{Ar}$ (biotite and whole-rock) ages of mafic dykes ranging between 106 and $75 \mathrm{Ma}$, noting that the ages were much younger than the U-Pb zircon ages of apparently coeval magmatic rocks. They suggested that the ${ }^{40} \mathrm{Ar}-{ }^{39} \mathrm{Ar}$ system might have been reset and that the ages probably represent a thermal event around 100-90 Ma in the region. Additionally, Campbell and 
Sewell (2005) also identified possible faulting events at 34, 10 and 3-4 Ma by dating sheared lithologies on major faults using ${ }^{40} \mathrm{Ar}-{ }^{39} \mathrm{Ar}$ methods on whole-rock and minerals (feldspar and pyrite).

To investigate the post-volcanic thermal-tectonic history hinted at by the ${ }^{40} \mathrm{Ar}-{ }^{39} \mathrm{Ar}$ ages, we have employed low-temperature thermochronology on the Middle Jurassic to Early Cretaceous volcanic-plutonic assemblages of Hong Kong. The only fission track (FT) studies previously reported (Nau and Yim, 1988) were based on seven ZFT ages, ranging between 42 and $103 \mathrm{Ma}$, from various granitic plutons. The reliability of these ages is somewhat questionable, however, because the analyses were carried out before the conventional standard method was established (Hurford, 1990).

In addition, a novel topic of our study is the depositional and thermal history of postvolcanic sediments in Hong Kong. We carried out U-Pb dating of detrital zircons from these sequences using the laser ablation inductively coupled plasma mass spectrometry (LA-ICP-MS) method to identify potential sources of the sediments and also to constrain maximum depositional ages. Detrital ZFT analysis was also employed on these strata to reveal their post depositional thermal records. Because these sediments were at the surface when they were deposited, by comparing and contrasting the thermal history of the igneous rocks with that of the sediments, we are able to establish the thermo-tectonic history in light of the local geological framework.

The specific objectives of this study were therefore to determine the post-magmatic thermal histories by (1) constraining temporally the burial and exhumation of the Mesozoic volcanic complexes in Hong Kong; (2) assessing whether there was significant sedimentation across the region after magmatism had ended and (3) identifying the timing of regional inversion, rock uplift and exhumation.

\subsection{Geological setting}

\subsubsection{Regional geology}

Southeast China comprises two major crustal blocks: the Yangtze Block in the north and the Cathaysia Block in the south (Fig. 5.1, Hsü et al., 1990; Jahn et al., 1990), collectively known as the South China Block. Isotopic and geochemical studies show that the basement rocks of the South China Block consist mainly of Archean, and Palaeo- to Mesoproterozoic 
rocks (Jahn et al., 1990; Li, 1994; Li and McCulloch, 1996; Darbyshire and Sewell, 1997; Duan et al., 2011). Overlying this basement are Palaeozoic sedimentary sequences, an extensive Mesozoic igneous province (SCMB, Fig. 5.1) forming the southeastern coastal belt, and relatively limited Mesozoic and Cenozoic sediments (Bureau of Geology and Mineral Resources of Guangdong Province, 1988). However, this simplified picture is rendered very complex owing to multiple phases of extension and rifting since the late Mesozoic.

Two Mesozoic orogenies, the Triassic Indosinian and the Middle Jurassic to Late Cretaceous Yanshanian, have been identified in southeast China. Over 90\% of the exposed igneous rocks were formed during the prolonged Yanshanian magmatism (Zhou et al., 2006) which lasted from the Middle Jurassic to the mid- to Late Cretaceous ( 180-80 Ma: Li, 2000; Zhou and Li, 2000; Li and Li, 2007). The Yanshanian magmatism has been generally linked to the subduction of the palaeo-Pacific Plate (Izanagi Plate) beneath the Eurasian Plate (e.g. Jahn, 1974; Charvet et al., 1994; Wang et al., 2011), although some researchers (e.g. Li et al., 2004; Chen et al., 2008) argued that the extensive silicic magmatism was instead related to rifting post-dating the Indosinian Orogeny.

Post-Yanshanian continental extension and rifting was considered to be associated with the retreat of the subduction zone in the late Mesozoic (Ren et al., 2002; Shi and Li, 2012). The extensional tectonics was manifested in the development of late Mesozoic terrestrial basins, filled with coarse, immature volcaniclastic-rich sediments (Zhou et al., 1995; Chan et al., 2010; Shi and Li, 2012). Oil-bearing Eocene basins subsequently developed at the attenuated continental margin in southeast China (Chung et al., 1997). The continental extension was followed by opening of the South China Sea during the Oligocene to Miocene (Ru and Pigott, 1986; Briais et al., 1993; Lee and Lawver, 1994). Eruption of Palaeocene-Eocene basalts probably signalled the initiation of rifting in the coastal region (e.g. Chung et al., 1994; Yan et al., 2006; K.L. Wang et al., 2012; Huang et al., 2013), prior to the beginning of sea-floor spreading in the South China Sea. 


\subsubsection{Geology of Hong Kong}

About $85 \%$ of the land area is made up of late Mesozoic Yanshanian magmatic rocks (Fig. 5.2), including the volcanic and intrusive products of four temporally distinct magmatic episodes at 164-160, 148-146, 143 and 141-140 Ma (table 3 of Sewell et al., 2012b). The volcanic rocks include dacitic to rhyolitic ignimbrites and lavas with intercalated tuffaceous sedimentary units, and the intrusive rocks are granodiorite, granite, quartz monzonite and minor dykes of various compositions (Sewell and Campbell, 1997; Sewell et al., 2000, 2012b). The volcanic and plutonic rocks are considered to be largely cogenetic and to represent ancient caldera-type large-scale silicic magmatic systems (Campbell and Sewell, 1997). Sewell et al. (2012a) have recently proposed a tilted nested caldera model for the two Cretaceous magmatic assemblages (143 and 141-140 Ma) in southeast Hong Kong.

Four post-volcanic sedimentary units have been identified: the Cretaceous Pat Sin Leng, Port Island and Kat $\mathrm{O}$ formations (collectively known as the Mirs Bay Group; Fig. 5.2), and the Eocene Ping Chau Formation (Fig. 5.2, Sewell et al., 2000). The Cretaceous units are dominated by non-fossiliferous, reddish sandstone, siltstone and conglomerate deposited in fluvial environments (Jones, 1995, 1996). All units unconformably overlie the Middle Jurassic to Lower Cretaceous volcanic rocks in northeast Hong Kong; their stratigraphic ages are only loosely constrained by correlation with the fossil-bearing Lower to Upper Cretaceous Baihedong, Sanshui and Dalangshan formations in the neighbouring Guangdong Province (Lai et al., 1996; Owen, 2000; Sewell et al., 2000). Lai et al. (1996) carried out a provenance study based on petrographic comparison of lithic clasts, concluding that the sediments were probably sourced in general terms from the underlying volcanic sequences. However, unambiguous identification of specific source rocks was not possible on this basis, because of the large internal lithological variations of the volcanic and intrusive sequences. The Eocene Ping Chau Formation consists of dolomitic and calcareous lacustrine siltstone, bearing a diverse assemblage of fossil plants and insects (Lai et al., 1996). This formation represents the youngest preserved rock formation in Hong Kong, and a major hiatus exists between these indurated Eocene rocks and unconsolidated Quaternary sediments (Sewell et al., 2000). 


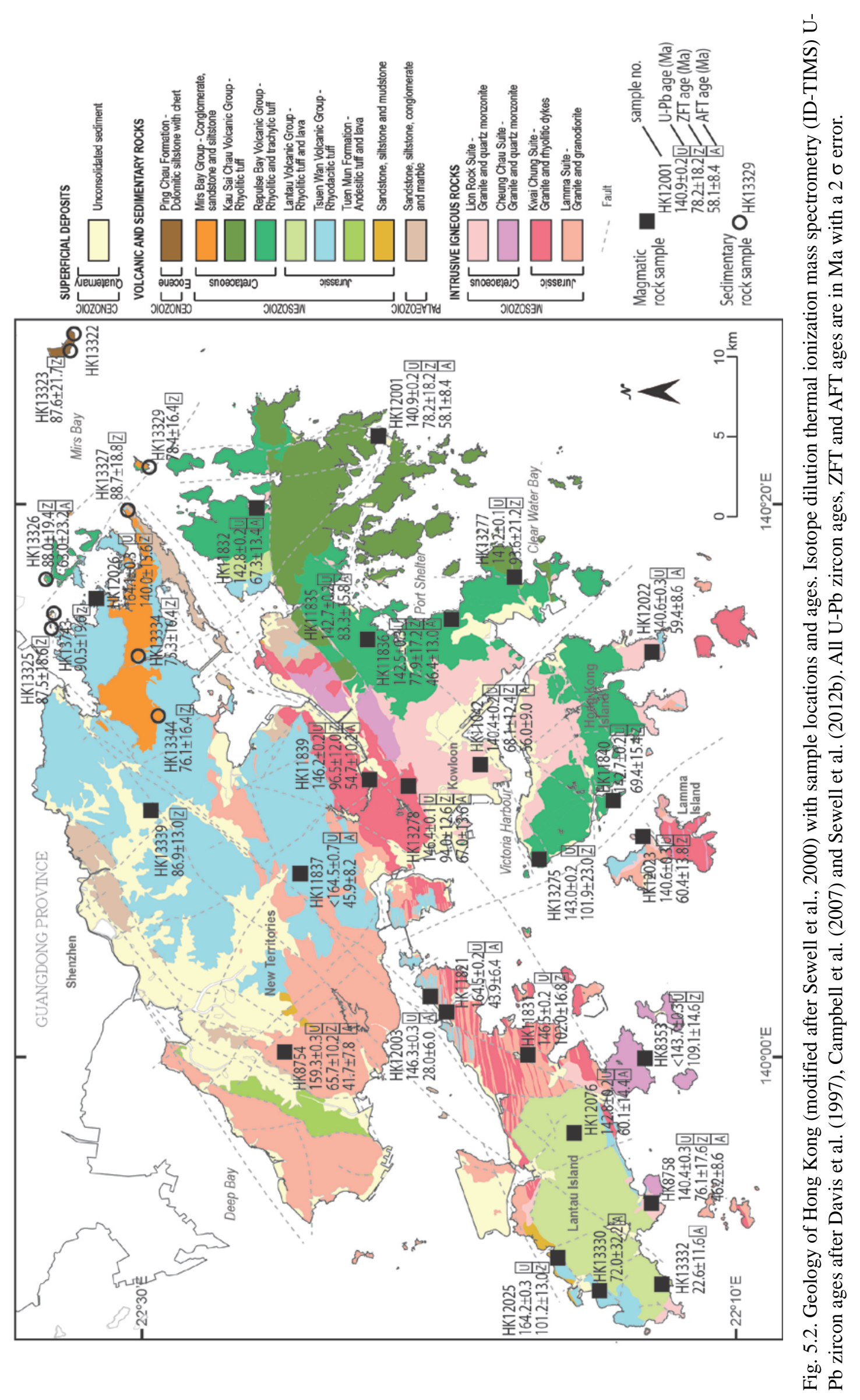




\subsection{Methods}

\subsubsection{Fission-track analysis}

Representative samples of both volcanic and plutonic units from all four late Mesozoic magmatic episodes were collected from a wide geographic distribution, especially across major fault structures in Hong Kong. In addition, rock samples from all four post-volcanic sedimentary units were collected from their type localities. Sample locations are shown in Fig. 5.2.

Bulk-rock samples were processed using mechanical crushing and conventional mineral separation techniques (through heavy liquids and magnetic separation). The sedimentary samples generally yielded insufficient detrital apatite grains for fission-track analysis. Aliquots of apatite and zircon were mounted in epoxy resin and Teflon sheet, respectively. For the detrital zircons, two mounts per sample were made to allow for etching at different lengths of time to adjust for the possibility of a range of ages. Mineral grains were then polished to expose the internal surfaces. The apatite grains were etched with $5 \mathrm{M} \mathrm{HNO}_{3}$ at $20{ }^{\circ} \mathrm{C}$ for $20 \mathrm{~s}$ and the zircons with eutectic $\mathrm{KOH}-\mathrm{NaOH}$ melt at $\sim 210{ }^{\circ} \mathrm{C}$ for $24-50 \mathrm{~h}$. The external detector method was used throughout (Gleadow, 1981; Hurford and Green, 1983). The neutron irradiation of the samples was carried out at the Oregon State University Radiation Facility, USA (samples analysed by D.L.K.T.) and in the FRM 11 thermal neutron facility at the University of Munich in Germany (samples analysed by A.C.). Dosimeter glasses CN1 (D.L.K.T.) and CN2 (A.C.) for zircon and CN5 for apatite were used. The spontaneous and induced fission tracks of single grains were counted under a Zeiss Axioplan microscope with a computer-controlled stage and a total magnification of 1250-x (A.C.), or with a Zeiss MM+ microscope at a total magnification of 1000-x (D.L.K.T.). The zeta $(\zeta)$ calibration method and IUGS recommended age standards (Hurford and Green, 1983; Hurford, 1990) were used throughout. Zircon CN1- $\zeta$ is $129 \pm 13$ (DLKT) and CN2- $\zeta$ is $127 \pm 4$ (AC) and apatite CN5- $\zeta$ is $339 \pm 5$ (AC). The reported ages are central ages (with 2- $\sigma$ error) calculated using the TRACKKEY programme (Dunkl, 2002). The lengths of horizontal confined fission tracks were measured by A.C.. Using FASTTRACKS software (Gleadow et al., 2012) the lengths of confined inclined tracks were additionally determined (D.L.K.T.). To infer the time-temperature history of the late Mesozoic igneous rocks, inverse modelling was carried out using the AFT ages and the 
confined track-length measurements, according to the procedures of Ketcham (2005, HeFTy programme version 1.8.0).

\subsection{2. $\mathrm{U}-\mathrm{Pb}$ dating of detrital zircon using LA-ICP-MS}

Five zircon suites from the post-volcanic sedimentary units that had already been dated by the fission track method were analysed for U-Pb ages using LA-ICP-MS techniques at the School of Earth Sciences, University of Melbourne using an Agilent 7700x coupled to a Helex ArF 193 nm laser ablation system. Ablation was conducted in a He atmosphere, and the sample and He were mixed with Ar en route to the mass spectrometer (see Woodhead et al., 2007). Baseline-corrected ${ }^{238} \mathrm{U}$ and ${ }^{206} \mathrm{~Pb}$ counts for reference zircon 91500 (Wiedenbeck et al., 2004) were typically 100,000 and 17,000 counts per second, respectively. All data were reduced using the $\mathrm{U}-\mathrm{Pb}-\mathrm{Geochronology3}$ data reduction scheme in Iolite (Paton et al., 2010, 2011). Zircon 91500 was used as a primary standard to correct for down-hole fractionation and U-Pb ratio normalisation. Temora 2 (417 Ma, Black et al., 2004) and Plesovice (337 Ma, Slama et al., 2008) reference zircons were also measured concurrently as secondary standards and produced ages in the range of $423 \pm 27$

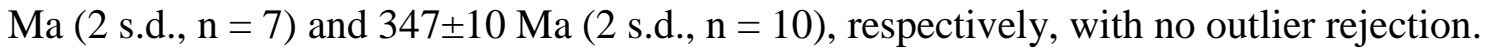
$\mathrm{U}-\mathrm{Pb}$ age components of the detrital zircons were determined using DensityPlotter, which allows visualization of both the kernel density estimate and probability density plot (Vermeesch, 2012).

\subsection{Results}

\subsubsection{Apatite and zircon fission-track analysis of magmatic rocks}

The ZFT and AFT data are summarised in Tables 5.1 and 5.2, respectively. The ZFT ages for granites range between $\sim 109$ and $60 \mathrm{Ma}$ and for volcanic rocks between $\sim 140$ and 69 Ma (Fig. 5.3a). Regardless of geographical location, all of the volcanic rocks and granites yielded ZFT ages younger (by 20 to $>100 \mathrm{Myr}$ ) than their eruption or emplacement ages (Fig. 5.3a). The AFT ages for all samples range from 83 to $40 \mathrm{Ma}$, except for two outliers of 28 and 23 Ma (Fig. 5.3b). They are on average 30 myr younger than their equivalent ZFT ages and also show no apparent pattern with respect to the geographical distribution. The sample elevations range from 0 to $700 \mathrm{~m}$ above sea level. No noticeable correlation is 
observed between the FT ages and the elevations of either volcanic or granitic samples from different regions of Hong Kong (Figs. 5.3c and d).
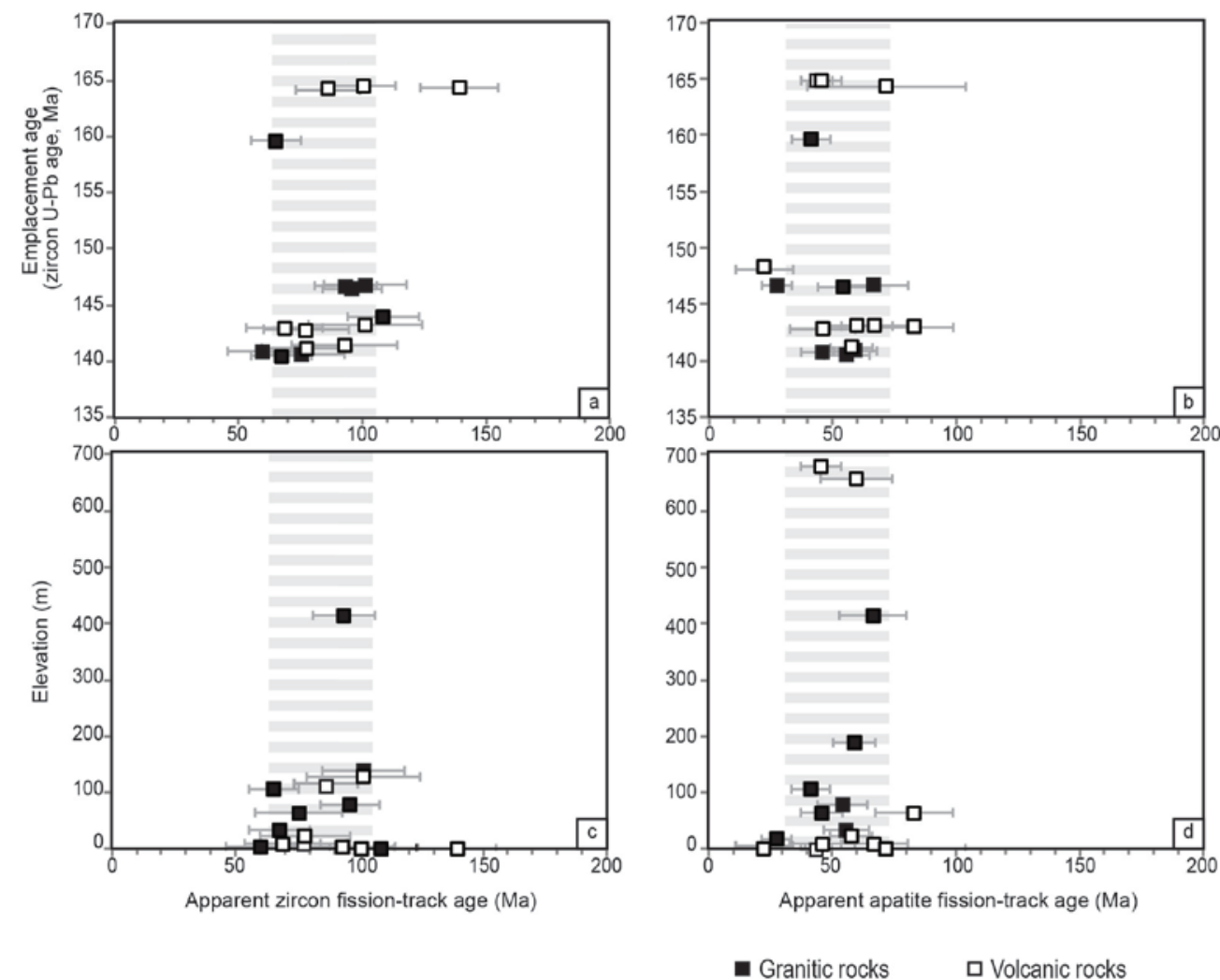

Fig. 5.3. Emplacement age v. (a) ZFT age and (b) AFT age; elevation of sample v. (c) ZFT age and (d) AFT age. Open symbols represent volcanic rocks and filled symbols intrusive rocks. Error bars $(2 \sigma)$ for zircon U$\mathrm{Pb}$ ages by ID-TIMS techniques are smaller than the size of symbols in the figure. 


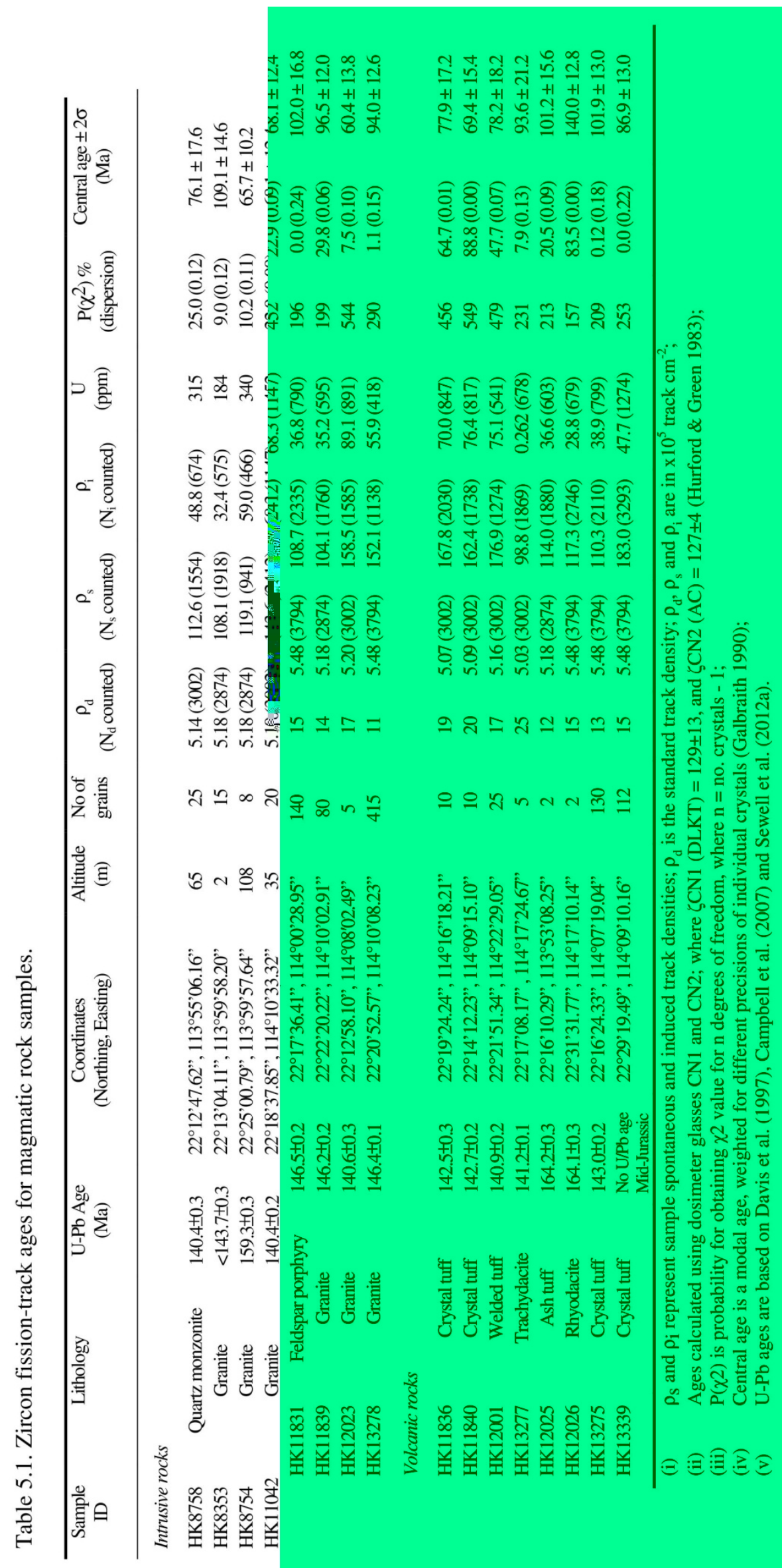




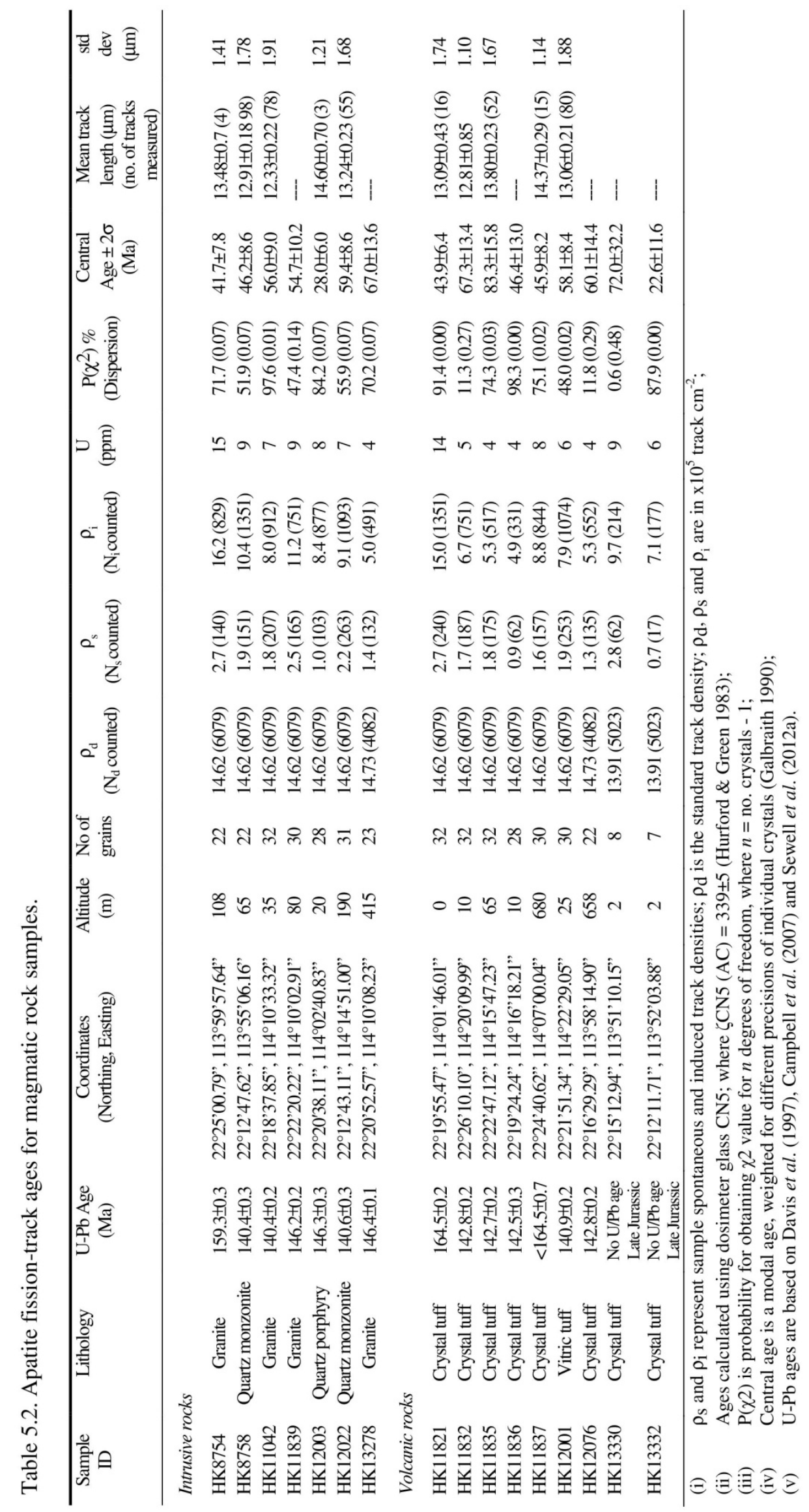




\subsubsection{Detrital U-Pb zircon dating using LA-ICP-MS}

The U-Pb age data are of good quality for provenance identification purpose, even though some of the detrital grains contain low uranium concentrations. The Pat Sin Leng Formation (sample HK13344) yields euhedral detrital zircons that contain age components of $\sim 120, \sim 142$ and $\sim 162$ Ma, with another possible peak at $\sim 152$ Ma (Fig. 5.4). Two of 53 analyses yield U-Pb ages of $>900$ Ma. Detrital zircons from the Port Island Formation (sample HK13329) are dominated by the 143 Ma population, with two minor populations at 156 and 205 Ma identified by DensityPlotter (Fig. 5.4). Only two out of 71 analyses from sample HK13329 are over 300 Ma. Two samples from the Kat O Formation (samples HK13326 and HK13325) have slightly dissimilar detrital age populations of 143, 152 and $\sim 164-160$ Ma (Fig. 5.4). Six out of a total of 94 analyses from this formation yield U$\mathrm{Pb}$ ages over $300 \mathrm{Ma}$.

The Eocene Ping Chau Formation (sample HK13322) contains mixed rounded and euhedral detrital zircon grains. Only 29 grains were analysed owing to a poor yield from the sample and generally small grain sizes. Of these analysed grains, 10 are of Palaeozoic to Palaeoproterozoic age. The remaining grains fall into age populations of $\sim 152$ and 164 Ma (Fig. 5.4). 


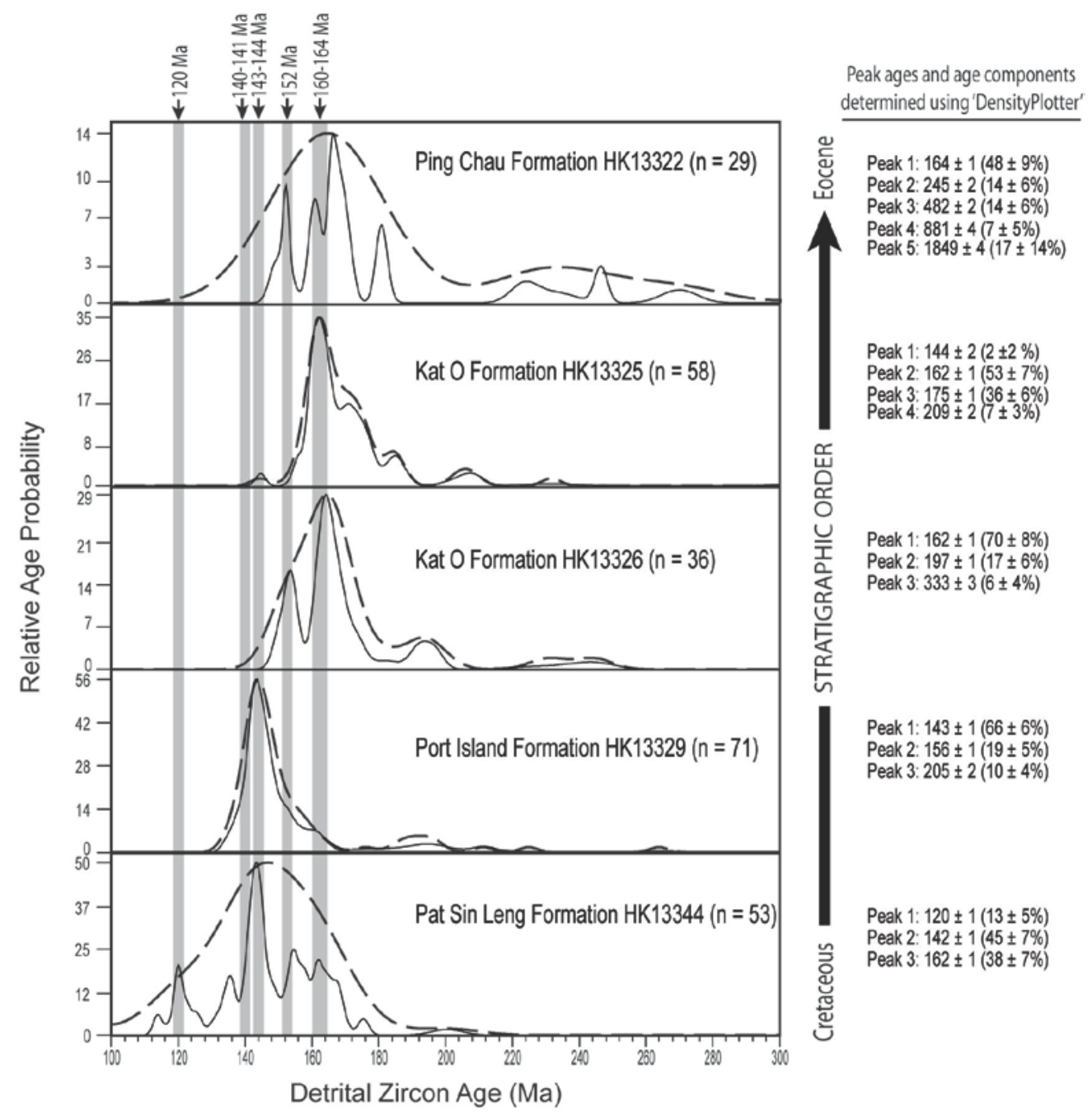

Fig. 5.4. Relative age probability plots of detrital U-Pb zircon ages of post-volcanic sedimentary units. Dashed lines represent kernel density estimate; continuous lines represent probability density plot. Peak age locations and proportions were estimated using on mixture modeling algorithm in DensityPlotter (Vermeersch, 2012). Age populations between 100 and $300 \mathrm{Ma}$, which made up over 90\% of all age data, are presented in the figure. 


\subsubsection{Detrital apatite and zircon fission-track analysis of sedimentary rocks}

All ZFT ages from the Cretaceous sedimentary rocks are younger than the detrital U-Pb ages and all analyses pass the $\chi^{2}$ test indicating a high probability that the source rock signature has been fully removed (Table 5.3). All ages overlap statistically between $\sim 75$ and $89 \mathrm{Ma}$ at $2 \sigma$ levels. This observation implies resetting of the system to $\geq 250{ }^{\circ} \mathrm{C}$ after deposition. Detrital apatite from the Kat O Formation yields an AFT age of about $63 \mathrm{Ma}$, which again falls within the range of AFT ages of the igneous samples. The Eocene Ping Chau Formation (sample HK13323), in contrast, yielded detrital ZFT grain ages ranging between $~ 70$ and 110 Ma (i.e. older than the stratigraphic age). These data imply that the detrital zircons have not been reset after deposition, but reflect primarily a record of the thermal history of the source rocks.

Two of the sedimentary samples (HK13326 and HK13329 from the Port Island and Pat Sin Leng formations, respectively) have yielded zircon He ages, with a closure temperature of

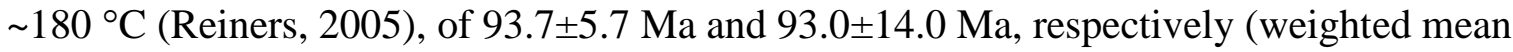
ages with $2 \sigma$ error; B. Kohn, unpublished data). These results are statistically similar to the ZFT ages at these sites, implying a rapid cooling from $>250$ to $180{ }^{\circ} \mathrm{C}$ at $\sim 90-95 \mathrm{Ma}$. 


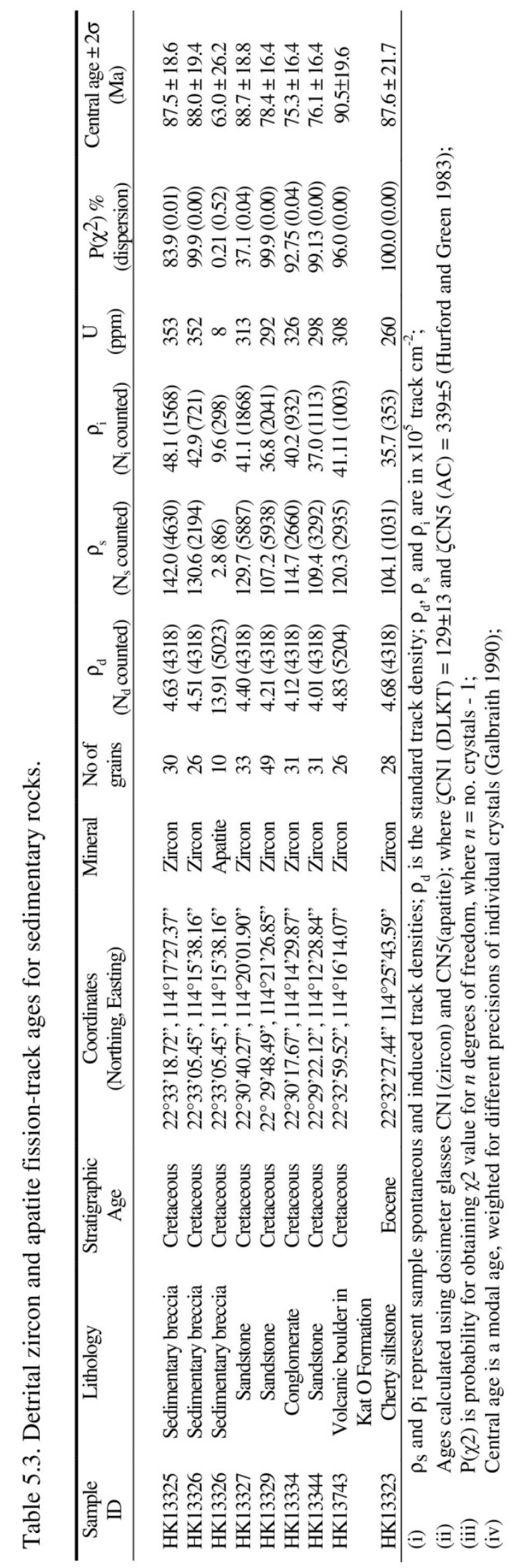




\subsubsection{Inverse modelling of low-temperature thermochronology data}

Only samples with over 20 dated grains and more than 50 track-length measurements were modelled. For each model (except that for sample HK11835; see discussion below), the computation was stopped after 100 'good' paths (i.e. when both the model FT age and length distribution matched the measured FT age and length distribution with a level of goodness-of-fit of 0.5; see Ketcham, 2005) were found. For samples HK11835 and HK12001 the absolute Cl content was used for the modelling, but for samples HK8758,

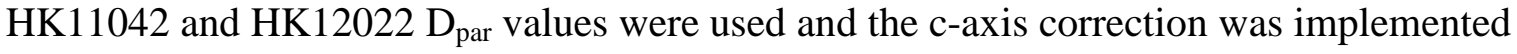
for all samples (Ketcham, 2005). The basic set of constraints for the intrusive rocks included the crystallisation temperature and age, and the present-day temperature of $20{ }^{\circ} \mathrm{C}$ (Figs. 5.5a-c). Additionally, the ZFT age, if available, was used as a third constraint assuming a closure temperature at $250 \pm 50{ }^{\circ} \mathrm{C}$ (Reiners and Brandon, 2006). The inverse models only operate between $120-60{ }^{\circ} \mathrm{C}$ (i.e. apatite partial annealing zone, APAZ) such that at the higher temperature, the modeled temperature-time paths are interpolated from the zircon closure temperature $\left(250 \pm 50{ }^{\circ} \mathrm{C}\right.$; Reiners and Brandon, 2006) to the lower limit of the APAZ. For volcanic rocks, the thermal history began at the surface at the time of eruption (Figs 5.5d and 5.5e) on the assumption that cooling took place within the time limits of the error on the sample age.

The modelled temperature-time paths of all samples show a similar cooling pattern through the APAZ (120-60 ${ }^{\circ} \mathrm{C}$ ) irrespective of the various sets of constraints imposed in the models (Fig. 5.5). All samples cooled rapidly from 85 to $60 \mathrm{Ma}$ after which time they were within the APAZ and the cooling rate decreased significantly. For sample HK11835, regardless of the constraints imposed, no statistically "good" paths could be found even after the programme had generated over $10^{7}$ paths. This sample has the oldest AFT age and the errors on the single-grain AFT ages are very high due to the low uranium contents (Table 5.2). 
Intrusive Rocks
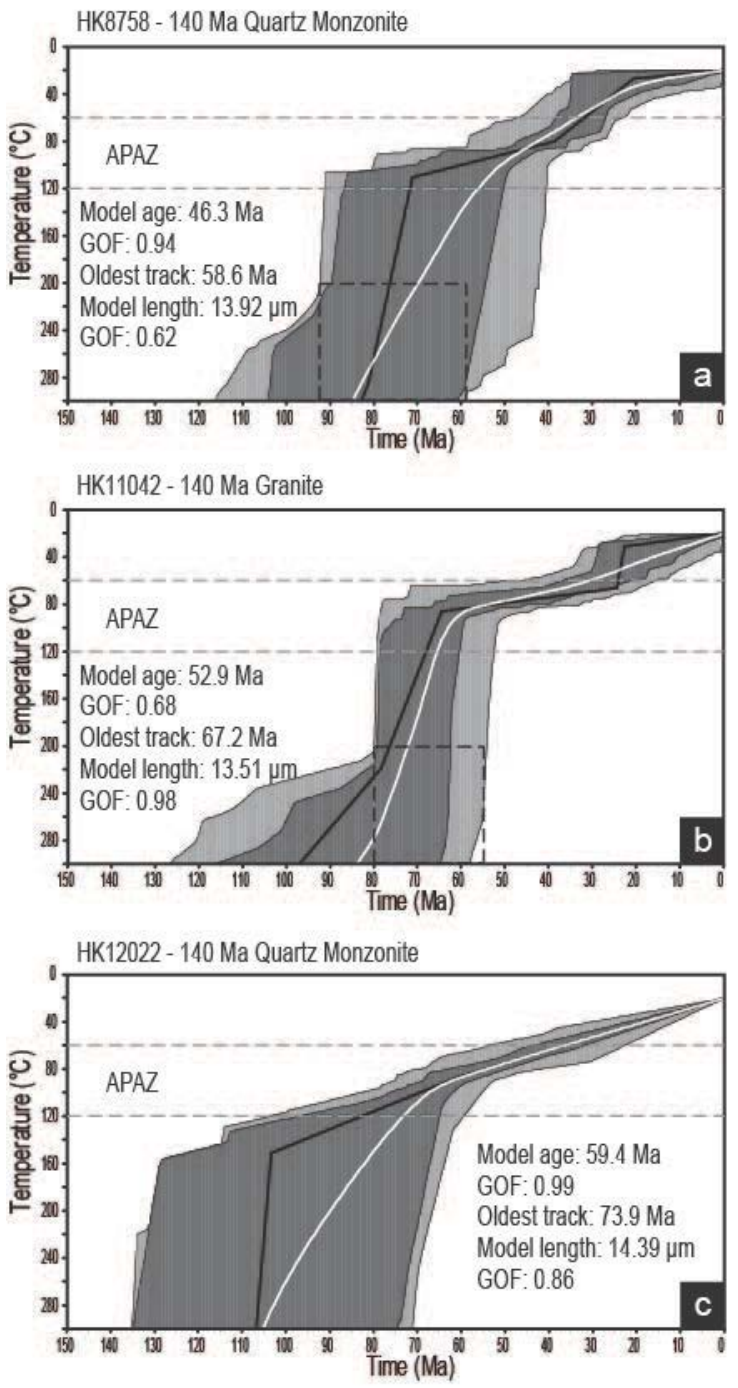

Volcanic Rocks
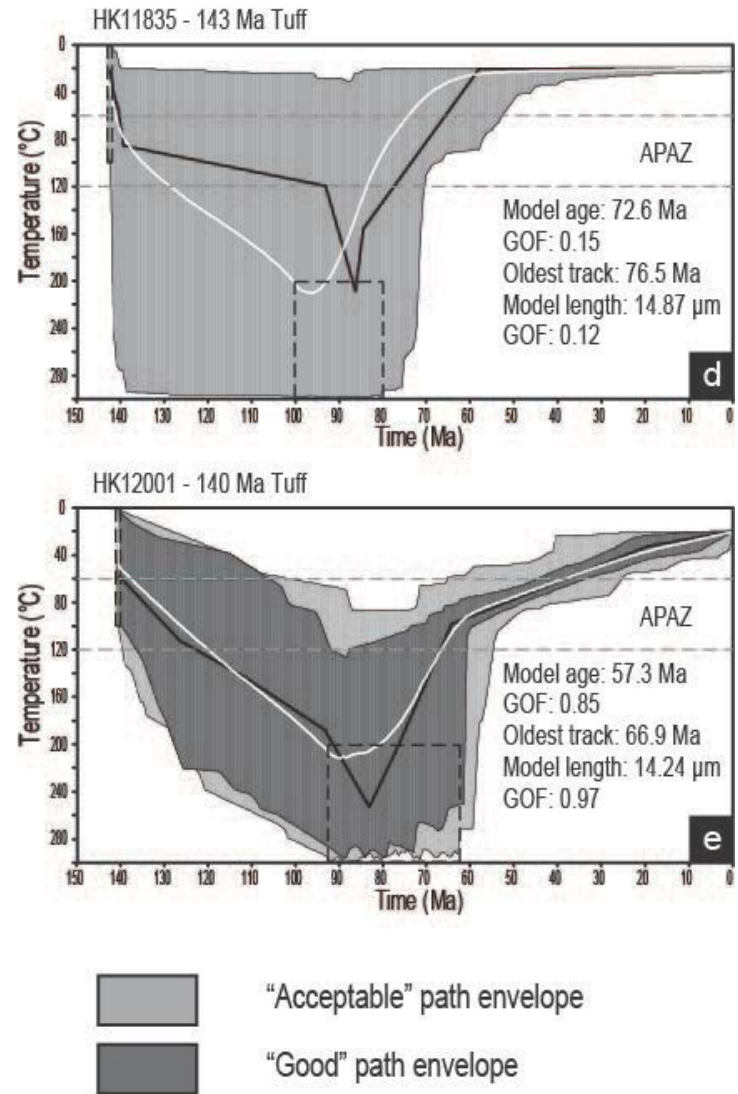

APAZ $=$ Apatite partial annealing zone $\left(120-60^{\circ} \mathrm{C}\right)$

Black line $=$ path of the best-fit model

White line $=$ the weighted mean path

Dash-lined box $=$ constraints for the model

GOF $=$ Goodness-of-fit

Fig. 5.5. Inverse modelled temperature-time paths (Ketcham, 2005) for samples (a) HK8758, (b) HK11042, (c) HK12022, (d) HK11835 and (e) HK12001. GOF, goodness of fit. 


\subsection{Discussion}

\subsubsection{Provenance of post-magmatic sediments}

The first-order observation of the detrital $\mathrm{U}-\mathrm{Pb}$ age data is that most of the age populations from the four sedimentary units match closely the four major known magmatic episodes in Hong Kong (Davis et al., 1997; Campbell et al., 2007; Sewell et al., 2012b). Three of the five samples from Ping Chau, Kat O and Pat Sin Leng formations (HK13322, HK13326 and HK13344) also yield an age population at 152 Ma, corresponding to a period of magmatic activity identified by Sewell et al. (2012b), but with very limited outcrop areas. These data provide strong support to the idea that the source rocks of these units were the local volcanic-plutonic assemblages that were exposed at the time of deposition. The slight divergence of age components between the Cretaceous formations may reflect shifting of fluvial pathways and/or the existence or not of exposed strata in the relevant catchment(s). By Eocene time, the detrital zircons from the Ping Chau Formation also include a notable proportion of older Palaeozoic to Palaeoproterozoic grains, most probably sourced from reworked older sediments and basement rocks either from Hong Kong or mainland China, matching the ages of major orogenies there (Duan et al., 2011).

The youngest zircon population of $~ 120$ Ma from the Pat Sin Leng Formation, inferred to be the oldest post-volcanic stratigraphic unit (Lai et al., 1996; Sewell et al., 2000), provides a maximum age on the Cretaceous sediments. The presence of 120 Ma euhedral detrital zircons also suggests the presence of younger magmatic activity in this part of southeast China after $140 \mathrm{Ma}$, although any surface expression of such volcanic or granitic rock is now missing in Hong Kong. Evidence, however, of a younger magmatic event is a granitic pluton, dated at 118.8 $\pm 2.0 \mathrm{Ma}$ (LA-ICP-MS U-Pb zircon age), exposed in the neighbouring Shenzhen region less than $10 \mathrm{~km}$ from the northern boundary of Hong Kong (Shenzhen Geology Compiling Group, 2009). The new data imply that the volcanic or granitic rocks were exposed, at the surface, and were eroded into Cretaceous basins at some time soon after 120 Ma.

\subsubsection{Post-eruption or post-emplacement reheating}

The ZFT ages for the magmatic rocks are significantly younger than their eruption or emplacement ages. For volcanic suites, this indicates that the ZFT system has been reset by 
post-eruption thermal events. The granite ZFT ages, on the other hand, could indicate either a protracted post-crystallization cooling history or a reheating event similar to that of the volcanic rocks and then cooling back again through the ZFT closure temperature prior to final exhumation. In the case of Hong Kong, we consider that the granites must have shared a similar thermo-tectonic history with the volcanic strata since the Early Cretaceous, and experienced the same post-eruption or post-emplacement reheating. This is based on the fact that the granites were shallowly emplaced within 3-4 km of the surface, and directly intruded the contemporaneous volcanic rocks; that is, they formed caldera-related volcanic-plutonic assemblages (Campbell and Sewell, 1997; Sewell et al., 2012a). There is no structural evidence that the granites were ever separate from the volcanic rocks. The volcanic-plutonic rocks were adjunct and must have behaved as a single unit. Thus, the cooling of the granites (Figs. 5.5a-c) does not represent the original primary magmatic cooling, but corresponds to a secondary cooling phase after a post-emplacement heating event in association with the conjunct volcanic rocks. The primary magmatic cooling history of the granites is obscured by the post-emplacement heating event.

Further, since the Cretaceous sediments contain detrital zircons with U-Pb ages comparable with those of the local igneous rocks, we infer, therefore, that the volcanicplutonic assemblages had ascended to the near-surface, and were being eroded during the middle to Late Cretaceous. This interpretation is also supported by the fact that the Cretaceous sediments were deposited on an erosion surface on the late Mesozoic volcanic strata. In addition, the reset detrital ZFT ages of the sediments are comparable with those of the igneous rocks, implying that the sediments and the volcanic-plutonic assemblages have probably all experienced a similar thermal history. These two lines of evidence imply that the volcanic-plutonic assemblages and the Cretaceous sequences have behaved in unison as a single package since middle to Late Cretaceous. They all underwent a postemplacement or post-depositional heating event above the ZFT closure temperature (250 $\pm 50^{\circ} \mathrm{C}$ ) and cooled through that temperature at $\sim 100-80 \mathrm{Ma}$. On the other hand, the detrital zircons from the Eocene Ping Chau Formation have not been reset and yield a range of detrital ZFT grain ages that is consistent with the reset ZFT ages of the local igneous and Cretaceous sedimentary rocks, serving to emphasise that the study area was exposed to temperatures of $\geq 250{ }^{\circ} \mathrm{C}$ prior to the Eocene. Our results also imply that some of the Cretaceous sediments and the igneous rocks were returned to the surface, at least locally, by Eocene time. 


\subsubsection{Source of heating: thermal event or re-burial heating?}

We have demonstrated that that both the magmatic rocks and the Cretaceous sedimentary units have experienced a post-emplacement or post-depositional heating event sufficient to fully reset the ZFT system. Such heating could be the result of an elevated thermal gradient, or simply associated with burial. Assuming a typical continental geothermal gradient of 30 ${ }^{\circ} \mathrm{C} \mathrm{km}^{-1}$, the rocks would have to have been buried to depths exceeding 7-8 km to have fully reset the ZFT system solely by heating owing to burial. However, the Cretaceous sediments in Hong Kong, as well as in neighbouring Guangdong Province, were deposited in intermontane basins with restricted areal coverage. Nowhere in the region is there any preserved evidence for widespread and thick regional sedimentation during midCretaceous time. In addition, if a 7-8 km thickness of sediments had been deposited regionally and subsequently eroded in the mid- to Late Cretaceous, an extraordinary tectonic mechanism, for which evidence is lacking, would be required for the rapid shift from a major depositional setting to an inversion of the Cretaceous strata. The rocks in general do not exhibit evidence for such a history (such as deformation, regional foliation and recrystallization), which would be expected had they undergone this hypothetical tectonic event.

Because it is thus unlikely that the heating was solely due to deep burial, we propose also that an enhanced geothermal gradient was present until $\sim 80 \mathrm{Ma}$. Two possibilities might account for such a gradient: (1) the Middle Jurassic to Early Cretaceous granitoids contain high concentrations of radioactive heat-generating elements ( $\mathrm{U}$, Th and $\mathrm{K}$ ) that could cause a high heat-flow, or (2) the continuing emplacement of younger intrusions. We consider that the first possibility is not valid because (a) the exposed granites in Hong Kong do not have enhanced concentrations of these elements (e.g. U ranges from $\sim 4$ to $12 \mathrm{ppm}$ in general; Sewell and Campbell 2001); and (b) if a higher heat flow owing to radiogenic sources was present in the mid-Cretaceous, such a heat flow should still be present. This is not the case, as regional heat flow in the Hong Kong area is at present $\sim 60-70 \mathrm{~mW} / \mathrm{m}^{2}$ (Tao and Shen, 2008), which is comparable to the background values in continental crust of similar age and tectonic setting (Sclater et al., 1980; Rudnick and Fountain, 1995). Therefore, the second explanation is more likely and implies that magmatism may have continued beneath Hong Kong until 100-80 Ma. These magmatic intrusions would have 
induced enhanced geothermal gradients, and driven geothermal or hydrothermal systems in rocks at shallower crustal levels above the plutons.

Evidence for hydrothermal activity at temperatures over $250{ }^{\circ} \mathrm{C}$ is plentiful in Hong Kong. Petrographic examination of the 141 Ma High Island Tuff (Sewell et al., 2012a) revealed the presence of secondary epidote, adularia and sericite, typically associated with hydrothermal alteration (Browne, 1978). Similar alteration mineral assemblages are evident in other volcanic and granitic rocks. The inferences from alteration mineral assemblages are supported by fluid inclusion micro-thermometry on two 140 Ma granites which showed that the hydrothermal fluid temperature was over $290^{\circ} \mathrm{C}$ (D.L.K.T., unpublished data). In addition, extensive quartz veins, indicative of hydrothermal events, and secondary epidote, which records formation temperatures of over $230-260{ }^{\circ} \mathrm{C}$ (Bird and Spieler, 2004), have been reported in the sedimentary rocks of the Pat Sin Leng, Port Island and Kat O formations (Lai et al., 1996).

We therefore interpret that these hydrothermal alterations were primarily driven by a heat pulse associated with magmatic intrusion or intrusions prior to the complete shutting down of Yanshanian magmatism in southeast China at 80 Ma (Zhou and Li, 2000).

Hydrothermally altered rocks in Hong Kong probably represent relict geothermal systems that were active during the late Mesozoic. Other fossil geothermal systems of similar age throughout the SCMB have been related to ore deposition (e.g. Wang et al., 2011). Because plutons normally cool reasonably fast (of the order of less than $1 \mathrm{Myr}$ : Cathles, 1977), the spread of the reset ZFT ages of over $20 \mathrm{Myr}$ ( 100-80 Ma) implies that multiple heat pulses, corresponding to multiple magmatic intrusions, probably occurred.

\subsubsection{Post-volcanic thermal and tectonic evolution}

The FT thermal modelling (Fig. 5.5) reveals two main phases of cooling after the postemplacement or post-eruptive heating event: a rapid cooling from mid-Cretaceous to Palaeocene-Eocene, followed by a decrease from then to the present. The phase of rapid cooling is inferred to primarily reflect geothermal readjustment after the cessation of the relevant intrusion-related hydrothermal system, with the combined effect of exhumation. As a result, we are unable to resolve the exhumation and erosion rate of the rock bodies inferred from the cooling rate determined by our FT data prior to $60 \mathrm{Ma}$. We infer that the slower cooling (long-term averaged rate of the order of $1{ }^{\circ} \mathrm{C} / \mathrm{Myr}$ ) since $60 \mathrm{Ma}$ was a 
response to erosion-driven exhumation. This is equivalent to an averaged erosion rate of $0.03 \mathrm{~mm} / \mathrm{yr}$, which is comparable with the average in the tectonically stable tropical and subtropical regions (e.g. Madagascar, Sri Lanka: Seward et al., 2004; Seward, unpublished data). The estimated thickness of rock that has been eroded away since $60 \mathrm{Ma}$ is $\sim 2-3 \mathrm{~km}$. A similar, long period of slow exhumation and erosion has been identified in the Sierra Nevada, western USA since $\sim 60 \mathrm{Ma}$, during which less than $\sim 3 \mathrm{~km}$ of material have been removed (House et al., 1997, 1998; Cecil et al., 2006). The sedimentary rocks that are now exposed at the surface in Hong Kong probably represent the remnant of a thicker, eroded Cretaceous sequence. We infer that the slow exhumation since the early Cenozoic reflects an extended period of tectonic quiescence after southeast China had made the transition to a passive continental margin.

Our data and those of Yan et al. (2009) both show two main phases of cooling since the Cretaceous, although the specific timing of the phases is slightly different. The overall pattern indicates a period of rapid cooling followed by much slower cooling to the present day. Yan et al. (2009) argued that the cooling was related to uplift and denudation rather than any changes in heat flow rates, but our study suggests that a change in the geotherm was an important factor. Additionally, Yan et al. (2009) had undertaken analyses only on granitic rocks, and suggested that their FT ages and thermal models reflected the primary post-emplacement, prolonged cooling of the granites, without reference to a reheating event. Our data from Hong Kong extrusive and sedimentary rocks show, however, that this explanation cannot be correct. The timing of the change from rapid to slow cooling in Hong Kong and southern Guangdong within the APAZ is broadly similar at about $60 \mathrm{Ma}$ (Fig. 5.5). Our FT data, however, are unable to verify the possible 34, 10 and 3-4 Ma tectonic events identified by Campbell and Sewell (2005), or the presence of higher cooling rates at $\sim 15-10 \mathrm{Ma}$ as proposed by Yan et al. (2009). This is because these age periods are positioned outside the upper boundary of the APAZ (at $\sim 60{ }^{\circ} \mathrm{C}$ ) in our modelled temperature-time paths where the inverse models of FT data are not reliable.

The presence of sodium-rich alteration minerals including aegirine and zeolite, which were interpreted as related to alkaline-rich hydrothermal alteration by Kemp et al. (1997), in the Eocene Ping Chau Formation indicates that a younger hydrothermal event, but of lower temperature, might have occurred. Our findings from the detrital ZFT analysis of this unit reveal that the ZFT system has not been reset since its deposition, implying that the Eocene 
hydrothermal event, if it occurred, must have reached temperatures below the ZFT closure temperature. The formation temperature of aegirine is debatable, although its presence has been recorded at a temperature of $>130-160{ }^{\circ} \mathrm{C}$ in some modern hydrothermal systems (e.g. Yellowstone, USA: Browne, 1978).

\subsubsection{Regional and global context}

Extensive Early Cretaceous granites ( 120-80 Ma) are now exposed in Zhejiang and Fujian provinces, 250 km northeast from Hong Kong, but are not exposed in the southern part of the SCMB (Fig. 5.1). The conventional interpretation of this spatial distribution is that Yanshanian magmatism ceased in the southern part of the SCMB after 140 Ma, and that subsequently the magmatic front shifted to the northeast to Zhejiang and Fujian provinces (e.g. Zhou et al., 2006; Sewell et al., 2012a). We suggest, in contrast, that the Yanshanian magmatism may have continued until at least 100-80 Ma in Hong Kong and the nearby region. We infer that the temporal distribution of Yanshanian magmatic rocks essentially reflects the variation in the depth of crustal exhumation and erosion along the SCMB, such that deeper crustal levels (and younger granites) are exposed in the northeast region, but remain buried in the southern region (including Hong Kong).

The record of Yanshanian magmatism and Pacific margin evolution seen in Hong Kong has close parallels with other large-scale silicic igneous provinces in circum-Pacific regions. These include the Coast Mountains Batholith along the northern coast of British Columbia, Canada (180-100 Ma, Gehrels et al., 2009), the Sierra Nevada batholiths along the western coast of North America (210-88 Ma, Stern et al., 1981; Chen and Moore, 1982), the Ibague, Anitoquia and Cordoba batholiths in Colombia (180-77 Ma, Villagomez et al., 2011), the Coastal Batholiths in central Chile (161-140 Ma, Gana and Tosdal, 1996, Maksaev et al., 2006, Creixell et al., 2011), the silicic volcanic rocks in Graham Land, Patagonia and Antarctica Peninsula, Antarctica (188-153 Ma, Pankhurst et al., 2000; Riley et al., 2001, 2010; Leat et al., 2009) and the Median Batholith in South Island, New Zealand (170-100 Ma, Allibone and Tulloch, 2004). This contemporeneity reinforces the link between the Yanshanian magmatism and the subduction of the palaeo-Pacific Plate, which formed a complete ring of circum-'Pacific' active plate margins during the late Mesozoic. 
Many previous workers have linked the end of the Yanshanian events to rollback of the subducting slab (e.g. Shi and Li, 2012), although the role of any larger-scale triggers (i.e. the interrelated circum-Pacific tectonic processes) has not been identified. All of the late Mesozoic silicic magmatic activity along the circum-Pacific regions, including the Yanshanian, came to an end at a similar time at $~ 80$ Ma. This coincident termination of magmatism around the Pacific coincided closely with the end of the Cretaceous Normal Superchron ( 125-83 Ma; Gibbard et al., 2008; He et al., 2012) and other major plate reorganisation events around the Pacific basin (e.g. Smith, 2007; Seton et al., 2012). A major shift in the stress field around the entire Pacific margin plausibly links these tectonic processes.

In particular, for the SCMB, the cessation of Yanshanian magmatism may have been triggered by the interaction between the Izanagi-Pacific spreading ridge and the western margin of Pacific at $~ 80$ Ma. The approach of the oceanic ridge in Japan and Korea was constrained by the heat flow anomalies and the cessation of granitic plutonism in the early Cenozoic (Muller et al., 2008; Seton et al., 2012). The collision of the Izanagi-Pacific spreading ridge along the southeast China margin, which has never been examined in detail, possibly induced a change in subduction dynamics, leading to slab rollback. This event may also signify the inception of subduction of the juvenile Pacific Plate.

Following the withdrawal of subduction and tectonic plate rearrangement in the western Pacific, the proto-South China Sea began to open as a back-arc marginal basin between the southeast China margin and the Borneo region at 80 Ma (Seton et al., 2012). Between this time and the beginning of full-scale opening of the South China Sea in the Oligocene, the southeast China margin transformed from an active to a passive continental margin. The original forearc of the late Mesozoic magmatic arc was dismembered and displaced by crustal extension and rifting (Shi and Li, 2012). Parts of the Yanshanian belt that originally lay outboard of Hong Kong (and the modern SE China seaboard) are found in the submerged continental shelf (Yan et al., 2014) or have been split off by spreading associated with the opening of the South China Sea. These granites and volcanic rocks with ages as young as 80-85 Ma are now found in Palawan, western Philippines and as micro-blocks in Nansha (e.g. Yan et al., 2010; Knittel, 2011; Aurelio et al., 2013). 


\subsection{Conclusions}

This study presents the first detailed investigation of the post-magmatic tectono-thermal history of Hong Kong by employing low-temperature thermochronological techniques coupled with U-Pb dating of detrital zircons from post-volcanic sediments. The major findings are as follows.

(1) ZFT ages of the Mesozoic magmatic rocks in Hong Kong range between 140 and 60 Ma. Most are between 100 and 80 Ma, whereas the AFT ages range between 83 and $40 \mathrm{Ma}$, with two outliers at 28 and $23 \mathrm{Ma}$. The results show that both the ZFT and AFT systems have been reset, implying that the rock bodies experienced postemplacement heating to temperature of $\geq 250^{\circ} \mathrm{C}$. We interpret the thermal effect to be a combined result of heating owing to burial plus the effects of an elevated geothermal gradient driven by continuing Yanshanian magmatism in the region.

(2) FT analysis and U-Pb dating of detrital zircons from the post-magmatic sedimentary sequences allow an improved understanding of the sediment provenance. The U-Pb age populations of detrital zircons from the Cretaceous sedimentary units match precisely the ages of the magmatic rocks exposed at present in Hong Kong, except for the earliest Pat Sing Leng Formation, which yielded an additional younger (120 Ma) detrital zircon population. This result confirms that the Cretaceous sediments were mostly sourced from local volcanic-plutonic assemblages. The 120 Ma detrital zircons from Pat Sing Leng Formation indicate (a) the occurrence of younger magmatic activity in Hong Kong or in nearby Guangdong Province, and (b) the maximum age of the Cretaceous basins in Hong Kong. The provenance of the Eocene sedimentary unit probably includes both the local volcanic sequences and recycled Cretaceous sediments, as well as the reworked sediments from Palaeozoic and older basement rocks, which are present both in Hong Kong and in mainland China.

(3) The late Mesozoic volcanic-plutonic assemblages and the Cretaceous sediments have behaved as a single package since at least 120 Ma. They were all heated to over 250 ${ }^{\circ} \mathrm{C}$ and began to cool again through the ZFT closure temperature by $100-80 \mathrm{Ma}$. We link the initial rapid cooling to both geothermal adjustment and unroofing by erosion. The slow cooling after 60 Ma was probably related solely to erosion-driven exhumation. 
Previous interpretations of post-140 Ma geological history in Hong Kong were restrained by limited outcrop, and generally considered that little had happened since the Early Cretaceous. The results of this study demonstrate a dynamic post-magmatic history that was connected to evolution of the continental crust in southeast China and its transition to a passive margin. We interpret that Yanshanian magmatic activity probably lasted longer than previously considered (e.g. Sewell et al., 2000; Zhou et al., 2006); that is, until at least 100-80 Ma in this part of southeast China. The cessation of magmatism accompanied the onset of continental arc collapse that was related to the large-scale crustal extension in the region. The focus of crustal extension shifted elsewhere in the region in the early Eocene, prior to the opening of South China Sea. By then, a passive continental margin had developed along the southeast zone of China.

\section{Acknowledgements}

We thank Victoria University for financial support for U-Pb age analyses from the University Research Fund and award of a Doctoral Scholarship to D.L.K.T. B. Kohn is acknowledged for providing zircon He ages of two sedimentary samples. We thank Y. Tian, A. Densmore and M. Cho for their constructive reviews and comments. D.L.K.T. and R.J.S. publish with the permission from the Head of the Geotechnical Engineering Office and the Director of Civil Engineering and Development, HK SAR Government. 
Chapter 6/ A New Overview of the Mesozoic Volcanic-plutonic Evolution of Hong Kong 


\subsection{Introduction}

Understanding how voluminous ignimbrites are linked to large granitic batholiths is important in identifying the processes involved in the construction and development of continental crust. Yet, contrasting opinions regarding the volcanic-plutonic relationships of large silicic magmatic systems and the mechanisms of building large chambers of eruptible (melt-dominant) magma versus granitic plutons have been developed based on different perspectives from volcanic and plutonic records (e.g. Bachmann et al., 2002; 2007; Coleman et al., 2004; Glazner et al., 2004; Hildreth, 2004; Hildreth and Wilson, 2007; Lipman, 2007; Miller et al., 2007; Walker et al., 2007; Barth et al., 2012; Davis et al., 2012, Mills and Coleman, 2013; Frazer et al., 2014). Many previous studies either focused on young caldera systems and their associated volcanic products to investigate the magma chamber dynamics (e.g. Taupo Volcanic Zone, New Zealand: Charlier et al., 2005; Allan et al., 2012; 2013; Barker et al., 2014; Long Valley Caldera, USA: Hildreth, 2004; Hildreth and Wilson, 2007; Chamberlain et al., 2014a, 2015); or on exposed granitic batholiths which were interpreted as fully crystallised, ancient magma systems (e.g. Sierra Nevada Batholith, USA: Miller et al., 2003; Claiborne et al., 2006; Walker et al., 2007; Barth et al., 2011, 2012). For young caldera systems, their volcanic roots are not available for direct observation, while the eruptive equivalents of the exhumed granites, if present, are rarely well enough preserved for detailed examination and comparison.

The paired volcanic-plutonic assemblages in Hong Kong, although some of the volcanic materials may have been eroded away, provide an excellent opportunity for investigating both types of record of large silicic magmatic systems. These volcanic-plutonic assemblages were the products of several sizable caldera systems that were active during the late Mesozoic Yanshanian events in southeast China (see Chapter 2 for outline). The youngest, largest and most clearly preserved is the High Island caldera complex in southeast Hong Kong. This complex was interpreted by Sewell et al. (2012a) as a nested caldera comprising Early Cretaceous volcanic strata, the Repulse Bay and Kau Sai Chau volcanic groups (RBVG and KSCVG, respectively), and their sub-volcanic plutons emplaced during two temporally distinct magmatic episodes at 143 Ma and 141-140 Ma (Table 2.1; Sewell et al., 2012b). The volcanic-plutonic assemblages were grouped primarily on the basis of whole-rock geochemistry (Sewell and Campbell, 1997) and zircon ID-TIMS ages (Davis et al., 1997; Campbell et al., 2007; Sewell et al., 2012b) of the 
mapped units. The caldera boundary was inferred from major fault structures and tectonomagmatic lineaments identified from geophysical surveys (Fig. 2.9; Campbell and Sewell, 1997; Fletcher et al., 1997; Sewell et al., 2012a). Sewell et al. (2012a) estimated that the 141 Ma High Island Tuff had an eruptive volume of $~ 570 \mathrm{~km}^{3}$ DRE (dense rock equivalent) and induced a major caldera collapse. Sewell et al. (2012a) further suggested that subsequent crustal uplift caused tilting of the nested caldera complex, which was then planed off by erosion to yield the present-day exposed relationships.

This chapter aims to revisit and summarise the key features of the nested High Island caldera complex in light of my field studies (Chapter 3), re-interpretation of existing whole-rock geochemical data, combined with the new information based on zircon chemistry, in-situ SIMS U-Pb zircon dating, and detailed thermochronological analysis, all carried out under this research and presented in Chapters 4 and 5. The field and age relationships and potential genetic connections of the two spatially overlapping volcanic groups and their associated sub-volcanic plutons are reviewed. The findings of this research also offer new perspectives which enable the comparison with other similar regional and global caldera-related volcanic-plutonic assemblages, as well as an attempt to understand the genetic relationships of the volcanic rocks and the sub-volcanic plutons. In addition, the implications of my research findings for the evolution of Yanshanian magmatism in southeast China, as a portion of the extensive Mesozoic circum-Pacific magmatic belts, are discussed here.

\subsection{Temporal relationships of volcanic and intrusive units}

\subsubsection{Repulse Bay Volcanic Group - Cheung Chau Suite}

In previous studies, the temporal associations of the volcanic sequences and the plutonic units were based primarily on the basis of high precision ID-TIMS U-Pb zircon ages (Davis et al., 1997; Campbell et al., 2007; Sewell et al., 2012b). The different advantages and limitations of ID-TIMS and in-situ SIMS dating techniques, in particular their respective resolutions and precisions for Mesozoic rocks, have been discussed in Chapter 4. Overall, the SIMS model ages obtained from this research match the stratigraphic relationships of the volcanic units observed in the field (Sewell et al., 2012a; and this study). Note, however, that the ages of some units overlap within error, which reflects the limits of resolution of the SIMS U-Pb age data for these late Mesozoic rocks. In such cases, 
relative age relationships observed from the field have been of paramount importance for interpreting the stratigraphy and age data.

The most obvious re-consideration is the temporal relationships of the RBVG and Cheung Chau Suite, which were previously interpreted as being coeval at $143 \mathrm{Ma}$ (Sewell et al., 2000; 2012b; Campbell et al., 2007). The SIMS ages of the RBVG units overlap at 95\% confidence and are indistinguishable, although field evidence suggests that the Mount Davis Formation is overlain by the Long Harbour, Ap Lei Chau and Che Kwu Shan ignimbrites (Sewell et al., 2012a; Chapter 3). The SIMS age data (Table 4.5) imply that the RBVG comprises volcanic successions from a series of eruptions occurring intermittently within a 2-Myr period between 143 and $141 \mathrm{Ma}$, rather than representing a distinct pulse of volcanism at $\sim 143 \mathrm{Ma}$ as previously proposed. In addition, previous studies had postulated that the Cheung Chau Suite (including the Chi Ma Wan and Shui Chuen O granites) was linked to the RBVG based on their comparable emplacement/eruption ages as determined by ID-TIMS (e.g. Sewell et al., 2000, 2012a, 2012b). However, the SIMS ages of Shui Chuen O and Chi Ma Wan granites presented in this study are $141.9 \pm 0.8 \mathrm{Ma}$ and 140.0 $\pm 1.0 \mathrm{Ma}$, respectively (Table 6.1), which are at least $1 \mathrm{Myr}$ younger than their published ID-TIMS age. Therefore, the pairing of RBVG and the Cheung Chau Suite is now open to re-evaluation.

\subsubsection{Kau Sai Chau Volcanic Group - Lion Rock Suite}

SIMS dating has confirmed that the KSCVG was erupted at 141-140 Ma. The autobrecciated rhyolite lava at Tai Long Tsui (sample HK13343) has been dated at 139.6 $\pm 0.5 \mathrm{Ma}$ (Table 6.1), consistent with field relationships that show that its extrusion post-dated the $140.9 \pm 0.4$ Ma High Island Tuff. For the intrusive units, the Sok Kwu Wan Granite and the D’Aguilar Quartz Monzonite are closely related to the perimeter of the High Island caldera and yield statistically indistinguishable SIMS ages of 140.7 $\pm 1.2 \mathrm{Ma}$ and 140.8 \pm 1.4 Ma, respectively (Table 6.1). The Kowloon and Mount Butler granites were emplaced at $138.9 \pm 1.5 \mathrm{Ma}$ and $137.8 \pm 0.8 \mathrm{Ma}$, respectively, 2-3 Myr after the eruption of the KSCVG. The SIMS ages confirm the field relationships of these two units which indicate that the Mount Butler Granite intruded the Kowloon pluton (Strange and Shaw, 1986; Sewell et al., 2000, this study Chapter 3). The temporal linkage of these two granitic units with the KSCVG, as previously proposed, is thus deemed to be spurious. Even though these granites were emplaced within the High Island Caldera, it is questionable 
whether they were co-magmatic with the KSCVG system. In modern analogues, the life span of large silicic caldera systems, such as those in the Taupo Volcanic Zone in New Zealand, generally lasts only for 0.1-1 Myr. Considering the time gap between the Kowloon Granite and Mount Butler Granite and the KSCVG, it is unlikely that the granites represent the remnant of the KSCVG system. Instead, these two granitic plutons probably represent separate magmatic pulses emplaced at shallow levels in the crust subsequent to the eruption of the KSCVG. The association of the two granitic plutons with other magmatic rocks within the High Island caldera complex will be discussed further in the next section and combined with information from the zircon trace element patterns.

Table 6.1. New groupings of volcanic-plutonic assemblages of the Cretaceous magmatic rocks in Hong Kong, based on in-situ SIMS U-Pb zircon ages reported at 95\% confidence levels and zircon trace element characteristics obtained from this study.

\begin{tabular}{|c|c|c|c|c|}
\hline & Volcanic unit & $\begin{array}{l}\text { SIMS U-Pb } \\
\text { age (Ma) }\end{array}$ & Plutonic unit & $\begin{array}{l}\text { SIMS U-Pb } \\
\text { age (Ma) }\end{array}$ \\
\hline \multicolumn{5}{|c|}{ Lion Rock Suite (granite sub-suite) } \\
\hline & $\begin{array}{l}\text { (no volcanic equivalents have yet } \\
\text { been identified) }\end{array}$ & & $\begin{array}{l}\text { Mount Butler Granite (HK13407) } \\
\text { Kowloon Granite (HK1 1042) }\end{array}$ & $\begin{array}{l}137.8 \pm 0.8 \\
139.1 \pm 1.0\end{array}$ \\
\hline \multicolumn{5}{|c|}{ Kau Sai Chau Volcanic Group - Lion Rock Suite (monzo-granite sub-suite) } \\
\hline $\begin{array}{l}\text { Southeast } \\
\text { Hong } \\
\text { Kong }\end{array}$ & $\begin{array}{l}\text { Autobrecciated lava (HK13343) } \\
\text { Rhyolite lava (HK12073) } \\
\text { High Island Tuff (HK12001) } \\
\text { Clear Water Bay (HK1 1834) } \\
\text { Pan Long Wan (HK13277) }\end{array}$ & $\begin{array}{l}139.6 \pm 0.4 \\
140.5 \pm 0.7 \\
140.9 \pm 0.4 \\
139.3 \pm 1.1 \\
141.0 \pm 1.3\end{array}$ & $\begin{array}{c}\text { Sok Kwu Wan Granite (HK12023) } \\
\text { D'Aguilar Qz Monzonite (HK12022) } \\
\text { Tei Tong Tsui Qz Monzonite }\end{array}$ & $\begin{array}{l}140.7 \pm 1.2 \\
140.5 \pm 1.0 \\
\text { (Not dated) }\end{array}$ \\
\hline $\begin{array}{l}\text { Lantau } \\
\text { Island }\end{array}$ & $\begin{array}{l}\text { Undifferentiated ignimbrite } \\
\text { (HK12070) }\end{array}$ & $140.7 \pm 0.7$ & $\begin{array}{l}\text { Tong Fuk Qz Monzonite (HK8758) } \\
\text { Chi Ma Wan Granite (HK8353) }\end{array}$ & $\begin{array}{l}140.6 \pm 1.5 \\
140.0 \pm 1.0\end{array}$ \\
\hline \multicolumn{5}{|c|}{ Repulse Bay Volcanic Group - Cheung Chau Suite } \\
\hline & $\begin{array}{c}\text { Mang Kung Uk } \\
\text { Che Kwu Shan (HK11836) } \\
\text { Ap Lei Chau (HK11840) } \\
\text { Long Harbour (HK11835) } \\
\text { Mount Davis (HK13275) }\end{array}$ & $\begin{array}{l}\text { (Not dated) } \\
141.6 \pm 1.0 \\
141.0 \pm 0.7 \\
141.4 \pm 1.0 \\
142.3 \pm 1.2\end{array}$ & Shui Chuen O Granite (HK12072) & $141.9 \pm 0.8$ \\
\hline
\end{tabular}

Note. All SIMS U-Pb zircon ages are weighted mean ages, reported in $95 \%$ confidence level. See Chapter 4 for details. 


\subsection{Zircon chemistry of igneous samples from the High Island caldera complex}

It is generally supposed that volcanic rocks represent snapshots of their magmatic systems for a relatively short period of time from the assembly of the magma chamber until eruption; whereas plutonic rocks record a much longer magmatic evolutionary history and preserve the evidence of near and sub-solidus magmatic processes (e.g. Bachmann et al., 2007; Lipman, 2007). Here in this section, the characteristics of zircon trace element patterns from the volcanic and plutonic units of the High Island caldera complex will firstly be discussed and then compared. The findings will help uncover the volcanicplutonic connections of large silicic systems to be presented later in this Chapter.

\subsubsection{Volcanic records}

Two Early Cretaceous volcanic groups, the RBVG and KSCVG, form the dominant surficial products associated with the High Island caldera complex (Table 6.1). Within the RBVG, the Mount Davis and Long Harbour crystal-rich ignimbrites share common zircon trace element signatures that in turn are somewhat distinct from those of the overlying Ap Lei Chau and Che Kwu Shan ignimbrites. Zircon trace element data of the younger two ignimbrites grade towards lower $\mathrm{Hf}, \mathrm{U}$ and $\mathrm{Th}$, but higher Ti concentrations than the older Mount Davis and Long Harbour ignimbrites. In the $\mathrm{Eu} / \mathrm{Eu}^{*}$ versus Hf plot, data from the Ap Lei Chau and Che Kwu Shan ignimbrites are split in two different zones: one (from 50$60 \%$ of the analyses) in common with the Mount Davis and Long Harbour ignimbrites and the other in common with eruptive units from the later KSCVG (Fig. 6.1). The close connection between the crystal-rich Long Harbour and Mount Davis ignimbrites is also evident from their whole-rock trace element characteristics (especially $\mathrm{TiO}_{2}$ versus $\mathrm{SiO}_{2}$ plot), which was first recognised by Sewell and Campbell (1997; "Phases 3 and 4" in Fig. 8 of their paper). The trace element characteristics identified in a subordinate proportion (40-50\%) of the Ap Lei Chau and Chek Kwu Shan zircon cores suggest the presence of a contribution from a second source common to that of the younger Pan Long Wan trachydacite (Fig. 4.9). These two younger units contain zircons with notable core-rim variations in CL emissions and trace element abundances: the brighter CL rims are characterised by low $\mathrm{Hf}, \mathrm{U}$ and total trivalent trace elements and high Ti concentrations (Chapter 4). 
All the KSCVG units, except the Pan Long Wan trachydacite lava, have similar zircon trace element patterns that are largely distinct from those of the underlying RBVG sequence. The most obvious distinction is that the KSCVG units commonly show restricted inter-grain variations in zircon trace element concentrations and ratios, whereas the RBVG units yield a wider spread. In addition, the KSCVG units contain zircons that have generally lower Hf, U, Th and REE concentrations than those of the RBVG (Figs. 4.10-4.12), and show notably smaller ranges and lower values of $\mathrm{Th} / \mathrm{U}$ and $\mathrm{Yb} / \mathrm{Gd}$ ratios (Figs. 4.17, 4.18 and 6.1). The Clear Water Bay Formation and High Island Tuff of the KSCVG are both high-silica rhyolite units with similar zircon chemistries. The most notable similarity is that both units show bimodal Hf concentrations, particularly evident in the Clear Water Bay ignimbrite but less obvious in the High Island Tuff (Fig. 6.2). As evident in Fig. 4.21B (for Clear Water Bay rhyolite), this bimodality cannot be explained by the effects of sector zoning (cf. Chamberlain et al., 2014b; Cooper et al., 2014).
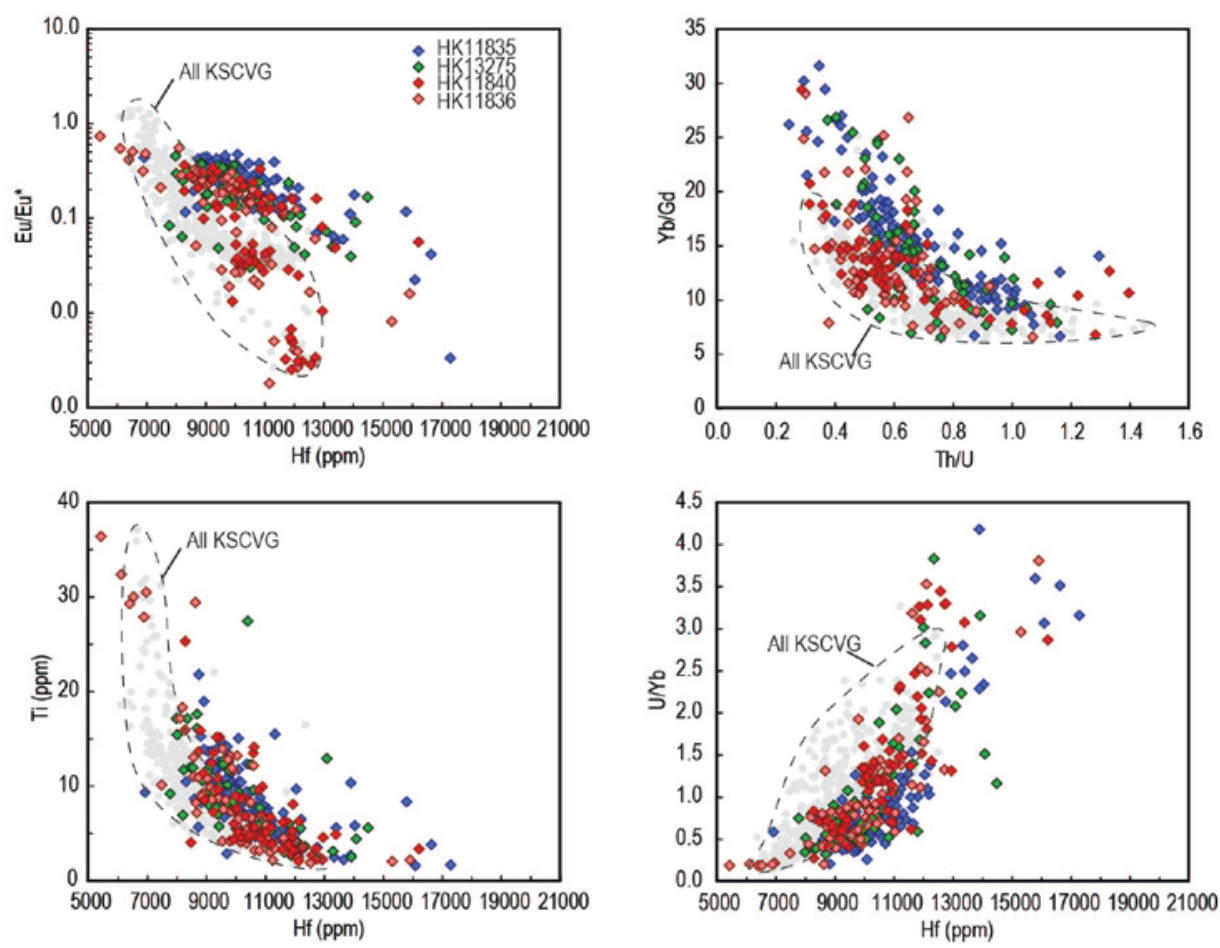

Fig. 6.1. Selected zircon trace element plots of the RBVG units (HK11835 - Long Harbour, HK13275 Mount Davis, HK11840 - Ap Lei Chau and HK11836 - Che Kwu Shan). Trace element data from all the KSCVG are plotted as grey circles for comparison. Zircon trace element data from the two crystal-rich ignimbrites (Long Harbour and Mount Davis, HK11835 and HK13275, respectively) are generally plotted outside the field in which the KSCVG data plot; while data from the Ap Lei Chau and Che Kwu Shan ignimbrites (HK11840 and HK11836) plot in the zone partly overlapping with the KSCVG data. 

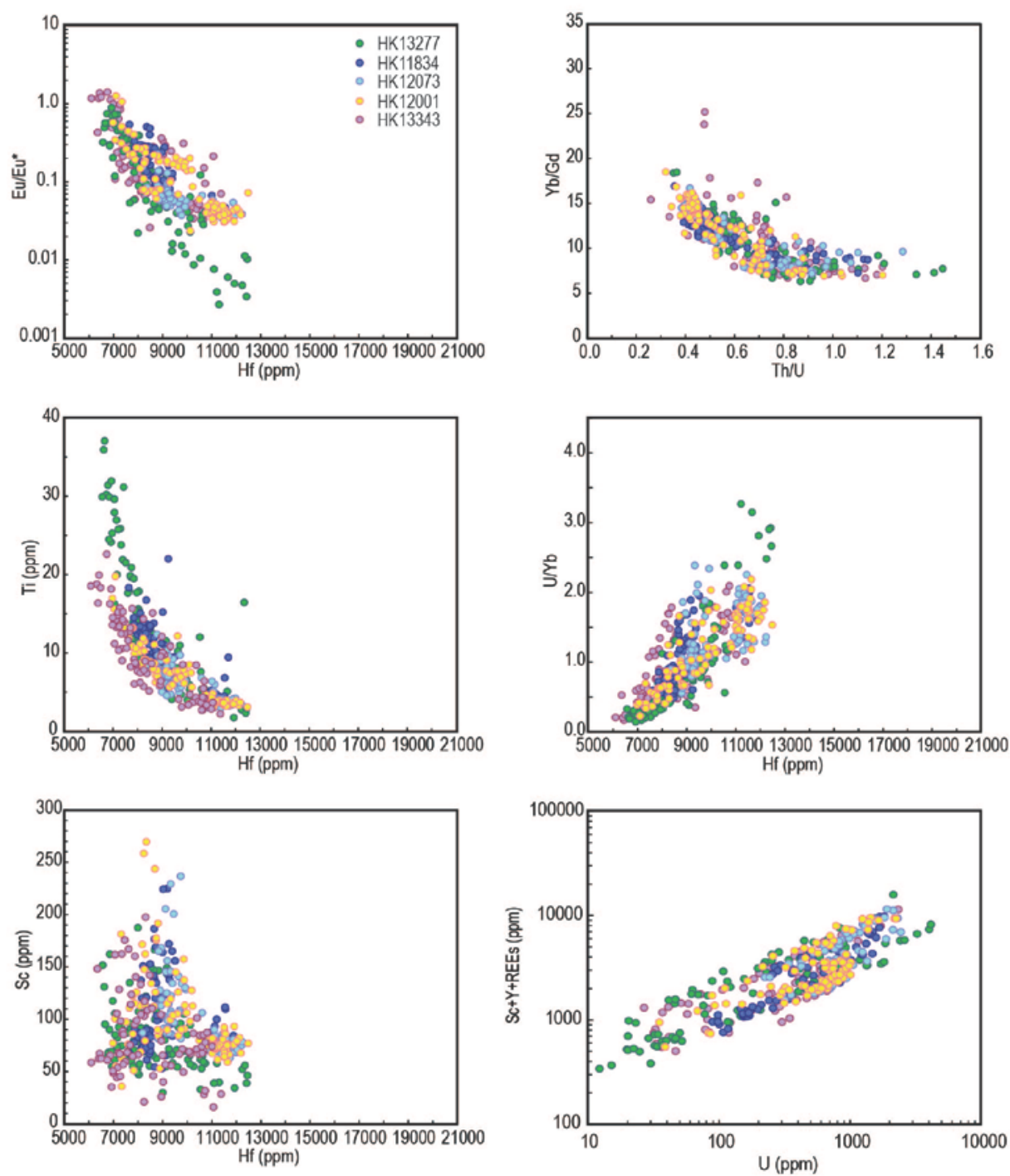

Fig. 6.2. Selected zircon trace element plots of the KSCVG units (HK13277 - Pan Long Wan, HK11834 Clear Water Bay tuff, HK12073 - Clear Water Bay rhyolite, HK12001 - High Island Tuff and HK13343 post-High Island rhyolite. 
Based on the dissimilarity of zircon trace element patterns, it is considered that the RBVG and KSCVG probably represent two spatially-overlapping and closely successive magmatic systems, with the arrival of magma represented by the Pan Long Wan trachydacite as the change-over between the two systems (Fig. 6.2). The two volcanic groups yield SIMS ages which largely overlap within error, suggesting that they are not as clearly temporally distinct as previously considered (Table 6.1). The Eu-anomaly against Hf concentration plots of these units (Fig. 6.2) provide useful information on two aspects of the magmatic system: (1) positive $\mathrm{Eu} / \mathrm{Eu}^{*}$ value from some analyses, implying possibly melting of feldspars at source and (2) steep Eu/Eu* versus Hf gradient, implying relatively effective fractionation of feldspar during melt evolution.

\subsubsection{Plutonic (intrusive) records}

Selected zircon trace element plots of intrusive units from the High Island caldera complex are shown in Fig. 6.3. Similar to those from the volcanic units, the zircon trace element records from the intrusive samples also display the presence of two different trends, which correspond to those of the RBVG and KSCVG individually.Two groups are defined here: Group 1 is represented by the Shui Chuen O, Kowloon and Mount Butler granites, and Group 2 by the Sok Kwu Wan Granite and D’Aguilar Quartz Monzonite. The two groups exhibit similar general trends in the zircon trace element plots (e.g. negative correlations between $\mathrm{Ti}$ and $\mathrm{Hf}$ concentrations and $\mathrm{Yb} / \mathrm{Gd}$ versus $\mathrm{Th} / \mathrm{U}$ ratios), but the ranges and patterns shown by these groups are distinct.

Overall, zircons from the Group 1 units yield wider ranges in Hf, Y, total 3+, Th and U concentrations than the Group 2 units. Of these trace elements, the variations of $\mathrm{Hf}$ abundance in zircons from Group 1 units ( 5,000-23,000 ppm) are notably greater than that from Group 2 units (Table 4.4, Fig. 4.10). Since Hf concentration increases with melt evolution (e.g. Claiborne et al., 2006; 2010; Wooden et al., 2006; Barth and Wooden, 2010; Reid et al., 2011), the larger inter-grain variation implies that these units were from magmatic systems that probably spanned higher degrees of melt fractionation during the development of their corresponding magma bodies. In comparison, the Group 2 units show a more restricted range in Hf concentrations ( 6,000-13,000 ppm, Table 4.4). In addition, larger inter-grain variations in the values of $\mathrm{Th} / \mathrm{U}, \mathrm{Yb} / \mathrm{Gd}$ and $\mathrm{U} / \mathrm{Yb}$ ratios are evident in Group 1 units (Figs. 4.17, 4.18 and 6.3). These trace element ratios have also been considered to reflect overall melt fractionation patterns (e.g. Barth and Wooden, 2010). 
Furthermore, the maximum Ti concentrations from Group 2 zircons are in general higher than that of the Group 1 (Table 4.4, Fig. 4.15). As Ti concentration in zircon is widely considered to be a general proxy of melt temperature and magmatic evolution (e.g. Ferry and Watson, 2007), the Group 2 units are inferred to reflect hotter, and/or less-evolved, and/or more $\mathrm{TiO}_{2}$ rich, melts than those of the Group 1 units.

A negative correlation between Eu-anomaly and Hf concentrations, corresponding to feldspar fractionation during melt evolution is common in zircon from both groups of plutonic units (Fig. 6.3). However, in the Eu/Eu* versus Hf plot, data from Group 2 units form an array with a steeper gradient than that from Group 1 units. This steeper gradient is interpreted to reflect more effective (more rapid) and/or higher degrees of feldspar fractionation during melt evolution. In addition to this dissimilarity, some analyses from Group 2 intrusive samples yield a positive Eu-anomaly, with no other analytical indications (e.g., elevated $\mathrm{Ca}, \mathrm{Na}$ or $\mathrm{K}$ abundances) that this represents the effects of feldspar micro-inclusions.

Zircon trace element patterns of the Group 1 plutonic units, the Shui Chuen O, Kowloon and Mount Butler granites, are most similar to those of the RBVG units (Fig. 6.3, left panels), despite the latter two plutonic rocks being of substantially younger age (Table 6.1). Their trace element data always plot in the same fields, although the granites contain some grains enriched in Hf (up to 21,000 ppm), implying higher degrees of melt evolution during the assembly of the granitic plutons than any of the RBVG volcanic deposits. The two, second-order compositional sub-groups seen in the volcanic units (Section 6.3.1.) are also seen in the separated arrays from the granites. Data from the Shui Chuen O Granite plot in similar fashion to the part of the Ap Lei Chau and Che Kwu ignimbrites that is out of the main trend of the RBVG (cf. Fig. 6.1); whereas the Kowloon and Mount Butler granites overlap with the Long Harbour and Mount Davis ignimbrites. The very high Hf values (15,000-20,000 ppm) generally represent zircon crystallisation in the latest-stage melts as the temperature crosses through the solidus (Barth and Wooden, 2010), with accompanying low values of $\mathrm{Ti}(1-2 \mathrm{ppm})$. In addition, the zircon rims from these two granitic units commonly yield high $\mathrm{U}$ abundance and very low $\mathrm{Th} / \mathrm{U}$ ratio, which also suggests that they were crystallised in relatively U-enriched melts. Thus, the zircons from the Kowloon and Mount Butler granites are inferred to have recorded the cooling of melts across the solidus. 
Zircons from Group 2 units, the Sok Kwu Wan Granite and the D’Aguilar Quartz Monzonite, share similar chemical characteristics, and their trace element data are commonly plotted in the identical zone to the KSCVG units (excluding the Pan Long Wan trachydacite). Zircon trace element patterns of these volcanic and intrusive units are comparable and are best seen in the $\mathrm{Eu} / \mathrm{Eu}^{*}$ versus $\mathrm{Hf}$ and $\mathrm{Yb} / \mathrm{Gd}$ versus $\mathrm{Th} / \mathrm{U}$ plots (Fig. 6.3). 
(A) Group 1
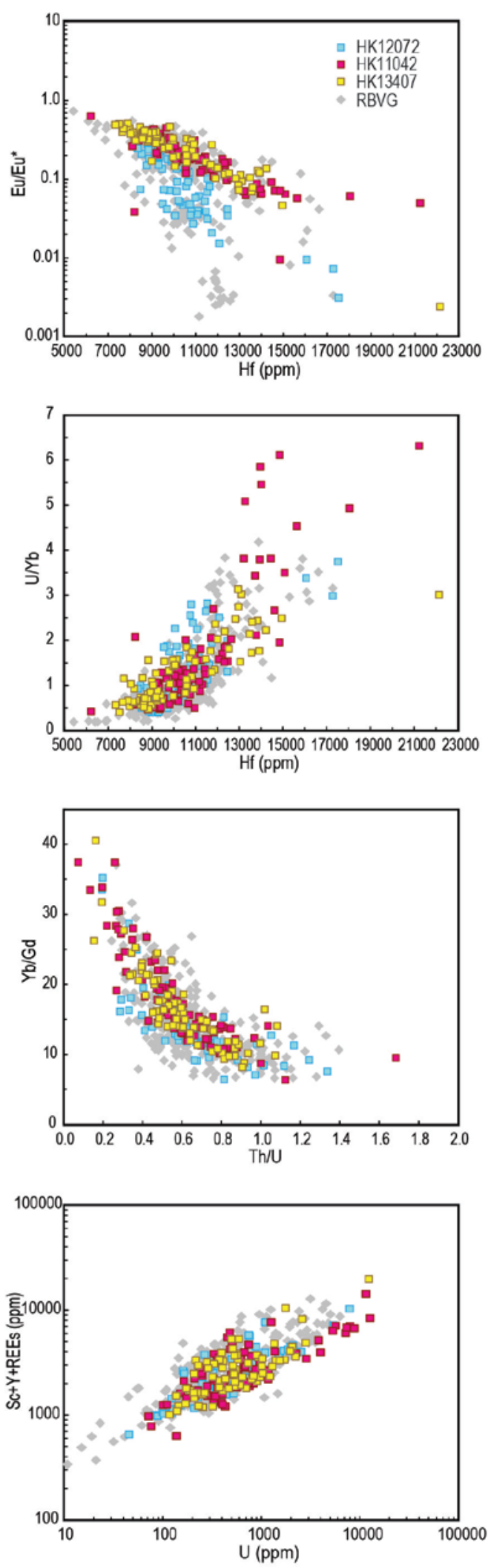

(B) Group 2
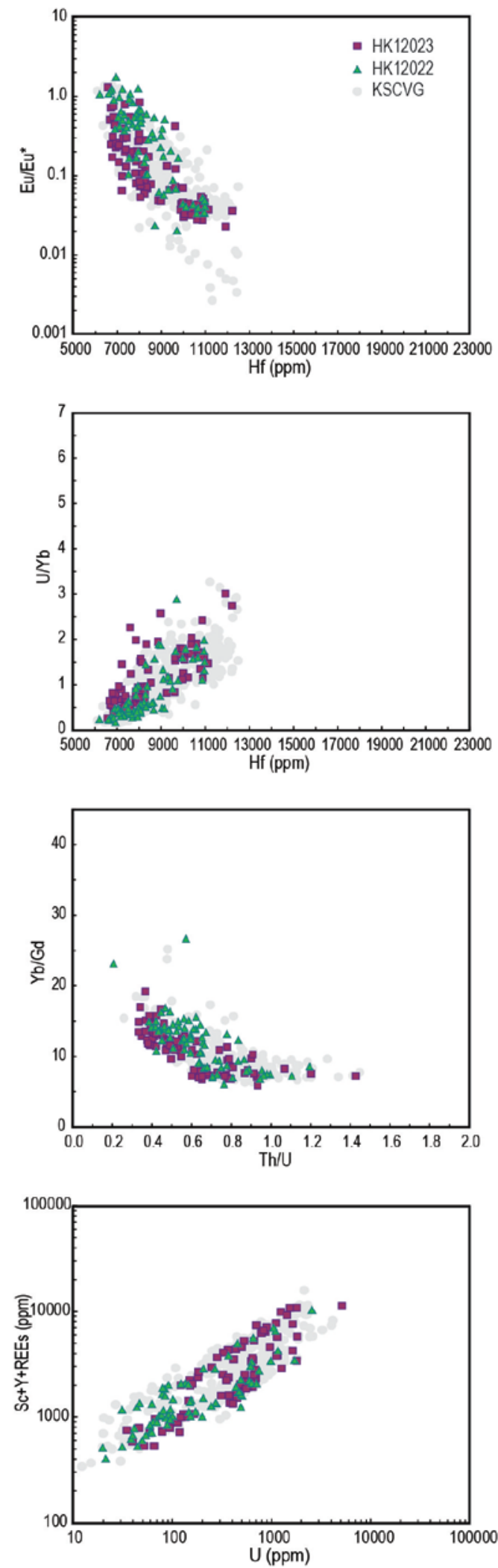

Fig. 6.3. Selected zircon trace element plots of intrusive units from the High Island caldera complex. Left panel: HK12072 - Shui Chuen O Granite, HK11042 - Kowloon Granite, HK13407 - Mount Butler Granite. Grey diamonds are data from the RBVG units for comparison. Right panel: HK12023 - Sok Kwu Wan Granite, HK12022 - D’Aguilar Quartz Monzonite. Grey circles are data from the KSCVG units for comparison. 


\subsection{Two granite types: "high-" and "low-temperature" granites}

The zircon inheritance characteristics of granitic plutons were discussed by Miller et al. (2003) in terms of zircon saturation temperature $\left(\mathrm{T}_{\mathrm{zr}}\right)$, calculated from the whole rock compositions using the thermometry proposed by Watson and Harrison (1983). Two types of granites, inheritance-rich “cold” granites and inheritance-poor "hot” granites, were defined based on the calculated $\mathrm{T}_{\mathrm{zr}}$ (either less than or over $800{ }^{\circ} \mathrm{C}$ respectively; Miller et al, 2003). Here, following Miller et al., I have used the whole rock geochemical data from Sewell and Campbell (2001) to determine the $\mathrm{T}_{\mathrm{zr}}$ for the granitic units studied here using the Watson and Harrison (1983) thermometry (Table 6.2). The applicability of the zircon saturation thermometry to determine the thermal conditions of magma, in particular for the Hong Kong samples which otherwise lack other thermometers (e.g. Fe-Ti oxides), is questionable, in large part because the composition of the fully crystallised rock may differ greatly from that of the melt at the time of zircon crystallisation. Nonetheless, the estimated temperatures provide useful broad indicators of the magmatic conditions under which zircons crystallise or dissolve in silicic melts (cf. Charlier et al., 2005; Reid et al., 2011; Barker et al., 2014). It is noted that Boehnkr et al. (2013) have recently proposed an updated thermometry for calculating $\mathrm{T}_{\mathrm{zr}}$ of silicic melt. However, their calibration yields temperatures that are several tens of ${ }^{\circ} \mathrm{C}$ lower than the value based on Watson and Harrison (1983)'s thermometry, and which are also inconsistent with other thermometric estimates (cf. Barker et al., 2014). Thus, the original method of Watson and Harrison (1983) has been used here for direct comparison with the results in Miller et al. (2003).

Two groups of intrusive units are identified based on their averaged $\mathrm{T}_{\mathrm{zr}}$ (Table 6.2). The Lantau, Chi Ma Wan, Shui Chuen O, Kowloon and Mount Butler granites all have averaged $\mathrm{T}_{\mathrm{zr}}$ values that range between $\sim 740$ and $770{ }^{\circ} \mathrm{C}$; whereas the averaged values of $\mathrm{T}_{\mathrm{zr}}$ for the Sok Kwu Wan Granite, and D’Aguilar and Tong Fuk quartz monzonites range between $\sim 820$ and $860{ }^{\circ} \mathrm{C}$ (Table 6.2). According to the scheme proposed by Miller et al. (2003), the first group of intrusive units with $\mathrm{T}_{\mathrm{zr}}<800{ }^{\circ} \mathrm{C}$ would be referred to as "cold" granites and those in the second group can be referred to as "hot" granites. The zircon inheritance characteristics of these two groups of intrusive units have been presented in Chapter 4 based on the findings of in-situ SIMS age determinations (Table 4.5). 
Table 6.2. Zircon saturation temperatures of rock units calculated using thermometry established by Watson and Harrison (1983) and whole-rock geochemical data from Sewell and Campbell (2001).

\begin{tabular}{lccc}
\hline \multicolumn{1}{c}{ Rock Unit } & Mean $\mathrm{T}_{r j}\left({ }^{\circ} \mathrm{C}\right)$ & $\begin{array}{c}\text { Standard Derivation } \\
\left({ }^{\circ} \mathrm{C}\right)\end{array}$ & No. of analyses \\
\hline Lantau Granite & 756 & 15 & 20 \\
Chi Ma Wan Granite & 764 & 28 & 15 \\
Shui Chuen O Granite & 746 & 25 & 11 \\
Kowloon Granite & 768 & 26 & 16 \\
Mount Butler Granite & 741 & 18 & 25 \\
Sok Kwu Wan Granite & 865 & 1 & 2 \\
Tei Tong Tsui Quartz Monzonite & 854 & 30 & 11 \\
Tong Fuk Quartz Monzonite & 826 & 16 & 9 \\
D'Aguilar Quartz Monzonite & 850 & 4 & 7 \\
\hline
\end{tabular}

Zircon saturation temperature was calculated based on the zircon saturation thermometry established by Watson and Harrison (1983), rearranged as follow:

$\mathrm{T}_{\mathrm{zr}}=12,900 /\left[2.95+0.85 \mathrm{M}+\ln \left(\mathrm{Zr}_{\mathrm{zircon}} / \mathrm{Zr}_{\text {rock }}\right)\right]$, where $\mathrm{M}$ is compositional factor $[(\mathrm{Na}+\mathrm{K}+2 * \mathrm{Ca}) /(\mathrm{Al} * \mathrm{Si})]$ (all in cation fraction), $\mathrm{Zr}_{\text {zircon }}$ is the concentration of $\mathrm{Zr}$ in zircon (i.e. $~ 497,646 \mathrm{ppm}$ ), $\mathrm{Zr}_{\text {rock }}$ is the concentration of $\mathrm{Zr}$ in the sample, and $\mathrm{T}_{\mathrm{zr}}$ is temperature (in Kelvin). The zircon saturation temperature of each unit was averaged value from multiple whole-rock geochemical analyses of that particular unit obtained from Sewell and Campbell (2001), with the number of analyses and the standard derivation presented.

According to Miller et al. (2003), the melt production mechanisms for these two types of granites are fundamentally different. The “cold” granites were considered to have been generated at lower temperatures with infiltration of water-rich fluids; whereas the "hot" granites were interpreted to have formed with influx of heat from mafic magma in extensional settings. The "low-temperature" granites must have been generated primarily by heating up of pre-existing zircon-bearing crustal rocks, and as such are representative of crustal recycling. The "high-temperature" granites, in contrast, must have come down from a state where any pre-existing zircon was dissolved out, either through fractionation from mafic magmas, or high-temperature crustal fusion, or a mixture between the two.

In the case for Hong Kong intrusive units considered in this thesis, the Sok Kwu Wan Granite and those quartz monzonite stocks and dykes satisfy the criterion of "hightemperature granites”, whereas the Kowloon and Mount Butler granites have some characteristics of “low-temperature granites”. Note, however, that the SIMS age patterns for the last two units are such that any significant inheritance (implied from the Miller et al., 2003, model) cannot be from ancient crust but has to be from only slightly older (i.e., 
Mesozoic igneous) crustal protoliths. This "hot/cold" subdivision matches the proposed groupings of granitic plutons based on zircon trace element patterns, as discussed in Section 6.4.2 above. Here, I reconsider the whole rock geochemical signatures of these granites using the data from Sewell and Campbell (2001) to highlight the intrinsic disparities of the two granitic types. The whole rock trace element patterns of the "hightemperature” versus "low-temperature” granites are shown in selected Harker diagrams (Fig. 6.4A). The "high-temperature granites" show a clear fractionation trends that are comparable to the KSCVG unit in the High Island Caldera. In contrast, the "lowtemperature granites” are scattered in the highly fractionated end in the Harker diagrams.

In the case for Hong Kong intrusive units, the "high-temperature" granitic units, i.e. Sok Kwu Wan Granite, and D’Aguilar and Tong Fuk quartz monzonites, were probably genetically related to those magma chambers that supported eruptions. These granitic units have exhibited zircon trace element signatures that are comparable to those of the coeval eruptives of the KSCVG, i.e. Clear Water Bay and High Island Tuff units (Section 6.4.2, Fig. 6.3). On the other hand, the Kowloon Granite and Mount Butler Granite, having the characteristics of "low-temperature" granites might have never erupted. The petrogenetic processes interpreted from the zircon zoning textures combined with trace element patterns (Section 4.5.3.2) suggest that the two granitic plutons probably crystallised in progressively more-evolved, cooler melts. This view of the two granitic plutons is in contrast to the previous interpretation that they were resurgent intrusions that emplaced within the High Island caldera after the cataclysmic eruptions of High Island Tuff (Sewell et al., 2012a). In fact, the new zircon SIMS age and trace element data also imply that the two granites are probably not co-magmatic with the KSCVG units (see sections 6.3.2 and 6.4.2), even though the plutons were emplaced within the High Island caldera complex. 
(A) Plutonic units

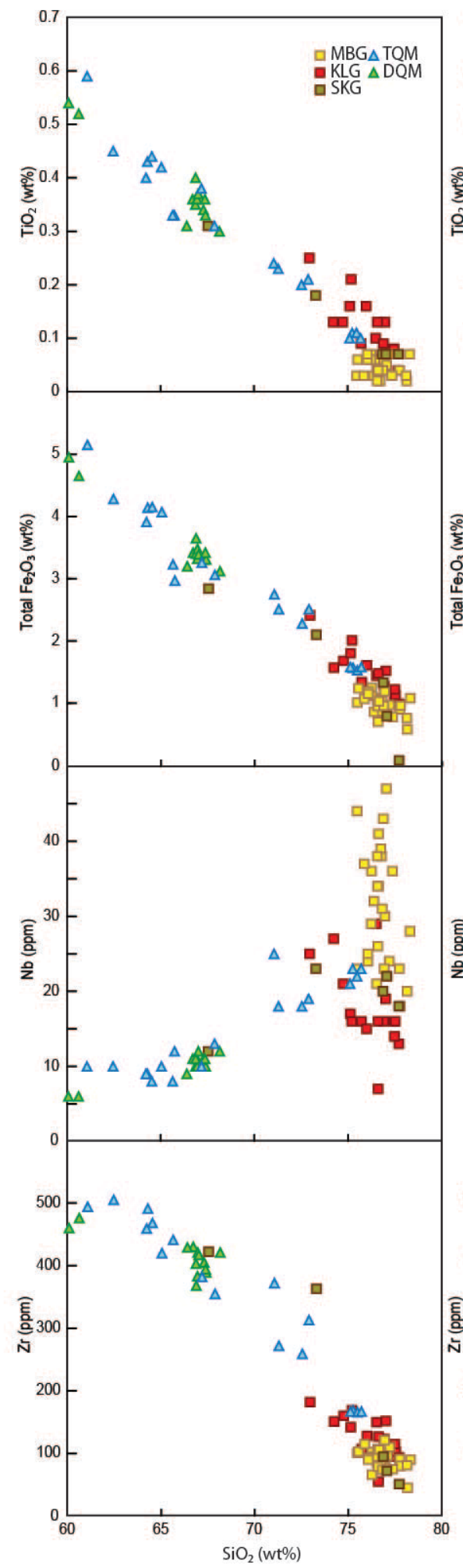

(B) Volcanic units

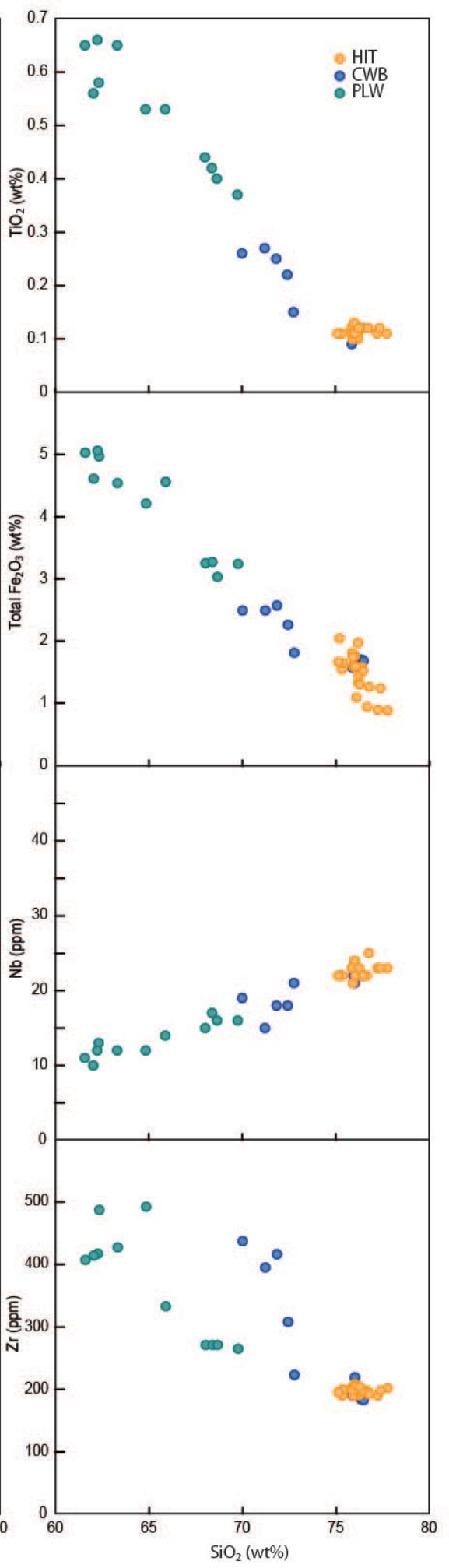

Fig. 6.4. Selected variation diagrams for (A) Lion Rock plutonic units and (B) KSCVG units within the High Island caldera complex. Data from Sewell and Campbell (2001). Left panel: MBG - Mount Butler Granite; KLG - Kowloon Granite; SKW - Sok Kwu Wan Granite; TQM - Tei Tong Tsui Quartz Monzonite; DQM D’Aguilar Quartz Monzonite. Right panel: HIT - High Island Tuff; CWB - Clear Water Bay Formation; PLW - Pan Long Wan trachydacite. 


\subsection{Assembly and storage of the High Island caldera magmatic system}

The volcanic units classified into the RBVG and KSCVG have somewhat distinct zircon trace element patterns and inheritance signatures, even though they overlap spatially within the High Island caldera complex. The SIMS age data have demonstrated that these volcanic units were the products of a series of magmatic units erupted over an extended period between 143 and $140 \mathrm{Ma}$, rather than being distinct entities. These two volcanic groups are considered here as a representation of a long-lived magmatic system that evolved through both open and closed system processes over $>3 \mathrm{Myr}$.

\subsubsection{Mount Davis and Long Harbour units}

At the beginning of its activity around $143 \mathrm{Ma}$, the magmatic system beneath what became the High Island caldera complex is inferred to have been initiated by reheating/partial melting of pre-existing Yanshanian granitic rocks and/or basement rocks with the arrival, ponding and fractionation of mafic magma at various crustal levels. In its early stages, the system probably developed from coalescing the crystal-rich roots to a magma chamber comprising a mush with crystallinity between $>50-90 \%$ and with only small or negligible proportion of crystal-poor rhyolitic melt cap. It is envisaged that the system was underlain by crystal-rich magma reservoir zones that had served as both thermal and material buffers for much of its life-span. The earlier eruptives of the RBVG were the crystal-rich, dacitic Mount Davis and crystal-rich low silica rhyolite to dacitic Long Harbour formations (SIMS ages: 142.5 Ma and 141.4 Ma respectively: Table 6.1). The Long Harbour ignimbrite has particularly high crystal contents of 40-50\% (quartz and feldspar), and contains clumps of granitic lithic fragments, in particular in the lower part of the ignimbrite (Strange et al., 1990; Section 3.2.1.1). The eruptions of the Mount Davis and Long Harbour formations are interpreted here as reflecting the intermittent 'defrosting' and evacuation of parts of the newly assembled crystal mush (or mushes) of the magma chambers (Fig. 6.5A). They can be considered as equivalent to the 'monotonous intermediates' summarised by Hildreth (1981) and exemplified by the Oligocene Fish Canyon and Monotony tuffs in the western USA (Bachmann et al., 2002; Maughan et al., 2002). 


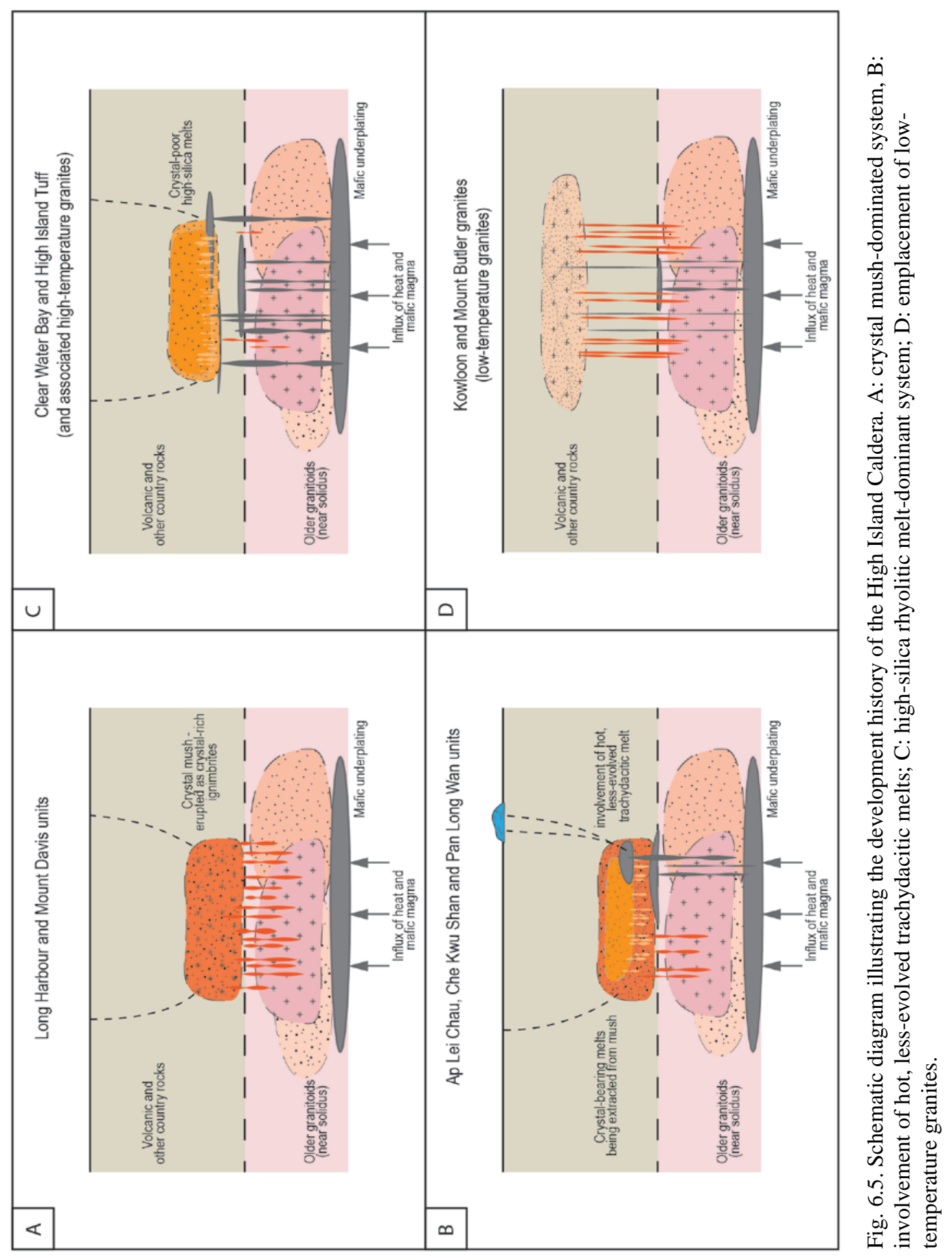




\subsubsection{Ap Lei Chau, Chek Kwu Shan and Pan Long Wan units}

The Ap Lei Chau and Che Kwu Shan ignimbrites (SIMS ages: 141.5 Ma and 141.8 Ma respectively, Table 6.1) of the RBVG contain zircons that yield very similar trace element signatures to the two earlier crystal-rich ignimbrites of the Long Harbour and Mount Davis formations. However, these older and younger units differ in their whole-rock geochemical composition (Sewell and Campbell, 1997; Sewell et al., 2000, 2012a). The Ap Lei Chau and Che Kwu Shan formations are trachyte to rhyolite in composition, with the latter generally having lower silica content than the Ap Lei Chau ignimbrites (Sewell and Campbell, 1997). Based on the geochemical characteristics of these units, Sewell and Campbell (1997) proposed that their magma sources were from the deeper part of the crust and migrated rapidly upward through crustal conduits without developing large magma reservoirs. In this study, however, it is envisaged that the compositions of the Ap Lei Chau and Che Kwu Shan units reflect a progressive involvement and interaction of mafic magma with the magma chamber(s). As the mafic influx heightened, melts were extracted from the crystal mush and/or crystal-rich root where zircons from the earlier granitic reservoir and/or basement rocks were released into the newly assembled melts (Fig. 6.5B). In Chapter 4, it is shown that zircon grains from these units are mostly characterised by "bright CL rim-dark cores", which could be correlated with high Ti, low-Hf, U, Th and total 3+ elements in zircons and imply the arrival of hotter and less-evolved melts shortly before the eruptions.

The observed zircon intra-grain variations from the Ap Lei Chau and Che Kwu Shan units are interpreted to be the end product of zircons being recycled from multiple sources from older Yanshanian granites (magmatic root) and basement rocks, then resorbed and overgrown again in less-evolved, hotter melts before the magma chambers were evacuated. Similarities in zircon trace element signatures coupled with comparable SIMS age data of the Shui Chuen O Granite with these two volcanic units (Fig. 6.3 and Table 6.1) suggest that they were genetically related. The most notable distinction is that the granitic zircons yield a larger range in Hf concentrations and lower Ti abundances compared with the volcanic zircons, interpreted to reflect crystallisation in the granite going to completion. Based on these observations, the Shui Chuen O Granite is inferred to be sourced from a magmatic root (probably earlier Yanshanian granites) common to the Ap Lei Chau and Che Kwu Shan ignimbrites. Part of the remobilised crustal materials assembled into the 
magma chamber(s), interacted with mafic melts, and led to the eruptions of the Ap Lei Chau and Che Kwu Shan ignimbrites; whereas at least a portion of the remobilised crustal materials remained at depth to form the Shui Chuen O Granite (Fig. 6.5B).

Following an increasing input from hotter melts, as earlier captured in some bright-CL zircon rims of the Ap Lei Chau and Che Kwu Shan ignimbrites (Fig. 6.5B), the Pan Long Wan trachydacite lava (SIMS age: 141.0 Ma) is interpreted as the product of the invigorated magmatic system. This interpretation is derived from several lines of evidence. (1) The similarities in age and trace element chemistry of the (recycled) zircon cores from the Pan Long Wan unit with the zircons from the RBVG systems strongly point to a common source. (2) The comparable trace element signatures of the CL-bright zircon rims from the Pan Long Wan, Ap Lei Chau and Che Kwu Shan units imply close connections with the involvement of less-evolved melts. (3) The presence of resorbed antecrystic zircon cores, inferred to be liberated from the crystal mush zone, in the Pan Long Wan magma suggests that the ascent, assembly and storage of the Pan Long Wan magma was geologically rapid (less than $\sim 10^{2}$ to $10^{3}$ years), or otherwise most of the inherited (antecrystic) zircon grains would have been completely dissolved back into the melt (cf. Miller et al., 2007; Charlier et al., 2010). From field evidence, the trachydacite lava extruded along a pre-existing fault structure (now mapped as the Tin Ha Shan Fault in Clear Water Bay Peninsula, Section 3.2.4.2) through the RBVG sequences. Field relationships observed in the Clear Water Bay Peninsula and Tung Lung Chau (island) to the south suggest that the Pan Long Wan trachydacitic lava vent exploited a forerunner to the Tin Ha Shan Fault and that the lava accumulated within a fault graben (Section 3.2.1.3).

\subsubsection{Clear Water Bay Formation and High Island Tuff}

The eruptions of the Clear Water Bay Formation and High Island Tuff are considered to represent a state where large body of crystal-poor rhyolite, probably sustained by underlying less-evolved crystal-richer magma, was developed beneath the High Island caldera system (Fig. 6.5C). The lack of inherited zircons in the analysed Clear Water Bay unit, and the High Island Tuff and post-High Island rhyolite (Section 4.5.4) can be explained by two possible scenarios: (1) any entrained antecrysts had all been re-dissolved in a zircon-undersaturated melt during the assembly and storage of the magma chamber; or

(2) the magmas were not assembled from partial melting of existing crust (i.e. not recycling any zircon phenocrysts), but generated directly from fractionation of a mafic, 
mantle-derived source. The later scenario is supported by the whole-rock geochemistry of the KSCVG units, which show fractionation trends in variation diagrams from intermediate to highly-evolved silicic compositions from the early Pan Long Wan trachydacite through the Clear Water Bay Formation to the High Island Tuff (Fig. 6.4B). In addition, the crystal content of the Clear Water Bay ignimbrites varies but is generally lower than that of the High Island Tuff (Strange et al., 1990), which can be explained by the gradual increase in crystallinity of the eruptible melts throughout the evolution of the magma chamber. The

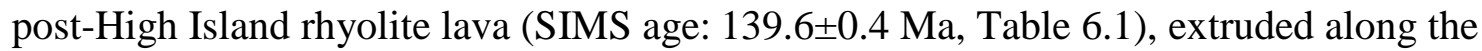
edge of the caldera, shares a similar chemical signature and zircon trace element patterns (Sewell et al., 2012a; Chapter 4) with the High Island Tuff, suggesting that the lava came from a common source.

The Sok Kwu Wan Granite and D’Aguilar Quartz Monzonite (SIMS ages: 140.8 Ma and 140.7 Ma, respectively) are considered to be comagmatic with the Clear Water Bay Formation and High Island Tuff on the basis of their similarity in zircon trace element characteristics and unimodal age patterns (Table 6.1). In addition, field relationships have shown that these two intrusive units are exposed close to the caldera margin of the High Island caldera complex and inferred to have been intruded along the caldera bounding faults (Chapter 3). The SIMS age data suggest that the two intrusive units were emplaced in close association with the KSCVG volcanic activities (Table 6.1). The Sok Kwu Wan Granite and D’Aguilar Quartz Monzonite show distinct zircon trace element patterns in contrast with the "high-temperature" granites. The most obvious difference is the narrower range in Hf concentrations, implying either a relatively limited degree (time?) of melt fractionation during zircon growth in the magma bodies, or that the magmas completely solidified within a narrow span of melt evolution.

\subsubsection{Kowloon and Mount Butler granites}

The Kowloon and Mount Butler granites both contain signatures of inheritance in their zircon age spectra that suggest recycling of pre-existing crustal materials that included the earlier Yanshanian granites and much older basement rocks (Table 4.5). The whole rock chemistry and zircon trace element signatures (Hf, U, Th, Ti concentrations) all confirm that the zircons in these granites were crystallised from highly-evolved melts at or near solidus temperature (Figs. 6.3 and 6.4A). As discussed in Section 6.5, the Kowloon and Mount Butler granites, characterised as "low-temperature” granites, probably never 
supported any significant eruption products. Their cooling and crystallisation is taken to indicate the final stages of shallow crustal magmatic activity in the High Island caldera system (Fig. 6.5D).

\subsubsection{Overall evolutionary model}

Zircon chemistry from both the volcanic and plutonic records indicate the presence of two groups of volcanic-plutonic products in the High Island caldera magmatic system: one of which is represented by the RBVG and "low-temperature" granites, and the other by the KSCVG and "high-temperature” granites (Sections 6.3 and 6.4). The first group is interpreted to reflect a cooler system, whereas the second group involved hotter melts. The mechanisms that have driven the production of different types of volcanic and granitic rocks in the High Island caldera magmatic system, however, cannot be fully established in this study, because the units considered in this thesis only represent a series of snapshots of the $\sim 3$ Myr evolutionary history of the entire magmatic system. In addition, the resolution is limited by the precision of the dating techniques and the fact that large amounts of the geological record have already been removed by erosion.

Two possible scenarios are proposed here for the development of the High Island caldera magmatic system (Fig. 6.6). First, the magmatic system can be interpreted as a single domain that oscillated in temperature, manifested by the varying degrees of involvement of hotter melts. In this scenario, the two sets of volcanic-plutonic products can be viewed as the records of a series of random snapshots of the fluctuating magmatic system.

Alternatively, the High Island caldera magmatic system may be considered as comprising two interacting domains of contrasting temperature and broad compositional characteristics. The lower temperature domain dominated the system at the initial development stage (recorded, for example, by the Mount Davis and Long Harbour ignimbrites), and was slowly overtaken by the higher-temperature domain that eventually produced the highsilica rhyolites of the KSCVG. Normally, crystal-rich monotonous intermediates are considered to be hotter than high-silica rhyolite in the crystal-mush model (e.g. Hildreth, 1981, 2004). The apparently contradictory observation of a cooler magmatic system for generating the crystal-rich Mount Davis and Long Harbour ignimbrites, may imply that these units are not "monotonous intermediates" in a strict sense. 


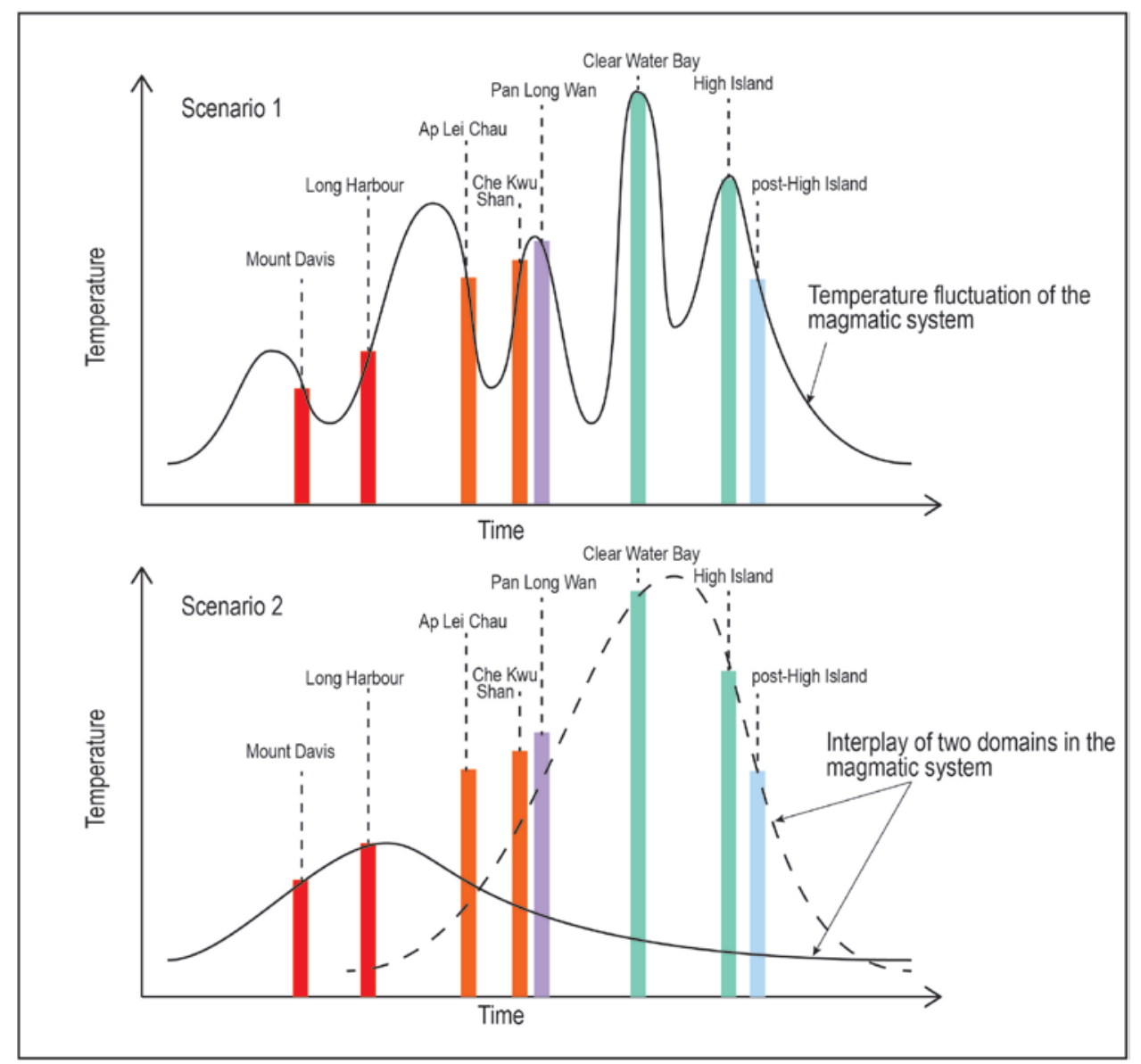

Fig. 6.6. Schematic diagram illustrating the two possible evolutionary models of the High Island caldera magmatic system. Scenario 1 (upper panel) shows the fluctuating temperature of a single domain; Scenario 2 (lower panel) show the interplay of two domains of contrasting temperature and/or broad compositional characteristics.

\subsection{New perspectives on the High Island caldera complex}

Here, the proposed nested caldera complex model for the High Island caldera complex in Sewell et al. (2012a) is revisited in light of the spatial and temporal relationships of the volcanic-plutonic units established from the field evidence gathered for this thesis (see Chapter 3), as well as from the SIMS zircon U-Pb age data (Chapter 4). The implications of the genetic connections evidenced by zircon trace element analyses (Chapter 4, and discussion earlier in this chapter) and the post-volcanic thermal history based on the findings of thermochronology studies (Chapter 5) are discussed below to present a new perspective in our understanding of the High Island caldera complex.

The anatomy of the High Island caldera complex has been reviewed and revised, based on the findings of my field studies. First, the structural relationships of the RBVG units are more complex than previously considered, in particular the interpretation of the volcanic 
strata in the southern part of Hong Kong Island (Section 3.2.1), where the volcanic successions are dipping gently at various angles and orientations (Chapter 3). Previously it was inferred that the strata in southeast Hong Kong Island represented the deeply foundered portions of the detached caldera floor (Sewell et al., 2012a), although it is clear from the field relationships that their intrusive contacts with the Kowloon and Mount Butler granites generally dip at low angles (Chapter 3). Second, at least two small volcanic depressions have been identified, nested within the High Island caldera complex, where the Long Harbour and Che Kwu Shan ignimbrites were locally ponded (Sections 3.2.1.1 and 3.2.1.3). Both of these volcanic basins were probably formed between major graben faults, now mapped as the Cheung Sheung-Chek Keng, Wong Chuk, Jordan Valley and Tin Ha Shan faults (Fig. 3.10). Third, the inclination of the columnar-jointed High Island Tuff, with the development of kink-bands due to slumping during consolidation of the ignimbrite layer, was formed soon after its deposition while the tuff was still hot and plastic (see Chapter 3). The tilting of the tuff is therefore considered to be syn-eruptive, and not related to any subsequent regional crustal movement (see discussion below).

The U-Pb dating of zircons from the RBVG and KSCVG presented in Chapter 4 have demonstrated that these two mapped volcanic groups of the High Island caldera complex were not generated during two temporally distinct magmatic episodes, but represent a series of volcanic activities between $\sim 143$ and 140 Ma. In addition, the new SIMS ages of the Kowloon and Mount Butler granites imply that these two granitic plutons were emplaced at 139-138 Ma (Table 6.1). The temporal gap and dissimilarity observed in the zircon chemistries (Section 6.3.2 above) are taken to mean that that the two plutons were not coeval with the eruptions of the KSCVG ( 141 Ma) and unlikely to be co-genetic. The field relationships and the trace element patterns have pointed to the fact that the two granitic plutons were crystallised from the latest-stage, highly-evolved, cooling melts, and emplaced within 2-3 km of the surface into the base of the RBVG units.

In contrast, the Sok Kwu Wan Granite and D’Aguilar Quartz Monzonite ( 140 Ma) are demonstrated to be coeval to and probably cogenetic with the KSCVG units (Chapter 4 and Section 6.3.2). The two plutons (stocks) were probably the remaining magma of the High Island caldera system, which had exploited and were emplaced along the ring fractures following caldera collapse. Thus, the caldera boundary can now be interpreted to be delineated by the intrusive bodies of the Sok Kwu Wan Granite, D’Aguilar Quartz 
Monzonite and associated porphyry dykes ( 140 Ma), which are coeval and probably cogenetic with the KSCVG units. This new interpretation implies that the structural size of the High Island caldera is larger than previously considered, up to $320 \mathrm{~km}^{2}$, and covers much of southern Hong Kong (Fig. 6.7). The caldera is roughly elliptical shaped with a NE-trending long-axis. The High Island caldera system is inferred to have been underlain by a magma chamber equal to or larger than the areal extent of the caldera structure itself.

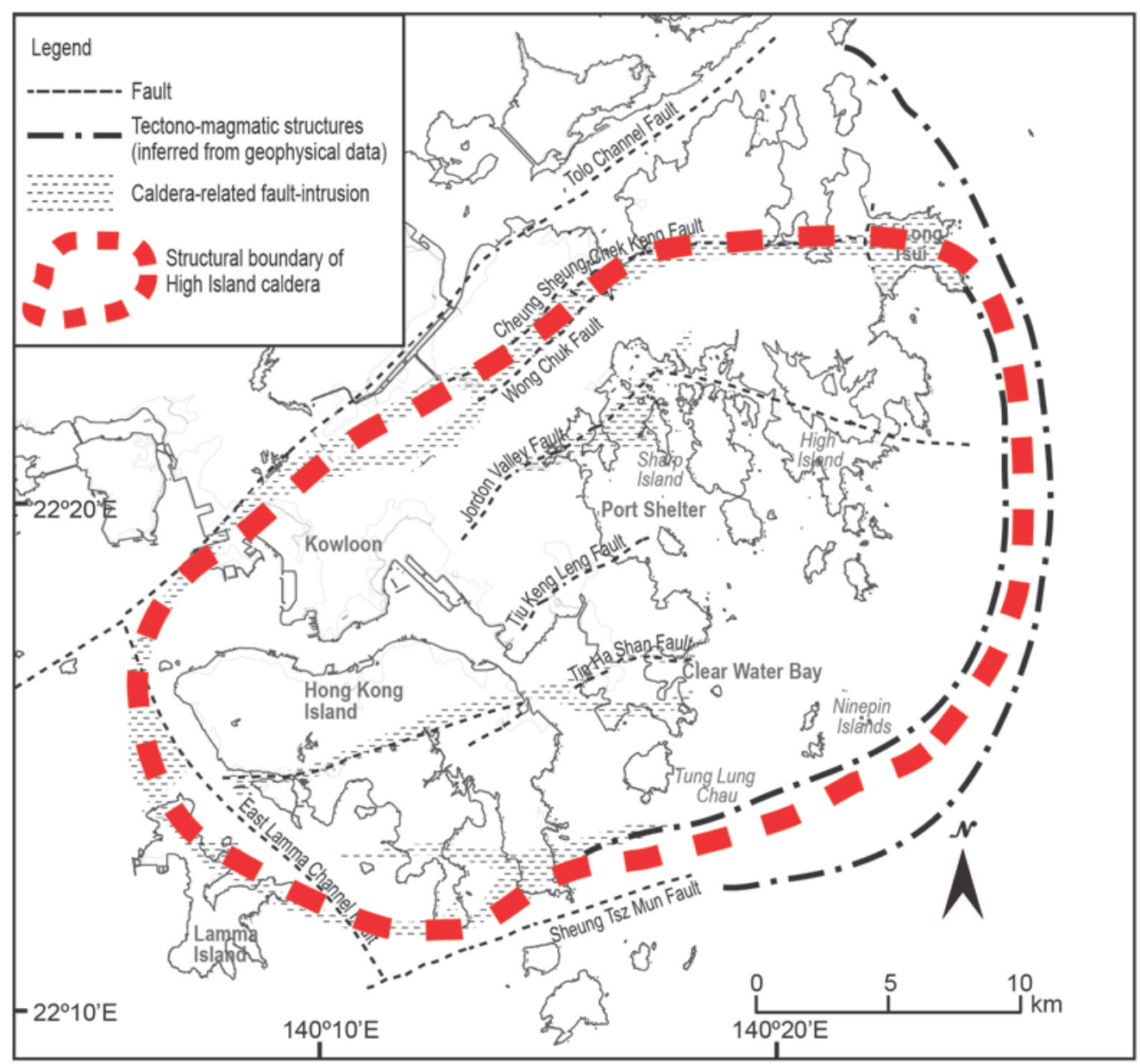

Fig. 6.7. Tectono-magmatic structures of the nested High Island caldera complex in southeast Hong Kong, based on new field observations (Chapter 3) and modified after Sewell et al. (2012a). 
Finally, the findings of the low-temperature thermochronological study (Tang et al., 2014: Chapter 5) have shown that the late Mesozoic volcanic-plutonic assemblages and postvolcanic sediments in Hong Kong had experienced the same thermal history since 120 Ma. Together, the rock bodies experienced post-emplacement heating to temperature of $\geq 250{ }^{\circ} \mathrm{C}$, interpreted to be the combined thermal effect as a result of heating owing to burial plus the effects of an elevated geothermal gradient driven by continuing Yanshanian magmatism in the region. The uniformity of the thermal histories recorded by all the rock units studied with thermochronology demonstrates that there has been no overall crustal tilting of the High Island caldera complex. The youngest exposed granitic plutons were emplaced within $\sim 2-3 \mathrm{~km}$ of the surface (based on observed thicknesses of the RBVG volcanic sequences) and brought to the surface as part of the overall exhumation history of the Hong Kong area.

The overall interpretations of the field evidence, zircon $\mathrm{U}-\mathrm{Pb}$ age data, volcanic-plutonic connections evidenced from zircon trace element patterns, and the findings of thermochronology studies suggest that the proposed model of an overall tilting of nested High Island caldera complex is no longer valid. The structure of the High Island caldera complex is instead re-interpreted here to be associated with asymmetric caldera collapse towards the east, such that the High Island Tuff unit and the underlying strata were deposited on the caldera floor and tilted syn-eruptively, while the RBVG strata on Hong Kong Island were faulted and the fault blocks moved up and down relative to each other, but without overall tilting of the crust. The exhumation of Kowloon and Mount Butler granites is considered to be side by side with the RBVG and KSCVG volcanic strata.

\subsection{Comparisons and contrasts with global and regional analogues}

Paired volcanic-plutonic assemblages associated with caldera volcanism have been identified in some ancient magmatic systems, where ignimbrite sheets and their subvolcanic roots have been exposed by tectonic uplift and erosion. Four regional and global examples, broadly similar to the late Mesozoic magmatism in Hong Kong in terms of dimensions, eruptive volumes, lithologies and longevities, are summarized here for comparison. 


\subsubsection{Spirit Mountain Batholith, western USA}

The Miocene Spirit Mountain Batholith (Nevada) case study employed zircon trace elements to investigate the magmatic evolution of a large granitic system (Claiborne et al., 2006; 2010). The intrusion comprises high silica leucogranites capping voluminous granite cumulates, and represents a silicic system active over a 2 Myr period (Claiborne et al., 2006; 2010; Walker et al., 2007). The field relationships, and textural and petrographic characteristics of Spirit Mountain (Walker et al., 2007) are comparable to the granites (Kowloon, Mount Butler and Sok Kwu Wan granites) of the Lion Rock Suite studied here. Here, the zircon trace element patterns of the volcanic and intrusive rocks from Hong Kong are plotted with the ranges of those of the Spirit Mountain granites and Lion Rock Suite granites illustrated for comparison (Fig. 6.8).

Overall, the zircon trace element data from the Hong Kong magmatic rocks overlap, but yield a wider range in Hf concentrations, when compared with those of the Spirit Mountain granites. The Ti concentration in granitic zircons from Hong Kong is generally lower than those of Spirit Mountain. The most obvious disparity is the generally higher $\mathrm{U}$ content in the magmatic zircons from Hong Kong, and therefore, a much lower Th/U ratio (generally $<1.5$, versus $1-5$ for Spirit Mountain). In addition, the $\mathrm{Yb} / \mathrm{Gd}$ ratio is commonly $<40$ and shows a positive trend with Hf in Hong Kong zircons, whereas the Spirit Mountain granites yield zircons with a larger range in $\mathrm{Yb} / \mathrm{Gd}$ ratio that can be $>70$. As pointed out by Barth et al. (2013), the Th/U and $\mathrm{Yb} / \mathrm{Gd}$ ratios (and $\mathrm{U} / \mathrm{Yb}$ ratio) in zircons reflect the influence of mantle-derived magmas and/or crustal sources during the evolution of arc magmas. As pointed out in Section 4, the two diverging positive trends in the molar ratio of (total 3+ elements)/P versus Hf plot from Hong Kong zircons reflect the influence of sector zoning. Zircon trace element data of the Spirit Mountain, however, show a generally linear trend in the same diagram, and may be explained by the approach used by Claiborne et al. (2010) of selecting analytical spots preferentially on the tips of the zircon crystals.

The overall zircon trace element patterns of the Hong Kong igneous rocks studied here are characterised by low $\mathrm{Th} / \mathrm{U}$ and $\mathrm{Yb} / \mathrm{Gd}$ ratios, which reflect the higher $\mathrm{U}$ concentration in source and additional involvement of continental crust than in the case of the Spirit Mountain batholith. The lower Ti concentrations in the former examples could also imply a generally cooler melt temperature of the magmatic systems, possibly linked to melts with a higher water activity. 

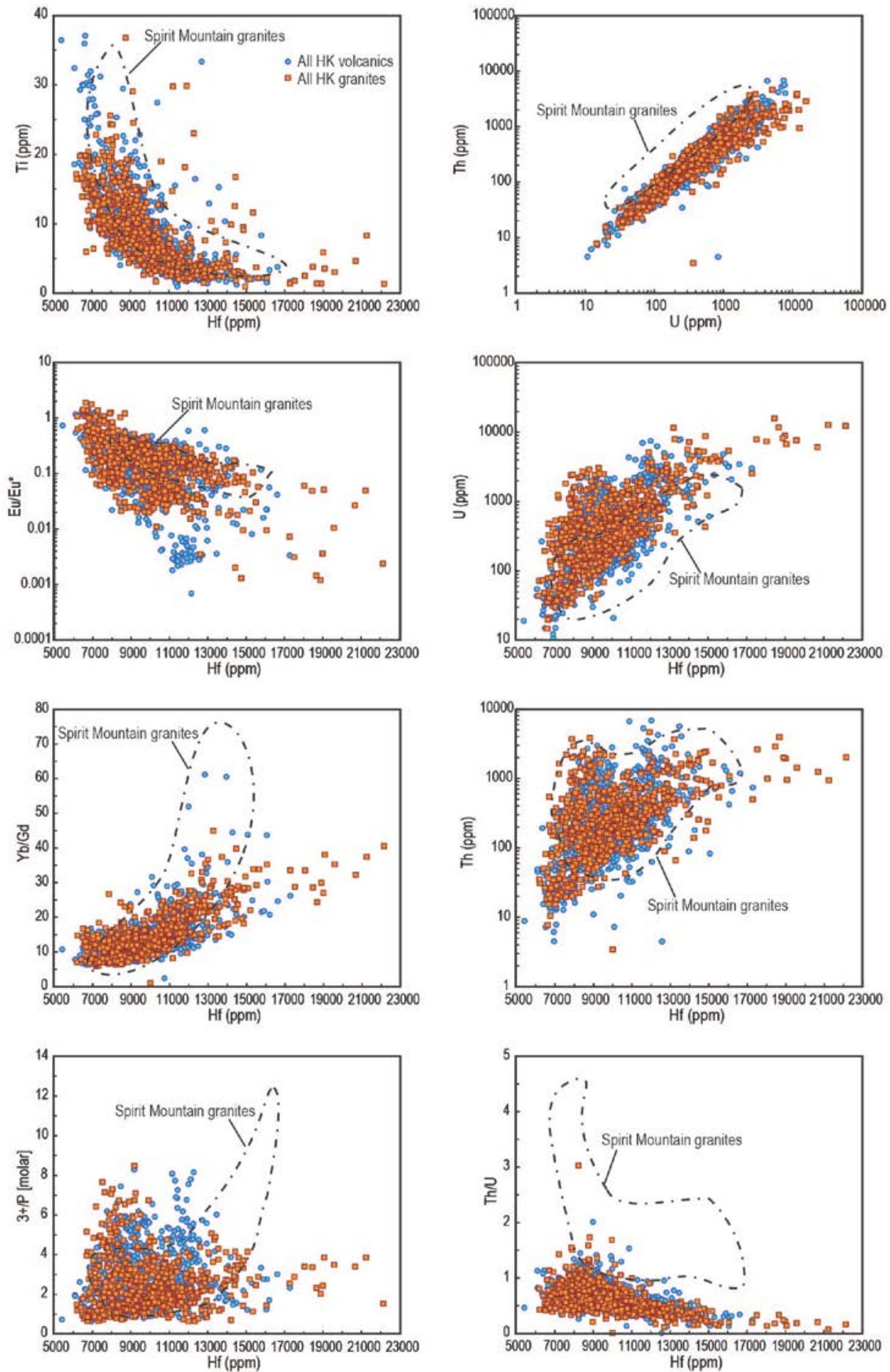

Fig. 6.8. Selected zircon trace element plots of all volcanic and intrusive units from Hong Kong. Dash lines illustrate the range of zircon trace element data from the Spirit Mountain Granites after Claiborne et al. (2006; 2010). 


\subsubsection{Lower Sidewinder volcanic series, central Mojave Desert, USA}

The Middle Jurassic Lower Sidewinder volcanic series is exposed in the central Mojave Desert, California, and represents a close analogue of the Early Cretaceous volcanic sequences in Hong Kong. The preserved sequence is $>4 \mathrm{~km}$ thick, and includes explosive volcanism from a nested caldera complex (Schermer and Busby, 1994; Schermer et al., 2002; Fohey-Breting et al., 2010). Based on field mapping, Schermer and Busby (1994) identified four major phases of caldera-forming volcanic eruptions. These eruptions produced tens to hundreds of cubic kilometres of ignimbrites that were, from the oldest to youngest, crystal-poor rhyolite followed by crystal-rich rhyolite to dacite, then crystal-rich biotite-dacite and finally lithic-bearing, crystal-rich dacite (Schermer and Busby, 1994). Subsequently zircon $\mathrm{U}-\mathrm{Pb}$ geochronology of the units suggested that volcanic activities lasted for 30 Myr, between 180 to 150 Ma (Schermer et al., 2002; Fohey-Breting et al., 2010). Multiple and nested calderas, of $\sim 20-25 \mathrm{~km}$ diameter, were recognised based on field evidence, including (1) the distribution of thick, monotonous intracaldera ignimbrite sheets, (2) outcrops of mega-breccias, which were inferred to reflect slumping of caldera walls, and (3) preservation of steeply dipping faults intruded by porphyritic dykes, which were inferred as caldera-bounding ring fractures and volcanic conduits (Schermer and Busby, 1994). These features are similar to those that have been used for delineating caldera bounding faults of the nested caldera complex in Hong Kong (Sewell et al., 2012a; this thesis). In addition, Schermer and Busby (1994) proposed that the continuing Middle Jurassic crustal extension, in connection to regional normal faulting, tilting and broadly coeval intrusions of porphyritic quartz monzonite plutons, was the key to the preservation of the Lower Sidewinder volcanic series.

\subsubsection{Glencoe caldera-volcano complex, Scotland}

The Silurian-Devonian Glencoe Caldera in Scotland is probably one of the earlieridentified and better-known examples of an ancient volcanic-plutonic complex that has been studied and mapped extensively (e.g. Clough et al., 1909; Bailey, 1960; Moore and Kokelaar, 1997; 1998; Kokelaar and Moore, 2006). The volcanic sequences comprise seven major silicic ignimbrite sheets, mostly of rhyodacitic and rhyolitic compositions, interbedded with andesite lavas and sedimentary units, all of which were ponded within the depressions formed during caldera-collapse (Kokelaar and Moore, 2006). The entire preserved succession is $\sim 3 \mathrm{~km}$ thick, which represents a period of 1-2 Myr of caldera- 
related magmatism (Kokelaar and Moore, 2006). The development of rectilinear calderarelated ring-faults was considered to have been strongly influenced by regional structures, which were activated during piecemeal caldera collapse with a cumulative subsidence of $\sim 1.4$ km (Moore and Kokelaar, 1997, 1998; Kokelaar and Moore, 2006). The ring-fault systems were associated with intrusive stocks and exploited locally by dykes (i.e. fault intrusions, including gabbro, diorite, tonalite, monzonite and granite), which delineate an incomplete and truncated ellipse-shaped caldera of $\sim 8 \mathrm{~km}$ x $14 \mathrm{~km}$ (Kokelaar and Moore, 2006). Granitic plutons, now exposed in the southern part of the caldera complex, were considered to be shallowly emplaced (within 1-2 km of the original surface) during or slightly after the fault intrusions (Kokelaar and Moore, 2006). Two features of the Glencoe complex have implications for my interpretation of the evolution of the High Island Caldera. Firstly, the tilting of volcanic successions in Glencoe Caldera, as in the High Island Tuff situation in Hong Kong, was demonstrated to have occurred during the caldera collapse, rather than during post-volcanic tectonic events. Secondly, the granitic plutons associated with the Glencoe volcanic complex, which were shallowly emplaced and probably reflected continuous magmatic activities after the active volcanism, represent an analogue to the Kowloon and Mount Butler granites in Hong Kong.

\subsubsection{Xiangshan volcanic-plutonic complex, southeast China}

The Early Cretaceous Xiangshan volcanic-plutonic complex is interpreted as a resurgent caldera of $26 \mathrm{~km}$ long by $16 \mathrm{~km}$ wide in northeast Jiangxi Province (Jiang et al., 2005). This is one of the few examples of a late Mesozoic volcanic-plutonic complex in the SCMB that has been documented in detail. Two stages of caldera-related volcanism were identified, comprising an early stage of fissure-fed dacite to rhyolitic welded ignimbrite eruptions, followed by caldera-forming rhyolitic ignimbrite eruptions (Jiang et al., 2005; Yang et al., 2011: LA-ICP-MS zircon U-Pb ages of 136 \pm 1 Ma, 135 $\pm 1 \mathrm{Ma}, 2 \sigma)$. Contemporaneously emplaced monzogranite porphyry and quartz monzonite (137 $\pm 1 \mathrm{Ma}$ and 136 $\pm 1 \mathrm{Ma}, 2 \sigma$, respectively, Yang et al., 2011), exposed at the northern margin of the caldera, were considered as the sub-volcanic equivalents of the erupted silicic ignimbrites for the two volcanic phases respectively (Jiang et al., 2005). The volcanic activities lasted from 137-132 Ma (Yang et al., 2011), a similar duration to individual magmatic episodes in Hong Kong. In addition, Yang et al. (2011) proposed that the magmatic system comprised a shallow felsic magma chamber fed by a deeper source that was underplated by 
high-K and -Mg mafic magmas. Their simple plutonic model was based on whole-rock geochemical and isotopic data from the volcanic-plutonic rocks and the mafic enclaves within the plutons.

\subsection{Implications for large silicic magmatic systems}

There are two main schools of thought on the volcanic-plutonic connections of large silicic systems. On one hand, large silicic magmatic systems are commonly described through the generalised crystal mush model, in which volcanic rocks and sub-volcanic plutons are considered to be genetically related and share a common magmatic origin (Bachmann and Bergantz, 2004; Hildreth 2004; Hildreth and Wilson, 2007). The crystal mush model suggests that the sub-volcanic granitic plutons represent in part either the completely solidified non-erupted crystal mush, or the remnant, crystal-dominated part of the system after the withdrawal of rhyolitic melt (e.g. Smith, 1979; Hildreth, 1981; Shaw, 1985; Bachmann et al., 2002; Bachmann and Bergantz, 2004). Contrasting views on the relationships between large-scale silicic ignimbrites and granitic batholiths have been raised, for example by Coleman et al. (2004) and Glazner et al. (2004), who argued that voluminous ignimbrites are not directly related to large granite batholiths. It has been considered instead that the large-scale ignimbrite eruptions are supported by transient magma chambers that are assembled very rapidly at shallow crustal levels during periods of intense heat influx (Glazner et al., 2004; Lipman, 2007; Miller, 2008).

Two aspects of large silicic magmatism systems are discussed here in the light of my data and observations from Hong Kong: (1) how large magmatic chambers are established, and what are the volcanic and plutonic connections; and (2) the timescale of development of magmatic chambers based on various geochronological data.

\subsubsection{Volcanic-plutonic connections}

In this study, revised linkages of volcanic and plutonic units in the High Island caldera complex are established based on the zircon trace element signatures and geochronological data of these units. The generation of volcanic rocks ranging from crystal-rich dacitic to rhyolitic ignimbrites (of the RBVG) to trachytic to high-silica rhyolite (of the KSCVG), is inferred to represent the evacuation of different parts (in space) or development stages (in time) of the magma chambers (the mush zones or rhyolitic melts extracted from the mush). 
The divergence in volcanic lithologies also points to separate modes of volcanic-plutonic connections in large silicic systems. These different modes of volcanic-plutonic connections can co-exist and spatially overlap, as in the case of the High Island caldera complex.

The magma chamber(s) of the two earlier units of the RBVG, i.e. Long Harbour and Mount Davis formations, which are characterised by their high phenocryst contents and relatively high proportions of inherited zircons, are inferred to have been sourced from partial melting of Yanshanian granites and older basement rocks, and assembled into a crystal-dominated, long-lived magma body. An eruptible, rhyolitic melt-dominant cap might not have developed at this stage, as there is no record of any crystal-poor rhyolitic volcanic rock from this period. Subsequent eruptions of the RBVG show evidence for additional input from less evolved, hotter sources related to the Ap Lei Chau, Che Kwu Shan and Pan Long Wan systems. These volcanic units are linked through their abundance of inherited zircon cores with the earlier 'cold' granites, as inferred from the similarities in zircon trace element patterns and age data. The volcanic-plutonic links are considered to have been indirect, through recycling in younger volcanic units of older, contrasting zircons from a much larger scale magmatic reservoir underneath the systems. The Shui Chuen O and Kowloon and Mount Butler granites (RBVG linked) are inferred to represent part of the remobilised crustal materials that slowly cooled and solidified subsequent to the major respective eruptive phases.

The less-evolved source or sources related to the younger units of the RBVG are inferred to be linked with crustal extension and upwelling of mantle-derived magma that continued to be important in the subsequent activity related to the eruptions of the KSCVG units. The Hong Kong case supports the idea that an influx of hotter magma to shallow crustal levels is probably crucial to development of voluminous high-silica rhyolite melts (e.g. Bachmann et al., 2007; Lipman, 2007; de Silva and Gregg, 2014). The KSCVG units and the plutons of Sok Kwu Wan Granite and D’Aguilar quartz monzonite are considered as genetically linked. The volumes of these intrusive bodies, estimated from the extent of their exposures, are relatively small when compared with their eruptive counterpart, i.e. the High Island Tuff. These intrusions, from their bulk compositions (Sewell and Campbell, 1997, 2001) and zircon age spectra are considered to be "high-temperature” granites. These remaining magmas were emplaced along the major volcanic conduits (now the caldera 
bounding structures) and solidified shortly after (from the SIMS age data) caldera development.

This study suggests that some granites (such as the Kowloon and Mount Butler granites) do not have a volcanic equivalent, either through it being small enough to have been completely eroded away or through there not having been any volcanic expression. Inferred from the zircon trace element patterns of the Kowloon and Mount Butler granites, the associated "magmatic chambers" of these granites were likely to be dominated both spatially and temporally by an interlocking crystal mush, within which melt evolution was sluggish and prolonged through relatively ineffective feldspar fractionation (Fig. 6.3).

\subsubsection{Lifespan of silicic magmatic systems}

Previous geochronological studies of large granitic batholiths in the western USA have led to the proposal that those batholiths were composites of smaller intrusions that assembled over several million years or more (e.g. Coleman et al., 2004; Glazner et al., 2004; Matzel et al., 2006; Walker et al., 2007; Lipman and Bachmann, 2015). These studies asserted that the apparent spans of millions of years of zircon ages obtained from the batholiths studied provided evidence for prolonged, incremental assembly of granitic batholiths. This incremental view of batholith growth has posed questions on the volcanic-plutonic connections inferred from the crystal mush model because the proposed stepwise growth of batholiths implies that the amount of melt that exists at any point of time would be too small to support large-scale ignimbrites under the same systems (Coleman et al., 2004; Glazner et al., 2004).

The late Mesozoic volcanic-plutonic assemblages in Hong Kong are of similar age to the Sierra Nevada Batholith in the western American Cordillera, and present a valid comparator. In the case of Hong Kong, over 20 mappable granitic plutons, stocks and dyke swarms were emplaced over a period of 26 Myr (Davis et al., 1997; Sewell et al., 2000; 2012b; this study). These granitic rocks are spatially superimposed, but are not necessarily genetically related. From the findings of zircon dating carried out in this study (Chapter 4), several of the dated plutons including, for instance, the Kowloon and Mount Butler granites (outcrop extent of $\sim 68$ and $25 \mathrm{~km}^{2}$, respectively; Sewell et al., 2000) yielded inherited zircons that were several to $>20$ Myr older that their emplacement ages (Section 6.3.3). Instead of interpreting those time spans as the duration of pluton growth, the age 
data from Hong Kong are better explained as the overall result of repeated recycling of igneous rocks from the earlier magmatic episodes. This contrasting interpretation clearly illustrates the need for reconsideration of the definition of zircon xenocrysts and antecrysts, and how to differentiate them for the purpose of understanding the evolution history of a magmatic system, within the constraints imposed by the precision of dating techniques.

In addition, the estimated long-term emplacement rate of composite plutons, as inferred from geochronological data and thermal modelling of heat transfer of the granitic system, appears to be too low (in an order of $10^{-3} \mathrm{~m} / \mathrm{yr}$ ) to sustain the development of any large magma chambers (Colemann et al., 2004; Glazner et al., 2004; Annen, 2009a). The geochronological data from my work (Chapter 4) show that the modal peaks in ages from both the granites yielding multiple age components and from the units showing unimodal age distributions commonly match the ages of the major volcanic-magmatic episodes identified earlier by Davis et al. (1997) and Sewell et al. (2012b). The coincidence of age peaks suggests that there were periods of increased rates of zircon growth, reflecting the pulsed nature of the emplacement and crystallisation of the intrusive units. This pulsed construction of large granitic bodies has been demonstrated in other case studies (e.g. Walker et al., 2007; Lackey et al., 2012), and implies that the construction of large granitic batholiths need not occur steadily or continuously. Therefore, it would be inappropriate to determine a long-term average emplacement rate for the growth of granitic bodies for the Hong Kong case, because such average timescales do not meaningfully reflect the specific timescale of any magmatic processes that operated in the system. In addition, such averaged growth rates are inappropriate to decide whether or not a given plutonic system ever gave rise to a substantial volume of volcanic products.

The age data from the High Island caldera system also show that the lifespan of large silicic magmatic systems within this constrained area of the broader SCMB extended for over several million years (Chapter 4). The prolonged development of the system is manifested by the presence of large, crystal-dominated magma reservoir (root). The good match in ages of, for instance, the KSCVG and the Sok Kwu Wan Granite and D'Aguilar Quartz Monzonite in the High Island caldera complex, implies that both of the eruptive and intrusive units were formed during sporadic periods of relatively intensive magmatic activities. This interpretation is at odds with the suggestion by Lipman (2007) who proposed that large volcanic eruptions occur during magmatic "flare-ups", i.e. higher 
magmatic influx, whereas plutonic rocks emplace and grow in the waning stages of magmatism. In short, the emplacement of most granitic plutons in Hong Kong occurred during pulsed, more intense magmatic influxes which might have also been related to the building up of large eruptible magmatic chambers leading to major eruptions.

\subsection{Insights into the evolution of Yanshanian magmatism}

The findings of this study provide a number of insights into the temporal framework and the evolutionary history of the extensive Yanshanian magmatism in southeast China. The prolonged 100-Myr duration of Yanshanian magmatism has been broadly subdivided into two phases, i.e. 'early' and 'late' Yanshanian, and the transition between the early and late events was generally considered as the manifestation of an abrupt change in either the local or regional tectonic regimes, leading to a hiatus of magmatic activity (e.g. Charvet et al., 1994; Zhou and Li, 2000; Li et al., 2004; Zhou et al., 2006; Li and Li, 2007). The proposed change in tectonic setting included, for instance, a transition from compression to extensional/continental rifting settings, subduction slab roll-back, a change in direction and/or angle of the subducting plate, or the arrival of a slab window (e.g. Li and $\mathrm{Li}, 2007$; He and Xu, 2012; Li et al., 2012; L. Liu et al., 2012; Jiang et al., 2015). However, these proposed tectonic interpretations and the timing of such events could only be applied to the particular locations in question, but not to the entire region in general (e.g. Li et al., 2004; Jiang et al., 2005, 2009; Li et al., 2007; He et al., 2009; He and Xu, 2012; L. Liu et al., 2012; Li et al., 2014).

In Hong Kong, the magmatic fluxes generating large-scale silicic eruptions and granitic plutons occurred episodically and were separated by long periods (several to $>10$ million years) of relatively quiescence before the next major magmatic phase (Chapter 4). A large quantity of latest zircon $\mathrm{U}-\mathrm{Pb}$ geochronological data recently made available from the exposed granitic plutons and volcanic units in other parts of the SCMB also show similar observations of the pulsatory character of magmatic activities (L. Liu et al., 2012; Y. Wang et al., 2012; Li et al., 2014). The zircon dating work presented in this thesis has demonstrated the common occurrence of recycling of zircons (crustal materials) in successive phases, leading to complications in the interpretation of crystallisation and eruption ages of the granitic and plutonic units. However, the existence of similar inheritance records has rarely been reported or discussed in existing geochronological studies of the SCMB (e.g. L. Liu et al., 2012). The rarity of such information could be 
explained by either inherited zircon being generally absent in most of the volcanic-plutonic rocks, or that inheritance age data have been neglected in such studies (e.g. age data have not systematically been collected from cores versus rims of grains), or that inheritance is obscured in the analytical techniques. If the last two explanations are valid, the actual lifespan of these large silicic magmatic systems collectively forming the SCMB in southeast China is likely to be more complex than currently considered. In essence, all of these arguments suggest that the simple, clear-cut temporal sub-division of the Yanshanian event is not practical and cannot be applied to the entire magmatic arc.

The petrogenesis and the tectonic evolution of the Yanshanian granitic rocks have been generally inferred from their whole rock geochemical characteristics, Sr-Nd isotopic compositions or, more recently, zircon Hf isotopes (e.g. Pei and Hong, 1995; Wang and Ren, 1996; Chen and Jahn, 1998; Chen et al., 2000; Li, 2000; Wang and Zhou, 2002; Wong et al., 2009; Jiang et al., 2010; He and Xu, 2012; Li et al., 2012; Hong et al., 2013; Huang et al., 2013; Li et al., 2014; Zhao et al., 2015). Similarly to the interpretation of age data, the findings of some of these studies, focused on different confined areas in the southeast China, have yielded inconsistent or ambiguous conclusions (e.g. Li, 2000; He and Xu, 2012; Y. Wang et al., 2012; Liu et al., 2014). However, the findings of zircon trace element analysis and age determination from this study (Chapter 4) clearly demonstrate that (1) crustal recycling of basement rocks, from Proterozoic to Mesozoic ages, has played an important role in the development of large silicic magmatic systems in Hong Kong, and (2) the spatially overlapping volcanic rocks and their sub-volcanic granitoids were generated through multiple magmatic episodes showing evidence for changeable interactions of the crust and mantle-derived magmas. Therefore, the interpretations of tectonic or geodynamic evolution solely based on geochemical data, such as those in the previous studies (cited above) in southeast China, may be questionable. In addition, given the close temporal connection of the magmatic activities around the Pacific margins and within the palaeo-Pacific Plate (Section 6.10), I consider that the magmatic activities were probably linked to the dynamics of the palaeo-Pacific Plate. As a result, a drastic change in tectonic regimes, from subduction to continental rifting, during the evolution of the Yanshanian events, as suggested by many previous studies (e.g. Jiang et al., 2006; He and Xu, 2012; Liu et al., 2012; Li et al., 2014), is considered inherently unlikely. 


\subsection{Southeast China Magmatic Belt to circum-Pacific silicic provinces}

The record of Mesozoic Yanshanian magmatism seen in Hong Kong and southeast China has close parallels with other large-scale silicic igneous provinces in the Pacific margins. The linkage is particularly obvious in the fact that the occurrence of intense magmatic pulses, generating voluminous ignimbrites and granitic plutons of the Yanshanian event were broadly contemporaneous with the emplacement of some large granitic batholiths in the circum-Pacific Cordillera (Section 5.5.5). These granitic provinces include, for example, the Coast Mountain Batholith in Canada, Sierra Nevada batholith in the USA, the Coastal Batholith in Peru and the Median Batholith in New Zealand. The pulsed and transient nature of magmatic activities of these silicic provinces was noted by Bryan et al. (2002). More recently, DeCelles et al. (2009) interpreted the apparent cyclic temporal characteristics of the large granitic batholiths in the America Cordillera as reflecting the repeated evolutionary stages of the subduction-related, strongly convergent continental margin. They proposed that each cycle, lasting for 25-50 Myr, would comprise a period of high magmatic flux associated with voluminous ignimbrite eruptions and emplacement of large granitic batholiths, followed by lithospheric delamination, and then hinterland extension and propagation of thrust belts. Their proposal, however, neglected a key factor, the driving force of these geological events, that is the subduction of the palaeo-Pacific Plate along the continental margin.

A brief summary of some notable geological events is given here to illustrate the temporal links and possible cause-and-effect of the development of the circum-Pacific magmatic belts with the evolution of the Pacific Plate, although a detailed tectonic reconstruction of the Pacific Plate is outside the scope of this thesis (see Seton et al., 2012, for a detailed account). The rapid growth of Pacific Plate began in the Middle Jurassic ( 190-180 Ma) following the breaking up of the Pangea supercontinent, and is inferred to have begun the inception of subduction along the continental margin (Anderson, 1994; Bartolini and Larson, 2002; Seton et al., 2012). This period coincides well with the earliest Yanshanian rocks recorded in the southeast China (Zhou et al., 2006; Li and Li, 2007; Liu et al., 2012; Y. Wang et al., 2012) and some early emplacement of granitic plutons in the American Cordillera and Antarctic regions (e.g. Pankhurst et al., 2000; Allibone and Tulloch, 2004; Dickson, 2004; Gehrels et al., 2009; Villagomez et al., 2011; Boeknout et al., 2012). 
At around 165-160 Ma, a notable magmatic flux has been identified in Hong Kong as well as in other regions in the SCMB (Davis et al., 1997; Li and Li, 2007; Sewell et al., 2012b; Liu et al., 2012; Y. Wang et al., 2012). Bartolini and Larson (2001) also noted a contemporaneous magmatic pulse from the Bonanza and Yakoun arcs in Canada, as well as in the igneous provinces in the Sierra Nevada arc and Antarctic Peninsula, and attributed the increased activities to an increase in the spreading rate of the northwest Pacific Plate that peaked at $\sim 162 \mathrm{Ma}$ (half spreading rate of $\sim 7 \mathrm{~cm} / \mathrm{yr}$ ). Another major pulse of magmatic activities in southeast China began at 120 Ma and coincided with the Cretaceous Normal Superchron ( 125-83 Ma; Gibbard et al., 2008; He et al., 2012). Although no igneous rocks of this age period have been found in Hong Kong, thermochronological results presented in Tang et al. (2014)(Chapter 5 of this thesis) suggest that magmatism over this age period continued at depth beneath the Hong Kong area (see below). Extensive now-exposed granitic plutons and silicic volcanic rocks in the SCMB, and elsewhere around the western Pacific margin were also generated in this magmatic period (e.g. Zhou et al, 2006; Dickinson, 2004; Gehrels et al., 2009). The generation of the Ontong Java-Hikurangi-Manihiki plateaux also occurred contemporaneously during the extended period of normal magnetic polarity in mid Cretaceous (Taylor, 2006).

The youngest phase of Yanshanian magmatism occurred variably at 90-80 Ma in different part of the SCMB (e.g. Z. Li et al., 2013, 2014). My thermochronology results (Chapter 5) imply that an elevated crustal thermal gradient inferred to relate to granitic intrusions continued in the southeast part of the magmatic belt (including Hong Kong) until 80 Ma. I consider that the cessation of Yanshanian magmatism was probably related to the major plate re-organisation in the Pacific basin that occurred around the same period. In particular, the collision of the Izanagi-Pacific spreading ridge with the eastern margin of southeast China might have caused the slab rollback which finally led to the seaward migration of the subduction zone (Section 5.5.5). For comparison, the final stage of emplacement of some large batholiths in the western North American margin also falls within a closely similar period. For example, the youngest plutons in both the eastern part of the Coast Mountain Batholith in Canada and the Sierra Nevada Batholith in California were emplaced at 80 Ma (DeCelles et al. 2009; Gehrels et al., 2009). 
Chapter 7/ Key Findings and Future Works 


\subsection{Key findings}

This thesis has employed multi-disciplinary methods to investigate the evolutionary history of the Mesozoic magmatic systems in Hong Kong. The resulting study offers new perspectives on the volcanic-plutonic connections in large silicic systems and the associated magmatic processes within the framework of the crystal mush model. This is the first focussed and detailed study of such large silicic magmatic systems in southeast China, and can provide a template for future investigations in the region. In addition, the results have yielded the opportunity for comparative studies of Mesozoic versus modern large caldera systems, illustrating the advantages and limitations of various approaches. The major techniques employed in this research include (a) field studies to establish the spatialtemporal relationships of individual volcanic units and exposed granitic plutons; (b) in-situ zircon trace element analyses and age determination using SIMS methods to track the magmatic evolution, and (c) low-temperature thermochronology to explore the postvolcanic thermo-tectonic history of Hong Kong.

\subsubsection{Age relationships in the $<143$ Ma period}

The interpretation of temporal relationships of the two Early Cretaceous volcanic-plutonic assemblages within the High Island caldera complex is refined based on the field studies and SIMS U-Pb zircon dating conducted in this thesis. First, the Repulse Bay Volcanic Group (RBVG) units are considered to be the products of a series of eruptions between 143-141 Ma, rather than representing a single pulse of closely spaced eruptions as previously suggested. My findings also imply that the RBVG and Kau Sai Chau Volcanic Group (KSCVG, 141-140 Ma) are closely successive. This interpretation is in contrast to the previous suggestion based on ID-TIMS age data that the two volcanic groups were generated from two distinct magmatic episodes separated by a time break of $~ 1-2 \mathrm{Myr}$ (Davis et al., 1997; Campbell and Sewell, 1997; Sewell et al., 2000; 2012b). Thus, the High Island caldera magmatic system was active and repeatedly replenished for $>5 \mathrm{Myr}$ between 143 and 138 Ma.

Second, the pairings of volcanic groups and their inferred equivalent plutonic suites are revised in light of my new SIMS zircon U-Pb age data. The two granitic plutons, Chi Ma Wan and Shui Chuen O granites, originally considered to be connected to the RBVG units (Davis et al., 1997; Sewell et al., 2000, 2012b), yield SIMS crystallisation ages ( 140 and 
142 Ma, respectively) that are at least 1-2 Myr younger than their published ID-TIMS ages. The Shui Chuen O Granite is now considered to be the only pluton that is coeval to the RBVG. From the previously proposed younger volcanic-plutonic pairing, the Sok Kwu Wan Granite and D’Aguilar Quartz Monzonite ( 140 Ma) were emplaced along the perimeter of the High Island caldera yield statistically identical SIMS ages to the KSCVG units, and are considered co-magmatic and coeval. In contrast, the Kowloon and Mount Butler granites ( 139-138 Ma) were emplaced 1-2 Myr after the eruption of the KSCVG and the previously proposed temporal linkage of these two granitic units with the KSCVG, is considered invalid.

Third, the SIMS age datasets presented in this study reveal the presence of two groups of sample: those that yield normally-distributed unimodal age spectra, and those that show multiple age components, the latter implying the presence of inherited grains. Those samples with unimodal age datasets yield SIMS model ages that are the same within uncertainty as their ID-TIMS ages. The good agreement in ages obtained from both approaches implies that for zircons with no inheritance and simple textural relationships, the SIMS data yield accurate results when multiple age determinations are averaged, even though these data are not as precise as those obtained by using ID-TIMS methods. Samples that have multiple modes in their age spectra generally show a mode that is inferred to represent the eruption or latest crystallization age that is younger than their respective IDTIMS age. The contrasting age estimates are considered to be due to either analytical issues or genuine differences in the age spectra. Two explanations are proposed. (1) During sample preparation, the ID-TIMS methodologies involved either air abrasion or chemical abrasion of zircon grains, which had the undesirable effect of removing some geochronological information present in the crystals. (2) The ID-TIMS techniques required dissolution of single or a group of zircon grains for age determination. For samples containing older zircon cores (antecrysts and/or xenocrysts), the reported ID-TIMS ages therefore may represent an 'averaged' value of the older cores, if present and surviving the chemical abrasion technique, and younger rims.

\subsubsection{The High Island caldera magmatic system}

The RBVG and KSCVG are considered here to represent a long-lived magmatic system that evolved through both open and closed system processes over >3 Myr. The results of 
zircon trace element determinations from both the volcanic and plutonic records indicates the presence of two sets of volcanic-plutonic products in the High Island caldera complex. One of these is represented by the RBVG and "low-temperature” granites, and the other by the KSCVG and “high-temperature” granites (sensu Miller et al., 2003), reflecting cooler versus hotter conditions, respectively. Two possible evolutionary models are proposed here for the High Island caldera magmatic system. One model considers the magmatic system to have comprised a single domain that fluctuated in temperature as a result of varying degrees of involvement of hotter melts, and was tapped at different, randomly varying points on its evolution. The other model considers that volcanic and plutonic records as reflecting the interplay of two crustal domains with contrasting constitutions corresponding respectively to the "low-“ and "high-temperature” systems.

Zircons from the RBVG and "low-temperature” granites yield wider ranges in Hf, Y, total trivalent element, Th and $\mathrm{U}$ concentrations and the values of $\mathrm{Th} / \mathrm{U}, \mathrm{Yb} / \mathrm{Gd}$ and $\mathrm{U} / \mathrm{Yb}$ than the KSCVG and "high-temperature" granites. In particular, the larger inter-grain variations in Hf concentrations could imply that the RBVG and "low-temperature" granites spanned larger degrees of melt fractionation during the development of their corresponding magma bodies. In addition, data from the KSCVG and "high-temperature" granites form an array with a steeper gradient in the plot of $\mathrm{Eu} / \mathrm{Eu}^{*}$ versus $\mathrm{Hf}$ for the zircons than that of the RBVG units. The steeper gradient may imply more effective (possibly more rapid) and/or higher degrees of feldspar fractionation during magmatic evolution for these units.

In-situ dating of zircon cores from the RBVG units, Pan Long Wan trachydacite and the "low-temperature" granites indicates that these units contain inherited zircons either from the earlier Mesozoic (Yanshanian) igneous units and/or from much older Palaeozoic to Archean basement rocks. The presence of inherited grains indicates recycling of crustal materials over successive magmatic episodes under relatively low-temperature magmatic conditions. In contrast, inherited zircons are lacking in the KSCVG units (except the Pan Long Wan trachydacite) and the "high-temperature” granites, which are interpreted to reflect an increased importance for hotter, less-evolved materials in the magmatic system.

\subsubsection{Post-eruptive thermo-tectonic history of Hong Kong}

Zircon fission-track (ZFT) ages of the Mesozoic magmatic rocks in Hong Kong range between 140 and 60 Ma. Most are between 100 and 80 Ma, whereas the apatite FT ages 
range between $\sim 83$ and $40 \mathrm{Ma}$, with two outliers at $\sim 28$ and $23 \mathrm{Ma}$. The thermal history as recorded in the FT system of the Mesozoic volcanic-plutonic assemblages and the postmagmatic sediments indicates that the rock bodies had experienced posteruption/emplacement heating event(s) with temperature over $250{ }^{\circ} \mathrm{C}$. The results are interpreted to suggest that magmatic activity might have lasted for much longer than previously considered in this part of southeast China, probably till as late as 80 Ma and coincident with cessation of major plutonism around the entire Pacific cordilleran margin. Any inferred magmatic activities are only represented by granitic intrusions at the deeper part of the crust and did not have a volcanic expression at the surface, or any of their volcanic counterparts had been completely removed by erosion. These magmatic activities are inferred to have driven the circulation of hydrothermal fluids in the overlying volcanic, granitic and overlying sediments, raising the crustal isotherms and thereby resetting the FT systems as well as causing pervasive alteration/mineralisation in the igneous rocks.

The inverse modeling of fission track data reflects the cooling history of the rock bodies after the last thermal event(s). As a result, the post-emplacement thermal-tectonic history of the volcanic-plutonic assemblages prior to $~ 80-60$ Ma could not be resolved.

Nonetheless, the low-temperature thermochronological work, together with detrital zircon dating and provenance analysis of the post-magmatic sedimentary rocks, have shown that extensive sedimentation in Hong Kong after the volcanic activities was unlikely. The study also confirms that most of the post-magmatic sediments were sourced very locally, from the nearby Yanshanian igneous rocks that were exposed at the surface during the Cretaceous. The inverse model of temperature-time path of the rock bodies reveals an extremely slow exhumation rate since $\sim 60$ Ma. After this time, Hong Kong became tectonically relatively stable, and later exhumation has been driven only by slow erosion.

\subsubsection{New perspectives on the High Island caldera complex}

The previously proposed model presented in Sewell et al. (2012a) of an overall tilting of the nested High Island caldera complex is inferred to no longer be valid on the basis of the volcanic-plutonic connections identified by a combination of field studies, zircon U-Pb age and trace element data and thermal-tectonic history. The anatomy of the High Island caldera complex is instead re-interpreted here to be associated with asymmetric caldera collapse, dipping towards the east. The structural features of the High Island Tuff imply 
that the unit was deposited on the caldera floor and tilted syn-eruptively, while the RBVG strata on Hong Kong Island were faulted, but without overall tilting of the crust.

Field observations and zircon U-Pb age data indicate that the Sok Kwu Wan Granite and D’Aguilar Quartz Monzonite intrusions were emplaced along the bounding structures of the caldera complex, shortly after the caldera collapse. This new interpretation then implies that the structural size of the High Island caldera is larger than previously considered, up to $320 \mathrm{~km}^{2}$, and covers much of southern Hong Kong. The caldera is roughly elliptical with a NE-trending long-axis. The High Island caldera system is inferred to have been underlain by a magma chamber of an equal or larger areal extent than the caldera structure itself. In the previous model of a tilted nested caldera complex, the Kowloon and Mount Butler granites were considered as having crystallised from the remaining materials of the High Island Tuff magma and been resurgently emplaced after caldera collapse. The temporal and genetic connections of the Kowloon and Mount Butler granites identified in this study, however, suggest that these granitic plutons are crystallised from latest-stage, highlyevolved, magmas that were independent of those that fed the KSCVG, and were emplaced within 2-3 km of the surface. The exhumation of Kowloon and Mount Butler granites is considered to be side by side with the RBVG and KSCVG volcanic strata.

\subsubsection{Implications for the evolution of Yanshanian magmatism in the SCMB}

The Southeast China Magmatic Belt (SCMB) has close parallels with other large silicic igneous provinces in the circum-Pacific regions in terms of its lithologies, areal coverage and period of activity. These other igneous provinces include the extensive granitic batholiths found along the western coast of North and South America (e.g. the Coast Mountain and Sierra Nevada batholiths in the North Americas, and Coastal Batholiths in Chile), as well as volcanic products and granitic plutons in Antarctica and New Zealand. As discussed in Chapter 6, these circum-Pacific igneous provinces were formed contemporaneously, suggesting that southeast China was an integral part of the ring of circum-Pacific active plate margin developed during the late Mesozoic. The cessation of Yanshanian magmatism in southeast China, as with the other circum-Pacific systems, has been correlated with the major plate re-organisation events around the palaeo-Pacific basin at $\sim 80$ Ma. 


\subsection{Future research}

In the course of this study, a number of future research opportunities have been identified that warrant following up.

(1) Although the framework of the Lantau caldera has long been recognised and mapped (Langford et al., 1995; Campbell and Sewell, 1997; Campbell et al., 2007), it is clear that the anatomy of the Lantau caldera area deserves more detailed study. For instance, a large part of the volcanic sequences within the Lantau caldera remain undifferentiated in the existing geological maps and their structural characteristics are obscure. Improved field mapping would help a better understanding of the development, evolution history, and collapse mechanism of the Lantau caldera. Furthermore, the sub-volcanic plutons beneath the Lantau caldera have never been clearly identified. The current model has broadly matched the Lantau Volcanic Group with the Kwai Chung Suite of similar age, although their spatial distributions do not provide convincing support for such correlations.

(2) The Mesozoic volcanic-plutonic assemblages in Hong Kong represent a microcosm of the southern part of the SCMB, which includes many more similar large caldera complexes that are ripe for detailed investigation. It is envisaged that comprehensive multi-disciplinary investigations as made in this present study of the multiple aspects of the volcanic-plutonic complexes in the SCMB, would provide invaluable information on the development of the magmatic province, and thereby resolve the long-standing questions about the geodynamic conditions and timings associated with Yanshanian magmatism.

(3) Finally, petrographic examination of the samples used in this study undertaken as part of sample selection has revealed that hydrothermal alteration to various degrees is common in the volcanic and plutonic rocks from Hong Kong. These minerals are an essential part of the alteration patterns in modern active geothermal systems (e.g. Kawerau , New Zealand: Milicich et al., 2013), but have never been examined and documented in detail from the Hong Kong rocks. These secondary minerals (especially the presence of epidote) are indicative of the presence of relict geothermal systems in Hong Kong that were active during the late Mesozoic. It is 
thus suggested that comprehensive petrographic studies be carried out on each igneous unit to characterise the nature of alteration, and to better understand the distribution and extent of the hydrothermal minerals. Knowledge of the hydrothermal alteration patterns in the Hong Kong rocks would be important for two reasons. First, it would enable better understanding of the thermal history of rock formations in Hong Kong, and offer comparisons with relict and modern geothermal systems. Second, any hydrothermal alteration involves generation of layered silicates (e.g. chlorite, illite, etc.: Browne 1970, 1978) the presence of which may influence the geomechanical characteristics of the rocks. As a major part of the interest in these rocks from the Hong Kong perspective arises from their geotechnical properties in civil engineering works, any factors that affect the rock properties should be investigated further. 


\section{References}

Addison, R., 1986. Geology of Sha Tin. Hong Kong Geological Survey Geological Memoir No. 1, Hong Kong, Geotechnical Control Office.

Allan, A.S.R., Wilson, C.J.N., Millet, M.-A., Wysoczanski, R.J., 2012. The invisible hand: tectonic triggering and modulation of a rhyolitic supereruption. Geology 40, 563-566.

Allan, A.S.R., Morgan, D.J., Wilson, C.J.N., Millet, M.-A., 2013. From mush to eruption in centuries: assembly of the super-sized Oruanui magma body. Contributions to Mineralogy and Petrology 166, 143-164.

Allen, P.M., Stephens, E.A., 1971. Report on the Geological Survey of Hong Kong 19671969. Hong Kong, Hong Kong Government Press.

Allibone, A.H., Tulloch, A.J., 2004. Geology of the plutonic basement rocks of Stewart Island, New Zealand. New Zealand Journal of Geology and Geophysics 47, 233-256.

Anderson, D.L., 1994. Superplumes or supercontinents. Geology 22, 39-42.

Annen, C., 2009a. From plutons to magma chambers: thermal constraints on the accumulation of eruptible silicic magma in the upper crust. Earth and Planetary Science Letters 284, 409-416.

Annen, C., 2009b. Implications of incremental emplacement of magma bodies for magma differentiation, thermal aureole dimensions and plutonism-volcanism relationships. Tectonophysics 500, 3-10.

Annen, C., Blundy, J.D., Sparks, R.S.J., 2006. The genesis of intermediate and silicic magmas in deep crustal hot zones. Journal of Petrology 47, 505-539.

Armstrong, P.A., 2005. Thermochronometers in sedimentary basins. In: Reiners, P.W. \& Ehlers, T.A. (eds) Low-temperature Thermochronology: Techniques, Interpretation, and Applications. Mineralogical Society of America and Geochemical Society, Reviews in Mineralogy and Geochemistry 58, 499-525.

Aurelio, M.A., Pena, R.E., Taguibao, K.J.L., 2013. Sculpting the Philippine archipelago since the Cretaceous through rifting, oceanic spreading, subduction, obduction, collision and strike-slip faulting: Contribution to IGMA5000. Journal of Asian Earth Sciences 72, 102-107.

Bachmann, O., Bergantz, G.W., 2004. On the origin of crystal-poor rhyolites: extracted from batholithic crystal mushes. Journal of Petrology 45, 1565-1582.

Bachmann, O., Bergantz, G.W., 2008. Rhyolites and their source mushes across tectonic settings. Journal of Petrology 49, 2277-2285.

Bachmann, O., Dungan, M.A., Lipman, P.W., 2002. The Fish Canyon magma body, San Juan volcanic field, Colorado: rejuvenation and eruption of an upper-crustal batholith. Journal of Petrology 43, 1469-1503.

Bachmann, O., Miller, C.F., de Silva, S.L., 2007. The volcanic-plutonic connection as a stage for understanding crustal magmatism. Journal of Volcanology and Geothermal Research 167, 1-23.

Bailey, E.B., 1960. The Geology of Ben Nevis and Glen Coe and the Surrounding Country. Memoirs of the Geological Survey of Great Britain, Sheet 53 (Scotland). HMSO, London, UK.

Barker, S.J., Wilson, C.J.N., Smith, E.G.C., Charlier, B.L.A., Wooden, J.L., Hiess, J., 
Ireland, T.R., 2014. Post-supereruption magmatic reconstruction of Taupo volcano (New Zealand), as reflected in zircon ages and trace elements. Journal of Petrology 55, 1511-1533.

Barker, S.J., Wilson, C.J.N., Allan, A.S.R., Schipper, C.I., 2015. Fine-scale temporal recovery, reconstruction and evolution of a post-supereruption magmatic system. Contributions to Mineralogy and Petrology 170, 5.

Barth, A.P., Wooden, J.L., 2010. Coupled elemental and isotopic analyses of polygenetic zircons from granitic rocks by ion microprobe, with implications for melt evolution and the sources of granitic magmas. Chemical Geology 277, 149-159.

Barth, A.P., Walker, J.D., Wooden, J.L., Riggs, N.R., Schweickert, R.A., 2011. Birth of the Sierra Nevada magmatic arc: early Mesozoic plutonism and volcanism in the eastcentral Sierra Nevada of California. Geosphere 7, 877-897.

Barth, A.P., Feilen, A.D.G., Yager, S.L., Douglas, S.R., Wooden, J.L., Riggs, N.R., Walker, J.D., 2012. Petrogenetic connections between ash-flow tuffs and a granodioritic to granitic intrusive suite in the Sierra Nevada arc, California. Geosphere 8, 250-264.

Barth, A.P., Wooden, J.L., Jacobson, C.E., Economos, R.C., 2013. Detrital zircon as a proxy for tracking the magmatic arc system: the California arc example. Geology 41, 223-226.

Bartolini, A., Larson, R.L., 2001. Pacific microplate and the Pangea supercontinent in the Early to Middle Jurassic. Geology 29, 735-738.

Bernet, M., Garver, J.I., 2005. Fission-track analysis of detrital zircon. In: Reiners, P.W. \& Ehlers, T.A. (eds) Low-temperature Thermochronology: Techniques, Interpretation, and Applications. Mineralogical Society of America and Geochemical Society, Reviews in Mineralogy and Geochemistry 58, 205-237.

Bird, D.K., Spieler, A.R., 2004. Epidote in geothermal systems. In: Liebscher, A. \& Franz, G. (eds) Epidote. Mineral Society of America and Geochemical Society, Reviews in Mineralogy and Geochemistry 56, 235-300.

Black, L.P., Kamo, S.L., Allen, C.M., Davis, D.W., Aleinikoff, J.N., Valley, J.W., Mundil, R., Campbell, I.H., Korsch, R.J., Williams, I.S., Foudoulis, C., 2004. Improved ${ }^{206} \mathrm{~Pb} /{ }^{238} \mathrm{U}$ microprobe geochronology by the monitoring of a trace-element-related matrix effect; SHRIMP, ID-TIMS, ELA-ICP-MS and oxygen isotope documentation for a series of zircon standards. Chemical Geology 205, 115-140.

Boehnke, P., Watson, E.B., Trail, D., Harrison, T.M., Schmitt, A.K., 2013. Zircon saturation re-revisited. Chemical Geology 351, 324-334.

Briais, A., Patriat, P., Tapponnier, P., 1993. Updated interpretation of magnetic-anomalies and sea-floor spreading stages in the South China Sea - Implications for the Tertiary tectonics of Southeast-Asia. Journal of Geophysical Research 98, 6299-6328.

Brophy, J.G., 1991. Compositional gaps, critical crystallinity, and fractional crystallization in orogenic (calc-alkaline) magmatic systems. Contributions to Mineralogy and Petrology 109, 173-182.

Browne, P.R.L., 1970. Hydrothermal alteration as an aid in investigating geothermal fields. Geothermics Special Issue 2, 564-570.

Browne, P.R.L., 1978. Hydrothermal alteration in active geothermal fields. Annual Review of Earth and Planetary Sciences 6, 229-250. 
Bryan, S.E., Ferrari, L., 2013. Large igneous provinces and silicic large igneous provinces: progress in our understanding over the last 25 years. Geological Society of America Bulletin 125, 1053-1078.

Bryan, S.E., Riley, T.R., Jerram, D.A., Leat, P.T., Stephens, C.J., 2002. Silicic volcanism: an under-valued component of large igneous provinces and volcanic rifted margins, In: Menzies, M.A., Klemperer, S.L., Ebinger, C.J., and Baker, J., (eds), Magmatic Rifted Margins. Geological Society of America Special Paper 362, 99-120.

Bryan, S.E., Ferrari, L., Reiners, P.W., Allen, C.M., Petrone, C.M., Ramos-Rosique, A., Campbell, I.H., 2008. New insights into crustal contributions to large-volume rhyolite generation in the mid-Tertiary Sierra Madre Occidental Province, Mexico, revealed by U-Pb geochronology. Journal of Petrology 49, 47-77.

Bureau of Geology and Mineral Resources of Guangdong Province, 1988. Regional Geology of Guangdong Province. Bureau of Geology and Mineral Resources of Guangdong Province, Geological Memoirs Series 1.

Busby, J.P., Evans, R.B., Lam, M.S., Ridley Thomas, W.N., Langford, R.L., 1992. The gravity base station network and regional gravity survey of Hong Kong. Geological Society of Hong Kong Newsletter 10, 2-5.

Cameron, M., Bagby, W.C., Cameron, K.L., 1980. Petrogenesis of voluminous midTertiary ignimbrites of the Sierra Madre Occidental, Chihuahua, Mexico. Contributions to Mineralogy and Petrology 74, 271-284.

Campbell, S.D.G., Sewell, R.J., 1997. Structural control and tectonic setting of Mesozoic volcanism in Hong Kong. Journal of the Geological Society, London 154, 1039-1052.

Campbell, S.D.G., Sewell, R.J., 2005. ${ }^{40} \mathrm{Ar}^{-39} \mathrm{Ar}$ Laser Microprobe Dating of Mafic Dykes and Fault Rocks in Hong Kong. Geotechnical Engineering Office, Civil Engineering and Development Department, HKSAR Government, GEO Report No 206.

Campbell, S.D.G., Sewell, R.J., Davis, D.W., So, A.C.T., 2007. New U-Pb age and geochemical constraints on the stratigraphy and distribution of the Lantau Volcanic Group, Hong Kong. Journal of Asian Earth Sciences 31, 139-152.

Cathles, L.M., 1977. Analysis of cooling of intrusives by groundwater convection which includes boiling. Economic Geology 72, 804-826.

Cecil, M.R., Ducea, M.N., Reiners, P.W., Chase, C.G., 2006. Cenozoic exhumation of the northern Sierra Nevada, California, from (U-Th)/He thermochronology. Geological Society of America Bulletin 118, 1481-1488.

Chamberlain, K.J., Morgan, D.J., Wilson, C.J.N., 2014a. Timescales of mixing and mobilisation in the Bishop Tuff magma body: perspectives from diffusion chronometry. Contributions to Mineralogy and Petrology 168, 1034.

Chamberlain, K.J., Wilson, C.J.N., Wooden, J.L., Charlier, B.L.A., Ireland, T.R., 2014b. New perspectives on the Bishop Tuff from zircon textures, ages and trace elements. Journal of Petrology 55, 395-426.

Chamberlain, K.J., Wilson, C.J.N., Wallace, P.J., Millet, M.-A., 2015. Micro-analytical perspectives on the Bishop Tuff and its magma chamber. Journal of Petrology 56, 605-640.

Chan, L.S., Shen, W., Pubellier, M., 2010. Polyphase rifting of greater Pearl River Delta region (South China): evidence for possible rapid changes in regional stress 
configuration. Journal of Structural Geology 32, 746-754.

Charlier, B.L.A., Wilson, C.J.N., 2010. Chronology and evolution of caldera-forming and post-caldera magma systems at Okataina volcano, New Zealand from zircon U-Th model-age spectra. Journal of Petrology 51, 1121-1141.

Charlier, B.L.A., Wilson, C.J.N., Lowenstern, J.B., Blake, S., Van Calsteren, P.W., Davidson, J.P., 2005. Magma generation at a large, hyperactive silicic volcano (Taupo, New Zealand) revealed by U-Th and U-Pb systematics in zircons. Journal of Petrology 46, 3-32.

Charlier, B.L.A., Wilson, C.J.N., Davidson, J.P., 2008. Rapid open-system assembly of a large silicic magma body: time-resolved evidence from cored plagioclase crystals in the Oruanui eruption deposits, New Zealand. Contributions to Mineralogy and Petrology 156, 799-813.

Charlier, B.L.A., Wilson, C.J.N., Mortimer, N., 2010. Evidence from zircon U-Pb age spectra for crustal structure and felsic magma genesis at Taupo volcano, New Zealand. Geology 38, 915-918.

Charvet, J., Lapierre, H., Yu, Y., 1994. Geodynamic significance of the Mesozoic volcanism of southeastern China. Journal of Southeast Asian Earth Sciences 9, 387396.

Chen, J., Jahn, B.-M., 1998. Crustal evolution of southeastern China: Nd and Sr isotopic evidence. Tectonophysics 284, 101-133.

Chen, J.H., Moore, J.G., 1982. Uranium-lead isotopic ages from Sierra Nevada batholith, California. Journal of Geophysical Research 87, 4761-4784.

Chen, P.R., Kong, X.G., Wang, Y.X., Ni, Q.S., Zhang, B.T., Ling, H.F., 1999. Rb-Sr isotopic dating and significance of Early Yanshanian bimodal volcanic-intrusive complex from south Jiangxi Province. Geological Journal of China Universities 5, 379-383 [in Chinese with English abstract].

Chen, C.H., Lin, W., Lu, H.Y., Lee, C.Y., Tien, J.L., Lai, Y. H., 2000. Cretaceous fractionated I-type granitoids and metaluminous A-type granites in SE China: the Late Yanshanian post-orogenic magmatism. Transactions of the Royal Society of Edinburgh-Earth Sciences 91, 195-205.

Chen, G., Grapes, R., Zhang, K., 2003. A model for Mesozoic crustal melting and tectonic deformation in Southeast China. International Geology Review 45, 948-957.

Chen, C.H., Lee, C.Y., Shinjo, R., 2008. Was there Jurassic paleo-Pacific subduction in South China?: constraints from ${ }^{40} \mathrm{Ar} /{ }^{39} \mathrm{Ar}$ dating, elemental and $\mathrm{Sr}-\mathrm{Rb}$ isotopic geochemistry of the Mesozoic basalts. Lithos 106, 83-92.

Cho, D.-L., Lee, S.R., Armstrong, R., 2008. Termination of the Permo-Triassic Songrim (Indosinian) orogeny in the Ogcheon belt, South Korea: occurrence of ca. $220 \mathrm{Ma}$ post-orogenic alkali granites and their tectonic implications. Lithos 105, 191-200.

Chung, S.L., Sun, S.S., Tu, K., Chen, C.H., Lee, C.Y., 1994. Late Cenozoic basaltic volcanism around the Taiwan Strait, SE China: product of lithosphere-asthenosphere interaction during continental extension. Chemical Geology 112, 1-20.

Chung, S.L., Cheng, H., Jahn, B.M., O’Reilly, S.Y., Zhu, B., 1997. Major and trace element, and Sr-Nd isotope constraints on the origin of Paleogene volcanism in South China prior to the South China Sea opening. Lithos 40, 203-220. 
Claiborne, L.L., Miller, C.F., Walker, B.A., Wooden, J.L., Mazdab, F.K., Bea, F., 2006. Tracking magmatic processes through $\mathrm{Zr} / \mathrm{Hf}$ ratios in rocks and $\mathrm{Hf}$ and Ti zoning in zircons: an example from the Spirit Mountain batholith, Nevada. Mineralogical Magazine 70, 517-543.

Claiborne, L.L., Miller, C.F., Wooden, J.L., 2010. Trace element composition of igneous zircon: a thermal and compositional record of the accumulation and evolution of a large silicic batholith, Spirit Mountain, Nevada. Contributions to Mineralogy and Petrology 160, 511-531.

Clough, C.T., Maufe, H.B., Bailey, E.B., 1909. The cauldron subsidence of Glen Coe and the associated igneous phenomena. Quarterly Journal of the Geological Society of London 65, 611-678.

Coleman, D.S., Gray, W., Glazner, A.F., 2004. Rethinking the emplacement and evolution of zoned plutons: geochronologic evidence for incremental assembly of the Tuolumne Intrusive Suite, California. Geology 32, 433-436.

Colombini, L.L., Miller, C.F., Gualda, G.A.R., Wooden, J.L., Miller, J.S., 2011. Sphene and zircon in the Highland Range volcanic sequence (Miocene, southern Nevada, USA): elemental partitioning, phase relations, and influence on evolution of silicic magma. Mineralogy and Petrology 102, 29-50.

Cooper, G.F., Wilson, C.J.N., Wooden, J.L., Charlier, B.L.A., Ireland, T.R., 2014. Temporal evolution and compositional signatures of supervolcanic systems recorded in zircons from Mangakino volcanic centre, New Zealand. Contributions to Mineralogy and Petrology 167, 1018.

Corfu, F., Hanchar, J.M., Hoskin, P.W.O., Kinny, P., 2003. Atlas of zircon textures. In: Hanchar, J.M. \& Hoskin, P.W.O. (eds) Zircon. Mineralogical Society of America and Geochemical Society, Reviews in Mineralogy and Geochemistry 53, 469-500.

Creixell, C., Parada, A. M., Morata, D., Vasquez, P., Perez de Arce, C., Arriagada, C., 2011. Middle-Late Jurassic to Early Cretaceous transtension and transpression during arc building in Central Chile: evidence from mafic dike swarms. Andean Geology 38, 37-63.

Crowley, J.K., Schoene, B., Bowring, S.A., 2007. U-Pb dating of zircon in the Bishop Tuff at the millennial scale. Geology 35, 1123-1126.

Darbyshire, D.P.F., Sewell, R.J., 1997. Nd and Sr isotope geochemistry of plutonic rocks from Hong Kong: implications for granite petrogenesis, regional structure and crustal evolution. Chemical Geology 143, 81-93.

Davis, D.W., Sewell, R.J., Campbell, S.D.G., 1997. U-Pb dating of Mesozoic igneous rocks from Hong Kong. Journal of the Geological Society, London 154, 1067-1076.

Davis, D.W., Williams, I.S., Krogh, T.E., 2003. Historical development of zircon geochronology. In: Hanchar, J.M. \& Hoskin, P.W.O. (eds) Zircon. Mineralogical Society of America and Geochemical Society, Reviews in Mineralogy and Geochemistry 53, 145-181.

Davis, J.W., Coleman, D.S., Gracely, J.T., Gaschnig, R., Stearns, M., 2012. Magma accumulation rates and thermal histories of plutons of the Sierra Nevada batholith, CA. Contributions to Mineralogy and Petrology 163, 449-465.

DeCelles, P.G., Ducea, M.N., Kapp, P., Zandt, G., 2009. Cyclicity in Cordilleran orogenic 
systems. Nature Geoscience 2, 251-257.

de Silva, S.L., Gregg, P.M., 2014. Thermomechanical feedbacks in magmatic systems: implications for growth, longevity, and evolution of large caldera-forming magma reservoirs and their supereruptions. Journal of Volcanology and Geothermal Research 282, 77-91.

Dickinson, W.R., 2004. Evolution of the North American Cordillera. Annual Review of Earth and Planetary Sciences 32, 13-45.

Duan, L., Meng, Q.R., Zhang, C.L., Liu, X.M., 2011. Tracing the position of the South China block in Gondwana: U-Pb ages and Hf isotopes of Devonian detrital zircons. Gondwana Research 19, 141-149.

du Bray, E.A., Pallister, J.S., 1999. Recrystallization and anatexis along the plutonicvolcanic contact of the Turkey Creek caldera, Arizona. Geological Society of America Bulletin 111, 143-153.

Dunkl, I., 2002. Trackkey: a Windows program for calculation and graphical presentation of fission track data. Computers and Geosciences 28, 3-12.

Ehlers, T.A., 2005. Crustal thermal processes and the interpretation of thermochronometer data. In: Reiners, P.W. \& Ehlers, T.A. (eds) Low-temperature Thermochronology: Techniques, Interpretation, and Applications. Mineralogical Society of America and Geochemical Society, Reviews in Mineralogy and Geochemistry 58, 315-350.

Ellis, S.E., Wilson, C.J.N., Bannister, S.C., Bibby, H.M., Heise, W., Wallace, L., Patterson, N., 2007. A future magma inflation event under the rhyolitic Taupo volcano, New Zealand: numerical models based on constraints from geochemical, geological and geophysical data. Journal of Volcanology and Geothermal Research 168, 1-27.

Fang, C., Yu, Y., Dong, Y., 1997. Petrogenetic sources and tectonic characteristics of Yandangshan Caldera, Zhejiang Province. Geology of Zhejiang 13, 18-25 [in Chinese with English abstract].

Farrell, J., Smith, R.B., Husen, S., Diehl, T., 2014. Tomography from 26 years of seismicity revealing that the spatial extent of the Yellowstone crustal magma reservoir extends well beyond the Yellowstone caldera. Geophysical Research Letters 41, 3068-3073.

Ferry, J.M., Watson, E.B., 2007. New thermodynamic models and revised calibrations for the Ti-in-zircon and Zr-in-rutile thermometers. Contributions to Mineralogy and Petrology 134, 429-437.

Finch, R.J., Hanchar, J.M., Hoskin, P.W.O., Burns, P.C., 2001. Rare-earth elements in synthetic zircon: part 2. A single-crystal X-ray study of xenotime substitution. American Mineralogist 86, 681-689.

Fletcher, C.J.N., Campbell, S.D.G., Carruthers, R.M., Busby, J.P., Lai, K.W., 1997.

Regional tectonic setting of Hong Kong: implications of new gravity models. Journal of the Geological Society 154, 1021-1030.

Fletcher, C.J.N., Collar, F.A., Lai, M.W.C., 2000. Magnetic survey of the offshore areas of Hong Kong: results, interpretation and significance. In: Page, A., and Reels, S. J.

(eds) The Geology of Hong Kong, Geological Society of Hong Kong Bulletin 6, 179188.

Fohey-Breting, N.K., Barth, A.P., Wooden, J.L., Mazdab, F.K., Carter, C.A., Schermer, 
E.R., 2010. Relationship of voluminous ignimbrites to continental arc plutons: petrology of Jurassic ignimbrites and contemporaneous plutons in southern California. Journal of Volcanology and Geothermal Research 189, 1-11.

Frazer, R.E., Coleman, D.S., Mills, R.D., 2014. Zircon U-Pb geochronology of the Mount

Givens Granodiorite: implications for the genesis of large volumes of eruptible magma. Journal of Geophysical Research-Solid Earth 119, 2907-2924.

Frost, D.V., 1992. Geology of Yuen Long. Hong Kong Geological Survey Sheet Report No. 1, Geotechnical Engineering Office, Hong Kong Government.

Fu, B., Page, F.Z., Cavosie, A.J., Fournelle, J., Kita, N.T., Lackey, J.S., Wilde, S.A., Valley, J.W., 2008. Ti-in-zircon thermometry: applications and limitations. Contributions to Mineralogy and Petrology 156, 197-215.

Gagnevin, D., Daly, J.S., Kronz, A., 2010. Zircon texture and chemical composition as a guide to magmatic processes and mixing in a granitic environment and coeval volcanic system. Contributions to Mineralogy and Petrology 159, 579-596.

Galbraith, R.F., 1990. The radial plot - graphical assessment of spread in ages. Nuclear Tracks and Radiation Measurements 17, 207-214.

Gana, P., Tosdal, R.M., 1996. U-Pb and K-Ar geochronology in Paleozoic and Mesozoic intrusive rocks of the Coastal Cordillera, Valparaiso, Chile. Revista Geologica de Chile 23, 151-164.

Gehrels, G., Rusmore, M., Woodsworth, G., Crawford, M., Andronicos, C., Hollister, L., Patchett, J., Ducea, M., Butler, R., Klepeis, K., Davidson, C., Friedman, R., Haggart, J., Mahoney, B., Crawford, W., Pearson, D., Girardi, J., 2009. U-Th-Pb geochronology of the Coast Mountains batholith in north-coastal British Columbia: constraints on age and tectonic evolution. Geological Society of America Bulletin 121, 1341-1361.

Geotechnical Control Office (GCO) 1986a. Sha Tin. Hong Kong Geological Survey Sheet 7, Solid and Superficial Geology, 1:20,000 Series HGM20, Hong Kong Government.

Geotechnical Control Office (GCO) 1986b. Hong Kong and Kowloon. Hong Kong Geological Survey Sheet 11, Solid and Superficial Geology, 1:20,000 Series HGM20, Hong Kong Government.

Geotechnical Control Office (GCO) 1987. Hong Kong South and Lamma Island. Hong Kong Geological Survey Sheet 15, Solid and Superficial Geology, 1:20,000 Series HGM20, Hong Kong Government.

Geotechnical Control Office (GCO) 1988a. Yuen Long. Hong Kong Geological Survey

Sheet 6, Solid and Superficial Geology, 1:20,000 Series HGM20, Hong Kong

Government.

Geotechnical Control Office (GCO) 1988b. Tsing Shan (Castle Peak). Hong Kong Geological Survey Sheet 5, Solid and Superficial Geology, 1:20,000 Series HGM20, Hong Kong Government.

Geotechnical Control Office (GCO) 1989a. San Tin. Hong Kong Geological Survey Sheet 2, Solid and Superficial Geology, 1:20,000 Series HGM20, Hong Kong Government. Geotechnical Control Office (GCO) 1989b. Sai Kung. Hong Kong Geological Survey Sheet 8, Solid and Superficial Geology, 1:20,000 Series HGM20, Hong Kong Government. 
Geotechnical Control Office (GCO) 1989c. Clear Water Bay. Hong Kong Geological Survey Sheet 12, Solid and Superficial Geology, 1:20,000 Series HGM20, Hong Kong Government.

Geotechnical Control Office (GCO) 1989d. Waglan Island. Hong Kong Geological Survey Sheet 16, Solid and Superficial Geology, 1:20,000 Series HGM20, Hong Kong Government.

Geotechnical Control Office (GCO) 1991. Sheung Shui. Hong Kong Geological Survey Sheet 3, Solid and Superficial Geology, 1:20,000 Series HGM20, Hong Kong Government.

Geotechnical Engineering Office (GEO) 1991. Silver Mine Bay. Hong Kong Geological Survey Sheet 10, Solid and Superficial Geology, 1:20,000 Series HGM20, Hong Kong Government.

Geotechnical Engineering Office (GEO) 1992. Kat O Chau. Hong Kong Geological Survey Sheet 4, Solid and Superficial Geology, 1:20,000 Series HGM20, Hong Kong Government.

Geotechnical Engineering Office (GEO) 1994. Tung Chung. Hong Kong Geological Survey Sheet 9, Solid and Superficial Geology, 1:20,000 Series HGM20, Hong Kong Government.

Geotechnical Engineering Office (GEO) 1995. Shek Pik. Hong Kong Geological Survey Sheet 13, Solid and Superficial Geology, 1:20,000 Series HGM20, Hong Kong Government.

Geotechnical Engineering Office (GEO) 1996. Cheung Chau. Hong Kong Geological Survey Sheet 14, Solid and Superficial Geology, 1:20,000 Series HGM20, Hong Kong Government.

Gibbard, P., Cohen, K., Ogg, J.G., 2008. Cretaceous Period. In: Ogg, J.G., Ogg, G. \& Gradsein, F.M. (eds) The Concise Geological Time Scale. Cambridge University Press, Cambridge, 118-125.

Gilder, S.A., Keller, G.R., Luo, M., Goodell, P.C., 1991. Timing and spatial-distribution of rifting in China. Tectonophysics 197, 225-243.

Gilder, S.A., Coe, R.S., Wu, H.R., Kuang, G.D., Zhao, X.X., Wu, Q., 1995. Triassic paleomagnetic data from south China and their bearing on the tectonic evolution of the western circum-Pacific region. Earth and Planetary Science Letters 131, 269-287.

Gilder, S.A., Gill, J., Coe, R.S., Zhao, X.X., Liu, Z.W., Wang, G.X., Yuan, K.R., Liu, W.L., Kuang, G.D., Wu, H.R., 1996. Isotopic and paleomagnetic constraints on the Mesozoic tectonic evolution of south China. Journal of Geophysical Research 101, 16137-16154.

Girard, G., Stix, J., 2009, Magma recharge and crystal mush rejuvenation associated with early post-collapse Upper Basin Member Rhyolites, Yellowstone Caldera, Wyoming. Journal of Petrology 50, 2095-2125.

Glazner, A.F., Bartley, J.M., Coleman, D.S., Gray, W., Taylor, R.Z., 2004. Are plutons assembled over millions of years by amalgamation from small magma chambers? GSA Today 14 (4/5), 4-11.

Gleadow, A.J.W., 1981. Fission-track dating methods: what are the real alternatives? Nuclear Tracks 5, 3-14. 
Gleadow, A.J.W., Kohn, B., Alimanovic, A., 2012. Integrated technologies for automated fission track analysis - sharpening the focus in low-temperature thermochronology. In: Proceedings of the $34^{\text {th }}$ International Geological Congress, Brisbane, August 5-10, 2012. Australian Geosciences Council, Brisbane, 2715.

Goetze, J., Kempe, U., Habermann, D., Nasdala, L., Neuser, R.D., Richter, D.K., 1999. High resolution cathodoluminescence combined with SHRIMP ion probe measurements of detrital zircons. Mineralogical Magazine 63, 179-187.

Goff, F., Warren, R.G., Goff, C.J., Dunbar, N., 2014. Eruption of reverse-zoned upper Tshirege Member, Bandelier Tuff from centralized vents within Valles caldera, New Mexico. Journal of Volcanology and Geothermal Research 276, 82-104.

Grimes, C.B., John, B.E., Kelemen, P.B., Mazdab, F.K., Wooden, J.L., Cheadle, M.J., Hanghoj, K., Schwartz, J.J., 2007. Trace element chemistry of zircons from oceanic crust: a method for distinguishing detrital zircon provenance. Geology 35, 643-646.

Grossenbacher, K.A., McDuffie, S.M., 1995. Conductive cooling of lava: columnar joint diameter and stria width as functions of cooling rate and thermal gradient. Journal of Volcanology and Geothermal Research 69, 95-103.

Guo, F., Fan, W., Li, C., Zhao, L., Li, H., Yang, J., 2012. Multi-stage crust-mantle interaction in SE China: temporal, thermal and compositional constraints from the Mesozoic felsic volcanic rocks in eastern Guangdong-Fujian provinces. Lithos 150, $62-84$.

Hanchar, J.M., Miller, C.F., 1993. Zircon zonation patterns as revealed by cathodoluminescence and backscattered electron images - Implications for interpretation of complex crustal histories. Chemical Geology 110, 1-13.

Hayes, D.E., Nissen, S.S., Buhl, P., Diebold, J., Yao, B.C., Zeng, W.J., Chen, Y.Q., 1995. Throughgoing crustal faults along the northern margin of the South China Sea and their role in crustal extension. Journal of Geophysical Research 100, 22435-22446.

He, H., Deng, C., Wang, P., Pan, Y., Zhu, R., 2012. Toward age determination of the termination of the Cretaceous Normal Superchron. Geochemistry, Geophysics, Geosystems 13, Q02002.

He, Z.Y., Xu, X.S., 2012. Petrogenesis of the Late Yanshanian mantle-derived intrusions in southeastern China: response to the geodynamics of paleo-Pacific subduction. Chemical Geology 328, 208-221.

He, Z.Y., Xu, X.S., Yu, Y., Zou, H.B., 2009. Origin of the Late Cretaceous syenite from Yandangshan, SE China, constrained by zircon U-Pb and Hf isotopes and geochemical data. International Geology Review 51, 556-582.

Heise, W., Caldwell, T.G., Bibby, H.M., Bennie, S.L., 2010. Three-dimensional electrical resistivity image of magma beneath an active continental rift, Taupo Volcanic Zone, New Zealand. Geophysical Research Letters 37, L10301.

Hildebrand, R.S., Hoffman, P.F., Housh, T., Bowring, S.A., 2010. The nature of volcanoplutonic relations and the shapes of epizonal plutons of continental arcs as revealed in the Great Bear magmatic zone, northwestern Canada. Geosphere 6, 812-839.

Hildreth, W., 1981. Gradients in silicic magma chambers: implications for lithospheric magmatism. Journal of Geophysical Research 86, 10153-10192.

Hildreth, W., 2004. Volcanological perspectives on Long Valley, Mammoth Mountain, and 
Mono Craters: several contiguous but discrete systems. Journal of Volcanology and Geothermal Research 136, 169-198.

Hildreth, W., Moorbath, S., 1988. Crustal contributions to arc magmatism in the Andes of central Chile. Contribution to Mineralogy and Petrology 98, 455-489.

Hildreth, W., Wilson, C.J.N., 2007. Compositional zoning of the Bishop Tuff. Journal of Petrology 48, 951-999.

Hildreth, W., Halliday, A.N., Christiansen, R.L., 1991. Isotopic and chemical evidence concerning the genesis and contamination of basaltic and rhyolitic magma beneath the Yellowstone Plateau volcanic field. Journal of Petrology 32, 63-138.

Hong, W., Xu, X., Zou, H., 2013. Petrogenesis of coexisting high-silica aluminous and peralkaline rhyolites from Yunshan (Yongtai), southeastern China. Journal of Asian Earth Sciences74, 316-329.

Hoskin, P.W.O., Ireland, T.R., 2000. Rare earth element chemistry of zircon and its use as a provenance indicator. Geology 28, 627-630.

Hoskin, P.W.O., Schaltegger, U., 2003. The composition of zircon and igneous and metamorphic petrogenesis. In: Hanchar, J.M. \& Hoskin, P.W.O. (eds) Zircon. Mineralogical Society of America and Geochemical Society, Reviews in Mineralogy and Geochemistry 53, 27-62.

Hoskin, P.W.O., Kinny, P.D., Wyborn, D., Chappell, B.W., 2000. Identifying accessory mineral saturation during differentiation in granitoid magmas: an integrated approach. Journal of Petrology 41, 1365-1396.

House, M.A., Wernicke, B.P., Farley, K.A., Dumitru, T.A., 1997. Cenozoic thermal evolution of the central Sierra Nevada, California, from (U-Th)/He thermochronometry. Earth and Planetary Science Letters 151, 167-179.

House, M.A., Wernicke, B.P., Farley, K.A., 1998. Dating topography of the Sierra Nevada, California, using apatite (U-Th)/He ages. Nature 396, 66-69.

Hsü, K.J., Li, J. L., Chen, H.H., Wang, Q.C., Sun, S., Sengor, A.M.C., 1990. Tectonics of south China: key to understanding west Pacific geology. Tectonophysics 183, 9-39.

Huang, H.H., Lin, F.C., Schmandt, B., Farrell, J., Smith, R.B., Tsai, V.C., 2015. The Yellowstone magmatic system from the mantle plume to the upper crust. Science 348, 773-776

Huang, X.L., Niu, Y.L., Xu, Y.G., Ma, J.L., Qiu, H.N., Zhong, J.W., 2013. Geochronology and geochemistry of Cenozoic basalts from eastern Guangdong, SE China: constraints on the lithosphere evolution beneath the northern margin of the South China Sea. Contributions to Mineralogy and Petrology 165, 437-455.

Huber, C., Bachmann, O., Dufek, J., 2011. Thermo-mechanical reactivation of locked crystal mushes: melting-induced internal fracturing and assimilation processes in magmas. Earth and Planetary Science Letters 304, 443-454.

Huber, C., Bachmann, O., Dufek, J., 2012. Crystal-poor versus crystal-rich ignimbrites: a competition between stirring and reactivation. Geology 40, 115-118.

Hurford, A.J., 1990. Standardization of fission-track dating calibration: recommendation by the Fission Track Working Group of the I.U.G.S. Subcommission on Geochronology. Chemical Geology (Isotope Geoscience Section) 80, 171-178.

Hurford, A.J., Green, P.F., 1983. The zeta-age calibration of fission-track dating. Isotope 
Geoscience 1, 285-317.

Husen, S., Smith, R.B., Gregory, P.W., 2004. Evidence for gas and magmatic sources beneath the Yellowstone volcanic field from seismic tomographic imaging. Journal of Volcanology and Geothermal Research 131, 397-410.

Ireland, T.R., Williams, I.S., 2003. Considerations in zircon geochronology by SIMS. In: Hanchar, J.M. \& Hoskin, P.W.O. (eds) Zircon. Mineralogical Society of America and Geochemical Society, Reviews in Mineralogy and Geochemistry 53, 215-241.

Jahn, B.M., 1974. Mesozoic thermal events in Southeast China. Nature 248, 480-483.

Jahn, B.M., Zhou, X.H., Li, J.L., 1990. Formation and tectonic evolution of southeastern China and Taiwan: isotopic and geochemical constraints. Tectonophysics 183, 145160.

Jiang, Y.-H., Ling, H.-F., Jiang, S.-Y., Fan, H.-H., Shen, W.-Z., Ni, P., 2005. Petrogenesis of a Late Jurassic peraluminous volcanic complex and its high-Mg, potassic, quenched enclaves at Xiangshan, Southeast China. Journal of Petrology 46, 11211154.

Jiang, Y.-H., Jiang, S.-Y., Dai, B.-Z., Liao, S.-Y., Zhao, K.-D., Ling, H.-F., 2009. Middle to late Jurassic felsic and mafic magmatism in southern Hunan province, southeast China: implications for a continental arc to rifting. Lithos 107, 185-204.

Jiang, Y.-H., Zhao, P., Zhou, Q., Liao, S.-Y., Jin, G.-D., 2010. Petrogenesis and tectonic implications of Early Cretaceous S- and A-type granites in the northwest of the GanHang rift, SE China. Lithos 121, 55-73.

Jiang, Y.-H., Wang, G.-C., Liu, Z., Ni, C.-Y., Qing, L., Zhang, Q., 2015. Repeated slab advance-retreat of the Palaeo-Pacific plate underneath SE China. International Geology Review 57, 472-491.

Jones, N.S., 1995. The sedimentology of the (Devonian) Bluff Head Formation, New Territories, Hong Kong, with sedimentological notes on other strata examined within the area. British Geological Survey Technical Report WH/95/101R, British Geological Survey, Keyworth, U.K.

Jones, N.S., 1996. The geology and sedimentology of Upper Palaeozoic and Mesozoic sedimentary successions in Hong Kong. British Geological Survey Technical Report WH/96/130R, British Geological Survey, Keyworth, U.K.

Kemp, S.J., Styles, M.T. and Merriman, R.J., 1997. Mineralogy of Tertiary Sedimentary Rocks from Ping Chau, Hong Kong. British Geological Survey Technical Report WG/97/27C, British Geological Survey, Keyworth, U.K.

Ketcham, R.A., 2005. Forward and inverse modeling of low-temperature thermochronometry data. In: Reiners, P.W. \& Ehlers, T.A. (eds) Low-temperature Thermochronology: Techniques, Interpretation, and Applications. Mineralogical Society of America and Geochemical Society, Reviews in Mineralogy and Geochemistry 58, 275-314.

Knesel, K.M., Davidson, J.P., 1997. The origin and evolution of large-volume silicic magma systems: Long Valley caldera. International Geology Review 39, 1033-1052.

Knittel, U., 2011. 83 Ma rhyolite from Mindoro - evidence for Late Yanshanian magmatism in the Palawan Continental Terrane (Philippines). Island Arc 20, 138-146. Kokelaar, B.P., Moore, I.D., 2006. Glenocoe Caldera Volcano, Scotland. Classical areas of 
British geology. British Geological Survey, Keyworth, U.K.

Koulakov, I., Yudistira, T., Luehr, B.-G., Wandono, 2009. P, S velocity and Vp/Vs ratio beneath the Toba caldera complex (Northern Sumatra) from local earthquake tomography. Geophysical Journal International 177, 1121-1139.

Krogh, T.E., 1982. Improved accuracy of U-Pb zircon ages by the creation of more concordant systems using an air abrasion technique. Geochimica et Cosmochimica Acta 46, 637-649.

Lackey, J.S., Cecil, M.R., Windham, C.J., Frazer, R.E., Bindeman, I.N., Gehrels, G.E., 2012. The Fine Gold Intrusive Suite: the roles of basement terranes and magma source development in the Early Cretaceous Sierra Nevada batholith. Geosphere 8, 292-313.

Lai, K.W., 1985. A review of the Late Cretaceous - Palaeogene fault basins around Hong Kong. In: Whiteside, P.G.D. \& Arthurton, R.S. (eds) Seminar on the Marine Geology of Hong Kong and the Pearl River Mouth. Geological Society of Hong Kong, Hong Kong, 39-46.

Lai, K.W., Campbell, S.D.G., Shaw, R., 1996. Geology of the Northeastern New Territories. Hong Kong Geological Survey Memoir No. 5: Hong Kong, Geotechnical Engineering Office.

Langford, R.L., Lai, K.W., Arthurton, R.S., Shaw, R., 1989. Geology of the Western New Territories. Hong Kong Geological Survey Memoir No. 3, Hong Kong, Geotechnical Control Office, Hong Kong Government.

Langford, R.L., James, J.W.C., Shaw, R., Campbell, S.D.G., Kirk, P.A., Sewell, R.J., 1995. Geology of Lantau District. Hong Kong Geological Survey Memoir No. 6, Hong Kong, Geotechnical Engineering Office, Hong Kong Government.

Lapierre, H., Jahn, B.M., Charvet, J., Yu, Y.W., 1997. Mesozoic felsic arc magmatism and continental olivine tholeiites in Zhejiang province and their relationship with the tectonic activity in southeastern China. Tectonophysics 274, 321-338.

Leat, P.T., Flowerdew, M.J., Riley, T.R., Whitehouse, M.J., Scarrow, J.H., Millar, I.L., 2009. Zircon U-Pb dating of Mesozoic volcanic and tectonic events in north-west Palmer Land and south-west Graham Land, Antarctica. Antarctic Science 21, 633-641.

Lee, T.Y., Lawver, L.A., 1994. Cenozoic plate reconstruction of the South China Sea region. Tectonophysics 235, 149-180.

Lee, C.M., Chan, K.W., Ho, K.H. 1997. Palaeontology and stratigraphy of Hong Kong, Volume 1. Science Press, Beijing [in Chinese].

Lee, C.M., Chan, K.W., Ho, K.H. 1998. Palaeontology and stratigraphy of Hong Kong, Volume 2. Science Press, Beijing [in Chinese].

$\mathrm{Li}$, X.H., 1994. A comprehensive U-Pb, Sm-Nd, Rb-Sr and ${ }^{40} \mathrm{Ar}-{ }^{39} \mathrm{Ar}$ geochronological study on Guidong Granodiorite, southeast China: records of multiple tectonothermal events in a single pluton. Chemical Geology 115, 283-295.

Li, X.H., 2000. Cretaceous magmatism and lithospheric extension in Southeast China. Journal of Asian Earth Sciences 18, 293-305.

Li, X.H., McCulloch, M.T., 1996. Secular variation in the Nd isotopic composition of Neoproterozoic sediments from the southern margin of the Yangtze Block: evidence for a Proterozoic continental collision in southeast China. Precambrian Research 76, 
67-76.

Li, Z.X., Li, X. H., 2007. Formation of the 1300-km-wide intracontinental orogen and postorogenic magmatic province in Mesozoic South China: a flat-slab subduction model. Geology 35, 179-182.

Li, X.C., Sewell, R.J., Fletcher, C.J.N., 2000. The dykes of northeastern Lantau Island. Geological Report, Geotechnical Engineering Office, Hong Kong SAR Government.

Li, X.H., Chen, Z., Liu, D.Y., Li, W.X., 2003a. Jurassic gabbro-granite-syenite suites from Southern Jiangxi province, SE China: age, origin, and tectonic significance. International Geology Review 45, 898-921.

Li, X.H., Wei, G., Shao, L., Liu, Y., Liang, X., Jian, Z., Sun, M., Wang, P., 2003b. Geochemical and Nd isotopic variations in sediments of the South China Sea: a response to Cenozoic tectonism in SE Asia. Earth and Planetary Science Letters 211, 207-220.

Li, X.H., Chung, S.L., Zhou, H.W., Lo, C.H., Liu, Y., Chen, C.W., 2004. Jurassic intraplate magmatism in southern Hunan-eastern Guangxi: Ar-40/Ar-39 dating, geochemistry, Sr-Nd isotopes and implications for the tectonic evolution of SE China. In: Malpas, J., Fletcher, C.J.N., Ali, J.R., and Aitchison, J.C. (eds), Aspects of the Tectonic Evolution of China. Geological Society Special Publication 226, 193-215.

Li, X.M., Wang, Y.J., Tan, K.X., Peng, T.P., 2005. Meso-Cenozoic uplifting and exhumation on Yunkaidashan: evidence from fission track thermochronology. Chinese Science Bulletin 50, 903-909.

Li, X.H., Li, Z.X., Li, W.X., Wang, Y., 2006. Initiation of the Indosinian Orogeny in south China: evidence for a Permian magmatic arc on Hainan Island. Journal of Geology 114, 341-353.

Li, X.-H., Li, Z.-X., Li, W.-X., Liu, Y., Yuan, C., Wei, G., Qi, C., 2007. U-Pb zircon, geochemical and Sr-Nd-Hf isotopic constraints on age and origin of Jurassic I- and A-type granites from central Guangdong, SE China: a major igneous event in response to foundering of a subducted flat-slab?. Lithos 96, 186-204.

Li, L.-M., Sun, M., Wang, Y., Xing, G., Zhao, G., He, Y., He, K., Zhang, A., 2011. U-Pb and Hf isotopic study of detrital zircons from the meta-sedimentary rocks in central Jiangxi Province, South China: implications for the Neoproterozoic tectonic evolution of South China Block. Journal of Asian Earth Sciences 41, 44-55.

Li, Z.X., Li, X.H., Chung, S.L., Lo, C.H., Xu, X., Li, W.X., 2012. Magmatic switch-on and switch-off along the South China continental margin since the Permian: transition from an Andean-type to a Western Pacific-type plate boundary. Tectonophysics 532-535, 271-290.

Li, P., Yu, X., Li, H., Qiu, J., Zhou, X., 2013. Jurassic-Cretaceous tectonic evolution of southeast China: geochronological and geochemical constraints of Yanshanian granitoids. International Geology Review 55, 1202-19.

Li, Z., Zhou, J., Mao, J., Santosh, M., Yu, M., Li, Y., Hu, Y., Langmuir, C. H., Chen, Z., Cai, X., Hu, Y., 2013. Zircon U-Pb geochronology and geochemistry of two episodes of granitoids from the northwestern Zhejiang Province, SE China: implication for magmatic evolution and tectonic transition. Lithos 179, 334-352.

Li, Z., Qiu, J.-S., Yang, X.-M., 2014. A review of the geochronology and geochemistry of 
Late Yanshanian (Cretaceous) plutons along the Fujian coastal area of southeastern China: implications for magma evolution related to slab break-off and rollback in the Cretaceous. Earth-Science Reviews 128, 232-248.

Lim, C., Cho, M., 2012. Two-phase contractional deformation of the Jurassic Daebo Orogeny, Chungnam Basin, Korea, and its correlation with the early Yanshanian movement of China. Tectonics 31, TC1004.

Lipman, P.W., 1984. The roots of ash flow calderas in western North-America: windows into the tops of granitic batholiths. Journal of Geophysical Research 89, 8801-8841.

Lipman, P.W., 1997. Subsidence of ash-flow calderas: relation to caldera size and magmachamber geometry. Bulletin of Volcanology 59, 198-218.

Lipman, P.W., 2007. Incremental assembly and prolonged consolidation of Cordilleran magma chambers: Evidence from the Southern Rocky Mountain volcanic field. Geosphere 3, 42-70.

Lipman, P.W., Bachmann, O., 2015. Ignimbrites to batholiths: integrating perspectives from geological, geophysical, and geochronological data. Geosphere 11, 705-743.

Lipman, P.W., McIntosh, W.C., 2008. Eruptive and noneruptive calderas, northeastern San Juan Mountains, Colorado: where did the ignimbrites come from? Geological Society of America Bulletin 120, 771-795.

Liu, L., Xu, X., Zou, H., 2012. Episodic eruptions of the Late Mesozoic volcanic sequences in southeastern Zhejiang, SE China: petrogenesis and implications for the geodynamics of paleo-Pacific subduction. Lithos 154, 166-180.

Liu, Q., Yu, J.-H., Wang, Q., Su, B., Zhou, M.-F., Xu, H., Cui, X., 2012. Ages and geochemistry of granites in the Pingtan-Dongshan Metamorphic Belt, Coastal South China: new constraints on late Mesozoic magmatic evolution. Lithos 150, 268-286.

Lu, Z.G., Tao, K., Xie, J.Y., Xie, D.K., Wang, W.B., Chen, H.N., 1997. Volcanic Geology and Mineral Resources of Southeast China Continent, Geological Publishing House, Beijing. [in Chinese]

Ludwig, K.R., 2008. Isoplot/Ex version 3.70, A Geochronological Toolkit for Microsoft Excel. Berkeley Geochronology Center Special Publication 4.

Ludwig, K.R., 2009. User's Manual for Isoplot 3.75., A Geochronological Toolkit for Microsoft Excel. Berkeley Geochronology Center Special Publication 5.

Mahood, G.A., 1990. Second reply to comment of R.S.J. Sparks, H.E. Huppert, and C.J.N. Wilson on: 'Evidence for long residence times of rhyolitic magma in the Long Valley magmatic system: the isotopic record in the precaldera lavas of Glass Mountain'.

Earth and Planetary Science Letters 99, 395-399.

Maksaev, V., Munizaga, F., Fanning, M., Palacios, C., Tapia, J., 2006. SHRIMP U-Pb dating of the Antucoya porphyry copper deposit: new evidence for an Early Cretaceous porphyry-related metallogenic epoch in the Coastal Cordillera of northern Chile. Mineralium Deposita 41, 637-644.

Mason, B.G., Pyle, D.M., Oppenheimer, C., 2004. The size and frequency of the largest explosive eruptions on Earth. Bulletin of Volcanology 66, 735-748.

Mattinson, J.M., 2005. Zircon U-Pb chemical abrasion ("CA-TIMS") method: combined annealing and multi-step partial dissolution analysis for improved precision and accuracy of zircon ages. Chemical Geology 220, 47-66. 
Mattinson, J.M., Graubard, C.M., Parkinson, D.L., McLelland, W.C., 1996. U-Pb reverse discordance in zircons: the role of fine-scale oscillatory zoning and sub-microscopic transport of Pb. American Geophysical Union, Geophysical Monograph 95, 355-370.

Matzel, J.E.P., Bowring, S.A., Miller, R.B., 2006. Time scales of pluton construction at differing crustal levels: Examples from the Mount Stuart and Tenpeak intrusions, North Cascades, Washington. Geological Society of America Bulletin 118, 14121430.

Maughan, L.L., Christiansen, E.H., Best, M.G., Grommé, C.S., Deino, A.L., Tingey, D.G., 2002. The Oligocene Lund Tuff, Great Basin, USA: a very large volume monotonous intermediate. Journal of Volcanology and Geothermal Research 113, 129-157.

Mazdab, F.K., Wooden, J.L., 2006. Trace element analysis in zircon by ion microprobe (SHRIMP-RG): technique and applications. Geochimica et Cosmochimica Acta 70, A405.

Metcalfe, I., 1994. Gondwanaland origin, dispersion, and accretion of East and Southeast Asian continental terranes. Journal of South American Earth Sciences 7, 333-347.

Metcalfe, I., 1996. Pre-Cretaceous evolution of SE Asian terranes. In: R. Hall \& D. J. Blundell (eds) Tectonic Evolution of Southeast Asia. Geological Society of London Special Publication 106, 97-122.

Milicich, S.D., Wilson, C.J.N., Bignall, G., Pezaro, B., Bardsley, C., 2013. Reconstructing the geological and structural history of an active geothermal field: a case study from New Zealand. Journal of Volcanology and Geothermal Research 262, 7-24.

Miller, C.F., Miller, J.S., 2002. Contrasting stratified plutons exposed in tilt blocks, Eldorado Mountains, Colorado River Rift, NV, USA. Lithos 61, 209-224.

Miller, C.F., McDowell, S.M., Mapes, R.W., 2003. Hot and cold granites? Implications of zircon saturation temperatures and preservation of inheritance. Geology 31, 529-532.

Miller, J.S., 2008. Assembling a pluton...one increment at a time. Geology 36, 511-512.

Miller, J.S., Matzel, J.E.P., Miller, C.F., Burgess, S.D., Miller, R.B., 2007. Zircon growth and recycling during the assembly of large, composite arc plutons. Journal of Volcanology and Geothermal Research 167, 282-299.

Mills, R.D., Coleman, D.S., 2013. Temporal and chemical connections between plutons and ignimbrites from the Mount Princeton magmatic center. Contributions to Mineralogy and Petrology 165, 961-980.

Moore, I; Kokelaar, P., 1997. Tectonic influences in piecemeal caldera collapse at Glencoe Volcano, Scotland. Journal of the Geological Society, London, 154, 765-768

Moore, I; Kokelaar, P., 1998. Tectonically controlled piecemeal caldera collapse: A case study of Glencoe volcano, Scotland. Geological Society of America Bulletin, 110, 1448-1466

Muller, R.D., Sdrolias, M., Gaina, C., Steinberger, B., Heine, C., 2008. Long-term sealevel fluctuations driven by ocean basin dynamics. Science 319, 1357-1362.

Nasdala, L., Zhang, M., Kempe, U., Panczer, G., Gaft, M., Andrut, M., Plotze, M., 2003. Spectroscopic methods applied to zircon. In: Hanchar, J.M. \& Hoskin, P.W.O. (eds) Zircon. Mineralogical Society of America and Geochemical Society, Reviews in Mineralogy and Geochemistry 53, 427-467.

Nau, P.S., Yim, W.W.S., 1988. Fission track dating of zircons from granitoid rocks of Hong 
Kong. Geological Society of Hong Kong Newsletter 6, 11-14.

Nelson, W.R., Dorais, M.J., Christiansen, E.H., Hart, G.L., 2013. Petrogenesis of Sierra

Nevada plutons inferred from the $\mathrm{Sr}, \mathrm{Nd}$, and $\mathrm{O}$ isotopic signatures of mafic igneous complexes in Yosemite Valley, California. Contributions to Mineralogy and Petrology 165, 397-417.

Nissen, S.S., Hayes, D.E., Buhl, P., Diebold, J., Yao, B.C., Zeng, W.J., Chen, Y.Q., 1995a. Deep penetration seismic-soundings across the northern margin of the South China Sea. Journal of Geophysical Research-Solid Earth 100, 22407-22433.

Nissen, S.S., Hayes, D.E., Yao, B.C., Zeng, W.J., Chen, Y.Q., Nu, X.P., 1995b. Gravity, heat-flow, and seismic constraints on the processes of crustal extension - northern margin of the South China Sea. Journal of Geophysical Research 100, 22447-22483.

Owen, R.B., 2000. Late Cretaceous-Early Tertiary continental lacustrine basins of Hong Kong and southeast China. In: Gierlowski-Kordesch, E. H. \& Kelts, K. R. (eds) Lake Basins through Space and Time. AAPG Studies in Geology 46, 329-334.

Pankhurst, R.J., Riley, T.R., Fanning, C.M., Kelley, S.P., 2000. Episodic silicic volcanism in Patagonia and the Antarctic Peninsula: chronology of magmatism associated with the break-up of Gondwana. Journal of Petrology 41, 605-625.

Parrish, R.R., Noble, S.R., 2003. Zircon U-Th-Pb geochronology by isotope dilution thermal ionization mass spectrometry (ID-TIMS). In: Hanchar, J.M. \& Hoskin, P.W.O. (eds) Zircon. Mineralogical Society of America and Geochemical Society Reviews in Mineralogy and Geochemistry 53, 183-213.

Paterson, B.A., Stephens, W.E., 1992. Kinetically induced compositional zoning in titanite: implications for accessory-phase melt partitioning of trace-elements. Contributions to Mineralogy and Petrology 109, 373-385.

Paton, C., Woodhead, J., Hellstrom, J., Hergt, J., Greig, A., Maas, R., 2010. Improved laser ablation $\mathrm{U}-\mathrm{Pb}$ zircon geochronology through robust down-hole fractionation correction. Geochemistry, Geophysics, Geosystems 11, Q0AA06.

Paton, C., Hellstrom, J., Paul, B., Woodhead, J., Hergt, J., 2011. Iolite: freeware for the visualisation and processing of mass spectrometric data. Journal of Analytical Atomic Spectrometry 26, 2508-2518.

Pei, R., Hong, D., 1995. The granites of south China and their metallogeny. Episodes 18, 77-82.

Qiu, J.S., Hu, J., McInnes, B.I.A., Jiang, S.Y., Xu, X.S., Allen, C.M., 2004. Geochronology, geochemistry and petrogenesis of the Longwo granodioritic pluton in Guangdong province. Acta Petrologica Sinica 20, 1363-1374.

Quick, J.E., Sinigoi, S., Peressini, G., Demarchi, G., Wooden, J.L., Sbisa, A., 2009. Magmatic plumbing of a large Permian caldera exposed to a depth of $25 \mathrm{~km}$. Geology 37, 603-606.

Reid, M.R., Vazquez, J.A., Schmitt, A.K., 2011. Zircon-scale insights into the history of a supervolcano, Bishop Tuff, Long Valley, California, with implications for the Ti-inzircon geothermometer. Contributions to Mineralogy and Petrology 161, 293-311.

Reiners, P.W., 2005. Zircon (U-Th)/He thermochronometry. In: Reiners, P.W. \& Ehlers, T.A. (eds) Low-temperature Thermochronology: Techniques, Interpretation, and Applications. Mineralogical Society of America and Geochemical Society, Reviews 
in Mineralogy and Geochemistry 58, 151-179, doi:10.2138/rmg.2005.58.6.

Reiners, P.W., Brandon, M.T., 2006. Using thermochronology to understand orogenic erosion. Annual Review of Earth and Planetary Sciences 34, 419-466.

Ren, J.Y., Tamaki, K., Li, S.T., Zhang, J.X., 2002. Late Mesozoic and Cenozoic rifting and its dynamic setting in Eastern China and adjacent areas. Tectonophysics 344, 175205.

Riley, T.R., Leat, P.T., Pankhurst, R.J., Harris, C., 2001. Origins of large volume rhyolitic volcanism in the Antarctic Peninsula and Patagonia by crustal melting. Journal of Petrology 42, 1043-1065.

Riley, T.R., Flowerdew, M.J., Hunter, M.A., Whitehouse, M.J., 2010. Middle Jurassic rhyolite volcanism of eastern Graham Land, Antarctic Peninsula: age correlations and stratigraphic relationships. Geological Magazine 147, 581-595.

Ru, K., Pigott, J.D., 1986. Episodic rifting and subsidence in the South-China Sea. American Association of Petroleum Geologists Bulletin 70, 1136-1155.

Rudnick, R.L., Fountain, D.M., 1995. Nature and composition of the continental crust: a lower crustal perspective. Reviews of Geophysics 33, 267-309.

Ruxton, B.P., 1960. The geology of Hong Kong. Quarterly Journal of the Geological Society of London 115, 233-260.

Sambridge, M.S., Compston, W., 1994. Mixture modeling of multicomponent data sets with application to ion-probe zircon ages. Earth and Planetary Science Letters 128, 373-390.

Schermer, E.R., Busby, C., 1994. Jurassic magmatism in the central Mojave Desert Implications for arc paleogeography and preservation of continental volcanic sequences. Geological Society of America Bulletin 106, 767-790.

Schermer, E.R., Busby, C.J., Mattinson, J.M., 2002. Paleogeographic and tectonic implications of Jurassic sedimentary and volcanic sequences in the central Mojave block. Geological Society of America Memoirs195, 93-115.

Schmitt, A.K., 2011. Uranium series accessory crystal dating of magmatic processes. Annual Review of Earth and Planetary Sciences 39, 321-349.

Schaltegger, U., Schmitt, A.K., Horstwood, M.S.A., 2015. U-Th-Pb zircon geochronology by ID-TIMS, SIMS, and laser ablation ICP-MS: recipes, interpretations, and opportunities. Chemical Geology 402, 89-110.

Schoene, B., Condon, D.J., Morgan, L., McLean, N., 2013. Precision and accuracy in geochronology. Elements 9, 19-24.

Sclater, J.G., Jaupart, C., Galson, D., 1980. The heat-flow through oceanic and continental crust and the heat loss of the Earth. Reviews of Geophysics 18, 269-311.

Seton, M., Muller, R.D., Zahirovic, S., Gaina, C., Torsvik, T., Shephard, G., Talsma, A., Gurnis, M., Turner, M., Maus, S., Chandler, M., 2012. Global continental and ocean basin reconstructions since 200 Ma. Earth-Science Reviews 113, 212-270.

Seward, D., Grujic, D., Schreurs, G., 2004. An insight into the breakup of Gondwana: Identifying events through low-temperature thermochronology from the basement rocks of Madagascar. Tectonics 23, TC3007.

Sewell, R.J., Campbell, S.D.G., 1997. Geochemistry of coeval Mesozoic plutonic and volcanic suites in Hong Kong. Journal of the Geological Society, London 154, 1053- 
1066.

Sewell, R.J., Campbell, S.D.G., 2001. Geochemical Data for Hong Kong Rocks. Hong Kong Geological Survey, Geotechnical Engineering Office.

Sewell, R.J., James, J.W.C., 1995. Geology of North Lantau Island and Ma Wan. Hong Kong Geological Survey Sheet Report No. 4, Geotechnical Engineering Office, Hong Kong Government.

Sewell, R.J., Darbyshire, D.P.F., Langford, R.L., Strange, P.J., 1992. Geochemistry and RbSr Geochronology of Mesozoic granites from Hong-Kong. Transactions of the Royal Society of Edinburgh-Earth Sciences 83, 269-280.

Sewell, R.J., Campbell, S.D.G., Fletcher, C.J.N., Lai, K.W., Kirk, P.A., 2000. The preQuaternary geology of Hong Kong. Civil Engineering Department, Hong Kong SAR Government, Hong Kong.

Sewell, R.J., Tang, D.L.K., Campbell, S.D.G., 2012a. Volcanic-plutonic connections in a tilted nested caldera complex in Hong Kong. Geochemistry, Geophysics, Geosystems 13, Q01006.

Sewell, R.J., Davis, D.W., Campbell, S.D.G., 2012b. High precision U-Pb zircon ages for Mesozoic igneous rocks from Hong Kong. Journal of Asian Earth Sciences 43, 164175.

Shane, P., Nairn, I.A., Smith, V.C., Darragh, M., Beggs, K., Cole, J.W., 2008a. Silicic recharge of multiple rhyolite magmas by basaltic intrusion during the $22.6 \mathrm{ka}$ Okareka eruption episode, New Zealand. Lithos 103, 527-549.

Shane, P., Smith, V.C., Nairn, I., 2008b. Millennial timescale resolution of rhyolite magma recharge at Tarawera volcano: insights from quartz chemistry and melt inclusions. Contributions to Mineralogy and Petrology 156, 397-411.

Shaw, H.R., 1985. Links between magma-tectonic rate balances, plutonism, and volcanism. Journal of Geophysical Research 90, 11275-11288.

Shenzhen Geology Compiling Group, 2009. Geology of Shenzhen. Beijing Geological Publishing House, Beijing.

Shi, H.S., Li, C.F., 2012. Mesozoic and early Cenozoic tectonic convergence-to-rifting transition prior to opening of the South China Sea. International Geology Review 54, 1801-1828.

Shu, L.S., Zhou, X.M., Deng, P., Wang, B., Jiang, S.Y., Yu, J.H., Zhao, X.X., 2009. Mesozoic tectonic evolution of the Southeast China Block: new insights from basin analysis. Journal of Asian Earth Sciences 34, 376-391.

Slama, J., Kosler, J., Condon, D., Crowley, J., Gerdes, A., Hanchar, J., Horstwood, M., Morris, G., Nasdala, L., Norberg, N., 2008. Plesovice zircon - A new natural reference material for $\mathrm{U}-\mathrm{Pb}$ and $\mathrm{Hf}$ isotopic microanalysis. Chemical Geology 249, $1-35$.

Smith, A.D., 2007. A plate model for Jurassic to Recent intraplate volcanism in the Pacific Ocean basin. In: Foulger, G.R. \& Jurdy, D.M. (eds) Plates, Plumes and Planetary Processes. Geological Society of America Special Papers 430, 471-495.

Smith, R.L., 1979. Ash-flow magmatism. Geological Society of America Special Paper 180, 5-27.

So, A.C.T., 1999. Petrology and Geochemistry of Volcanic Rocks of the Lantau Peak Area, 
Lantau Island, Hong Kong. MPhil thesis, The University of Hong Kong.

Sparks, R.S.J., Walker, G.P.L., 1977. Significance of vitric-enriched air-fall ashes associated with crystal-enriched ignimbrites. Journal of Volcanology and Geothermal Research 2, 329-341.

Speer, J.A., 1980. Zircon. In: Ribbe, P.H. (ed) Orthosilicates (2nd Ed.). Mineralogical Society of America, Reviews in Mineralogy 5, 67-112.

Spry, A., 1962. The origin of columnar jointing, particularly in basalt flows. Australian Journal of Earth Sciences 8, 191-216.

Stacey, J.S., Kramers, J.D., 1975. Approximation of terrestrial lead isotope evolution by a two-stage model. Earth and Planetary Science Letters 26, 207-221.

Stern, T.W., Bateman, P.C., Morgan, B.A., Newell, M.F., Peck, D.L., 1981. Isotopic U-Pb ages of zircons from the granitoids of the central Sierra Nevada. US Geological Survey Professional Papers 1071.

Storm, S., Shane, P., Schmitt, A.K., Lindsay, J.M., 2012. Decoupled crystallization and eruption histories of the rhyolite magmatic system at Tarawera volcano revealed by zircon ages and growth rates. Contribution to Mineralogy and Petrology 163, 505519.

Strange, P.J., Shaw, R., 1986. Geology of Hong Kong Island and Kowloon. Hong Kong Geological Survey Memoir No. 2, Hong Kong, Geotechnical Control Office.

Strange, P.J., Shaw, R., Addison, R., 1990. Geology of Sai Kung and Clear Water Bay. Hong Kong Geological Survey Memoir No. 4, Hong Kong, Geotechnical Control Office.

Sutton, A.N., Blake, S., Wilson, C.J.N., Charlier, B.L.A., 2000. Late Quaternary evolution of a hyperactive rhyolite magmatic system: Taupo volcanic centre, New Zealand. Journal of the Geological Society, London 157, 537-552.

Tagami, T., O'Sullivan, P.B., 2005. Fundamentals of fission-track thermochronology. In: Reiners, P.W. \& Ehlers, T.A. (eds) Low-temperature Thermochronology: Techniques, Interpretation, and Applications. Mineralogical Society of America and Geochemical Society, Reviews in Mineralogy and Geochemistry 58, 19-47.

Tam, S.W., Chan, Y.M., 1983. Late Jurassic ash-flow tuffs in the eastern part of Hong Kong, south China. Asian Geographer 2, 47.

Tang, D.L.K., Seward, D., Wilson, C.J.N., Sewell, R.J., Carter, A., Paul, B.T., 2014. Thermo-tectonic history of SE China since the late Mesozoic: insights from detailed thermochronological studies of Hong Kong. Journal of the Geological Society, London 171, 591-604.

Tappa, M.J., Coleman, D.S., Mills, R.D., Samperton, K.M., 2011. The plutonic record of a silicic ignimbrite from the Latir volcanic field, New Mexico. Geochemistry, Geophysics, Geosystems 12, Q10011.

Tao,W., Shen, Z.K., 2008. Heat flow distribution in Chinese continent and its adjacent areas. Progress in Natural Science-Materials International 18, 843-849.

Tao, K.Y., Gao, T.J., Lu, Z.G., 1998. Basement Tectonics of Volcanic Rock and VolcanicIntrusion Related to Mineralization of Coastal Area of Southeast China. Beijing, Geological Published House [in Chinese].

Taylor, B., 2006. The single largest oceanic plateau: Ontong Java-Manihiki-Hikurangi. 
Earth and Planetary Science Letters 241, 372-380.

Trail, D., Watson, E.B., Tailby, N.D., 2011. The oxidation state of Hadean magmas and implications for early Earth's atmosphere. Nature 480, 79-82.

Trail, D., Watson, E.B., Tailby, N.D., 2012. Ce and Eu anomalies in zircon as proxies for the oxidation state of magmas. Geochimica et Cosmochimica Acta 97, 70-87.

Tsang, D.P.W., 2010. Thermochronology Inferring Post-orogenic Exhumation Model around Greater Pearl River Delta Region. MPhil thesis, University of Hong Kong.

Vavra, G., Gebauer, D., Schmid, R., Compston, W., 1996. Multiple zircon growth and recrystallization during polyphase Late Carboniferous to Triassic metamorphism in granulites of the Ivrea Zone (Southern Alps): an ion microprobe (SHRIMP) study. Contributions to Mineralogy and Petrology 122, 337-358.

Vermeesch, P., 2012. On the visualisation of detrital age distributions. Chemical Geology 312-313, 190-194.

Villagomez, D., Spikings, R., Magna, T., Kammer, A., Winkler, W., Beltran, A., 2011. Geochronology, geochemistry and tectonic evolution of the Western and Central Cordilleras of Colombia. Lithos 125, 875-896.

Walker, B.A., Miller, C.F., Claiborne, L.L., Wooden, J.L., Miller, J.S., 2007. Geology and geochronology of the Spirit Mountain batholith, southern Nevada: implications for timescales and physical processes of batholith construction. Journal of Volcanology and Geothermal Research 167, 239-262.

Wang, H.Z., Mo, X.X., 1995. An outline of the tectonic evolution of China. Episodes 18, 616.

Wang, D.Z., Ren, Q.J., 1996. The Mesozoic volcanic-intrusive complexes and their metallogenic relations in East China. In: Peng, B. (ed), A Series of Solid Earth Sciences in China. Beijing, Science Press [in Chinese].

Wang, D.Z., Zhou, X.M., 2002. Crustal evolution and petrogenesis of Late Mesozoic granitic volcanic-intrusive complexes in Southeast China. Beijing, Science Press [in Chinese].

Wang, X., Griffin, W.L., O'Reilly, S.Y., Zhou, X.M., Xu, X.S., Jackson, S.E., Pearson, N.J., 2002. Morphology and geochemistry of zircons from late Mesozoic igneous complexes in coastal SE China: implications for petrogenesis. Mineralogical Magazine 66, 235-251.

Wang, F.Y., Ling, M.X., Ding, X., Hu, Y.H., Zhou, J.B., Yang, X.Y., Liang, H.Y., Fan, W.M., Sun, W., 2011. Mesozoic large magmatic events and mineralization in SE China: oblique subduction of the Pacific plate. International Geology Review 53, 704-726.

Wang, K.L., Chung, S.L., Lo, Y.M., Lo, C.H., Yang, H.J., Shinjo, R., Lee, T.Y., Wu, J.C., Huang, S.T., 2012. Age and geochemical characteristics of Paleogene basalts drilled from western Taiwan: records of initial rifting at the southeastern Eurasian continental margin. Lithos 155, 426-441.

Wang, Y., Fan, W., Zhang, G., Zhang, Y., 2012. Phanerozoic tectonics of the South China Block: Key observations and controversies. Gondwana Research 23, 1273-1305.

Watson, E.B., 1996, Surface enrichment and trace-element uptake during crystal growth. Geochimica et Cosmochimica Acta 60, 5013-5020. 
Watson, E.B., Harrison, T.M., 1983. Zircon saturation revisited: temperature and composition effects in a variety of crustal magma types. Earth and Planetary Science Letters 64, 295-304.

Watson, E.B., Harrison, T.M., 2005, Zircon thermometer reveals minimum melting conditions on earliest Earth. Science 308, 841-844.

Watson, E.B., Liang, Y., 1995. A simple model for sector zoning in slowly grown crystals: implications for growth rate and lattice diffusion, with emphasis on accessory minerals in crustal rocks. American Mineralogist 80, 1179-1187.

Watson, E.B., Wark, D.A., Thomas, J.B., 2006. Crystallization thermometers for zircon and rutile. Contributions to Mineralogy and Petrology 151, 413-433.

Watts, K.E., Bindeman, I.N., Schmitt, A.K., 2012. Crystal scale anatomy of a dying supervolcano: an isotope and geochronology study of individual phenocrysts from voluminous rhyolites of the Yellowstone caldera. Contributions to Mineralogy and Petrology 164, 45-67.

Wenner, J.M., Coleman, D.S., 2004. Magma mixing and Cretaceous crustal growth: geology and geochemistry of granites in the Central Sierra Nevada Batholith, California. International Geology Review 46, 880-903.

White, L.T., Ireland, T.R., 2013. High-uranium matrix effect in zircon and its implications for SHRIMP U-Pb age determinations. Chemical Geology 306-307, 78-91.

Wiedenbeck, M., Hanchar, J.M., Peck, W.H., Sylvester, P., Valley, J., Whitehouse, M., Kronz, A., Morishita, Y., Nasdala, L., Fiebig, J., Franchi, I., Girard, J.-P., Greenwood, R.C., Hinton, R., Kita, N., Mason, P.R.D., Norman, M., Ogasawara, M., Piccoli., P. M. , Rhede, D., Satoh, H., Schulz-Dobrick, B., Skår, Ø., Spicuzza, M.J., Terada, K., Tindle, A., Togashi, S., Vennemann, T., Xie, Q., Zheng, Y.-F., 2004. Further characterisation of the 91500 zircon crystal. Geostandards and Geoanalytical Research 28, 9-39.

Wilcock, J., Goff, F., Minarik, W.G., Stix, J., 2013. Magmatic recharge during the formation and resurgence of the Valles Caldera, New Mexico, USA: evidence from quartz compositional zoning and geothermometry. Journal of Petrology 54, 635-664.

Wilson, C.J.N., 1993. Stratigraphy, chronology, styles and dynamics of late Quaternary eruptions from Taupo volcano, New Zealand. Philosophical Transactions of the Royal Society of London A343, 205-306.

Wilson, C.J.N., 2001. The 26.5 ka Oruanui eruption, New Zealand: an introduction and overview. Journal of Volcanology and Geothermal Research 112, 133-174.

Wilson, C.J.N., Charlier, B.L.A., 2009. Rapid rates of magma generation at contemporaneous magma systems, Taupo volcano, New Zealand: insights from U-Th model-age spectra in zircons. Journal of Petrology 50, 875-907.

Wilson, C.J.N., Blake, S., Charlier, B.L.A., Sutton, A.N., 2006. The 26.5 ka Oruanui eruption, Taupo volcano, New Zealand: development, characteristics and evacuation of a large rhyolitic magma body. Journal of Petrology 47, 35-69.

Wolff, J.A., Ramos, F.C., 2014. Processes in caldera-forming high-silica rhyolite magma: $\mathrm{Rb}-\mathrm{Sr}$ and $\mathrm{Pb}$ isotope systematics of the Otowi Member of the Bandelier Tuff, Valles Caldera, New Mexico, USA. Journal of Petrology 55, 345-375.

Wong, J.F.C., Shaw, R., 2010. Updating of Hong Kong Geological Survey 1:20,000-scale 
Maps - Major Findings and Revisions Map Sheet 15 - Hong Kong South and Lamma Island, Geological Report GR 5/2010, Geotechnical Engineering Office, Civil Engineering and Development Department, The Government of the Hong Kong Special Administrative Region, Hong Kong.

Wong, J., Sun, M., Xing, G., Li, X.-H., Zhao, G., Wong, K., Yuan, C., Xia, X., Li, L., Wu, F., 2009. Geochemical and zircon U-Pb and Hf isotopic study of the Baijuhuajian metaluminous A-type granite: extension at 125-100 Ma and its tectonic significance for South China. Lithos 112, 289-305.

Wooden, J.L., Mazdab, F.K., Barth, A.P., Miller, C.F., Lowery, L.E., 2006. Temperatures (Ti) and compositional characteristics of zircon: early observations using high mass resolution on the USGS-Stanford SHRIMP-RG. Geochimica et Cosmochimica Acta 70 (Issue 18, Supplement), A707.

Woodhead, J., Hellstrom, J., Hergt, J., Greig, A., Maas, R., 2007. Isotopic and elemental imaging of geological materials by laser ablation inductively coupled plasma-mass spectrometry. Geostandards and Geoanalytical Research 31, 331-343.

Wotzlaw, J.F., Schaltegger, U., Frick, D.A., Dungan, M.A., Gerdes, A., Gunther, D., 2013. Tracking the evolution of large-volume silicic magma reservoirs from assembly to supereruption. Geology 41, 867-870.

Wu, J.M., 1994. Evaluation and models of Cenozoic sedimentation in the South China Sea. Tectonophysics 235, 77-98.

Yan, P., Deng, H., Liu, H., Zhang, Z., Jiang, Y., 2006. The temporal and spatial distribution of volcanism in the South China Sea region. Journal of Asian Earth Sciences 27, 647659.

Yan, Y., Carter, A., Xia, B., Ge, L., Brichau, S., Hu, X., 2009. A fission-track and (UTh)/He thermochronometric study of the northern margin of the South China Sea: An example of a complex passive margin. Tectonophysics 474, 584-594.

Yan, Q., Shi, X., Liu, J., Wang, K., Bu, W., 2010. Petrology and geochemistry of Mesozoic granitic rocks from the Nansha micro-block, the South China Sea: constraints on the basement nature. Journal of Asian Earth Sciences 37, 130-139.

Yan, P., Wang, L., Wang, Y., 2014. Late Mesozoic compressional folds in Dongsha Waters, the northern margin of the South China Sea. Tectonophysics 615-616, 213-223.

Yang, S.Y., Jiang, S.Y., Jiang, Y.H., Zhao, K.D., Fan, H.H., 2010. Zircon U-Pb geochronology, Hf isotopic composition and geological implications of the rhyodacite and rhyodacitic porphyry in the Xiangshan uranium ore field, Jiangxi Province, China. Science China-Earth Sciences 53, 1411-1426.

Yang, S.Y., Jiang, S.Y., Jiang, Y.H., Zhao, K.D., Fan, H.H., 2011. Geochemical, zircon U$\mathrm{Pb}$ dating and $\mathrm{Sr}-\mathrm{Nd}-\mathrm{Hf}$ isotopic constraints on the age and petrogenesis of an Early Cretaceous volcanic-intrusive complex at Xiangshan, Southeast China. Mineralogy and Petrology 101, 21-48.

Yin, J.H., Ruan, H.H., Xie, J.Y., Feng, Z.Z., Yu, Y.W., 1991. Mesozoic Volcanic Cycles, Volcanic Structures and Its Ore-Controlling Significance of Southeast Continent of China, People's Republic of China Ministry of Geology and Mineral Resources Geological Memoirs, Beijing, Geological Publishing House [in Chinese].

Ying, S., Stepashko, A.A., Ren, J., 2015. The Cretaceous climax of compression in Eastern 
Asia: age 87-89 Ma (late Turonian/Coniacian), Pacific cause, continental consequences. Cretaceous Research 55, 262-284.

Yu, M.G., Xing, G.F., Shen, J.L., Chen, R., Zhou, Y.Z., Wei, H.M., Tao, K.Y., 2006. Chronologic study on volcanic rocks in the Mt Yandangshan World Geopark. Acta Geologica Sinica 80, 1683-1690 [in Chinese with English abstract].

Zhao, J.-L., Qiu, J.-S., Liu, L., Wang, R.-Q., 2015. Geochronolgoical, geochemical and $\mathrm{Nd}-\mathrm{Hf}$ isotopic constraints on the petrogenesis of Late Cretaceous A-type granites from the southeast coast of Fujian Province, South China. Journal of Asian Earth Sciences 105, 338-359.

Zeh, A., Ovtcharova, M., Wilson, A. H. \& Schaltegger, U. (2015). The Bushveld Complex was emplaced and cooled in less than one million years - results of zirconology, and geotectonic implications. Earth and Planetary Science Letters 418, 103-114.

Zheng, J.P., Griffin, W.L., Li, L.S., O'Reilly, S.Y., Pearson, N.J., Tang, H.Y., Liu, G.L., Zhao, J.H., Yu, C.M., Su, Y.P., 2011. Highly evolved Archean basement beneath the western Cathaysia Block, South China. Geochimica et Cosmochimica Acta 75, 242255.

Zheng, Y.F., Xiao, W.J., Zhao, G., 2013. Introduction to tectonics of China. Gondwana Research 23, 1189-1206.

Zhou, X.M., Li, W.X., 2000. Origin of Late Mesozoic igneous rocks in Southeastern China: implications for lithosphere subduction and underplating of mafic magmas. Tectonophysics 326, 269-287.

Zhou, D., Ru, K., Chen, H.Z., 1995. Kinematics of Cenozoic extension on the South China Sea continental margin and its implications for the tectonic evolution of the region. Tectonophysics 251, 161-177.

Zhou, X.M., Sun, T., Shen, W.Z., Shu, L.S., Niu, Y.L., 2006. Petrogenesis of Mesozoic granitoids and volcanic rocks in South China: a response to tectonic evolution. Episodes 29, 26-33.

Zimmerer, M.J., McIntosh, W.C., 2012. The geochronology of volcanic and plutonic rocks at the Questa caldera: constraints on the origin of caldera-related silicic magmas. Geological Society of America Bulletin 124, 1394-1408. 
Appendix A

Lithological map of Hong Kong

(with key location names mentioned in this thesis) 


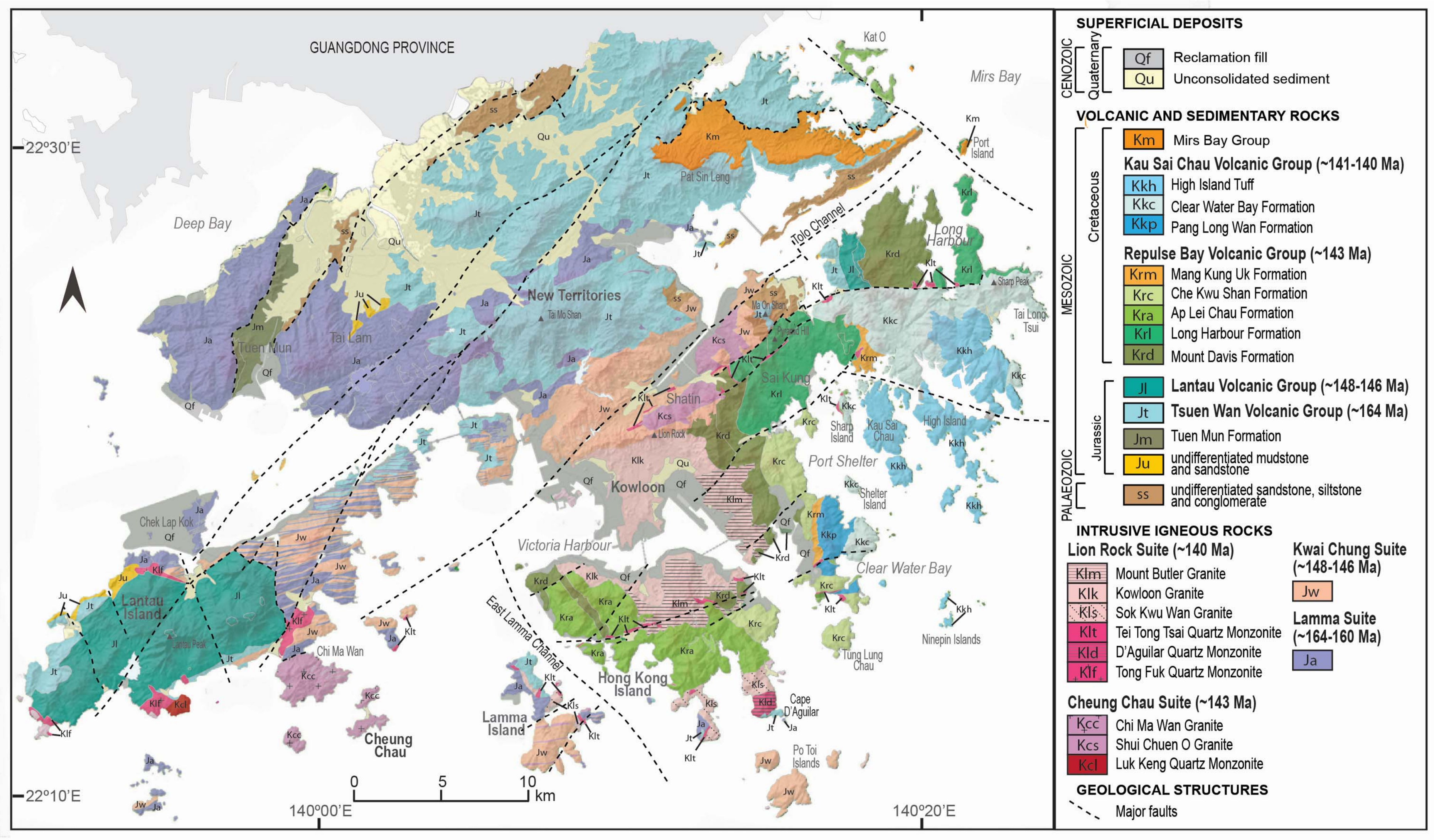

Appendix A - Lithological map of Hong Kong (modified from Sewell et al., 2000).

(The ages of volcanic groups and intrusive suites are based on the reported ID-TIMS ages (Davis et al., 1997; Campbell et al., 2007; Sewell et al., 2012b). Some age figures are modified by this work.) 
Appendix B

List of rock samples analysed in this thesis 


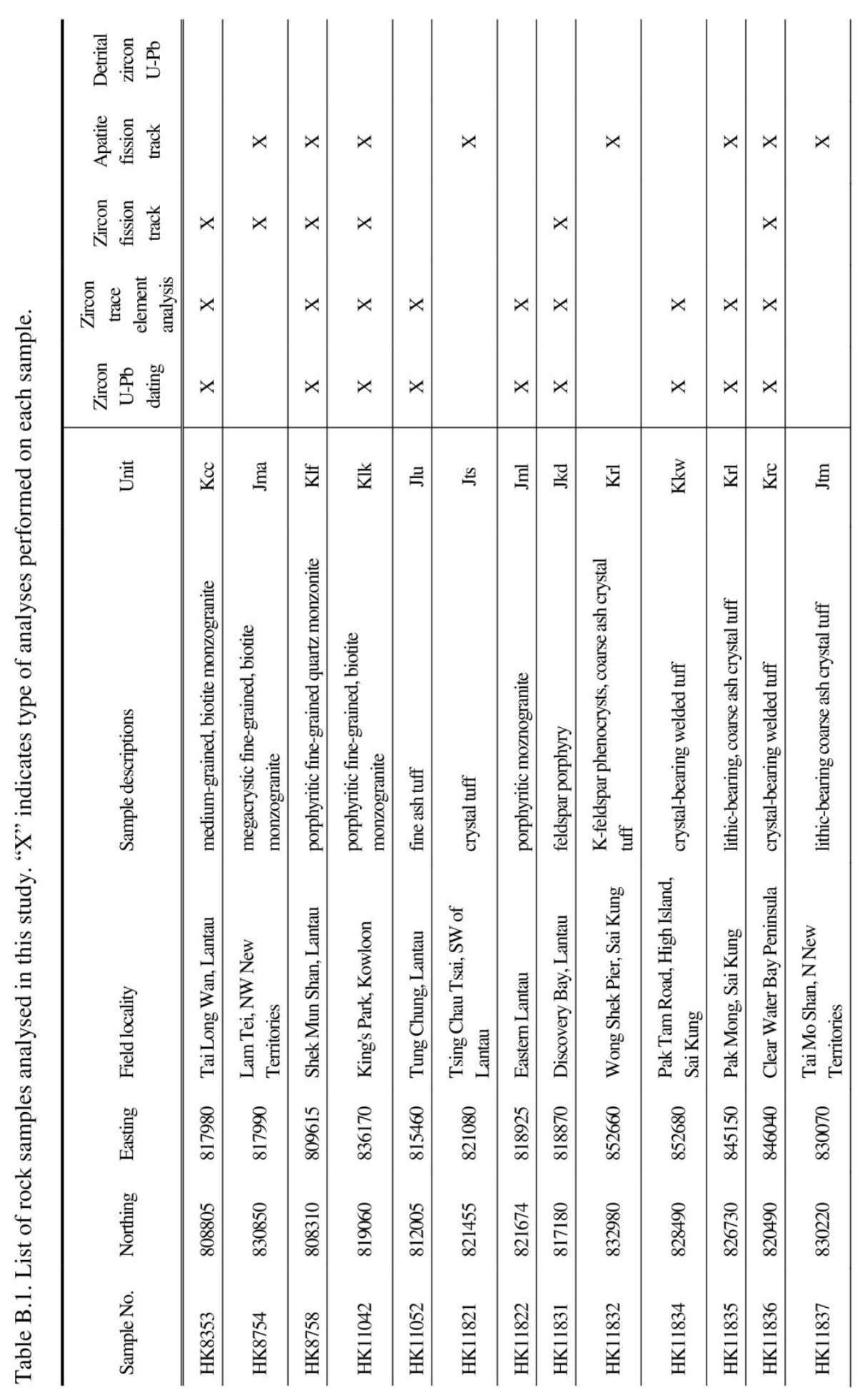




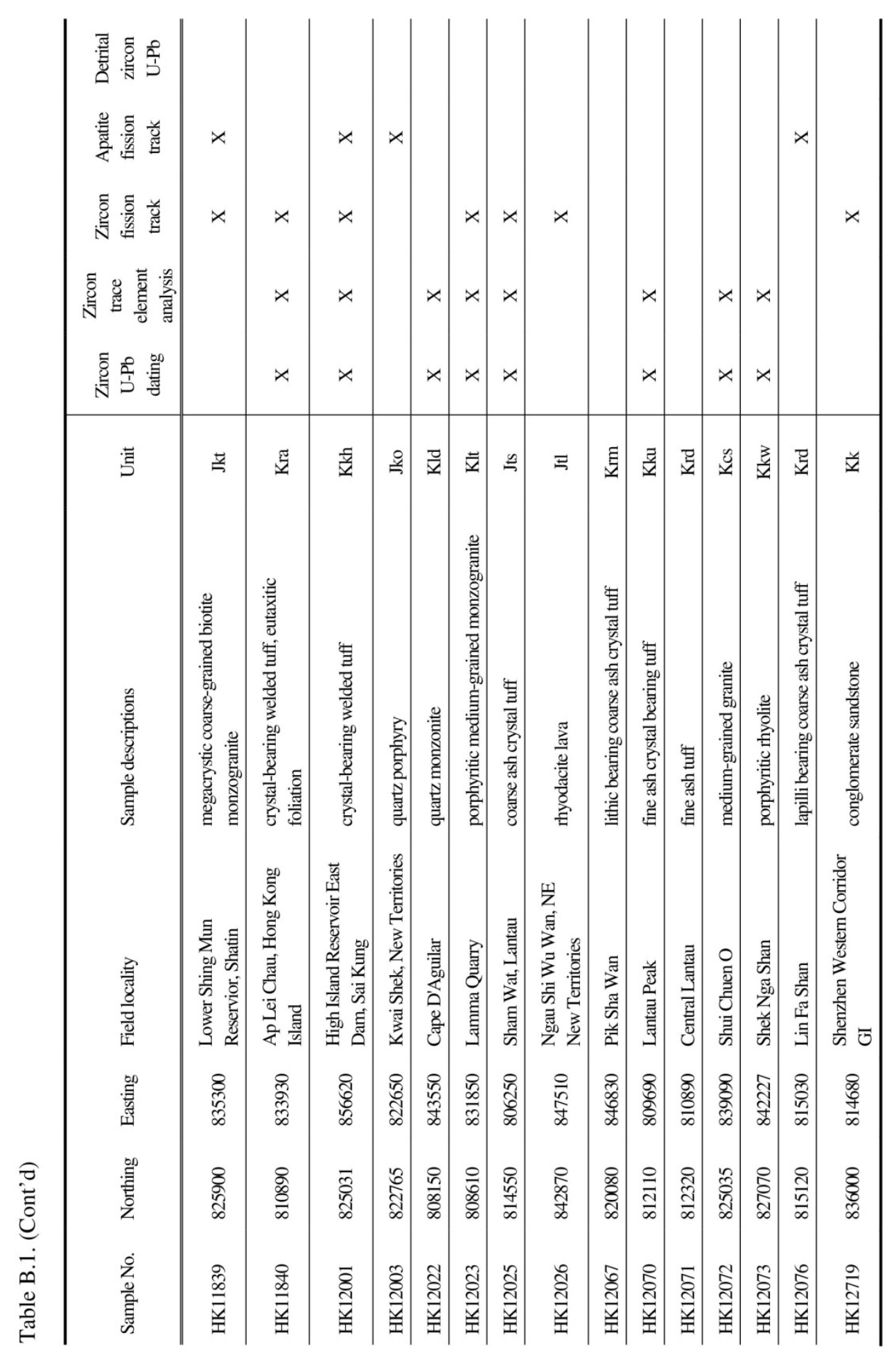




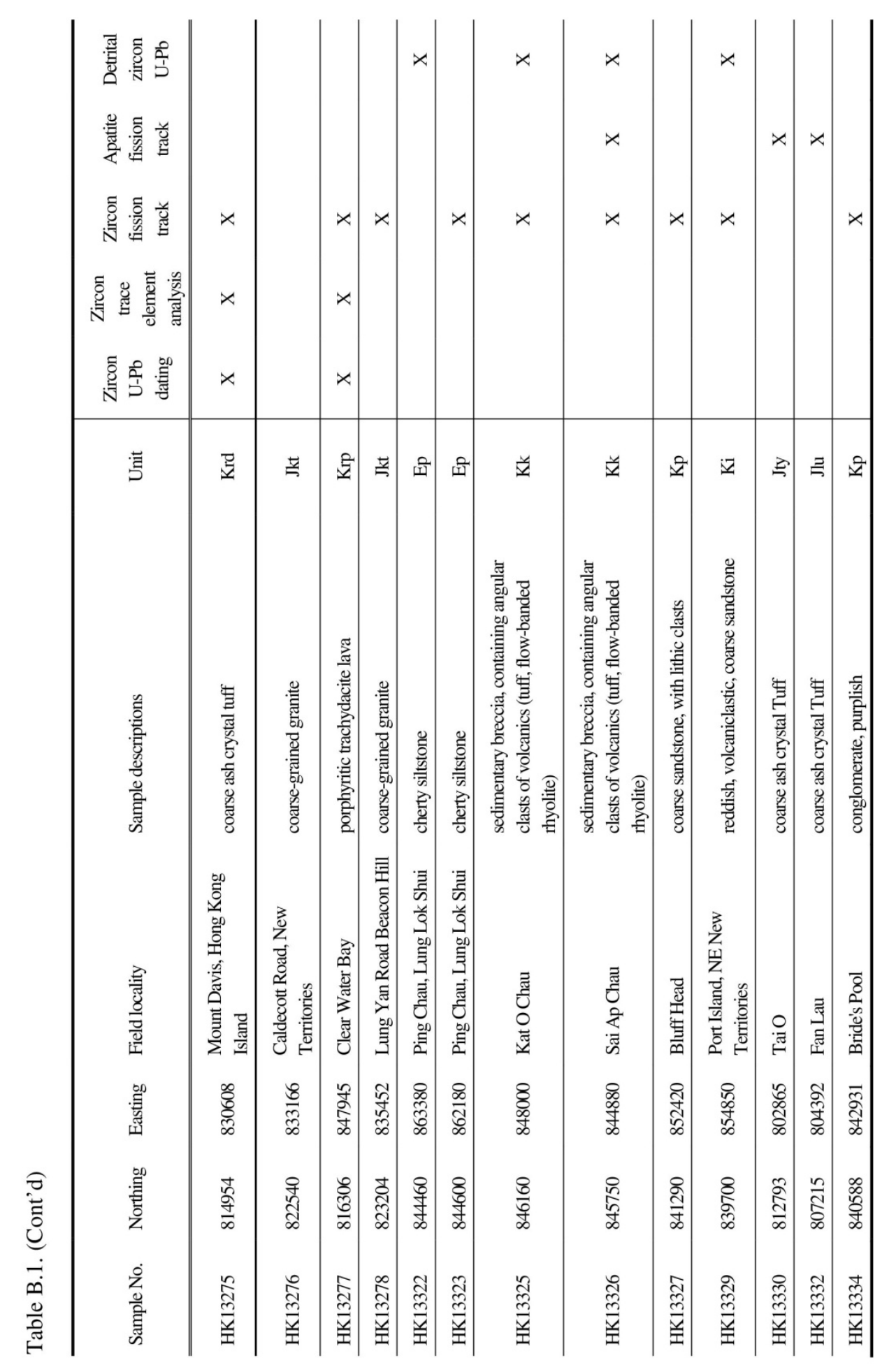




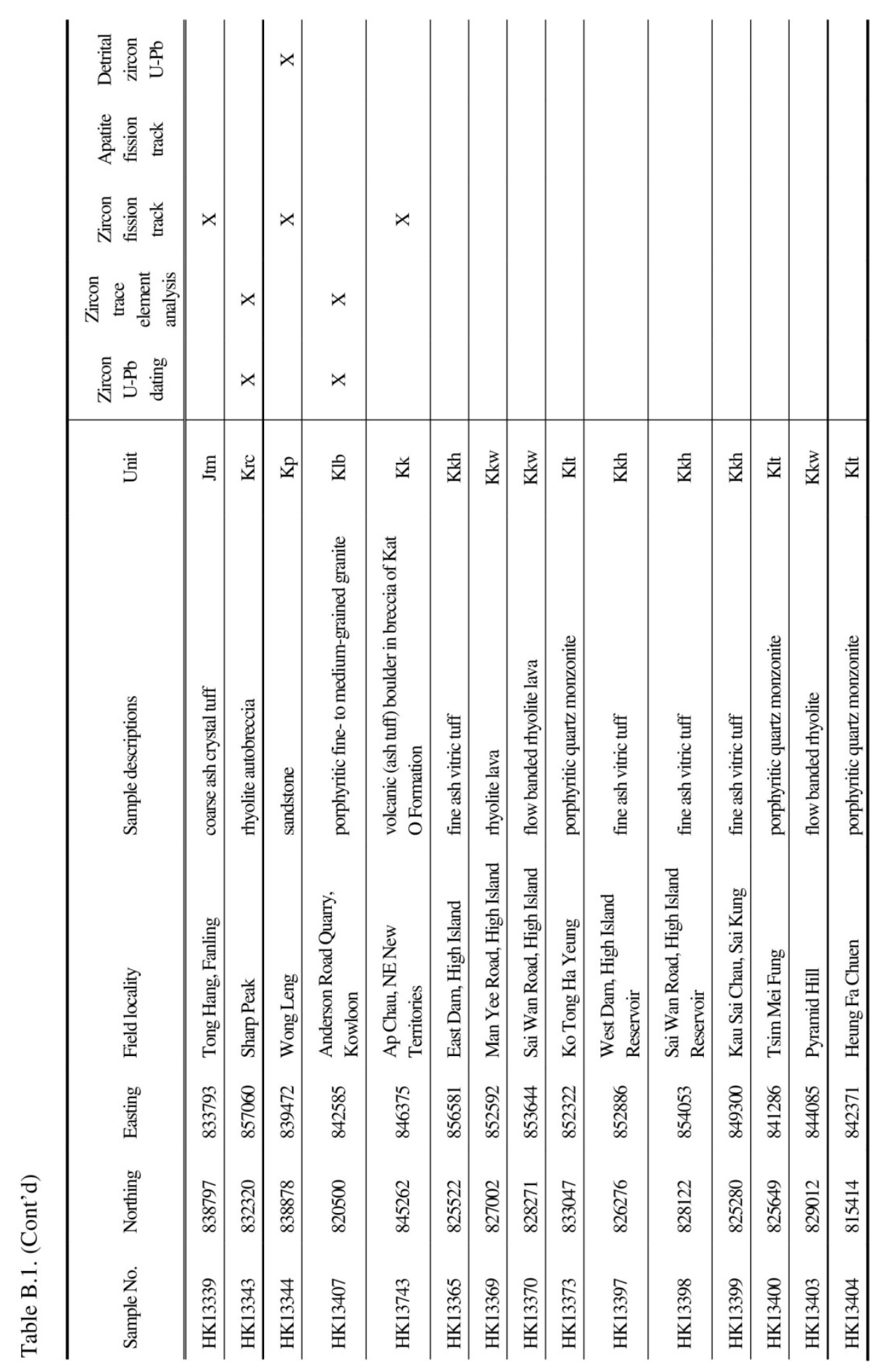




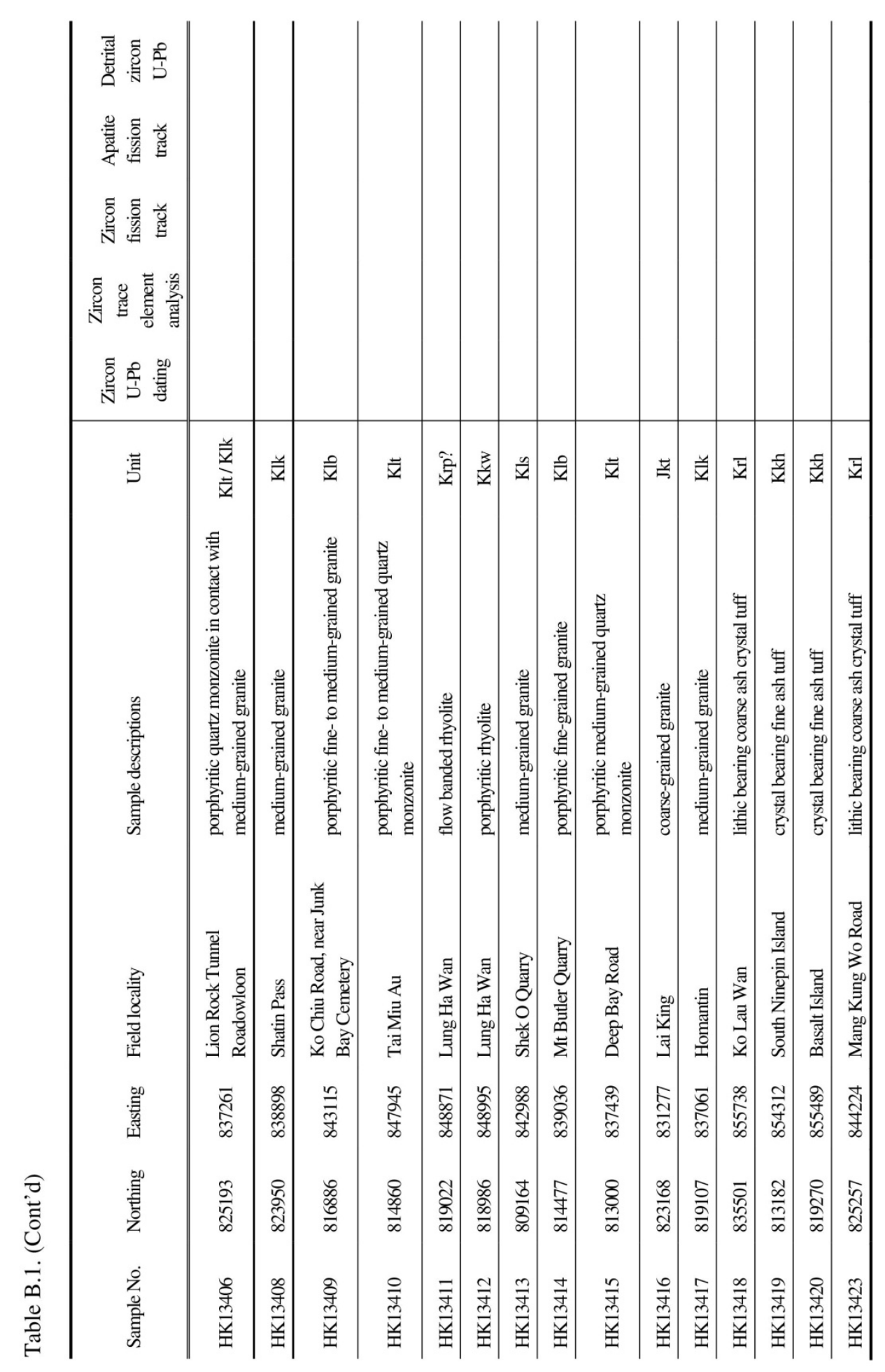


Appendix C

Low-temperature fission track thermochronology Principles and Methodology 


\section{C.1. Principles of Fission Track Thermochronology}

Fission-track (FT) thermochronology provides a mean to determine the time-versus-temperature histories of rocks. The technique is commonly used to establish the low-temperature thermal history of rocks, particularly related to exhumation through the crust caused by tectonic and / or surface processes (Tagami and O'Sullivan, 2005; Reiners and Brandon, 2006). The timing and the rate of exhumation (or cooling) can then be determined, provided that the geothermal gradient is known or inferred (Reiners and Brandon, 2006). A brief review of the principles and methods of FT technique is given here and illustrated in Fig. C.1.

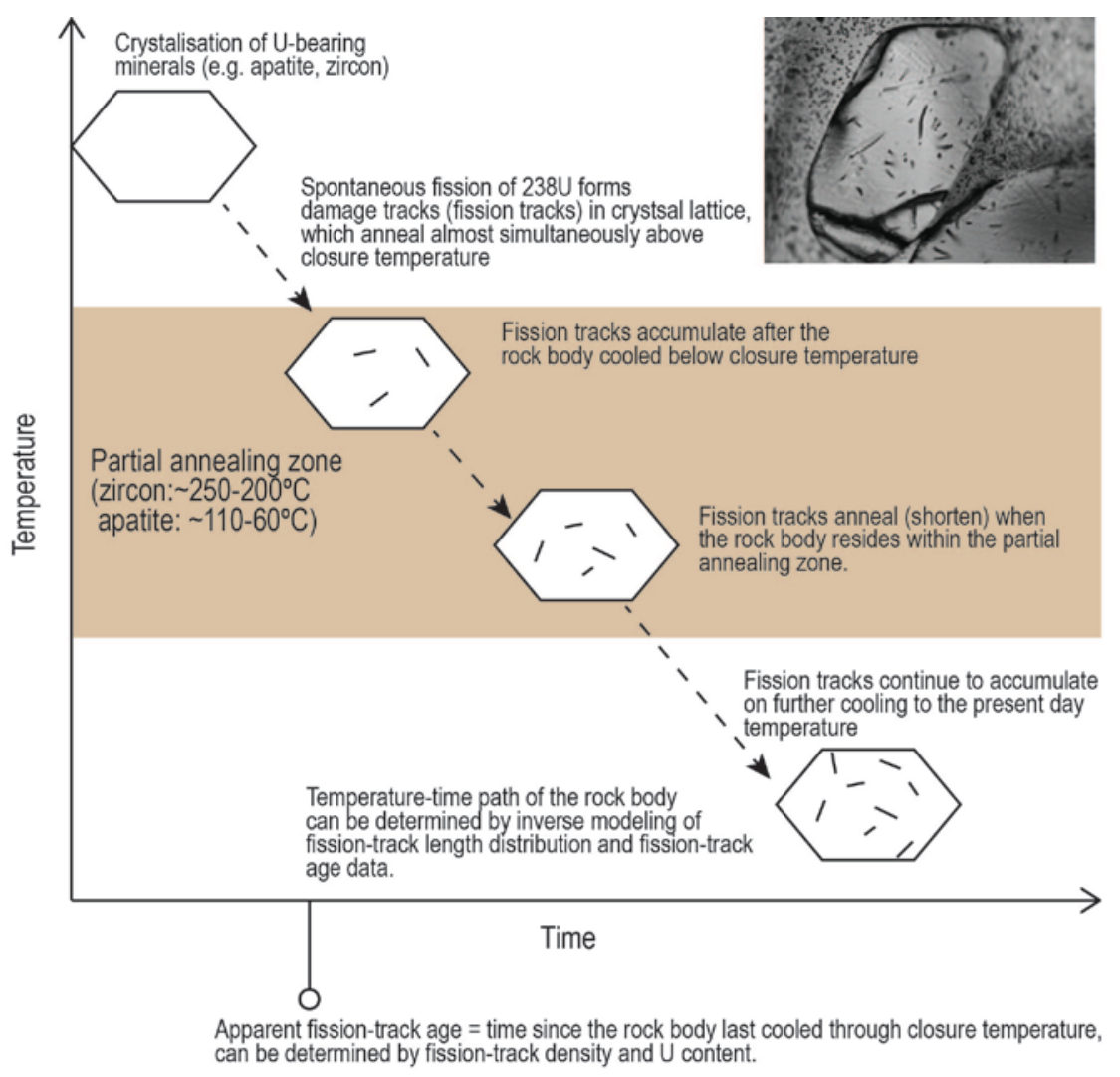

Fig. C.1. Illustration of the principle of fission track thermochronology techniques

FT thermochronology makes use of the damage produced by spontaneous fission decay of uranium-238 $\left({ }^{238} \mathrm{U}\right)$ in uranium-bearing minerals, such as apatite, zircon and titanite (Fleischer et al., 1975). Spontaneous fission decay of ${ }^{238} U$ is a slow but constant natural process, in which spontaneous fission decay of uranium nucleus produced two highly charged particles that expel each other. As the high charged particles "fly" apart, they produce ionization damage in the crystal lattice along their paths and form a single fission track. The defects in the crystal lattice are recovered by thermally activated diffusion of the dislocated atoms, and the fission tracks are said to have "annealed". Therefore, the retention of fission tracks depends on the temperature experienced by the host rocks. FT age is the time since the mineral (i.e. its host rock) cooled below its effective closure temperature, and is determined by counting the accumulated fission tracks and calculating the track density of mineral grains. The track density depends on both the rate of formation of fission tracks and the uranium content of the crystal grains. 
The effective closure temperature is the temperature below which fission tracks are fully retained, i.e. the closure of the FT system, and therefore, is the temperature of the dated mineral at the time indicated by the thermochronometer (Garver et al., 2005; Reiners and Brandon, 2006). The effective closure temperature for zircon FT under typical geological settings is about $250 \pm 40^{\circ} \mathrm{C}$ (Brandon et al., 1998). However, the effective closure temperature of zircons is dependent on the rate of cooling as well as the radiation damage of grains (Garver et al., 2000). Brandon et al. (1998) discussed the thermal stability of fission tracks in apatite and zircon. The partial annealing zones and effective closure temperatures are dependent on the chlorine content and radiation damages for apatite and zircon minerals respectively. For apatite, thermal stability of fission tracks decreases with decreasing chlorine concentration (Green et al., 1985; Carlson, 1990; Crowley et al., 1991); whereas for zircons, thermal stability decreases with increasing radiation damages (Kasuya and Naeser, 1988; Garver et al., 2000).

Rather than being simply considered as the ages when a rock body had cooled through the corresponding closure temperatures of zircon and apatite, FT ages represent apparent ages which reflect the overall cooling history of the rock body. As the rock body cooled through the partial annealing zones of zircon and apatite, or if the rock body was reheated back to the partial annealing zone due to reburial or heating, the accumulated fission tracks are shortened. The track length varies depending on the amount of time the rock body retained in the partial annealing zones. The distribution of track lengths, therefore, records the cooling history of the rock body within the partial annealing zones. Experimental studies on track annealing kinematics in apatite enable the fission track apparent ages and track length data be used to constrain the thermal history of the rock body in the apatite partial annealing zone (APAZ: 60-120 ${ }^{\circ} \mathrm{C}$ ) using inverse modeling approaches (e.g. Lutz and Omar, 1991; Corrigan, 1991; Gallagher, 1995; Willett, 1997; Ketcham et al., 2003; Ketcham, 2005). The annealing kinematics of zircon fission tracks is less well-understood as compared with apatite fission tracks (Ketcham, 2005). It is not yet possible to carry out inverse modeling on the zircon fission track length data.

\section{C.2. Calculation of Fission Track Age and Zeta-Calibration}

In principle, the FT ages for individual grains (i.e. the time since fission tracks have been accumulating in a crystal) can be calculated from the ratio of spontaneous to induced fission tracks, and the spontaneous fission decay rate (Fleischer et al., 1975; Wagner and van den Haute, 1992) using the following equation.

$$
\mathrm{t}=\left(\frac{1}{\lambda_{\mathrm{t}}}\right)\left\{\ln \left[1+\left(\frac{\lambda_{\mathrm{t}}}{\lambda_{\mathrm{f}}}\right)\left(\mathrm{g} \frac{\rho_{\mathrm{s}}}{\rho_{\mathrm{i}}}\right) I a \phi\right]\right\}
$$

$\mathrm{t} \quad=\quad$ the fission track age;

$\lambda_{\mathrm{t}}=$ the total (alpha plus fission) decay constant of ${ }^{238} \mathrm{U}$;

$\lambda_{\mathrm{f}}=\quad$ the spontaneous fission decay constant of ${ }^{235} \mathrm{U}$;

$\rho_{\mathrm{s}}=\quad$ the measured spontaneous track density from natural fission of ${ }^{238} \mathrm{U}$; 
$\rho_{\mathrm{i}}=\quad$ the measured induced track density from induced fission of ${ }^{235} \mathrm{U}$;

$I=\quad$ the isotopic ratio of ${ }^{235} \mathrm{U} /{ }^{238} \mathrm{U}\left(7.527 \times 10^{-3}\right)$;

$a=\quad$ the thermal neutron capture cross-sectional area of ${ }^{235} \mathrm{U}$

$\left(584.25 \times 10^{-24} \mathrm{~cm}^{2}\right.$ neutron $\left.{ }^{-1}\right)$;

$\phi \quad=\quad$ the thermal neutron flux received in the nuclear reactor;

$\mathrm{g}=$ a geometry factor; 0.5 for external detector method

(see Wagner and van den Haute, 1992)

However, owing to the uncertainty of the value for the spontaneous fission decay constant, $\lambda_{\mathrm{f}}$, and the complexities of neutron flux measurement, $\phi$, the FT age of a sample is determined using the zeta $(\zeta)$ calibration method and IUGS recommended age standard (Hurford and Green, 1983; Hurford, 1990). This is an international calibration of the FT system against a series of age standards agreed by the IUGS. The calibration parameter, zeta $(\zeta)$, is defined as:

$$
\zeta=I a \frac{\mathrm{B}}{\lambda_{\mathrm{f}}}
$$

In this equation, $\mathrm{B}=\phi / \rho_{\mathrm{d}}$, which defines a calibration factor between the measured induced track density in the mica detector of the dosimeter glass, $\rho_{d}$, and the absolute neutron flux, $\phi$. Therefore,

$$
\zeta=I a \frac{\mathrm{B}}{\lambda_{\mathrm{f}}}=I a \phi /\left(\rho_{\mathrm{d}} \lambda_{\mathrm{f}}\right)
$$

By substituting into Equation 1,

$$
\mathrm{t}=\left(\frac{1}{\lambda_{\mathrm{t}}}\right)\left\{\ln \left[1+\left(\frac{\lambda_{\mathrm{t}}}{\lambda_{\mathrm{f}}}\right)\left(\mathrm{g} \frac{\rho_{\mathrm{s}}}{\rho_{\mathrm{i}}}\right) \zeta \rho_{\mathrm{d}} \lambda_{\mathrm{f}}\right]\right\}
$$

The calibration parameter, zeta $(\zeta)$, is empirically determined by counting the spontaneous and induced fission tracks of a sample of known age (i.e. an age standard). For a sample of a known age, $t_{\text {std }}$

$$
\mathrm{t}_{\mathrm{std}}=\left(\frac{1}{\lambda_{\mathrm{t}}}\right)\left\{\ln \left[1+\left(\frac{\lambda_{\mathrm{t}}}{\lambda_{\mathrm{f}}}\right)\left(\mathrm{g} \frac{\rho_{\mathrm{s}}}{\rho_{\mathrm{i}}}\right) \zeta \rho_{\mathrm{d}} \lambda_{\mathrm{f}}\right]\right\}
$$


i.e.

$$
\zeta=\left(\frac{1}{\lambda_{\mathrm{t}}}\right)\left[\exp \left(\mathrm{t}_{\mathrm{std}} \lambda_{\mathrm{t}}\right)-1\right]\left(\frac{\rho_{\mathrm{i}}}{\rho_{\mathrm{s}} \mathrm{g}}\right)\left(\frac{1}{\rho_{\mathrm{d}}}\right)
$$

In this study, the calibration parameter, zeta $(\zeta)$, for dosimeter glass $\mathrm{CN}-1$ is determined using zircons from the Fish Canyon Tuff (FCT). Personal zeta-calibration parameter values obtained during the period of this study are tabulated and shown in Table A3.1 and Fig. A3.2. The weighted mean of personal zeta values obtained during the period of this study is $129 \pm 13$.

Table C.1. Personal zeta-calibration parameter values using Fish Canyon Tuff (FCT) zircons and $\mathrm{CN}-1$ age standard and glass dosimeter respectively.

\begin{tabular}{l|l|l|l|l|l|l|l|l}
\hline \hline $\begin{array}{l}\text { Irradiation } \\
\text { number }\end{array}$ & $\begin{array}{l}\text { No. } \\
\text { of } \\
\text { grains }\end{array}$ & $\begin{array}{l}\text { Standard } \\
\text { track } \\
\text { density } \rho_{\mathrm{d}} \\
\mathrm{x} 10^{5} \mathrm{~cm}^{-2}\end{array}$ & $\begin{array}{l}\mathrm{N}_{\mathrm{d}} \\
\text { counted }\end{array}$ & $\begin{array}{l}\mathrm{N}_{\mathrm{s}} \\
\text { counted }\end{array}$ & $\begin{array}{l}\mathrm{N}_{\mathrm{i}} \\
\text { counted }\end{array}$ & $\begin{array}{l}\text { Density } \\
\text { Ratio } \\
\left(\mathrm{N}_{\mathrm{s}} / \mathrm{N}_{\mathrm{i}}\right)\end{array}$ & Zeta, $\zeta$ & $\pm 2 \sigma$ \\
\hline ETH251-08 & 20 & 3.298 & 2282 & 3651 & 3037 & 1.2022 & 141.05 & 10.42 \\
\hline VUW003-13 & 20 & 5.031 & 2440 & 1204 & 1236 & 0.9741 & 114.11 & 11.12 \\
\hline ETH253-10 & 20 & 3.313 & 2773 & 2448 & 2128 & 1.1504 & 139.85 & 9.84 \\
\hline ETH276-15 & 20 & 3.217 & 3191 & 2498 & 1876 & 1.3316 & 130.55 & 10.34 \\
\hline VUW004-09 & 20 & 4.290 & 4318 & 2527 & 2789 & 0.9061 & 143.86 & 11.14 \\
\hline VUW010-07 & 20 & 4.806 & 4676 & 2073 & 2126 & 0.9751 & 119.33 & 9.20 \\
\hline \hline
\end{tabular}

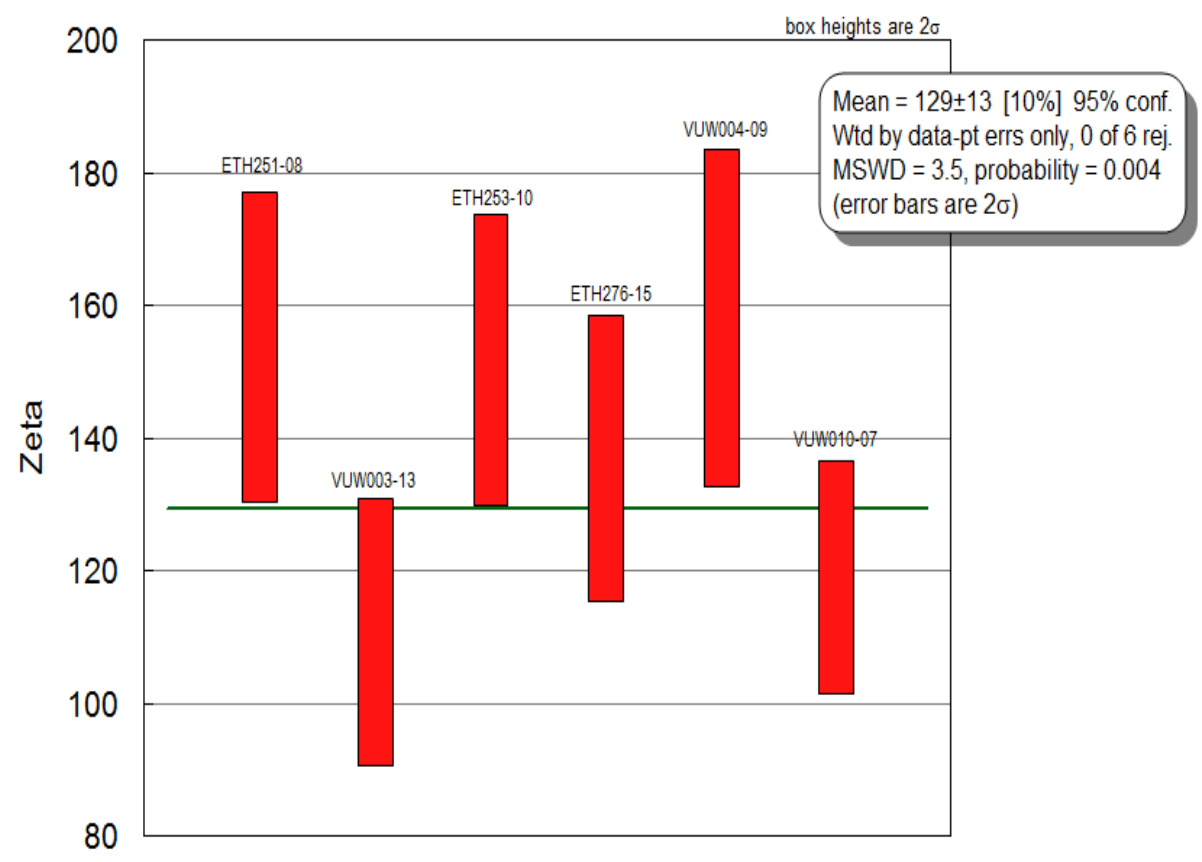

Fig. C.2. Personal zeta-calibration factor values obtained during the period of this study. 


\section{AC.3 Experimental Procedures}

Bulk rock samples collected from the field were processed by using mechanical crushing and then conventional mineral separation techniques (through heavy liquids and magnetic separation). Over $2 \mathrm{~kg}$ materials for each igneous rock sample were crushed, whereas for sedimentary rock samples, at least $4 \mathrm{~kg}$ materials for each sample were processed to ensure sufficient detrital apatite and zircon could be obtained.

Aliquots of apatite and zircon minerals separated from the samples were mounted in epoxy resin and Teflon sheets, respectively. Mineral grains were then polished to expose the internal mineral surfaces (i.e. to achieve $4 \pi$ geometry) using carbide papers and diamond water. Fission tracks were revealed by chemical etching of the mineral grains that had been mounted and polished. The etched fission tracks were visible under a high power optical microscope.

For apatite grains, etching was done with $5 \mathrm{M} \mathrm{HNO}_{3}$ at $20^{\circ} \mathrm{C}$ for 20 seconds; whereas for zircon grains, etching was done with eutectic $\mathrm{KOH}-\mathrm{NaOH}$ melt at $\sim 220^{\circ} \mathrm{C}$ for $24-50$ hours (Gleadow et al., 1976; Tagmai et al., 1990). The optimum etch time for zircons for individual samples was determined by the step-etch and observation procedure (Gleadow, 1981; Hasebe et al., 1994). For detrital zircon fission track analysis, two mounts per sample were made to allow for different lengths of etching time. This is because the detrital sample might contain several zircon populations with variable radiation damage, which might require different optimal etching times (Naeser et al., 1987; Garver et al., 2000).

We used the external detector method (Gleadow, 1981; Hurford and Green, 1983. The uranium content of grains was determined by neutron irradiation method (also named as external detector method). A sheet of uranium-free mica is attached to the mount of the etched mineral grains. Both the mount and the mica were sent to a nuclear reactor for low-energy neutron irradiation, which induced fission of uranium-235 $\left({ }^{235} \mathrm{U}\right)$ in the etched minerals. Two pieces of glass dosimeter with known uranium contents (CN5 for apatite; CN1 for zircon) were put at either ends of the sample stack to monitor the neutron flux, which dictated the number of induced fission tracks on the mica detector. The neutron irradiation of the samples was carried out at the Oregon State University Radiation Facility, USA and in the FRM 11 thermal neutron facility at the University of Munich in Germany. After the irradiation and cooling, the mica detector sheets were detached from the sample mounts and etched. The induced fission tracks on the mica were revealed by etching with $48 \% \mathrm{HF}$ at $20^{\circ} \mathrm{C}$ for 25 minutes.

The spontaneous ${ }^{238} \mathrm{U}$ and induced ${ }^{235} \mathrm{U}$ fission tracks of individual grains were counted in the measured areas of the crystal and in the mirror-imaged mica detector respectively under a high power Zeiss MM+ microscope with a computer-controlled stage and a total magnification of 1000times. The spontaneous and induced fission track densities for individual mineral grains were then calculated. The ${ }^{235} \mathrm{U}$ content was determined based on the induced fission track density on the mica. Based on the fact that the natural ratio of ${ }^{235} \mathrm{U} /{ }^{238} \mathrm{U}$ is fixed, the ${ }^{238} \mathrm{U}$ content of the mineral grains could be estimated. For each sample analysed, normally 10 to 30 single grain ages were obtained.

The lengths of horizontal as well as inclined confined fission tracks in apatite grains were measured under a Zeiss MM+ microscope with a total magnification of 1000-times and using the 'FASTTRACKS' programme (Gleadow et al., 2012). In addition to the length of confined fission tracks, the size of etch pits (Dpars), as a proxy for chlorine contents, and the orientation of c-axis were determined. These parameters were implemented for inverse modelling using the Hefty 
programme (version 1.8.0; Ketcham, 2005). Only samples with over 20 dated grains and more than 50 track-length measurements were modelled. For each model, the computation was stopped after 100 "good" paths (i.e. when both the model FT age and length distribution matched the measured FT age and length distribution with a level of goodness-of-fit of 0.5: see Ketcham, 2005) were found using the Monte Carlo approach.

\section{C.4. Data Presentation}

In the conventional age calculation, it is assumed that all crystals in a sample would have a single age population, such that the spontaneous and induced track counts from all crystals can be pooled for determining a mean age (Hurford and Green, 1982). If this assumption is valid, the variation in single grain ages would only be allowed for within the Poissonian statistics related to the determination of spontaneous and induced track densities $\left(\rho_{\mathrm{s}}\right.$ and $\left.\rho_{\mathrm{i}}\right)$ and the track density $\left(\rho_{\mathrm{d}}\right)$ of the age standard (Tagami and O'Sullivan, 2005). This assumption, however, is not always valid, in particular for sedimentary rocks in which crystals from multiple sources are present or for samples having apatite minerals of a wide range of chlorine contents (Green, 1981). A statistic procedure, known as $\chi^{2}$ test (Galbraith, 1981), is introduced to assess whether the variation in single grain ages is within the Possionian statistics.

In the study, the reported ages are central ages (with $2 \sigma$ ) calculated using the "TRACKKEY" programme (Dunkl, 2002). The central age, age dispersion (i.e. the spread of the single grain ages), and the $\chi^{2}$-value of each sample are reported along with the spontaneous and induced track densities $\left(\rho_{\mathrm{s}}\right.$ and $\left.\rho_{\mathrm{i}}\right)$, the track density $\left(\rho_{\mathrm{d}}\right)$ of the age standard and the total numbers of counted tracks for $\rho_{\mathrm{s}}, \rho_{\mathrm{i}}$ and $\rho_{\mathrm{d}}$. The central age is a modal age weighted to account for the differing precisions of individual grain ages. When the $\chi^{2}$ test is failed, the central age is a better representation of the population age than the mean age determined from the conventional calculation. On the other hand, if the age dispersion is low $(<10 \%)$, suggesting a single age population is valid for the sample, the central age would converge to the mean age. The single grain age data is presented using the radial plot method introduced by Galbraith (1990). The raw data and radial plot for each sample are contained in the Electronic Appendix C.

\section{C.5. References}

Brandon, M.T., Roden-Tice, M.K., Garver, J.I., 1998. Late Cenozoic exhumation of the Cascadia accretionary wedge in the Olympic Mountains, northwest Washington State. Geological Society of America Bulletin 110, 985-1009.

Carlson, W.D., 1990. Mechanisms and kinetics of apatite fission-track annealing. American Mineralogist 75, 1120-1139.

Corrigan, J., 1991. Inversion of apatite fission-track data for thermal history information. Journal of Geophysical Research-Solid Earth and Planets 96, 10347-10360.

Crowley, K.D., Cameron, M., Schaefer, R.L., 1991. Experimental studies of annealing of etched fission tracks in fluorapatite. Geochimica et Cosmochimica Acta 55, 1449-1465.

Dunkl, I. 2002. Trackkey: a Windows program for calculation and graphical presentation of fission track data. Computers and Geosciences 28, 3-12.

Fleischer R.L., Price, P.B., Walker, R.M., 1975. Nuclear Tracks in Solids: Principles and Applications. University of California Press, Berkeley.

Galbraith, R.F., 1981. On statistical-models for fission-track counts. Journal of the International Association for Mathematical Geology 13, 471-478.

Galbraith, R.F., 1990. The radial plot - graphical assessment of spread in ages. Nuclear Tracks and Radiation Measurements 17, 207-214. 
Gallagher, K., 1995. Evolving temperature histories from apatite fission-track data. Earth and Planetary Science Letters 136, 421-435.

Garver, J.I., Soloviev, A.V., Bullen, M.E., Brandon, M.T., 2000. Towards a more complete record of magmatism and exhumation in continental arcs, using detrital fission-track thermochrometry. Physics and Chemistry of the Earth Part A-Solid Earth and Geodesy 25, 565-570.

Garver, J.I., Reiners, P.W., Walker, L.J., Ramage, J.M., Perry, S.E., 2005. Implications for timing of Andean uplift from thermal resetting of radiation-damaged zircon in the Cordillera Huayhuash, northern Peru. Journal of Geology 113, 117-138.

Gleadow, A.J.W., 1981. Fission-track dating methods - what are the real alternatives. Nuclear Tracks and Radiation Measurements 5, 3-14.

Gleadow, A.J.W., Hurford, A.J., Quaife, R.D., 1976. Fission-track dating of zircon - improved etching techniques. Earth and Planetary Science Letters 33, 273-276.

Gleadow, A.J.W., Kohn, B., Alimanovic A, 2012. Integrated technologies for automated fission track analysis - sharpening the focus in low-temperature thermochronology. Proceedings of the 34th International Geological Congress, Brisbane, August 2012, 2715.

Green, P.F., 1981. Track-in-track length measurements in annealed apatites. Nuclear Tracks and Radiation Measurements 5, 121-128.

Green, P.F., Duddy, I.R., Gleadow, A.J.W., Laslett, G.M., Hegarty, K.A., Lovering, J.F., 1985. The changing face of fission track dating: recent advances. Fourth Australian Conference on Nuclear Techniques of Analysis Proceedings, 231-5.

Hasebe, N., Tagami, T., Nishimura, S., 1994. Towards zircon fission-track thermochronology reference framework for confined track length measurements. Chemical Geology 114, 281281.

Hurford, A.J., 1990. Standardization of fission-track dating calibration - recommendation by the fission-track working group of the IUGS subcommission on geochronology. Chemical Geology 80, 171-178.

Hurford, A.J., Green, P.F., 1982. A users guide to fission-track dating calibration. Earth and Planetary Science Letters 59, 343-354.

Hurford, A.J., Green, P.F., 1983. The zeta-age calibration of fission-track dating. Isotope Geoscience 1, 285-317.

Kasuya, M., Naeser, C.W., 1988. The effect of alpha-damage on fission-track annealing in zircon. Nuclear Tracks and Radiation Measurements 14, 477-480.

Ketcham, R.A., Donelick, R.A., Donelick, M.B., 2003. AFTSolve: A program for multi-kinetic modeling of apatite fission-track data. American Mineralogist 88, 929-929.

Ketcham, R.A., 2005. Forward and inverse modeling of low-temperature thermochronometry data. Reviews in Mineralogy and Geochemistry 58, 275-314.

Lutz, T.M., Omar, G., 1991. An inverse method of modeling thermal histories from apatite fissiontrack data. Earth and Planetary Science Letters 104, 181-195.

Naeser, N.D., Zeitler, P.K., Naeser, C.W., Cerveny, P.F., 1987. Provenance studies by fission-track dating of zircon - etching and counting procedures. Nuclear Tracks and Radiation Measurements 13, 121-126.

Reiners, P.W., Brandon, M.T., 2006. Using thermochronology to understand orogenic erosion. Annual Review of Earth and Planetary Sciences 36, 419-466.

Tagami, T., Ito, H., Nishimura, S., 1990. Thermal annealing characteristics of spontaneous fission tracks in zircon. Chemical Geology 80, 159-169.

Tagami, T., O'Sullivan, P.B., 2005. Fundamentals of fission-track thermochronology. Reviews in Mineralogy and Geochemistry 58, 19-47.

Wagner, G.A., van den Haute, P., 1992. Fission-track Dating. Kulwer Academic Publishers, Dordrecht.

Willett, S.D., 1997. Inverse modeling of annealing of fission tracks in apatite 1: A controlled random search method. American Journal of Science 297, 939-969. 
